\title{
Building America Industrialized Housing Partnership (BAIHP)
}

\author{
Final Project Report \\ September1, 1999 - June 30, 2006 \\ FSEC-CR-1663-06 \\ Produced by the \\ BAIHP Team
}

Janet McIlvaine, FSEC

Subrato Chandra, FSEC

Stephen Barkaszi, FSEC

David Beal, FSEC

David Chasar, FSEC

Carlos Colon, FSEC

Ken Fonorow, FLHERO

Andrew Gordon, WSU

David Hoak, FSEC

Stephanie Hutchinson, ALACF

Mike Lubliner, WSU
Eric Martin, FSEC

Ross McCluney, FSEC

Mark McGinley, NCA\&TSU

Mike McSorley, WSU

Neil Moyer, FSEC

Mike Mullens, UCFIE

Danny Parker, FSEC

John Sherwin, FSEC

Rob Vieira, FSEC

Susan Wichers, FSEC

Compiled by Janet McIlvaine and Susan Wichers, FSEC

University of Central Florida/ Florida Solar Energy Center

12443 Research Parkway, Suite 207

Orlando, Florida 32826

October 2006

PREPARED FOR THE UNITED STATES

DEPARTMENT OF ENERGY

Under Cooperative Agreement

No. DE-FC26-99GO10478 


\begin{abstract}
This final report summarizes the work conducted by the Building America Industrialized Housing Partnership (www.baihp.org ) for the period 9/1/99-6/30/06. BAIHP is led by the Florida Solar Energy Center of the University of Central Florida and focuses on factory built housing. In partnership with over 50 factory and site builders, work was performed in two main areas - research and technical assistance.

In the research area -- through site visits in over 75 problem homes, we discovered the prime causes of moisture problems in some manufactured homes and our industry partners adopted our solutions to nearly eliminate this vexing problem. Through testing conducted in over two dozen housing factories of six factory builders we documented the value of leak free duct design and construction which was embraced by our industry partners and implemented in all the thousands of homes they built. Through laboratory test facilities and measurements in real homes we documented the merits of "cool roof" technologies and developed an innovative night sky radiative cooling concept currently being tested. We patented an energy efficient condenser fan design, documented energy efficient home retrofit strategies after hurricane damage, developed improved specifications for federal procurement for future temporary housing, compared the Building America benchmark to HERS Index and IECC 2006, developed a toolkit for improving the accuracy and speed of benchmark calculations, monitored the field performance of over a dozen prototype homes and initiated research on the effectiveness of occupancy feedback in reducing household energy use.
\end{abstract}

In the technical assistance area we provided systems engineering analysis, conducted training, testing and commissioning that have resulted in over 128,000 factory built and over 5,000 site built homes which are saving their owners over $\$ 17,000,000$ annually in energy bills. These include homes built by Palm Harbor Homes, Fleetwood, Southern Energy Homes, Cavalier and the manufacturers participating in the Northwest Energy Efficient Manufactured Home program. We worked with over two dozen Habitat for Humanity affiliates and helped them build over 700 Energy Star or near Energy Star homes. We have provided technical assistance to several show homes constructed for the International builders show in Orlando, FL and assisted with other prototype homes in cold climates that save $40 \%$ over the benchmark reference. In the Gainesville Fl area we have several builders that are consistently producing 15 to 30 homes per month in several subdivisions that meet the $30 \%$ benchmark savings goal. We have contributed to the 2006 DOE Joule goals by providing two community case studies meeting the $30 \%$ benchmark goal in marine climates.

\title{
DISCLAIMER
}

This report was prepared as an account of work sponsored by an agency of the United States government. Neither the United States government, nor any agency thereof, nor any of their employees, makes any warranty, express or implied, or assumes any legal liability or responsibility for the accuracy completeness, or usefulness of any information, apparatus, product, or process disclosed, or represents that its use would not infringe privately owned rights. Reference herein to any specific commercial product, process, or service by trade name, trademark, manufacturer, or otherwise does not necessarily constitute or imply its endorsement, recommendation, or favoring by the United States government or any agency thereof. The views and opinions of authors expressed herein do not necessarily state or reflect those of the United States government or any agencies thereof. 


\section{TABLE OF CONTENTS}

ABSTRACT FISCLAIMER

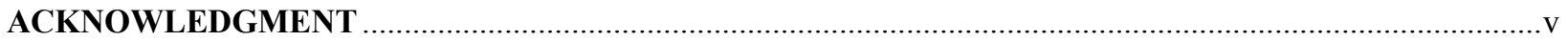

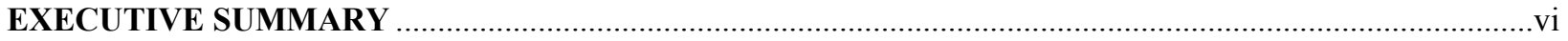

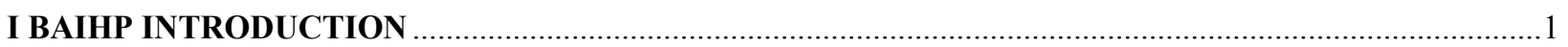

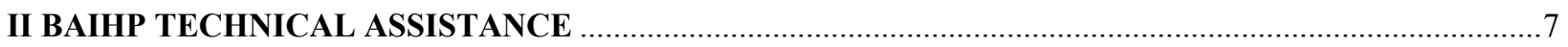

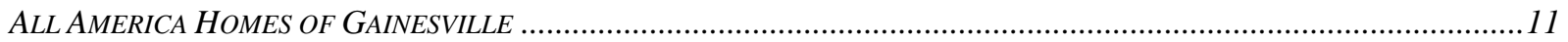

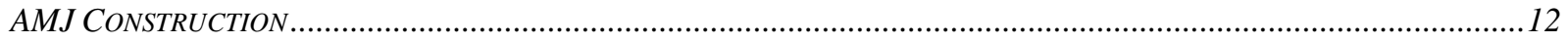

APPLEGREN CONSTRUCTION, EASTERN DAKOTA HOUSING ALLIANCE (EDHA)....................................................12

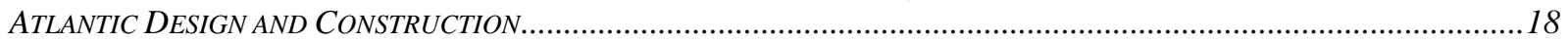

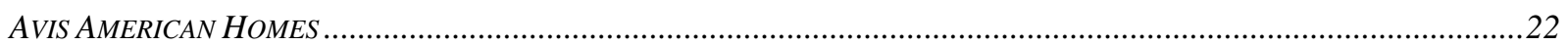

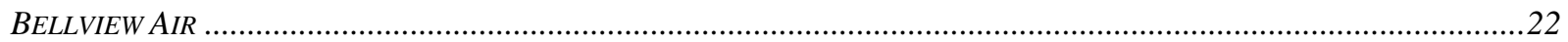

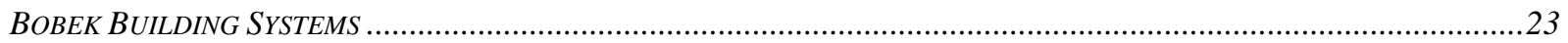

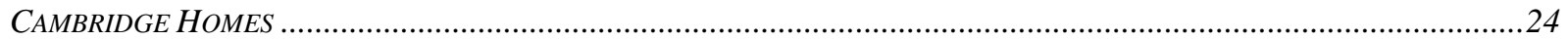

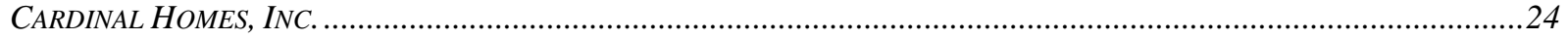

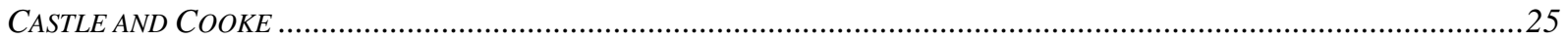

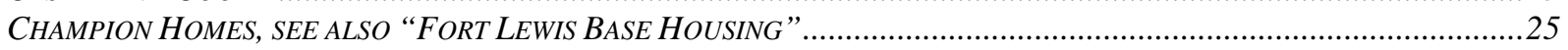

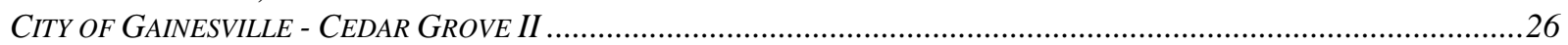

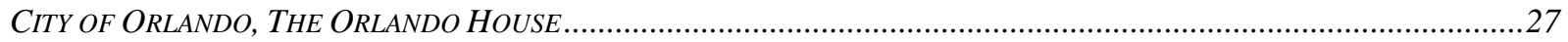

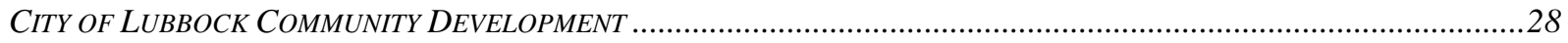

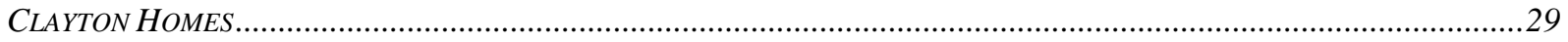

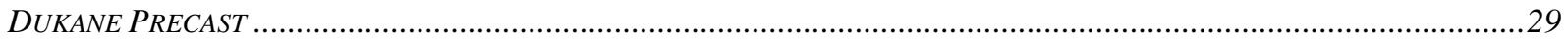

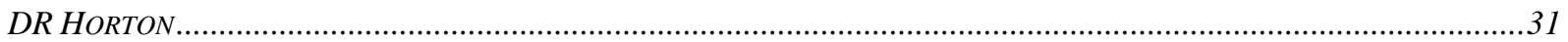

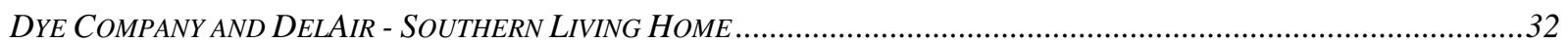

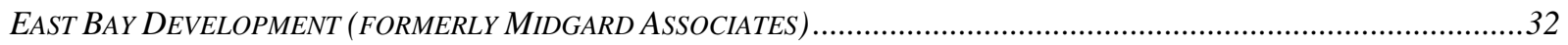

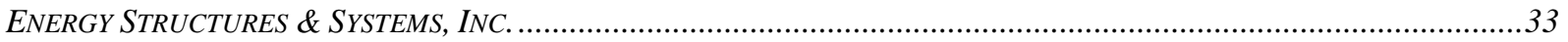

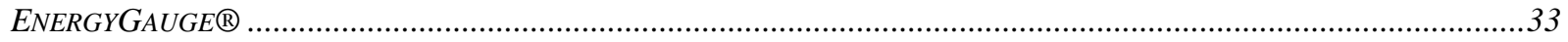

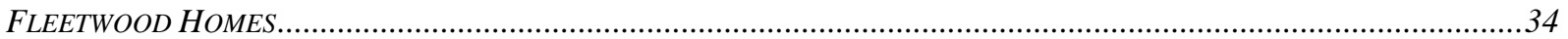

FORT LEWIS MILITARY HOUSING, CHAMPION HOMES, EQUITY RESIDENTIAL ………...............................................39

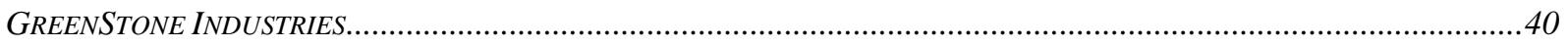

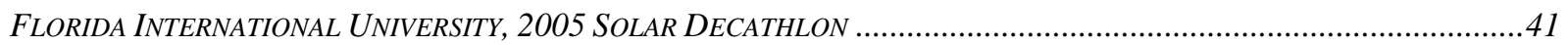

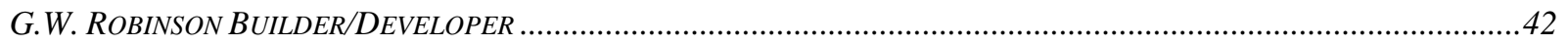

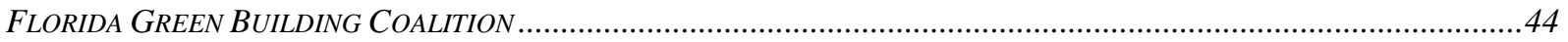

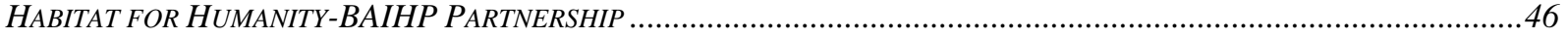

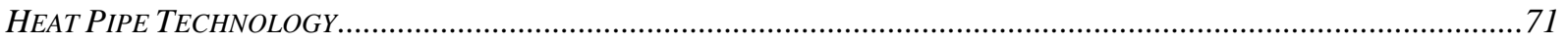

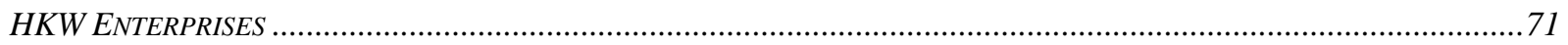

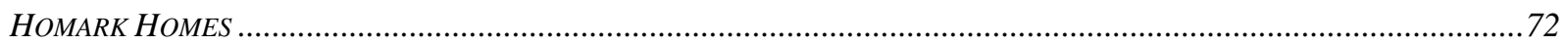

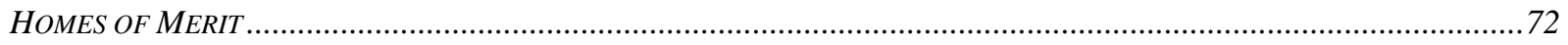

2005 INTERNATIONAL BUILDERS SHOW SHOWHOMES ( ${ }^{\text {TH }}$ BUDGET PERIOD) …….............................................73

A. New American Home, Built by Goehring Morgan Construction ..................................................................73

B. Discovery Custom Homes Modular Showhome........................................................................................73

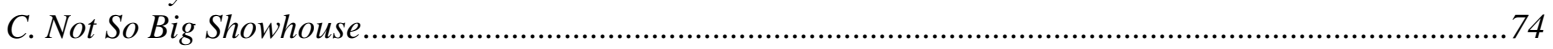

2006 INTERNATIONAL BUILDERS SHOW SHOWHOMES.......................................................................................75

The 2006 International Builders Show Showhomes was held in Orlando, Florida in January. BAIHP staff

worked in the Building America booth and provided technical assistance to several IBS show homes .............75

A. New American Home ..........................................................................................................................75

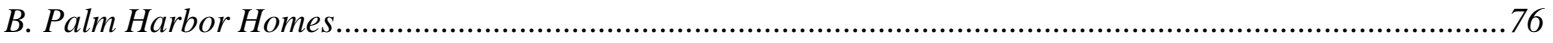

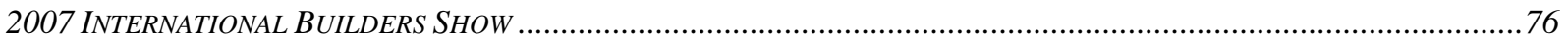




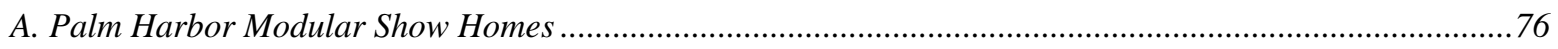

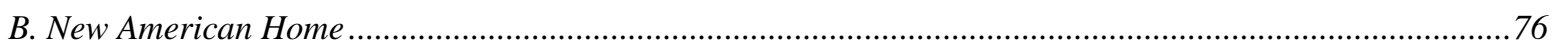

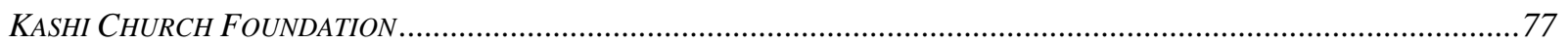

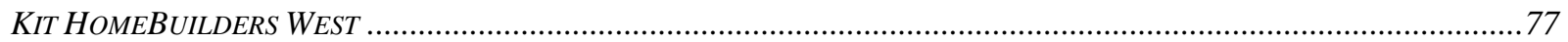

MARLETTE HOMES, KOKANEE CREEK ......................................................................................................77

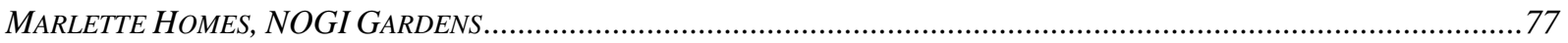

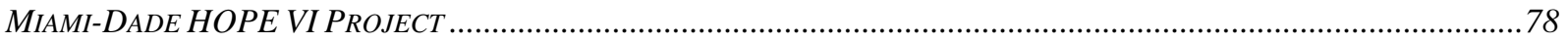

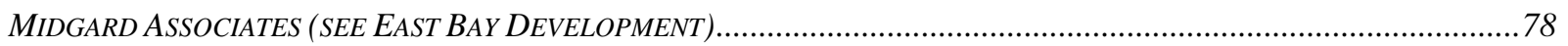

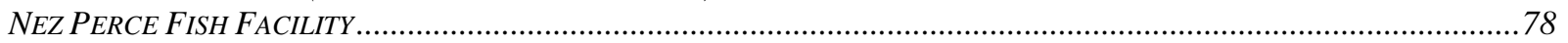

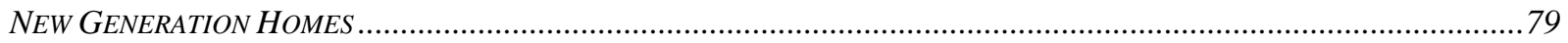

NORTHWEST ENERGY EFFICIENT MANUFACTURED HOUSING PROGRAM (NEEM) .................................................. 79

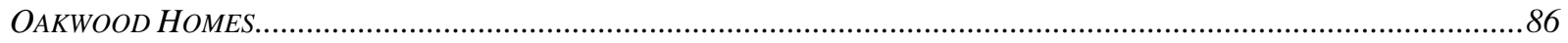

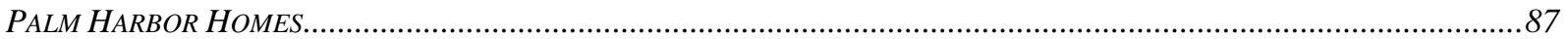

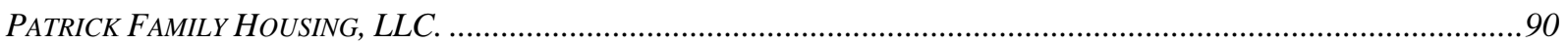

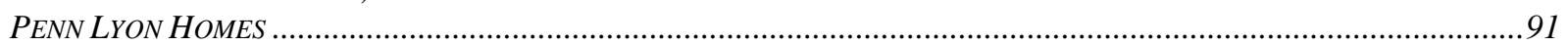

PODIA CONSTRUX/RAINBOW SPRINGS CONSTRUCTION ……...........................................................................

ROYAL CONCRETE CONCEPTS ..........................................................................................................92

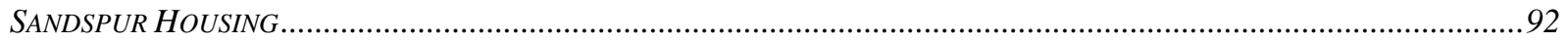

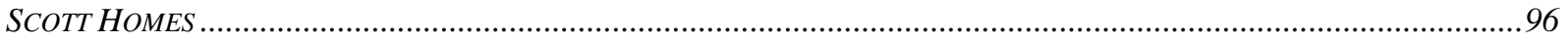

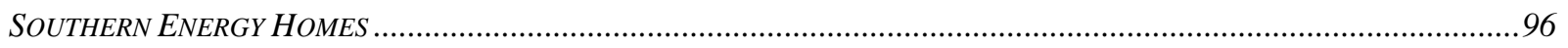

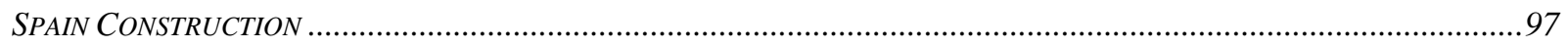

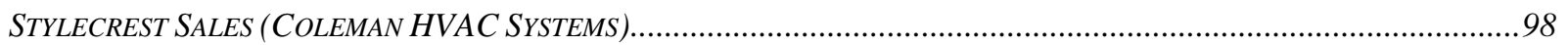

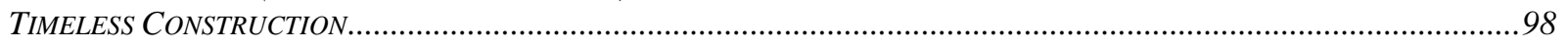

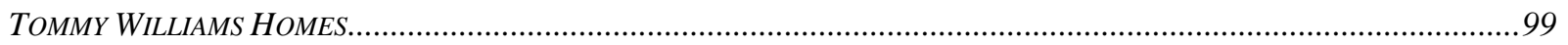

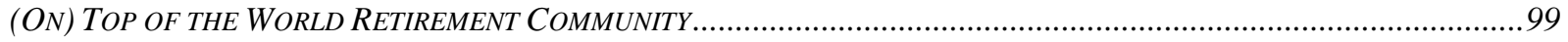

TRINITY CONSTRUCTION CORPORATION ………………….........................................................................100

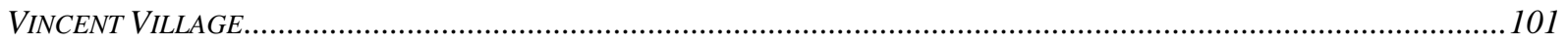

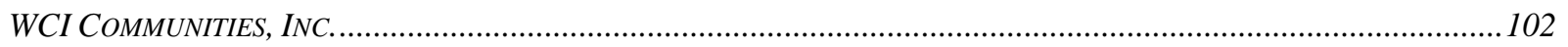

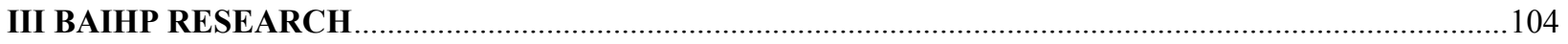

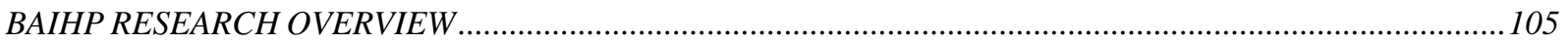

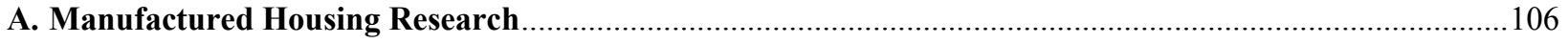

BUILDING SCIENCE AND MoISTURE PROBLEMS IN MANUFACTURED HOUSING - BACKGROUND .................................107

BAIHP FIELD VISITS TO PROBLEM MANUFACTURED HOMES ...............................................................................109

MANUFACTURERS PARTICIPATING IN BUILDING SCIENCE RESEARCH (INCLUDING ACTIVITY WITH INDIVIDUAL

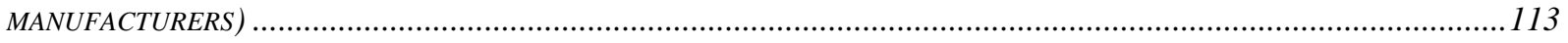

SIDE BY SIDE STUDY OF ENERGY USE AND MOISTURE CONTROL COMPARING STANDARD SPLIT SYSTEM AIR
CONDITIONING AND A COLEMAN® PROTOTYPE HEAT PUMP, BOSSIER CITY, LA...................................................117

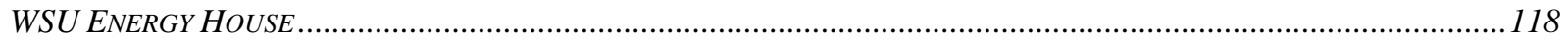

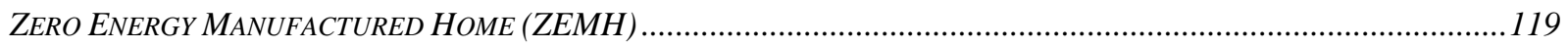

MANUFACTURED HOUSING INDOOR AIR QUALITY STUDY.............................................................................122

MANUFACTURED HOUSING LABORATORY - VENTILATION STUDIES....................................................................128

SIDE BY SIDE MANUFACTURED HOUSING ENERGY USE STUDY, NORTH CAROLINA A\&T .........................................133

PORTABLE CLASSROOMS .............................................................................................................................1

DUCT TESTING DATA FROM MANUFACTURED HOUSING FACTORY VISITS ............................................................... 143

CRAWL SPACE MOISTURE RESEARCH FOR HUD CODE HOMES .........................................................................145

RECOMMENDATIONS FOR FEMA RUGGEDIZED MANUFACTURED HOME FOR TEMPORARY HOUSING ........................148

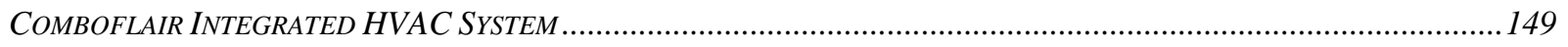

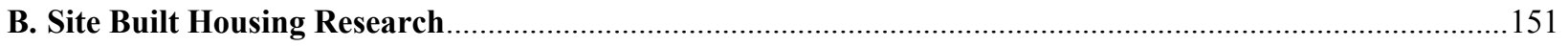

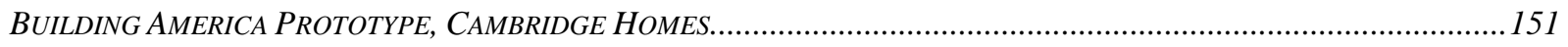

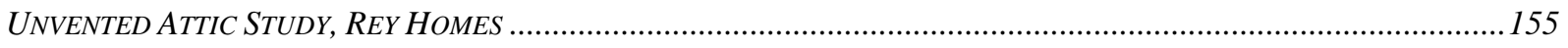

SHARPLESS CONSTRUCTION, HOAK RESIDENCE ENERGY AND MOISTURE STUDIES ..................................................156

ZERO ENERGY AFFORDABLE HOUSING, ORNL AND LOUDON COUNTY HABITAT FOR HUMANITY................................159

APARTMENT VENTILATION AND HUMIDITY STUDY WITH SANDSPUR HOUSING ………............................................160

FEDERATION OF AMERICAN SCIENTISTS’ RASBACH PROVIDENT HOME ……………..................................................162 


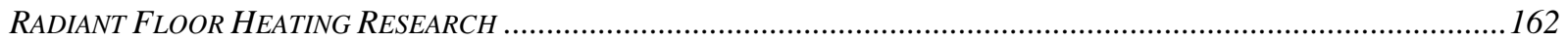

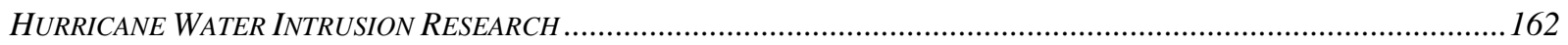

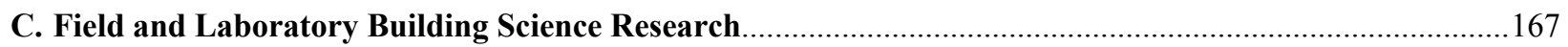

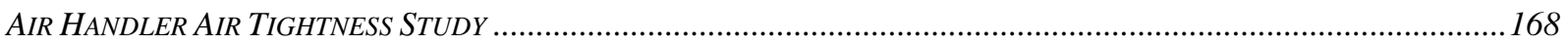

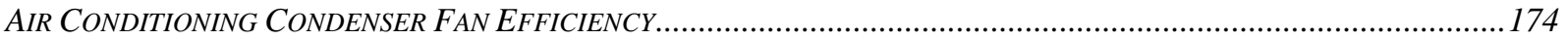

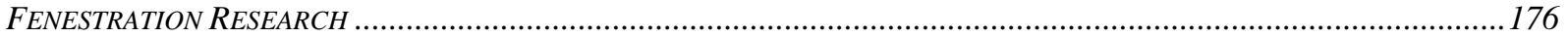

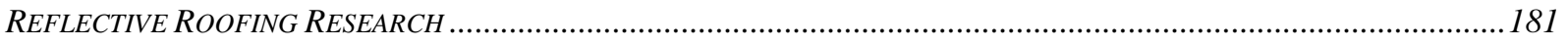

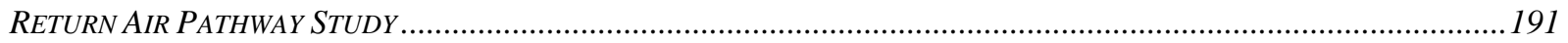

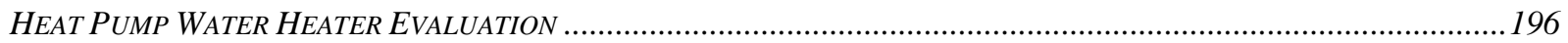

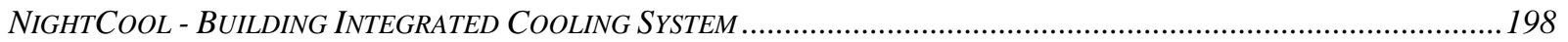

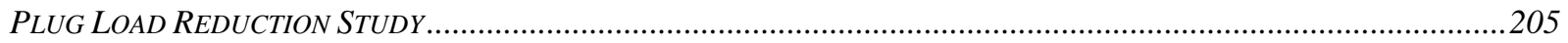

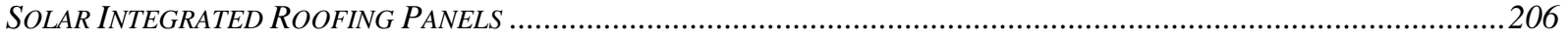

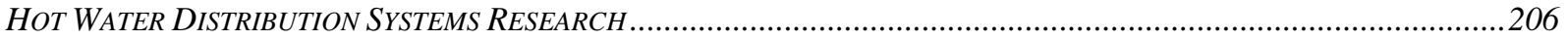

BUILDING AMERICA BENCHMARK TOOLKIT FOR PROGRAMMERS .......................................................................206

COMPARISON OF CURRENT BUILDING ENERGY ANALYSIS STANDARDS FOR BUILDING AMERICA, HOME ENERGY RATINGS AND THE 2006 INTERNATIONAL ENERGY CONSERVATION CODE ....................................................................207

COOLING PERFORMANCE ASSESSMENT OF BUILDING AMERICA HomeS............................................................211

IV BAIHP WEB PAGE, TRAINING PRESENTATIONS, and PUBLICATIONS ...............................215

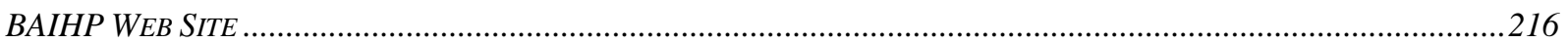

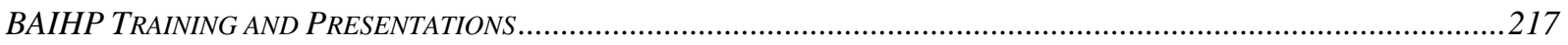

BAIHP PUBLICATIONS LIST - ALL BUDGET PERIODS (09/99-06/06)...............................................................230

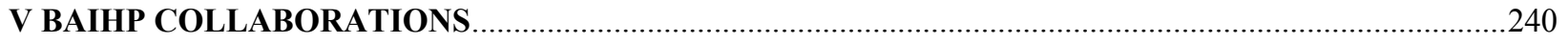

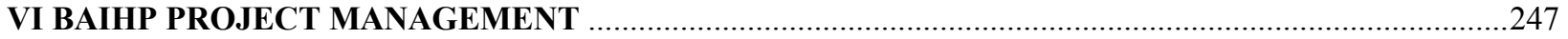




\section{ACKNOWLEDGMENT}

This work is sponsored, in large part, by the US Department of Energy (DOE), Office of Energy Efficiency and Renewable Energy, Building Technologies Program under cooperative agreement number DE-FC26--99GO10478. This support does not constitute an endorsement by DOE of the views expressed in this report. Additional funding was provided by the Florida Department of Community Affairs and the Northwest Energy Efficiency Alliance. Their support is appreciated.

The authors appreciate the encouragement and support from George James, Ed Pollock, and Chris Early, program personnel at DOE, Keith Bennett, project officer in Golden, Colorado and Bill Haslebacher, project officer at the National Energy Technology Laboratory. We also are grateful to our colleagues Philip Fairey, and Safvat Kalaghchy for advice and assistance. Thanks to project staff (Bob Abernethy, Mable Flumm, Wanda Dutton, Rafik Alidina and Joy Mayne) and students (Matt Lombardi, Mike McCloud, Matt McCloud, Josh Newland, and Jamie Cummings) for their contributions.

This work could not have been completed without the active cooperation of our industry partners and all collaborators. We greatly appreciate their support.

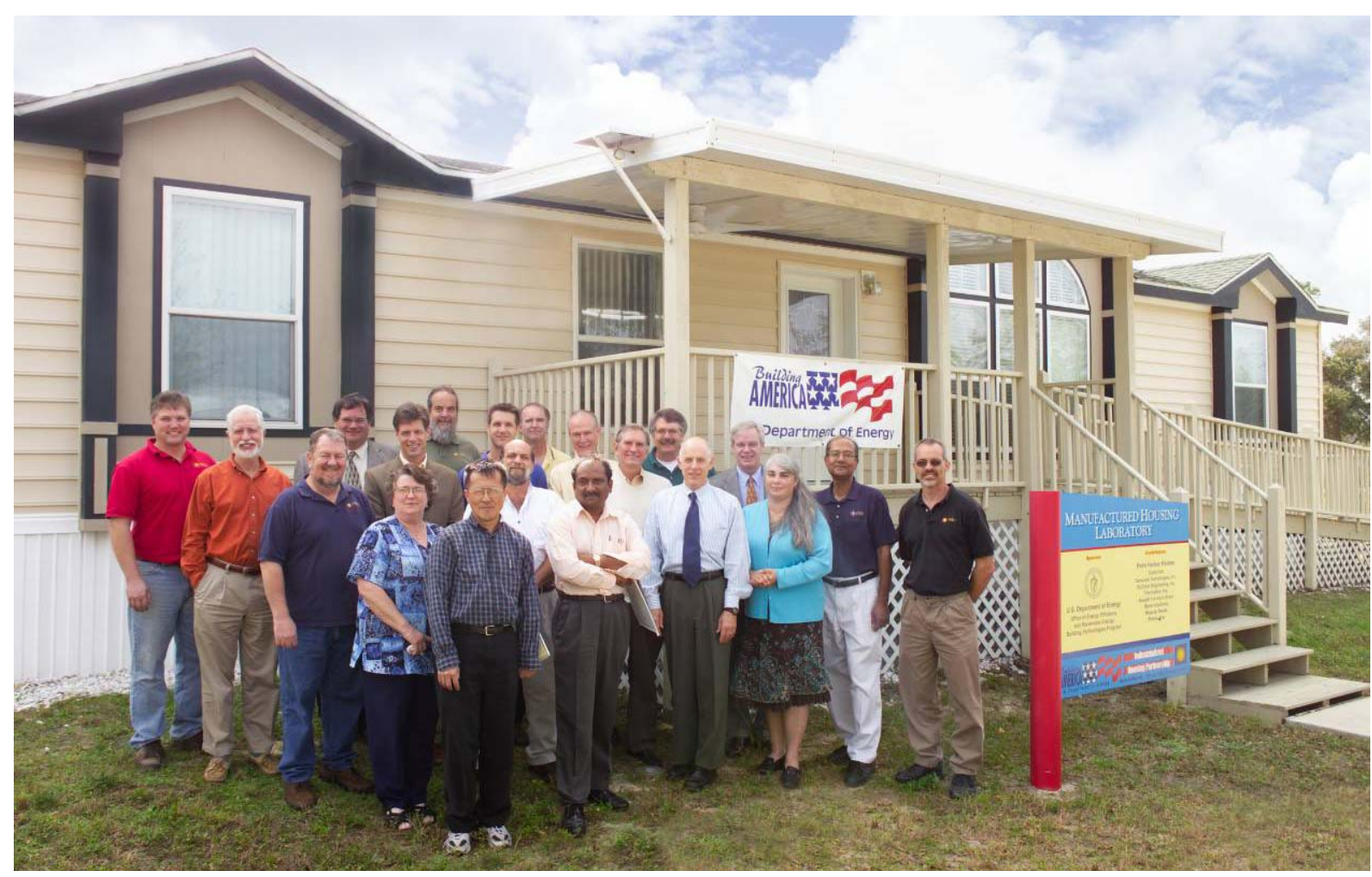

BAIHP Project Team in front of the Manufactured Housing Lab at FSEC. Left to right, back row: Stephen Barkaszi, Steve Baden, David Beal, David Hoak. Next row: Danny Parker, Rob Vieira, Eric Martin, Mike Mullens, Neil Moyer. Next row: Bob Abernethy, Ken Fonorow, Charlie Cromer, Philip Fairy. Front row: Wanda Dutton, Lixing Gu, Muthusamy Swami, David Rodgers (Acting Deputy Assistant Secretary, EERE, DOE), Janet McIlvaine, Subrato Chandra, and Dave Chasar. 


\title{
EXECUTIVE SUMMARY
}

\author{
Project Final Report for Contract DE-FC26-99GO10478
}

\section{Scope of this Report}

This report aims to summarize the work performed during the entire project period of 9/1/1999 through 6/30/06 for a comprehensive account of the Building America Industrialized Housing Partnership (BAIHP) project. It describes in greater detail, the work performed during the last year of the contract, $4 / 1 / 05$ through $6 / 30 / 06$, as efforts prior to $4 / 1 / 05$ are comprehensively documented in previous project annual reports. For the previous three annual reports, see:

- http://www.baihp.org/pubs/year6/index.htm

- http://www.baihp.org/pubs/year5/index.htm, and

- http://www.baihp.org/pubs/year4/index.htm

\section{BAIHP Team}

The BAIHP team is the only university based Building America team competitively funded by the US Department of Energy, Office of Energy Efficiency and Renewable Energy-Building Technologies program. BAIHP began work on September 1, 1999 with a focus on improving energy efficiency, durability, and indoor air quality of new industrialized housing.

The BAIHP team is comprised of:

- Florida Solar Energy Center (Lead)

- Washington State University Energy Program (WSU)

- University of Central Florida Industrial Engineering (UCFIE)

- Florida Home and Energy Resources Organization (FL H.E.R.O.)

- Calcs-Plus

In addition the American Lung Association, North Carolina A\&T University, D.R.Wastchak, Oregon Dept. of Energy, Idaho Dept of Water Resources and the Blue Sky Foundation were subcontractors in prior years. The Florida Energy Office and the NorthWest Energy Efficiency Alliance provided cost share funding in the early years of the project. The project website is www.baihp.org.

\section{Background}

Industrialized housing includes manufactured housing (built to the HUD code), modular housing (factory built housing modules assembled on site), panelized/kit housing (factory built subassemblies put together on site) production housing (site built housing produced in a systematic manner). Figure E-1 shows 2005 U.S. home production by sector. BAIHP work includes

- Technical Assistance

- $\quad$ Field and Laboratory Research

- Training and Education

- Collaborations

- Project Management 


\section{Housing Starts and Placement}

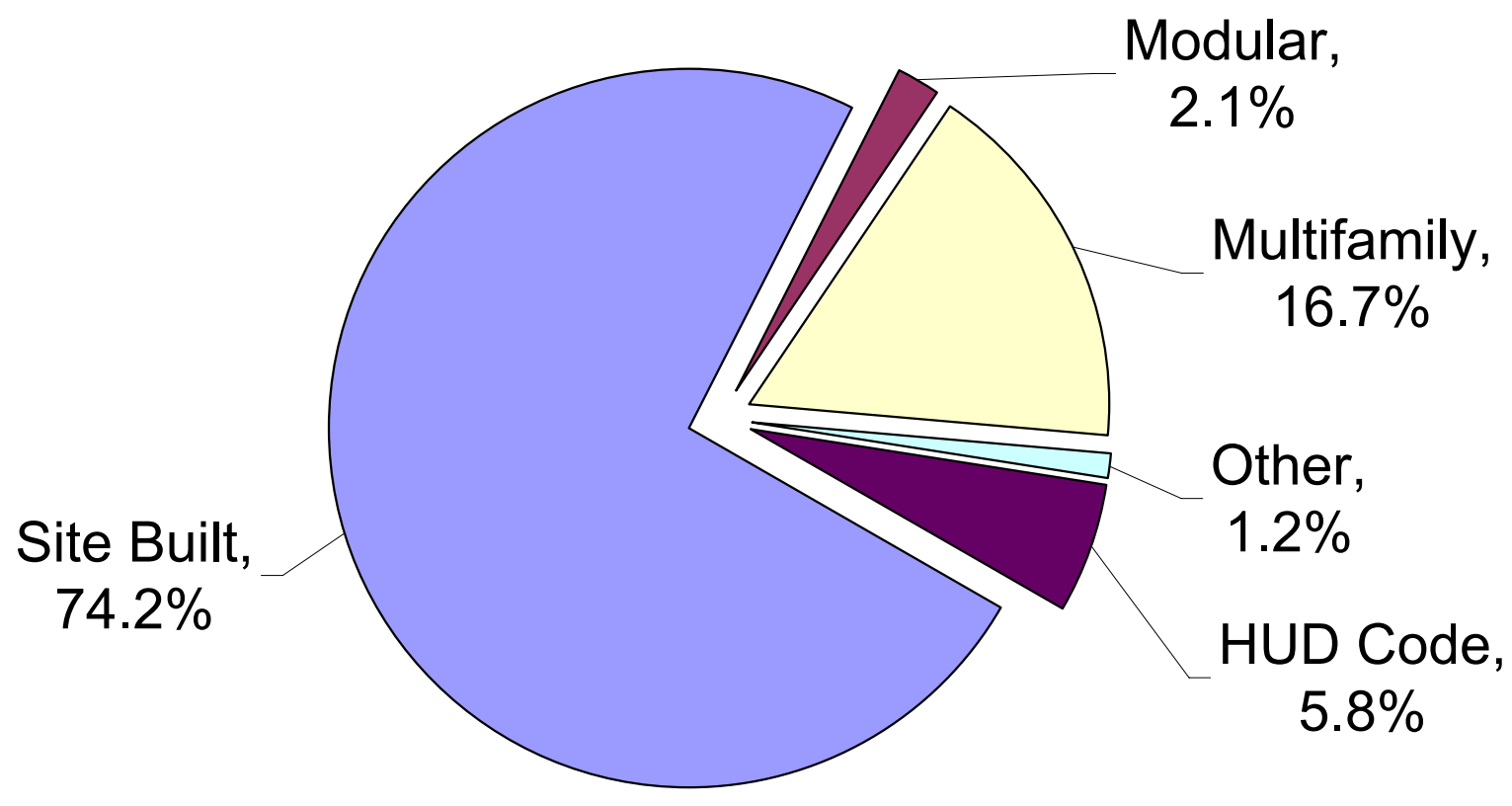

Figure E-1 2005 Census data shows 2.0683 million housing starts (site built) and placements (manufactured)

Note: Total exceeds $100 \%$ because of disagreement among sources on total starts Sources of Housing Starts Statistics:Multi-Family: http://www.census.gov/const/startsan.pdf Site Built and Modular: http://www.census.gov/const/C25Ann/sftotalconstmethod.pdf

Manufactured Housing Placement: http://www.census.gov/const/mhs/mhstabplcmnt.pdf

\section{BAIHP Technical Assistance}

The BAIHP team provided technical assistance to a wide variety of home manufacturers, builders, developers, and industry suppliers including Habitat for Humanity International and its affiliates throughout the nation. Site builders receiving technical assistance are located primarily North and Central Florida.

BAIHP also collaborates with suppliers and non-profit organizations See Table E-1 for a list of BAIHP Industry Partners. Industry Partners list is kept updated at http://www.baihp.org/partners/index.htm

Systems engineering forms the core of the Building America approach. BAIHP industry partners evaluate the integration of their construction standards and consider improvements that enhance energy efficiency, durability, indoor air quality, and health. 
In providing technical assistance BAIHP generally recommends improving equipment efficiency and reducing conditioning loads while taking durability and health issues into consideration.

Some examples include:

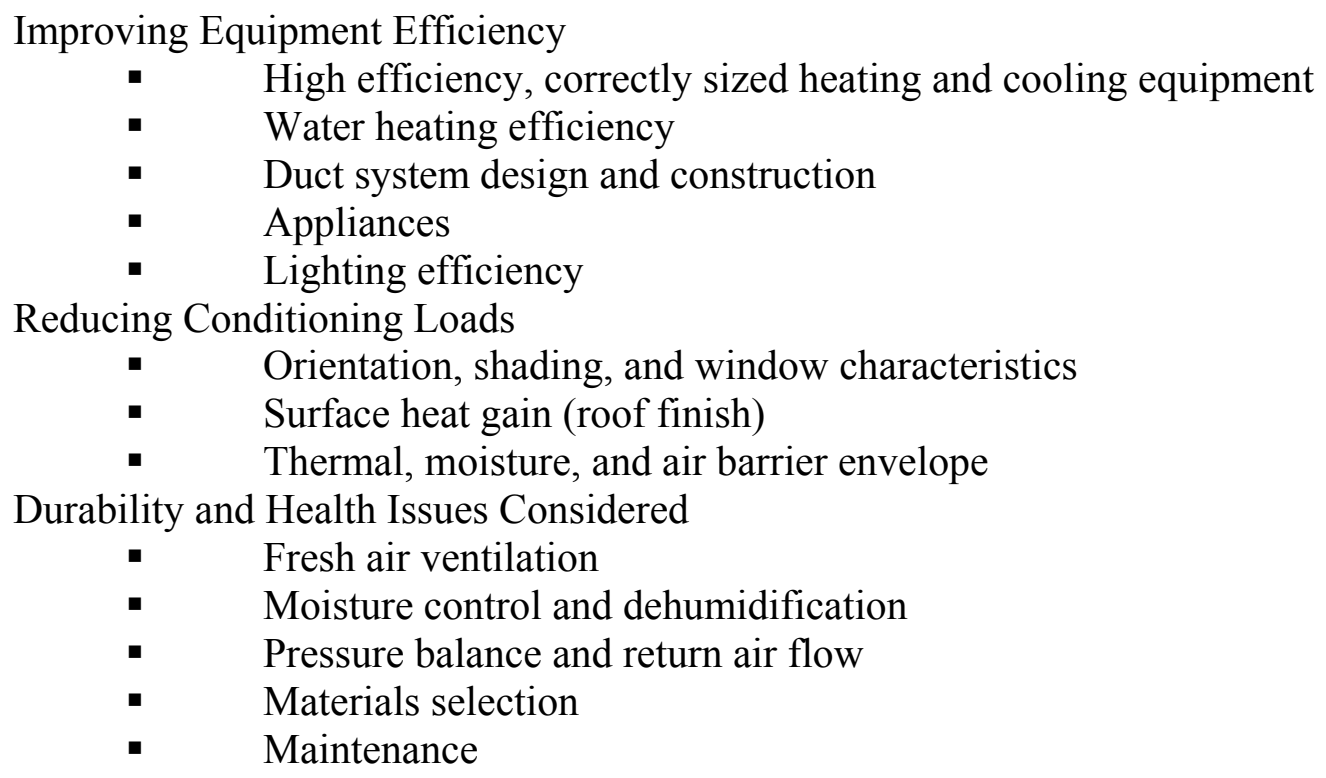

It is the combination of these improvements that enables the BAIHP industry partners to achieve high performance homes like those documented in Table E-2, Homes Built in Partnership with BAIHP.

BAIHP tracks Industry Partners production in 4 categories:

- Category A: Homes meeting the Building America program goal of saving at least $30 \%$ of whole house energy use compared to the 2005 Building America benchmark, incorporating fresh air ventilation, and including superior durability and health features. HERS '99 Score results are greater than 88.6.

- $\quad$ Category B: Homes meeting the EPA Energy Star criteria for saving 30\% of heating, cooling, and water heating energy use.

- Category C: Homes with energy efficiency improvements falling slightly short of the EPA Energy Star criteria for saving 30\% of heating, cooling, and water heating energy use. HERS '99 score of approximately 85. Also homes designed and built to this level or higher but not specifically rated and tested by BAIHP. - $\quad$ Category D: Manufactured homes built with substantially leak free ducts ( $\mathrm{Qn}_{\mathrm{OUT}}$ $\leq 0.03$ ). This category may include some Category $\mathrm{B}$ and $\mathrm{C}$ homes.

Since inception, BAIHP has assisted home builders and manufacturers to construct:

- 20,445 homes built to Energy Star level or better (Category A and B, Table E-2)

- 14,991 homes built $30 \%$ to $50 \%$ better than the HUD code - approx 5\% below Energy Star (Category C, Table E-2)

- $\quad 98,250$ manufactured homes with airtight duct systems (Category D, Table E-2)

These homes are estimated to save over $\$ 17$ million annually in reduced energy bills for their owners. 
Table 1 BAIHP Industry Partners (Present and Past)

\begin{tabular}{|c|c|}
\hline \multicolumn{2}{|c|}{ HUD Code Home Manufacturers } \\
\hline Cavalier Homes & Homes of Merit \\
\hline CAVCO Industries LLC & Karsten Company \\
\hline Champion Homes (Redman) & Kit Manufacturing \\
\hline Champion Homes (Silvercrest) & Liberty Homes \\
\hline Clayton Homes & Marlette Homes \\
\hline Fleetwood Homes & Nashua Homes \\
\hline Fuqua Homes & Oakwood Homes \\
\hline Golden West Homes & Palm Harbor Homes \\
\hline Guerdon Enterprises & Skyline Corporation \\
\hline Hi-Tech Homes & Southern Energy Homes \\
\hline Homark Homes & Valley Manufactured Housing \\
\hline Homebuilders North West & Western Homes \\
\hline \multicolumn{2}{|c|}{ Modular and Panelized Builders } \\
\hline Avis America Homes & Genesis Homes \\
\hline Cardinal Homes & Nationwide Homes \\
\hline Discovery Homes & Penn Lyon Homes \\
\hline DuKane Precast Inc. & Royal Concrete Concepts \\
\hline Epoch Corporation & The Homestore \\
\hline Excel Homes & Trinity Construction Corp. \\
\hline General Homes & \\
\hline \multicolumn{2}{|c|}{ Production Builders } \\
\hline All America Homes & GMD Construction Co. \\
\hline American Energy Efficient Homes \& & G.W. Robinson Builder \\
\hline Investments Inc. & New Generation Homes by Kingon Inc. \\
\hline AMJ Construction & On Top of the World \\
\hline Arvida Homes & Patrick Family Housing, LLC \\
\hline Atlantic Design and Construction & Podia Construx \\
\hline Bobek Building Systems, Inc & Regents Park (Condominiums) \\
\hline Cambridge Homes & Rey Homes \\
\hline Centex Homes & Tommy Williams Homes \\
\hline Dye Company & WCI Communities \\
\hline DR Horton & Winton/Flair Homes \\
\hline \multicolumn{2}{|c|}{ Affordable Housing Builders } \\
\hline East Dakota Housing Alliance & Homes in Partnership \\
\hline City of Gainesville, FL & HKW Enterprises \\
\hline City of Lubbock, TX & Miami-Dade Hope VI Project \\
\hline City of Orlando, FL & Sandspur Housing (Apartment builders) \\
\hline Habitat for Humanity International & Williamsburg (townhouses) \\
\hline
\end{tabular}




\begin{tabular}{|ll|}
\hline \multicolumn{2}{|c|}{ Custom Builders } \\
\hline All America Homes of Gainesville, Inc. & New Generation Homes by Kingon Inc. \\
Energy Structures \& Systems, Inc. & Pruett Builders, Inc. \\
Fallman Design and Construction & Scott Homes \\
L.F. Custom Homes & Spain Construction \\
Marquis Construction \& Development, Inc & Stitt Energy Systems \\
NatMax & Timeless Construction \\
\hline \multicolumn{2}{|c|}{ Developers } \\
\hline Castle \& Cooke & Kashi Church Foundation, Inc. \\
East Bay Development Company of FL & \\
LLC (Formerly Midgard Associates) & \\
\hline \multicolumn{2}{|c|}{ Research, Education, and Industry Association Partners } \\
\hline Auburn University School of Architecture & Northwest Energy Efficient Manufactured \\
Building Science Consortium & Housing Program (NEEM) \\
Florida Green Building Coalition & Pacific Northwest National Laboratory \\
Florida International University, 2005 Solar & Portland Cement Association \\
Decathlon Team & RADCO, Inc \\
Florida Solar Energy Research and & RESNET \\
Education Foundation & Structural Insulated Panel Association \\
IBACOS, New American Home (Goehring & Stevens Associates (Home Ventilation \\
Morgan Construction) & Institute) \\
Not-So-Big-House, (Sarah Susanka, AIA) & Washington Manufactured Housing Assoc \\
\hline \multicolumn{2}{|c|}{ Industry Suppliers } \\
\hline Allsolar Service Company Inc. & Hard Cast \\
Basement Systems, Inc. & Heat Pipe Technology \\
Bellview Air & Honeywell \\
Beam Industries & Icynene Inc. \\
Classic Products & LaSalle Air Systems \\
Energy Conservatory & Minority Development Resource Group \\
Flexible Technologies & SSHC Inc. \\
GreenStone Industries & Style Crest Products \\
& Tamarack Technologies, Inc \\
\hline
\end{tabular}


Table E-2 Homes Built in Partnership with BAIHP (through 06/06)

\begin{tabular}{|c|c|c|c|c|c|}
\hline \multicolumn{6}{|l|}{ List of BAIHP homes as of $6 / 30 / 06$} \\
\hline \multicolumn{6}{|c|}{ A) Homes with HERS scores $>=88.6$ (counts as 89 in NREL database) } \\
\hline $\begin{array}{l}\text { Homes assisted by FL HERO } \\
\text { (Bldrs- Atlantic Design, GW Robinson, Tommy } \\
\text { Williams }+\sim 12 \text { others) }\end{array}$ & 341 & \multicolumn{4}{|c|}{$(10 / 02-6 / 06)$} \\
\hline Fallman design and construction & 2 & \multicolumn{4}{|c|}{$(09 / 01-08 / 03)$} \\
\hline Palm Harbor Homes & 5 & \multicolumn{4}{|c|}{$\begin{array}{c}\text { (Aug 04- Jan } \\
06)\end{array}$} \\
\hline Marquis Construction & 1 & \multicolumn{4}{|c|}{ "Feb 06} \\
\hline WCI & 2 & \multicolumn{4}{|c|}{ "Aug 04} \\
\hline Applegren Construction (East Dakota Housing Alliance) & 10 & \multicolumn{4}{|c|}{ "March 05} \\
\hline Habitat for Humanity, Lakeland, FL & 6 & \multicolumn{4}{|c|}{ "4/06 } \\
\hline Category A Total & 367 & & & & \\
\hline B) Homes with HERS scores of approx 86 or more & \multicolumn{5}{|c|}{ (Includes Category A homes for now) } \\
\hline SGC/NC West of the Cascades+Natural Choice & 15,258 & \multicolumn{4}{|c|}{$(09 / 99-6 / 06)$} \\
\hline Homes by FL HERO & 1592 & \multicolumn{4}{|c|}{$(\sim 01 / 00-6 / 06)$} \\
\hline Ft.Lewis modular & 86 & \multicolumn{4}{|c|}{ "06/06 } \\
\hline Palm Harbor Homes & 18 & \multicolumn{4}{|c|}{$(\sim 01 / 00-01 / 06)$} \\
\hline Habitat for Humanity & 446 & \multicolumn{4}{|c|}{$(1998-2 / 06)$} \\
\hline Homes by D.R.Wastchak in Phoenix, AZ & 2,658 & \multicolumn{4}{|c|}{$(\sim 01 / 00-10 / 02)$} \\
\hline Marquis Construction & 4 & \multicolumn{4}{|c|}{ "Feb 06} \\
\hline Applegren Construction (East Dakota Housing Alliance) & 13 & \multicolumn{4}{|c|}{ "March 05} \\
\hline New Generation by Kingon & 1 & \multicolumn{4}{|c|}{ "Apr 05} \\
\hline Cambridge Homes & 2 & \multicolumn{4}{|c|}{ "Dec 03} \\
\hline Category B Total & 20,078 & & & & \\
\hline \multicolumn{6}{|c|}{ C) Homes just below Energy Star (HERS approx 85, homes not rated) } \\
\hline Old Natural Choice (thru 11/01) + SGC east of the Cascades & 13,086 & \multicolumn{4}{|c|}{$(09 / 99-6 / 06)$} \\
\hline Energy Efficient Div of PHH in North Carolina & 1,645 & \multicolumn{4}{|c|}{$(09 / 99-02 / 01)$} \\
\hline Habitat Homes (approx.) & 260 & \multicolumn{4}{|c|}{$(1995-2001)$} \\
\hline \multirow[b]{2}{*}{ D) Homes with just airtight ducts } & 14,991 & & & & \\
\hline & (May in & lude som & Category B anc & Chome & \\
\hline & Total & $\begin{array}{r}2000- \\
02 \\
\end{array}$ & 2003 & 2004 & 2005 \\
\hline Palm Harbor Homes & 52,561 & 32,000 & 6,871 & 6,897 & 6,793 \\
\hline Cavalier & 1,132 & 1,132 & 0 & 0 & 0 \\
\hline Southern Energy & 26,231 & 12,803 & 4,000 & 4,328 & 5,100 \\
\hline Fleetwood & 18,327 & 500 & 1,280 & 9,482 & 7,065 \\
\hline Category D Total & 98,251 & & & & \\
\hline Total number of Homes & 133,320 & & & & \\
\hline Number of HUD code homes & 128,258 & & & & \\
\hline Number of Site built (incl modular) homes & 5,062 & & & & \\
\hline Approximate Energy Savings (mBtu/yr) & $1,248,295$ & & & & \\
\hline Approx. \$/yr savings@\$14./mBtu & $\$ 17,476,129$ & & & & \\
\hline
\end{tabular}




\section{BAIHP Research}

BAIHP's ongoing research strives to identify the strategies and technologies that will enable Industry Partners to reach the Department of Energy's 2010 goals for energy savings. By systematically evaluating the savings potential technologies and construction techniques, research provides the home building industry with vital information needed to meet this challenge. BAIHP Research presented here is grouped into three categories: Manufactured Housing Research, Site Built Housing Research, and Field and Laboratory Building Science Research.

\section{Manufactured Housing Research}

BAIHP has found that using the systems engineering approach to help Industry Partners solve building science related problems develops a strong working relationship and increases the likelihood of the Partner incorporating concepts central to achieving Building America goals such as sealed and tested ducts, right sizing air conditioning, and moisture management. BAIHP's work with the manufactured housing industry illustrates this principal.

BAIHP conducted research for manufactured homes in both field and laboratory which is reported in the following summaries in the main body of the report:

- Building Science and Moisture Problems in Manufactured Housing - Background

- $\quad$ BAIHP Field Visits to Moisture Problem Homes

- Manufacturers Participating in Building Science Research

- $\quad$ Side By Side Study Of Energy Use And Moisture Control Comparing Standard Split System Air Conditioning And A Coleman ${ }^{\circledR}$ Prototype Heat Pump, Bossier City, LA

- WSU Energy House

- $\quad$ Zero Energy Manufactured Home (ZEMH)

- Manufactured Housing Indoor Air Quality Study

- Manufactured Housing Laboratory - Ventilation Studies

- Side by Side Manufactured Housing Energy Use Study, North Carolina A\&T

- $\quad$ Portable Classrooms

- Duct Testing Data from Manufactured Housing Factory Visits

- Crawl Space Moisture Research for HUD Code Homes

- Recommendations for FEMA Ruggedized Manufactured Home for Temporary Housing

- $\quad$ Comboflair Integrated HVAC System

Site Built Housing Research

Industry Partners rise above "business as usual" production to strive toward the Building America program goals of saving $40 \%$ of total energy use while improving durability, indoor air quality, and comfort. BAIHP assists the builders, much as described in Section II, Technical Assistance, but goes on to instrument and collect relevant data to validate the approach.

BAIHP conducted research for site built housing which is reported in the following summaries:

- $\quad$ Building America Prototype, Cambridge Homes

- Unvented Attic Study, Rey Homes

- Sharpless Construction, Hoak Residence Energy and Moisture Studies 
- Zero Energy Affordable Housing, ORNL and Loudon County Habitat for Humanity

- $\quad$ Apartment Ventilation and Humidity Study with Sandspur Housing

- $\quad$ Federation of American Scientists' Rasbach Provident Home

- Radiant Floor Heating Research

- Hurricane Water Intrusion Research

- Hurricane Retrofit Research

Field and Laboratory Building Science Research

BAIHP builds on a 20 year foundation of basic building science research at the Florida Solar Energy Center. This research generally focuses on issues important in hot-humid climates similar to Florida's but is relevant to our understanding of building science concepts manifest in all climatic regions. BAIHP has conducted field and laboratory building science research in these areas:
- $\quad$ Air Handler Air Tightness Study
- $\quad$ Air Conditioning Condenser Fan Efficiency
- Fenestration Research
- Reflective Roofing Research
- Return Air Pathway Study
- Heat Pump Water Heater Evaluation
- $\quad$ NightCool - Building Integrated Cooling System
- $\quad$ Plug Load Reduction Study
- $\quad$ Solar Integrated Roofing Panels
- Hot Water Distribution Systems Research
- $\quad$ Building America Benchmark Toolkit for Programmers
- Comparison of Current Building Energy Analysis Standards for Building America, Home Energy Ratings and the 2006 International Energy Conservation Code
- Cooling Performance Assessment of Building America Homes

\section{BAIHP Training and Education Summary}

BAIHP research is communicated to public and industry audiences through the BAIHP web page, conference papers and presentations, and various media coverage. Training events are listed in reverse chronological order.

BAIHP has presented research findings and Building America systems engineering concepts to a variety of audiences including architects, builders, HUD Code home manufacturers, and housing decision makers; construction trades and realtors; attendees at building science conferences; portable classroom producers and decision makers; energy raters and green home certifiers, and college students in academic venues.

The BAIHP web page offers access to any interested parties with presentation of case studies, research, publications, and partnership summaries with links to our partners' web pages, BAIHP monitored data pages, and BAIHP case studies. 


\section{BAIHP Collaboration}

BAIHP researchers collaborate with a variety of entities in the homebuilding industry and the energy efficiency and research realm including DOE National Labs, Code and Standards Bodies, and Industry/Professional Organizations, Universities, and Product Suppliers. BAIHP research has provided data to update the NFPA codes that serve as the basis for the HUD code

\section{BAIHP Project Management}

BAIHP project management includes participating in Building America program

reviews/meetings and preparing monthly and yearly reports for project activities as well as managing all project tasks (see Sections 1-6) and subcontracts. In the $5^{\text {th }}$ Budget Period, BAIHP also held a Project Review Meeting at FSEC in January 2004 to give interested parties an opportunity to give feedback to the project management team. BAIHP participated in DOE's Peer Review process in June of 2006. BAIHP Peer Review submittals for technical systems are available online at. http://www.baihp.org/pubs/doe_review/index.htm

\section{Project Contact}

Subrato Chandra, BAIHP Project Director

Florida Solar Energy Center

1679 Clearlake Road

Cocoa, FL 32922

321-638-1412 www.baihp.org

www.fsec.ucf.edu

subrato@fsec.ucf.edu 


\section{I BAIHP INTRODUCTION}




\section{BAIHP INTRODUCTION}

The Building America Industrialized Housing Partnership (BAIHP) team is the only university based Building America team competitively funded by the US Department of Energy, Office of Energy Efficiency and Renewable Energy-Building Technologies program.

\section{BAIHP History}

BAIHP began work on September 1, 1999 with a focus on improving energy efficiency, durability, and indoor air quality of new industrialized housing. DOE funding for the project has been supplemented by cost share funding from the Florida Energy Office (now defunct) of the Florida Department of Environmental Protection, the Northwest Energy Efficiency Alliance (NEEA), Florida Solar Energy Center (FSEC), and many Industry Partners. FSEC, a research institute of the University of Central Florida (UCF), serves as the project prime contractor.

\section{Scope of this Report}

This report aims to summarize the work performed during the entire project period of 9/1/1999 through 6/30/06 for a comprehensive account of the Building America Industrialized Housing Partnership (BAIHP) project. It describes in greater detail, the work performed during the last year of the contract, $4 / 1 / 05$ through $6 / 30 / 06$, as efforts prior to $4 / 1 / 05$ are comprehensively documented in previous project annual reports. For the previous three annual reports, see:

- http://www.baihp.org/pubs/year6/index.htm

- http://www.baihp.org/pubs/year5/index.htm, and

- http://www.baihp.org/pubs/year4/index.htm

\section{BAIHP's Goals}

1. Cost effectively reduce the energy cost of industrialized housing and portable classrooms by up to $50 \%$ while enhancing indoor air quality, durability and productivity.

2. Assist in the construction of thousands of energy efficient industrialized houses annually.

3. Make our partners pleased and proud to be working with us.

\section{BAIHP Team}

The BAIHP team is the only university based Building America team competitively funded by the US Department of Energy, Office of Energy Efficiency and Renewable Energy-Building Technologies program. BAIHP began work on September 1, 1999 with a focus on improving energy efficiency, durability, and indoor air quality of new industrialized housing.

The BAIHP team is comprised of:

- Florida Solar Energy Center (Lead)

- Washington State University Energy Program (WSU)

- University of Central Florida Industrial Engineering (UCFIE)

- Florida Home and Energy Resources Organization (FL H.E.R.O.)

- Calcs-Plus

In addition the American Lung Association, North Carolina A\&T University, D.R.Wastchak, Oregon Dept. of Energy, Idaho Dept and the Blue Sky Foundation were subcontractors in prior 


\section{Housing Starts and Placement}

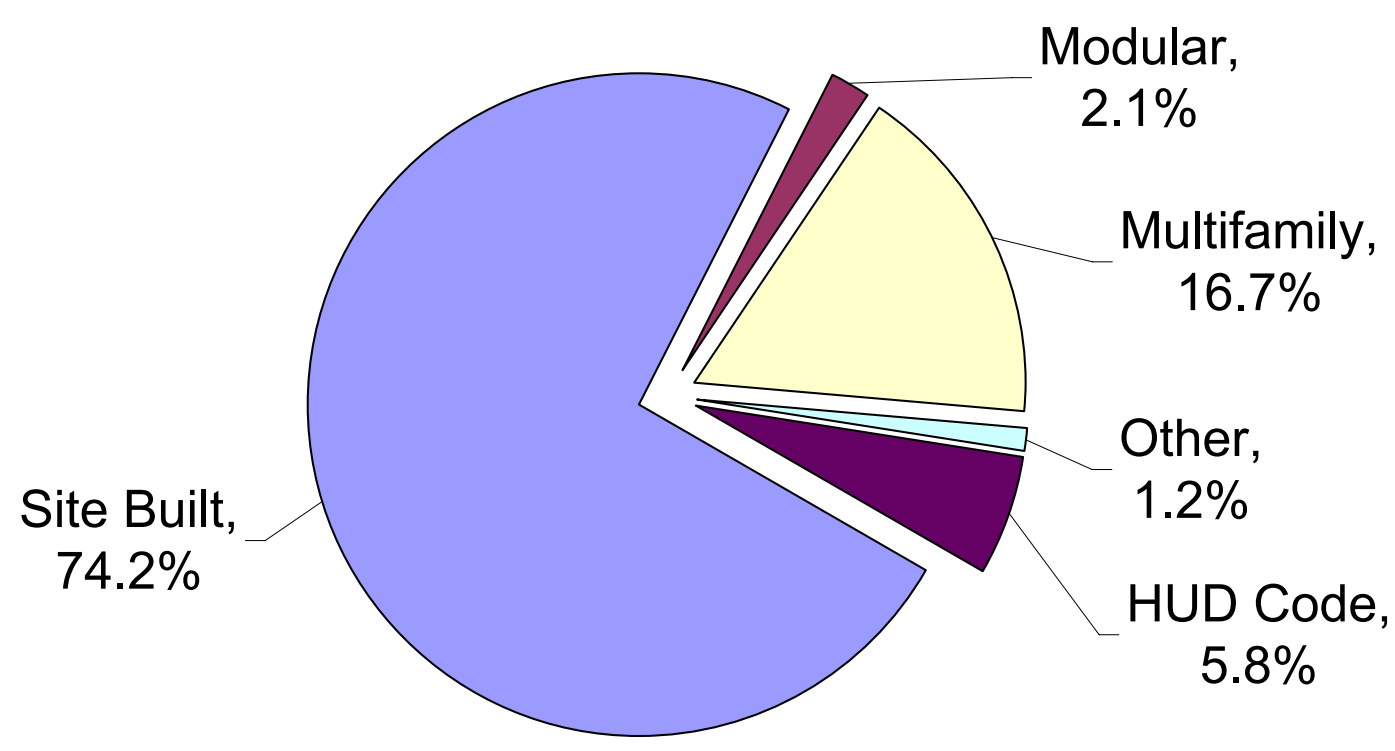

Figure E-1 2005 Census data shows 2.0683 million housing starts (site built) and placements (manufactured)

Note: Total exceeds $100 \%$ because of disagreement among sources on total starts Sources of Housing Starts Statistics:Multi-Family: http://www.census.gov/const/startsan.pdf Site Built and Modular: http://www.census.gov/const/C25Ann/sftotalconstmethod.pdf Manufactured Housing Placement: http://www.census.gov/const/mhs/mhstabplcmnt.pdf

years. The Florida Energy Office and the NorthWest Energy Efficiency Alliance provided cost share funding in the early years of the project.

What is industrialized Housing?

Industrialized housing encompasses much of modern American construction including:

- Manufactured Housing - factory-built to the nation wide HUD Code

- Modular Housing - factory-built, site assembled modules meeting local code

- Panelized/kit Housing - factory produced sub-assemblies put together on site to meet local codes

- $\quad$ Production Housing - site-built systematically, factory built components

The project scope has also included portable classrooms during 2000-2002.

Of the two million homes built in the US in 2005 (Figure 1), approximately 6\% were factory built to US Housing and Urban Development (HUD) code (U.S. Department of Commerce, 2003(a)(b) referred to as HUD Code Homes or Manufactured Homes. Manufactured Homes are one of the most affordable types of single-family detached housing available anywhere in the world, generally costing less than $\$ 35 / \mathrm{ft}^{2}$ plus land costs for centrally air conditioned and heated homes with built-in kitchens. Available in all parts of the country, manufactured homes are more popular in rural areas and in the southern and western US where land is still plentiful. Modular homes accounted for about $2 \%$ of 2005 housing starts. Many HUD Code home producers offer 
modular homes also which are built to local codes and take advantage of many factory production benefits.

Scope of BAIHP Activities

Within the larger context of the Building America program, BAIHP works to foster achievement of the Department of Energy's goals. BAIHP researchers work in these areas:

- Technical Assistance (Section I)

- $\quad$ Field and Laboratory Research (Section II)

- Training and Education (Section III)

- Collaborations with the Homebuilding and Energy Industries (Section IV)

- $\quad$ Project Management (Section V)

Industry Partnerships

BAIHP has partners in many stakeholder groups of the U.S. housing including HUD Code home manufacturers; modular, multifamily, and production site builders; product and material suppliers. Research organizations and other non-profits have worked with BAIHP to collaborate on field work, ventilation studies, ASHRAE committee work, and training. Partners receiving Technical Assistance for their projects are described Section II of this report. BAIHP Research efforts are described in Section III. Table 1 lists current and past BAIHP Project Industry Partners. The geographic distribution of our current partners is depicted on the map in Figure 2. Industry Partners list is kept updated at http://www.baihp.org/partners/index.htm

$\underline{\text { Project Contact }}$

Subrato Chandra, BAIHP Project Director

Florida Solar Energy Center

www.baihp.org

1679 Clearlake Road

Cocoa, FL 32922

www.fsec.ucf.edu

subrato@,fsec.ucf.edu

321-638-1412

Table 1 BAIHP Industry Partners (Present and Past)

\begin{tabular}{|ll|}
\hline \multicolumn{2}{|c|}{ HUD Code Home Manufacturers } \\
\hline Cavalier Homes & Homes of Merit \\
CAVCO Industries LLC & Karsten Company \\
Champion Homes (Redman) & Kit Manufacturing \\
Champion Homes (Silvercrest) & Liberty Homes \\
Clayton Homes & Marlette Homes \\
Fleetwood Homes & Nashua Homes \\
Fuqua Homes & Oakwood Homes \\
Golden West Homes & Palm Harbor Homes \\
Guerdon Enterprises & Skyline Corporation \\
Hi-Tech Homes & Southern Energy Homes \\
Homark Homes & Valley Manufactured Housing \\
Homebuilders North West & Western Homes \\
\hline \multicolumn{2}{|c|}{ Modular and Panelized Builders } \\
\hline Avis America Homes & Genesis Homes
\end{tabular}




\begin{tabular}{|c|c|}
\hline Cardinal Homes & Nationwide Homes \\
\hline Discovery Homes & Penn Lyon Homes \\
\hline DuKane Precast Inc. & Royal Concrete Concepts \\
\hline Epoch Corporation & The Homestore \\
\hline Excel Homes & Trinity Construction Corp. \\
\hline General Homes & \\
\hline \multicolumn{2}{|c|}{ Production Builders } \\
\hline All America Homes & GMD Construction Co. \\
\hline American Energy Efficient Homes \& & G.W. Robinson Builder \\
\hline Investments Inc. & New Generation Homes by Kingon Inc. \\
\hline AMJ Construction & On Top of the World \\
\hline Arvida Homes & Patrick Family Housing, LLC \\
\hline Atlantic Design and Construction & Podia Construx \\
\hline Bobek Building Systems, Inc & Regents Park (Condominiums) \\
\hline Cambridge Homes & Rey Homes \\
\hline Centex Homes & Tommy Williams Homes \\
\hline Dye Company & WCI Communities \\
\hline DR Horton & Winton/Flair Homes \\
\hline \multicolumn{2}{|c|}{ Affordable Housing Builders } \\
\hline East Dakota Housing Alliance & Homes in Partnership \\
\hline City of Gainesville, FL & HKW Enterprises \\
\hline City of Lubbock, TX & Miami-Dade Hope VI Project \\
\hline City of Orlando, FL & Sandspur Housing (Apartment builders) \\
\hline Habitat for Humanity International & Williamsburg (townhouses) \\
\hline \multicolumn{2}{|c|}{ Custom Builders } \\
\hline $\begin{array}{l}\text { All America Homes of Gainesville, Inc. } \\
\text { Fnerov Structures \& Svstems }\end{array}$ & $\begin{array}{l}\text { New Generation Homes by Kingon Inc. } \\
\text { Pruett Builders Inc }\end{array}$ \\
\hline Fallman Design and Construction & Scott Homes \\
\hline L.F. Custom Homes & Spain Construction \\
\hline Marquis Construction \& Development, Inc & Stitt Energy Systems \\
\hline NatMax & Timeless Construction \\
\hline \multicolumn{2}{|c|}{ Developers } \\
\hline Castle \& Cooke & Kashi Church Foundation, Inc. \\
\hline \multicolumn{2}{|l|}{$\begin{array}{l}\text { East Bay Development Company of FL } \\
\text { LLC (Formerly Midgard Associates) }\end{array}$} \\
\hline \multicolumn{2}{|c|}{ Research, Education, and Industry Association Partners } \\
\hline Auburn University School of Architecture & Northwest Energy Efficient Manufactured \\
\hline Building Science Consortium & Housing Program (NEEM) \\
\hline Florida Green Building Coalition & Pacific Northwest National Laboratory \\
\hline Florida International University, 2005 Solar & Portland Cement Association \\
\hline Decathlon Team & RADCO, Inc \\
\hline Florida Solar Energy Research and & RESNET \\
\hline
\end{tabular}




\begin{tabular}{|c|c|}
\hline $\begin{array}{l}\text { Education Foundation } \\
\text { IBACOS, New American Home (Goehring } \\
\text { Morgan Construction) } \\
\text { Not-So-Big-House, (Sarah Susanka, AIA) }\end{array}$ & $\begin{array}{l}\text { Structural Insulated Panel Association } \\
\text { Stevens Associates (Home Ventilation } \\
\text { Institute) } \\
\text { Washington Manufactured Housing Assoc }\end{array}$ \\
\hline \multicolumn{2}{|c|}{ Industry Suppliers } \\
\hline $\begin{array}{l}\text { Allsolar Service Company Inc. } \\
\text { Basement Systems, Inc. } \\
\text { Bellview Air } \\
\text { Beam Industries } \\
\text { Classic Products } \\
\text { Energy Conservatory } \\
\text { Flexible Technologies } \\
\text { GreenStone Industries }\end{array}$ & $\begin{array}{l}\text { Hard Cast } \\
\text { Heat Pipe Technology } \\
\text { Honeywell } \\
\text { Icynene Inc. } \\
\text { LaSalle Air Systems } \\
\text { Minority Development Resource Group } \\
\text { SSHC Inc. } \\
\text { Style Crest Products } \\
\text { Tamarack Technologies, Inc } \\
\end{array}$ \\
\hline
\end{tabular}

Figure 2 BAIHP research and technical assistance partner locations.

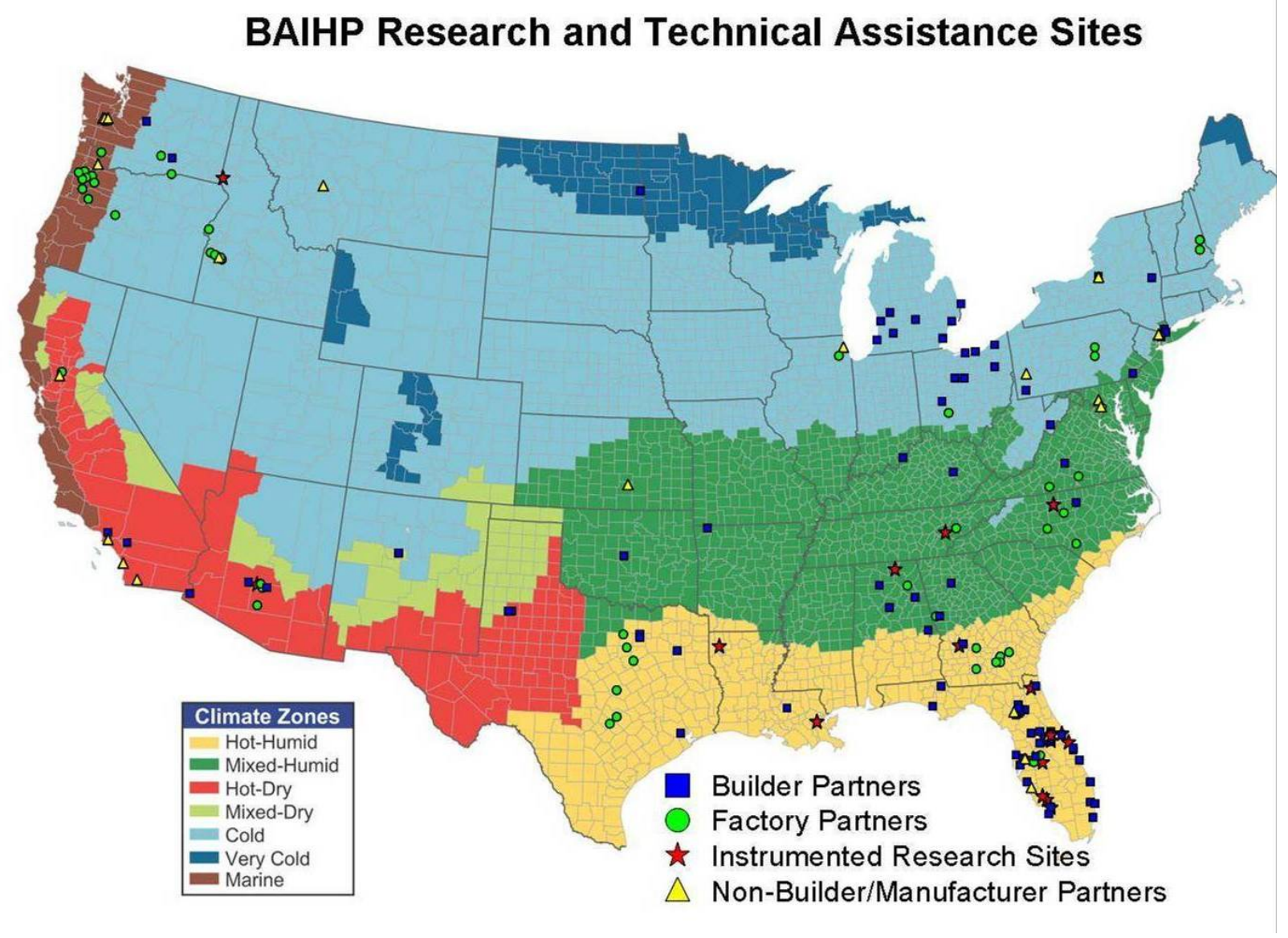




\section{II BAIHP TECHNICAL ASSISTANCE}




\section{BAIHP TECHNICAL ASSISTANCE}

The BAIHP team provided technical assistance to HUD Code Home manufactures, modular home manufacturers, and site builders including Habitat for Humanity International and its affiliates throughout the nation. Site builders receiving technical assistance are located primarily in the hot-humid region of North and Central Florida.

Systems engineering forms the core of the Building America approach. BAIHP Industry Partners evaluate the integration of their construction standards and consider improvements that enhance energy efficiency, durability, indoor air quality, and health of their homes. The Industry Partner decides which improvements to implement.

In providing technical assistance BAIHP generally recommends improving equipment efficiency and reducing conditioning loads while taking durability and health issues into consideration. Some examples include:

\section{Improving Equipment Efficiency}

- High efficiency, correctly sized heating and cooling equipment

- Interior duct systems and unvented attics

- High efficiency water heating, appliances, and lighting.

\section{Reducing Conditioning Loads}

- Well orientated and shaded windows

- Climate appropriate windows characteristics

- Reflective or absorptive surfaces (roof, wall)

- Continuous thermal, moisture, and air barriers

Durability and Indoor Air Quality

- Fresh air ventilation

- Moisture control

- Balanced/controlled air flow

- Reduced long term maintenance needs

It is the combination of these improvements that enables the BAIHP Industry Partners to achieve high performance homes (Figure 3) to move the homebuilding industry toward DOE's 2010 goals. Table 2, Homes Built in Partnership with BAIHP, shows BAIHP Industry Partner housing production in 4 categories:

- Category A: Homes meeting the Building America program goal of saving at least $30 \%$ of whole house energy use compared to the 2005 Building America benchmark, incorporating fresh air ventilation, and including superior durability and health features. HERS ' 99 Score results are greater than 88.6.

- Category B: Homes meeting the EPA Energy Star criteria for saving 30\% of heating, cooling, and water heating energy use HERS ' 99 of 86.0 or higher.

- Category C: Homes with energy efficiency improvements that fall slightly short of the EPA Energy Star criteria for saving 30\% of heating, cooling, and water heating energy use. HERS ' 99 score of approximately 85 . Also homes designed and built to this level or higher that have not been specifically rated and tested by BAIHP. 
- Category D: Manufactured homes built with substantially leak free ducts ( $\mathrm{Qn}_{\mathrm{OUT}} \leq$ $0.03)$. This category may include some Category B and C homes.

Since inception, BAIHP has assisted home builders and manufacturers to construct:

- 20,445 homes built to Energy Star level or better (Category A and B, Table 2)

- 14,991 homes built $30 \%$ to $50 \%$ better than the HUD code - approx 5\% below Energy Star (Category C, Table 2)

- $\quad 98,250$ manufactured homes with airtight duct systems (Category D, Table 2)

- Estimated energy savings to homeowners: over \$17 million annually

Section II describes each BAIHP Industry Partnership, arranged alphabetically. These summaries are also available on the BAIHP website at www.baihp.org by selecting from the Partners page. In many cases, more detailed case studies are also available on the web site.

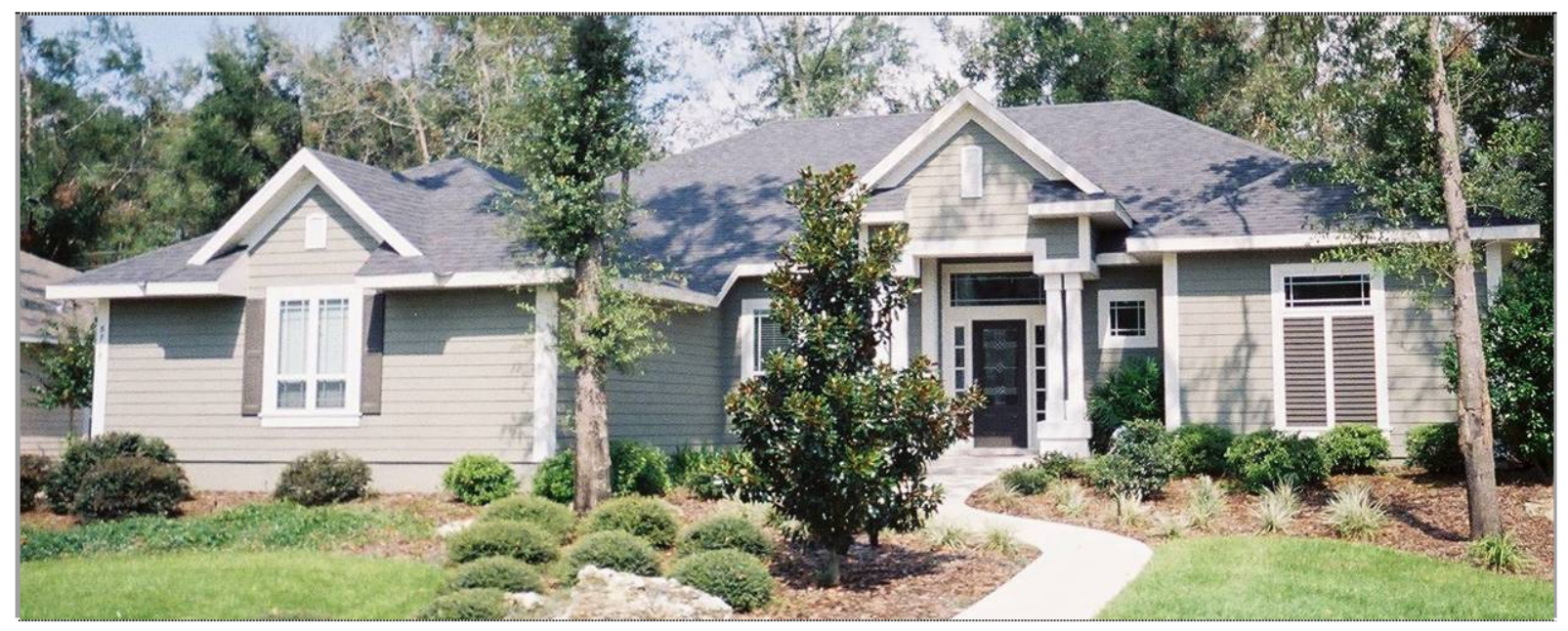

Figure 3 Building America homes like this one built by BAIHP Industry Partner G.W. Robinson Homes in the Cobblefield community (Gainesville, Florida) reduce energy bills for individual homeowners while pushing the standard of building closer to DOE's 2010 goals saving 30\% in whole house energy use (source energy) compared to the 2005 Building America benchmark. 
Table 2 Homes Built in Partnership with BAIHP

\begin{tabular}{|c|c|c|c|c|c|}
\hline \multicolumn{6}{|l|}{ List of BAIHP homes as of $6 / 30 / 06$} \\
\hline \multicolumn{6}{|c|}{ A) Homes with HERS scores $>=88.6$ (counts as 89 in NREL database) } \\
\hline $\begin{array}{l}\text { Homes assisted by FL HERO } \\
\text { (Bldrs- Atlantic Design, GW Robinson, Tommy } \\
\text { Williams }+\sim 12 \text { others) }\end{array}$ & 341 & \multicolumn{4}{|c|}{$(10 / 02-6 / 06)$} \\
\hline Fallman design and construction & 2 & \multicolumn{4}{|c|}{$(09 / 01-08 / 03)$} \\
\hline Palm Harbor Homes & 5 & \multicolumn{4}{|c|}{$\begin{array}{c}\text { (Aug 04- Jan } \\
06)\end{array}$} \\
\hline Marquis Construction & 1 & \multicolumn{4}{|c|}{ "Feb 06} \\
\hline WCI & 2 & \multicolumn{4}{|c|}{ "Aug 04} \\
\hline Applegren Construction (East Dakota Housing Alliance) & 10 & \multicolumn{4}{|c|}{ "March 05} \\
\hline Habitat for Humanity, Lakeland, FL & 6 & \multicolumn{4}{|c|}{ "4/06 } \\
\hline Category A Total & 367 & & & & \\
\hline B) Homes with HERS scores of approx 86 or more & \multicolumn{5}{|c|}{ (Includes Category A homes for now) } \\
\hline SGC/NC West of the Cascades+Natural Choice & 15,258 & \multicolumn{4}{|c|}{$(09 / 99-6 / 06)$} \\
\hline Homes by FL HERO & 1592 & \multicolumn{4}{|c|}{$(\sim 01 / 00-6 / 06)$} \\
\hline Ft.Lewis modular & 86 & \multicolumn{4}{|c|}{ "06/06 } \\
\hline Palm Harbor Homes & 18 & \multicolumn{4}{|c|}{$(\sim 01 / 00-01 / 06)$} \\
\hline Habitat for Humanity & 446 & \multicolumn{4}{|c|}{$(1998-2 / 06)$} \\
\hline Homes by D.R.Wastchak in Phoenix, AZ & 2,658 & \multicolumn{4}{|c|}{$(\sim 01 / 00-10 / 02)$} \\
\hline Marquis Construction & 4 & \multicolumn{4}{|c|}{ "Feb 06} \\
\hline Applegren Construction (East Dakota Housing Alliance) & 13 & \multicolumn{4}{|c|}{ "March 05} \\
\hline New Generation by Kingon & 1 & \multicolumn{4}{|c|}{ "Apr 05} \\
\hline Cambridge Homes & 2 & \multicolumn{4}{|c|}{ "Dec 03} \\
\hline Category B Total & $\mathbf{2 0 , 0 7 8}$ & & & & \\
\hline \multicolumn{6}{|c|}{ C) Homes just below Energy Star (HERS approx 85, homes not rated) } \\
\hline Old Natural Choice (thru 11/01) + SGC east of the Cascades & 13,086 & \multicolumn{4}{|c|}{$(09 / 99-6 / 06)$} \\
\hline Energy Efficient Div of PHH in North Carolina & 1,645 & \multicolumn{4}{|c|}{$(09 / 99-02 / 01)$} \\
\hline Habitat Homes (approx.) & 260 & \multicolumn{4}{|c|}{$(1995-2001)$} \\
\hline \multirow[b]{2}{*}{ D) Homes with just airtight ducts } & 14,991 & & & & \\
\hline & (May in & lude som & Category B and & Chome & \\
\hline & Total & $\begin{array}{r}2000- \\
02 \\
\end{array}$ & 2003 & 2004 & 2005 \\
\hline Palm Harbor Homes & 52,561 & 32,000 & 6,871 & 6,897 & 6,793 \\
\hline Cavalier & 1,132 & 1,132 & 0 & 0 & 0 \\
\hline Southern Energy & 26,231 & 12,803 & 4,000 & 4,328 & 5,100 \\
\hline Fleetwood & 18,327 & 500 & 1,280 & 9,482 & 7,065 \\
\hline Category D Total & 98,251 & & & & \\
\hline Total number of Homes & 133,320 & & & & \\
\hline Number of HUD code homes & 128,258 & & & & \\
\hline Number of Site built (incl modular) homes & 5,062 & & & & \\
\hline Approximate Energy Savings (mBtu/yr) & $1,248,295$ & & & & \\
\hline Approx.\$/yr savings@\$14./mBtu & $\$ 17,476,129$ & & & & \\
\hline
\end{tabular}




\begin{abstract}
All America Homes of Gainesville
Gainesville, Florida

Category A, 2 Homes

Awards: 2003 Energy Value Housing Award, Silver Medal, Custom Home/Hot Climate

2002 South East Builder's Conference, Grand Aurora Award for Solar Energy
\end{abstract}

All America Homes has been in business for 17 years and builds 10 homes each year in the Gainesville (FL) area. After providing design assistance for the award wining 2002 home (Figure 4) during the $4^{\text {th }}$ budget period, BAIHP provided additional assistance to All America for a second home with solar and energy efficiency concepts during the $5^{\text {th }}$ budget period. The home was built with a photovoltaic (PV) system, and achieved a HERS '99 rating of 90.6. This home serves as a model for the hot-humid climate using a combination of on-

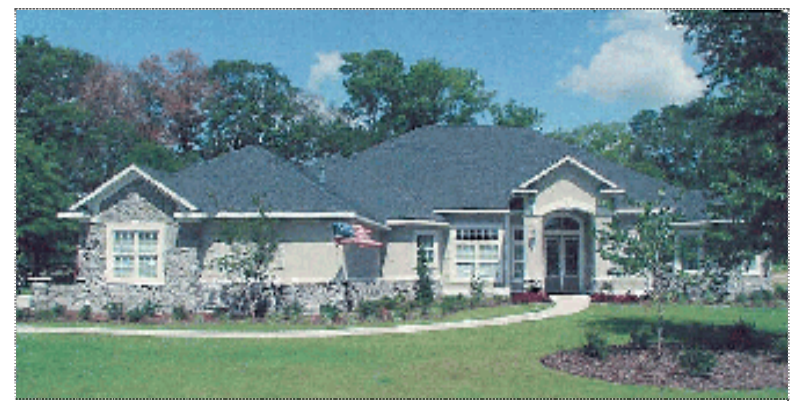

Figure 4 All America Homes of Gainesville, 2003 Energy Value Housing Award, Silver Medal, Custom Home/Hot Climate. site power generation and energy efficiency to reach near-zero utility demand, similar to the home built in 2002 (Table 3).

It incorporates energy efficient air conditioning, hydronic solar water heating, excellent air distribution design and construction (pressure tested for validation) and right sizing of the heating and cooling capacity. It also incorporates envelope improvements in the roof, ceiling, walls, windows and infiltration control. A passive fresh sir ventilation system provides filtered outside air to the return side of the mechanical system during operation.

Table 3 All America Homes of Gainesville (FL) Specifications

\begin{tabular}{|c|c|c|}
\hline Component & 2002 Home & 2003 Home \\
\hline Conditioned Area & $3644 \mathrm{sq} \mathrm{ft}$ & $2884 \mathrm{sq} \mathrm{ft}$ \\
\hline HERS '99 Score & 90.6 & 90.6 \\
\hline Utility Cost & $\begin{array}{l}\$ 150 \text { for summer (including water, } \\
\text { sewer, and trash pickup) (Source: } \\
\text { Homeowner records.) }\end{array}$ & $\begin{array}{l}\text { Average summer energy use } \\
=58 \mathrm{kw} / \text { day (Source: } \\
\text { Gainesville Regional Util.) }\end{array}$ \\
\hline Solar: PV Array & $2.5 \mathrm{~kW}$ & $1.8 \mathrm{~kW}$ \\
\hline Solar: Water Heating & $\begin{array}{l}\text { Integrated storage solar collector } \\
\left(4^{\prime} \times 8^{\prime}\right) \text { EF. } 2.4\end{array}$ & $\begin{array}{l}\text { Integrated storage solar } \\
\text { collector }\left(4^{\prime} \times 8^{\prime}\right) \text { EF } .4 .7\end{array}$ \\
\hline Solar: Water Heating & Solar pool heater & N/A - no pool \\
\hline Solar: Attic Ventilation & PV powered attic fan & N/A - Unvented attic \\
\hline Solar: Outdoor Lighting & PV (low-voltage) patio lighting. & N/A - No pool. \\
\hline Heating & $\begin{array}{l}\text { Hydronic coil with solar heated } \\
\text { water and gas backup }\end{array}$ & $\begin{array}{l}\text { Hydronic coil with solar } \\
\text { heated water and } \\
\text { instantaneous gas backup }\end{array}$ \\
\hline Cooling & $\begin{array}{l}\text { SEER } 14 \text { AC } \\
\text { Variable speed AHU fan } \\
\text { Maintains indoor } \mathrm{RH}=<60 \%\end{array}$ & $\begin{array}{l}\text { Dual compressor SEER } 17 \\
\text { Variable speed AHU fan } \\
\text { Maintains indoor } \mathrm{RH}=<60 \%\end{array}$ \\
\hline Ducts & Interior Duct System & Interior Duct System in \\
\hline
\end{tabular}


Table 3 All America Homes of Gainesville (FL) Specifications

\begin{tabular}{|c|c|c|}
\hline & Fur down construction & Unvented Attic \\
\hline Duct Leakage & CFM $25_{\text {ouT }}<5 \%$ of AHU flow & CFM $25_{\text {oUT }}<5 \%$ of AHU flow \\
\hline Roof/Ceiling Assembly & $\begin{array}{l}\text { Radiant barrier roof decking } \\
\text { R-30 dense pack cellulose (ceiling) }\end{array}$ & $\begin{array}{l}\text { R-20 Icynene at roof decking } \\
\text { unvented attic }\end{array}$ \\
\hline Wall Assembly & R-13 Dense pack cellulose & R-15 Blown in batt fiberglass \\
\hline Windows & Reduced window area & \\
\hline Glazing \& Frame & Double pane, vinyl frame & Same \\
\hline Window Radiant Gain & $\begin{array}{l}\text { Large overhangs (high windows } \\
\text { located beneath the roof overhangs } \\
\text { to provide daylighting without } \\
\text { contributing to solar heat gain) }\end{array}$ & $\begin{array}{l}\text { Low-E glazing for unshaded } \\
\text { east and west windows }\end{array}$ \\
\hline Lighting & $85 \%$ fluorescent. & $95 \%$ fluorescent \\
\hline Infiltration & Natural ACH $<0.1$ & Est. natural ach $=0.059$ \\
\hline Ventilation & $\begin{array}{l}\text { Filtered passive fresh air inlet on } \\
\text { the return side of AHU }\end{array}$ & Same \\
\hline
\end{tabular}

AMJ Construction

Gainesville, Florida

Category A, 54 Town homes (ongoing)

Florida Home Energy Rating Organization (Florida H.E.R.O.) provided an engineered duct system for 26 models in the Regents Park Townhouse development. This downtown urban infill project will result in 54 units with Building America features including ductwork in the conditioned space, outside air ventilation, and combo hydronic heat and 13 SEER cooling. Each of the 54 units will be individually performance tested. Three completed units were tested, each scoring well over a HERS '99 score 89.

\section{Applegren Construction, Eastern Dakota Housing Alliance (EDHA) Grand Forks, North Dakota \\ Category A, 10 Homes \\ Category B, 13 Homes}

Awards: $\quad$ North Dakota Housing Finance Agency’s Champion of Affordable Housing Production Award

Papers: $\quad$ Cold Climate Case Study: High Efficiency North Dakota Twin Homes

See Cold Climate Case Study: High Efficiency North Dakota Twin Homes on www.baihp.org.

EDHA set a goal of achieving up to 50\% energy savings over the 1993 Model Energy Code with superior indoor air quality (AIQ). Phase I (March 2003) and Phase II (Feb 2004) each included two twin homes (duplexes) for a total of eight homes.

The two story dwellings (Figure 5) include an insulated basement with air circulation to the main house, suitable for conversion to living space. Features of the Phase I and Phase II homes are summarized in Table 4 which also shows a theoretical base case house using local conventional construction and code minimums modeled in DOE2 to determine energy savings and cost effectiveness. Estimated combined gas and electric utility savings ranged from $25 \%$ on Phase I homes to $35 \%$ on Phase II homes over the base case. The homes also met the BA goal of $40 \%$ 
savings compared to the Benchmark house.

\section{Annual Energy Use}

A performance comparison of the base case and improved structures is shown in Table 5. The DOE2 model predicts the need for very little cooling, however many new homes in this area, including these, are being built with central air conditioning.

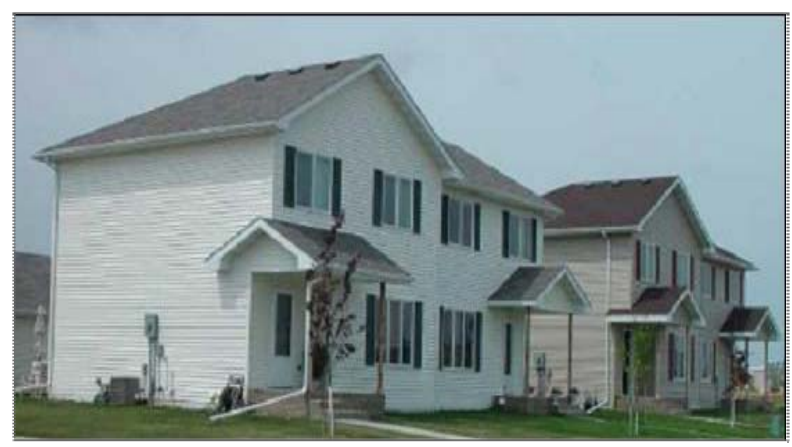

Figure 5 Selkirk Twin Homes, Grand Forks, ND.

Moisture Issues

Phase II of construction added a layer of R-10 rigid extruded polystyrene (XPS) to the exterior side of the wall assembly. The low water vapor permeance of rigid XPS foam sheathing (1.1 perms) presents a dilemma in this climate where an interior vapor barrier (usually 6-mil polyethylene) is considered mandatory to minimize moisture diffusion from the conditioned space into the wall cavity. The installation of two vapor barriers leaves the wall vulnerable to moisture accumulation should water unintentionally enters the cavity. One BAIHP recommendation calls for removing the interior vapor barrier and relying on two coats of latex paint on the interior to limit diffusion from the conditioned space into the wall. This option allows the wall to dry to some extent in both directions, but was not chosen by the builder.

Ventilation

A heat recovery ventilator (HRV) mounted in the basement provides controlled mechanical ventilation with an energy penalty estimated at $\$ 45 /$ year. The unit contains an 80 -watt fan that introduces $75 \mathrm{CFM}$ of outside air while exhausting a similar amount at a heat transfer efficiency of $70 \%$. The HRV can operate either continuously or on an intermittent 20 minutes on, 40 minutes off cycle. Intermittent operation was simulated to meet the old guideline. Attempting to meet the new ASHRAE 62.2 standard (ASHRAE 1999) would require 42 CFM of continuous ventilation. For these simulations however, the old ASHRAE guideline of $0.35 \mathrm{ACH}$ was used, calling for a continuous rate of $25 \mathrm{CFM}$. 
Table 4 Applegren Twin Home Specifications

\begin{tabular}{|c|c|c|c|}
\hline Component & Base Case & Phase I (March 2003) & Phase II (Feb 2004) \\
\hline $\begin{array}{l}\text { Conditioned Area Of } \\
\text { Each Dwelling }\end{array}$ & 1840 sq. ft. (w/basement) & Same & Same \\
\hline Hers Score & 85.2 & 89.7 & 92.2 \\
\hline $\begin{array}{l}\text { Estimated Annual Energy } \\
\text { Cost }\end{array}$ & $\$ 1179$ & $\$ 815$ & $\$ 701$ \\
\hline $\begin{array}{l}\text { \% Cost Savings } \\
\text { Compared to Base }\end{array}$ & & $25 \%$ & $35 \%$ \\
\hline Heating Cost & $\$ 458$ & $\$ 366$ & $\$ 294$ \\
\hline Cooling Cost & $\$ 15$ & $\$ 11$ & $\$ 10$ \\
\hline Hot Water Cost & $\$ 245$ & $\$ 157$ & $\$ 116$ \\
\hline H/C/WH Total Cost & $\$ 718$ & $\$ 534$ & $\$ 420$ \\
\hline \multicolumn{4}{|l|}{ Envelope } \\
\hline $\begin{array}{l}\text { Above-Grade Wall } \\
\text { Structure }\end{array}$ & $2 \times 6$ wood frame & Same & $2 \times 4$ wood frame \\
\hline $\begin{array}{l}\text { Above-Grade Wall } \\
\text { Insulation }\end{array}$ & R-19 fiberglass batt & Same & R-15 blown fiberglass \\
\hline $\begin{array}{l}\text { Above-Grade Wall } \\
\text { Sheathing }\end{array}$ & Plywood & Same & $\begin{array}{l}\text { R10 XPS foam } \\
\text { corners: R7.5+plywood }\end{array}$ \\
\hline Basement Walls & $\mathrm{R}-11$ & Same & Same \\
\hline Vented Attic & $\mathrm{R}-49$ & Same & Same \\
\hline Windows & $\begin{array}{l}\text { Double pane, Low-E, } \\
\text { Argon-filled, } \\
\text { vinyl slider frame } \\
\mathrm{U}=0.34, \mathrm{SHGC}=0.33\end{array}$ & $\begin{array}{l}\text { Casement } \\
\text { (instead of slider) }\end{array}$ & Same as Phase I \\
\hline $\begin{array}{l}\text { Infiltration } \quad \text { (ACH50) } \\
\text { (Including Basement) }\end{array}$ & 5 (assumed) & 2.8 (average of 4 units) & 2.4 (average of 4 units) \\
\hline \multicolumn{4}{|l|}{ Equipment } \\
\hline Gas Furnace & $60 \mathrm{kBtu}, \mathrm{AFUE}=78$ & $\begin{array}{l}\text { 60kbtu, AFUE }=92 \\
\text { w/sealed combustion }\end{array}$ & $60 \mathrm{kBtu}, \mathrm{AFUE}=92$ \\
\hline Gas Furnace Capacity & $29.8 \mathrm{kBtu} / \mathrm{h}$ & $33.4 \mathrm{kBtu} / \mathrm{h}$ & $30.7 \mathrm{kBtu} / \mathrm{h}$ \\
\hline Air Conditioner & 1.5 ton, 10 SEER & Same & Same \\
\hline Air Conditioner Capacity & $9.9 \mathrm{kBtu} / \mathrm{h}$ & $10.6 \mathrm{kBtu} / \mathrm{h}$ & $10.3 \mathrm{kBtu} / \mathrm{h}$ \\
\hline Thermostat & Standard & Programmable & Same as Phase I \\
\hline Ventilation & None & 70\% efficient HRV & Same as Phase I \\
\hline Water Heater & 40 gallon, $\mathrm{EF}=0.88$ Electric & $\begin{array}{l}40 \text { gallon, } \mathrm{EF}=0.62 \\
\text { Natural gas with power } \\
\text { vent }\end{array}$ & $\begin{array}{l}\text { Tankless, EF=0.83 } \\
\text { Natural gas }\end{array}$ \\
\hline Lighting & $10 \%$ fluorescent & $\begin{array}{l}85 \% \text { fluorescent } \\
\text { (linear and CFL) } \\
\text { Note: only bathroom and } \\
\text { dimmable fixtures were } \\
\text { incandescent }\end{array}$ & Same as phase I \\
\hline Appliances & Standard & $\begin{array}{l}\text { Energy Star dishwasher } \\
\text { Horizontal-axis washer } \\
\text { Energy Star refrigerator }\end{array}$ & Same as Phase I \\
\hline
\end{tabular}

Cost Analysis

Tables 5 (Phase I) and 6 (Phase 2) show the cumulative effect of All Measures in comparison to the base case home. The heat recovery ventilator (HRV) is also shown separate from the other measures because the HRV is an essential IAQ feature, yet it increases energy use by $\$ 45 /$ year. 


\begin{tabular}{|l|c|c|c|c|}
\hline \multicolumn{5}{|c|}{ Table 7 Completed Selkirk Homes } \\
\hline & Phase I & Phase II & Phase III & Phase IV \\
\hline Number of Homes & 4 & 4 & 4 & 4 \\
\hline Completion Date & Mar-03 & Jan-04 & Aug-04 & Jun-05 \\
\hline HERS '99 score range & $88-90$ & 92.5 & $88-89.5$ & 91 \\
\hline BA Benchmark range & $25-30 \%$ & $40 \%$ & TBD & TBD \\
\hline
\end{tabular}

In 2005 and 2006, BAIHP provided technical assistance this partner for Phases III, IV, and V (Table 7, Completed Selkirk Homes). Lower HERS ' 99 scores (88.3 - 89.5) on the Phase III units was primarily due to electric resistance water heating (instead of tankless gas) and higher overall duct and envelope leakage. All of the 16 dwellings have outside air brought to the air handler return plenum with 14 of 16 units utilizing heat recovery ventilators (HRVs). Other specifications are outlined in Table 8.

\begin{tabular}{|l|l|}
\hline \multicolumn{2}{|c|}{ Table 8 Selkirk Split-level Twin Home Specifications - Phase IV } \\
\hline Conditioned Area & 1864 sq.ft. (including basement) \\
\hline Above-grade Walls & Wood Frame (R15+R10 sheath) \\
\hline Sub-grade Basement Walls & R22 Insulated Concrete Forms \\
\hline Ventilated Attic & R-49 \\
\hline IG Vinyl Windows & U-0.34, SHGC-0.33 \\
\hline Heating System & Sealed Combustion Gas Furnace 60kBtu, AFUE-93 \\
\hline Ducts/Return air & Central return / hi-lo bdrm return \\
\hline Air Conditioning & Straight AC 1.5-ton, 10 SEER \\
\hline Water Heater & Tankless Gas EF 0.83 \\
\hline Thermostat & Programmable \\
\hline Lighting & $85 \%$ Fluorescent \\
\hline Ventilation & $70 \%$ HRV \\
\hline
\end{tabular}

Phase IV floor plans were nearly identical to that used in Phase III featuring a split level design and attached garage instead of the below grade basements and detached garages used in Phases I and II. (Figure 6)

Significant improvements in duct leakage to the outside were seen in Phase IV over Phase III. The improvements resulted from moving the air handler from an enclosed closet in the garage to the basement and using a central return instead of distributed returns which were found

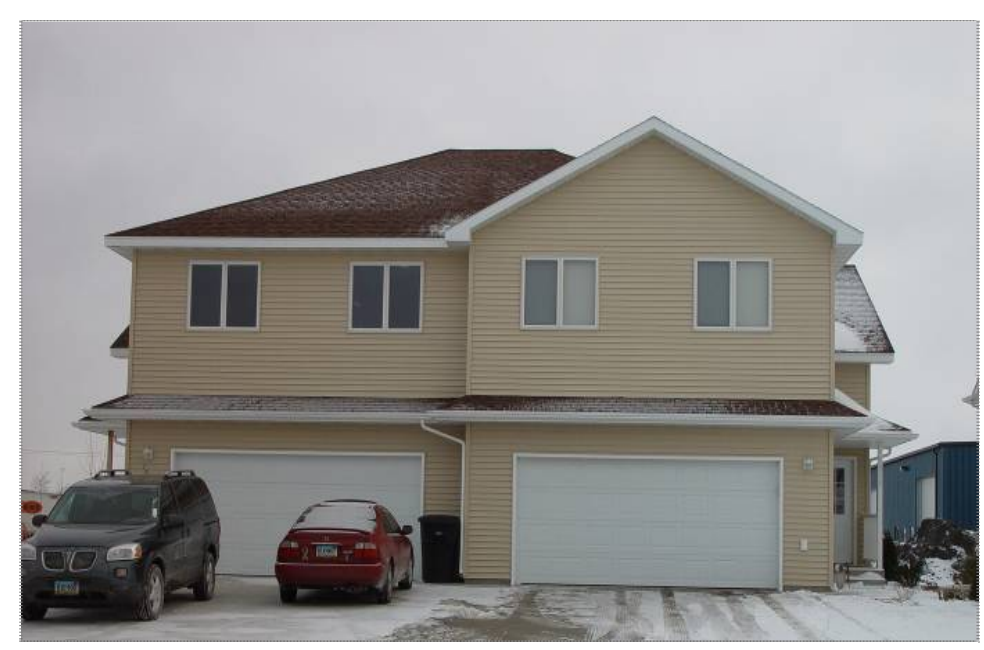

Figure 6 Two completed Phase IV units (Dec 2005) at Selkirk 
to be very leaky with QnOUT measurements of 0.05-0.09 compared to the improved QnOUT measurements in Phase IV of 0.01 to 0.03 .

As with previously tested homes, total leakage was still very high and concentrated mostly on the return side where duct pathways were partially constructed by enclosing building cavities.

Pressure measurements revealed that with interior doors closed, bedrooms pressures were around +1.0 Pascal, well within the acceptable range. Only the larger bedroom was fitted with a high/low return area pathway.

Each Phase IV unit was tested individually for envelope tightness. Leakage was noticeably higher with an average ACH50 of 4.3, versus the 3.5 seen in the similar Phase III design. No attempt was made to determine leakage through the shared wall of the adjoining unit but this should be similar to the test results on Phase II which found 50CFM of inter-unit leakage.

Table 9 HERS ‘99 Scores and Test Results for Selkirk Phase IV

\begin{tabular}{|c|c|c|c|c|c|c|c|c|}
\hline & Rating & \multicolumn{6}{|c|}{ Envelope } & Ducts \\
\hline Unit & HERS ‘99 & CFM50 & ACH50 & $\mathrm{ACH}$ & $\mathbf{C}$ & n & $\mathbf{R}$ & $\underset{t}{\text { CFM25ou }}$ \\
\hline 1034 & 91.2 & 973 & 3.89 & 0.26 & 72.7 & 0.66 & 0.99 & 30 \\
\hline 1042 & 90.7 & 1096 & 4.4 & 0.20 & 48 & 0.80 & 0.99 & 58 \\
\hline 1050 & 91.3 & 1153 & 4.6 & 0.35 & 106 & 0.61 & 0.99 & 26 \\
\hline 1058 & 90.3 & 1070 & 4.3 & 0.35 & 114 & 0.57 & 0.99 & 62 \\
\hline
\end{tabular}

Improved HERS '99 scores in Phase IV can be attributed to reduced duct leakage and switching from electric resistance water heating back to tankless gas units.

\section{Phase V Selkirk Homes}

The final phase of Selkirk will consist of six single-level, duplex homes with basement and attached garage, bringing the total build-out to 22 units. Based on past construction practices and equipment efficiencies, this home design should attain a HERS '99 score of at least 90 assuming an electric resistance water heater and 92.5 with a tankless gas water heater. Discussions for improving efficiency on these final units even further have centered on the use of a combined space and water heating boiler which may boost the HERS ' 99 score beyond 93. Favorable solar orientation for these homes may allow the use of high solar gain windows to further reduce heating loads.

Other ideas discussed:

- Combining space heating and hot water with a high efficiency central gas boiler.

- A central boiler design would require an air handler with a hydronic heating coil which could also incorporate an air conditioning coil.

- An air handler with integrated HRV is available from at least one manufacturer (Lifebreath) which could reduce first cost by eliminating a separate HRV.

- The air conditioning load for Phase 5 appears even lower than in previous designs and may justify a heating-only system. In that case, additional savings could be achieved with base-board hydronic heat. 
Atlantic Design and Construction

Gainesville, Florida

Category A and B, 340 Homes (built out in 2006)

Awards: 2001 EPA Energy Star Small Builder of the Year

Papers: $\quad$ Fonorow, Ken, Subrato Chandra, Eric Martin and Janet McIlvaine, 2006. Energy

and Resource Efficient Communities through Systems Engineering: Building

America Case Studies in Gainesville, FL. Proceedings of the 2006 ACEEE

Summer Study, American Council for an Energy Efficient Economy, Washington, DC, August 2006.

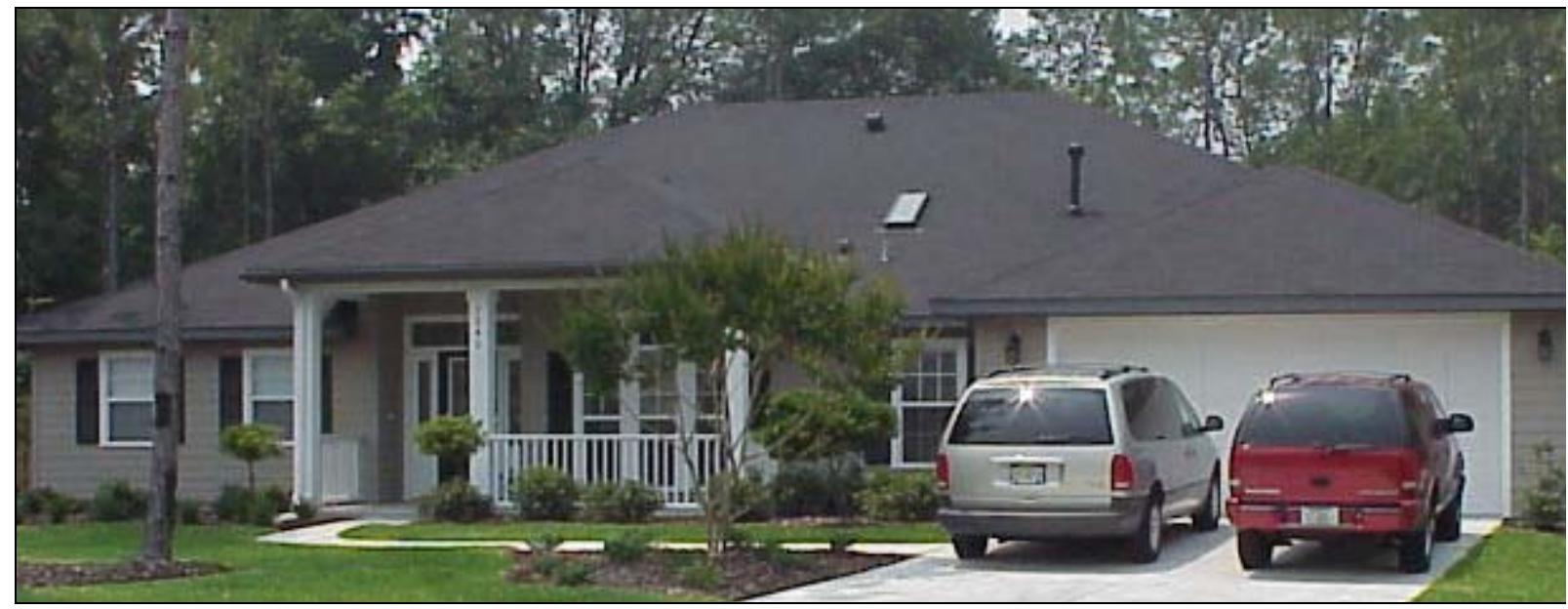

Figure 7 Atlantic Design and Construction home in the Mentone neighborhood.

Atlantic Design (AD) and Construction's Mentone Subdivision in Gainesville, FL: 340 homes built out fully in 2006. AD was the winner of the 2001 US Environmental Protection Agency's (EPA) Energy Star Small Builder of the Year and has achieved their current level of performance through an incremental process of improvements over several years. AD is a small, privately held residential construction company located in Gainesville, FL. Founded in 1985, the firm now directly employs 15 full-time employees and sells about 50 - 60 homes a year. See Figure 7 for a typical home. Like any business, AD is interested in both short-term and long-term profitability.

While having developed a reputation for building high "quality" homes, the only aspects of their homes which were greater than minimum code requirements was the use of double pane glass and R-30 attic insulation (see Table 10). New materials and systems have been adopted over time. Two factors lead the builder to implement quality control/energy cost changes. First, the builder genuinely had the desire to do the right thing and wanted to provide his clients with a quality home. If the quality of that product could be quantified - all the better. Second, AD had just shifted from a custom homebuilding company to a production company with this subdivision. Though they were already exceeding the minimum Florida Energy code required, they were still flexible enough in these early stages to consider practice changes if those changes could be streamlined/standardized to minimize disruption to the production schedule. Any changes to the production procedures or standard features, however, would need to be backed with proof of their efficacy. 
Table 10 Atlantic Design and Construction Specifications

\begin{tabular}{|c|c|c|}
\hline Component & Original & Mentone \\
\hline Conditioned Area & $1800-2400$ sq. ft & $1800-2400$ sq. $\mathrm{ft}$ \\
\hline Hers Score & $\sim 82$ & $\sim 89$ \\
\hline Selling Price & $\sim \$ 90,000$ & $\$ 190,000-\$ 325,000$ \\
\hline Cooling & $\begin{array}{l}\text { SEER } 10 \text { with standard } \\
\text { thermostat }\end{array}$ & $\begin{array}{l}\text { System sized using Manual J } \\
\text { (reduced } 1 \text { ton), SEER } 13 \text { with } \\
\text { passive, filtered ventilation air and } \\
\text { programmable thermostat }\end{array}$ \\
\hline Ducts & $\begin{array}{l}\text { Local conventional } \\
\text { construction }\end{array}$ & $\begin{array}{l}\text { System engineered using Manual D, } \\
\text { mastic sealed, and performance tested } \\
\text { to have cfm } 25 \text { out }<5 \% \text { of AHU flow }\end{array}$ \\
\hline Ceiling Insulation & R-30 fiberglass & R-30 cellulose \\
\hline Wall Assembly & R-11 fiberglass & R-13 cellulose \\
\hline Windows & $\begin{array}{l}\text { Double pane clear metal } \\
\text { frame }\end{array}$ & Double pane Low-E \\
\hline Lighting & Standard & Air lock can lights \\
\hline
\end{tabular}

At this point, $\mathrm{AD}$ was interested in determining what features would need to be added and procedural changes that would need to be made to market their product as Energy Star. To make that determination, Florida Home Energy and Resources Organization (FL H.E.RO.) performed a room-by-room Air Conditioning Contractors Association (ACCA) Manual J load calculation from building plans for a model/Parade home about to begin construction. Results found that right-sizing equipment and developing and implementing strict procedural insulation and mechanical system specifications allowed the mechanical system to be reduced by a full ton. Increasing the air conditioner seasonal energy efficiency ratio (SEER) from 10 to 12 resulted in the home meeting the minimum level required for Energy Star home certification (Home Energy Rating System score of 86 or greater). Savings derived from decreasing the cooling system capacity more than offset the additional $\$ 250$ - \$375 needed for improved duct sealing and insulation and air sealing protocol adjustments. This savings, while sufficient to offset the costs associated with improved sealing methods, was NOT enough to pay for all implemented measures. Increasing the price of the home by $\$ 1,250$ - $\$ 2,500$ was sufficient to cover all additional costs AND derive an excellent profit margin. In order to ensure consistent pricing and profit, part of the builder's job was to bid the criteria for insulation and mechanical specifications among multiple subcontractors. FL H.E.R.O. followed up with the contractors during duct rough-in to educate workers on the specifications and ensure quality installation.

Energy Star ${ }^{\circledR}$. The builder decided to include “Energy Star" on the homebuyer's option checklist. If this option was selected, the builder agreed to upgrade the cooling system efficiency to SEER 12, install an electronic programmable thermostat, install sealed and verified ductwork and increase wall insulation to R-13. As one of a list of options, sales of the Energy Star option were not brisk initially. After an analysis of the options program, FL H.E.R.O pointed out to AD that the Energy Star option was the most profitable option on their list, based on the percentage mark-up. As a result, marketing of Energy Star became more aggressive and included sales force training on selling the program. Buyers who didn't select Energy Star during the closing process were contacted directly by the Project Superintendent. His goal was to explain the value of 
including energy efficiency, the loss of revenue from not selecting it, and to allow buyers a second chance to include the option. A study commissioned by the EPA and conducted by the University of Florida (UF) verified the energy savings from implemented improvements. By comparing the actual electricity and gas usage from utility billing information, and comparing this to similarly sized and aged code minimum homes, UF determined that the energy efficient homes built by AD resulted in an average annual energy savings of $12.7 \mathrm{Mbtu}$ (savings ranged from 8.4 Mbtu minimum to 17.5 Mbtu maximum). Using this study's data to proportion approximately $50 \%$ of the energy use as electric, and approximately $50 \%$ of the energy use as gas, and applying current Gainesville Regional Utilities rates results in an average monthly savings of $\$ 23$ and a maximum monthly energy cost savings of approximately $\$ 30$. Finally, AD's President negotiated a deal with the preferred lender's mortgage broker that resulted in a 1/8th point discount of the prevailing rates for every home that was designated Energy Star. This allowed the sales representatives an opportunity to demonstrate how much it would COST the buyer NOT to select the Energy Star option! After more than 120 buyers in a row selected this option, it became a standard feature for the builder.

The value of an Energy Star home in the Gainesville, FL market can now also be communicated to buyers in terms of increased resale value. An appraisal obtained on an AD Energy Star home showed a $\$ 4,000$ increase in appraised value over a similar home in the same area that did not contain the energy efficient features (www.natresnet.org/ratings/resources/appraiser.htm). Also, the local area Multiple Listing Service (MLS) service has become the first in the nation to include information regarding a home's status with regard to Energy Star on all listings.

Building America. With Energy Star so ingrained in the AD production process, FL H.E.R.O. worked to ratchet-up the builder's home parameters by introducing him to Building America (BA) concepts. Having been exposed already to a systems engineering approach, the builder was primed to consider additional ways they could enhance their homes and their marketability. BA opened new avenues for them to increase energy efficiency, durability and enhance indoor air quality. Shifting their minimum standard upward to include a 13-SEER air-conditioning system, $0.90+$ annual fuel utilization efficiency (AFUE) heating system and low emissivity (low-E) spectrally selective glass, the builder also embraced positive home pressurization principles through the introduction of filtered outside air to the return side of the plenum. The new upgrades resulted in this production builder's homes achieving an average Home Energy Rating System (HERS '99) score of 89.

Location. Location. Location. Blueprints called for garage air handler (AH) installations in AD's standard home. In a hot and humid climate, this architectural design element alone can cause all sorts of problems for the homeowner. In moisture laden climates, ambient conditions in a garage can accelerate rusting in the ferrous heat exchanger and increase evaporator coil sweating, both of which reduce the life expectancy of the heating and cooling system. Any air leakage especially at the blower fan, the point of greatest pressure differential, can introduce the home to moisture, outdoor irritants, automobile exhaust and toxic fumes from the substances most people store in their garage. Insufficient insulation of the AH and leaks on the supply side also lead to moisture condensation on the equipment and its associated ductwork. On the return side of the system, ductwork holes bypass all filters and create a pathway for hot moist air and/or pollen laden outside air to enter the home. 
An on-site demonstration with a simple smoke stick, made invisible airflows visible and clinched this builder's interest. Armed with a clearer understanding of the ramifications of locating the $\mathrm{AH}$ in the garage, the builder was convinced of the value of an indoor installation. Initial design modifications forced the mechanical contractor to work in a closeted space that was simply not large enough to allow a good installation. The addition of a duct board plenum adjacent to the furnace from an extended return, made sealing the system almost impossible. Code also required the provision of high and low combustion air to a furnace located within the thermal envelope of a home. Supply of this combustion air put the closet into communication with the attic and resulted in the movement of attic air to the living space via leaks in the duct system.

After multiple approaches were tried, an acceptable method was developed using a .90+ AFUE sealed combustion gas furnace. The sealed system eliminated the need for combustion air from the attic and allowed the equipment room to be completely sealed from the garage and the attic. Supply and return plenums were stubbed-out in the mechanical closet during rough in, and duct, plenum and refrigerant lines were sealed to the sheetrock with an expandable foam at all seams and penetrations. During equipment set, the supply side plenum was first affixed, and then completely sealed with mastic and pressure sensitive tape. A metal tap installed in the return air plenum at ceiling height, was attached to an insulated flex duct, which was connected to a second tap on the furnace side. All duct connects are made with mastic and fiberglass mesh. An insulated exterior door for the mechanical closet with appropriate weather-stripping and threshold sealing completed the installation. Realizing that this approach would increase profits by increasing the home's conditioned square footage and provide clients with a safer and more energy efficient home, $\mathrm{AH}$ location changes were made to all model blueprints.

Indoor air quality. Though indoor air quality was a subject not yet broached, demonstrating the principles of air movement into a tightly constructed home was an educational experience for the superintendent. It quickly became clear to him that controlling how and where outside air was introduced into the home could make a big difference in the indoor air quality (IAQ). In many new homes it is common to have some amount of supply duct leakage resulting in the home being negatively pressurized because the ductwork is commonly located outside the home's air and thermal boundaries. In a negatively pressurized home, outside air is introduced in an uncontrolled fashion through inadvertent gaps around windows, doors or top and bottom wall plates. Installing a simple, low cost, non-mechanical fresh air system helps restrict the uncontrolled entry of hot, humid, pollen-laden air into a home and its interstitial areas. Filtering the outside air and directing it through the home's air conditioning system prior to entry ensures mitigation of the outside air's hot, humid, and pollen-laden characteristics. Including this fresh air system not only made AD's home more efficient, but more importantly it improved IAQ. This fresh air system now is a standard feature in all of the homes they build. 


\section{Avis American Homes}

Avis, Pennsylvania

Papers: $\quad$ Mullens, M., \& Burdick, J. (2003). "Energy Test Results and Recommendations for Avis America Homes." University of Central Florida Housing Constructability Lab BAIHP Report, Cocoa, FL.

Broadway, R. and M. Mullens (2004). "Shop Floor Information Systems for Industrialized Housing Production,' Industrial Engineering Research '04 Conference Proceedings, Houston, May, 2004.

In the summer of 2003 , Avis American Homes tested an alpha prototype Status and Control System (STACS) developed by the UCF Constructability Lab researchers (BAIHP Partner). The system is a real-time shop floor labor data collection and reporting system.

Production workers use wireless laser scanners to report their current work assignment. STACS reporting is web based and provides both real time manufacturing status and

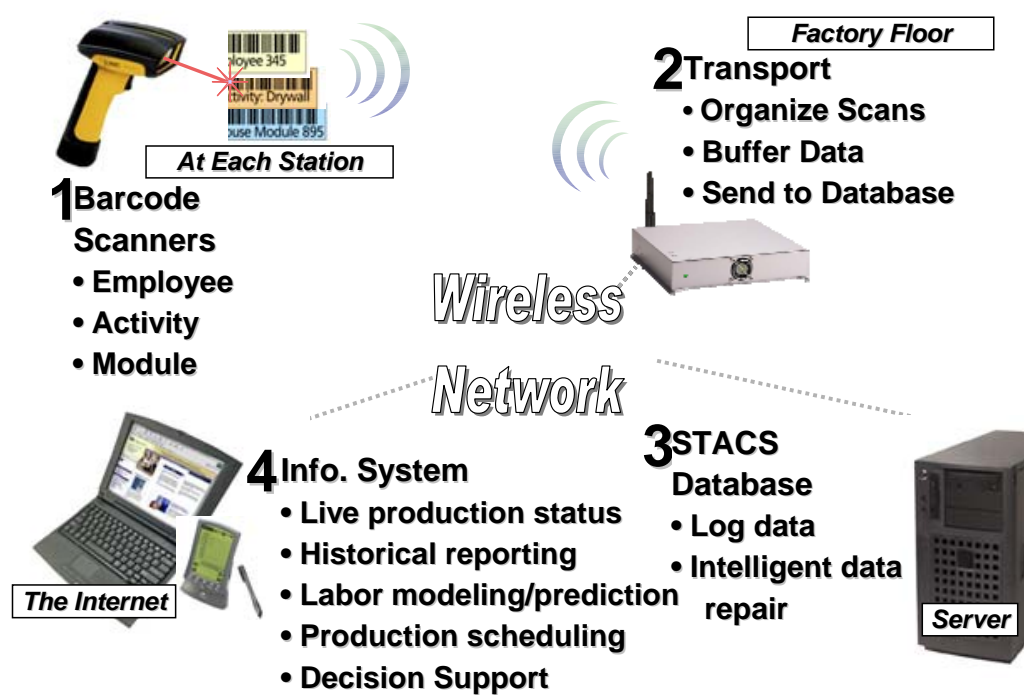

Figure 8 STACS system components and relationships. summaries of historical production performance (Figure 8). While labor represents a relatively modest fraction of production cost, typically $10-15 \%$, it has a profound impact on operations, including product quality, cycle time, material waste, and labor productivity.

Avis American employees tested STACS in drywall finishing operations. Test results demonstrated that production workers could operate the system effectively and that the system accurately captured scanned activity.

See also Penn Lyon Homes (Technical Assistance section) and Status and Control System (STACS) (Research Section III).

\section{Bellview Air \\ Gainesville, Florida}

Florida H.E.R.O. discussed a range of issues with Bellview Air, including the impact of input data on Manual $\mathbf{J}$ equipment sizing and the air handler location in an effort to improve indoor air quality, comfort, and energy performance. The potential benefits of unvented cathedralized roof systems were also addressed. 


\section{Bobek Building Systems \\ Oviedo, Florida}

BAIHP conducted a testing visit to new BAIHP partner. Bobek Building Systems building exclusively with steel frame and partial panelized construction (Figure 9) to measure whole house and duct leakage and to evaluate envelope insulation with IR camera. BAIHP compiled the results of the testing and sent design recommendations to the builder.

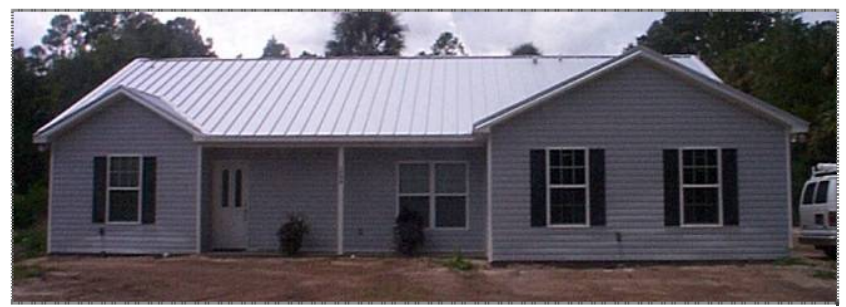

Figure 91800 sq.ft. Steel Frame Residence near Oviedo, Florida

Table 11 Air Tightness Testing

\begin{tabular}{|l|l|}
\hline Blower Door Test Results & Duct System Air tightness \\
\hline CFM50 $=1693$ & CFM25total $=285$ \\
\hline$A C H 50=7.05$ & CFM25out $=42$ \\
\hline$C=157.8, n=0.607, \mathrm{r}^{2}=0.999$ & Qn $=2.3 \%$ \\
\hline
\end{tabular}

Duct testing shows low leakage to out $(2.3 \%)$ but an excessive level of total leakage. The ducts are located in the attic which is largely sealed (essentially unvented) with an insulated steel panel roof deck. During blower door testing, the attic space was found to depressurize to 13 Pascals while the home was at -50 Pascals, showing the space is better connected to the conditioned space than to the outside. One known area of attic leakage to outdoors occurs at the front porch overhang.

The high total duct leakage should be addressed to ensure proper distribution and mixing. In many cases this is caused by leakage where the supply register ties into the supply boot. Supply registers with integral foam seals are recommended to provide a tight fit at the boot connection and where the register meets the ceiling surface.

Infrared Imaging

The IR picture in Figure 10 shows a corner, side and front wall from inside the home. This picture is typical of IR images from inside the house perimeter. Portions of the wall shown violet in color reflect an indoor temperature of approximately $67^{\circ}$. Lighter and brighter colors indicate higher temperatures. Metal studs and points of joining between the ceiling and side walls can be seen in orange and light yellow.

As can be seen from the IR picture, thermal shorts exist between the outdoor and interior space. Though the overall differential

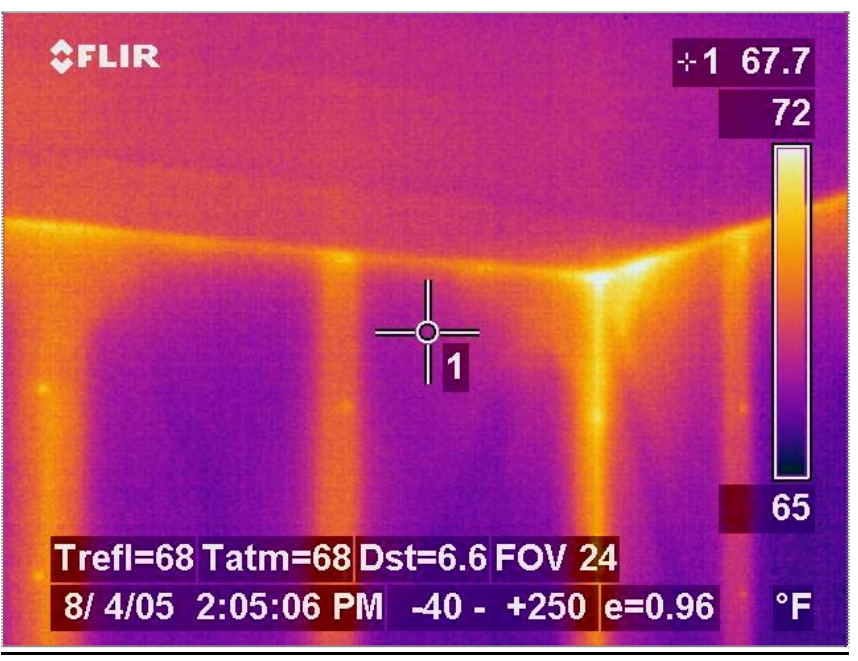
between room temperature and stud

Figure 10 Thermal Image of Exterior, Steel-framed Walls 
temperature is relatively small $\left(5^{\circ} \mathrm{F}\right)$, the cumulative effect may represent a significant conduction load on the space conditioning system. Reducing thermal bridging between outside and inside the home will reduce thermal loading taking place inside the home. This, in turn, will reduce air conditioning run times.

BAIHP Recommendations included:

- Sealed supply and return registers to reduce total duct leakage and improve distribution efficiency

- More attention to sealing the attic space from outdoors since this is essentially a buffer to the conditioned interior space. This will also lessen any duct leakage to outdoors.

Additionally, some method of breaking the thermal short between the stud and the back of the drywall should be deployed in future construction efforts. Consideration should be given to applying foam board, $3 / 4$ " minimum, between the stud and the drywall. At a minimum, application of adhesive backed foam strips applied to the stud prior to drywall installation should be considered.

Cambridge Homes

Orlando, Florida

Category B, 1 Home

Note 100\% Energy Star Builder

This BAIHP partnership resulted in continuation of monitored field research in the Augusta Building America model (Figure 11) and a control home. See BAIHP Research (Section III), Site Built Housing Research, Cambridge Homes.

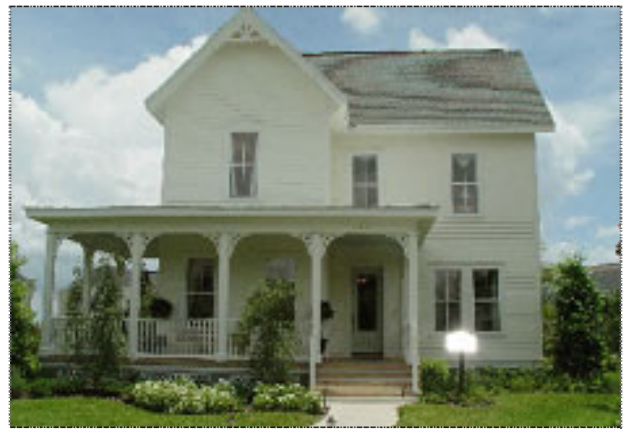

Figure 11 The Augusta, Cambridge Homes BA Prototype

In November 2004, BAIHP participated in a meeting

with this partner to discuss water damage incurred in recently built homes as a result of the 2004 active hurricane season. Approximately 12 people took part in the meeting including BAIHP researchers, and Cambridge Homes design, construction, and architecture personnel. Results of field investigations were shared, and potential solutions discussed.

\section{Cardinal Homes, Inc.}

Papers: $\quad$ Mullens, M., \& Chasar, D. (2002). "Energy Test Results and Recommendations for Cardinal Homes." University of Central Florida Housing Constructability Lab BAIHP Report, Cocoa, FL.

During the $4^{\text {th }}$ budget period in cooperation with the University of Central Florida Industrial Engineering Department (UCFIE), FSEC researchers tested four Cardinal modular homes with the Cardinal sales manager and plant quality engineer. Initial results found that peak loads for heating were almost double that for cooling. All four of the homes had leaky ducts. These leaks accounted for the largest peak load in the homes, averaging $28 \%$ of the winter peak and $21 \%$ of the summer peak. 


\section{Castle and Cooke \\ Windermere, Oakland/Winter Garden, Florida}

In early 2006, BAIHP researchers met with builder, developer, and architectural representatives from Castle \& Cooke, a development group planning a new community called Oakland Park located in Orlando Florida. Work is underway to assist with the systems engineering of a residential building that is to act as a sales center/office before it is sold as housing. Building America principles will also be extended to the rest of the approximately 500 homes located in the development.

\section{Champion Homes, see also "Fort Lewis Base Housing" Washington (state)}

Category B, 160+ homes

Papers: $\quad$ Baechler, M.; Lubliner, M; Gordon, A (2002). "Pushing the Envelope: A Case Study of Building the First Manufactured Home Using Structural Insulated Panels" 2002 ACEEE Summer Study on Energy Efficiency in Buildings Conference, American Council on an Energy Efficient Economy, Washington, DC, August 2002.

Also see Fort Lewis Case Study in the Building America Marine Climate Best Practice Guide

In 2000 Champion Homes built the first stress skin insulated panel (SIP) manufactured home now sited in western Washington. The house air tightness was measured at $\mathrm{ACH} 50=3.55$, well below the average numbers for all homes previously tested in the WSU random home study (see Northwest Energy Efficient Manufactured Homes). Energy savings are estimated at 50\% greater than a home constructed to the HUD Code. These results were presented at the 2002 ACEEE Summer Study, authored by Pacific Northwest National Laboratory (PNNL), and BAIHP staff and partners.

In 2004 Champion Homes was chosen by Equity Properties to provide house components for up to $\mathrm{r} 850$ modular homes to be used as base housing at Fort Lewis Army Base also in western Washington State. Equity made the decision to use modular due to the large number of unit going up at one time, and significantly drier conditions inside the factory to minimize moisture and mold damage during construction.

While QA indicates that duct leakage protocols are being implemented well, WSU staff is continuing to work with Champion, Equity Consulting (the developer) and Oregon Department of Energy in plant QA staff assess issues associated with attic insulation levels, HVAC, DHW and lighting system, .

By November of 2005, 64 homes had been ENERGY STAR certified, with an anticipated build out of 70 additional homes for the rest of the year. Results indicate that duct leakage protocols are being implemented well, but issues of attic insulation need to be addressed. WSU, ODOE, Equity and Champion working with PNNL recently completed a Ft. Lewis case study, which is feature in the Building America Marine Climate Best Practice Guide.

As of June 2006 over 160 homes have been completed and certified as Energy Star. 
Plans are underway in 2006 to implement HVAC research with Building America partner Carrier Aeroseal $^{\mathrm{TM}}$ on a tri-plex test building. These plans include the installation of a $94 \%$ AFUE furnace with ECM motors, and the Aeroseal ${ }^{\mathrm{TM}}$ duct leakage/testing system. A utility analysis is planned to compare gas and electric bills in these homes to the larger sample of identical of homes at Ft. Lewis.

\section{City of Gainesville - Cedar Grove II}

Gainesville, Florida

Category B, 139 Homes

Award: HUD award for Innovation in Housing in 2004

Florida H.E.R.O. began working with the City of Gainesville before the ground-breaking in the Cedar Grove II subdivision of HUD housing. Project manager Judy Raymond envisioned a new urban style development (HUD's first) with single family homes featuring high quality construction and individualized character with front porches and front façade details (Figure 12). She worked with Florida H.E.R.O. to develop engineered plans for mechanical and air distribution systems and a whole house

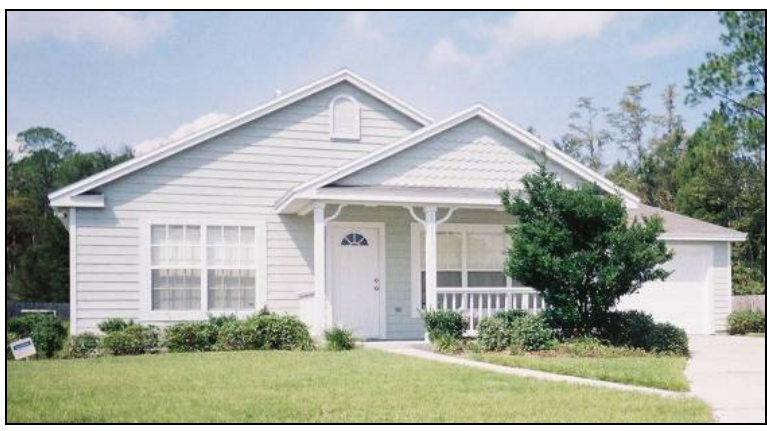

Figure 12 City of Gainesville house in Cedar Grove II package that was recognized with a HUD award in 2004. Table 12 summarizes the specifications.

Table 12 City of Gainesville, Cedar Grove II Subdivision, HUD Home

\begin{tabular}{|l|l|}
\hline \multicolumn{1}{|c|}{ Component } & \multicolumn{1}{|c|}{ Specification } \\
\hline Conditioned Area & $\sim 1200-1400$ (139 units) \\
\hline HERS 99 Rating & $\begin{array}{l}86-88 \text { (goal }=86) \\
\text { CEoling And Heating }\end{array}$ \\
\hline Duct System & $\begin{array}{l}\text { Def } 12 \text { with hydronic heating; some 80\% AFUE furnaces } \\
\text { phase. Return duct and air handler still conditioned space. } \\
\text { Duct system engineered using Manual D, sealed with mastic, } \\
\text { all homes performance tested for duct air tightness. } \\
\text { CFM25 }\end{array}$ \\
\hline System Capacity & $\begin{array}{l}\text { Cooling and heating systems sized using Manual J calculation } \\
\text { procedure }\end{array}$ \\
\hline Walls & R-13 cellulose \\
\hline Ceiling & Double pane metal frame \\
\hline Windows & \\
\hline
\end{tabular}




\section{City of Orlando, The Orlando House}

Orlando, Florida

Category A, 1 House

The City of Orlando, through the office of Housing and Community Development in the Planning and Development Department, constructed an environmentally friendly demonstration home called The Orlando House: Florida's Future, on an infill site within the city (Figure 13). The City requested FSEC assistance to assure the home met Building America goals and the Florida Green Home Designation Standards. Ground broke on the demonstration home in December 2001 and the home was open to the public for community education purposes for approximately one year. Specifications are listed in Table 13.

The City acquired more than $\$ 100,000$ in donated materials and services for the project, and completed much of the construction using their own staff. Along with public education, a primary purpose for this project was to give the city staff first hand experience in the use of green building materials and techniques - especially those relating to energy efficiency, indoor air quality, durability, disaster mitigation, and termite resistance. That experience would allow the products and techniques to be effectively used in future low-income housing constructed by the city.

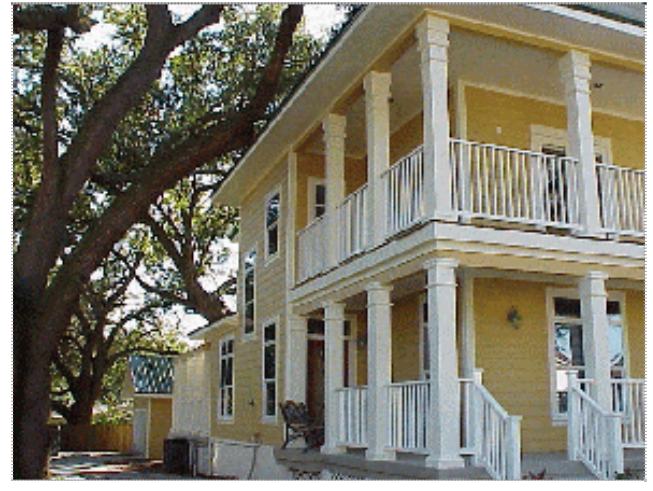

Figure 13 The Orlando House

One particular focus of this project was disaster resistance. For protection from wind storms, a durable steel structure was used along with a safe room located in the detached garage. For termite resistance, all structural and exterior finish materials were selected on the basis of providing the least amount of available food source. Materials such as borate treated lumber and sheathing, steel structural components, and plastic/composite finishes were used extensively in conjunction with a Termi-mesh barrier system.

FSEC certified the house for the Florida Green Home Designation Standard in February 2003. FSEC staff also presented information regarding Florida Green Home Designation as part of a builder training event held at the Orlando House. Two CEUs were available to attendees, and approx. 30 people attended from the central Florida area. Training also included talks on Zero Energy Homes, Florida Sun Built Program, and a "builder panel" that included 3 BAIHP partner builders.

The demonstration home was sold in May 2003, and money acquired from the sale will go directly towards the construction of low income housing that utilizes several green building techniques. 
Table 13 City of Orlando - Orlando House

\begin{tabular}{|c|c|}
\hline Component & Specifications \\
\hline Conditioned Area & 2148 sq. ft. \\
\hline HERS ‘99 Score & 88.3 \\
\hline \multicolumn{2}{|l|}{ Envelope } \\
\hline Above-grade Wall Structure & Steel Frame $1^{\text {st }}$ and $2^{\text {nd }}$ floors \\
\hline Above-grade Wall Insulation & R-19 Icynene \\
\hline Exterior Wall and Roof Sheathing & OSB - Borate treated \\
\hline Attic & Unvented R-19 Icynene \\
\hline Roof & Metal \\
\hline Windows & Double pane Low-E \\
\hline \multicolumn{2}{|l|}{ Equipment } \\
\hline Heating \& Cooling & 13 SEER heat pump \\
\hline Thermostat & Programmable \\
\hline Ventilation & Passive outside air vent \\
\hline Water Heater & 50 gal, $\mathrm{EF}=0.88$ (Electric) \\
\hline Lighting & $100 \%$ fluorescent \\
\hline Appliances & Energy Star \\
\hline $\begin{array}{l}\text { Additional Green Features: } \\
\text { - Termi-mesh } \\
\text { - } \quad \text { Safe Room } \\
\text { - } \quad \text { VOC source control } \\
\text { - } \quad \text { Resource efficient interior finishes }\end{array}$ & $\begin{array}{l}\text { - } \text { Durable exterior finishes } \\
\text { - Ultra-low-flow water fixtures } \\
\text { - } \text { Low water using landscape } \\
\text { - Pervious driveway/walkway }\end{array}$ \\
\hline
\end{tabular}

\section{City of Lubbock Community Development Lubbock, Texas}

Through the Portland Cement Association (PCA), contact was established with the City of Lubbock who is building low income houses with insulated concrete form (ICF) systems (Figure 14). FSEC researchers visited Lubbock twice to conduct diagnostic tests and provide training and technical assistance. FSEC also conducted initial HERS '99 ratings on four Lubbock Habitat for Humanity (see Habitat for Humanity,

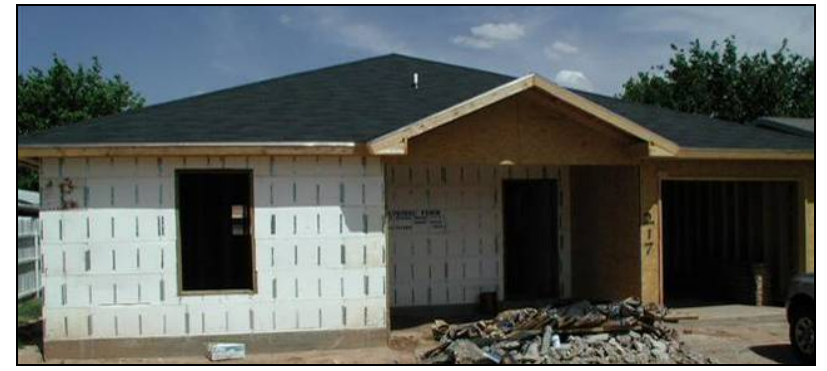

Figure 14 Low income housing built by the City of Lubbock using insulated concrete forms. Texas) homes plans and introduced the Habitat affiliate to the City of Lubbock's other low-income housing activities. 


\section{Clayton Homes}

Waycross, Georgia

FSEC personnel conducted a plant visit of the Clayton Homes factory in Waycross, Georgia in June 2002. A singlewide home was tested and observations recorded of home and duct construction techniques. Findings and remedies for leaky ducts found during the visit were reported to factory representatives in a follow-up trip report.

\section{Dukane Precast \\ Naperville, Illinois}

FSEC made a February 2002 site visit to Dukane Precast in Naperville, Illinois and provided technical design assistance in a follow-up telephone conference call in March '02.

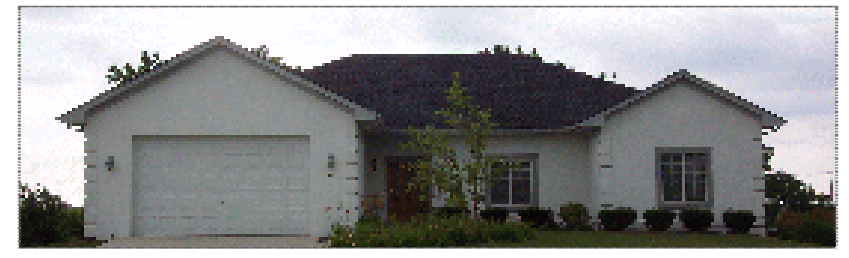

Figure 15 Completed Dukane Precast home tested by BAIHP

In 2003, Dukane Precast requested BAIHP assistance in the design phase and monitoring of the first prototype of a new line of homes called "The Fortified House" (Figure 15). Objectives of Dukane's Fortified House include energy efficiency, comfort, durability, and good indoor environment conditions.

In December 2003, FSEC visited 3 prototype buildings in various stages of construction in. One was complete. Researchers made recommendations regarding window flashing, below grade drainage and waterproofing, interior ducts, air sealing, attic access detail, floor finishes with radiant heating, radiant heat zoning, ventilation system design and operation.

In February, FSEC returned to Dukane for testing and infrared evaluation of 3 completed prototype Fortified Homes built by Dukane's sister company, Mustang Construction at Keller Court, Boilingbrook, IL, just west of Chicago.

Infrared images were recorded from the inside and outside during a calm morning with ambient air temperature of about $25 \mathrm{~F}$ and interior temperatures of about $70 \mathrm{~F}$, and whole house air tightness was assessed with a blower door test. Whole house infiltration was ACH50 $=1.28$ (very low). 11 Keller Court data (Table 14) was obtained with a multipoint blower door test. IR scans found no major infiltration pathways.

The ceiling and gable end of the vaulted living room were built with wood frame construction instead of precast concrete. Both showed higher heat loss than was generally found in the precast panels. Flaws in the continuity of ceiling insulation over the vaulted ceiling were visible from the vented attic, especially around can lights. The flat ceilings in this home were insulated with R-38 rigid polyisocyanurate loosely laid on the concrete ceiling panels. Dukane has now switched to an $\mathrm{R}-23$ precast panel for ceilings. 
Table 14 Dukane Precast's Fortified Home Specifications

\begin{tabular}{|l|l|}
\hline \multicolumn{1}{|c|}{ Component } & \multicolumn{1}{c|}{ Dukane Home } \\
\hline Conditioned area & 5100 (with basement) \\
\hline HERS 99 score & NA \\
\hline Envelope & \\
\hline Floors and Ceiling & Precast concrete panels \\
\hline Walls & R-23 $(\sim 3$ ") Polyisocyanurate between precast concrete \\
\hline Attic & Vented with R-38 Polyisocyanurate and Batt \\
\hline Windows & Insulated glass, vinyl frame, u-value=0.36, \\
\hline Infiltration & SHGC=0.45 \\
\hline Equipment & Ach50=1.28 \\
\hline Heating & Radiant floor \\
\hline Boiler & $140 \mathrm{kBtu}, 50$ gallon AFUE=92 Gas Boiler \\
\hline Cooling & 3 ton, 10 SEER, Unico-type \\
\hline Ducts & High velocity, small ducts, unconditioned space \\
\hline Thermostat & Programmable \\
\hline Ventilation & Honeywell 150cfm HRV \\
\hline Water Heating & From Boiler \\
\hline
\end{tabular}

\section{Opportunities for Improvement}

Infrared scans were performed on the ranch home and two other homes nearing completion on Keller Court. All three had the space heating system in operation holding the interior near $70 \mathrm{~F}$. Initial scans of the exterior clearly showed increased heat conduction at the truss locations in the precast panels (Figure 16). The metal truss members are cast into the assembly to connect the interior and exterior panels and allow for approximately 3 inches of polyisocyanurate foam (R-23). Exterior infrared scans showed a $2-4^{\circ} \mathrm{F}$ temperature rise at truss locations; exterior temperatures were between $12^{\circ}$ and $24^{\circ} \mathrm{F}$.

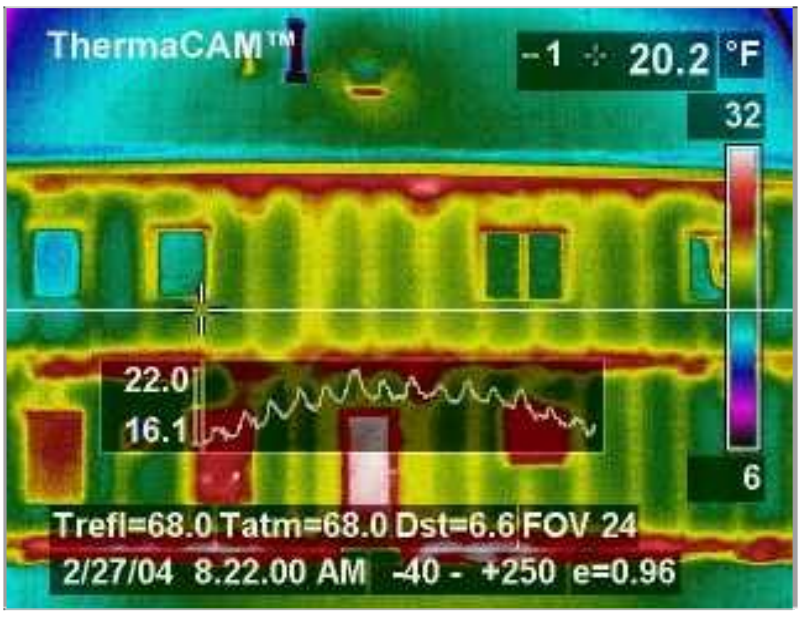

Figure 16 IR-scan showing metal trusses in precast walls. Temperature at the crosshairs is $20.2^{\circ} \mathrm{F}$. Overlaid temperature graph shows temperature variation of the surfaces at the white line running horizontally through the crosshairs. 
Increased heat loss was also visible at the top and bottom of precast sections where field connections are made during construction and filled with grout. Each panel has at least two lifting fasteners imbedded in the top edge for the crane to connect to during home construction. Foam insulation around these fasteners is sometimes removed to connect the lifting hook and the void is re-insulated in the field. Insulation levels are reduced where precast walls are connected to floors and ceilings. These areas have one inch of rigid XPS foam (R-5) next to the outer panel but are otherwise left open until structural and electrical conduit connections are made in the field after which they are filled with grout.

Interior Ducts and Moisture Issues

FSEC Researchers met with Dukane Precast staff, their architect and mechanical contractor to identify a way to incorporate interior ducts into a new model of the Fortified House. Ducts are used primarily for cooling and ventilation as all Dukane Precast homes are designed with in-floor radiant heat driven by a high efficiency ( 92 AFUE) boiler. The boiler also provides domestic hot water in conjunction with a 50-gallon storage tank.

The main obstacle to building interior ducts was finding a place to run ducts from the basement mechanical room to the first and second floors. Agreement was made to run supply risers near the center of the home and returns in a chase on an outside. The two-story foyer offers the best placement for a central return for both the first and second floor supplies.

Dukane is currently using a high velocity, small duct air conditioning system by Unico with 2inch diameter supply branches that are easier to fit into walls and chases than low velocity ducts. One unoccupied home had problems with condensation accumulating on the attic-mounted ducts. The cause was traced to humid indoor air contacting cold metal trunk lines in the vented attic.

No occupant-related moisture was present but the precast panels, which are still in the process of drying, are one possible source. Periodic mixing of the indoor air may be all that is required until moisture output from the panel is reduced. Otherwise, introducing dry air was recommended to prevent condensation. Findings and recommendations were sent of the Dukane Precast in a Trip Report.

\section{DR Horton}

Orlando, Florida Division

In December 2005, E. Martin met with the Orlando Division of DR Horton Homes to discuss resources available to them through the Building America and LEED for Homes program. DR Horton Staff from land development, purchasing, and home building divisions were present. They expressed interest in receiving assistance from BAIHP on multiple levels, and follow up conversations will take place in January. 


\section{Dye Company and DelAir - Southern Living Home Category A, 1 Home \\ Category $B, 1$ Home}

Florida H.E.R.O. met with Dye Company president and his staff to discuss the new Southern Living Home planned for showcase at the 2003 Southeast Building Conference (SEBC) in Orlando, Florida. This firm has a strong desire to differentiate their homes by emphasizing healthy and energy efficient homes. Florida HERO introduced the Building America systems engineering approach to the builder and subsequent discussions resulted in Dye's commitment to partner with Building America in this project. As a result, researcher met with DelAir mechanical contracting to discuss the development of mechanical specifications for the Southern Living project.

This home did have a Honeywell ERV added and had a HERS '99 score of 88.5. While this home did not meet the BA standard of performance for the 2003 SEBC show, retrofits were being completed to bring it up to BA performance level.

The 2004 home achieved a HERS ' 99 score of 89.6. Both homes have unvented attics with ducts in conditioned space, and used heat pumps with SEERs ranging from $13.5-14.1$. Windows in the 2004 home had a SHGC of .29 and gas (LP) instant hot water heaters were used.

\section{East Bay Development (formerly Midgard Associates) \\ Panama City, Florida \\ Category A, 358 Homes (when built out)}

Midgard Associates, now East Bay Development, began a new community in the Florida panhandle in the summer of 2005. Although the developers will not be building any of the homes, they have a wealth of building knowledge in the hot/humid climate, and are responsible for the construction of the Captain Planet Zero Energy Cottage.

The developers have a vision to oversee development of a high-performance, sustainable community that responds to the environment of Florida's gulf coast. They have enlisted the assistance of BAIHP to help develop a builder program, including home specifications and performance reviews. They have also inquired about having BAIHP develop and deliver training to the selected builders. And they have expressed an interest in all homes achieving green certification, and implementing other innovative community scale measures such as community scale geothermal heat pumps.

In March 2005, Midgard toured select developments in Central Florida including Lakewood Ranch to see how others have implemented builder programs that emphasize high performance home construction. The visit culminated at FSEC, where collaborations and partnership was discussed. Discussions are currently underway for the design of a demonstration/info center. This will be similar in nature to the Captain Planet Zero Energy Cottage, yet be more stylistically similar to the scale and architecture of other homes to be built within East Bay. 


\section{Energy Structures \& Systems, Inc.}

\section{Stuart, FL}

In April of 2006, BAIHP researchers conducted a field inspection and welcomed new partner Energy Structures \& Systems, Inc. in Stuart, FL. BAIHP will monitor two occupied homes they are constructing in the Stuart area which will feature unvented attics, AAC walls, solar water heating, outside air ventilation, high efficiency air conditioning, compact fluorescent lighting, Gossamer Wind fans, and green attributes such as xeriscaping and native plants. Instrumentation will commence in the Fall of 2006.

\section{EnergyGauge ${ }^{\circledR}$}

FSEC - Cocoa, Florida

This software uses the hourly DOE 2.1E engine with FSEC enhancements and a FSEC-designed user friendly front end. As of June 2006, BAIHP researchers use version 2.5.9 of the software to calculate home energy ratings under RESNET 1999 and 2006 guidelines, International Energy Code compliance (2002-2006 versions), 2005 federal tax credit assessments, annual energy use, and all DOE2.1E reports. (Figure 17) Researchers continue to improve the software's features and accuracy. It now incorporates many enhancements, such as detailed solar thermal and solar electric system analysis. For more information, please visit www.energygauge.com.

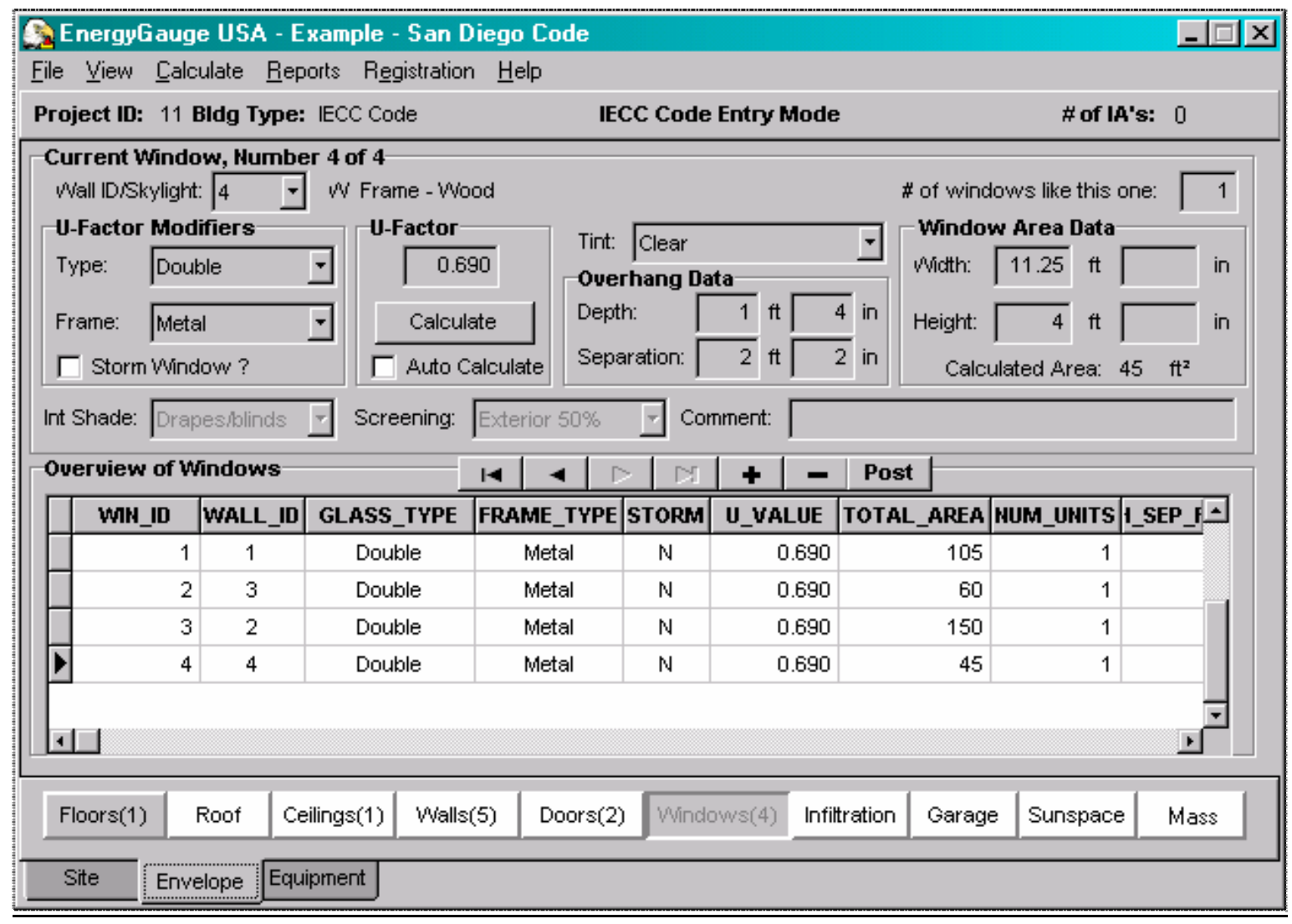

Figure 17 Window input page from EnergyGauge USA. 


\section{Fleetwood Homes}

Category D, 18,327 Homes,

Fleetwood Factory and Field Work in 2002-06

In 2002, researchers visited four Fleetwood factories in southern Georgia to investigate the cause of moisture-related building failures when units were installed in a hot-humid climate. The factories are located in Douglas, Alma, Pearson, and Willacootche. As a result of FSEC recommendations, the factories have changed their duct construction practices and are now constructing airtight ducts with mastic.

Six Fleetwood homes, all in Florida, were tested for moisture and mold damage from April 2002 through March 2003. All of the homes had damaged flooring due in part to a lack of ground cover and poor crawlspace ventilation. Damage to the floor in one home was exacerbated by a plumbing leak. Only one home had moisture damage to the wallboard material, and this home showed a history of thermostat settings below $72^{\circ} \mathrm{F}$. A report for each home was submitted to Fleetwood for corrective measures. One additional high bill complaint in Cobb, Georgia was investigated during that period. Between April 2003 and October 2004 ten Fleetwood moisture damaged homes were investigated by BAIHP, seven in Florida, one in Texas, and two in Georgia.

In May 2003, FSEC researchers were asked by Fleetwood and Coleman to travel to Fleetwood's five southeastern plants and test three homes built by each factory to get their plants certified for building ENERGYSTAR Homes. A sample of the data collected is shown in Table 15.

At the Auburndale, FL plant, BAIHP researchers conducted the tests in houses set up in the factory's parking lot. The houses did not have air handlers, but total duct leakage was within range to achieve Fleetwood's goal for this plant which was to build houses according to the EPA EnergyStar Building Option Packages (BOPs) for manufactured housing, Climate Zone 4, and to attain a less than 5\% duct leakage rate (Qn,total\#5\%). The houses showed some need for additional envelope sealing which was implemented after the first house was tested. The other two houses showed marked improvement in whole house air tightness. Recommendations and test results were provided to Fleetwood via email (no formal trip report). Similar testing was conducted at the Georgia Fleetwood factories in Willacoochee, Pearson, Douglas, and Alma.

Table 15 Test Results, Factory Certification at Fleetwood's Auburndale facility

\begin{tabular}{|c|c|c|c|c|}
\hline House \# & Size & ACH50 & $\begin{array}{c}\text { Estimated natural } \\
\text { ach (ACH50/18) }\end{array}$ & $\begin{array}{c}\text { Qn }_{\text {TotaL }} \\
\text { (CFM25 }\end{array}$ \\
\hline 1 & 24 X 48 & 8.7 & 0.48 & 0.031 \\
\hline 2 & 28 X 52 & 5.5 & 0.31 & 0.034 \\
\hline 3 & 28 X 52 & 5.5 & 0.31 & 0.029 \\
\hline
\end{tabular}


After being asked to participate in a Corrective Action Team by Fleetwood Regional VP Charles Stapleton to address moisture related building failures and steps the factory could take to alleviate them, a trip to evaluate the factory's assembly methods was undertaken in October of 2005. At that time the entire regions' production capacity was dedicated to FEMA relief house manufacturing. This allowed for examination of their floor duct systems, but no overhead duct systems were on-line at that time. The four Georgia factories (Alma, Pearson, Douglas, and Willacoochee) were revisited, with specific emphasis on overhead duct manufacturing. Spot testing of overhead duct systems was carried out. Factory production managers and quality control people participated, and factory floor workers were trained on the spot when problems were found. A report addressing the specific opportunities for improvement in production and quality control was generated, but only distributed internally and to Fleetwood management. Illustrated, detailed assembly instructions for assembling overhead and floor ducts, tailored to the factory, were sent to Fleetwood management.

The list of factory corrective steps to be made to reduce or eliminate moisture based floor and wall failures are:

- No vinyl on walls, find paper covered product

- Air tight duct work factory tested

- No oversized A/C systems

- Preset blower speed lower

- Better diffusers

- Better return air paths

- Seal belly board

- Vent dryer to outside at factory

- Dealer training

o Over vent crawl space

o Install ground cover

o "Turtle mound" of soil dirt mounded under the house with a turtle shaped profile, to promote drainage under house

\section{Fleetwood FEMA Homes}

In September of 2004 BAIHP researchers tested and inspected single-wide homes built by Fleetwood under contract with the Federal Emergency Management Agency (FEMA) to identify possible areas of moisture-related damage and provide recommendations to mitigate problems.

These homes were destined for victims of hurricane Charley in Southwest Florida. Various singlewide floor plans were constructed with the typical size being $14 \times 66$, several of which were tested for duct and envelope tightness. Other construction specifics include:

- In-line, metal floor duct system with 1 or 2 short branch ducts

- Duct risers sealed with mastic

- Branch duct joints sealed with mastic, then covered with metal tape

- Down flow gas furnace installed in central hallway

- Large door undercuts plus small door-mounted return vent in bedrooms

- Central exhaust fan ventilation strategy

- Vinyl interior wallboard throughout

- Vinyl exterior siding 
FEMA-required specifications that differ from typical Fleetwood design include:

- Vinyl flooring throughout

- Double floor decking ( $1 \frac{1}{2}$-inch OSB over $1 / 2$-inch plywood)

- R22 floor insulation

- "Chicken wire" installed below the belly board

- $80 \%$ AFUE, $70 \mathrm{kBtu}$ gas furnace with no cooling installed

- FEMA provides a 2.5-ton split system (coil \& condenser) to be installed on-site

o Goodman CKL30-1L condenser \& Mortex 96-842J-OP A-coil

\section{Cooling System and Air Handler Issues}

The immediate concern with these homes is the FEMA-provided cooling system that, at 2.5 tons, may be oversized for the application. This, coupled with the fact that a vapor barrier is located on the wrong side of the exterior wall and floor assemblies, increases the potential for moisture damage to those surfaces. Other issues that can impact the moisture durability of these homes are addressed below, but initial envelope and duct test results indicate no immediate cause for concern.

A properly sized cooling system should be an integral part of any strategy to mitigate moisture damage in a hot humid climate. We recommend using the latest version of Manual $\mathrm{J}$ calculations to determine proper cooling system size and it appears these homes may be oversized by as much as one ton. Oversized systems are prone to short-cycling for much of the year which tends to cause higher indoor humidity levels than properly-sized systems.

Another issue with an oversized system is it allows homeowners to maintain lower indoor temperatures than might otherwise be possible. Maintaining indoor temperatures below the outdoor dewpoint can lead to moisture damage over time especially in homes with interior vapor barriers (vinyl floor and wallboard). Average summer ambient dew point temperatures in Southwest Florida are in the low to mid-seventies.

Beyond reducing the cooling system size, some benefit can be gained from adjusting the air handler fan speed in cooling mode and adding outdoor air ventilation. Lower airflow over the coil will remove more moisture, help to reduce indoor RH levels and possibly encourage higher thermostat settings by the occupant. Adding a passive supply (not more than 40CFM) of outside air to the return side of the air handler will promote positive pressurization of the home which may lessen the likelihood of moisture damage to wall and floor assemblies.

\section{In-Plant Construction}

Metal duct fabrication was observed during production where mechanical fastening and sealing methods appeared suitable for a tight durable system. Duct ends and branch duct joints were first fastened with screws then mastic was applied by tube. Metal tape was placed over the mastic (shown below at top right). This method produced tight duct systems as demonstrated by the 3 to $4 \%$ leakage rate found in four completed homes. 
The continued use of mastic is encouraged for a long-lasting, positive seal. While there is little harm in using metal tape over mastic it does not provide much additional sealing. One possible drawback of tape over mastic is that it may hide gaps that could otherwise be seen and corrected by workers. Applying mastic alone by brush should prove adequate and less costly. A fabglass mesh is useful when applying mastic by brush to cover any large gaps that may occur.
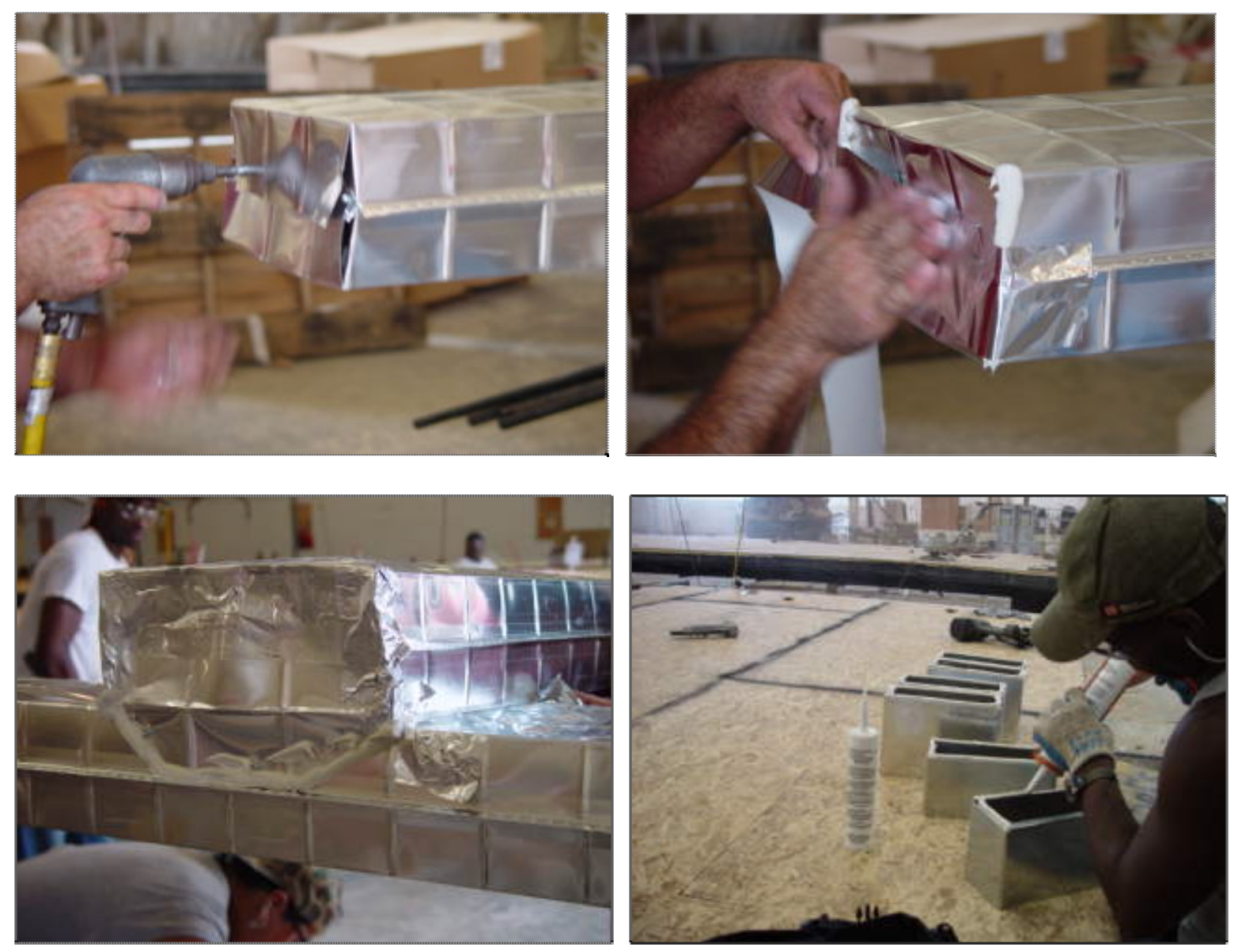

Figure 18 Metal duct fabrication on FEMA homes, Fleetwood plant - Douglas, GA

A bead of mastic was applied to supply risers (Figure 18 bottom right photo) prior to being attached to the trunk line with screws. Once the riser was attached an opening in the trunk line was cut out. The same method was used for the return plenum riser. This method can provide a positive seal when adequate mastic is applied - not always certain from observations on the production floor. Although testing showed four such systems to be fairly tight, some leakage at the risers was evident at the interface of the thin metal of the trunk and riser collar where unfilled gaps where found.

To prevent leakage at risers, mastic should be visibly squeezed out at the interface when attached. The mastic bead should be $1 / 2$ to $5 / 8$ inch in diameter (size of your little-finger) to allow full contact between surfaces. 


\section{Post-Production Testing}

Four newly completed singlewides (all 14x66) were tested at the Douglas plant. Total duct leakage was measured on all homes but only two homes were measured for envelope tightness and duct leakage to out.

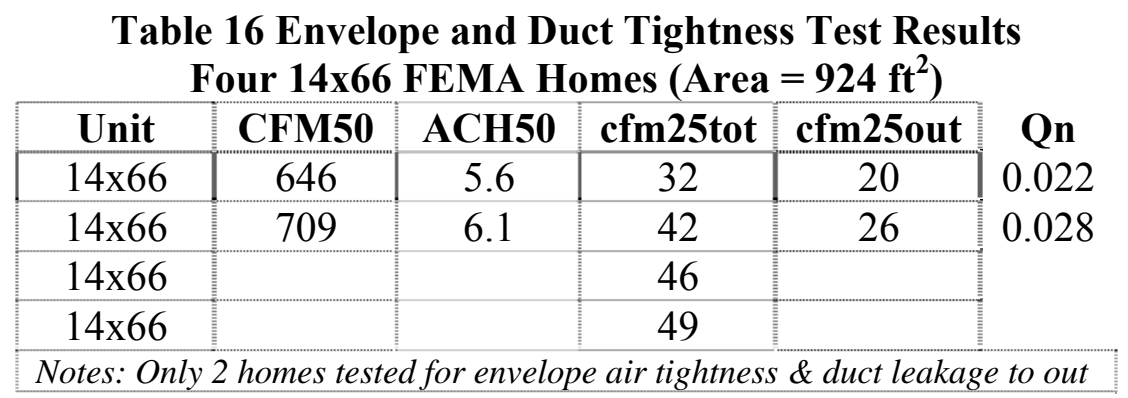

Blower door testing showed the envelope on the tighter side $\left(0.73 \mathrm{CFM} 50 / \mathrm{ft}^{2}\right)$ of the air tightness range typically found in new homes $\left(0.75\right.$ to $\left.1.0 \mathrm{CFM} 50 / \mathrm{ft}^{2}\right)$. Of greater importance is where this leakage occurs. With sheet vinyl flooring installed throughout these homes, air leakage through the floor is the biggest concern. A history of floor moisture damage has been documented in manufacture homes located in hot/humid climates where vinyl products are installed. Increased air leakage between the floor and belly has greater potential to force outside air into the belly should a negative pressure situation arise in the home (caused by duct leakage and/or inadequate return air transfer). Both the interior floor surface and the exterior belly board should be sealed as tightly as practicable. Plumbing penetrations make up most of the holes through upper floor surface and can be difficult to seal. One simple option currently being used by the Fleetwood plant in Washington state involves the use of a EPDM rubber sheet cut to fit plumbing pipes and stapled in place prior to vinyl flooring installation, providing a durable, flexible seal

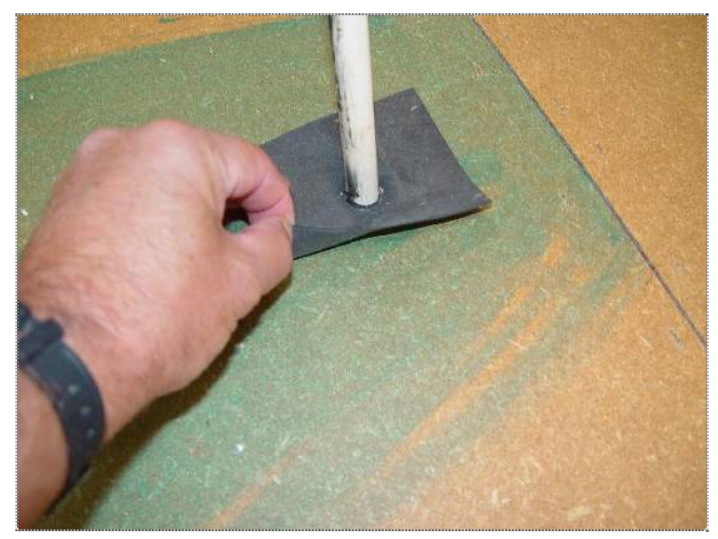

Figure 19 Rubber seal - Washington Fleetwood plant

(Figure 19).

One 14x66 home was tested for interior pressure imbalances by turning on the air handler fan. Depressurization of the interior space can occur if duct leakage is excessive or insufficient return air pathways exist between rooms with closed door. No detectable depressurization was measured during the test indicating sufficiently tight ducts and adequate return air pathways from closed rooms.

Duct system air tightness testing showed four systems in 14x66 singlewide homes to have duct leakage rates to out of between 2 and $4 \%$ of conditioned floor area at 25 Pascals. A value of $3 \%$ is generally considered sufficient to inhibit negative pressurization of the conditioned space. Leakage to out was directly measured in the first two test homes at 2 and $3 \%$, while the last two homes were judged to be slightly higher as inferred by the measured total leakage rate. While 
these leakage numbers are good, only a small amount of leakage is necessary to dramatically increase the leakage percentage in homes of such relatively small size.

There are three general areas in these duct systems where leakage is likely to occur:

- End of duct runs

- Trunk to branch connection

- Supply risers and the air handler supply plenum

The first two of these areas were isolated and tested by duct blaster in the plant on a newly fabricated system prior to installation in the home. This particular duct system had only one branch connection whereas the four previously tested homes had two branches. Results showed a leakage rate of about 8-10 CFM at 25 Pascals, attributed to two closed duct ends and one branch to trunk connection. This would indicate that on the four duct systems tested earlier (with two branches each), roughly one-half to two-thirds of the leakage to out (20 to 30 CFM50) occurs at duct ends and branch connections with the remainder occurring at the risers and plenum.

Fleetwood Crawl Space Analysis In May of 2006 BAIHP researchers simulated crawlspace performance of various floor types primarily to assess Fleetwood undercoating against uncoated floors. A report was submitted to Fleetwood.

\section{Fort Lewis Military Housing, Champion Homes, Equity Residential} Washington (state)

Category B: 86

In 2004 Champion Homes was chosen by Equity Properties to provide house components for up to 850 modular homes to be used as base housing at Fort Lewis in western Washington State. Equity made the decision to use modular due to the large number of units going up at one time, and significantly drier conditions inside the factory to minimize moisture and mold damage during construction.

Fort Lewis was one of the first four bases in the country to privatize its housing in response to the Military Housing Privatization Initiative established by Congress in 1996. This is the first military base project for Equity Residential, which is one of the country's largest real estate investment trusts, with more than 225,000 units nationwide according to Lucas

During the seventh budget period, WSU, ODOE, Equity, and Champion, working with PNNL, completed a Ft. Lewis case study, which is featured in the Building America Marine Climate Best Practice Guide.

The homes will feature:

- Insulation Package: R21 walls, R33 floors, R38 loose fill cellulose in ceilings

- Double pane- low-E, vinyl framed windows with a U value of 0.35

- Metal, foam core exterior doors with thermal break and U value of 0.2 doors.

- $90 \%$ AFUE condensing natural gas furnace located in mechanical room

- R8 Ducts

- Ducts tightness target: Qn,total $\leq 6 \%$ (field tests indicate tighter). 
- Envelope air tightness target: ACH50 $\leq 7.0$ air changes (field tests indicated tighter)

- Power vented (for combustion safety) natural gas water heater $E F=0.61$

- Crawlspace Ventilation: Humidity controlled, fan in vented crawlspace

- Whole-house Ventilation: Quiet exhaust fan in central hallway.

- ENERGY STAR compact fluorescent lamps (CFLs) in 50\% of fixtures

- ENERGY STAR Dishwasher.

Initial testing and duct leakage estimates by the WSU Energy Office using Energy Gauge software showed that the energy-efficient homes would use 377 therms/year for space heat, compared to similar standard construction homes, which were estimated to use 442 therms/year for space heat, resulting in possible net savings of 65 therms per year.

\section{GreenStone Industries}

Woodland, Washington

Industry partner Greenstone has been working with BAIHP staff and SGC/E-STAR manufacturers to evaluate a hybrid floor insulation system. These systems, composed of one R11 belly blanket and R-22 blown cellulose insulation eliminates over-compression and reduces the chance of leakage during transport and set-up, while minimizing material and labor costs. Fleetwood Homes of Washington adopted this system for all of their homes in 2001. Other manufacturers have adopted the hybrid floor insulations system, which provides less insulation voids and reduces first cost of R33 floor system over 3-R11 fiberglass batts. One potential consequence of using the hybrid system is increased moisture in the belly; in 2003, BAIHP staff installed data loggers in two homes to determine whether this is a problem; after the data loggers were retrieved in 2004, BAIHP staff submitted a report to Fleetwood suggesting no dew point problems within the floor system (Figure 20).

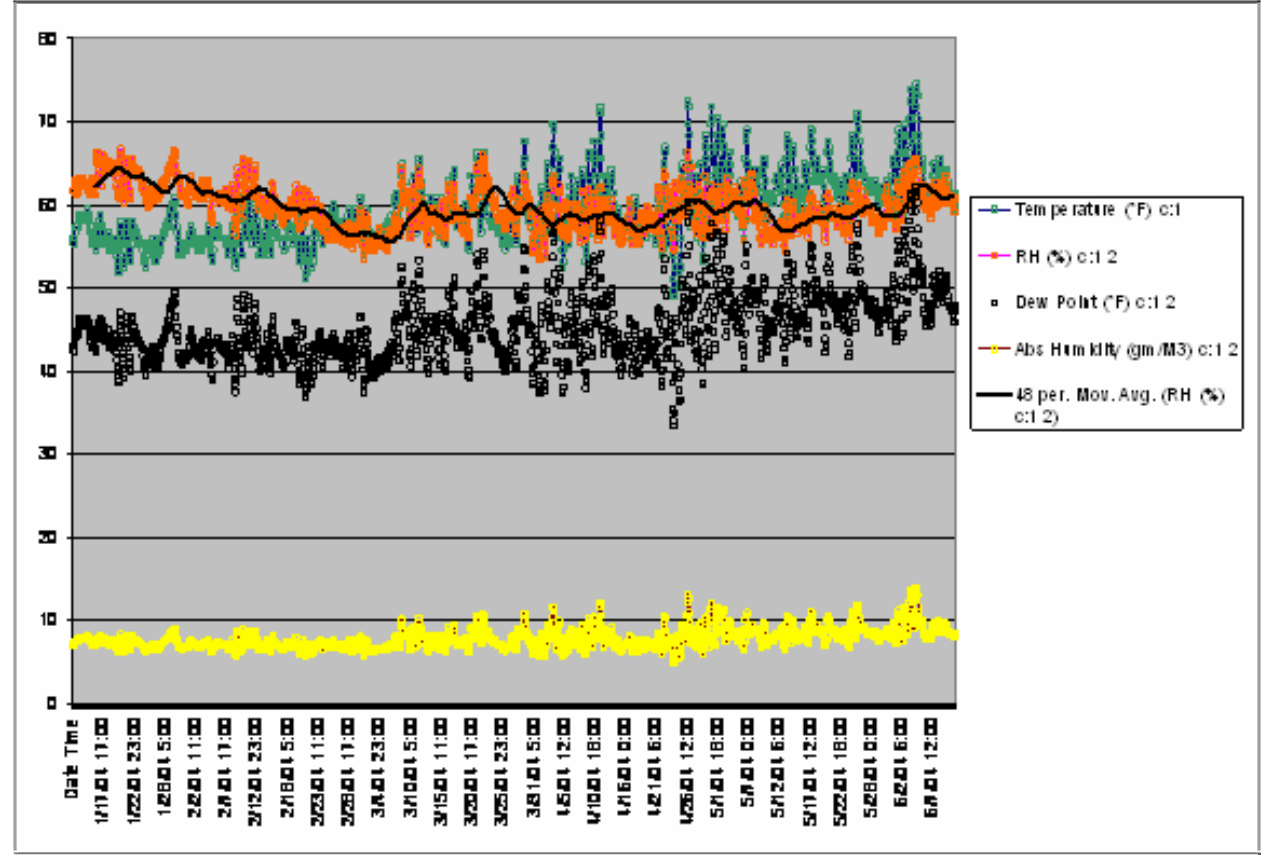

Figure 20 Temperature and Dew Point Under Hybrid Floor Decking 
Florida International University, 2005 Solar

Decathlon

Miami, FL

FSEC provided technical assistance to FIU (Florida International University) for the 2005 Solar Decathlon (http://www.eere.energy.gov/solar decathlon/). An introductory meeting was held at FSEC in October 2003. Subsequently, a design competition was held among FIU students and the team (Figure 21),

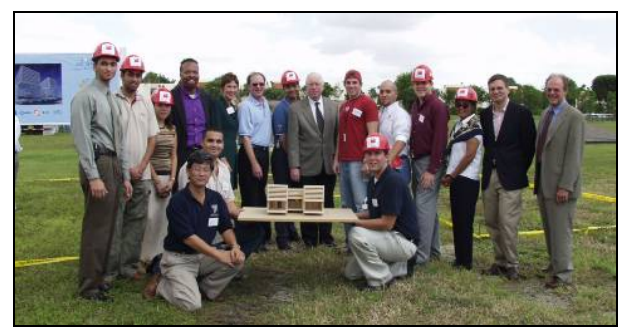

Figure21 FIU Solar Decathlon team with model of house. comprised of architecture and engineering students, merged the 10 winning designs into a single conceptual design. In April, the team met with BAIHP researchers at FIU to review the schematic drawings and model.

Researchers discussed strengths, weaknesses and technical needs of the schematic design including cooling loads and strategies for mitigating each (reflective roofing, advanced glazing, shading, ventilation, point source moisture exhaust, etc.), building integrated solar (PV) systems, solar water heating, mechanical system design, energy storage, construction challenges, and the aesthetics of energy efficiency. Students planned to use ray tracing capability of the CAD tools that they are already using to study shading and daylighting.

Design development continued during the summer of 2005. Researchers reviewed the overall project and assisted with specifics for the solar thermal and photovoltaic systems. Feedback was provided for the photovoltaic system electrical schematic drawings that were in development for the installation. Students worked together to build their design, disassemble it transport it to Washington DC, and set it up on the National Mall in October of 2005 (Figure 22). The FIU team ranked $13^{\text {th }}$ out of 18 entries, with high marks awarded for Architecture, Dwelling, and Energy Balance categories. Visit the team's website at http://htd.fiu.edu/fiusolar/index.html

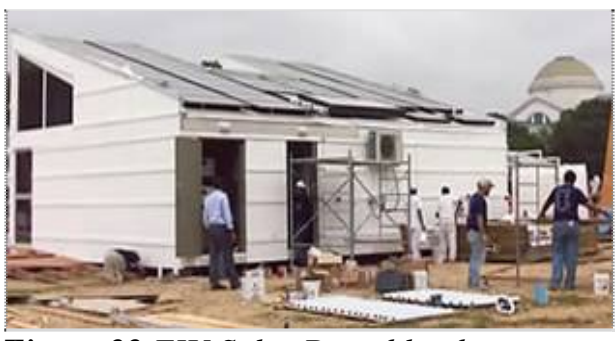

Figure 22 FIU Solar Decathlon house. South facing façade (above) and north facing façade below.

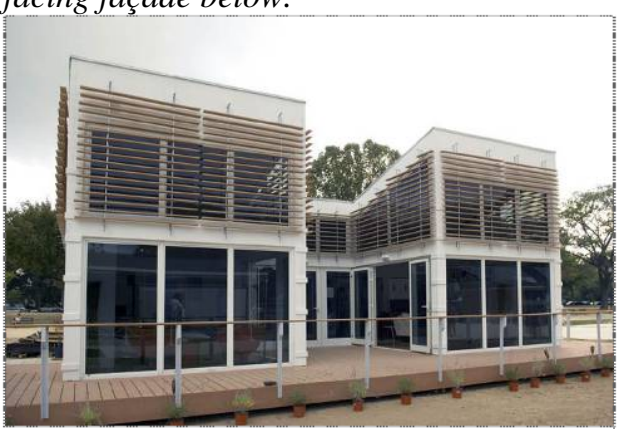




\section{G.W. Robinson Builder/Developer \\ Gainesville, Florida \\ Category A}

Cobblefield community: Build out 265 homes, 241 built

Turnberry Lake community: Build out 186 homes, 30 completed

Despite the recommendation of a market survey, it was this developer's desire to build the healthiest, most energy efficient and "Green" subdivision possible for move up buyers within reasonable financial constraints. Typical home sizes in the Cobblefield and Turnberry Lake communities (Figure 23) are 2,500 to 3,500 square feet with a selling price of $\$ 300,000$ to $\$ 400,000$. Homes implement right sized 12+ SEER air conditioners; engineered air distribution system; double pane low-E windows; radiant barrier; air handler located within the thermal envelope; programmable thermostat; cellulose insulation, passive outside air and new quality assurance procedures.

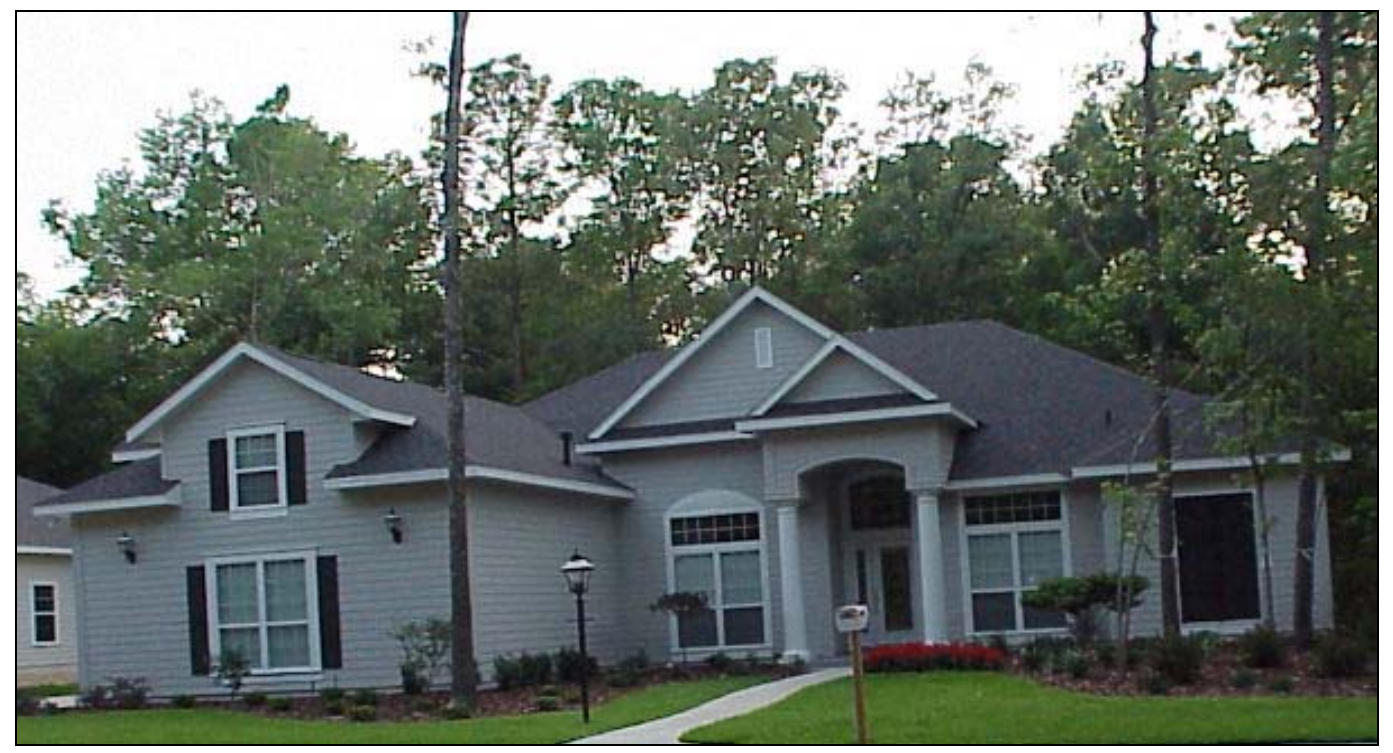

Figure 23 Home built by GW Robinson, Gainesville, FL

While recognizing that a home's most significant environmental impact will be the energy needed for its ongoing operation, this builder also addressed the issues of durability, health, maintenance, landscaping and irrigation. To enhance durability each home is treated with BoraCare ${ }^{\circledR}$, a termiticide whose active ingredient is Disodium Octoborate Tetrahydrate (DOT), which is a mixture of borax and boric acid. A 50+ year cementitious lap siding is installed over a continuous drainage plane. The entire exterior of the home receives three coats of paint which carries a ten year warranty. Thirty year architectural shingles have been selected.

To help insure better indoor air quality low volatile organic compound (VOC) paint is used in the interior, all gas burning fireplaces receive outside combustion air and all rigid duct board material used in the distribution system is a coated style to help separate the air stream from any raw fiberglass. Where applicable, alkaline copper quaternary (ACQ) wood is used, which is arsenic and chromium free. 
After protecting wooded areas whenever possible, homes are landscaped with drought tolerant indigenous species which are grouped according to their watering needs. No islands of turf are created. Irrigation is provided through a municipal reclaimed water system where water that would normally be discharged via a deep well injection system is routed to the subdivision to meet the irrigation needs. It is important to note that this service is being provided to homeowners by the developer for $\$ 10$ a month while a homeowner who uses the potable water for irrigation often pays $\$ 40-50$ a month.

This initial broad based adoption of the high performance specifications provided the opportunity to develop formal scopes of work for each of the different subcontractors, with consideration of the interrelationship of the different components and trades. At the completion of the framing of the model center at Cobblefield, a "Team" meeting was held at this venue. In attendance was the builder, all senior office staff, the project real estate agents and representatives or owners of all subcontractors. The builder's goals, objectives and expectations were clearly articulated with the opportunity for the Team to ask questions.

In spite of the real estate agents' concern of the increased price per square foot, this BA partner chose to move forward with his vision and was rewarded by market acceptance of his high performance homes. This BA partner's success with the program has resulted in an increased level of performance for his latest subdivision, Turnberry Lake (build out 186 homes, 30 completed so far) where homes feature: 14 SEER air conditioners, 0.93 AFUE sealed combustion natural gas furnaces with variable speed motor located within the thermal envelope; natural gas instantaneous water heaters, and double pane vinyl frame windows with SHGC of 0.28. See Table 1.

All of the homes built by this builder achieve a HERS ' 99 score of 88.6 or better and qualify for the $\$ 2,000$ Federal Energy Tax Credit. All homes are individually performance tested as part of a commissioning process. These homes are calculated to have whole house energy savings in excess of $30 \%$ as calculated by the BA benchmark methodology.

The Systems Engineering And Commissioning Process.

The BA integrated systems engineering approach was used in both of these examples to optimize the performance of homes within a financial framework which enhanced the builder's profits. Our approach is that upon receipt of a floor plan, elevations and specifications for a home, we begin by reviewing the materials and characteristics to determine if there are opportunities for improvements within the context of the design. An example would be to recommend that an air handler be enclosed to bring it within the thermal envelop of the home or using low-E windows. Then a room-by-room ACCA Manual J load calculation, using Elite Software RHVAC8, is performed to determine the heating and cooling equipment size. Next, a duct system is designed using the Elite Ductsize software, which is based on ACCA Manual D criterion. Finally the duct system is drawn on a full size print. All software is continually updated. Site visits are conducted to assure quality, e.g. air barrier continuity and duct system layout without kinks. Upon completion, seven performance tests are conducted:

- A computerized multi point whole house air tightness depressurization test is performed using the Energy Conservatory Automated Performance Testing (APT) equipment. The pressure of the house with respect to the attic is performed concurrently. 
- A Duct Blaster ${ }^{\circledR}$ is used to perform a duct air tightness depressurization test and quantify duct leakage (cfm25 total and cfm 25 to out).

- The home is pressure mapped using a digital manometer. All rooms with doors that can isolate them from the main return pressures with reference to the house are measured with the air handler operational, and the pressure that the home operates under with reference to the outside is measured.

- The flow of the outside air intake is measured using the Energy Conservatory Exhaust Fan Flow Meter and the damper is adjusted as required to insure that the house is operating under positive pressure with reference to outside when the air handler is operating.

- A digital manometer and static pressure probes are used to measure the pressure that the air handler is operating under and expressed as inches of water column (IWC).

- The temperature difference (delta T) across the coil is measured using digital thermometers.

- The flow of all bath exhaust fans is measured.

House characteristics such as make and model of the air handler and condenser section, water heater size, energy efficiency of appliances, and lighting types are noted and reported to the builder using a form entitled "Home Energy Rating Report" which also notes areas of deficiency. Meeting with the trades and training often occur to correct deficiencies - a hallmark of the systems engineering approach.

\section{Florida Green Building Coalition}

"Green" or sustainable housing is defined as energy efficient housing with added features such as disaster resistance, improved indoor air quality, universal design, resource efficient products and materials, and low water landscaping. BAIHP collaborates with the Florida Green Building Coalition (FGBC), and other organizations to develop or define green home standards, participate in educational programs, and assist in demonstration houses and related activities.

BAIHP staff has been extensively involved with the Florida Green Building Program administered by the Florida Green Building Coalition (FGBC), Inc. (www.floridagreenbuilding.org). The intended result of this involvement has been to create Building America homes that include additional "green" or sustainable attributes like those listed above, and to promote the incorporation of various Building America principles to the home building community at large.

The primary tool used to incorporate "green" concepts into homes built by BAIHP partners is the Florida Green Home Designation Standard, developed and maintained by the Florida Green Building Coalition, Inc. with significant support and technical assistance from BAIHP staff. Select BAIHP partner builders have constructed homes that have achieved the designation in this budget period including G.W. Robinson and WCI Communities. Since the inception of this standard, WCI Communities has constructed over 100 homes that meet this standard, including two showcase homes to educate the public about the benefits of green construction. In addition, the Palm Harbor Homes Showhouse and the Not So Big Showhouse for the 2005 IBS were each certified under this program. In all homes, BAIHP staff assisted with outreach, implementation, 
and certification. The standard has been incorporated in affordable homes, with several achieving the designation.

The standard also has proved useful to other Building America teams when they work with Florida partners who are interested in achieving green and sustainable housing. One example is the Lakewood Ranch community in Sarasota/Bradenton, FL, which recently began requiring all builders to build all homes to the Florida Green Home Designation Standard. Much of the technical assistance has been provided by CARB (Consortium for Advanced Residential Buildings), but FSEC staff has been involved with each builder to ensure minimum requirements are achieved, and to assist with development of submittal packages.

Florida city and county governments have begun to incorporate this standard into the permitting process to offer incentives. The City of Gainesville was the first, passing an ordinance allowing certified properties half price permit fees and free fast track permitting. Sarasota and MiamiDade County have similar ordinances.

BAIHP staff developed and delivers training to individuals interested in how to use the Florida Green Home Designation Standard to achieve the outreach, implementation, and certification phases of green housing. The course has been taught at least biannually since 2001 and attendance averages continue to grow. The course is now required by the Florida Green Building Coalition for anyone aspiring to certify homes to the Florida Green Home Designation Standard. Several builders and subcontractors have also attended the class to gain insight on green construction. Sarasota County building officials are now offered a salary incentive for completing the course.

Also during the sixth budget period, BAIHP staff contributed an article as part of a "green series" for the Florida Real Estate Journal in the Orlando Sentinal.

During the seventh budget period, BAIHP staff continued to be active in the FGBC including conducting FGBC Certifier training, participating in committee work, and developing guidance for incorporating the new Energy Star program criteria into the existing FGBC Green Home Standard and certifying three IBS Show Homes as Green Homes under the FGBC Standard. BAIHP has four researchers certified to conduct such evaluations.

BAIHP staff also built on previous involvement the LEED Homes Committee of the US Green Building Council. In June 2005 FSEC / BAIHP was selected as a LEED Homes Program Provider for Florida during the pilot implementation phase of the newly drafted LEED Home Standard. Providers are expected to interact with 3-4 builders and certify approximately 1-12 homes during the pilot. BAIHP partner Royal Concrete Concepts has certified one of their homes in Pt. St. Lucie (FL) Florida under the LEED Homes pilot standard, with FSEC coordinating ACCA Manual J and Manual D calculations, which are part of the requirements. Calcs-Plus will be performing the Manual $\mathrm{J}$ and $\mathrm{D}$ calculations.

BAIHP members are currently developing a certification path that suits the affordable and volunteer friendly nature of Habitat for Humanity and affordable housing home builders. In March 2005 BAIHP members met with representatives from partner Lakeland Habitat for Humanity to discuss their involvement in the LEED for Homes program. The primary motivator 
for the affiliate is the potential for environmental designations to increase their competitiveness when applying for grants.

In the seventh budget period, work continued with the Enterprise Foundation to implement the national Green Communities program in Florida, whose goal is to help non-profit developers build "green" by supplying low-cost loan capital, funding and management tools.

In 2005-06, BAIHP also organized and moderated a conference session on Green Products and Processes at the $3^{\text {rd }}$ annual statewide GreenTrends conference in May of 2006. Participating speakers included a representative from the Palm Harbor Homes' Plant City plant and a representative from Royal Concrete Concepts (LEED Home pilot participant), and a representative from Resolution 4 Architecture, a design firm that has developed the "Modern Modular" concept - a systematic methodology of design that leverages existing methods of prefabrication and results in high performance residential construction. Each speaker discussed how prefabrication methods are leveraged to create high performance green products.

\section{Habitat for Humanity-BAIHP Partnership}

Americus, Georgia (HFHI) and Habitat affiliates nationwide

Category A, 11 Homes (Lakeland HFH)

Category B, 446 Homes

Category C, 260 Homes

Papers: $\quad$ Case Study: 2003 Jimmy Carter Work Project, LaGrange Site

Case Study: Florida Habitat Homes in Lakeland, Broward and Alachua Counties

Case Study: Houston Habitat for Humanity

Beal, David and Janet McIlvaine (2006.) "Energy and Indoor Air Quality

Recommendations for Cold Climate Habitat for Humanity Homes.” FSECCR-1647-06, Florida Solar Energy Center, Cocoa, Florida. August 2006.

The Building America-Habitat for Humanity partnership, formed in 1995 at Habitat's Environmental Initiative Kickoff, has brought BAIHP into the design, construction, and evaluation process of over 600 Habitat homes across the nation built by 50 Habitat for Humanity affiliates in more than 20 states. BAIHP activities with Habitat (including those conducted under the Energy Efficient Industrialized Housing Project) are listed in Table 19 (page 61). Activities generally fall into three categories:

I. Technical Assistance to Habitat for Humanity International (HFHI), high profile HFHI projects (Congress Building America, Builders Blitz, and Katrina Recovery, and HFH affiliates (local chapters)

II. Research

III. Training at regional and national HFH conferences

Introduction: BAIHP energy efficiency recommendations for Habitat homes all meet the following four criteria in increase likelihood of sustainable change and to ensure a good fit with Habitat's construction process and business model:

- Proven reliable and cost effective

- Volunteer friendly

- Readily available in current market

- Easily maintained and repaired by normal trades 
Since the inception of FSEC's partnership with Habitat, researchers have been privileged to work along side some of America's brightest building scientists representing SouthFace Energy Institute, Oak Ridge National Laboratory, National Renewable Energy Laboratory, contractors with the California Energy Commission, the Alliance to Save Energy, various electric and multifuel utilities, members of Habitat's own Green Team (defunct in 2004), and volunteer members of the Energy Efficient Building Association. In 2005, BAIHP and Habitat partnered with RESNET to team volunteer Home Energy Raters with Habitat affiliates in HFHI's Congress Building America Program (more information on this project below), expanding that partnership in 2006 to include all interested Habitat affiliates.

Partially because of Building America (and other DOE supported organizations) involvement with Habitat over the past 10 years, HFHI adopted Energy Star as one of their two Best Construction Practices for all U.S. affiliates. Best Practices are used to evaluate affiliate status. This represents a major commitment to energy efficiency from the highest ranks of Habitat International. Affiliates are encouraged to consistently achieve Best Practices and the requests for and prevalence of Energy Star ratings for Habitat affiliates has surged as a result.

I A Technical Assistance to Habitat for Humanity International (HFHI), high profile HFHI projects (Congress Building America, Builders Blitz, and Katrina Recovery, and HFH affiliates (local chapters)

Congress Build America (CBA) (February 2005 - June 2006)

Background: In February of 2005, BAIHP researchers announced DOE's Building America partnership with Habitat for Humanity International's (HFHI) Congress Building America (CBA) project. The announcement was made at the dedication of Almost Heaven's CBA house (Figure 24) which was built in partnership with Shelley Moore Capito, United States Representative second congressional district of West Virginia. Identical concurrent resolutions--Senate Concurrent Resolution 43 and House Concurrent Resolution 184 express the Congressional support of this project.

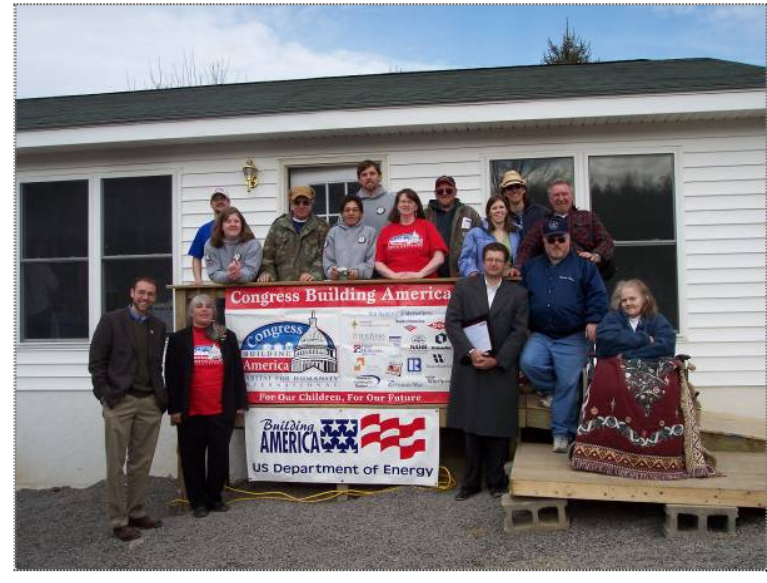

Figure 24 Almost Heaven Habitat for Humanity' Congress Building America house on day of dedication.

The memorandum of understanding between the affiliates and the HFHI includes language making the Building America technical review part of the standard process. All CBA affiliates were invited to submit designs to BAIHP researchers for evaluation. Researchers expected to conduct about 30 evaluations based on an expected response of $30 \%$ of the projected 100 houses to be built under the program.

Actual construction of CBA houses fell dramatically short of this 100 house expectation due to a nationwide re-direction of effort to support the Gulf Coast Recovery (see next section for more info) and to participate in another HFHI program called the Builders Blitz. 
CBA-BA Partnership Kick Off: After announcing the CBA-BA partnership formally in West Virginia at the dedication of the first WV CBA house (February 2005), researchers attended HFHI's Urban Conference in Washington D.C. where they talked about the technical support being made available to Habitat's CBA affiliates (and other affiliates). Response was very positive. Mr. Edward Pollock and George James attended a CBA luncheon and addressed the group with an introduction into Building America and our systems engineering approach.

CBA Communications: A database populated with 226 stakeholders including Habitat affiliates and congressional staff members. Researchers use the CBA database for tracking communications, technical assistance, and progress. In 2006, BAIHP began expanding this database to include all HFH technical assistance activities.

All of the CBA affiliates received two information packages, one in the Spring of 2006 and one in the Winter of 2006. Packages included information on shared goals of CBA and U.S. DOE BA program, resources available to CBA affiliates, a "Partnership Updates," and an offer of BA technical assistance. Three affiliates responded with interest to the first package with requests for assistance. Package 2 was an update of CBA-BA activities based on field visits with CBA affiliates in Michigan in June.

Congressional members and their staff members specializing in housing and energy issues also received both packages as well. A separate package was sent to all five Building America teams. BAIHP staff visited the office of Senator Bill Nelson, a native of Brevard County, home of the Florida Solar Energy Center, and met with Ms. M. Bridget Walsh, Deputy Legislative Director, introducing her to Building America program and encouraging Senator Nelson's office to participate in the Congress Building America project.

CBA-BA-RESNET Partnership: BAIHP worked with Steve Baden at RESNET to recruit volunteer raters for the effort. RESNET issued a "Call for Volunteers" in their newsletter in April and in May posted an article about the partnership on their website along with material that McIlvaine developed to explain the partnership to the RESNET volunteers. Response has been very strong and several dozen RESNET members volunteered within the first month. Materials describing the benefits to RESNET volunteers are online at: http://www.baihp.org/casestud/hfh partner/index.htm In 2006, RESNET and HFHI decided to expand the partnership beyond CBA to accommodate those volunteer raters outside the CBA affiliate areas.

CBA Plan Packages: The Building Science Consortium developed full plan packages with complete sets of building plans (per Mr. Garman and Mr. Pollock's request), including building science. BAIHP reviewed the plans specifically for volunteer friendliness. The packages are available free online at www.buildingscience.com (search for "Affordable House Plans" or "Congress Building America"). Habitat International is strongly supportive of this effort, and has regularly recommended that affiliates review the materials.

CBA-BA Partnership Website: A map of all CBA affiliates is posted on http://www.baihp.org/casestud/hfh partner/index.htm along with a summary of the partnership, a link to request more information, an activities update and other communication pieces. An update of BA-CBA activities has been added to that web page and was distributed to all participants in CBA. 
Certificates of Recognition: CBA affiliates partnering with Building America received Certificates of Recognition (approved by DOE). Affiliate staff showed a surprising interest in them and seemed genuinely pleased to receive them.

CBA Restructuring: HFHI recently announced that the CBA program would be restructured. BA staff awaits details of the changes but plan to continue working with these progressive affiliates to demonstrate achievable energy efficiency in affordable housing - setting an example for the whole building community.

CBA Michigan Affiliates: While in Michigan for the 2005 Jimmy Carter Work Project, researchers met with five other CBA-HFH affiliates who (in addition to Harbor Habitat) responded to BAIHP's initial mailing with interest in partnership:

- Kalamazoo Valley HFH in Kalamazoo, MI

- HFH of Lansing in Lansing, MI

- $\mathrm{HFH}$ of Monroe County in Monroe, MI

- Blue Water HFH in Port Huron, MI

- Lakeshore HFH in Holland, MI

A Congress Building America contract report was written summarizing the findings of these visits with recommendations and best practices. The report was distributed all the affiliates, HFHI staff, and the Michigan Habitat Association, a statewide support arm of HFHI, who requested parametric analysis for use with their energy efficiency grant program.

\section{HFHI Builders Blitz}

The Builders Blitz program grew exponentially during the 2005 and 2006 projects. Designed to draw the local building community into Habitat partnership, the program teams local home builder associations (HBAs) with local HFH affiliates. The HBA works out a sponsorship scheme with its members who usually chip materials, sub-contractors, site supervision, and volunteers. The affiliate generates local press coverage and introduces the whole group to the Habitat building process. BAIHP supported two affiliates participating in the Builder Blitz in the summer of 2005 and 2006 through sub-contractors Calcs Plus in Venice (FL) and Guaranteed Watt Saver in Oklahoma City (OK). Calcs Plus produced HERS '99 ratings, Manual J and D calculations for two Energy Star houses in the summer of 2005 and three houses in the spring of 2006. GWS produced the same for 10 homes built by the affiliate in Oklahoma City in the summer of 2006. In the future, BAIHP will invite more Builder Blitz affiliates to participate in BA activities.

Gulf Coast Recovery Effort, Recommendations for Rebuilding (September 2005- June 2006) In the weeks following Hurricane Katrina, HFHI staff called on BAIHP for assistance with a variety of concerns including guidelines for safely reoccupying homes, minimizing moisture damage, and priorities for deconstruction and reconstruction.

Initially, BAIHP provided Energy Star ratings and two Building America packages for HFHI's first design for rebuilding. BAIHP's major contribution to the recovery effort was support to HFHI's Department of Construction and Environmental resources and HFHI's Operation Home Delivery (OHD), a new department set up to handle Gulf Coast rebuilding activities. 
Researchers participated in vigorous discourse about how Habitat should rebuild, responding to in excess of 1000 emails from HFHI staff, HFH affiliate staff, and other building scientists involved with the recovery effort including DOE's Katrina Informal Green Working Group.

BAIHP completed and delivered energy analysis comparing typical Louisiana construction specs to the new HFHI minimum standards. Annual energy use, HERS ' 99 ratings (1999 and 2006), IECC compliance were calculated for each of HFHI's 8 new floor plans that will be used for both HFH affiliate site building and modular construction in the Gulf Coast region. Additional analysis of several improvements was requested and delivered.

In June, a first draft of construction standards that encompass site safety, occupant health, building durability, and energy efficiency was produced with launch scheduled for October of 2006. As the main energy elements of the standards were finalized, BAIHP provided analysis of eight designs including Energy Star '99 rating, HERS '06 Index, IECC '03-06 compliance, and projected annual energy use in comparison to typical specifications (developed with LSU faculty member Dr. Claudette Reichel.)

In addition to this primary activity, BAIHP staff directed many inquiries to existing resources, some developed under partial DOE funding. Researchers also responded to inquires directly from Habitat affiliates in the recovery region and participated in a number of collaborative activities related to rebuilding:

- In October of 2005, BAIHP coordinated early discussion between the Federation of America Scientists (FAS) and HFHI. FAS built a prototype house in partnership with LSU on a lot donated by Baton Rouge HFH.

- In November of 2005, J. McIlvaine participated in a USGBC technical design charrette at the GreenBuild Conference in Atlanta to evaluate the applicability of the new LEED for Homes program to the Habitat homes to be built in the Katrina Recovery zone. The results indicate that achieving the "Certified" level of the program is within HFH capability. These results will be drawn into HFHI planning activities in the "Operation Home Delivery" department. J. McIlvaine led the break out session during the charrette related to energy efficiency and indoor air quality. Two Gulf Coast HFH affiliates and numerous HFHI staff attended.

- In November of 2005, J. McIlvaine visited HFHI headquarters in Americus, GA to plan recovery strategies. It was decided that BAIHP would support construction by the 17 affected HFH affiliates in the Gulf Coast region and construction by HFHI's new Operation Home Delivery Department. The analysis mentioned above served both audiences. 
- In March of 2006, BAIHP researchers conducted a field visit to the region beginning in Mobile (AL) and traveling west to Gulf Port and Waveland (MS) then on to Covington and Slidell (LA.) J. Mcllvaine met with HFHI field manager Greg Graves, three HFH affiliates, and staff at a volunteer-housing camp. The draft standards were discussed at length and observations were made about the current practice at the Covington and Slidell affiliates. They reorganized and prioritized the standards and subsequently drafted a narrative to explain why the standards were selected. The finished narrative, written by J. McIlvaine, grouped the standards into three categories: Occupant Health and Safety, Building Durability, and Energy Efficiency and Comfort. BAIHP recommended that the narrative be used when introducing affiliates to the new standards to give affiliates the reasoning behind the standards. Parts of the narrative were incorporated into HFHI's version of the Minimum Standard but no final document has been issued.

\section{Gulf Coast Recovery, OHD Modular Housing Factory Study}

In the seventh budget period, UCF researchers assisted Habitat for Humanity in the design of a Habitat modular housing factory. The team assisted with:

- Selection of an existing facility

- Identifying the retrofits that will be necessary

- Layout alternatives for the factory incorporating lean production principles

The team also recommended changes to interior layouts to open up the designs, making them more compatible with conventional home designs, and introduced the issue of factory installation of HVAC equipment and its effect on production. The UCF-IE research team and FSEC researcher D. Beal hosted a workshop in May 2006 for Habitat representatives to review progress in planning the new factory. Revised drafts of the following design products were presented: value stream map, factory layout and detailed process descriptions. Lean production principles were embedded throughout the factory design. Many possible enhancements were discussed during the workshop. The team followed up by exploring each idea, refining the factory design to incorporate viable enhancements, and resubmitting to Habitat.

Ultimately, OHD decided against launching a factory in favor of working with modular manufacturers. In subsequent months, BAIHP provided contacts to HFHI in the manufactured housing industry including long time BAIHP partner Palm Harbor Homes. In a related project, one of OHD's high profile sponsors, Oprah Winfrey, worked out the details of a community with Baton Rouge HFH to be comprised of 15 Palm Harbor modular homes. In the fall, BAIHP will continue to support this effort providing both analysis and on-site support during production. All the houses will be Energy Star qualified.

\section{Habitat Builder Option Packages - HabiBOPs}

During the $6^{\text {th }}$ budget period FSEC researchers met with Habitat for Humanity International staff at HFHI headquarters in Americus, Georgia to discuss the need and possible solutions for the challenges that Habitat affiliates face in their effort to achieve Energy Star status. 
HFHI drafted a new Habitat initiative named "Habitat Better Built" to encourage affiliates to embrace energy efficiency, durability, and healthy indoor air quality as part of a larger move toward increasing construction capacity. This built from BAIHP efforts in previous budget years to develop an Energy Star equivalency program (called HabiBOPs) for Habitat affiliates. The BAIHP-HFHI draft (2002) included a request for EPA analysis of additional Builder Option Packages (BOPs) for various Climate Zones as a pilot study for adding BOPs that emphasize envelope improvements over expensive equipment improvements. The simulation work was never funded and was outside the scope of BAIHP's work plan.

With the advent of the 2006 Energy Star New Homes Program, there is some interest at EPA in evaluating the feasibility of achieving Energy Star for affordable housing. EPA contacted BAIHP researchers three times during the final year of the project to discuss concerns that drove the original HabiBOP effort including the emphasis of equipment efficiency, rather than envelope improvements, to achieve Energy Star via the National Building Option Package path as well as the unavailability of raters in many locations (a concern for all builders - not just Habitat).

HFH affiliates in Jacksonville (FL), Indian River County (FL), Birmingham (AL) and Houston, TX had all agreed to field test the pilot HabiBOP program in Year 5 of the BAIHP project.

\section{Joint Grant Proposal}

In 2002, BAIHP supported a HFHI proposal to fund writing and production of a national $\mathrm{HFH}$ homeowner's manual. Homeowner education, particularly about energy efficiency, indoor air quality, and maintenance issues is a frequently cited area of weakness in Habitat's homeownership program. The proposal was not funded, but HFHI later used a portion of it to successfully apply for an EPA grant to produce a homeowner guide about indoor air quality. The electronic version is available free to all affiliates.

\section{Survey of Affiliate Energy Practices} In 2001 and 2002, BAIHP worked with

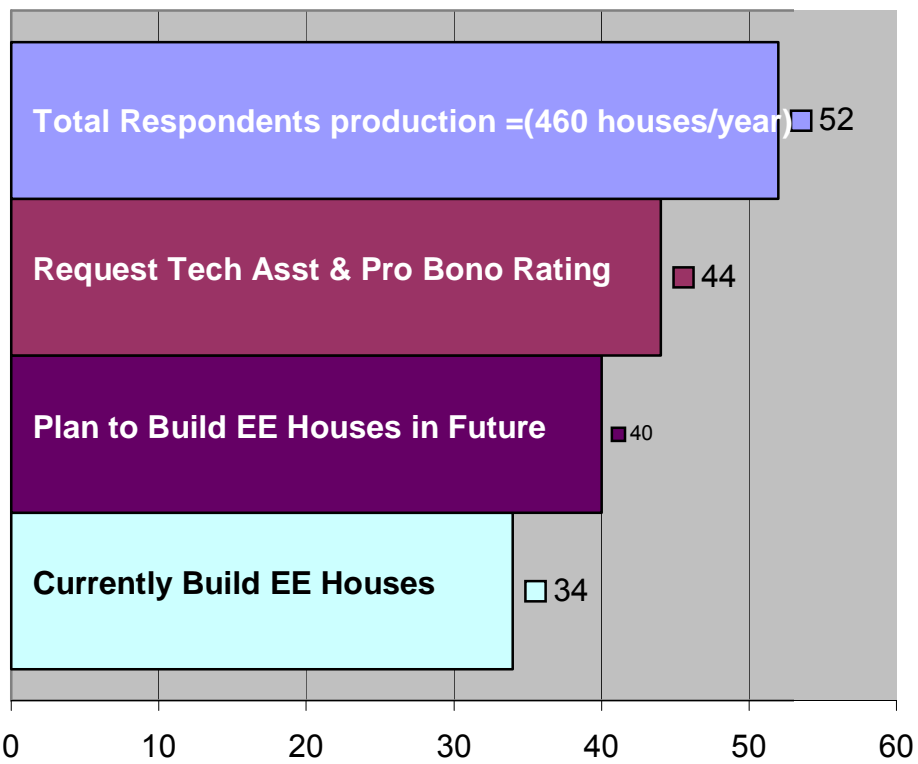

Figure 25 Responses to a 2002 BAIHP-HFHI survey of affiliate interest in energy efficiency and Home Energy Ratings.

HFHI to conduct a survey among the most productive domestic affiliates about current energy practices. The survey helped to illuminate the progress that HFHI training had foster since the inception of the Environmental Initiative in 1995 when very few affiliates actively embraced energy efficiency.

Fifty-two affiliates responded (Figure 25) representing a construction capacity of 460 homes annually. Of the 52 affiliates, 34 indicated that, after learning about Energy Star in the BAIHP session, they thought that some of the homes they had built would qualify for Energy Star status and 44 affiliates indicated that they would be interested in a HERS ' 99 rating if it were available 
for free and BAIHP design assistance (DA). Follow up to the survey involved helping affiliates make contact with a home energy rater in the region to produce a preliminary Energy Star rating - a precursor to the RESNET-BA-HFHI partnership launched in the final year of the project

\section{Technology Evaluation}

Over the past decade, affiliate interest in alternative building systems has escalated and BAIHP has frequently conducted simulation analyses to provide affiliates with performance comparisons.

At the request of HFHI, BAIHP tested a home built by Home Front, Inc. in Sarasota, Florida. The house scored an 87.6 on the HERS ' 99 scale. Built with structural insulated panels (SIP), which contain a polystyrene core faced on both sides with a thin concrete board. The exterior finish is stucco with Hardy board trim. A structural steel wind-frame welded to steel plates imbedded in the slab was engineered to withstand hurricane force winds. The panels passed Dade County large missile impact and wind load testing.

Interior ducts are housed in a central corridor and connect to a heat pump in a central closet. Return air is drawn from each room through extra registers on the duct chase. A whole house fan at one end of the chase provides ventilation during shoulder seasons. Findings were reported to HFHI.

\section{HFHI 2005 Jimmy Carter Work Project}

A team of 4 BAIHP researchers joined the 2005 JCWP in Benton Harbor MI. Working with Harbor Habitat for Humanity, 2 team members conducted training of all house leaders (plus some crew leaders) the before the JCWP began (Saturday), and were in charge of an Energy Crew during the week-long build that implemented energy efficiency improvements (air sealing, insulation, crawlspace sealing, and duct sealing) in 20 homes. 2 more BAIHP researchers joined them on Friday and assisted with the testing of the 20 homes built during the 2005 JCWP.

All 24 homes built in the JCWP 2005 in Benton Harbor were tested and rated by a local group, WARM Training, soon after the JCWP. All were Energy Star homes, each featuring a conditioned crawl space, high efficiency (direct vent combustion) gas furnace, excellent windows, Energy Star appliances, outside air ventilation, and very low infiltration. Certificates in "Recognition of Excellence" were prepared for both affiliates and delivered to Trevor Riggen (HFHI Washington Office). All Benton Harbor JCWP houses were registered at Energy Star homes and each homeowner received notice of such with a cover letter from BAIHP.

HFHI 2003 Jimmy Carter Work Project (2003 JCWP) Habitat International Director of Construction and Environment requested FSEC assistance for all three Carter Project affiliates: Calhoun County (AL) and LaGrange (GA). The JCWP affiliate in Valdosta (GA) did not request BAIHP assistance; however, a former Energy Monitor working at the Valdosta site organized an informal corps of volunteers to tackle air sealing and insulation details. The construction manager and executive director made the 2003 JCWP an example of high performance, high quality housing for affiliates and other builders in the region and consequently asked BAIHP for assistance in reviewing construction techniques. 
Calhoun County HFH: The Calhoun County HFH affiliate (Anniston, Alabama) built 35 near Energy Star homes during the 2003 JCWP.

BAIHP worked closely with the mechanical contractor and the construction supervisors prior to the build to bring the initial HERS '99 ratings of 78 up to 86. Though the houses had been slated to be Energy Star, a miscommunication resulted in the air conditioning efficiency being SEER 10 instead of SEER 12. In Anniston's mixed-humid climate the difference was enough to drop HERS ' 99 ratings below the 86 target. However, the homes are much more efficient than the previous convention and many volunteers were exposed to energy efficient design and construction as well as combustion safety design (Figure 26). Radon mitigation systems were provided by an Alabama environmental group.

Troup-Chambers HFH (LaGrange, Georgia): The executive director for this affiliate adopted the Energy Star goal and spearheaded the construction of 22 Energy Star homes during the 2003 JCWP (Figure 27). Four plans were rated and scores ranged from 86.5 to 88.5. BAIHP consulted with the affiliate on window specifications, insulation levels, AC efficiency, and air sealing details particularly with regard to the air handler closets which were previously built with return plenums open to the attic. The affiliate plans to continue building using the JCWP specifications.

In the final year of the project, BAIHP researchers converted the LaGrangre HFH write up in the BA Best Practices document into an independent four-page case

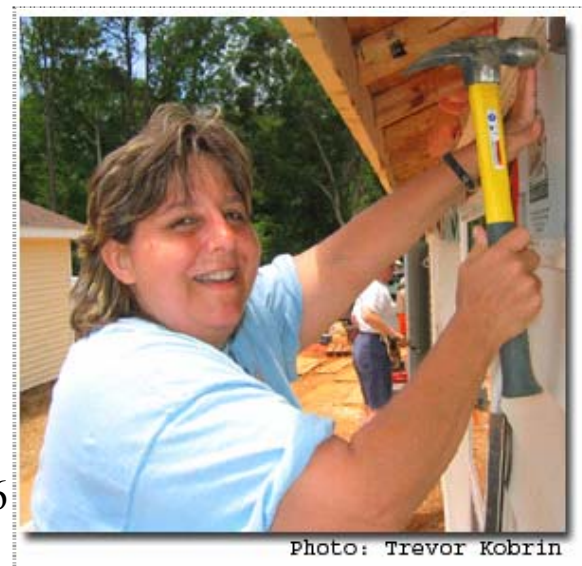

Figure 26 Homeowner Sandy Sedano installs rigid insulation (part of the energy package) on her new home during the 2003 JCWP at the Anniston $(A L)$ site.

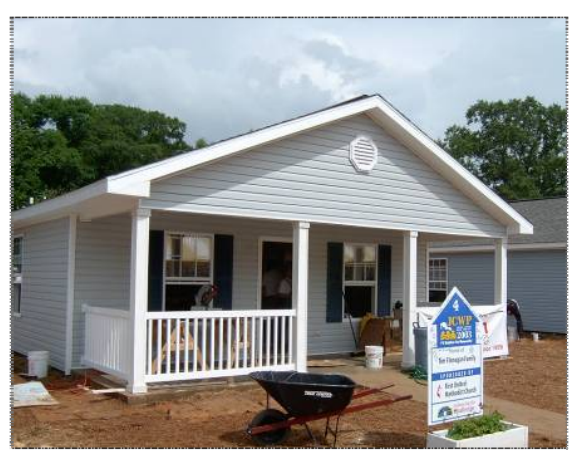

Figure 272003 Jimmy Carter Work Project house in LaGrange GA - one of 22 Energy Star homes built in one week. study. BAIHP worked with staff at NREL to revise the BAIHP Habitat Partnership fact sheet to encompass all BA work with Habitat and to produce 2 new Habitat case studies, the LaGrange and another for the HFH affiliate in Lakeland, FL.

\section{Technical Assistance to Habitat for Humanity Affiliate}

During the fifth and sixth budget periods BAIHP's technical assistance to Habitat affiliates shifted away from general assistance to individual affiliates toward focused technical assistance to progressive affiliates, high production affiliates, and regional and national initiatives including

- Regional Initiative: Gulf coast rebuilding efforts (described above)

- National Initiative: Congress Building America and the Builders Blitz (described above)

- Regional: Ohio's First Energy grant program for Energy Star affiliates

- Progressive affiliates in Lakeland (FL), Houston, and Loudon County (TN), the latter being an ORNL zero energy home initiative with FSEC monitoring assistance. 
A cumulative list of affiliates receiving direct design assistance from BAIHP is shown in Table 19 at the end of this section. Work conducted with individual Habitat affiliates, independent of national and regional initiatives, is presented here, organized by state.

\section{Alabama: Auburn University}

David Hinson from the Auburn University

College of Architecture contacted BAIHP about a prototype "DESIGNhabitat" home. Three Energy Star homes have now been built with the local Habitat affiliates in Auburn. The prototype will be offered to affiliates statewide through the Alabama Association of Habitat Affiliates (AAHA) and non-profit Design Alabama. AHA requested indoor air quality and combustion safety testing plus design input on the prototype home in 2002 and 2003. The design features vernacular touches that enhance energy efficiency such as the screened front porch, operable transoms over doors (for ventilation and return air flow), metal roofing, and large overhangs (Figure 28). A sealed combustion closet for the gas water heater, sealed and tested ducts, and high efficiency heating and cooling complete the energy package. In February of 2006, BAIHP participated in studio jury at the Auburn School of Architecture. Competing designs incorporated modular housing into Habitat's volunteer construction process. A winning design was selected for construction. Palm Harbor Homes built two modules and students construction a joining module on site. The home will be tested and rated in the Fall of 2006 with participation from students.

\section{Alabama: Birmingham HFH}

In 2001, BAIHP researchers tested and rated 3 homes for this affiliate and provided the local construction manager with energy analysis and recommendations. Birmingham HFH continued to build Energy Star homes in 2004 - many with HUD approved safe room construction.

\section{Alabama: Calhoun County HFH}

Please see 2003 JCWP above, in the summary of work conducted with HFHI.

\section{Florida: Alachua $\mathrm{HFH}$}

Florida H.E.R.O. has worked with Alachua Habitat for Humanity for many years. Currently the affiliate is building a subdivision called Celebration Oaks. Summary of specifications is provided in Table 17. 


\begin{tabular}{|l|l|}
\hline \multicolumn{1}{|c|}{ Table 17 Alachua Habitat for Humanity Specifications for Celebration Oaks } \\
\hline Component & Specification \\
\hline Conditioned Area & $\sim 1100$ (2 built, 6 in progress, 64 units total) \\
\hline HERS '99 Rating & $\begin{array}{l}\text { SEER 12 Air Conditioning with homeowner } \\
\text { choice of heat pump or standard gas furnace } \\
\text { heating, Air handler in the conditioned space. }\end{array}$ \\
\hline Cooling and Heating & Filtered passive fresh air ventilation. \\
\hline Ventilation & $\begin{array}{l}\text { Duct system engineered using Manual D } \\
\text { calculations, sealed with mastic, performance } \\
\text { tested for air tightness }\end{array}$ \\
\hline Duct System & $\begin{array}{l}\text { Cooling and heating systems sized using } \\
\text { Manual J calculation procedure }\end{array}$ \\
\hline System Capacity & Standard Gas (considering tankless gas) \\
\hline Water Heating & $\begin{array}{l}\text { ICF Construction with wood frame roof and } \\
\text { interior walls }\end{array}$ \\
\hline Walls & R-30 cellulose insulation \\
\hline Ceiling & Double pane Low-E vinyl frame \\
\hline Windows &
\end{tabular}

Florida: East Orange County HFH

After attending courses and seminars taught by BAIHP staff over several years, this affiliate's construction manager began building interior duct systems. One of those homes was tested in April of 2003 and found to have good separation from the unconditioned attic above.

\section{Florida: Indian River County HFH}

Analysis and recommendations were done for Indian River County HFH (Vero Beach, FL). In early 2005 ( $6^{\text {th }}$ Budget Period), this affiliate agreed to pilot a duct leakage sealing checklist to determine if a prescriptive protocol can be used to consistently achieve tight ducts as part of the HabiBOPs pilot project which did not come to fruition. During the final year of the project, WCI Communities sponsored a house with this affiliate providing extra grant money to fund green features. Trifecta Consulting Group, LLC is providing Green Home Certification and BAIHP will provide the Energy Star rating.

\section{Florida: Jacksonville (HabiJAX) HFH}

This affiliate, located in Jacksonville, Florida, is one of Habitat's most productive alliances. In anticipation of HabiJAX involvement in the HabiBOP pilot program, BAIHP completed preliminary HERS ' 99 ratings on planned homes. Follow-up test results indicate that HabiJAX is a good candidate for the program, particularly after the construction manager agreed to incorporate a ventilation strategy and energy efficient lighting into their home designs. This progressive affiliate worked with FSEC (under another contract) to incorporate solar water heating. This affiliate is a regional and national pace setter. 
Florida: Lakeland HFH

Category A: 10 houses

Category B: 1 house

BAIHP has rated 11 Building America level houses that this affiliate has built since 2002. (Figure 29) The average HERS '99 rating was 89.7. Lakeland Habitat Homes Feature:

- Radiant barrier

- Double pane, vinyl frame, low-E windows placed under 24-inch overhangs to limit direct solar gain

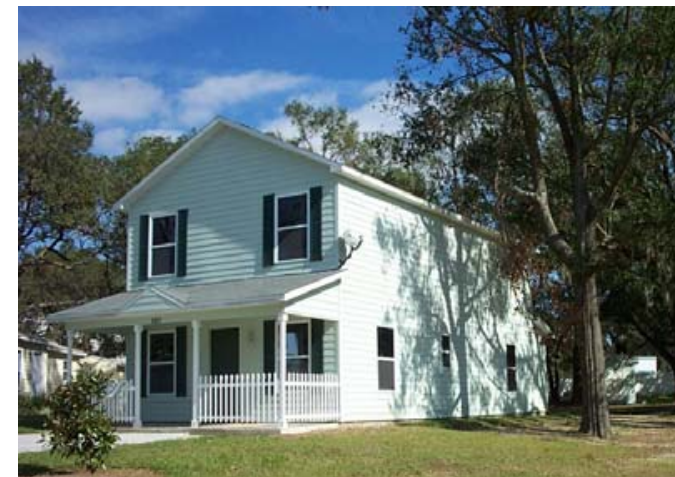

Figure 29 Habitat for Humanity energy efficient home in Lakeland, Florida.

- Houses oriented to limit thermal gain where possible

- Ducts in conditioned space using a framed-in duct chase and interior air handler closet

- Duct system joints and plenums sealed with water-based mastic and fiberglass mesh then tested to ensure duct leakage below 5\%

- Heat recovery from hot water

- Water-heater timers

- Passive outside air ventilation ducted to the return side of the air handler with a filterbacked intake grill mounted in the soffit (at back door or porch)

- 14 SEER air conditioner (up from 10 SEER in 1999)

- Extensive air sealing of building envelope after dry in.

In the final year of the project, BAIHP researchers wrote a case study with PNNL about Lakeland HFH.

Florida: Venice HFH

In 2005 and 2006, Venice HFH worked with BAIHP sub-contractor Calcs-Plus. The affiliate wrote a press release using the BAIHP template and was written up in the local newspaper (see Builders Blitz description above).

Florida: Space Coast and South Brevard HFH

Since the late 1990's, FSEC has provided Florida Energy Code calculations for one of the Habitat affiliates in Brevard County (where FSEC is located.) Energy Star ratings have been produced for the affiliate (Space Coast Habitat) over the years with recommendations as requested. In 2004, FSEC conducted a rating for the other Brevard County affiliate, South Brevard Habitat. Neither affiliate has yet achieved Energy Star. In the summer of 2005, the affiliates merged and have not requested any additional technical assistance.

\section{Florida, Sumter County HFH}

This affiliate attended several courses and seminars taught by BAIHP staff in recent years. As a result, in 2000 the Sumter construction manager began building interior duct systems. One of those systems was tested in March 2002, as part of the Air Handler Air Tightness Study, and found to be connected to the unconditioned attic above. These results were similar to findings in BAIHP's sister project on Interior Duct Systems. After discussions at the April construction roundtable, modifications were made to the construction approach which became part of their standard building practice for the affiliate. 


\section{Georgia: Atlanta HFH}

Energy simulations were conducted for insulated concrete form (ICF) homes in Houston and Atlanta. Comparative studies could be conducted in both cities since the same floor plans will be used to build ICF and wood frame homes in those areas. Simulation results from the homes were evaluated to develop suggested improvements that would bring the homes to Energy Star levels. The Houston affiliate is planning a 100-home development and is looking for home performance strategies that would allow them to reach Energy Star at a minimum. Simulations using the measured test data were conducted and recommendations made for their consideration.

The Atlanta home will incorporate substantial thermal mass with concrete ceilings and concrete interior walls. Simulations on the thermal mass benefits were completed and reported. These simulations focused on the use of thermal mass to reduce the size of the heating, ventilation, and air conditioning systems.

Georgia: LaGrange (Troup-Chambers) $\mathrm{HFH}$ Please see 2003 JCWP above.

\section{Georgia: Sumter County HFH}

(See also Plains SIP study in Research with Habitat following Habitat Technical Assistance) BAIHP staff worked with the Sumter County HFH affiliate on the Easter Morning Community from inception in 1995 to completion in 2003. 171 Energy Star or near Energy Star homes were built between 1997 and 2003. Easter Morning blitz builds were used as training activities for Habitat's Green Team (now defunct). Other energy organizations particularly Oak Ridge National Laboratory and SouthFace Energy Institute provided excellent technical assistance to this affiliate, the original Habitat affiliate based in Americus, GA. As of 2003, Sumter County $\mathrm{HFH}$ is no longer building houses because they have partnered with all qualifying residents to meet the goal of HFHI's $21^{\text {st }}$ Century Challenge which is to eliminate poverty housing in America - one county at a time.

\section{Ohio Affiliates}

A utility grant program in Ohio spurred a broad interest among HFH affiliates in reaching Energy Star level. Affiliate with homes built to the Energy Star standard in the utility's service area will receive a grant that equals the cost of the home. Several affiliates acquired the Example Energy Star Packages from HFHI's web site and called to discuss them. In response to this interest, HFHI conducted a workshop in early July 2002 attended by sixty people. Subsequently, all affiliates ( 30) attending the course have built and had certified at least one Energy Star home. Each has collaborated with a local certified HERS '99 rater. Several affiliates contacted BAIHP to clarify aspects of the process and only one affiliate experienced difficulty with the certifying process and received direct support from BAIHP.

\section{Louisiana Affiliates}

(See Gulf Coast Recovery above)

FSEC arranged a partnership with Superior Environments in Metarie to provide support to the Baton Rouge HFH affiliate's April Energy Star home "blitz build." Four high efficiency homes were built during the 2002 blitz build. Though all home met Energy Star status, documentation has not yet been received that the homes were registered. (Please see Table 18) 
Table 18 HERS '99 Scores for Baton Rouge Habitat Energy Star Homes

\begin{tabular}{|c|c|c|}
\hline House ID \# & Score & Est. Utilities \\
\hline 118 & 88.7 & 959 \\
\hline 119 & 87.2 & 1122 \\
\hline 120 & 87.2 & 1364 \\
\hline 121 & 87.2 & 1120 \\
\hline
\end{tabular}

Nevada Affiliates

FSEC was contacted by Portland Cement Association (PCA) to collaborate on an HFH house planned for the 2003 Builders' Show in Las Vegas. This collaboration was a joint effort between BAIHP, PCA, and the Las Vegas Habitat for Humanity. For more information on the project, visit: http://www.cement.org/countonconcrete/

New Mexico: Albuquerque HFH

BAIHP completed an initial home design analysis for the Albuquerque HFH which was revised with feedback from the affiliate. Final recommendations were submitted to Albuquerque HFH to assist them in reaching Energy Star status.

Texas: Ellis County HFH

This affiliate reports that they have been building Energy Star homes and now are interested in moving toward a Zero Energy Home similar to the Loudon County HFH project in Tennessee.

\section{Texas: Houston HFH}

In 2001, BAIHP completed a preliminary evaluation of the concrete homes built in partnership between Houston HFH and the Portland Cement Association. Staff tested and rated the homes in January 2002 and made recommendations for reaching beyond Energy Star to the Building America standard. Later that year, the affiliate's construction manager reported that they were now implementing BAIHP energy efficiency, durability, and indoor air quality recommendations. Final home design recommendations included construction of a passive ventilation system and an interior duct system. In 2004, this affiliate reported that all homes ( 100) built since FSEC's 2002 recommendations have exceed Energy Star (rated by local utility) and have passive fresh air ventilation ducted to the air handler with a separate, soffitmounted filter. In 2005, Houston Habitat built dozens of homes for affiliates the Gulf Coast recovery region.

\section{Washington DC HFH}

BAIHP met with DC Habitat's Executive Director and separately with the Energy and Environment Committee in November of 2005. Current DC HFH specifications would be considered "Energy Improved" and the affiliate was interested in pursuing water conservation and energy improvements that would be very low first cost. Researchers provided information and visited a Solar Decathlon home slated to be sited on DC Habitat land. The house unfortunately was subsequently sold by the team's university to cover the budget short fall of the project. 


\section{Washington State: Grant County HFH}

In 2004, WSU staff began providing technical support to Habitat for Humanity for two site built projects in Olympia, WA (marine climate) and Grant Co. (cold climate). Technical support included HVAC design, EnergyGauge analysis and field testing assistance. WSU continues to evaluate these homes; final case studies were being completed in the spring of 2006 for inclusion in the Building America Best Practice series.

The Grant country home utilized standard construction materials and framing, ENERGY STAR HVAC, lighting and appliances. This home moved $100 \%$ of the duct system into the conditioned space; from the attic, crawlspace and garage where it was to be installed, at little or no additional cost.

Washington State: HFH of Greater Moses Lake WSU BAIHP staff worked with this affiliate to build a home (Figure 30) that was among the first to be certified under the Energy Star Homes Northwest program in the state. With additional assistance from Grant County PUD, Habitat exceeded Energy Star program specifications for heat pump efficiency, glazing, ceiling insulation, lighting and envelop tightness. Features included:

- Heat Pump HSPF= 8.25 SEER=13.6

- Air handler and all duct work in conditioned space

- 4.0 ACH50 tested envelope tightness

- $128 \mathrm{ft}^{2}$ glazing $\mathrm{U}=0.32$

- Lighting - 95\% Energy Star lamps

- Electric water heating $\mathrm{EF}=.93$

- Ceiling R-49

- Floor over crawlspace R-30

- Walls 2x6 R=21

- Energy Star dishwasher

- Whole house ventilation meeting Washington State Ventilation and Indoor Air Quality Code

Built in 2004 in a 6835 heating degree day climate with four occupants, this all electric home used only $11,041 \mathrm{kWh}$ of electricity $\left(1.1 \mathrm{kWh} / \mathrm{ft}^{2}-\mathrm{yr}\right)$ in the first year of occupancy. Total metered energy use $(11,041 \mathrm{kWh})$ conformed closely to the total modeled energy use $(11,107 \mathrm{kWh})$ predicted by the Energy Gauge program (see Figure 30).

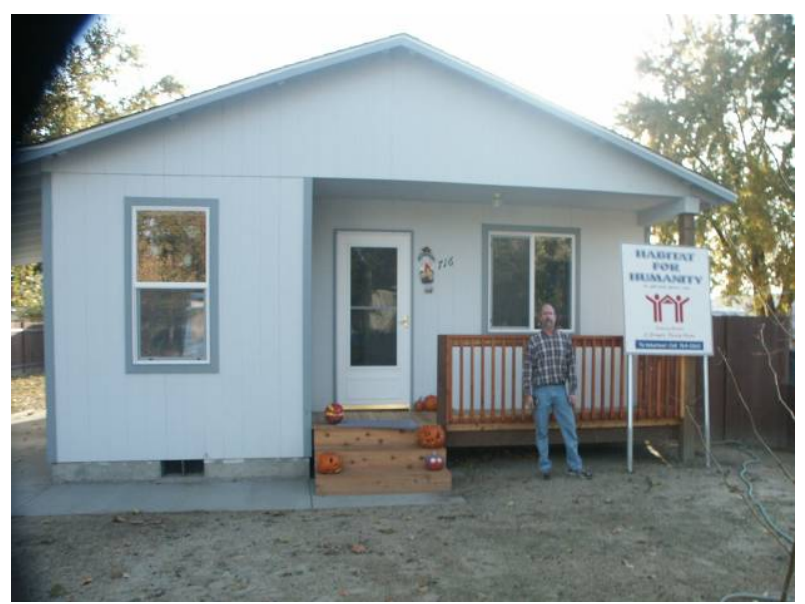

Figure $30 \mathrm{HFH}$ of Greater Moses Lake (WA) Energy Star Home.

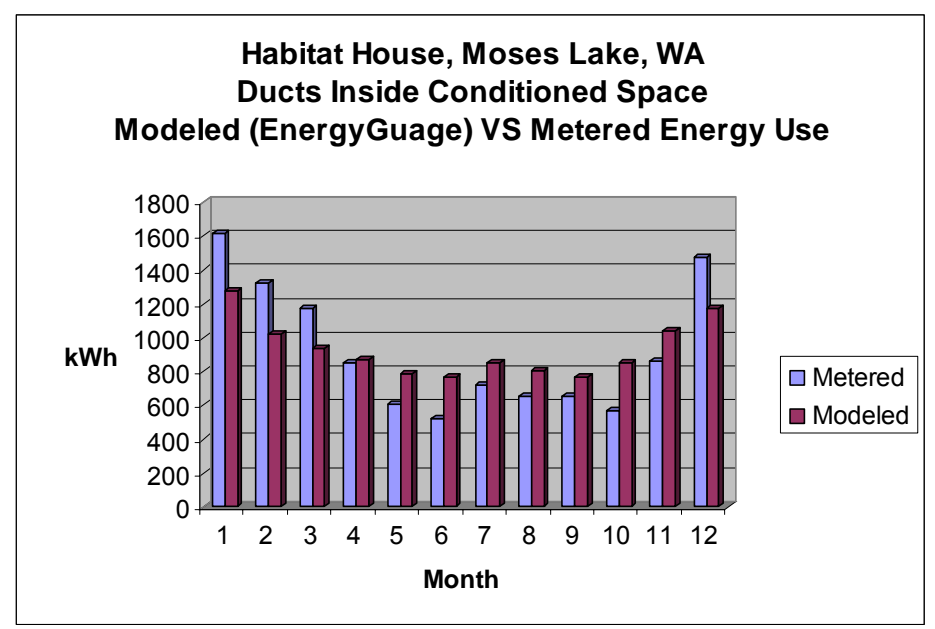

Figure 30 Total Metered Use (11,041 kWh) VS Total Modeled Use (11,107 kWh) 
Washington State: Greater Puget Sound HFH

In 2004, WSU staff began providing technical support to Habitat for Humanity for a site built project in Olympia, WA (marine climate). Technical support included HVAC design,

EnergyGauge analysis and field testing assistance. The Olympia home highlighted the challenges of integrating "green" technologies such as Icynene insulation and Rastra block walls. The home also used instant flow gas combo hydronic HVAC and HRV systems, and energy star lighting, appliances and was built "solar ready". WSU continues to evaluate these homes; case studies were completed in the spring of 2006.

Table 19 Summary of BAIHP

Technical Assistance to Habitat for Humanity 1999-2006

\begin{tabular}{|c|c|c|c|}
\hline Year & Project/Location & State & Houses/Description \\
\hline $05-06$ & $\begin{array}{l}\text { Gulf Coast Rebuilding Technical } \\
\text { Assistance BAIHP provided on call } \\
\text { building science and energy efficiency } \\
\text { technical assistance to any Habitat } \\
\text { affiliate in the Katrina/Rita hurricane } \\
\text { impact region. Staff was instrumental in } \\
\text { drafting minimum construction standards } \\
\text { for region at the request of Habitat } \\
\text { International. Staff visited the region in } \\
\text { March of } 2006 \text { to meet with key affiliates } \\
\text { located in Gulf Port (MS), Covington and } \\
\text { Slidell (LA). }\end{array}$ & $\begin{array}{l}\text { MS } \\
\text { LA }\end{array}$ & \\
\hline $05-06$ & $\begin{array}{l}\text { Congress Building America affiliates } \\
\text { Researchers visited with one CBA } \\
\text { affiliate in West Virginia and six CBA } \\
\text { affiliates in Michigan (including the } \\
\text { Benton Harbor JCWP affiliate). } \\
\text { All CBA affiliates (nationwide) as well } \\
\text { as their congressional partners received } 2 \\
\text { editions of BAIHP's Partnership Update } \\
\text { and an invitation to partner with BAIHP. }\end{array}$ & MI & $\begin{array}{l}\text { Researchers tested } 11 \\
\text { houses in West Virginia } \\
\text { and provided the affiliate } \\
\text { with recommendations. } \\
1 \text { House at each of the six } \\
\text { affiliates was tested. All } \\
\text { affiliates received a report } \\
\text { (Contract Report FSEC- } \\
\text { CR-1647-06) with } \\
\text { findings, } \\
\text { recommendations, and } \\
\text { best practices }\end{array}$ \\
\hline $05-06$ & $\begin{array}{l}\text { Builders Blitz } \\
\text { Sub-Contractor Calcs Plus provided } \\
\text { technical assistance to affiliate building } \\
\text { in Venice Florida during Nationwide } \\
\text { Builders Blitz in both } 05 \text { and } 06 . \\
\text { BAIHP-RESNET partner Guaranteed } \\
\text { Watt Saver provided technical assistance } \\
\text { to the Greater Oklahoma City affiliate. }\end{array}$ & OK & $\begin{array}{l}5 \text { houses total - all } \\
\text { achieved ' } 99 \text { Energy Star } \\
10 \text { houses - all '99 Energy } \\
\text { Star }\end{array}$ \\
\hline
\end{tabular}


Table 19 Summary of BAIHP

Technical Assistance to Habitat for Humanity 1999-2006

\begin{tabular}{|c|c|c|c|}
\hline Year & Project/Location & State & Houses/Description \\
\hline 2005 & Alachua HFH & FL & $\begin{array}{l}2 \text { houses completed with a } \\
\text { total build out of } 64\end{array}$ \\
\hline $\begin{array}{l}2005 \\
\text { (June) }\end{array}$ & $\begin{array}{l}\text { Jimmy Carter Work Project } \\
\text { Training, Energy Efficiency } \\
\text { Improvements, Testing } \\
\text { Harbor HFH-Benton Harbor, }\end{array}$ & MI & 24 Energy Star \\
\hline $02-05$ & $\begin{array}{l}2 \text { Zero Energy Houses } \\
\text { Loudon County HFH \& Oak Ridge } \\
\text { National Lab } \\
\text { BA fully instrumented two high } \\
\text { performance homes to evaluate features } \\
\text { including HPWH, PV, and waste water } \\
\text { heat recovery. Data available on line and } \\
\text { streamed to ORNL for analysis; See } \\
\text { publication } 2004 \text { Christian et al. } \\
\\
\text { Loudon County HFH, Lenoir City }\end{array}$ & $\mathrm{TN}$ & $\begin{array}{l}\text { SIP houses with many } \\
\text { features developed by Jeff } \\
\text { Christian at ORNL }\end{array}$ \\
\hline $\begin{array}{l}02-03 \\
\text { (June) }\end{array}$ & $\begin{array}{l}\text { Jimmy Carter Work Project } \\
\text { Energy Details, Program Development, } \\
\text { and Volunteer Training } \\
\text { Calhoun County HFH, Anniston } \\
\text { Troup-Chambers County HFH, } \\
\text { LaGrange }\end{array}$ & $\begin{array}{l}\mathrm{AL} \\
\mathrm{GA}\end{array}$ & $\begin{array}{l}35 \text { Near Energy Star (c) } \\
22 \text { Energy Star (B) }\end{array}$ \\
\hline $\begin{array}{l}2003 \\
\text { (Fall) }\end{array}$ & $\begin{array}{l}\text { Jacksonville Habitat for Humanity } \\
\text { Largest U.S. affiliate; plans to build } \\
\text { Energy Star in } 2003 \text { and BA in } 2004 . \\
\text { Pilot for HabiBOPs Program. HabiJAX, } \\
\text { Jacksonville }\end{array}$ & FL & $\begin{array}{l}3 \text { Ratings - near Energy } \\
\text { Star (C) }\end{array}$ \\
\hline $02-03$ & $\begin{array}{l}\text { DESIGNHabitat House - Energy } \\
\text { Efficient Prototype developed by Auburn } \\
\text { University and the Alabama Association } \\
\text { of Habitat Affiliates. }\end{array}$ & $\mathrm{AL}$ & $\begin{array}{l}\text { 3 BA - Provided design } \\
\text { review, analysis, rating, } \\
\text { and technical support. (B) }\end{array}$ \\
\hline 2005 & $\begin{array}{l}\text { DESIGNHabitat House - Energy } \\
\text { Efficient Prototype developed by Auburn } \\
\text { University and the Alabama Association } \\
\text { of Habitat Affiliates }\end{array}$ & $\mathrm{AL}$ & $\begin{array}{l}1 \text { house composed of two } \\
\text { modular sections built by } \\
\text { Palm Harbor Homes and } \\
\text { one site built section }\end{array}$ \\
\hline 2004 & $\begin{array}{l}\text { Grant County HFH } \\
\text { HVAC design and EnergyGauge } \\
\text { analysis, Field Testing. }\end{array}$ & WA & \\
\hline 2002 & Greater Denver Habitat & $\mathrm{CO}$ & 6 Building America (A) \\
\hline 01-06 & Lakeland Habitat, Lakeland & FL & $\begin{array}{l}10 \text { Category } \mathrm{A} \\
1 \text { Category } \mathrm{B}\end{array}$ \\
\hline 2001 & Birmingham HFH & $\mathrm{AL}$ & 3 homes tested and rated \\
\hline 1997- & Easter Morning Build & & 117 Energy Star (B) \\
\hline
\end{tabular}


Table 19 Summary of BAIHP

Technical Assistance to Habitat for Humanity 1999-2006

\begin{tabular}{|c|c|c|c|}
\hline Year & Project/Location & State & Houses/Description \\
\hline 2003 & Sumter County Habitat, Americus & GA & $\begin{array}{l}\text { On Site Training and } \\
\text { testing }\end{array}$ \\
\hline 2000 & $\begin{array}{l}\text { Jimmy Carter Work Project } \\
\text { New York City HFH, Harlem } \\
\text { Sumter County HFH, Americus }\end{array}$ & $\begin{array}{l}\text { NY } \\
\text { GA }\end{array}$ & $\begin{array}{l}\text { Volunteer and } \\
\text { Homeowner Training with } \\
\text { HFHI } \\
\text { Produced } 23 \text { Ratings (C) }\end{array}$ \\
\hline $98-01$ & Broward County HFH & FL & 40 Energy Star (B) \\
\hline $99-03$ & Brevard County HFH & FL & 20 Energy Improved (C) \\
\hline $99-01$ & $\begin{array}{l}\text { Energy Fact Sheets } \\
\text { Developed by organizations supporting } \\
\text { HFHI. }\end{array}$ & USA & $\begin{array}{l}\text { BA reviewed/contributed } \\
\text { to various documents }\end{array}$ \\
\hline $97-99$ & $\begin{array}{l}\text { Easter Morning Community } \\
\text { Sumter County HFH, Americus }\end{array}$ & GA & 125, Most Energy Star (B) \\
\hline $98-03$ & Greater Houston HFH & TX & $\begin{array}{l}\text { 97-65 Energy Star Houses } \\
\text { (B) } \\
\text { 98-100 Energy Star } \\
\text { Houses } \\
\text { 02-began striving for BA } \\
\text { (B) }\end{array}$ \\
\hline $97-00$ & Greater Canton HFH, Canton & $\mathrm{OH}$ & 20, Energy Improved (C) \\
\hline $99-01$ & Durham County HFH, Durham & $\mathrm{NC}$ & 20, Energy Star (B) \\
\hline 1997 & Jimmy Carter Work Project & $\mathrm{TN}, \mathrm{KY}$ & 50 Energy Improved (C) \\
\hline $95-97$ & $\begin{array}{l}\text { Energy Affordable House } \\
\text { Greater Houston HFH }\end{array}$ & $\mathrm{TX}$ & 65 Energy Improved (C) \\
\hline & Design Assistance and Energy Analysis & & \\
\hline $02-06$ & $\begin{array}{l}\text { Design Assistance and Energy Analysis } \\
\text { DC: Washington DC HFH } \\
\text { FL: Pasco, Orange, Brevard Counties, } \\
\quad \text { Indian River County } \\
\text { GA: Atlanta HFH } \\
\text { NM: Albuquerque } \\
\text { NV: Las Vegas HFH } \\
\text { OH: Clark, Geauga, Lorain, Marion, \& } \\
\quad \text { Morrow Counties; Firelands. } \\
\text { OK: Central Oklahoma } \\
\text { PA: Greene County } \\
\text { TX: Lubbock, Smith County } \\
\text { KY: Greater Louisville }\end{array}$ & & \\
\hline $00-01$ & $\begin{array}{l}\text { AL: Birmingham } \\
\text { MS: Jackson }\end{array}$ & $\mathrm{AL}$ & 1 Energy Star Cert (B) \\
\hline $98-99$ & $\begin{array}{l}\text { CA: Long Beach HFH } \\
\text { DE: Wilmington HFH }\end{array}$ & & \\
\hline
\end{tabular}


Table 19 Summary of BAIHP

Technical Assistance to Habitat for Humanity 1999-2006

\begin{tabular}{|l|l|l|l|}
\hline Year & Project/Location & State & Houses/Description \\
& FL: Indian River, Lake, \& Sumter & & \\
& Counties, & & \\
& MI: Grand Rapids HFH & & \\
& NY: Albany, Syracuse, \& Yonkers & & \\
VA: Lynchburg HFH & &
\end{tabular}

\section{Research with Habitat for Humanity}

\section{Tennessee: Loudon County HFH}

At the request of ORNL Buildings Program Director Jeff Christian, BAIHP instrumented a third zero energy home (ZEH) built by Loudon County (TN) HFH (Figure 32) in the final year of the project. ORNL has built more than four such homes with the affiliate, and BAIHP previously instrumented and collected data on ORNL's behalf from Loudon County's first ZEH which showed results of $\$ 80$ net annual electric cost and an ACEEE paper was authored by ORNL and FSEC. BAIHP assisted with data collection on the fourth ZEH also. The affiliate has provided valuable feedback on the SIP construction process to other interested affiliates. Data is available online at www.baihp.org in the "Current Data" section of the site.

West Virginia: Almost Heaven HFH During the final year of the project, BAIHP commenced instrumentation of a SIP house with radiant floor heating built by Almost Heaven HFH's (Franklin WV), a CBA affiliate. Actual data on the performance of radiant slab heating

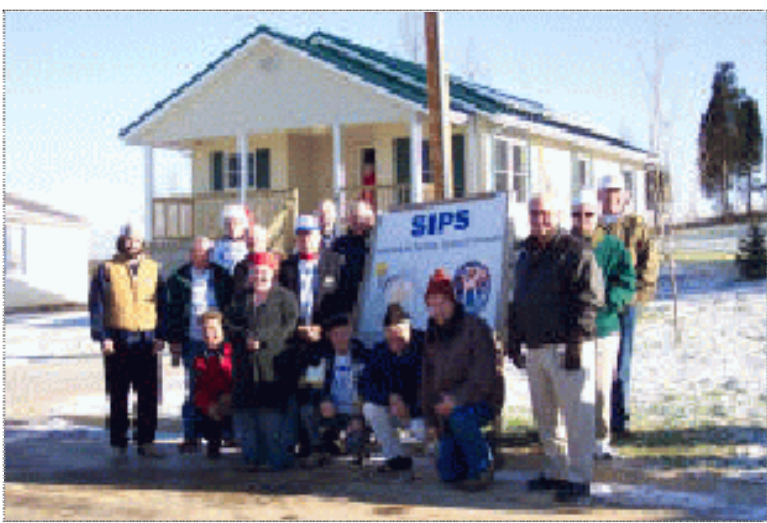

Figure 32 Local sponsors in front of 2nd ZEH built by Loudon County HFH in partnership with ORNL. FSEC provided monitoring for the $1^{\text {st }}$ and $4^{\text {th }}$ ZEHs. systems is scant; however, there are many claims of energy savings and greatly improved comfort. BAIHP staff members were on hand for the construction and pouring of the radiant slab. Instrumentation consists of temperature probes embedded in the ground 1 and 3 meters from the slab, on the sides of the slab, and at three interior locations under and in the slab; the middle of the house, 1 meter form the edge of the slab, and in between these two locations. When the house is completed, and heating equipment is set in place, a final trip to complete the instrumentation will be carried out. At the end of this Budget Period, construction of the house was still under way with completion anticipated in the fall of 2006 or early in the spring of 2007.

\section{Structural Insulated Panel Construction Study}

Plains, GA (Sumter County HFH, now defunct)

Most of Habitat's 1400+ American affiliates build wood frame houses. However, some affiliates are experimenting with other systems including straw bale construction, ICFs, and SIPs. Sumter County Habitat for Humanity, the original affiliate started by Habitat founder Millard Fuller, 
partnered with the Department of Energy and the Structural Insulated Panel Association (SIPA) to build two SIP houses in Plains, Georgia. This field project seeks validation of heating energy savings from SIPs.

The affiliate built the two SIP houses and a frame house on three neighboring lots. The Structural Insulated Panel Association (SIPA) provided some assistance with the SIP houses. The three houses were intentionally built with their calculated energy performance (HERS '99 score) similar to each other as seen in Table 20. The frame house (Figure 33) featured energy related details typical for the affiliate which resulted in an ACH50 of 5.3. With the home's whole-

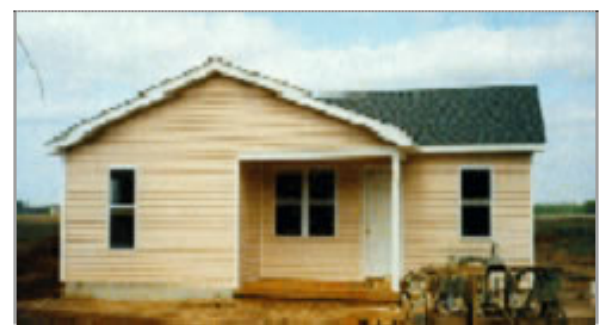

Figure 33 Energy Use in this Sumpter County Habitat Home, Built with Conventional 2x4 Framing in Plains, GA, was Compared to SIP Construction house fan cover installed the ACH dropped to 3.9, very good for frame construction. However, testing results revealed much better performance in the SIP houses with a measured ACH50 of 1.8. Though this indicates a 50\% decrease in infiltration, that does not correlate directly into a 50\% heating energy savings since infiltration determines only a portion of the total heating energy use. Other factors include insulation levels, conditioned square footage, window area, number of occupants, occupancy patterns, use of supplemental heaters, heater operation strategy, and indoor temperature. Monitoring equipment was installed to measure total, heating, and water heating energy use, as well as indoor and outdoor temperature.

Table 20 Sumter County (GA) Habitat for Humanity Field Study

\begin{tabular}{|l|l|l|l|l|l|}
\hline House & $\begin{array}{l}\text { Structural } \\
\text { System }\end{array}$ & ACH50 & $\begin{array}{l}\text { Average } \\
\text { Hourly Indoor } \\
\text { Temp. (F) }\end{array}$ & $\begin{array}{l}\text { Condit. } \\
\text { Floor Area } \\
\text { (sq. ft.) }\end{array}$ & $\begin{array}{l}\text { HERS ‘99 } \\
\text { Score }\end{array}$ \\
\hline 1 & SIP & 1.8 & 75 & 1036 & 82.7 \\
\hline 2 & SIP & 1.8 & 75 & 1069 & 83 \\
\hline 3 & Frame & 5.3 & 80 & 1208 & 82.9 \\
\hline
\end{tabular}

A 1995 study of 10 Habitat homes in Florida City, Florida revealed that the maintained indoor air temperature heavily influences conditioning energy use (Parker, et al. 1995). Analysis suggests that this may be a significant factor in this Sumter County study. The frame house consistently maintained a higher indoor temperature than the SIP houses. The impact of this considerable difference (average of 5F) is accounted for an analysis of heating energy use (per $1,000 \mathrm{ft} 2$ of conditioned space) relative to the indoor to outdoor temperature difference. This revealed that the SIP houses saved $25 \%$ compared to the frame house.

A previous study conducted in Louisville, Kentucky comparing SIP to frame construction found a 15\% savings for the SIP construction (Rudd, 1997). In that study, the duct systems for both houses were located in conditioned spaces. The Plains SIP houses had ducts in the conditioned space while the frame house had ducts in the unconditioned attic. The $10 \%$ difference in the Plains and the Louisville findings are attributed to the differences in duct system locations. Together, these two studies suggests that homes of 1,200 $\mathrm{ft}^{2}$ and smaller stand to gain significant energy performance from SIP construction with heating energy savings of $15-25 \%$ depending on duct location and average indoor-outdoor temperature differences. 
BA Roofing Study with Lee County HFH (FL)

Ft Myers, Florida

Roof and attic thermal performance exert a powerful influence on cooling energy use in Florida homes. Unshaded residential roofs are heated by solar radiation causing high afternoon attic air temperatures. The large influence on cooling is due to increased ceiling heat transfer as well as heat gains to the duct systems which are typically located in the attic space (Figure 34).

The Florida Power and Light Company and the Florida Solar

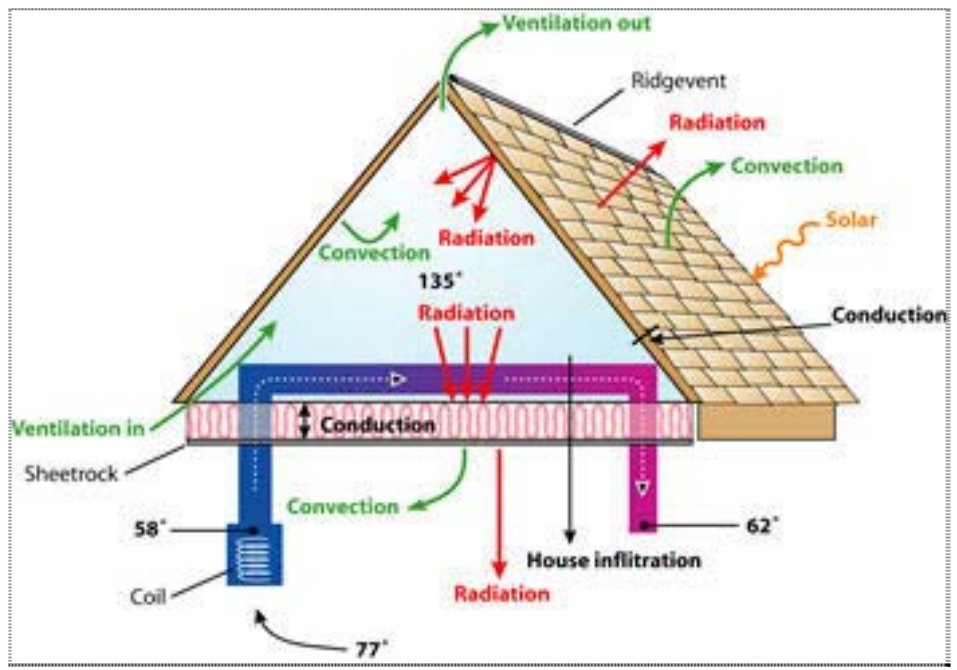

Figure 34 Vented Attic Thermal Processes Energy Center instrumented six side-by-side Habitat homes in Ft. Myers, Florida (Figure35) with identical floor plans and orientation, R-19 ceiling insulation, but with different roofing systems designed to reduce attic heat gain. A

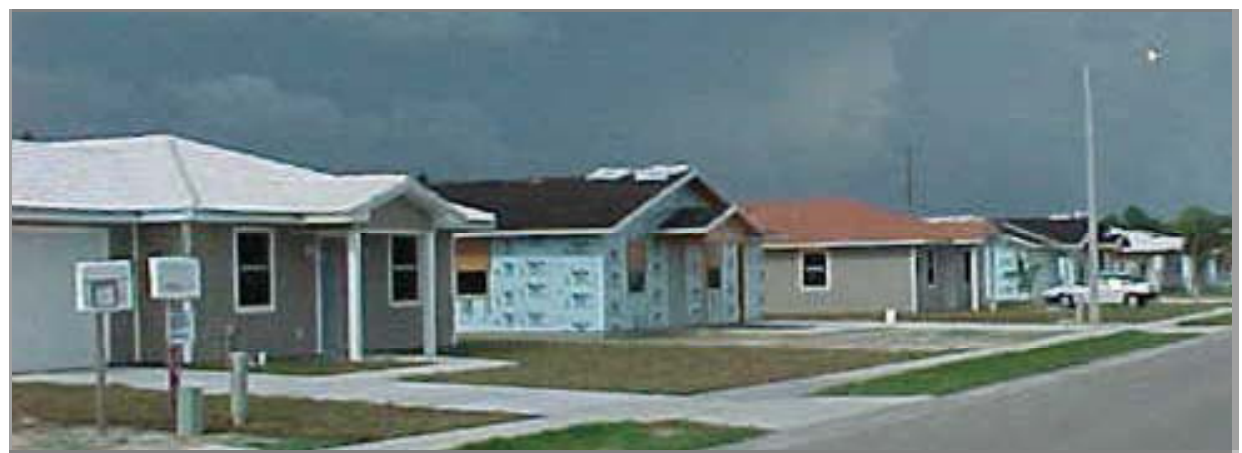

Figure35 Street scene showing the three closest homes (from left: white "barrel" s-tile (RWB), terra cotta s-tile (RTB) and white metal (RWM)). seventh house had an unvented attic with insulation on the underside of the roof deck rather than the ceiling:

- (RGS) Standard dark shingles (control home)

- (RWS) Light colored shingles

- (RSL) Standard dark shingles with sealed attic and $\mathrm{R}-19$ roof deck insulation
- $\quad$ (RWB) White "Barrel" S-tile roof

- (RWF) White flat tile roof

- $\quad$ (RTB) Terra cotta S-tile roof

- (RWM) White metal roof

All seven houses were completed by June 26th, 2000 with extensive testing to assure the buildings were similar. Each home was monitored simultaneously from July 8th - 31st in an unoccupied state. 
Building thermal conditions and air conditioning power were obtained on a 15-minute basis. Each of the examined alternative constructions exhibited superior performance to dark shingles. Figure 37 plots the maximum daily air temperature to the maximum recorded at mid-attic in each construction. Figure 38 shows the average daily attic air temperature profile.

The maximum attic temperature during the peak summer hour is $40 \mathrm{~F}$ greater than ambient air temperature in the control home while no greater

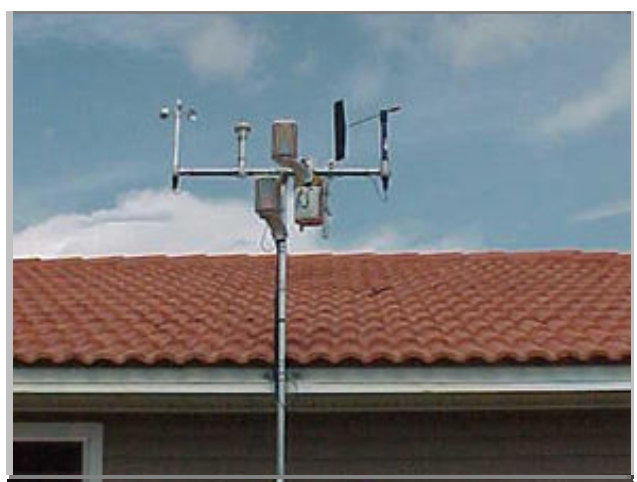

Figure 36 Project Meterological Station than ambient with highly reflective roofing systems. Light colored shingles and terra cotta roofs show temperatures in between. Table 21 summarizes the metered data from the unoccupied period and Figure 39 shows the variation in space cooling load profiles in the test homes.

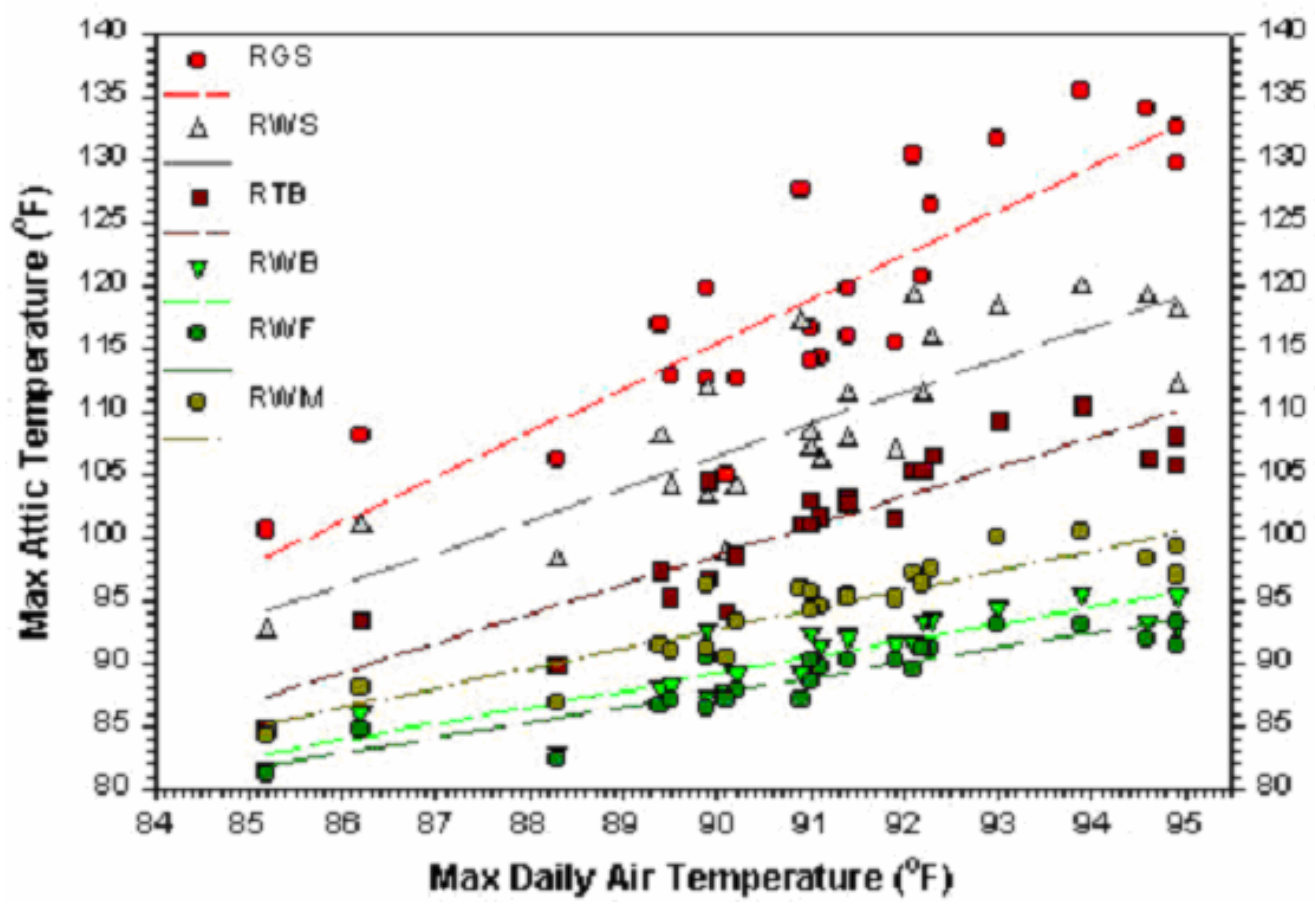

Figure 37 Relationship of peak air to peak attic temperatures. 


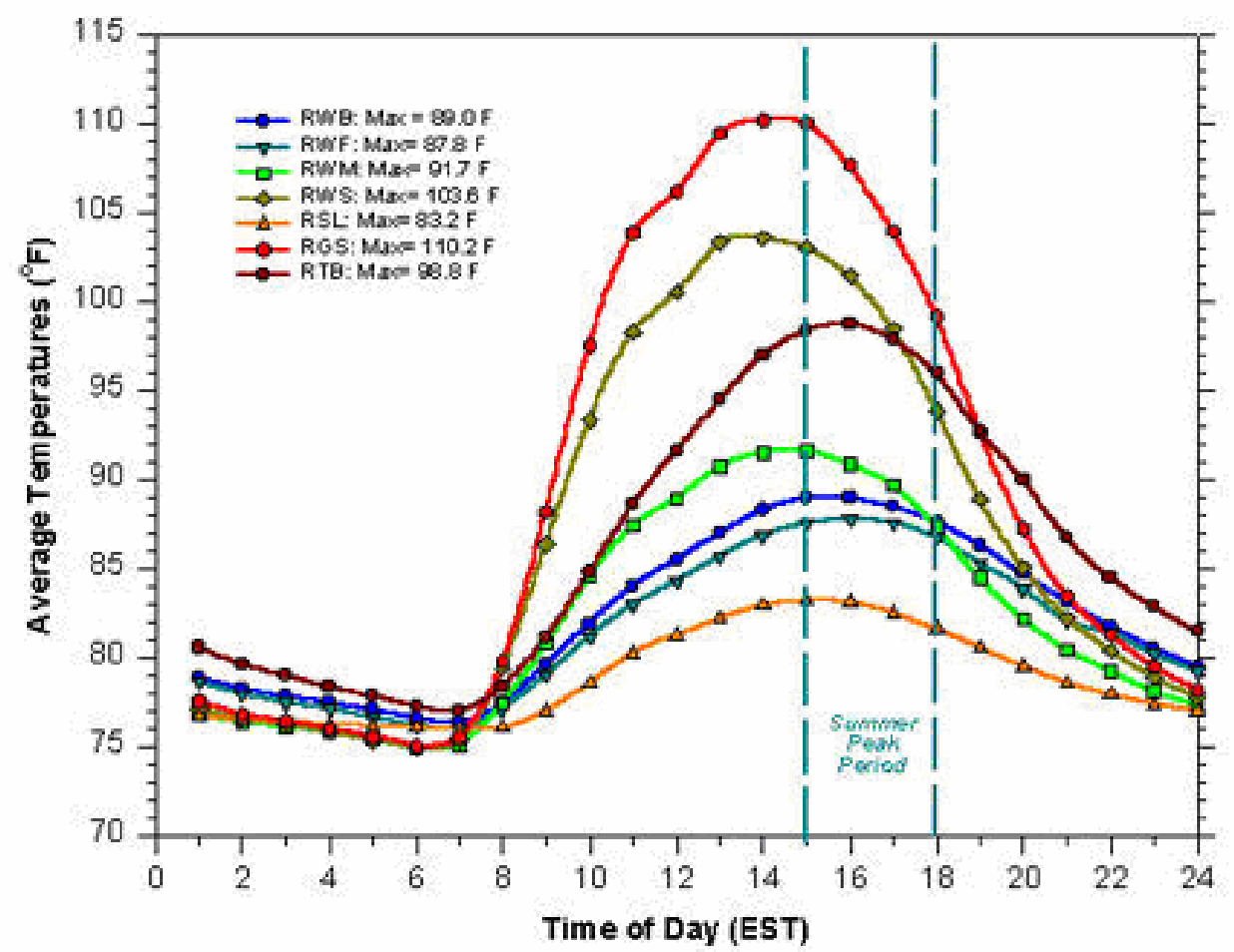

Figure 38 Average attic air temperatures over unoccupied period.

Table 21. Cooling Performance During Unoccupied Period July 8th - 31st, 2000

\begin{tabular}{|l|c|c|c||c|c|c|}
\hline Site & $\begin{array}{c}\text { Total } \\
\mathrm{kWh}\end{array}$ & $\begin{array}{c}\text { Total } \\
\text { Savings } \\
\mathrm{kWh}\end{array}$ & $\begin{array}{c}\text { Total } \\
\text { Saved } \\
\text { Percent }\end{array}$ & $\begin{array}{c}\text { Cooling } \\
\text { Demand } \\
\mathrm{kW}\end{array}$ & $\begin{array}{c}\text { Cooling } \\
\text { Savings } \\
\mathrm{kW}\end{array}$ & $\begin{array}{c}\text { Cooking } \\
\text { Savings } \\
\%\end{array}$ \\
\hline RGS (base) & 17.03 & ---- & ---- & 1.63 & ---- & ---- \\
\hline RWS & 15.29 & 1.74 & $10.2 \%$ & 1.44 & 0.19 & $11.80 \%$ \\
\hline \hline RSL & 14.73 & 2.30 & $13.5 \%$ & 1.63 & 0.01 & $0.30 \%$ \\
\hline RTB & 16.02 & 1.01 & $5.9 \%$ & 1.57 & 0.06 & $3.70 \%$ \\
\hline RWB & 13.32 & 3.71 & $21.8 \%$ & 1.07 & 0.56 & $34.20 \%$ \\
\hline RWF & 13.20 & 3.83 & $22.5 \%$ & 1.02 & 0.61 & $37.50 \%$ \\
\hline RWM & 12.03 & 5.00 & $29.4 \%$ & 0.98 & 0.65 & $39.70 \%$ \\
\hline
\end{tabular}




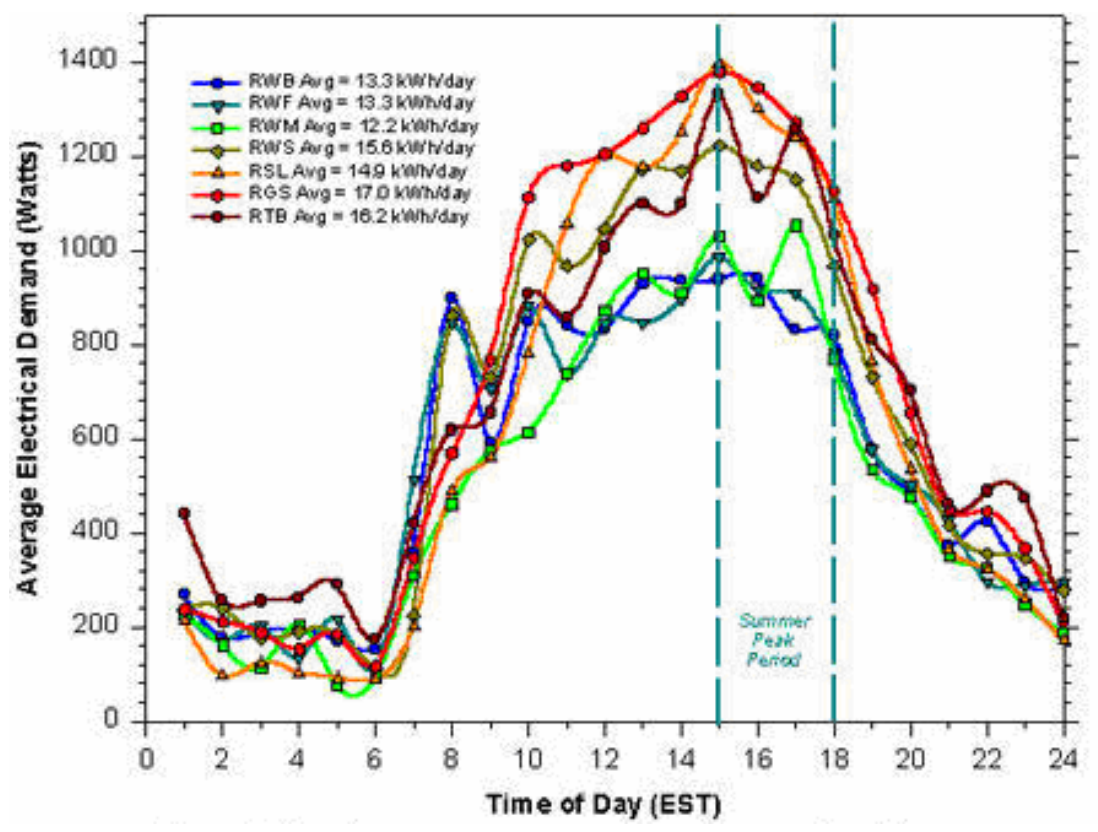

Figure 39 Average space cooling demand and profiles over the unoccupied period.

The above results are for the 1,144 square foot homes in the study. Since savings largely scale with ceiling area, the $\mathrm{kWh}$ and $\mathrm{kW}$ values should be normalized by the applicable ratio. For instance, typical FPL homes of 1,770 square feet would have estimated absolute savings 55\% greater than above. Also, normalizations were made for slightly different thermostat set points and the measured performance of individual $\mathrm{AC}$ units.

Table 22 Summary of Normalized Savings and Demand Reductions from Regression Estimates

\begin{tabular}{|c|c|c|c|c|}
\hline \multirow[t]{2}{*}{ Case Description } & \multicolumn{2}{|c|}{ Cooling Savings } & \multicolumn{2}{|c|}{$\begin{array}{c}\text { Peak Demand } \\
\text { Reduction }\end{array}$} \\
\hline & $\mathrm{kWh}$ & Percent* & $\mathrm{kW}$ & Percent* \\
\hline RGS(Control) & --- & --- & --- & --- \\
\hline RWS (White Shingle) & 300 & $4 \%$ & 0.48 & $17 \%$ \\
\hline RSL (Sealed Attic) & 620 & $9 \%$ & 0.13 & $5 \%$ \\
\hline RTB (Terra Cotta Tile) & 180 & $3 \%$ & 0.36 & $13 \%$ \\
\hline RWB (White S-Tile) & 1,380 & $20 \%$ & 0.92 & $32 \%$ \\
\hline RWF (White Flat Tile) & 1,200 & $17 \%$ & 0.98 & $34 \%$ \\
\hline RWM (White Metal) & 1,610 & $23 \%$ & 0.79 & $28 \%$ \\
\hline
\end{tabular}

Additional monitoring took place over a month long period with the homes occupied, but the thermostat set points were kept constant. Although average cooling energy use rose by $36 \%$, analysis indicated no decrease to savings or demand reduction from the highly reflective roofing 
systems. The added heat gains from appliances and people increase cooling system run-time causing the duct system to run for longer periods to exchange heat from the often hot attic space.

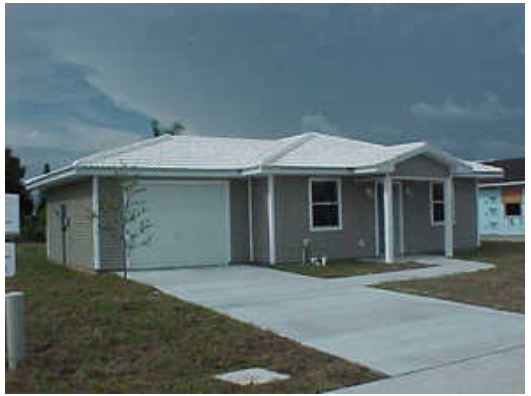

White -tile roof home

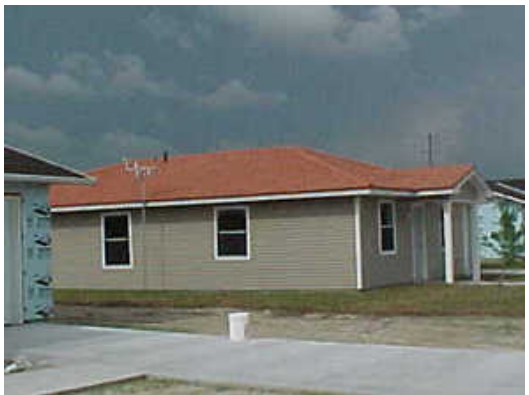

Terra cotta -tile roof home

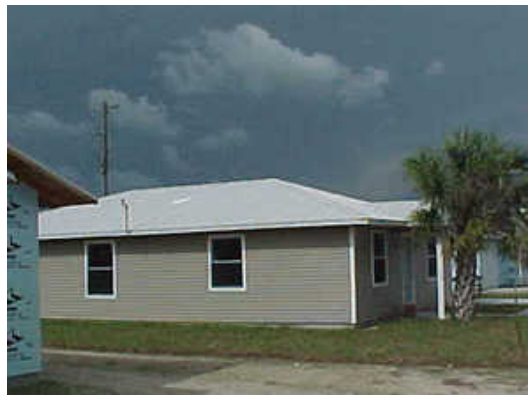

White metal roof home

Figure 40 Examples of different roof materials used.

The results in Tables 21 and 22, show essentially two classes of performance: white shingles, terra cotta tile and sealed attic construction which produce energy savings of $200-600 \mathrm{kWh} / \mathrm{yr}$ and demand reductions of $0.05-0.5 \mathrm{~kW}$. Highly reflective roof systems produce energy savings of $1,000-1,600 \mathrm{kWh}$ with demand reductions of $0.8-1.0 \mathrm{~kW}$. A separate analysis of the data using a special version of the DOE-2.1E computer simulation verified the magnitude of the measured energy and demand reductions.

In summary, this evaluation strongly confirms the energy-saving benefits of using more reflective roofing systems in Florida. Selection of colors with higher solar reflectance will result in tangible cooling energy savings for customers. This is particularly true for roofing materials such as tile and metal, which are currently available with solar reflectance of $65 \%-75 \%$ range. The selection of reflective roofing systems represents one of the most significant energy-saving options available to homeowners and builders. Such systems also strongly reduce the cooling demand during utility coincident peak periods and may be among the most effective methods for controlling demand.

\section{Training with Habitat for Humanity}

BAIHP participates regularly in Habitat regional and national conferences providing 1 hour, 2 hours, or 4 hour sessions on building science topics including the BA systems engineering approach. More detail on this activity is included in the "BAIHP Training" portions of this report. A summary of training activities is provided here:

- $\quad$ Southeastern HFH Conference 1996 - 2006

- HFHI 20th Anniversary 1997

- Florida HFH Conference 1998

- Cocoa, FL Building Science Focus Training 1999

- $\quad$ Syracuse, NY Building Science Focus Training 1999

- Affordable Comfort 2 day HFH Training 1999

- Portland, OR Building Science Focus Training 2000

- New York City, NY JCWP Homeowner Energy Course 2000

- Florida Construction Roundtable 2001

- Top 40 Conference 2001

- Ohio Building Science Focus Training 2002 
- Central Atlantic Regional Conference 2004

- National Leadership Conference 2004

- National Urban Conference 2005

- Florida Construction Roundtable 2005

- Pacific North West. Construction Roundtable 2005

- USGBC Charrette for Habitat's Gulf Coast Recovery, 2005

- National Leadership Conference/ Urban Conference 2005

- Western States Leadership Conference/Rural Conference 2006

- Phoenix, AZ National Building Science Focus Training 2006

\section{Heat Pipe Technology}

Gainesville, Florida

Florida H.E.R.O. met with Chuck Yount, National Sales Manager, and the residential engineering staff to discuss the requirements and anticipated performance of their stand-alone dehumidification system, the BKP series. This system has the ability to provide outside air and maintain positive pressurization, and it can be used in conjunction with a condensing section to reject heat generated through dehumidification. During the $4^{\text {th }}$ budget period, Florida H.E.R.O. suggested the use of this technology to several contractors who build large homes.

\section{HKW Enterprises}

(Lewis Place Association, Ltd., Meadowbrook Development Inc., Millpond Development Corp., and Joyner Construction.)

Gainesville, Florida

Category B, 333 Homes

Awards: NHBA Energy Value Gold Medal Award

Florida H.E.R.O. worked with HKW Enterprises and its subsidiaries to incorporate Building America specifications in

- 1 apartment complex with 112 units (Lewis Place)

- 2 town house developments with 210 units (Williamsburg and Monticello),

- 1 single family home built by Joyner Construction.

Lewis Place was the first Energy Star low income apartment complex in the country and it incorporated an interior duct system (Figure 41) with a comprehensive air sealing protocol that included cellulose wall insulation with a gasket between the top plate and the drywall. The units also featured direct vent gas water heaters for good indoor air quality. The Williamsburg and Millpond townhouse developments and the single family home built by Joyner Construction were built with similar features.

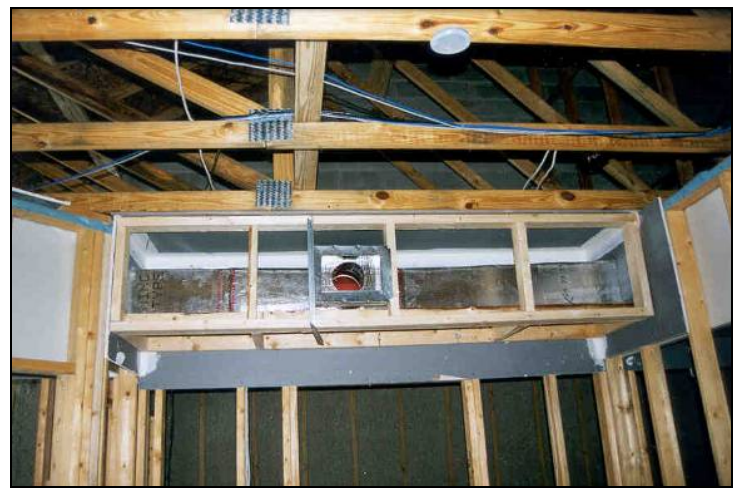

Figure 41 Interior duct system under construction at Lewis Place - the first Energy Star apartment complex in the country. 


\section{Homark Homes}

Initial Visit and Testing, Eastern Dakota Housing Alliance (EDHA)

Red Lake Falls, Minnesota

The Eastern Dakota Housing Alliance, a BAIHP partner whose work is further described under Applegren Construction, is considering a partnership with Homark Homes of Red Lake Falls, Minnesota as part of a larger plan to provide affordable housing options in rural areas. Homark Homes is a HUD code and modular manufacturer. BAIHP visited their facility to determine their ability to produce Energy Star level homes. Researchers toured the factory and tested a model home for envelope and duct air tightness.

Construction techniques were consistent with Energy Star level quality and several model specifications are already being produced to Manufactured Housing Research Alliance (MHRA) Energy Star standards. Of special interest was the use of duct and plumbing crossover connections through the rim joist and through-the-wall electrical crossovers, all of which eliminate belly penetrations and their contribution to envelope leakage as is reflected in the ACH50 test result of 3.4. Test results were consistent with Energy Star standards (Table 23).

Table 23 Envelope \& Duct Tightness Test Results

Homark Model 980, dbl section, 1560 sq.ft

\begin{tabular}{|l|l|l|}
\hline Ducts & $\begin{array}{l}\text { CFM25out }=27 \\
\text { Qn }=1.7 \%\end{array}$ & CFM25total $=210$ \\
\hline Envelope & CFM50 $=700$ & ACH50 $=3.4$ \\
\hline
\end{tabular}

A follow-up visit is planned to Homark to certify the plant for production of HUD code Energy Star homes per the MHRA guidelines. This will involve testing at least two more homes and at least three duct systems on the factory floor.

\section{Homes of Merit \\ Marathon, Florida \\ Category B, 14 Homes}

In 2002, Florida H.E.R.O. performed multiple diagnostic tests and conducted a site survey on a mobile home with mold problems in Marathon, Florida. Florida H.E.R.O. determined that the mechanical system was significantly oversized, and the home was operating under negative pressure during system operation. The owner left the central system fan in the "on" position, further exacerbating the indoor humidity problem. Measured indoor relative humidity levels were about $70 \%$, consistent with outdoor humidity levels. Since this case has gone into litigation, researchers have not had the opportunity to determine the final outcome.

In 2001, Florida H.E.R.O. met with plant personnel and LaSalle Air Systems at Lakeland Homes of Merit factory to discuss Energy Star compliance for model homes and HUD code factories. The researcher also performed duct tests on several models at the Bartow manufacturing plant, assisted in development of material and system specifications, and conducted the Energy Star Energy Star Manufactured Home Plant Certification at the Lake City and Bartow plants. 


\section{International Builders Show Showhomes $\left(6^{\text {th }}\right.$ Budget Period) $^{-}$}

From January 13 to January 16, 2005, Orlando was host to the 2005 International Builders' Show, sponsored by National Association of Home Builders. The show was a massive success; the best attended International Builders' Show on record, with over 105,000 housing professionals in attendances. Located adjacent to the International Builders' Show is an adjunct show, the Show Village.

The Reed Building Group, publishers of Professional Builder, Professional Remodeler, Custom Builder and GIANTS magazines, sponsored the Show Village. The show village is a unique environment where attendees explore showcase homes. Attendees see and learn about products in actual houses, which allows for interaction with manufacturers' products and gives some idea how the products will appear and function in their actual installed environment.

\section{A. New American Home, Built by Goehring Morgan Construction Orlando, Florida \\ Category A, 1 home}

Builder of the New American Show Home for the 2005 National Builders Show in Orlando, Florida. BAIHP supported IBACOS by testing (Table 24) and rating the home and. Data collected at this home by IBACOS will be processed and archived with support from FSEC's data management system.

Table 24 Test Results for 2005 New American Home

\begin{tabular}{|c|c|c|}
\hline Test & Measurements & Notes \\
\hline Whole House Air Tightness & $\begin{array}{l}\text { CFM50 }=5552 \\
\text { ACH50 }=5.0\end{array}$ & $\mathrm{C}=549, \mathrm{n}=0.591, \mathrm{r}=.9996$ \\
\hline Duct Leakage AHU1 Master Suite & $\begin{array}{l}\text { CFM25, total }=160 \\
\text { CFM25, out }=48\end{array}$ & $\begin{array}{l}3 \text { Ton } \\
\text { AHU Flow }=1203\end{array}$ \\
\hline Duct Leakage AHU2 & $\begin{array}{l}\text { CFM25, total }=300 \\
\text { CFM25, out }=\text { zero }\end{array}$ & $\begin{array}{l}5 \text { Ton } \\
\text { AHU Flow }=1550\end{array}$ \\
\hline Duct Leakage AHU3 Suite 2 & $\begin{array}{l}\text { CFM25, total = } 104 \\
\text { CFM25, out }=32\end{array}$ & $\begin{array}{l}2 \text { Ton } \\
\text { AHU Flow }=898\end{array}$ \\
\hline Duct Leakage AHU4 Foyer & $\begin{array}{l}\text { CFM25, total }=155 \\
\text { CFM25, out }=40\end{array}$ & $\begin{array}{l}2 \text { Ton } \\
\text { AHU Flow }=1120\end{array}$ \\
\hline All Duct Leakage & $\begin{array}{l}\text { CFM25, total }=719 \\
\text { CFM25, out }=120\end{array}$ & $\begin{array}{l}12 \text { Tons } \\
\text { AHU Flow }=4771\end{array}$ \\
\hline
\end{tabular}

B. Discovery Custom Homes Modular Showhome

Orlando, Florida

Category A, 1 home

In 2005 the Show Village featured a Discovery Custom home, made by a division of Palm Harbor Homes in their Plant City, Florida factory. The Tuscany model of the Palm Harbor show house is a one-story, three-section, modular factory-crafted home. It has three bedrooms, two bathrooms, and a home office. It has $2084 \mathrm{ft}^{2}$ of air-conditioned space, a 528- $\mathrm{ft} 2$ garage, a $48-\mathrm{ft}^{2}$ portico, and a $385-\mathrm{ft}^{2}$-patio deck. 
When Palm Harbor was presented with this opportunity to showcase one of their homes, they solicited help from BAIHP to showcase energy efficiency, good indoor air quality, and green building practices. Features incorporated into the home are:

Energy Features

- Unvented structurally insulated panel (SIP) roof over master bedroom and hearth rooms

- R-33 vented ceiling over first two sections

- Conditioned, unvented insulated crawlspace

- Low-E Argon metal windows $\mathrm{U}=.47, \mathrm{SHGC}=.32$

- R-22 walls

- SEER 17.95/ HSPF 7.95 two-speed compressor right-sized heat pump, programmable thermostat with outdoor thermostat which prevents strip heat turn-on above freezing

- Instantaneous propane water heater

- Compact fluorescent lights in selected areas

- Energy Star Appliances

- Estimated energy savings $=35 \%$ on a whole house basis

- Home Energy Rating Scale (HERS ‘99) Score = 93 Out of 100

Indoor Air Quality Features

- Fresh air ventilation with filter on outside air intake (fresh air is provided only when the air handler unit is on)

- Humidistat (built-in with thermostat)

- MERV9 media filter with 3500-hour life

- Ultra-violet A lights with catalyst to reduce volatile organic compounds

- Low VOC materials and VOC Source Control

Green Building Features

- Enhanced indoor air quality and energy efficiency

- Resource efficient construction and construction waste management

- Water efficient appliances and fixtures

- Durable, low maintenance design

- Meets Florida Green Building Coalition standards

After the show, the home will be donated to Orlando's Home Builders Association's Foundation. Palm Harbor is the 2001 Gold Award winner of the National Housing Quality Award.

C. Not So Big Showhouse

Orlando, Florida

Category A, 1 home

Sarah Susanka Not So Big Showhouse for the 2005 Builders show. (Figure42) FSEC assisted CARB with the HVAC system design. FSEC tested the air tightness of the ducts and the envelope, assisted in the design and installation of the PV and solar water heater, performed the Energy Star and FGBC certifications. 
The home's energy saving features which were selected with the hot-humid Florida climate in mind, include:

- High efficiency air conditioning (SEER 16)

- Active dehumidification and ventilation

- Solar water heating with tankless gas backup

- High performance glazing

- Reflective metal roofing

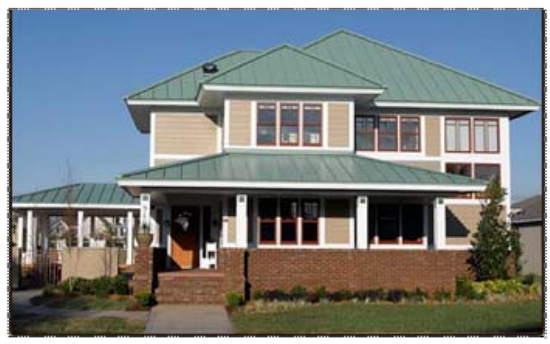

Figure 42 Not So Big showhouse in Orlando, FL.

FSEC installed instrumentation and data was regularly collected and displayed on an InfoMonitors website. The measured energy was used to determine if the energy features are working out as planned and in InfoMonitors web-site was developed.. More info at http://www.notsobigshowhouse.com/

- Comfort conditions (temperature and relative humidity)

- Total energy use

- Detailed data on cooling, heating, and water heating energy use (the three main energy users in American homes)

After the show was over, conversations continued with the new owner of the NSBSH and a site visit was made by BAIHP researchers to review all the features of the home. There were some issues regarding the electrical service entrance panel where wires were not properly insulated and a short had occurred. The homeowner contacted the builder to resolve the issue. The DC disconnect for the PV system was never installed and the homeowner was informed of this. The solar water heating system was not operating properly at the time of the site visit and it appeared that the DC circulation pump had failed or a connection was damaged. The homeowner agreed to contact the installer for assistance.

\section{International Builders Show Showhomes}

The 2006_International Builders Show Showhomes was held in Orlando, Florida in January. BAIHP staff worked in the Building America booth and provided technical assistance to several IBS show homes

A. New American Home

Orlando, Florida

Category A, 1 home

BAIHP supported IBACOS - the primary technical assistance provider for the annual New America Home - by making site visits to document progress in the months leading up to the 2006 IBS. During construction, pictures were taken on a bi-monthly basis and made available for public view. The home achieved a Florida Energy Star rating of 90.8.

Green building and energy star certifications were awarded to Hannigan Homes for the New American Home 2007. The presentation was conducted during a press event at the home during the 2006 International Builders Show. 


\section{B. Palm Harbor Homes}

NextGen Show Home; First Time Show Home, and Move-Up Show Home

Orlando, Florida

Category A, 2 houses

Category $B, 1$ house

FSEC personnel provided design input and made several visits to Palm Harbor Home's Plant City manufacturing and sales facility to inspect and test prototypes of the three show homes for the 2006 IBS show. Recommendations to improve the air distribution system and HVAC installation were made to help PHH meet the FGBC guidelines and Building America levels of energy efficiency for all three houses.

In December 2005 the houses were evaluated in both Energy Gauge Florida and USA, as well as evaluated for compliance with Florida's Green Building Program. Of the three homes, the NextGen home met the Green Standards, and the other two needed only simple improvements to meet the Green Home standard which were made. The NextGen house was built to the Institute for Business and Home Safety's Fortified Home standard to further enhance Palm Harbor's already outstanding durability and wind resistance.

In January 2006 before the show, all three homes were inspected, tested and certified as Florida Energy Star compliant and qualified for the Florida Green Building Coalition Green Home Certification. The December 2005 energy and green recommendations were followed, resulting in homes that met the Building America HERS ' 99 rating of $90+$ except the Move-Up house, which had duct work problems in the field which prevented it

\begin{tabular}{|l|l|}
\hline \multicolumn{2}{|c|}{ Table 25 2006 IBS Palm Harbor } \\
Homes HERS ‘99 scores \\
\hline Model & HERS ‘99 Score \\
\hline NextGen & 90.6 \\
\hline Move-Up & 89.6 \\
\hline First Time & 90.0 \\
\hline
\end{tabular}
achieving a HERS '99 score of over 89.6. (Table 25)

One-page BA summaries of each Palm Harbor Homes Showhouses were written and framed Energy Star and Green Home certificates made for display in each model.

\section{$\underline{2007 \text { International Builders Show }}$}

\section{A. Palm Harbor Modular Show Homes}

Preparations for the 2007 IBS began early in 2006. Meetings were held with representatives from Schneider Electric (Square D), Sharp Electronics, Fronius USA (solar inverter manufacturer), DOE, and many other show participants. Schneider Electric announced a new Intelligent Load Center with an automatic disconnect to backup power sources such as generators and PV systems for distributed generator-ready homes. The load center is estimated to save $\$ 800$ to $\$ 1200$ in product and labor costs.

\section{B. New American Home}

BAIHP will again support IBACOS in this project and during the final year of the project, construction progress is being documented with weekly pictures at the FSEC website, available for public viewing. 


\section{Kashi Church Foundation}

Sabastian, Florida

On February 2 BAIHP met with representatives from the Kashi Church Foundation located in Sebastian, Florida. This group oversees a private development which is expanding through construction of new residential housing. Preliminary discussions were held regarding green certification and a Building America partnership. The Building America partnership was initiated in early 2006 to assist with the design and construction of 33 new homes.

\section{Kit HomeBuilders West}

Caldwell, Idaho

See also "Zero Energy Manufactured Home" in the Research section of the report.

Kit Home Builders West was the builders of the Zero Energy Manufactured Home in response to an RFP issued by the Bonneville Power Authority in partnership with BAIHP staff in Washington and Idaho. See Zero Energy Manufactured Home in the Research section of this publication.

\section{Marlette Homes, Kokanee Creek Everett, Washington}

In 2004, Marlette was involved with a new 32 home multi-story development called Kokanee Creek (Figure 43a). BAIHP staff conducted field evaluation on the first set of homes and provided technical assistance to Marlette and the developer HomeSight, related to the envelope and duct leakage improvements. This was a follow-up project to the successful collaboration with Marlette Homes in the NOGI Gardens community.

\section{Marlette Homes, NOGI Gardens}

Seattle, Washington

Technical Assistance by BAIHP Contractors Washington State University Energy Program, Oregon Office of Energy and Idaho Department of Water Resources, Energy Division

Awards: $\quad H U D$ Secretary's Gold Award for Excellence

$$
\text { Energy Value Housing Award }
$$

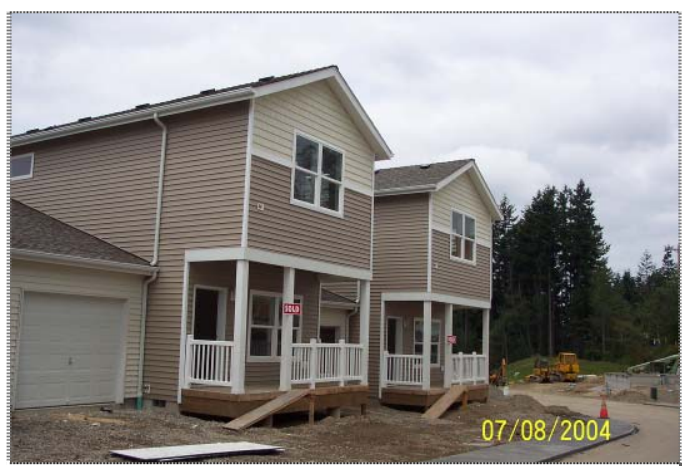

Figure 43a Kokanee Creek HUD-code MultiStory HUD-code housing

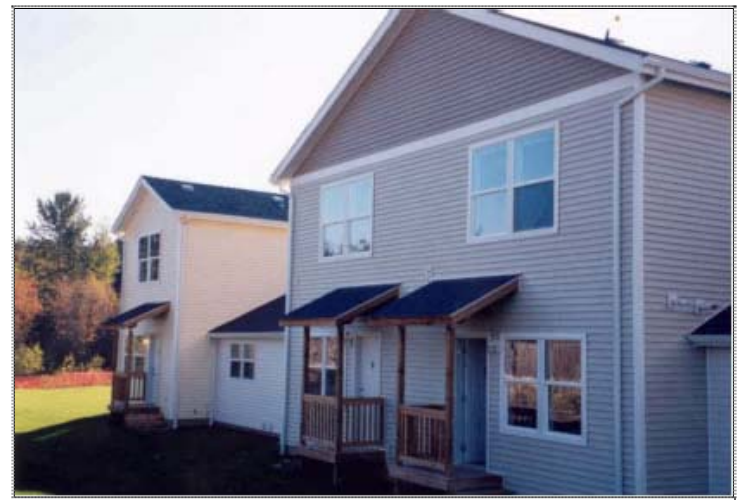

Figure 43b. Nogi Gardens, America's first HUD Code attached town houses.

Nogi Gardens is a 75-home community

located in southeast Seattle The project contains the first two-story, HUD Code attached "townhouse homes" (Figure 43b). All the homes have been built by Marlette Homes in Hermiston, OR to Super Good Cents/Energy Star specifications. A blower door test of the 
building envelope showed 5.0 ACH at 50PA, average for a manufactured home in the Pacific Northwest. Duct leakage is very low, due to Marlette's use of mastic and duct risers.

Miami-Dade HOPE VI Project

Miami (Dade County), Florida

Technical Assistance by BAIHP Researchers Rob Vieira and Eric Martin

This project was a community revitalization program aimed at lessening poverty density by demolishing dilapidated public housing and replacing it with new, less dense housing. In this HUD-sponsored inner city redevelopment project, about 860 public housing units were to be torn down and replaced with 450 new units. The new units would have included duplexes, townhouses, and single-family homes.

As part of a sustainability team, FSEC participated in the initial design charrette which reviewed project home designs, made architectural recommendations on wall and roof assemblies, exterior finishes, and other energy-related design and construction features.

During 2002, FSEC provided assistance to Miami-Dade Department of Environmental Resources Management when they emphasized the importance of Building America principles and techniques to the Miami-Dade Housing Authority. The Housing Authority conducted a mandatory value-engineering meeting to ensure that their Hope VI Project would meet the available budget. FSEC staff, as well as other stakeholders, took part in housing discussions and analysis to ensure that the Building America principles and techniques specified early in the project would be considered and not engineered out of the project.

Unfortunately, this project never got past the design stage due to a lack of cooperation among existing residents of the area.

Midgard Associates (see East Bay Development)

\section{Nez Perce Fish Facility \\ Cle Elum, Washington}

Three SGC homes were built at the Nez Perce tribal fish facility in Cle Elum, WA. One of these homes is equipped with Energy Star appliances and lighting; all three homes are heated with Insider heat pumps. Monitoring equipment was installed in Year 2. In Year 3, preliminary blower door testing indicated a high leakage rate. During Year 4, tests found significant duct leakage due to failure of butyl tape at risers on 2 year old home. (See also Section III Research Zero Energy Manufactured Home.) 


\section{New Generation Homes}

Ft. Myers, FL

Category B: 1 house

Ken Kingon of New Generation Homes became a BA partner at the end of the $5^{\text {th }}$ budget period. Of particular interest is the performance of the high efficiency 5 ton 15 SEER AC system and the use of outside air ventilation (measured air flow $=32 \mathrm{cfm}$ ) to the air handler. A house was tested and instrumented in February 2005 by FSEC researchers, showing that duct leakage and air tightness are consistent with new home

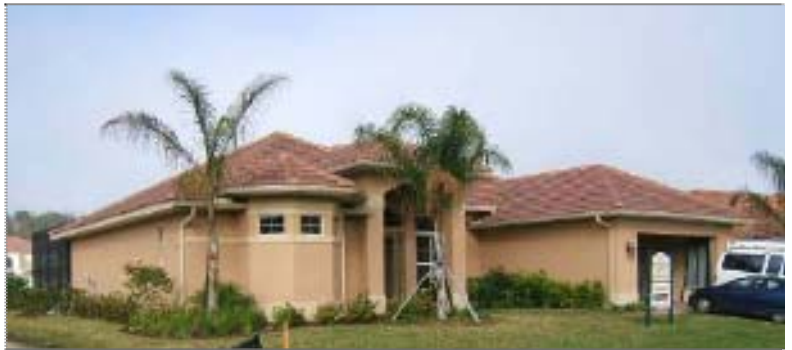

Figure 44 New Generation Home construction, there are opportunities for improvement. The HERS '99 score is 87.9.

\section{Northwest Energy Efficient Manufactured Housing Program (NEEM)} Idaho, Oregon, and Washington (State)

(See also Champion Homes and Fort Lewis Military Housing)

The Washington State University Energy Program (WSU), together with partners Oregon Office of Energy and Idaho Department of Water Resources, Energy Division, continue to provide technical and research support to the Northwest Energy Efficient Manufactured (NEEM) Housing Program in the Pacific Northwest. The NEEM program involves 20 plants in three states, hundreds of retailers and thousands of homebuyers.

The NEEM program includes the brands Super Good Cents and ENERGY STAR, and includes homes heated by electricity and Natural Gas/propane. Prior to 2003, the NEEM program also included the Natural Choice brand, which was exclusive to homes heated with Natural Gas or propane. In 2003, the Natural Choice brand was phased out; now, all gas heated homes are branded ENERGY STAR. In 2004, a new path for ENERGY STAR was developed for Super Good Cents homes with electric furnaces. Homes will be built to this path beginning in 2005 .

In the fall of 2004, NEEM staff began to provide technical assistance to Champion Homes on an 850 unit private military modular housing development at Ft. Lewis. In-plant verification, certification and on-site verification of these homes began in spring of 2005 and continues as a major BAIHP effort. (See Champion Homes in Technical Assistance.)

In the fall of 2004, technical assistance by NEEM staff to the Energy Trust of Oregon resulted in the development of a million dollar utility incentive program that promotes the production of a more NEEM homes built to higher benchmarking levels consistent with BAIHP goals. A technical analysis of the ETO program has been provided to FSEC.

\section{Aligning with New Building America Goal}

In the summer of 2004, BAIHP staff performed a benchmarking evaluation to assess the improvement of NEEM homes over the entire BAIHP project period (note that this evaluation was included in the Year 5 (April 2003 - March 2004) annual report). The benchmarking was based on a home defined by NREL (built to IECC requirements). The savings over the 
benchmark home were estimated using version 2.2 of Energy Gauge USA. Evaluations were performed for a typical $1600 \mathrm{ft}^{2}$ double wide home with $12 \%$ glazing to floor area (the NEEM fleet average) in three Pacific Northwest climate zones: Portland, OR; Spokane, WA; and Missoula MT.

The homes were benchmarked assuming a continuously operating whole house ventilation system, resulting in a significant thermal energy penalty. Additional benchmarking was also conducted using the $164 \mathrm{kWh} /$ year ventilation assumption in the NREL benchmark, in an effort not to penalize the homes for improved IAQ associated with HUD whole house ventilation system requirements and ASHRAE 62.2.

In 2004-2005, improvements were made to NEEM HVAC systems and duct specifications as a result of BAIHP research (see Refinement of NEEM Specifications, below.) Additional benchmarking is presented that reflects these improvements.

The results of the benchmarking vary considerably by HVAC type, water heat and climate, as noted in Table 26 below. Some key observations:

- In all climate zones, electric homes result in negative savings if the ventilation penalty is assumed. This is largely the result of the assumption that the benchmark home has a heat pump that performs without installation problems; an assumption that will be evaluated by BAIHP research.

- Gas heated NEEM homes came closest to meeting the overall BAIHP goal of $40 \%$ over the NREL benchmark, but only met the goal if gas heat is paired with electric water heat, in cold climates with no ventilation system penalty.

- Eliminating the ventilation system penalty has a higher impact on benchmarking results ( 9 to 23 percentage points) than improved duct leakage tightness ( 3 to 11 percentage points).

- It should be noted that Benchmarking these NEEM homes against the HUD-FMCSS requirements $(\mathrm{Uo}=.079)$ for manufactured homes rather than the IECC $(\mathrm{Uo}=0.06)$ would yield considerably higher savings than current benchmark assumptions. 
Table 26 Benchmarking Savings Results

\begin{tabular}{|l|c|c|c|c|}
\hline \multicolumn{1}{|c|}{ Duct Leakage } & Pre-2004* & $2004^{* *}$ & Pre-2004* & $2004^{* *}$ \\
\hline Portland & Yes & Yes & No & No \\
\hline Electric Furnace & -31 & -20 & -8 & 0 \\
\hline Heat Pump & 11 & 14 & 20 & 22 \\
\hline Gas Heat/Elec DHW & 16 & 22 & 32 & 37 \\
\hline Gas Heat/Gas DHW & 15 & 20 & 30 & 34 \\
\hline Spokane & -18 & -9 & 2 & 10 \\
\hline Electric Furnace & 17 & 21 & 27 & 30 \\
\hline Heat Pump & 22 & 27 & 36 & 41 \\
\hline Gas Heat/Elec DHW & 21 & 26 & 35 & 39 \\
\hline Gas Heat/Gas DHW & -12 & -3 & 8 & 15 \\
\hline Missoula & 17 & 22 & 28 & 32 \\
\hline \begin{tabular}{l} 
Electric Furnace \\
\hline Heat Pump
\end{tabular} & 21 & 26 & 35 & 40 \\
\hline $\begin{array}{l}\text { Gas Heat/Elec DHW } \\
\text { Gas Heat/Gas DHW }\end{array}$ & 20 & 25 & 34 & 38 \\
\hline $\begin{array}{l}\text { * Pre-2004-Duct leakage of -132 cfm@25PA } \\
* * 2004-\text { Duct leakage of -60 cfm@25PA }\end{array}$ & & & \\
\hline
\end{tabular}

Figure 45 shows, by program year, the number of homes produced with technical assistance from BAIHP, as well as the number of homes submitted for ENERGY STAR designation by BAIHP staff and the breakdown of homes by benchmarking score. Please note the following:

- The benchmarking includes the assumption, based on the NEEM $5^{\text {th }}$ Budget Period random that showed $24 \%$ of all homes included after-market heat pumps.

- No benchmarking was performed for Years 1 and 2, due to a lack of accurate regional data.

- In 2003 and 2004, the appearance of homes that achieved a 30+\% benchmark is the result of the improvements made to the NEEM HVAC specifications.

- Figure 45 averages benchmarks for Spokane and Missoula for homes in cold climates and uses the Portland benchmark for marine climates. Figure 45 also assumes an average value between ventilation penalty and no ventilation penalty.

The continued success of the program is due to several factors. BAIHP and NEEM staff worked to increase awareness within the manufactured housing industry of the marketing value of energy efficiency, increase participation by utilities in incentive programs, and promote the co-branding of NEEM with ENERGY STAR. 


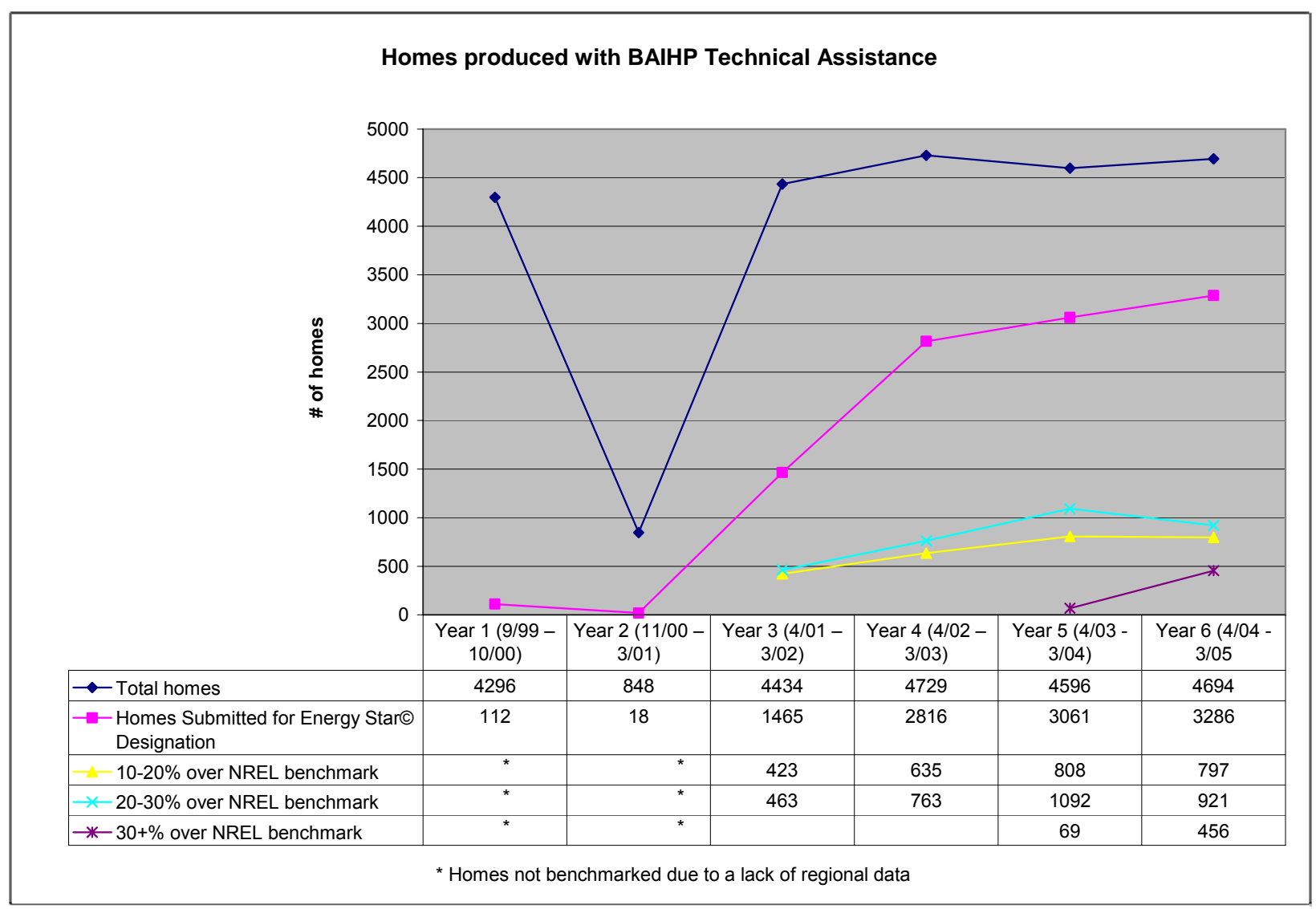

Figure 45 Homes Produced with BAIHP Technical Assistance

The increase in ENERGY STAR designations is due to refinement of the SGC duct sealing specifications, resolving a discrepancy between the SGC specifications with ENERGY STAR's duct sealing protocols (while this question was being resolved September of 1999 through early 2001, BAIHP staff did not submit homes to DOE for ENERGY STAR designation). In 2003, remaining discrepancies with manufacturers in Idaho were further resolved, allowing BAIHP staff to accurately report all qualifying homes.

\section{NEEM Refinement of SGC specifications}

BAIHP staff continually work to refine the existing SGC specifications, a result in large part to innovative building technologies researched in BAIHP.

In 2003, BAIHP staff worked with NEEM staff and manufacturers to develop revisions to NEEM specifications, including allowing only mastic for duct sealing, requiring metal flex duct for whole house ventilation fans, and changing the air infiltration specification from $7.0 \mathrm{ACH}_{50}$ to $5.0 \mathrm{ACH}_{50}$.

The revised specifications were voted on and accepted by the manufacturers; they took effect on January 1, 2004. 
In year 2004 in Oregon and Idaho plants began testing the ducts in all the NEEM homes they produce, which is expected to result in even tighter duct systems. Field testing of a sub-sample of these homes duct testing began in 2004 and continues. This field testing is also evaluating homes that employed a "thru-rim" crossover duct system.

BAIHP staff continues to work with EPA and other regional partners on clarifying the equivalency of SGC with ENERGY STAR. In 2002, BAIHP staff developed a new ENERGY STAR compliance path for climate zone 2 that does not require a heat pump. The non-heat pump path uses a heat recovery ventilation system, a .93 EF hot water heater and tighter ducts and envelope. This path was not utilized due to reluctance by manufacturers to install HRV systems. In 2004, this path was modified to eliminate the HRV, and include options such as set-back Tstats, ENERGY STAR dishwasher, adjusted glazing limits, improved window U-factors, and inplant tested duct systems.

\section{NEEM Revised In-plant Manual}

In 2003, in light of the revisions to the NEEM specifications, BAIHP staff from the Oregon Department of Energy developed an updated in-plant inspection manual, with new graphics, including details on correct installation of heat recovery ventilation. Many of the manual updates are the result of BAIHP research and demonstration efforts, including use of hybrid floor systems and proper duct sealing with mastic. The manual also now includes a regionally consistent problem home inspection protocol.

\section{NEEM In-plant QC Training}

In 2004, BAIHP staff from the Oregon Department of Energy developed a PowerPoint presentation, based on the revised In-plant manual. In 2004, BAIHP staff began using this presentation to train QA staff at each plant; this effort will continue until all NEEM plants have received this training.

\section{NEEM In-Plant Inspections}

On a quarterly basis, BAIHP staff visits each of the manufactured housing plants to verify compliance with SGC/E-Star specifications. Inspections include a plant audit, ventilation system testing, and troubleshooting construction-related problems with plant staff and independent inspectors. Consistent issues in the plant include wall insulation compression or voids due to improper cutting of batts, attention to duct installation and air sealing. Specific in-plant inspection reports conducted in Washington in program Year 6 (March 2004 - April 2005) are provided to FSEC.

\section{NEEM Manufacturers' Transition to Mastic}

As mentioned above, the NEEM program eliminated the use of butyl tape for duct sealing, and required the use of mastic. By the spring 2004 (year 6), ten manufacturers have successfully transitioned to mastic. Testing in-plant has indicated significant improvement in duct leakage rates of homes in these factories- an average 36.8 cfm@25 PA (versus 50.1 cfm @ 25 PA premastic), a 27\% improvement. This trend continued into 2005.

Also in the $6^{\text {th }}$ budget period, WSU and ODOE began working with Fleetwood engineers to evaluate a new lower cost duct leakage testing device that Fleetwood is considering using in all of its plants throughout the USA. The preliminary results suggested a need utilize 10 second 
averaging and set a higher pressure ratio from $86 \%$ to $90 \%$ to be consistent with NEEM duct leakage targets. This work will continue through program 2005-06.

In the final year of the project, thirty homes built by manufacturers with the most experience using mastic and in-plant duct leakage testing were tested to represent the highest efficiency ducts achievable by the improved 2004 NEEM specifications. These "best case" ducts were compared with previous random sample BAIHP research of NEEM homes that used butyl and acrylic foil tape. In addition, researchers conducted field and modeling assessment of the energy impacts and implementation challenges of through-rim crossover duct systems. The report of these findings will be published as part of the HUD-code Symposium at the ASHRAE 2007 Winter Meeting.

\section{NEEM Duct Testing Workshops}

Through the spring of 2005, BAIHP staff continued to provide workshops focused on improved duct installation and inspection oversight, working in partnership with BAIHP partners. One inplant duct leakage workshop resulted in the identification of significant duct leakage (branch disconnect) which re-enforced the need to consider duct testing of all units at that plant.

Since January of 2006, all 10 Oregon factories, four out of five Idaho plants, and one out of two Washington plants test all duct systems in each floor to ensure low leakage ducts using testing equipment - very good progress in a two year period.

\section{NEEM New Technology Evaluations}

High Efficiency Gas Furnaces Initial evaluations of $90 \%$ efficient gas furnaces indicates that there is no incremental installation cost to the use of these furnaces, as no field modifications are required. In 2003, Nordyne and Evcon came out with furnaces with an appropriate footprint for manufactured housing; Intertherm also continues to offer a $90 \%$ efficient model. Discussion with BAIHP home manufacturer partners Fuqua, Marlette, Champion, and Fleetwood, and furnace manufacturer partners Evcon and Nordyne, indicate the that this market is

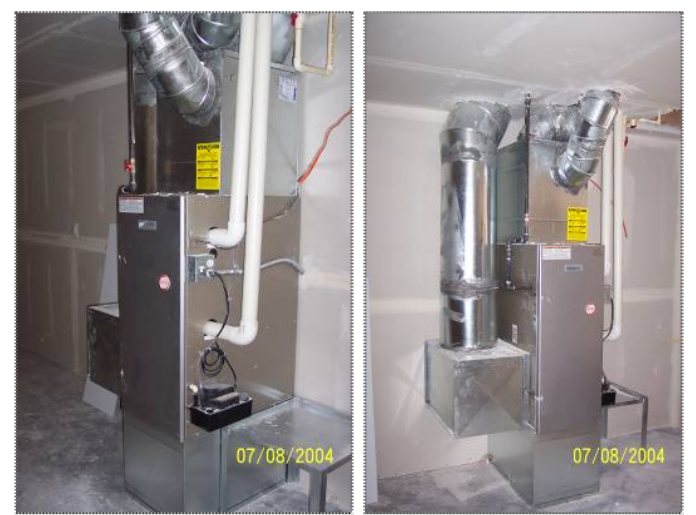

Figure 46 90\% AFUE Furnace, as installed at Kokanee Creek growing quickly, especially in homes with high pitch "tilt-up" roof systems, and multi-story homes such as the ones at Nogi Gardens and Kokanee Creek. The ability to use wall venting instead of roof venting with condensing furnaces makes them more attractive where tilt-up roofs are employed.

Through the rim crossover duct system Three Oregon manufacturers, Marlette, Skyline and Homebuilders Northwest, adopted a crossover duct system that runs through a cut out section of the rim joist, effectively placing the entire crossover system in the heated space. A gasket on the marriage line provides a seal between sections. Challenges with the use of this system include the need for very accurate measurements to insure matching of the duct connection, and careful treatment of the gasket material during set up, so that it doesn't detach from the rim. Evaluations suggest that that further improvement to gasket systems may be needed to ensure set-up that achieves effective duct sealing. 
La Salle Duct Riser BAIHP staff worked with BAIHP partner La Salle Air to design and produce a duct riser for manufactured homes that uses mastic instead of tape. BAIHP staff demonstrated prototype designs of the riser to Northwest manufacturers in year 3. Most NEEM manufacturers adopted the new risers or equivalent systems in year 6. BAIHP staff worked with Fleetwood's national office to promote the use of the riser in all Fleetwood plants. During 2003-2004, BAIHP staff promoted the use of this technology at the annual MHI conferences and energy roadmapping meetings.

Flexible Technologies: BAIHP partner Flexible Technologies has developed innovative systems that improves the heat and tear resistance of the duct inner liner, reduces the crimping of ductwork without the use of sheet metal elbows, and an improved system to air seal where the crossover duct penetrates the bottom board. BAIHP staff evaluating the use of this system in the WSU Energy House and ZEMH, and worked with Flexible Technologies staff to promote the use of the new system to the region's manufacturers. Efforts to gain market adoption of the technology remain challenging due to first cost increases and lack of demonstrated benefits.

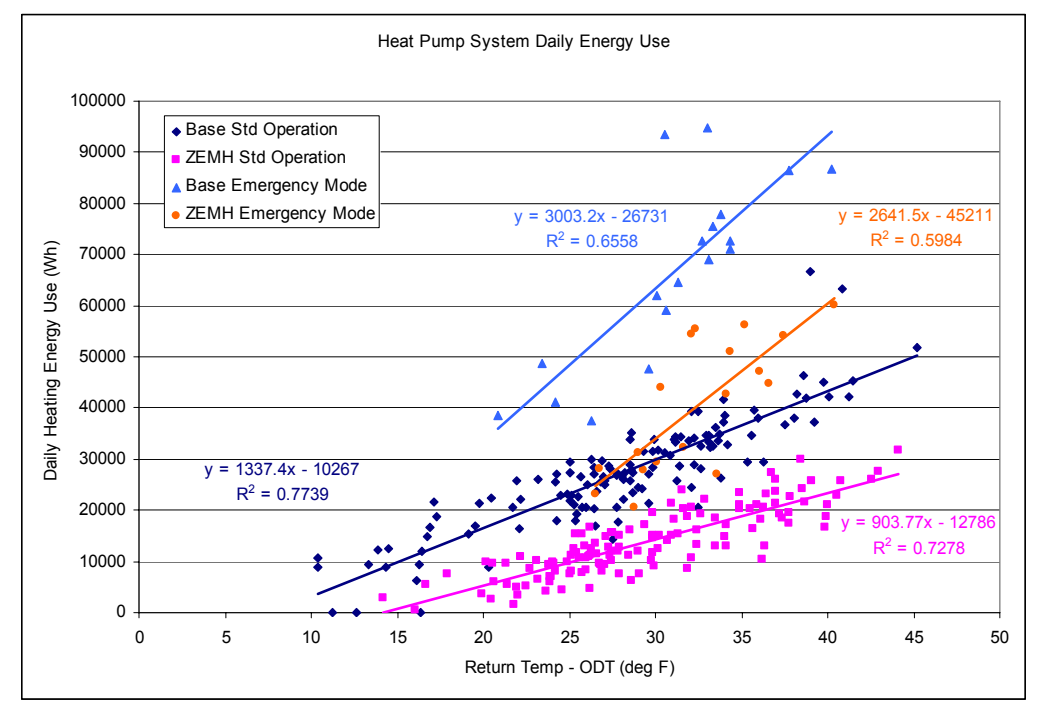

Figure 47 Insider Heat Pump in ZEMH and Base Home - Operation in HP and Strip Heat Mode

Insider Heat Pump: Monitoring of the Insider heat pump at the WSU Energy House was begun in 1999. Measured flow rate of the indoor unit was good ( 850 CFM total, 425 CFM per ton), but BAIHP staff identified two performance issues: a too-frequent operation of the defrost cycle and a lower than expected airflow at the outdoor coil. Continued testing of the Insider in 2002 indicated a 10\% increase in COP due to increased airflow at the outdoor coil. At Vincent Village, the property manager indicated a high degree of satisfaction with the Insider heat pumps, with no comfort complaints. Flip flop testing that varies the compressor and electric resistance heat was conducted in the WSU and ZEMH. The results of those tests being analyzed for an ASHRAE paper to be submitted in 2005. The Insider Flip flop test results are presented in Figure 47.

Energy Conservatory Products: BAIHP staff work with the Energy Conservancy (EC) to evaluate their new products for measuring air handler and exhaust fan flows. In 2004, BAIHP staff worked with EC staff to develop an automated test that will provide duct leakage to outside. 
Discussion with EC indicated significantly increased sales of duct blasters to HUD-code manufacturers as a result of BAIHP efforts. WSU continues to work with EC to develop new building science tools for HUD-code housing.

NEEM Work with Other Technologies: In 2004, BAIHP staff submitted a status report summarizing program efforts to introduce BAIHP manufacturers to new technologies. The report highlights the barriers and successes made regarding:

- 24" OC Wall Framing

- Air-Tight Can Lighting Fixtures

- Solar Ready design

- Improved flashing/drainage systems

- High Efficiency Water Heaters

- Blown Cellulose Hybrid Floor Insulation

- Condensing Gas Furnaces

- Heat Pump Water Heaters - Site built

- Hi-R wall Systems (Foam Sheathing + Icynene) - Site Built

\section{Oakwood Homes}

Moultrie, Georgia

Hillsboro, Texas

Kileen, Texas

Technical Support by BAIHP Researcher David Beal

BAIHP assisted Oakwood Homes with one problem home investigation between April 2003 and March 2004. This large HUD code manufacturer previously requested an FSEC duct installation review and consultation on ways to make the home's systems work better together. In 2002, plant visits were made to the Oakwood plant in Moultrie, Georgia and to the Hillsboro and Kileen, Texas plants. Recommendations for appropriate duct system design and manufacture were reported to Oakwood Homes.

An EnergyGauge USA analysis of Energy Star and non-Energy Star homes in Boston, Minneapolis, and Indianapolis was performed. Researchers determined that Oakwood Homes could meet Energy Star standards if they increased installed gas heating and cooling system efficiencies, and floor and roof insulation levels. These results were communicated to Oakwood management via email. 


\author{
Palm Harbor Homes \\ Category A, 5 Homes \\ Category B, 18 Homes \\ Category C, 1,645 Homes (North Carolina factories) \\ Category D, 52.561 Homes \\ Awards: 2001 Gold Award winner of the National Housing Quality Award \\ 2004 Energy Value Housing Award \\ 2006 Gold Award (Hot/Humid/Climate), Energy Value Award \\ See also 2005, 2006, and 2007 International Builders Show Showhouses.
}

First under the Energy Efficient Industrialized Housing Program (EEIH) and now under BAIHP, FSEC collaborates with Palm Harbor Homes (PHH) offering building science advice, energy ratings, and conducting diagnostic testing including infrared building and duct air tightness thermal imaging camera inspection. As a result, PHH now incorporates added return air transfer ducts to minimize pressure imbalances in the conditioned space and measures leakage of every duct system to ensure losses below 3\% $\left(\mathrm{Qn}_{\text {total }}\right)$ at

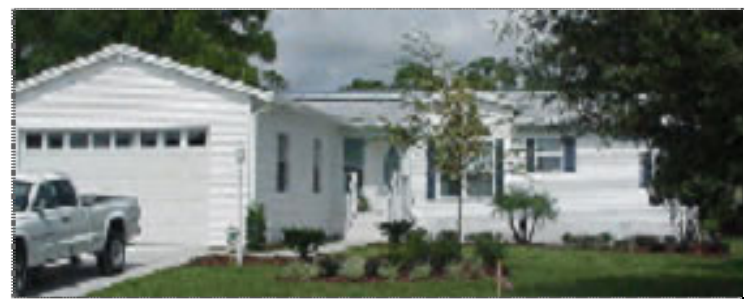

Figure 48 A Palm Harbor Energy Star home manufactured in Plant City, Florida. every factory.

FSEC provided assistance to Bert Kessler (PHH VP of Engineering) with submission of an NAHB nomination for the 2004 Energy Value Housing Award.

PHH Nationwide Energy Star Plant Certification

With FSEC guidance, PHH Plant City produced the world's first two HUD-code Energy Star homes in 1997 (Figure 35). Since then, EPA has implemented an Energy Star factory certification procedure which involves testing in both the factory and at the home sites. The procedure verifies consistent factory production of Energy Star level manufactured homes.

Nine Palm Harbor factories have completed certification (Table 27) under the new Energy Star guidelines for manufactured homes.

Table 27 Energy Star Certified Palm Harbor Plants

\begin{tabular}{|l|l|}
\hline Plant Location & Certification Date \\
\hline Plant City, FL & April 2002 $\left(4^{\text {th }}\right.$ Budget Period $)$ \\
\hline $\begin{array}{l}\text { Sabina, OH } \\
\text { Austin, Buda, Ft. Worth, } \\
\text { and Burleson, TX }\end{array}$ & June $2002\left(4^{\text {th }}\right.$ Budget Period $)$ \\
\hline Boaz, AL & June $2003\left(5^{\text {th }}\right.$ Budget Period $)$ \\
\hline $\begin{array}{l}\text { Albemarle, NC } \\
\text { La Grange, GA }\end{array}$ & September 2003 $\left(5^{\text {th }}\right.$ Budget Period $)$ \\
\hline
\end{tabular}




\section{PHH Energy Star Ratings using EnergyGauge USA}

In the fifth budget period, FSEC rated two PHH modular homes produced in Texas. Prior to that, FSEC staff conducted several EnergyGauge ratings and related energy analyses for PHH Plant City (FL) and performed two energy analyses comparing standard HUD code specifications to PHH energy improved homes sited in Detroit, Morgantown (WV), and Missoula (MT).

In October of 2005 researchers performed a comparison of a PHH spec-FEMA unit with a costeffective Energy Star upgraded unit and sent the results to the DOE. This led to more analysis of energy efficiency features for FEMA temporary housing.

\section{PHH EnerGMiser Energy Management System}

Researchers conducted an analysis of the PHH EnerGMiser Energy Management System and quantified the energy savings over base-case HUD code homes in 40+ US cities. Energy savings ranged from $28 \%$ to $42 \%$. The results of these analyses are listed at the PHH corporate web site at www.palmharbor.com/our_homes/home_features/energy_management_system.

\section{PHH Energy Tax Credits}

In 2005-06, BAIHP staff Chasar, Beal, and Moyer met several times with PHH GM Draper, along with members of production, purchasing, sales, and engineering staff to discus the 2006 tax credit, and what PHH would have to do to receive the credit. Several EnergyGauge USA simulations were performed on two different PHH plans to provide feedback. In general, PHH is building an Energy Star quality envelope, and needs only to increase the SEER of their A/C installation to 14 or 15 to qualify for the $\$ 2,000$ credit.

\section{PHH Factory in Albemarle, North Carolina}

FSEC contacted the North Carolina engineering manager for information on Palm Harbor's typical model construction specifications in order to begin Energy Star qualifying procedures. Two PHH model analyses for three different climate zones were run to assess initial energy efficiency. These tests were rerun once specific window SHGCs were received from PHH.

On February 24 and 25, 2003, FSEC conducted a plant visit to direct and oversee Energy Star certification tests on six floor models. Tests were completed by FSEC and by factory personnel with FSEC oversight. All models passed the $3 \%$ leakage limit. To complete the certification, three additional site installed homes will be tested for compliance.

FSEC staff also worked with the plant engineer on builder option packages (BOPs) versus software options as a means to qualify homes for Energy Star. It was determined that qualifying homes in Energy Star zones 3 and 4 will be feasible using BOPs, but EnergyGauge USA will be needed to certify at least some of the zone 2 homes.

\section{PHH Factory in Austin, Texas}

PHH initiated certification procedures for Energy Star per the EPA/MHRA guidelines. Staff completed the reporting and certification on two PHH Austin homes in the Houston area for Energy Star compliance. One home passed and the other failed due to belly board installation problems. (Figures 49 and 50) These belly board problems have since been addressed and the Austin plant and the remaining three Texas plants are currently being certified for Energy Star production. 


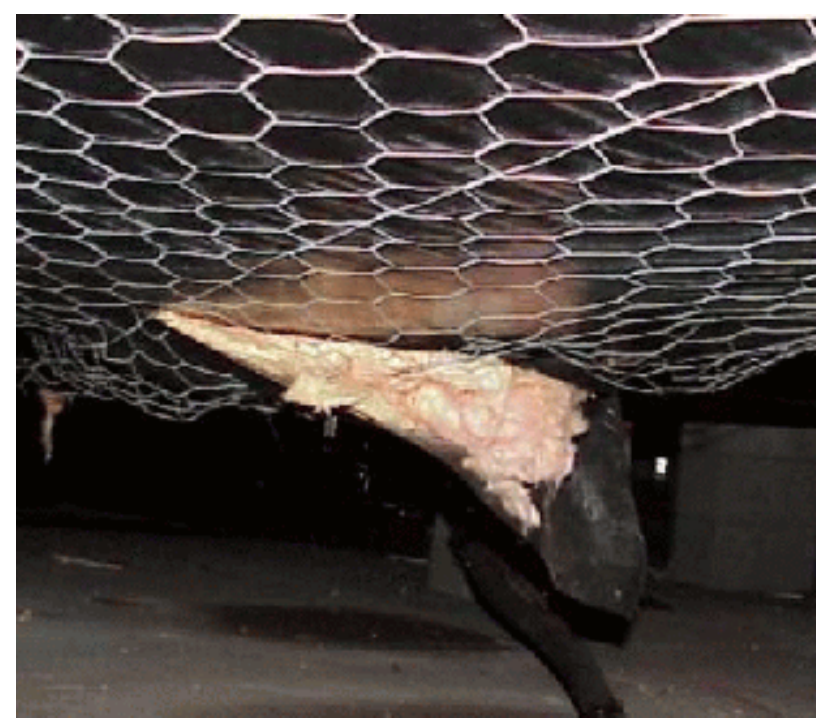

Figure 49 Another belly tear found during inspection.

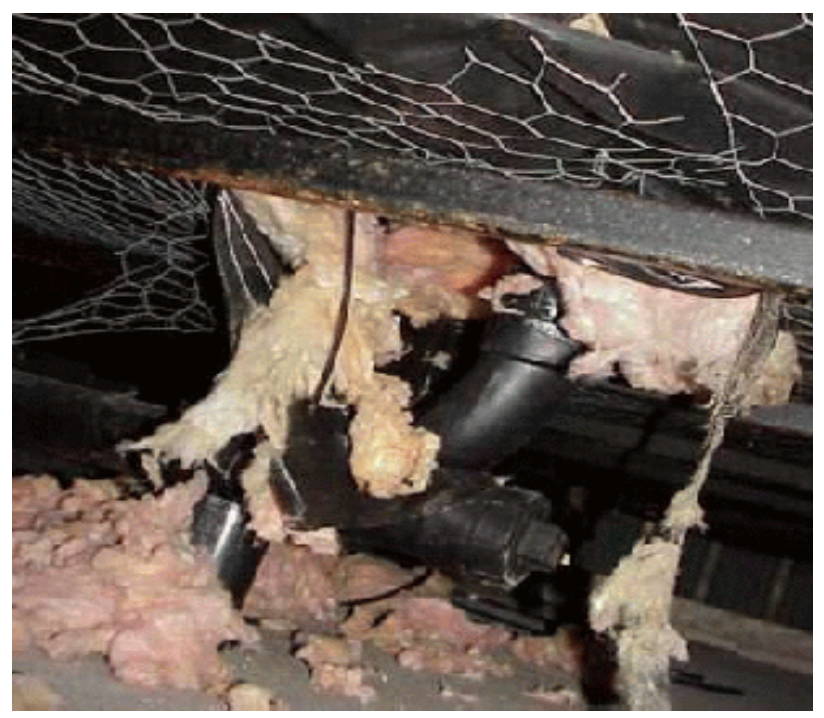

Figure 50 Worst belly tear near plumbing penetration.

\section{PHH Home with Comboflair Integrated VAC System}

(See III BAIHP Research, B. Site Built Housing Research, Comboflair Integrated HVAC System) A Manufactured home in Austin, TX owned by Palm Harbor Homes, Inc was assembled with a prototype Comboflair HVAC system. The Comboflair system was tested, using a datalogger collecting interior living conditions throughout the home as well as detailed measurements of the Comboflair's thermal and electrical performance. Analysis of the data began. Researchers redesigned the water injection system to provide a less problematic delivery of interior water vapor.

\section{$\underline{\text { PHH Factory in Plant City, Florida }}$}

\section{Energy Star Plant Certification}

Researchers initiated certification procedures for Energy Star per the EPA/MHRA guidelines. FSEC reviewed the Design Approval Inspection Agency (DAPIA) packages and design procedures. The PHH Plant City factory was certified in February 2003 and registered one Energy Star home in Polk County, Florida.

FSEC met with the plant engineer on September 16 and 17, 2002 to analyze several new models for Energy Star eligibility. The analysis was conducted using EG USA software (v-1.32). Researchers assisted the plant engineer with a combination of EG USA software and BOPs, so that all plant models over several states could reach Energy Star levels.

\section{Insider Heat Pumps}

In 2001, five model homes at PHH-Plant City were tested for return air performance. Two of the homes were modular with Insider heat pumps. Performance results and recommendations were submitted to the plant engineer.

Staff retested two modular homes with Insider heat pumps and determined that leakage in the condenser fan compartment was depressurizing the homes. Further testing on other Insider 
installations is needed to uncover the scope of this problem and plans are in progress to find the best corrective course of action. BAIHP will visit PHH Plant City and observe the installation when the next Insider heat pump is requested. Researchers will look for installation problem areas and perform additional home tests.

\section{Technical Assistance}

Diagnostic tests were conducted in 2002 and 2004 on homes in Odessa and Plant City, Florida manufactured by PHH-Plant City. These visits were requested by $\mathrm{PHH}$ after they received a homeowner high-utility bill complaint. In Odessa, inspections with the infrared (IR) camera found no insulation problems and duct blaster and blower door tests revealed airtight duct and envelope systems. Other than an oversized air conditioning system, there were no obvious reasons for the high bills. The homeowner was satisfied with the investigation and apologized for their written complaint. In Plant City, problems with the sizing of the field-installed A/C ducting had caused temperature differences in the home. PHH redid the ducting and BAIHP hasn't heard further complaints.

\section{PHH Building America Homes}

Palm Harbor Plant City built two homes that meet or exceeded current Building America energy goals, one study home used in the Manufactured Housing Indoor Air Quality (IAQ) study detailed in Section III, and a high visibility modular home built for the 2005 International Builders Show (IBS) in Orlando FL. Both homes were built in cooperation with BAIHP researchers. The IAQ house's HERS '99 score was 91.1, the IBS building scored a 93. The IAQ home demonstrated a 50\% saving in A/C energy compared to an Energy Star rated home (HERS ' 99 of 86.5) used for control in the same experiment. The IBS showhouse is detailed in the Technical Assistance section under "International Builders Show Showhouses."

\section{$\underline{\text { PHH Factory in Sabina, Georgia }}$}

PHH signed an Energy Star Partnership Agreement to begin certification of the Sabina Plant. Two model home plans were analyzed, each with a gas furnace and a heat pump, using EnergyGauge USA software. The plant certification visit and site-installed home ratings were done in Spring 2002 and certification paperwork was forwarded to the EPA for plant registration. $\mathrm{PHH}$ is planning a 54-unit development in Wilmington, Ohio. Modifications made at the Sabina Plant should be very helpful for the Wilmington endeavor.

\section{Patrick Family Housing, LLC.}

\section{Satellite Beach, FL}

The Patrick Family Housing group represents a partnership between the US Air Force and American Eagle Communities, and is handling a housing privatization project, taking place on Patrick Air Force Base in Satellite Beach, FL. Plans are underway to construct several hundred single-family housing units (begun in 2005), which will be leased to Air Force personnel. In 2005, BAIHP provided design assistance (specific advice on adapting systems to Florida's hothumid climate) and met with the group to discuss mechanical design issues in five model homes. A review of HVAC design and system sizing was conducted by sub-contractor Calcs-Plus.

FSEC staff visited the site where the five prototype homes are being constructed and made recommendations on insulation, stucco application, and attic venting. 


\section{Penn Lyon Homes}

Selinsgrove, Pennsylvania

See also, Avis American Homes (Technical Assistance section) and Status and Control System (STACS) (Section III, Research).

In March of 2004, Penn Lyon Homes (Selinsgrove, PA) began a large scale plant wide test of a prototype Status and Control System (STACS) developed by BAIHP researchers at the UCF Constructability Lab. The system is a real time shop floor labor data collection and reporting system. Production workers use wireless laser scanners (Figure 51) to report their current work assignment.

STACS reporting is web based and provides both real time manufacturing status and summaries of historical production performance. While labor represents a relatively modest fraction of production cost, typically $10-15 \%$, it has a profound impact on operations, including product quality, cycle time, material waste, and labor productivity. The test will continue through the summer of 2004, and results will be used to develop labor models using linear regression and neural nets.

\section{Podia Construx/Rainbow Springs Construction \\ Gainesville, Florida \\ Category B, 22 Homes}

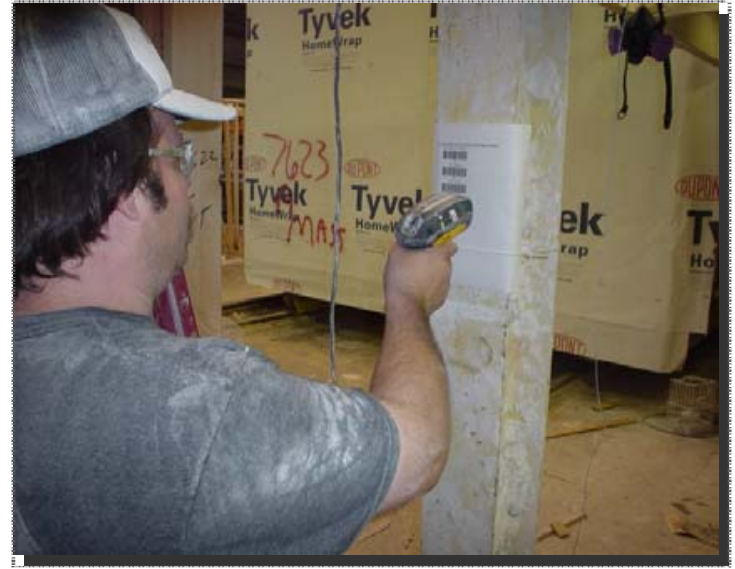

Figure 51 Scanning drywall activities with new STACs device.

Florida H.E.R.O. worked with David Sullivan, owner of Podia Construx, his sales staff, project management, and principal sub-contractors to incorporate Building America concepts into the communities of Rainbow Springs, Hidden Lake, and Ocala Waterway.

Podia builds mostly concrete block homes with a continuous, interior layer of $3 / 4$ " unfaced rigid wall insulation and unvented attics. Spray foam insulation is applied to the underside of the roof deck and is sometimes used for wall insulation. Some of Podia's homes are performance tested for duct and whole house air tightness. The homes also feature SEER 13 heat pumps or SEER 13 air conditioners coupled with standard gas furnaces. All homes have filtered outside air ventilation and double pane Low-E vinyl frame windows.

Podia tried replacing roofing felt with Tri-Flex material for moisture transmission reduction on home, but after complaints from the roofers regarding a lack of footing on the slick material, the Tri-Flex was removed and replaced with standard felt paper.

\section{Condensation Complaint}

In response to a homeowner's concern about excessive condensation on interior windows, Florida H.E.R.O. performed a site survey of ambient, interior, surface, and subsurface moisture readings to determine the cause. This home has Icynene sprayed on the underside of the roof 
sheathing and an outside air duct. The outside air duct damper had been shifted to the closed position. The damper was reopened and the moisture related complaints were eliminated.

\section{Royal Concrete Concepts}

West Palm Beach, Florida

Royal Concrete Concepts in West Palm Beach became a BAIHP partner during the final year of the project,. BAIHP researchers toured their West Palm Beach, FL facilities and observed the process used to create poured concrete modular buildings and poured concrete panelized wall systems.. Discussions regarding expansion of the Building America partnership were held and included providing assistance with optimization of a new modular factory currently underway in Okeechobee, FL and detailed monitoring of performance of a poured concrete modular unit.

In the spring of 2006, UCF researchers began technical assistance to Royal Concrete Concepts in the design of their concrete modular plant in Okeechoobe. Project scope was refined, focusing on supply chain improvement for selected critical materials, including HVAC equipment. Valueadded processes and material flow will be examined, from the vendor through installation in the module, and will include the disposition of waste generated by the production process. In May of '06, the research team visited the existing Royal factory in West Palm Beach. The team observed production processes and collected data, focusing on four types of building materials: EPS foam, rebar, steel framing, and HVAC equipment. Initial drafts of value stream maps were developed, documenting value-added processes and material flows, from the vendor through installation in the module, and including the disposition of waste generated by the production process.

\section{Sandspur Housing \\ Maitland, Florida \\ Category $B$}

Since 2002, FSEC staff has been working with Sandspur Housing, the largest affordable home builder in the nation. Sandspur constructs approximately 4,000 apartment units per year, primarily in Florida and Georgia. The company's primary interest in Building America is in receiving assistance for designing low energy-use units with good indoor air quality and resolving recurrent moisture problems in Florida's hot-humid climate. Contact with Sandspur was initiated by BAIHP subcontractor Florida H.E.R.O. in Gainesville, Florida.

Sandspur Housing staff toured David Hoak's high efficiency demonstration home to learn about various equipment and control options and the systems engineering approach. This allowed personnel to view firsthand some of the Building America principles and practices so that they could explain these concepts to others in the Sandspur organization. After the tour, discussions continued on the Landing Community analysis.

BAIHP has worked with Sandspur in Naples, Orlando, Gainesville, Lady Lake and Leesburg all in Florida - and Cary Park, North Carolina.

In 2006, BAIHP worked with Sandspur in regards to two complexes in Lady Lake and Leesburg. BAIHP researchers performed random duct tests at the complexes, finding that the ducts were tight but the air handler cavity was leaky. The researchers made recommendations for fixing the leakage. 


\section{Sandspur Housing, Naples, Florida}

For Camden Cove, Sandspur's community in Naples, BAIHP researchers conducted an energy analysis on all individual units and several apartment buildings slated for construction in 2003 and 2004. Information from Sandspur's building plans was combined with Florida H.E.R.O.'s field experience in Sandspur's Gainesville apartment complex Harbor Cove Community. Results indicated an opportunity to cost-effectively reduce energy use/cost in a 16-unit apartment building by more than $20 \%$ while improving indoor air quality and durability. Since Sandspur was already building fairly tight duct systems, savings potential in this area was already being achieved. Additionally, heating and cooling loads in multi-dwelling buildings are lower than similar size and construction single family detached housing because there are fewer exterior surfaces.

Energy efficiency recommendations included:

- Switching to $75 \%$ fluorescent lighting

- Reducing duct leakage to the outside to $3 \%\left(\mathrm{Qn}_{\text {OUT }} \leq 0.03\right)$

- Reducing window area to $6 \%$ of floor area

- Window shading strategies to provide overall solar heat gain coefficient of 0.2

- Installing ducts inside the conditioned space

- SEER 13.0 cooling systems

- White metal roofing or radiant barrier

- Programmable thermostats

- Ceiling fans in all bedrooms and main living areas

Air quality improvement strategies focused on including:

- Pleated return air filters rated with an Minimum Efficiency Reporting Value (MERV) of 11

- Filtered mechanical ventilation of $7.5 \mathrm{CFM} /$ person $+0.01 \mathrm{CFM} / \mathrm{ft}^{2}$

- Supplemental dehumidification

- Quiet, energy efficient bathroom exhaust fans with timer switches $\left(\leq 0.3 \mathrm{watts} / \mathrm{ft}^{3}\right)$

- Quiet, energy efficient vented kitchen range hoods in each unit

A summary of all analysis results and building design features was prepared and submitted to Sandspur Housing. Two meetings were held to review the recommendations.

Sandspur Housing, Orlando Moisture Investigations

FSEC staff tested four Sandspur-built apartment units and installed datalogging equipment in six units at the Landings Community in Orlando where some units had reported moisture problems. Measured envelope leakage was typical for new construction, and all but one unit had very tight duct systems. Dataloggers (stand alone temperature RH loggers) were deployed in the air handler of each unit to record interior moisture levels. Three weeks of data were plotted for six apartments as temperature, relative humidity, and dew point. Ambient weather data from the nearby Hoak house datalogger was included and compared favorably with published Orlando airport weather.

To continue investigating the cause of excess moisture in the apartment units, datalogging equipment was installed in six additional units. To remedy problems, prototype schemes were 
evaluated such as utilizing a humidistat in conjunction with thermostat, and installation of a dedicated dehumidifier. Data analysis was completed in April 2005.

Sandspur Housing, Gainesville, Brookside Apartment Complex

During the $5^{\text {th }}$ budget period, work was completed on testing and rating all 176 units in Sandspur's Energy Star apartment complex Brookside in Gainesville, FL. The report was approved for release and disseminated to DOE and others in the final year of the project. Apartment features are given in Table 38. Each apartment was individually tested for envelope and duct air tightness as well as flow through the passive outdoor air system by Bob Abernethy, FSEC technician, in collaboration with Florida H.E.R.O. Results are listed in Table 38 below. The complex consists of one to four bedroom models grouped into two-story buildings of eight to 16 units.

Table 38 Brookside Apartments Characteristics

\begin{tabular}{|c|c|}
\hline Component & Description \\
\hline Conditioned area & $\begin{array}{l}1 \text { Bedroom unit }=717 \text { sq. } \mathrm{ft} . \\
2 \text { Bedroom unit }=990 \text { sq. } \mathrm{ft} . \\
3 \text { Bedroom unit }=1313 \text { sq. } \mathrm{ft} . \\
4 \text { Bedroom unit }=1582 \text { sq. } \mathrm{ft} .\end{array}$ \\
\hline HERS '99 Score & $86.1-87.7$ \\
\hline Mechanical and System & $\begin{array}{l}\text { Interior air handler } \\
\text { Fresh air ventilation } \\
\text { Engineered and right sized systems } \\
\text { Engineered duct design }\end{array}$ \\
\hline Fresh Air Ventilation & $\begin{array}{l}\text { 4" fresh air duct provides } 34 \text { to } 45 \mathrm{cfm} \text { to house side } \\
\text { of HVAC filter when mechanical system is running. } \\
\text { Manual damper provided. }\end{array}$ \\
\hline Heating & $\begin{array}{l}\text { Hydronic heat coils fed by a conventional gas water } \\
\text { heater in an exterior closet }\end{array}$ \\
\hline Cooling & $\begin{array}{l}\text { SEER } 12 \text { AC }- \text { was SEER } 10 \\
1 \text { and } 2 \text { Bedroom units }=1.5 \text { Ton }- \text { was } 2-2.5 \text { Ton } \\
3 \text { and } 4 \text { Bedroom Units }=2 \text { Ton }- \text { was } 2.5-3 \text { Ton }\end{array}$ \\
\hline Ducts & Mastic sealed and tested \\
\hline Duct Leakage & CFM $25_{\text {OUT }}<5 \%$ of AHU flow \\
\hline Wall insulation & $\begin{array}{l}\text { Unfaced fiberglass batt (first cost savings of } \\
\$ 0.22 / \text { sq } \mathrm{ft} \text { and reduced site labor) }\end{array}$ \\
\hline Windows & \\
\hline Glazing \& Frame & \\
\hline
\end{tabular}




\section{Sandspur Housing, Cary Park, North Carolina}

BAIHP researcher compared two energy savings improvements: (1) upgrade from SEER-10 to SEER-11, and (2) add a programmable thermostat to the SEER-10 unit.

The Groves at Cary Park Apartments include a group of five buildings with 12 units each for a total of 120 units. A detailed computer simulation analysis was performed on a single, representative unit to compare the two energy saving measures using Energy Gauge USA version 2.3, which is based on the DOE2.1E simulation engine. The apartment chosen was a top floor 2-bedroom unit with north-facing windows since these units make up $50 \%$ of the complex whereas the remaining 1, 3 and 4 bedroom units make up $17 \%, 20 \%$ and $13 \%$ respectively and because the top floor 1 and 2 bedroom apartments are the only ones with exposure to an attic space over their entire floor area. The top floor 3 and 4 bedroom apartments are only partially exposed to an attic space while the remainder (about half the floor area) is below a 1-bedroom unit. The added attic exposure increases the heating and cooling loads on the top floor 1 and 2 bedroom units and is likely to present a worse-case scenario in terms of space conditioning load per square foot.

An hourly computer simulation of a top floor 2-bedroom apartment with north-facing windows was performed using TMY weather data for Raleigh, North Carolina. Four of the five buildings shown on the site plan are oriented at or very near to an east-west axis, causing the majority of windows to have either north or south exposures. The fifth building is oriented on a north-south axis. Specifications as taken from the plans provided are listed in Table 39.

Table 39 2-Bedroom Apartment Specifications

\begin{tabular}{|l|l|}
\hline Conditioned Area & 1,081 sq.ft. \\
\hline Walls & Wood Frame $(\mathrm{R}-13)$ \\
\hline Ventilated Attic & R-30 \\
\hline Roof & Dark shingles, $1: 300$ ventilation \\
\hline Floor & R-99 (to simulate no load) \\
\hline Double Pane Vinyl Windows & U-0.57, clear glass \\
\hline Infiltration & $5.0 \mathrm{ACH} 50$, or $0.183 \mathrm{ACH}$ \\
\hline Ducts & R-6, Qn- $0.06,9.4 \%$ air loss \\
\hline Thermostat & Non-programmable \\
\hline Set points & Cooling $75^{\circ} \mathrm{F}$, Heating $70^{\circ} \mathrm{F}$ \\
\hline Lighting & $10 \%$ Fluorescent \\
\hline Ventilation & None \\
\hline
\end{tabular}

\section{SEER-10}

The HVAC schedule in the building plans specifies a Carrier 38YKC024 heat pump compressor and FF1CN024 air handler for the 2-bedroom apartments. Literature downloaded from the Carrier website lists this combination as having efficiency ratings of SEER-10.3 for cooling and HSPF-7.0 for heating.

SEER-11

Product data on the $38 \mathrm{YKC}$ shows that several other air handler models (most of which are variable speed) can be used to achieve a SEER rating of 11 or higher and can boost the HSPF to 
7.2. These efficiency ratings were compared against the SEER-10 unit in an hourly simulation and showed a savings of $138 \mathrm{kWh} /$ year or $\$ 12 /$ year at an electric utility rate of $\$ 0.0826 / \mathrm{kWh}$.

SEER-10 plus Programmable Thermostat

Estimated savings from using a programmable thermostat in conjunction with the SEER-10 heat pump slightly exceeded the savings from going to the SEER 11 efficiency upgrade alone and showed a savings of $177 \mathrm{kWh} /$ year or $\$ 15 /$ year. A $3^{\circ} \mathrm{F}$ temperature difference was used for a nighttime heating set-back from $11 \mathrm{pm}$ to $7 \mathrm{am}$ and daytime cooling set-up from $9 \mathrm{am}$ to $3 \mathrm{pm}$.

Table 40 Estimated Annual Heating and Cooling Energy Use

\begin{tabular}{|l|c|c|c|}
\hline & SEER-10.3 / HSPF-7.0 & SEER-11 / HSPF-7.2 & SEER-10.3 w/prog.t-stat \\
\hline Heating kWh & 1,542 & 1,511 & 1,397 \\
\hline Cooling kWh & 2,006 & 1,899 & 1,974 \\
\hline Total kWh & 3,548 & 3,410 & 3,371 \\
\hline Annual Savings $(\$)^{*}$ & $\$ 12$ & $\$ 15$ \\
\hline *Estimated annual savings based on electric utility rate of $\$ 0.0826 / \mathrm{kWh}$ & \\
\hline
\end{tabular}

While it appears from the Carrier literature that the cooling efficiency on this heat pump model can be brought to SEER-11 by upgrading only the air handler, equivalent or better savings can also be obtained by employing a modest $\left(3^{\circ} \mathrm{F}\right)$ set-back/set-up schedule with a programmable thermostat.

\section{Scott Homes}

Thurston and Pierce County, Washington

Scott Homes is a site builder who has built a dozen spec and custom Energy Star NW/BAIHP homes using SIP panels and radiant slabs heating. The SIP wall/ceiling homes are some of the tightest homes built in the Energy Star Northwest Homes program coming in at less than 2.0 ACH50. The homes, built in the Marine climates of Thurston and Pierce County, Washington, use tank-less gas "combo" space and domestic hot water systems and employs both heat and non-heat recovery ventilators, Energy Star lighting and appliances. Scott has installed and is in the process of evaluating the TED device to help homebuyers reduce "plug load" energy use. A "solar ready" options is offered on his three home development currently under construction in Olympia. These homes are expected to benchmark in the $40 \%$ range without solar.

\section{Southern Energy Homes \\ Addison, Alabama \\ Category D, 26,231 Houses \\ Trip Report}

During the $1^{\text {st }}$ budget period, BAIHP held a meeting to introduce Building America to the industry. Representatives from Southern Energy Homes attended in hopes of finding solutions to moisture problems they were experiencing in coastal areas. In 2000, BAIHP researchers conducted building science diagnostics in several moisture damaged homes in coastal Louisiana and found contributing factors to be duct leakage and inadequate return air pathways from bed rooms. 
Southern Energy Homes took steps to achieve substantially leak free duct systems in all their homes. They switched from UL 181 approved tapes to mastic and fiberglass mesh for forming component connections in all their duct systems and began testing duct systems during production (Figure 52).

In 2002 FSEC received a request to certify the Southern Energy Homes (SEH) factory in Addison, Alabama for Energy Star compliance. A plant visit in August 2001 examined opportunities to enhance manufacturing productivity. Three model homes were tested for Energy Star certification, recommendations were made, and Energy Star plant certification paperwork submitted to US EPA.

In 2003 discussions continued with SEH plant personnel for conducting an analysis at one of their factories using the UCFIE simulation tool. On January

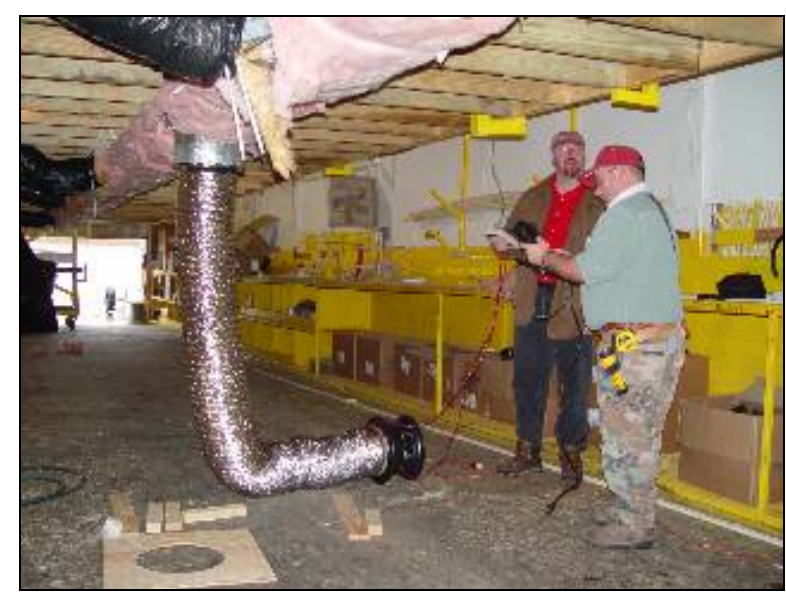

Figure 52 Southern Energy Homes quality control engineer conducts in-plant duct leakage test.

27 and 28, FSEC conducted site visits and performed diagnostic tests on several problem homes and submitted recommendations in a trip report in February. Based on these recommendations, FSEC conducted duct test training for factory personnel in four Southern Energy Homes factories.

In May of 2003 FSEC certified a Southern Energy Homes factory for EnergyStar production. FSEC conducted diagnostic field visits to Southern Energy homes in December 2003 and January of 2004 and provided recommendations in trip reports. Infrared inspection of the recommended retrofits was done in April 2004.

In 2004 two moisture related home inspections were done, the first in August and the second in September. Recommendations were made in trip reports.

\section{Spain Construction}

Gainesville, Florida

Category B, 33 Homes

In the $6^{\text {th }}$ budget period an evaluation of a homeowner complaint of significant condensation on the interior of the windows was made. Recommendations made were the installation of a passive outside air system which solved "95\%" of the problem according to the homeowner, and the use of independent dehumidification to eliminate the rest.

Florida H.E.R.O. worked with Spain Construction in the 5th reporting period to address a homeowner comfort complaint and to assist the builder's mechanical contractor in designing a distribution system in a new Willowcraft community custom home. Diagnostic tests and Manual $\mathrm{J}$ calculations performed for the homeowner complaint determined that the mechanical system was oversized by one ton. In addition to the air handler filter, the researcher also located a 
second filter at the return grill. The homeowner was unaware of this filter, so its replacement significantly improved the system airflow. Florida HERO recommended the introduction of outside air to the return side of the system to facilitate positive pressurization and to slightly increase the load and diminish some of the effects of oversizing.

The builder has improved his specifications from standard code compliance (SEER 10, single pane windows, etc.) to HERS '99 ratings of 87.5 - 89.4 for $100 \%$ of his homes. They feature SEER 13 air conditioning, double pane vinyl frame with low-E glass (SHGC of .34), air handler in conditioned space, R-30 ceiling and R-13 wall cellulose insulation. A few homes had ducts in conditioned space.

\section{Stylecrest Sales (Coleman HVAC Systems)}

Stylecrest Sales, formerly called Coleman HVAC Systems, is a major provider of mechanical system components to the manufactured housing industry. In helping various home manufacturers resolve duct leakage issues, BAIHP has worked extensively with the engineering staff at Stylecrest to resolve such problems as dimensional coordination of duct components, assembly procedures, and standards in duct joining recommendations.

BAIHP researchers also met with Stylecrest Sales to discuss Energy Star plant/home certification procedures and collected cost data for a variety of HVAC system sizes. In 2004, FSEC visited a moisture damaged home in Port Fouchon (LA) at the request of Stylecrest that was built by Southern Energy Homes using Stylecrest components. (See Section III, Research, Moisture Damaged Homes.)

\section{Timeless Construction}

\section{Long Island, New York}

Technical Assistance by BAIHP Researchers Subrato Chandra and Dave Chasar

This custom builder planned to build a large energy efficient custom home in New York with photovoltaic (PV) grid-connected panels. Discussions began on optimizing electrical energy use and including solar water heating panels for household water. The builder planned to use gas appliances wherever possible and a floor radiant heating system (pump energy is one-third that for a fan air distribution system). FSEC recommended a solar water heating system with gas backup and forwarded information on two solar water heater designs available from Duke Solar. FSEC also provided several choices in heat recovery ventilator (HRV) units which would provide $200 \mathrm{CFM}$ of outside air.

New construction drawings were received and EnergyGauge USA analysis results were discussed with the builder and Alten Design, since PV grid-interconnect requirements and architectural changes were needed to accommodate the PV panels. FSEC's PV group laid out a 7 $\mathrm{kW}$ PV system that included $4.5 \mathrm{~kW}$ 's of flat roof panels (unique for a residential application) and sent information to the architect. This activity ended in 2002 with no home construction. 


\section{Tommy Williams Homes}

Gainesville, FL

Category A, 19 Homes completed, 231 ongoing

This builder has gone from Florida energy building code minimum homes to being committed to build over 250 homes in two new sub-divisions that meet the BA goal of a HERS ' 99 score of 88.6 or above. Each home will be serviced with a "right-sized" Seer 14 heat pump with a variable speed air handler, double pane low-E windows with a SHGC of .36 or less, passive OA system and a programmable thermostat. Each home will be performance tested and commissioned.

\section{(On) Top of the World Retirement Community}

Gainesville, Florida

Category B, 212 Homes

Technical Support by BAIHP Subcontractor: Florida H.E.R.O.

Florida H.E.R.O. worked with project managers in charge of On Top of the World Central, a retirement community in Ocala developed by Sidney and Kenneth Colen who have built 15,000+ homes for senior citizens and have a commitment to developing communities that meet the needs and desires of that unique population.

Project managers of On Top of the World Central have every home performance tested for duct and whole house air tightness. Other features of the homes are summarized in Table 41.

This is the largest plotted sub-division in Florida, with over 24,000 homes slated to be built. Top of the World has gone from code minimum construction to Energy Star.

Table 41 On Top of the World Characteristics

\begin{tabular}{|l|l|}
\hline Component & \multicolumn{1}{|c|}{ Specification } \\
\hline Conditioned area & $1120-2093$ sq. $\mathrm{ft}$. \\
\hline HERS ‘99 Score & $86-89$ \\
\hline Mechanical and System & $\begin{array}{l}\text { Engineered and right sized systems } \\
\text { Engineered duct design }\end{array}$ \\
\hline Heating & Standard $80 \%$ AFUE furnace \\
\hline Cooling & SEER $12 \mathrm{AC}$ \\
\hline Ducts & Mastic sealed and tested \\
\hline Duct Leakage & CFM25out $<5 \%$ of AHU flow \\
\hline Wall & Block with steel interior framing \\
\hline Windows & Double pane \\
\hline
\end{tabular}




\section{Trinity Construction Corporation}

Coral Springs, Florida

Trinity Construction Corporation is a large shell contractor serving Florida homebuilders. Faced with increasing demands for higher quality, lower cost and more timely delivery, Trinity is actively exploring innovative alternatives to conventional concrete block construction, the predominant homebuilding technology in the central and south Florida market. Trinity operates a pre-cast concrete panel production facility, in South Bay, Florida

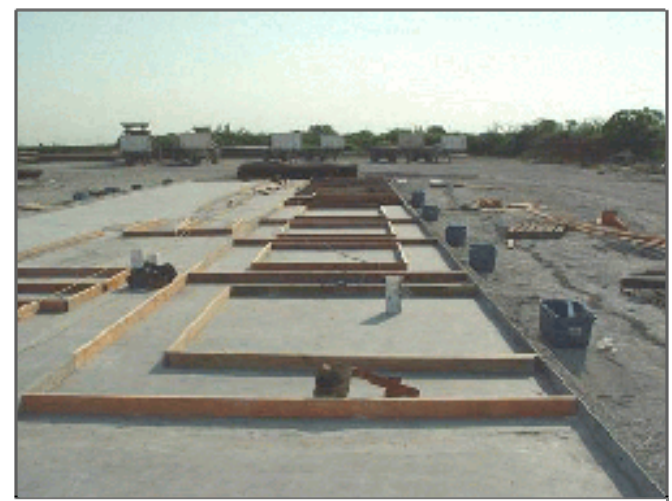

Figure 53 Panel forms on forming bed. where concrete panels are pre-cast (Figure 53), transported to the construction site, and quickly assembled using a construction crane (Figure 54). The UCF Housing Constructability Lab (HCL) was asked to assist Trinity in improving the current panelizing process by incorporating lean production principles such as "just in time" materials handling.

Preliminary research involved extensive observation and analysis. Value stream mapping, a process to isolate waste and production efficiency opportunities, identified activities that contributed value to the customer as well as activities that added little or no value. Material handling and rework were primary contributors to the $47 \%$ of labor consumed by non-value added activities. Once construction started, the flow of value-added activity was routinely interrupted. Poor access to materials and tools, rework, ill-defined process flows, and workforce $/ 1^{\text {st }}$ line supervision issues were

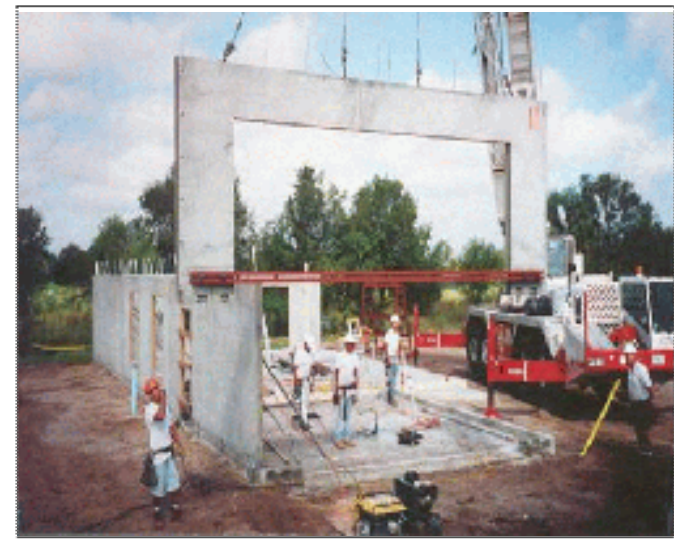

Figure 54 Setting pre-cast concrete wall panel. contributing factors. To address these issues, BAIHP researchers utilized lean production principles - challenging non-value added activities and removing the obstacles to continuous production flow. Recommendations addressed issues of organization/communication, structured procedures and work flow, material handling, and off-line sub-assembly.

Table 42 Panel Productivity in Square Foot of Wall per Labor Hour

\begin{tabular}{|l|c|c|c|c|}
\hline $\begin{array}{l}\text { Process } \\
\text { Phase }\end{array}$ & $\begin{array}{c}\text { "Tested } \\
\text { Sample" } \\
\text { Process }\end{array}$ & $\begin{array}{c}\text { Potential } \\
\text { Process Results }\end{array}$ & $\begin{array}{c}\text { Pilot } \\
\text { Test Process }\end{array}$ & $\begin{array}{c}\text { Productivity } \\
\text { Increase During Test }\end{array}$ \\
\hline Layout & 53 & 152 & 91 & $72 \%$ \\
\hline Prep & 52 & 149 & 79 & $52 \%$ \\
\hline Pouring & 146 & 211 & 296 & $103 \%$ \\
\hline Lifting & 75 & 440 & $75^{*}$ & $0 \%$ \\
\hline Total & 17 & 49 & 25 & $47 \%$ \\
\hline *Not altered during pilot test. & & \\
\hline
\end{tabular}


To test the recommendations, Trinity allowed BAIHP researchers to perform a 3-day pilot test. The test involved a single house consisting of 25 panels. The panels had a total of 21 window and door openings and a gross wall area of $3,119 \mathrm{ft}^{2}$. The first day was used to organize and train the test production team. The second and third days were dedicated to production. All 25 panels were produced. Productivity increased (Table 42) for all observed activities. Lifting productivity was not observed. Conservatively assuming that lifting activity will remain at historical levels, overall labor productivity increased by $47 \%$ during the Pilot Test. If lifting productivity is assumed to increase at the average rate observed for the other activities, overall productivity increase of the Pilot Test would be $68 \%$. Not all recommendations could be realized during the test. Some equipment and personnel issues could not be resolved on a short-term test basis. This suggests that the true potential is significantly greater than that observed during the Pilot Test possibly approaching $200 \%$ increase in labor productivity. Corresponding cycle time reductions are estimated to be $20-25 \%$.

The BAIHP research team recommended that Trinity precede with implementation of the lean production recommendations. In addition to the technical recommendations, the research team also made recommendations involving worker empowerment, dealing with the heat and sun, and material/equipment availability. Potential future research areas include covers for the production area, on-site factories in new home developments, and factory installed wall insulation. This successful pilot test has given Trinity the opportunity to develop a competitive advantage in the housing construction market and a solid foundation to gain dominance.

Vincent Village

Richland, Washington

Papers: $\quad$ Lubliner, Michael, 2007. HVAC Improvements in Manufactured Housing Crawlspace-Assisted Heat Pumps. Proceedings of the 2007 ASHRAE Winter Meeting.

Vincent Village is a 49 home rental community, located in Richland, WA. All of the homes are small, single section HUD Code homes, heated and cooled by Insider heat pumps since 1996. Half the homes were built to Super Good Cents standards, the other half were not. Metered utility data indicate average yearly savings of \$241 for the SGC homes. Investigations in 2006 with the current property manager found no maintenance problems or consumer complaints associated with the Insider heat pumps in these homes. These findings will be included in an ASHRAE report as part of a HUD-code Symposium at the ASHRAE 2007 Winter Meeting. The paper entitled "HVAC Improvements in Manufactured Housing Crawlspace-Assisted Heat Pumps". 
WCI Communities, Inc.

Bonita Springs, Florida

Category A, 2 Houses

Awards: 2004 SEBC Green Demonstration Home Aurora Award

2004 SEBC Green Production Home Aurora Award

2004 SEBC Green Home Grand Aurora Award

2004 Energy Value Housing Award, Silver Medal, Custom /Hot-Humid Climate

2004 NAHB America’s Best Builder, 501-plus closing category

Builder/Developer WCI Communities continues to embrace green building by having constructed over 100 homes to the Florida Green Home Standard, including two very high performance demonstration homes. They received the second ever Florida Green Land Development certification for their Venetian Development in Venice, FL in which all homes constructed within will also be green certified. Upon build-out, this will amount to over 1,000 homes.

WCI Communities architecture division is providing architectural services for the $2006 \mathrm{New}$ American Home. During a meeting at FSEC in July 2004, elements of green certification of this home were discussed. The principal architects have completed the green certification training offered by FSEC, and the project is on track to receive the Florida Green Home Designation once complete.

WCI is also planning another high performance demonstration home in a new community being developed on the south east coast of Florida. They have expressed interest in this being a Zero Energy home, and BAIHP conducted training in October 2004 for WCI staff and subcontractors providing an overview of $\mathrm{ZEH}$ design strategies and implications to the WCI architecture staff.

During the fourth budget period, in November of 2002, BAIHP staff members were planning to meet with WCI to discuss a partnership. Because of

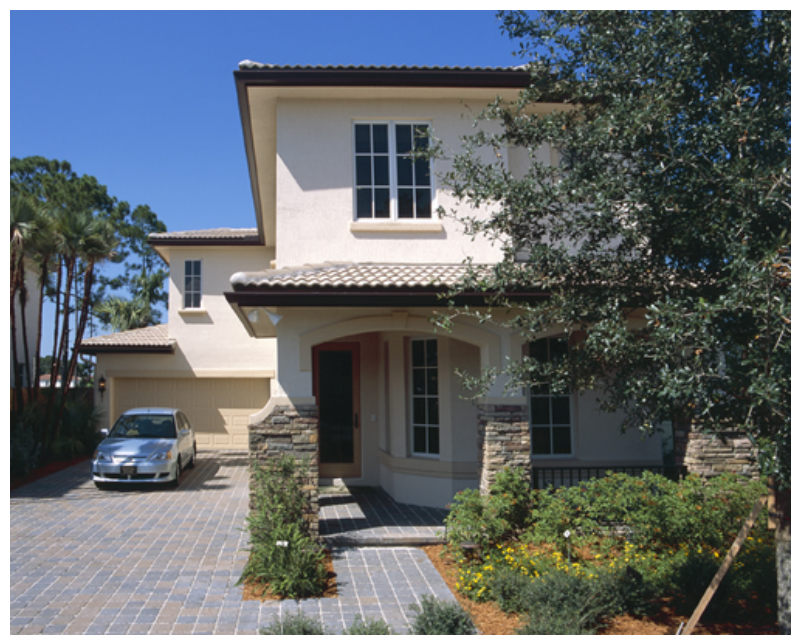

Figure 55 WCI Home in Evergrene Community, Palm Beach Gardens (FL), HERS ‘99 Score = 92. their corporate environmental mission, WCI plans to build a significant number of homes to the Florida Green Home Designation Standard and has requested the help of Building America to ensure a systems engineering approach, to conduct efficiency monitoring, and to offer staff training. WCI constructs approximately 2,000 homes per year across south Florida. In 2002 they committed to having houses incorporate a variety of green principles. In some WCI communities, every home will meet the Florida Green Standard.

FSEC received sample home plans and conducted an energy analysis using EG USA.

Recommendations were adopted by WCI (Table 26) for a model "green home" in the Evergrene 
Community (Figure 55) in Palm Beach Gardens (FL). BAIHP monitored progress on the prototype and installed monitoring instrumentation in April 2003 (fifth budget period).

The home and the instrumentation were completed in August 2003. A device called WebDAQ was installed, which acts as a server to provide an internet web page to display real time data as part of WCI's community education approach. WCI maintains a website dedicated to the home at www.greengeneration.org.

In September 2003, WCI held a grand opening at Evergrene. Staff from BAIHP and the DOE Atlanta Regional Office attended the event which included tours of the home and a program of distinguished speakers such as local government and business leaders.

This prototype "green home" received the highest score to date on the Florida Green Home Designation Standard. With a HERS ' 99 score of 92, it is estimated to save $31 \%$ compared to the Building America benchmark home and 38\% compared to the HERS ' 99 reference home on a whole house basis.

In February 2004, FSEC staff visited the Venetian Development in Venice, FL developed and built by WCI Communities, Inc. Over 1,000 homes will be constructed in Venetian, and all will meet the requirements of the Florida Green Home Designation Standard.

Table 43 WCI Evergrene Community - Green Home Model Specifications

\begin{tabular}{|c|c|}
\hline Conditioned Area & $1460 \mathrm{sq} f \mathrm{ft}$ \\
\hline HERS '99 Score & 92 \\
\hline \multicolumn{2}{|l|}{ Envelope } \\
\hline Above-grade Wall & ICF - first floor; $2 X 6$ with Icynene - second floor \\
\hline Attic & Unvented, insulated at roof deck w/Icynene \\
\hline Roof & Tile \\
\hline Windows & Laminated Impact Resistant with SHGC $=0.42$ \\
\hline \multicolumn{2}{|l|}{ Equipment } \\
\hline Ducts & Sealed with mastic; Located in unvented (Insulated) attic \\
\hline Heating \& Cooling & Variable speed SEER 15 with strip electric heating \\
\hline Thermostat & Programmable thermidistat \\
\hline Water Heater & Conventional gas unit with $\mathrm{EF}=0.62$ \\
\hline Lighting & CFL and fiber optic lighting with occupancy and daylight sensors \\
\hline Appliances & Energy Star \\
\hline Indoor Air Quality & Extensive VOC source control through paint, cabinet, and counter top selection \\
\hline Ventilation & Passive fresh air duct to mechanical closet; Whole house filtration with UV sterilization \\
\hline \multicolumn{2}{|l|}{ Green Features } \\
\hline Lumber & All lumber certified sustainable, treated lumber is ACQ, other lumber is engineered \\
\hline Water Conservation & $\begin{array}{l}\text { Dual flush toilets, automatic faucets, drought tolerant landscape, micro irrigation, } \\
\text { rainwater harvesting. }\end{array}$ \\
\hline Resource Efficiency & $\begin{array}{l}\text { Eco-friendly flooring and finishes } \\
\text { Construction waste management plan }\end{array}$ \\
\hline
\end{tabular}

In addition, WCI constructed another "ultra green" model. WCI consulted BAIHP during the initial planning stages, and this home was expected to have higher performance and contain more green features than the Evergrene Community home. WCI took the initiative to develop in-house expertise and capabilities in this area and needed much less support from BAIHP. BAIHP did involve IBACO, another BA Team, to help develop an advanced lighting design. 


\section{III BAIHP RESEARCH}




\section{BAIHP RESEARCH OVERVIEW}

BAIHP conducts research with Industry Partners in manufactured and site built housing and using the laboratory facilities at the Florida Solar Energy Center.

$\underline{\text { Research Context for Hot-Humid }}$ Climate

The primary opportunities for improving energy efficiency can be generalized into two categories: increasing equipment efficiency and reducing equipment loads. The latter of these contributes to improving comfort, durability, and indoor air quality also.

In hot humid regions, the primary building energy use (Figure 56) is air conditioning (AC) with heating making up only a small portion of total. As in other climates, water heating constitutes the second largest residential energy draw. Refrigerators follow just ahead of other household appliances such as stoves and dryers.

The primary loads on residential AC systems (Figure 57) are appliance generated heat, window radiant heat gain, attic and duct related heat gain, infiltration (primarily latent heat gain), and wall heat gain coming in last.

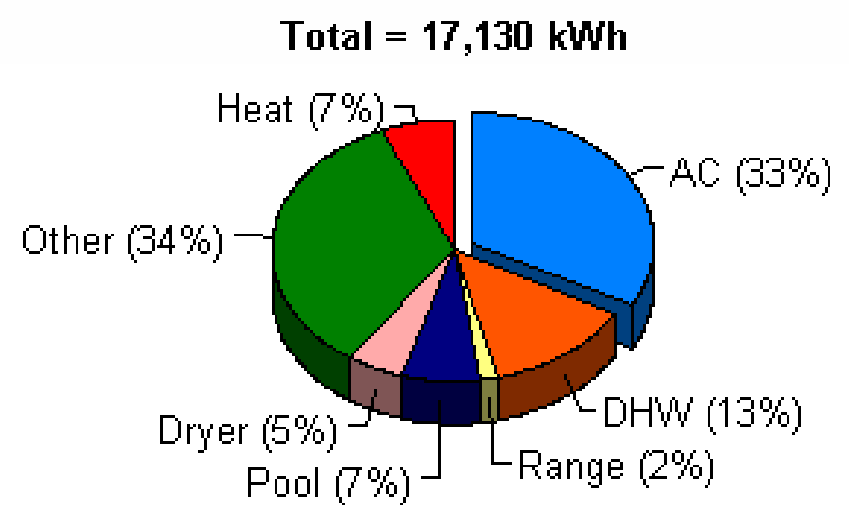

Figure 56 Distribution of Residential Energy Consumption measured in 171 Florida homes shows typical energy profile for homes in hot-humid climates. Source: Parker, D. S., 2002. "Research Highlights from a Large Scale Residential Monitoring Study in a Hot Climate." Proceedings of International Symposium on Highly Efficient Use of Energy and Reduction of its Environmental Impact, pp. 108-116, Japan Society for the Promotion of Science Research for the Future Program, JPS-RFTF97P01002, Osaka, Japan, January 2002. (Also published as FSEC-PF369-02, Florida Solar Energy Center, Cocoa, FL.)

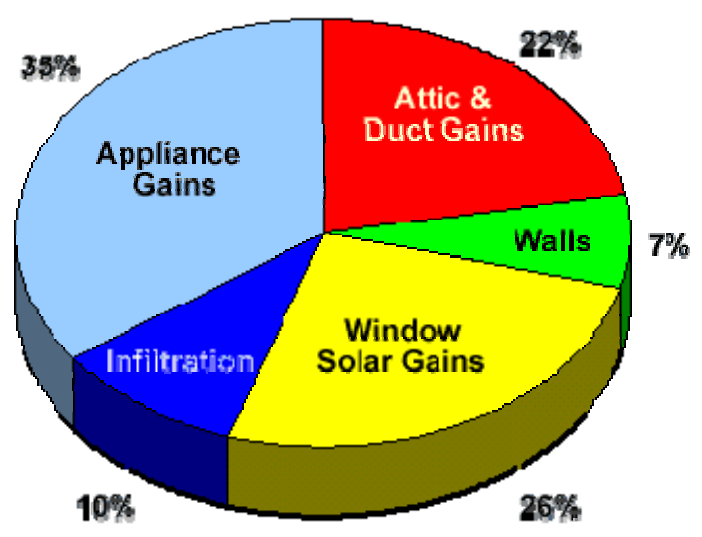

Figure 57 Typical components of annual residential cooling load in hot-humid climates.

Source: Florida Solar Energy Center web site:

http://www.fsec.ucf.edu/bldg/fyh/priority/Index.htm

By systematically evaluating the savings potential technologies and construction techniques, research provides the home building industry with vital information needed to meet the Department of Energy's industry challenges of building high performance homes. BAIHP Research presented here is grouped into three categories:

- Manufactured Housing Research

- $\quad$ Site Built Housing Research

- Field and Laboratory Building Science Research. 


\section{A. Manufactured Housing Research}

BAIHP has found that using the systems engineering approach to help Industry Partners solve building science related problems develops a strong working relationship and increases the likelihood of the Partner incorporating concepts central to achieving Building America goals such as sealed and tested ducts, right sizing air conditioning, and moisture management. BAIHP's work with the manufactured housing industry illustrates this principal.

BAIHP conducted research for manufactured homes in both field and laboratory which is reported in the following summaries:

- Building Science and Moisture Problems in Manufactured Housing - Background

- BAIHP Field Visits to Moisture Problem Homes

- Manufacturers Participating in Building Science Research

- Side By Side Study Of Energy Use And Moisture Control Comparing Standard Split System Air Conditioning And A Coleman ${ }^{\circledR}$ Prototype Heat Pump, Bossier City, LA

- WSU Energy House

- $\quad$ Zero Energy Manufactured Home (ZEMH)

- Manufactured Housing Indoor Air Quality Study

- Manufactured Housing Laboratory - Ventilation Studies

- Side by Side Manufactured Housing Energy Use Study, North Carolina A\&T

- $\quad$ Portable Classrooms

- Duct Testing Data from Manufactured Housing Factory Visits

- Crawl Space Moisture Research for HUD Code Homes

- $\quad$ Recommendations for FEMA Ruggedized Manufactured Home for Temporary Housing

- Comboflair Integrated HVAC System 


\section{Building Science and Moisture Problems in Manufactured Housing - Background}

Papers: $\quad$ Subrato Chandra, Danny Parker, David Beal, David Chasar, Eric Martin, Janet McIlvaine, Neil Moyer. Alleviating Moisture Problems in Hot, Humid Climate Housing. Position Paper for NSF Housing Research Agenda Workshop, UCF Feb. 12-14, 2004.

Moyer, N., Beal, D., Chasar, D., McIlvaine, J., Withers, C, \& Chandra, S. (2001). "Moisture Problems in Manufactured Housing: Probable Causes and Cures." ASHRAE - IAQ 2001 Conference Proceedings, San Francisco, CA.

Manufactured homes have a permanent steel chassis attached below the floor and are constructed in a factory (Figure 58) to meet a national code maintained by the U.S. Department of Housing and Urban Development (HUD). After production, homes may travel a few hundred miles, hauled by truck, before final setup. The homes are setup by placing blocks under the steel I-beams and anchoring the beams firmly to the ground. A skirting covers the blocks and steel frame in a fully setup home (Figure 59).

Manufactured homes are typically heated or cooled by a system of ductwork, which delivers hot or cold air from the air handler unit (AHU). The ductwork can be in the attic or in the belly cavity of the home. The ducts are typically made of aluminum or fiberglass trunk lines which supply air to the floor registers through in-line boots or flex ducts. The boots or ducts terminate at perimeter registers on the floor. Supply duct leaks represent one of the biggest causes of moisture problems in manufactured homes. (Figures 60 and 61). Poor design and construction leave holes at the AHU connection to the main trunk, and where the boots connect to the trunk, supply registers, end caps, cross-over duct

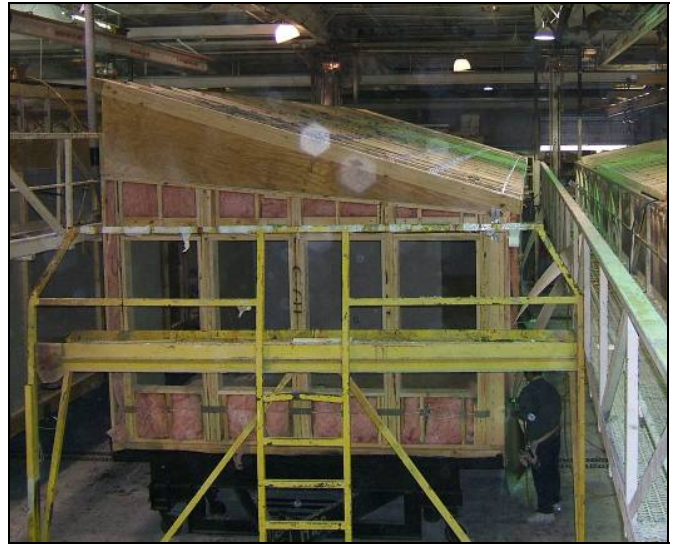

Figure 58 Palm Harbor HUD Code Manufactured Housing factory - production line.

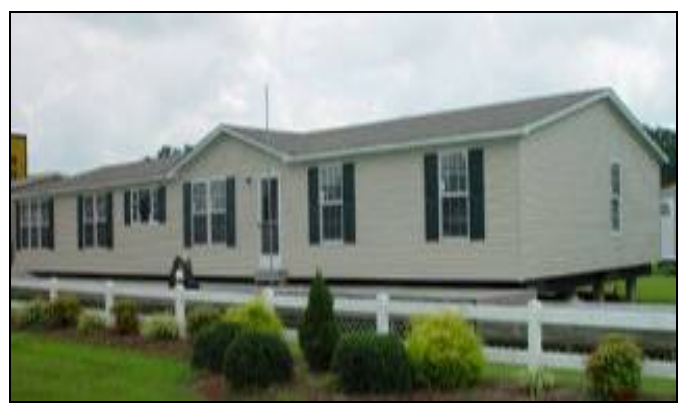

Figure 59 Completed HUD Code Manufactured Home, Palm Harbor Homes connections, and other connection points. When the AHU blows air, some air leaks into the belly and eventually to the outside through belly board tears. This loss of air creates a negative pressure inside the house and a positive pressure in the belly. The negative pressure pulls outside or attic air into the house through cracks and crevices which connect the inside of the house to the outside or to the attic. During northern winters, this outside air is cold and dry and its entry increases occupant discomfort and heating energy use.

During summer in the Southeastern US, the air is consistently at or above the dewpoint of $75^{\circ}$. If a homeowner keeps their home thermostat set below this $75^{\circ} \mathrm{F}$ dewpoint, the moisture laden outside air condenses as it comes into contact with the cold inside surfaces. If it condenses 
behind an impermeable surface such as vinyl flooring or wallpaper, serious mold, mildew, and floor buckling problems can result.

Many manufactured and site-built homes have only a single return and, therefore, very little return air transfer from the bedrooms (basically via the undercut at the bottom of interior doors). When interior doors are closed, rooms off the main body (e.g., bedrooms) become pressurized and the main body of the house depressurizes. Even though negative pressures are usually only one to three

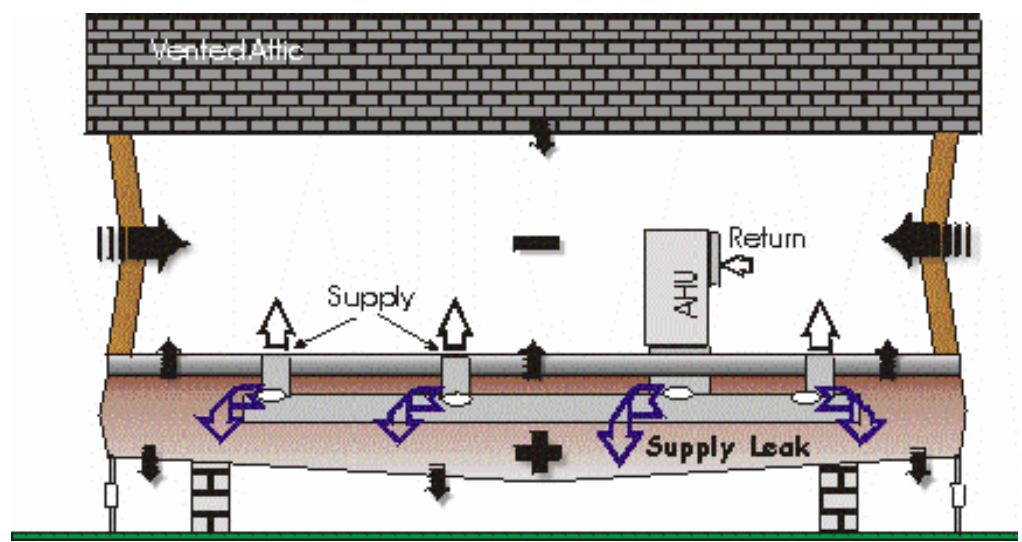

Figure 60 Pressure field and unintentional air flow created by supply duct leaks.

pascals $(\mathrm{Pa})$ - they can cause serious problems in a home.

Researchers use a calibrated fan called a ductblaster to measure duct leakage. The ductblaster is attached to the return grill or the crossover duct opening (Figure 62) and all supply registers are masked off and the fan is turned on. Once the house ductwork reaches $-25 \mathrm{~Pa}$, airflow through the fan is read (in CFM). The resultant measure is the total duct leakage. In good airtight ductwork, total duct leakage (CFM@25 Pa) should be less than 6\% of the homes square footage.

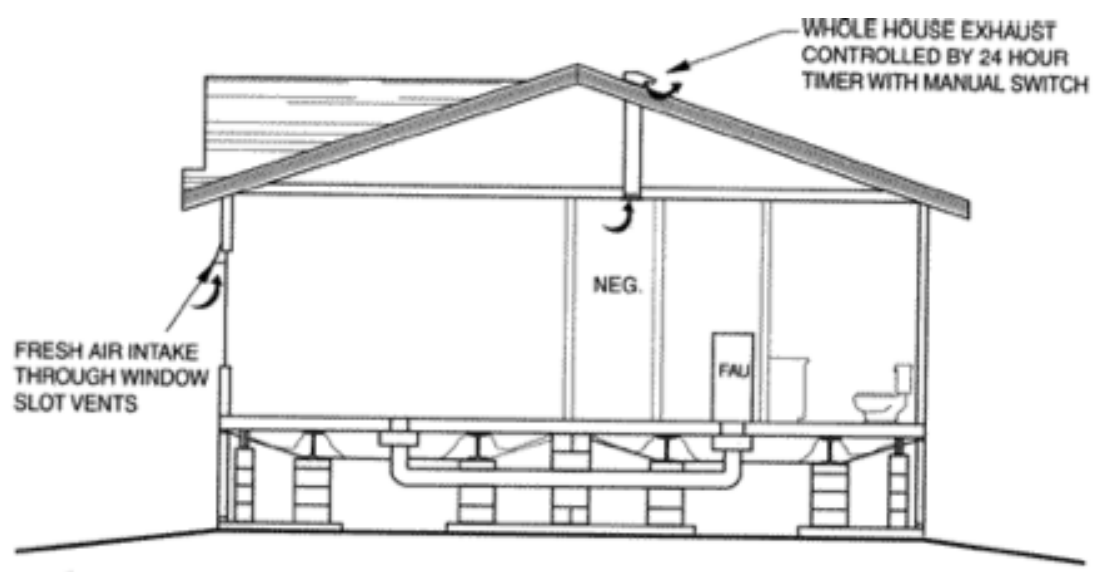

Figure 61 Cross section showing foundation support, crossover duct, and one type of ventilation system in a manufactured home.

A second duct leakage test measures leakage to the outside. This leakage is calculated by depressurizing the entire house to $-25 \mathrm{~Pa}$ with a blower door, then adjusting the ductblaster flow so there is no pressure difference between the house and the ducts. This measurement is a true indicator of duct air loss to the outside and is used in energy calculations for estimating the 
energy loss from leaky ducts. In good duct systems, duct leakage to the outside (in CFM) is less than $3 \%$ of the home's square footage.

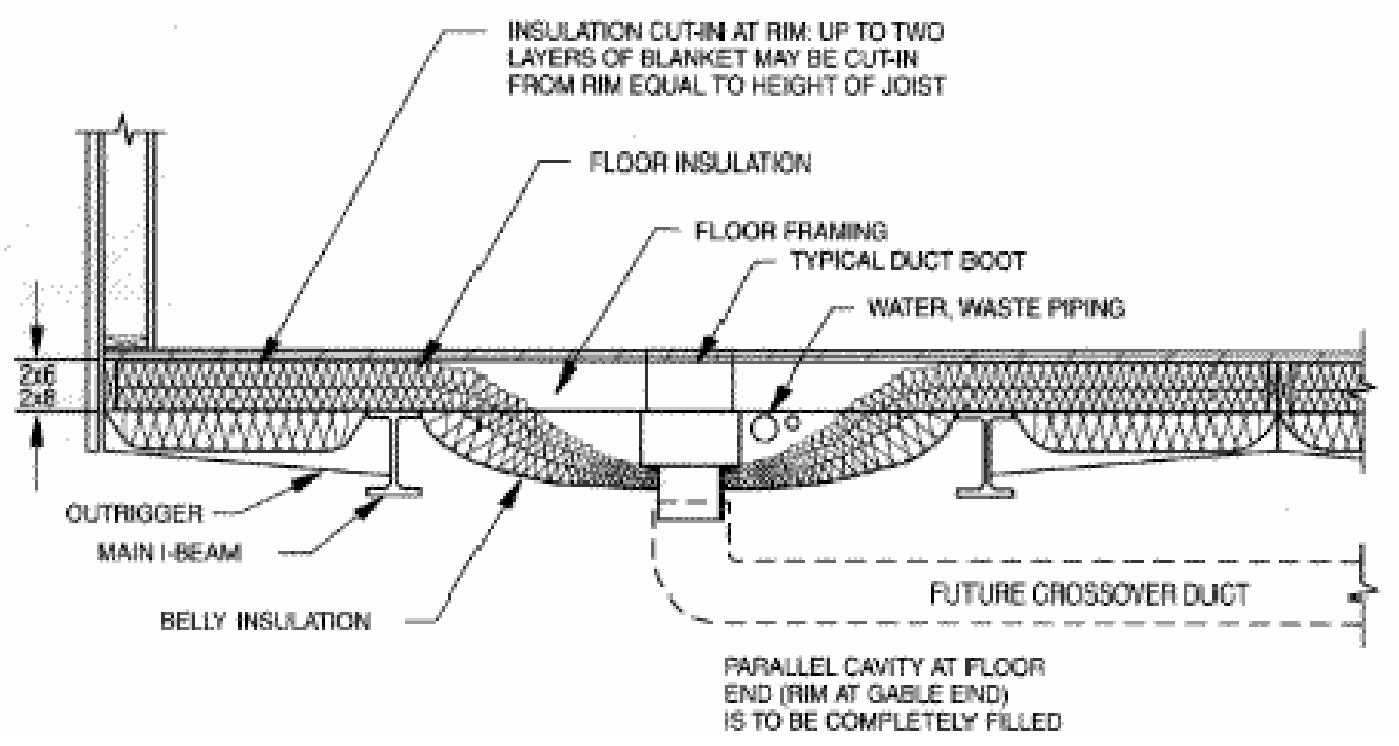

Figure 62 Floor and belly area with supply ducts. These ducts supply conditioned air to all rooms through floor vents, a common duct system layout in manufactured homes.

The battery of tests run in a problem house typically includes measuring the air tightness of the house with a blower door, depressurizing the house to -50 Pa. At that time, the house to belly and belly to crawlspace pressures also can be measured. Researchers also test pressure differentials caused by AHU operation and closed interior doors. An additional measurement of duct leakage, called pressure pan, is conducted on some houses to pinpoint specific registers which might have large leaks. In this measurement the house is first depressurized to $-50 \mathrm{~Pa}$ and all the register vents are unmasked. Then the registers are covered one by one and the pressure difference between the covered register and the house is measured. A zero reading indicates no leakage at that register. Readings over one $\mathrm{Pa}$ indicate a sizeable leak that should be repaired.

\section{BAIHP Field Visits to Problem Manufactured Homes}

A significant number of new manufactured houses built to HUD code and located in the hot, humid Southeast have exhibited moisture problems. Soft wallboards, buckled floors, damaged wood molding, and extensive mold growth are the most common symptoms. These problems do not respond to the standard service and repair strategies for water intrusion.

Summary of $1^{\text {st }}-4^{\text {th }}$ Budget Period Field Visits to Moisture Problem Homes

At the request of six manufacturers, 69 such moisture damaged homes were investigated from 1999 to the end of reporting year four (through March 31, 2003) to determine likely causes. In Year 4 alone, 18 homes were investigated by FSEC. One-time blower door, duct tightness, and pressure differential measurements were performed on all homes. Field data on ambient, crawlspace, belly and house temperatures, plus relative humidity levels were collected on a few of the homes. Recommendations and reports were prepared for the manufacturers' service, 
production, and design staff. Field repairs were performed in most of these homes. A general theme was found in the houses investigated.

- Air conditioner thermostat settings (typically $68^{\circ}$ to $73^{\circ} \mathrm{F}$ ) set below the ambient dew point.

- Negative pressures across the envelope from high supply duct leakage (CFM @25Pa $>10$ per 100 square feet of conditioned floor area), inadequate return air paths, interior door closures, exhaust fans, or a combination thereof.

- Inadequate moisture removal from disconnected return ducts, continuous fan operation (air handler or ventilation), inadequate condensate drainage, oversized air conditioners, or a combination thereof.

- Moisture diffusion from the ground into the house because of poor site drainage, inadequate crawl space ventilation, tears in the belly board, or a combination thereof.

- Vapor-retardant in the wrong location (i.e., vinyl or other impermeable wall or floor coverings located on the colder surfaces).

Recommended solutions provided to the manufacturers to eliminate moisture problems included:

- Maintain air conditioning thermostat settings above the ambient dew point (at least $\left.75^{\circ} \mathrm{F}\right)$.

- Eliminate long-term negative pressures created by air handler fans or ventilation equipment.

- Tightly seal all ductwork and provide adequate return air pathways.

- Enhance moisture removal from the conditioned space by correct equipment sizing and maintenance.

- Eliminate ground source water and provide an adequate moisture barrier for the floor assembly.

- If possible, remove vapor barriers located on the wrong surfaces.

Research continues to determine if these steps will be sufficient to prevent problems even when vapor barriers are incorrectly located in homes in the hot, humid climate. Preliminary results are encouraging. One manufacturer has not reported a single new moisture problem in any of the homes produced since 2000 in a factory that previously had a significant number of problem homes. Steps taken by the factory were inclusion of airtight duct systems (a zero net-cost increase), right-sized cooling systems (a negative cost), return air ducts from all bedrooms (a cost of about \$15), installation of a ground vapor barrier (no change from previous practice). 
Summary of $5^{\text {th }}$ Budget Period Field Visits to Moisture Problem Homes

BAIHP researchers at FSEC received fewer requests in the $5^{\text {th }}$ budget period for assistance with moisture damaged homes (Table 44), reflecting improvement of duct construction and sealing, addition of return air pathways from bedrooms, and reduction of vapor impermeable interior surfaces. Additionally, service personnel who have attended BAIHP training and participated in field work with BAIHP are more prepared to resolve problems without assistance. Service personnel report installing passive return air vents in bedrooms, providing appropriate moisture barriers, and sealing duct leaks to resolve humidity, comfort, and moisture damage call backs.

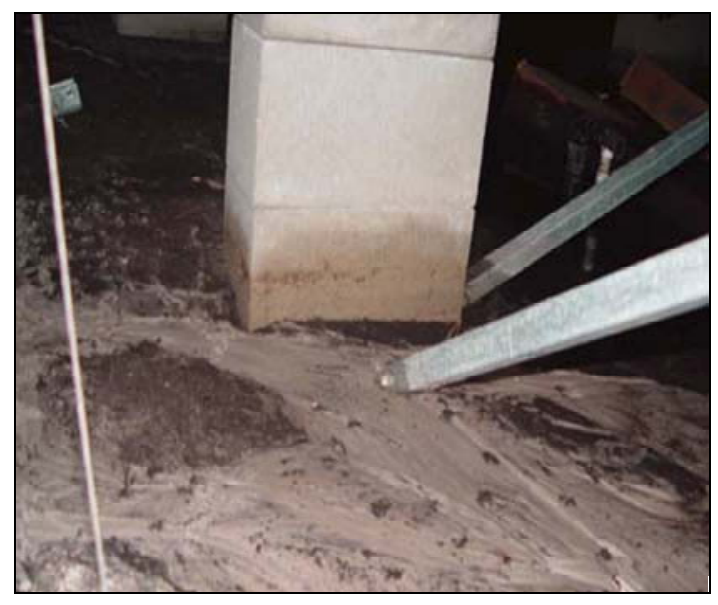

Figure 63 Flow lines under house, indicating running water under the house. Also note the "tide line" on the support column.

When service personnel have been unable to resolve a problem, they request assistance from BAIHP researchers who attend a service call and conduct various diagnostic tests to identify factors contributing to the moisture, comfort, or high energy bill problem. (MHRA has been providing similar services on a fee basis to the industry also.) After BAIHP researchers complete a field visit, a trip report is issued detailing the findings and recommendations, include basic building science background material.

Table $445^{\text {th }}$ Budget Period - FSEC Field Visits to Problem Manufactured Homes

\begin{tabular}{|c|c|c|}
\hline \multirow{5}{*}{\begin{tabular}{|l} 
Manufacturer \\
Fleetwood Homes \\
\end{tabular}} & Location & Date \\
\hline & Florida (2 homes) & August 03 \\
\hline & Florida (2) & November 03 \\
\hline & Texas (1) & December 03 \\
\hline & West Virginia (1) & March04 \\
\hline Cavalier Homes & Florida (1) & November 03 \\
\hline Southern Energy Homes & Kentucky(1) & December 03 \\
\hline & Texas (1) & January 04 \\
\hline Style Crest & Louisiana (1) & February 03 \\
\hline $\begin{array}{l}20 \text { NEEM Program } \\
\text { Manufacturers }\end{array}$ & $\begin{array}{l}\text { Field Visits in } \\
\text { Washington, Oregon, } \\
\text { and Idaho (19) }\end{array}$ & April 03-March 04 \\
\hline Total Homes & 29 & \\
\hline
\end{tabular}

It has been BAIHP's experience that corrective measures from repeated moisture problem Diagnostics have been incorporated into the production process, resulting in thousands of improved manufactured homes. These are noted in Category D of Table 2. 
A common problem that remains unresolved involves the combination of abundant crawl space moisture (Figure 63 and 64) and poorly vented skirting (Figure 65). In the hot-humid coastal regions, this combination raises vapor pressure across the belly to critical levels. This was evident in several of the homes visited this year. As a result of this field research, BAIHP has designed a study that was completed in the summer of 2004 to evaluate the moisture flow characteristics of crawl space conditions, and a second study in the summer of 2005. (See Crawl Space Moisture Research for HUD Code Homes section).

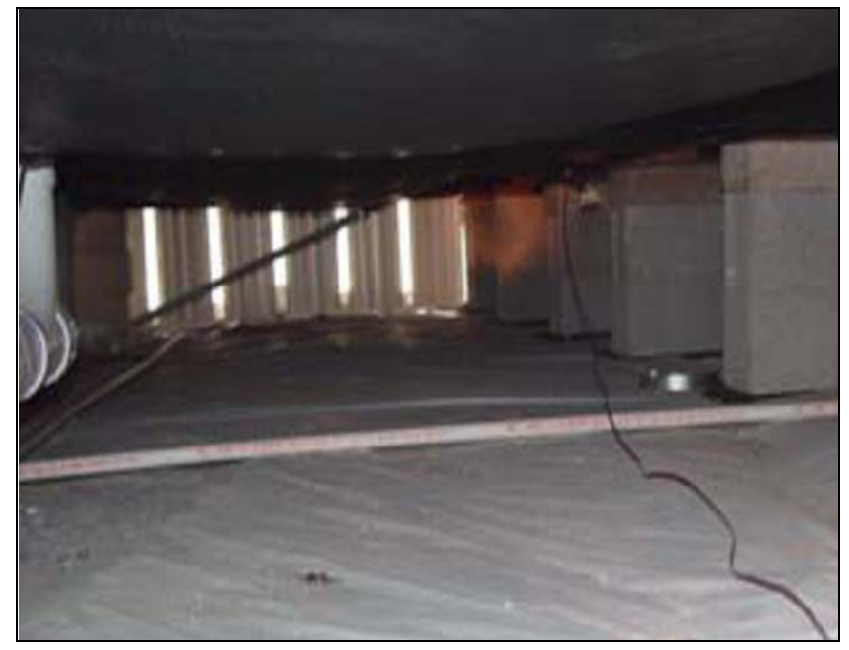

Figure 65 HUD Code required perforations in skirting may not allow adequate volumes of ventilation, creating higher than usual vapor pressure difference across the floor assembly even though the ground cover and belly board are in good condition.

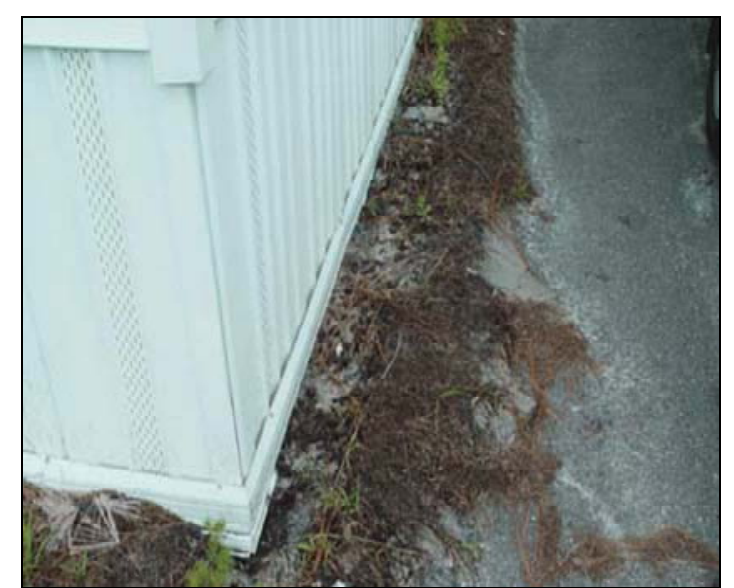

Figure 64 The downstream exit for the water draining across the site via the crawl space. Note flow pattern away from house.

During the final year of the project, BAIHP staff worked with field staff of several HUD Code Home manufacturers as illustrated in Table 45. Palm Harbor Homes again had no moisture damage homes in the final year of the project; however, BAIHP researchers returned to the Southern Energy Homes plant in Addison AL to train field service personnel on use of blower door, duct tester, pressure measurements and infrared diagnostics.

Table 45 April 2005 - June 2006 - FSEC Field Visits to Problem Manufactured Homes

\begin{tabular}{|l|l|l|}
\hline Manufacturer & Location & \# of Houses \\
\hline Fleetwood Homes & Florida (4), Georgia (2) & 6 Houses \\
\hline Southern Energy Homes & $\begin{array}{l}\text { Mississippi and } \\
\text { Louisiana }\end{array}$ & 4 Houses \\
\hline Total Homes & & $\mathbf{1 0}$ Houses \\
\hline
\end{tabular}


Northwest BAIHP Field Visits to Problem Manufactured Homes

In offering technical support to owners of over 100,000 homes built since 1990, the BAIHP staff in the Northwest answers questions from homeowners, manufacturers, retailers and others. In The 6th budget period, staff from Washington, Oregon and Idaho responded to over 70 phone calls and conducted 27 field visits. The number of field visits to problem homes has significantly decreased over the history of the program, in large part because of manufacturers' and installers' increased adoption of the NEEM Super Good Cents/Energy Star (SGC/E-Star) specifications which include duct air tightness specifications (duct leakage is a major contributor to pressure and air flow related moisture problems), and the requirement that manufactured home installers be certified in Washington and Oregon.

Northwest BAIHP staff began to utilize Energy Gauge USA as a tool for evaluating high bill complaints in 2003-2004.

BAIHP staff participated in quarterly meetings of the Washington State Manufactured Housing Technical Working Group, which coordinates the certification of manufactured housing set-up crews.

While butyl duct tape is no longer allowed under current NEEM SGC/E-Star specifications, a consistent issue in the field continues to be excessive duct leakage, due in large part to failures of duct tape. These findings were brought to the attention of the NFPA-501 Manufactured Housing Standards Committee, resulting in a successful proposal to revise the duct sealing specifications to eliminate the use of duct tape in favor of better performing mastic and fiberglass mesh in the NFPA-501 standard. See a summary of supporting research findings in BAIHP Duct Data Compilation.

\section{Manufacturers Participating in Building Science Research (including activity with individual manufacturers)}

\section{Super Good Cents Random Home Testing}

In 1994-1995 (prior to implementation of BAIHP), SGC staff conducted field testing of 178 SGC homes built in 1992-1993. In 1999, the first year of the BAIHP effort, staff in Idaho and Washington field-tested 49 SGC homes built in 1997-98. In 2000, analysis of field test data confirmed some improvements to home set-up procedures and air leakage control, while highlighting a need to improve duct tightness and ventilation system operation (through homeowner education.) In 2001, BAIHP staff produced an updated homeowner ventilation brochure.

In 2002 and 2003, BAIHP staff worked with Ecotope to develop a valid sample for the next round of field testing, and began to develop the field testing protocol. In 2004, Ecotope selected 105 homes from the total production for the years 2001-2002. The field testing took place in the summer of 2004. Findings from the testing include:

- Average house size is $1769 \mathrm{ft}^{2}$; double section homes are also getting bigger, on average. The house size is very comparable to the homes built in 1997-1998 but 20\% larger than the homes in 1994-1995 study

- Houses are getting tighter, according to the blower door results. The average air leakage rate at $50 \mathrm{~Pa}$ is 4.2 , which represents a tightening of almost $25 \%$ over the original MAP 
home average. The median equivalent leakage area (ELA) for double-section homes has decreased by about $12 \%$ despite a substantial increase in house size.

- Only about $20 \%$ of NEEM homes in this study contain intentional outside air inlets. This is the result of BAIHP research indicating that intentional outside air inlets are unnecessary to provide adequate fresh air.

- $2 / 3$ of homes in the study have dedicated whole house fans and a substantial fraction of homeowners are using their whole house fans. However, a significant minority $(30 \%)$ does not turn them on.

- About half of homes in the study use central cooling, with more than half of these homes using a heat pump.

- Duct systems are about $20 \%$ leakier than in the Year 1 study and about $10 \%$ leakier than in the 1994-1995 study (when the comparison is normalized by house size).

- The median supply leakage fraction is $11-13 \%$ for the homes in this sample. The duct loss translates into a heating system efficiency loss of between $10-20 \%$ overall, depending on the location of the home (west side or east side of the mountains) and type of heating equipment (heat pumps perform worse).

In 2004, BAIHP staff conducted a billing analysis on a limited number of random field study homes. The conclusions (although not statistically significant) suggest that temperature related energy use in NEEM homes remains similar to previous larger studies on cost-effectiveness. The analysis attempted to evaluate total and space conditioning energy use by HVAC system types but was limited by small sample size.

In 2004, a sub-sample of homes that are believed to represent the best case for duct tightness was selected for additional field testing. These homes include those with in-plant tested ducts and thru-rim crossover duct systems. The goal of this effort is to establish a "tightest" duct case benchmark. Field testing was completed in 2005.

\section{Blue Sky Foundation}

Blue Sky Foundation, in coordination with FSEC, conducted an evaluation of energy efficiency and the moisture damage potential in 16 North Carolina homes in the summer of 2001. Blue Sky foundation proposed that the energy and moisture evaluation focus on the building envelope integrity, HVAC duct systems, and the moisture impact of unvented space heaters. All of the homes in the study were manufactured models located in Carteret and Craven counties, each located on the North Carolina coast. Field teams gathered additional energy and moisture information from homeowners.

Only three of the 15 tested homes recorded moisture and/or mildew problems. Because of the small sample size, the results are mostly anecdotal and would need to be evaluated within a larger data set. Planning for this is underway. Data from the summer field program as well as the final report are now on the BAIHP website (www.baihp.org) under Publications. 


\section{Cavalier Homes}

BAIHP visited one Cavalier Home in Florida for a moisture damage investigation in response to home owner complaints of persistent air flow problems and floor damage. BAIHP made recommendations to correct the installation of the duct system and supply registers, repair the rodent barrier to make it air tight, do site work to reduce flooding under house, place a ground cover if site work done, increase crawl space venting, and replace damaged flooring with plywood. Cavalier Homes adjusted in plant procedures to ensure air tight duct construction completing 1,132 homes with this improvement in 2002. In the final year of the project, BAIHP visited the Cavalier Homes plant in Addison AL to discuss future research projects, review house construction of FEMA units, and discussed possible duct plenum construction problems in FEMA Houses.

\section{Fleetwood Homes}

(See also Fleetwood Homes under Section II of this report “BAIHP Technical Assistance.”) During the $5^{\text {th }}$ budget period, BAIHP continued to support Fleetwood's service department making six visits to moisture damaged homes in Florida (4), Texas (1), and West Virginia (1). Six Fleetwood homes, all in Florida, were tested for moisture and mold damage from April 2002 through March 2003, the $4^{\text {th }}$ budget period. All of the homes had damaged flooring due in part to a lack of ground cover and poor crawlspace ventilation. Damage to the floor in one home was exacerbated by a plumbing leak. Only one home had moisture damage to the wallboard material, and this home showed a history of thermostat settings below $72 \mathrm{~F}$. A report for each home was submitted to Fleetwood for corrective measures. One additional high bill complaint in Cobb, Georgia was investigated during this reporting period.

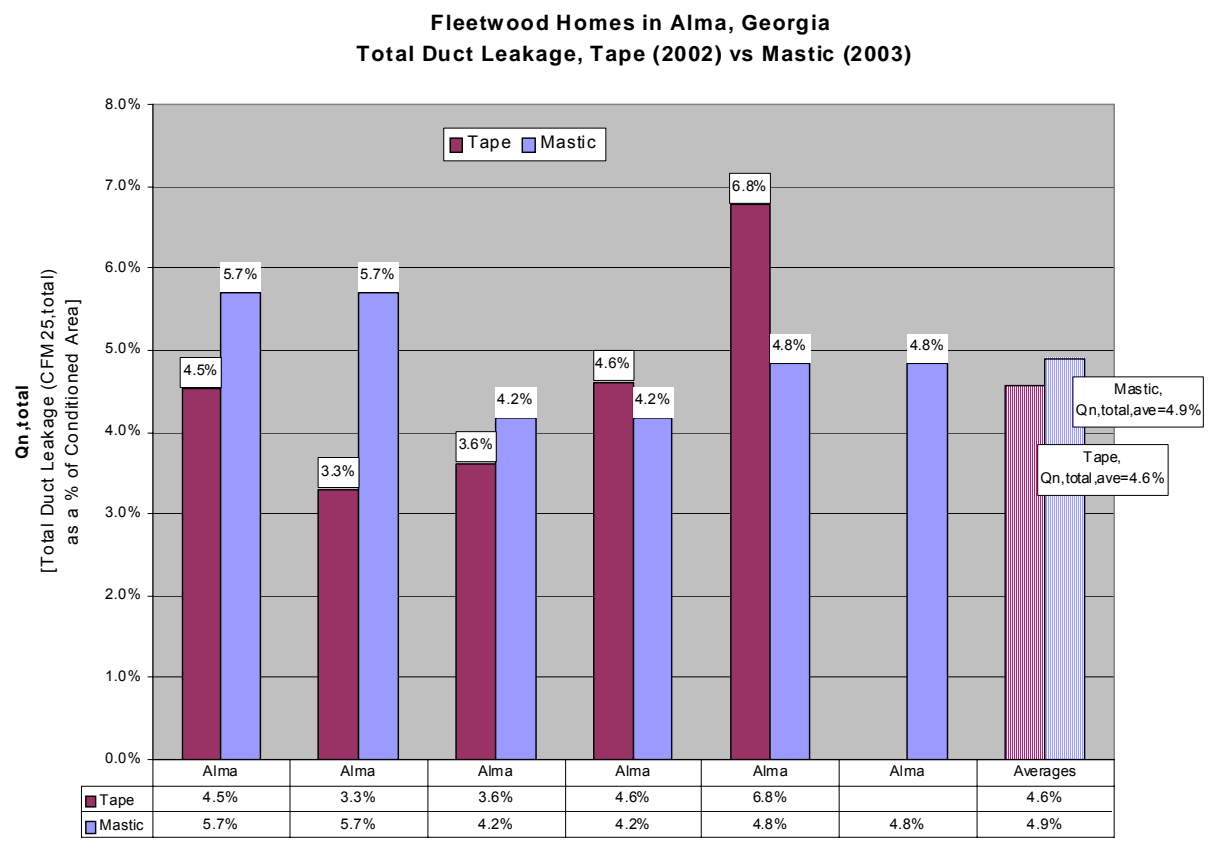

Figure 66 Testing Results from Fleetwood Homes Plant in Alma, Georgia illustrate that tape sealed ducts can result in total duct leakage under $Q n=<6 \%$. This initial tightness, however, is often eroded by adhesive failure. 
In 2002, four Fleetwood factories in Southern Georgia were visited to investigate possible causes of moisture related building failures found in homes installed in hot, humid climates. The factories were located in Douglas, Alma, Pearson, and Willacootche. (Figure 66.)

\section{Homes of Merit}

(See also Homes of Merit under II BAIHP Technical Assistance.)

In 2002, researchers performed multiple diagnostic tests on a home located in Marathon, Florida that was experiencing "mold problems." Researchers determined that the mechanical system was significantly oversized and that the home was operating under negative pressure when the system was operational. The home's owner exacerbated humidity problems by leaving the fan in the "on" mode. On-site relative humidity readings showed that indoor and outdoor relative humidity were the same, approximately $70 \%$.

\section{Palm Harbor Homes}

(See also Indoor Air Quality Study in this section and Palm Harbor Homes under II BAIHP Technical Assistance.)

Palm Harbor Homes, James Hardie ${ }^{\circledR}$, and FSEC performed two separate drywall assembly tests to determine the cause of some moisture damage occurring in homes sheathed with Hardipanel. Hobo dataloggers recorded temperature and relative humidity measurements inside the assembled panels on eight different wall panel configurations.

(Figure 67)

Results determined that the unprimed, unwrapped sheathing performed best. The painted drywall assemblies allowed the greatest moisture movement - or wall assembly drying. (Table 46) The vinylcovered drywall held moisture longest, recording the slowest drying time. Adding perforations to the vinyl reduced the drying time.

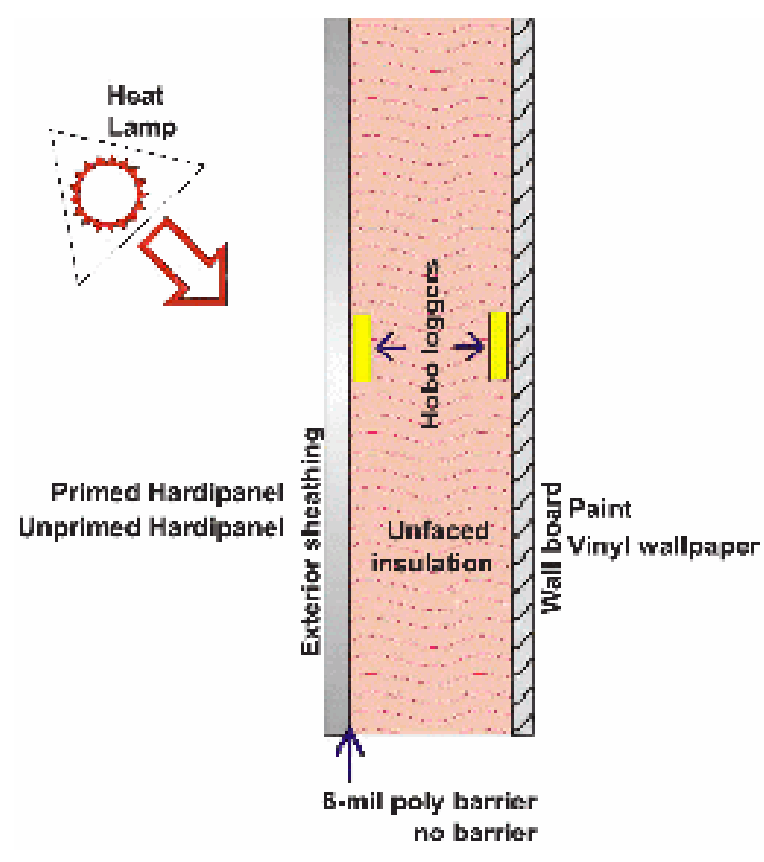

Figure 67 Wall assembly used in moisture transmission experiment.

Table 46 Hardipanel exterior wall configurations

\begin{tabular}{|l|l|l|l|l|}
\hline Test Panel & Drywall & Insulation & Wall Wrap & Sheathing \\
\hline$\# 1$ & vinyl & unfaced & none & primed \\
\hline$\# 2$ & vinyl & unfaced & none & unprimed \\
\hline$\# 3$ & vinyl & unfaced & house wrap & primed \\
\hline$\# 4$ & $\begin{array}{l}\text { House wrap glued to } \\
\text { drywall }\end{array}$ & unfaced & none & primed \\
\hline$\# 5$ & vinyl & unfaced & house wrap & primed \\
\hline$\# 6$ & painted & unfaced & Thermo Ply & primed \\
\hline$\# 8$ & painted & unfaced & none & primed \\
\hline
\end{tabular}


In 2002, two Palm Harbor homes with comfort problems were tested in Ocala and Okahumpka, Florida and one high bill complaint was investigated in Odessa, Florida. Duct leakage testing and infrared imaging revealed a duct disconnect near the attic crossover in the Ocala home. Inspections with the IR camera found no insulation problems in the Odessa home. Ductblaster and blower door tests revealed airtight duct and envelope systems. Other than an oversized air conditioning system, there were no obvious reasons for the high bills.

\section{Side By Side Study Of Energy Use And Moisture Control Comparing Standard Split System Air Conditioning And A Coleman ${ }^{\circledR}$ Prototype Heat Pump, Bossier City, LA}

Paper: Withers, C., Chasar, D., Moyer, N., and Chandra, S. "Performance and Impact from Duct Repair and Ventilation Modifications of Two Newly Constructed Manufactured Houses Located in a Hot and Humid Climate", Thirteenth Symposium on Improving Building Systems in Hot and Humid Climates, May 20-22, 2002 Houston, Texas.

In 2001, the BAIHP team conducted research on two homes to define how tight ducts and a prototype Coleman ${ }^{\circledR}$ heat pump (proprietary technology) affect energy use and moisture control in a hot, humid climate. FSEC, in collaboration with Fleetwood Homes, York International Manufactured Housing Division (now Stylecrest Sales), and Coleman ${ }^{\circledR}$, monitored two nearly identical side-by-side homes in Bossier City, Louisiana. The homes contained different air conditioning systems. House A used a standard split air conditioner, while House B used the Coleman ${ }^{\circledR}$ prototype unit (a more efficient, two-speed split air conditioner).

Figure 68 shows the reduced power draw of the two-speed compressor (green, dotted line) over a 24-hour period on September 2, 2000. With the unit operating at low-speed for most of the day, the cooling energy savings were $28 \%$ when compared to the energy use in House A. Average daily cooling energy was reduced by about $12 \%$ over the monitored period. An added benefit of the two-speed air conditioner was $20 \%$ greater moisture removal on days with an outdoor dewpoint above $60 \mathrm{~F}$.

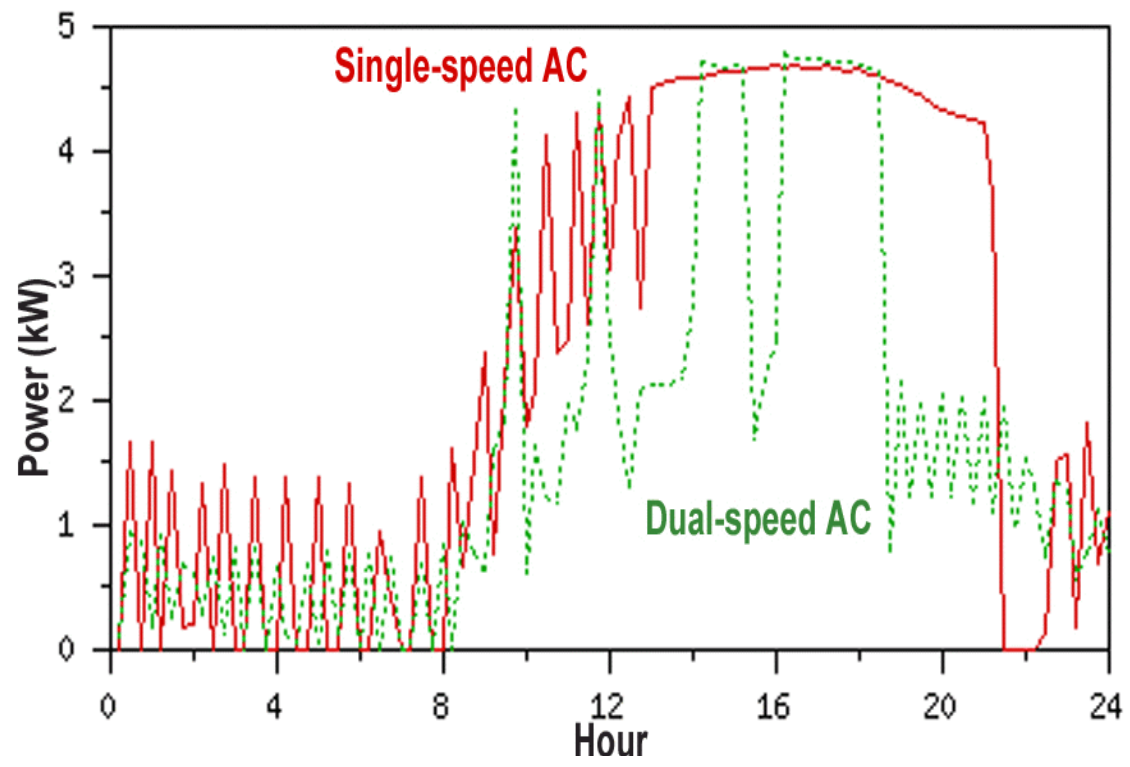

Figure 68 Power draw over a 24-hour period, September 2, 2000. 
Savings from Duct Repair and POS Ventilation: In addition to comparing one house to the other, the BAIHP team also compared home performance before and after ductwork and ventilation system changes were made.

To make the comparison, duct and other leaks were sealed in both houses until the two were equally airtight. The ventilation method in each home also was changed from exhaust-only to a positive pressure system (POS). With exhaust-only ventilation, bathroom fans removed stale air from the home which caused fresh air to be pulled in through the building envelope. To simulate occupant use, two bath exhaust fans were operated by a timer for three hours in the morning and six hours in the evening.

In contrast to exhaust ventilation, the POS system introduced a small amount of fresh air on the return side of the air conditioning cooling coil. A POS system was installed in each home at the same time the ducts were repaired. Subsequent monitoring looked at the effects of this alternate ventilation system. Tightening the ducts and installing a POS ventilation system resulted in an $18 \%$ and $37 \%$ cooling savings in the two homes. Only about $2 \%$ of these savings were attributable to the ventilation system change, the remaining savings are a result of duct repair.

\section{WSU Energy House}

Olympia, Washington

Technical Assistance by BAIHP Contractors Washington State University Energy Program, Oregon Office of Energy and Idaho Department of Water Resources, Energy Division

This $2600 \mathrm{ft}^{2}$ home was built beyond SGC standards and incorporates Energy Star lighting and appliances. The home (Figure 69) has received significant national exposure through WSU campus and alumni newsletters, tours, the BAIHP website, and local and trade media including an article in the Automated Builder magazine and a feature by KING 5 News of Seattle.

WSU staff uses the house to try out innovative technologies and testing methods. In 2003, BAIHP staff developed a moisture case study based on research at the WSU Energy House, published under a separate Building America project. The WSU Energy House has been monitored since 2000. Collected monitoring data includes weather, temperature, humidity, $\mathrm{CO}_{2}, \mathrm{CO}$, and eight differential pressures. Energy use data is being collected for water heating, laundry, fireplace and heating, ventilating, and air conditioning (HVAC). Data from the house is available on the BAIHP web page (under Current Data) and has been presented to the building science, indoor air quality (IAQ) and HVAC research communities at conferences sponsored by ASHRAE, Air Infiltration and Ventilation Center (in the UK), HUD/NIST, NFPA, and BTECC.

Working with Ecotope, ASHRAE, and the Energy

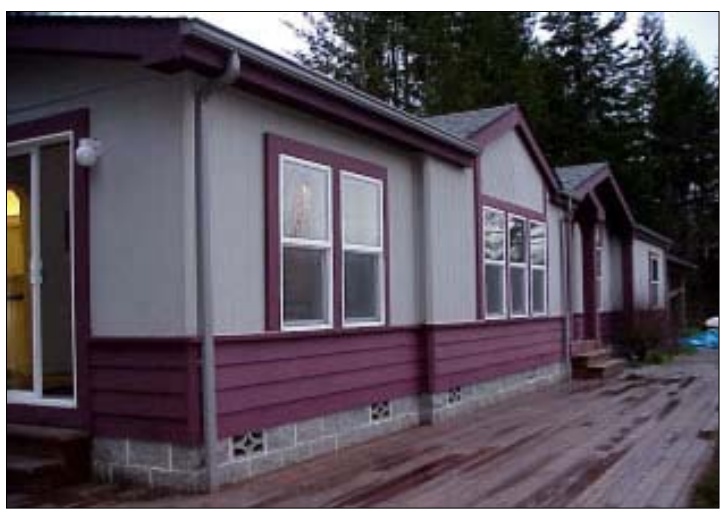

Figure 69 WSU Enerqy House in Olympia, WA Conservancy, BAIHP staff conducted "Delta Q" and "nulling" duct leakage tests in 2001. Follow up pressure tests and analysis of test data conducted in 2002 indicate these tests are effective 
methods of measuring duct leakage in manufactured homes, and may be included in the upgrades to the National Fire Protection Association-501 standards for manufactured homes.

Blower door and duct leakage testing indicate very good whole house and duct air tightness (2.4 ACH50 and 61.6 CFM50 out). Tracer gas testing demonstrated that the use of a furnace-based intake damper does not change the leakage rate of the home.

In 2004, moisture problems associated with siding and trim details were eliminated using and an improved window flashing system. The adoption of this system is currently under discussion with some manufacturers, and NFPA-501

\section{Zero Energy Manufactured Home (ZEMH)}

Nez Perce Fish Hatchery, Idaho

Category A, 1 home

Paper: $\quad$ Lubliner, M.; Gordon, A.; Hadley, A. (2004). “Manufactured Home Performance; Comparing Zero Energy and Energy Star”. Proceedings of Performances of Exterior Envelopes of Whole Buildings IX International Conference, Clearwater Beach, Florida, December 2004.

BPA, working with BAIHP staff in Idaho and Washington, provided funding for the most energy efficient manufactured home in the country. The RFP was sent to 18 Northwest manufacturers; Kit HomeBuilders West of Caldwell, Idaho was selected as the manufacturer of the home. BAIHP staff solicited 24 industry partners to provide energy efficient building components, including Icynene wall, floor and roof insulation, a low-cost HUD-approved solar system, suntempered solar design, and Energy Star $(\mathrm{C}$ windows, appliances and lighting. Partners include Building America Team members such as Flexible Technologies, Icynene and LaSalle.

Complete list of specifications provided in Table 47.

The ZEMH (Figure 70) was built in the Fall of 2002 along with a control home. The ZEMH was displayed at the 2002 Spokane County Interstate Fair before siting at the Nez Perce tribal fish facility near Lewiston Idaho.

Blower door and duct leakage tests at the plant and on-site indicate that this is the tightest home ever tested by BAIHP staff.

Working with FSEC and BPA, BAIHP staff installed monitoring equipment for the ZEMH. Monitoring began in the 2003 and includes the following:

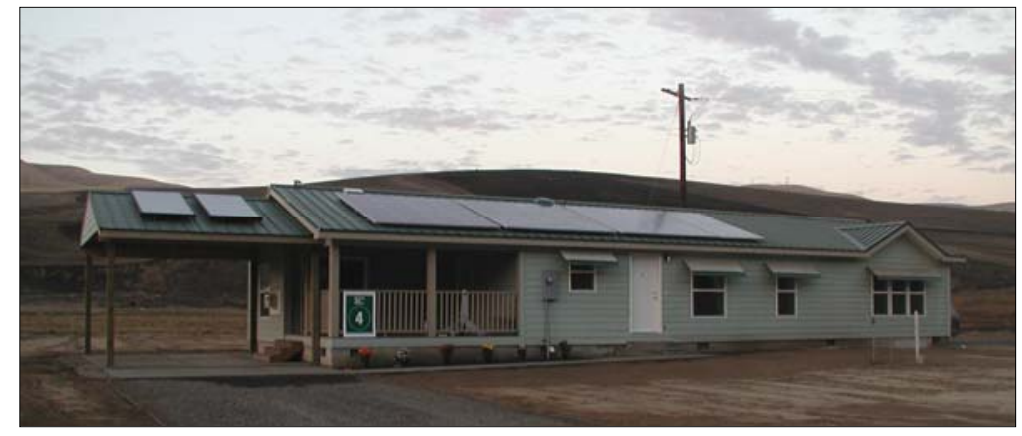

Figure 70 Zero Energy Manufactured Home, on site at the Nez Perce Fish Hatchery

- Total electric use from grid

- Resistance elements in heat pump

- Heat pump compressor and fan motors

- Water heating equipment, including gallons used

- $\quad$ PV energy production (ZEMH) 
Table 47 Zero Energy Manufactured Home (ZEMH) and Base Case Home (Control)

\begin{tabular}{|c|c|c|}
\hline Component & ZEMH & Base \\
\hline Wall Structure & $2 \times 6 \mathrm{ft}, 16$ in on center & Same \\
\hline Wall Insulation & R21 foam-spray & R21 batt \\
\hline Floor Structure & $2 \times 8 \mathrm{ft}, 16$ in on center & Same \\
\hline Floor Insulation & R33 (R22 Foam + R11 batt) & R33 Blown Cellulose \\
\hline $\begin{array}{l}\text { Vented crawl space } \\
\text { wall }\end{array}$ & R14 foil faced foam & None \\
\hline $\begin{array}{l}\text { Roof/Attic Structure } \\
\text { and Finish }\end{array}$ & $\begin{array}{l}16 \text { in on center } \\
40 \mathrm{lb} \text { roof load } \\
4 / 12 \text { pitch metal roofing }\end{array}$ & $\begin{array}{l}24 \text { in on center } \\
\text { Standard } 30 \mathrm{lb} \text { roof load } \\
\text { Same pitch and finish }\end{array}$ \\
\hline Roof/Attic Insulation & R49 foam & R33 blown cellulose \\
\hline $\begin{array}{l}\text { Window/Floor area } \\
\text { ratio }\end{array}$ & $12 \%$ & Same \\
\hline Windows & $\begin{array}{l}\text { Vinyl Frame, Argon filled, low- } \\
\text { e, Energy Star Approved }\end{array}$ & Same \\
\hline Window Shading & $\begin{array}{l}\text { Dual blinds, heavy drapes, } \\
\text { awnings }\end{array}$ & Single blinds, light drapes \\
\hline Doors & $\begin{array}{l}\mathrm{U}=0.2 \text { metal, foam } \mathrm{w} / \text { thermal } \\
\text { break }\end{array}$ & Same \\
\hline Solar & $\begin{array}{l}\text { Solar ready design (mounts, } \\
\text { flashings and electrical chase) } \\
4.2 \mathrm{~kW} \text { peak rated PV system } \\
\text { with a } 4 \mathrm{~kW} \text { inverter and } 12 \mathrm{kWh} \\
\text { battery array }\end{array}$ & None \\
\hline HVAC & $\begin{array}{l}2 \text { ton unitary air-source heat } \\
\text { pump } \\
12 \text { seer, } 7.8 \mathrm{HSPF}\end{array}$ & Same \\
\hline Zone heat & $150 \mathrm{~W}$ Radiant Panel in kitchen & None \\
\hline Ducts and cross over & $\begin{array}{l}\text { R8 crossover } \\
\text { Flex Flow crossover system } \\
\text { Mastic with screws } \\
\text { More efficient duct design }\end{array}$ & $\begin{array}{l}\text { R8 crossover } \\
\text { Sheet metal elbows } \\
\text { Standard foil tape }\end{array}$ \\
\hline Lighting & $\begin{array}{l}100 \% \text { Energy Star T8 and CFL } \\
\text { fixtures }\end{array}$ & T12 and Incandescent fixtures \\
\hline Appliances & $\begin{array}{l}\text { Energy Star washer and dryer, } \\
\text { refrigerator, dishwasher }\end{array}$ & Standard equipment \\
\hline $\begin{array}{l}\text { Whole House } \\
\text { Ventilation }\end{array}$ & $\begin{array}{l}\text { Heat Recovery Ventilator } \\
\text { w/HEPA, continuous operation } \\
\text { (turned off in } 8 / 04 \text { ) }\end{array}$ & $\begin{array}{l}\text { Quiet (low-sone) Energy Star } \\
\text { exhaust fan, continuous } \\
\text { operation }\end{array}$ \\
\hline Spot Ventilation & $\begin{array}{l}\text { Energy Star bath fans, std. } \\
\text { Kitchen fan }\end{array}$ & $\begin{array}{l}\text { Quiet (low-sone) bath fans, } \\
\text { std. Kitchen fan }\end{array}$ \\
\hline Ceiling Fans & Energy Star with dimmable CFL & $\begin{array}{l}\text { Standard with Incandescent } \\
\text { bulbs }\end{array}$ \\
\hline Domestic Hot Water & $\begin{array}{l}\text { PV controlled, active anti-freeze } \\
\text { solar water system, with } 80\end{array}$ & $\mathrm{EF}=0.88$ standard electric \\
\hline
\end{tabular}


Table 47 Zero Energy Manufactured Home (ZEMH) and Base Case Home (Control)

\begin{tabular}{|l|l|l|}
\hline \multicolumn{1}{|c|}{ Component } & \multicolumn{1}{|c|}{ ZEMH } & \multicolumn{1}{|c|}{ Base } \\
\hline Air Sealing & $\begin{array}{l}\text { gallon storage, and } 64 \mathrm{ft}^{2} \text { of } \\
\text { collector area solar pre-heat tank } \\
\text { (pre-plumbed), 40 gallon } \\
\text { standard tank EF=0.93 } \\
\begin{array}{l}\text { Wrap with tape flashing } \\
\text { Marriage line gasket (new } \\
\text { product) } \\
\text { Penetrations sealed with foam } \\
\text { insulation }\end{array}\end{array}$ & $\begin{array}{l}\text { Wrap without tape flashing } \\
\text { Standard practice marriage } \\
\text { line sealing }\end{array}$ \\
\hline Air/Vapor Barrier & $\begin{array}{l}\text { Walls and Ceiling: Painted } \\
\text { Drywall } \\
\text { Floor: Floor decking }\end{array}$ & Same \\
\hline
\end{tabular}

Data logger collects 15 minute data from wired sensors and transmits daily to the host computer at FSEC via modem. Summary data reports are available at www.baihp.org under "Current Data." Plug-type loggers were installed in mid March 2003 to sub-meter the energy use of the refrigerator, freezer and clothes washer in each home, as well as the radiant heat panel and HRV in the ZEMH. Data from these loggers was collected by occupant readings in mid-December 2003.

\section{Findings}

Measured net energy use of the ZEMH is $6 \%$ lower than the base home, not normalized for occupant behavior. This also does not take into account the fact that the ZEMH's PV system was only fully operational for one month.

The ZEMH required $45 \%$ less space heating energy, possibly due to improved building envelope measures, and the lack of consistent HRV operation.

The measured envelope leakage in the ZEMH was 2.0 ACH50, much lower than the base home (indeed, lower than any other NEEM home tested in the field) and substantially tighter than typical HUD code homes.

The ZEMH total duct leakage was $46 \%$ lower than the base home; leakage to the outside was $405 \%$ lower than the base home. The BAIHP staff speculates that the unprecedented low leakage to the outside value is the result of the ducts in the ZEMH being located within the conditioned space, and effectively within the pressure envelope of the home, surrounded as they are by foam insulation.

The solar water heating system in the ZEMH provides most, if not all of the hot water needed during the summer months, and roughly $45 \%$ of the total hot water demand. The PV system with net metering provides $38 \%$ of the total $\mathrm{ZEMH}$ energy use.

The project highlights the importance of occupant choices and behavior on the performance of energy efficient housing. Based on the preliminary monitoring data and occupant surveys, the behavior patterns of the ZEMH occupants are not themselves "energy efficient". These patterns 
create the appearance of a less efficient home. On the other hand, the behavior of the ZEMH occupants may shorten the payback for the innovative technologies of the ZEMH.

BAIHP staff also performed a benchmarking analysis on the ZEMH, as part of the overall benchmarking effort. The ZEMH reached a level of $60 \%$ above the NREL prototype, which indicates the difficulty of obtaining a high benchmarking score.

In December of 2004, a research paper was presented at BTECC which provided a preliminary evaluation of the ZEMH performance without the full operation of the PV net metering system.

\section{Follow up}

In December of 2005, dataloggers were installed to collect two minute interval data for the Idaho ZEMH and base case home. One week of data using the Insider heat pump was gathered, paying special note to the defrost cycle power usage and the effect that the unit's crawl space air flow changes conditions in the crawl space. This data was compared to a week of data from an electric strip heater

\section{Manufactured Housing Indoor Air Quality Study}

Plant City, Florida, and FSEC MHLab

Papers: $\quad$ Hodgson, A.T., Apte, M.G., Shendell, D.G., Beal, D. and McIlvaine, J.E.R. (2002a). Implementation of VOC source reduction practices in a manufactured house and in school classrooms. In Levin, H. (Ed.), Proceedings of the 9th International Conference on Indoor Air Quality and Climate. Indoor Air 2002, Santa Cruz, CA, Vol. 3. pp. 576-581.

Hodgson, A.T., D. Beal and J.E.R. McIlvaine. 2002b. Sources of formaldehyde, other aldehydes and terpenes in a new manufactured house. Indoor Air12: 235242.

Hodgson, A.T., A.F. Rudd, D. Beal and S. Chandra. 2000. Volatile organic compound concentrations and emission rates in new manufactured and site-built houses. Indoor Air10: 178-192.

This is a summary of several indoor air quality (IAQ) projects designed to improve the IAQ of manufactured homes; specifically to find ways to reduce the formaldehyde levels found in manufactured homes. This was a collaborative effort of the Florida Solar Energy Center (FSEC), Lawrence Berkeley National Laboratory (LBNL) and Palm Harbor Homes, Inc. (PHH), a leading nationwide producer of multi-section, high-end, manufactured houses with corporate offices in Addison, TX.

In 1999 - 2000 a study was conducted to identify and verify the major sources of formaldehyde, aldehydes, and terpene HCs in a new manufactured house. Laboratory emission tests were conducted with a number of wood and engineered wood products and aldehyde and volatile organic chemical (VOC) measurements were made in the house. Although only a single house was studied, the information on sources is anticipated to have broad application to residential construction due to the widespread use of similar materials and building practices. 
The manufactured house was typical of better quality two-section houses produced in Florida. It was completed in November 1999. Within three weeks of manufacture, it was installed at a nearby site. The house was used daily as a sales model. It was decorated, fully furnished, but unoccupied. There were three bedrooms and two bathrooms.

The manufacturer supplied a detailed list of materials used in the house. Between December 1999 and January 2000, 30 specimens of the major materials were collected from the production facility. These were cataloged, packaged in aluminum foil, and shipped to the laboratory by airfreight. The specimens were stored at room conditions in their original packages until they were tested. Most materials were tested within three months of collection.

Measurements were made after about a 3-week exposure, and area-specific emission rates (i.e., emission factors) were calculated.

Air sampling in the house and outdoors was conducted in March 2000. The house ventilation rate was quantified concurrently by tracer gas decay. The ventilation rate measurement and the VOC air sampling and analytical methods for field and chamber work have been described previously (Hodgson et al., 2000)

Whole-house emission rates for combined materials were predicted based on the emission factors and the corresponding material quantities. These predicted values were compared to whole-house emission rates derived from measurements of VOC concentrations and ventilation rates. For 10 of the 14 target compounds, including formaldehyde, the predicted and derived rates agreed within a factor of two, which considering the uncertainties involved is considered good agreement. The predominant sources of formaldehyde in the house were bare particleboard (PB) and medium density fiberboard (MDF) surfaces in the cabinetry casework and molded highdensity fiberboard doors. The plywood subfloor under the carpet was a smaller source of formaldehyde and the major source of higher molecular weight aldehydes and terpene hydrocarbons.

As the result of this study, recommendations were developed for reducing concentrations of formaldehyde and other VOCs in new house construction (Hodgson et al., 2002a). These are reproduced here in Table 48. The first five recommendations are aimed at controlling or eliminating important sources of formaldehyde. Other potential sources of formaldehyde not addressed in the house study or in the table include tack strips used for the installation of wall-towall carpet and fiberglass insulation used in wall, floor and ceiling cavities. Use of barrier materials on the floor may result in moisture condensation problems in hot-humid climates and possibly other situations and, therefore, should be used with caution.

\section{Table 48. Recommended VOC Source Reduction Practices For New House Construction}

\begin{tabular}{|l|l|}
\hline No. & Source Reduction Practice \\
\hline 1 & When alternates exist, avoid wood products with urea-formaldehyde resin system \\
\hline 2 & Construct cabinet cases with fully encapsulated wood products \\
\hline 3 & Use frameless cabinets to eliminate MDF stiles \\
\hline 4 & Apply laminate backing sheet to undersides of PB countertops \\
\hline 5 & Use alternate low-formaldehyde emitting passage doors \\
\hline 6 & Apply barrier material over plywood subfloor in carpeted areas \\
\hline
\end{tabular}


In 2004 a pilot demonstration project was conducted at PHH's production facility and sales office in Plant City, FL. The project was originally conceived in 2002 as a side-by-side demonstration of simultaneous improvements in energy performance and IAQ to be achieved using existing technologies. The concept was to build two houses, essentially identical with respect to their size, floor plan, and major materials. One house would have added features to improve energy performance and IAQ. The other house would have no special modifications and would serve as the control. They would be sited in a residential community on adjacent, identical lots. Both would have computer-simulated occupancy (i.e., controlled use of lights, appliances, heating and cooling). Monitoring of energy usage and performance and IAQ metrics would be conducted over at least a one-year period. Finding the appropriate residential site and the funds needed to cover the costs associated with maintaining the houses at the site for a year proved difficult. Consequently, the study plan was modified in 2003 to reduce costs and take advantage of PHH's model home sales office in Plant City.

Approximately on an annual cycle, PHH builds examples of their new houses for display at their sales office. The houses present PHH's range of models and features. They are decorated and furnished, but unoccupied. The houses are open to the public during normal business hours seven days a week and their heating and cooling systems are operated accordingly. The use of these houses as study houses has some limitations. The houses generally vary somewhat with respect to size and floor plan, interior finishes and furnishings may vary, orientation with respect to sun and wind may vary, monitoring instrumentation must be kept out of sight, and sampling can only be conducted outside of normal business hours. In addition, computer controlled simulations of occupancy are not possible.

To the extent possible, the study plan was revised to accommodate these factors. In June 2003, two model houses, then in the planning stage, were selected for use in the project. A 1,440-ft2, double-wide house designated as "Monte Carlo" was selected to receive the energy and IAQ modifications. A 1,540-ft2 double-wide house designated as "Edison 2" was selected to serve as the primary control house. The houses were to be installed on nearby lots in the sales center in approximately the same orientation.

The project participants early on developed specifications for enhanced IAQ. These specifications were reviewed and revised in June 2003 to reflect those energy and IAQ modifications determined by PHH management to be relatively easily installed on the production line and/or during installation. The revised IAQ specifications are listed in Table 49. 
Table 49 Revised IAQ Specifications

\begin{tabular}{|c|c|}
\hline Component & Specification \\
\hline Cabinet Construction & $\begin{array}{l}\text { Medium-density fiberboard (MDF) face frame material } \\
\text { and vinyl-two-sides (V2S) particleboard for all casework }\end{array}$ \\
\hline Countertops & $\begin{array}{l}\text { Construct all countertops with V1S particleboard with } \\
\text { vinyl surface on underside of tops }\end{array}$ \\
\hline Carpeted Floors & $\begin{array}{l}\text { Install Tyvek (Dupont) house wrap over plywood subfloor } \\
\text { before installing carpet. Use Nylon 6,6 carpet and } \\
\text { synthetic fiber carpet cushion (both CRI Green Label) } \\
\text { with standard tack strips with unquantified emissions of } \\
\text { formaldehyde }\end{array}$ \\
\hline Wall \& Ceiling Paint & $\begin{array}{l}\text { Use low VOC interior paints (Sherwin-Williams Harmony } \\
\text { brand) }\end{array}$ \\
\hline Passage Doors & Standard molded high-density fiberboard \\
\hline Trim & $\begin{array}{l}\text { Use wood lumber trim throughout house; avoid use of } \\
\text { MDF trim }\end{array}$ \\
\hline Recessed Light Fixtures & Install gasketed light fixtures \\
\hline
\end{tabular}

The two houses were produced in late July and early August 2003. Installation of the two houses was completed and the heating and air conditioning (HAC) systems were operational by the end of September.

Energy Gauge ratings of the experimental house (Monte Carlo) and the control (Edison) showed that the control house was an Energy Star home, scoring 86.5, while the experimental house was a Building America house, scoring 91.1. There were many obstacles to successfully retrieving data from the houses, but available results show that the BA house saved about $50 \%$ more air conditioning energy than the control house. Figure 71 illustrates this. The plot normalizes the data by plotting the daily air conditioner energy use pre $\mathrm{ft}^{2}$ of conditioned space versus the average daily temperature difference between the inside and the outside (Average Daily )T).

IAQ work started with an initial set of active air samples for VOCs and aldehydes collected outdoors and in the Study and Control houses on December 11, 2003, approximately 2.5 months after the houses were fully operational. The second set of active samples was collected three months later on March 2, 2004. Passive aldehyde samples were obtained in the Study and Control houses and in an additional triple-wide house of the same age over four one-week intervals between these dates.

There were some distinct differences between the concentrations measured in the two houses. Notably, the concentrations of formaldehyde in the Study house were about three times higher than concentrations in the Control house. This difference was not anticipated based on the source reduction measures aimed at lowering the emissions of formaldehyde in the Study house.

Based on previous laboratory measurements of formaldehyde emissions from interior components, we anticipated a minimum $25 \%$ reduction in the formaldehyde emission rate in the Study house relative to the Control house. This was anticipated due to the use of fully encapsulated particleboard for the cabinetry casework, a diffusion barrier on the undersurface of 
the particleboard countertops, and the weatherization barrier applied over the plywood subfloor (Hodgson et al., 2002b). We additionally expected the difference to persist over the course of a year. The two-fold higher formaldehyde emissions in the Study house prompted us to abandon our original plan of quarterly measurements and instead to focus on identifying the unexpected source of formaldehyde emissions in this house. Firstly, FSEC and PHH staff jointly inspected the houses. This inspection confirmed that the intended formaldehyde source reduction measures had been implemented in the Study house.

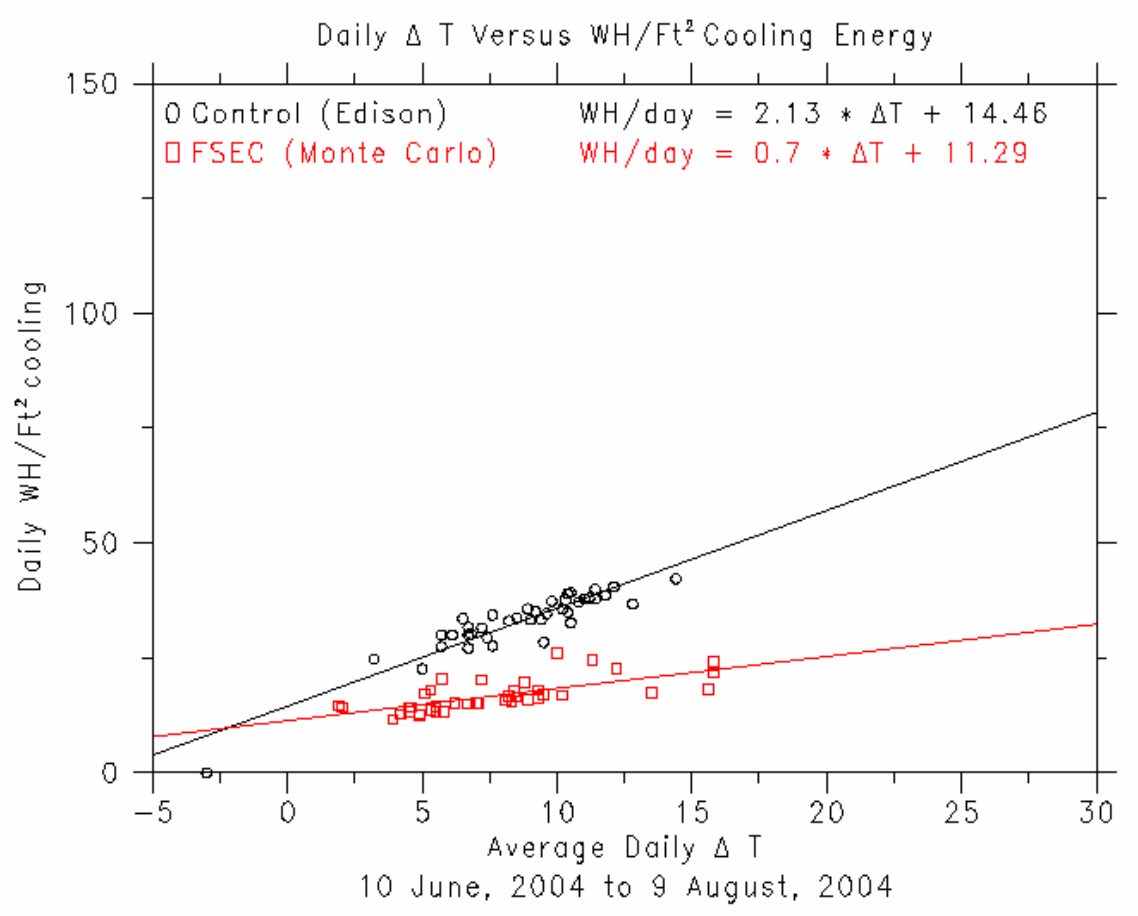

Figure 71

Two other potentially relevant differences between the houses were known at the time. Due to the energy efficiency specifications for the Study house, a different manufacturer than the HAC system in the Control house produced the HAC mechanical system in the house. Secondly, some furniture believed to be solid wood had been newly purchased for decoration of the Study house. Older furniture taken from PHH's stock was used to decorate the Control house.

In July 2004, the potential for the HAC systems to emit formaldehyde was investigated. Each system is located in a closet near the central living area. Active sampling for formaldehyde was conducted in each house. The differences between the return and supply measurements were small, about plus $3 \%$ for the study house and about minus $8 \%$ for the control house. These differences are within the uncertainties of the measurements and, therefore, are not significant. Another inspection revealed that some of the backsides and undersurfaces of the new wood furniture were fabricated from particleboard, a typically high formaldehyde emission source (Kelly et al., 1999; Hodgson et al., 2002b). Due to delays imposed by PHH model center needs and 2004's hurricane season, in December 2004, approximately 14 months after the furniture was first delivered, we located the furniture pieces in a storage garage. From one accessible 
piece, we obtained 4.4-cm diameter specimens of 3-mm thick particleboard using a hole-saw. Specimens of 13-mm thick particleboard were similarly collected from a furniture piece that was several years old and was used in the sunroom of the house.

The emissions of formaldehyde from the two specimens of furniture particleboard individually were measured in the laboratory using small-scale environmental chambers as described by Hodgson et al. (2002b).

From the purchase requisition and the company's sales literature it was determined there were eight new pieces of living room and master bedroom/retreat furniture that likely contained some particleboard. The total exposed surface area (one side) of particleboard in these pieces was estimated to be $8.5 \mathrm{~m} 2$. Thus, the estimated formaldehyde emission rate attributable to the new furniture was about $80 \%$ of the total formaldehyde emission rate derived for the house in December 2003. Based on the formaldehyde emissions from the particleboard from the older furniture, it is likely that the formaldehyde emissions attributable to furniture would have been substantially lower if older furniture pieces had been used.

This study did not progress as originally intended, and the results did not conclusively show the efficacy of low-cost measures intended to reduce the sources of formaldehyde in the Study house. However, it is likely that the source of the elevated formaldehyde emissions was correctly identified to be a component of the new wood furniture installed in this house and not in the Control house. If one-half the estimated formaldehyde emission rate from the new furniture (i.e., approximately the difference between the emissions from new and old furniture particleboard) is subtracted from the whole-house emission rate, the formaldehyde emission rate in the Study house is nearly equivalent to the rate in the Control house.

A formaldehyde concentration of $50 \mathrm{ppb}$ and below has been suggested as a reasonable target for new houses (Sherman and Hodgson, 2004). The source reduction measures directed toward other VOCs were successfully demonstrated. The use of the weatherization barrier applied over the plywood subfloor in the Study house appeared to function as predicted to reduce the emissions of higher molecular weight aldehydes and terpene hydrocarbons from this source, and the use of the low VOC interior paint reduced the emissions of a major VOC component associated with latex paints.

Data collection was curtailed by the onset of 2004's hurricanes, three of which impacted Plant City, and sales activity resulting in houses moving. The collected data did show that the energy goals established for the house were met, with a 50\% reduction of energy use for air conditioning compared to the control house. 


\section{Manufactured Housing Laboratory - Ventilation Studies}

FSEC, Manufactured Home Laboratory

Paper: $\quad$ Moyer, Neil, Chasar, Dave, Hoak, Dave, Chandra, Subrato, "Assessing Six

Residential Ventilation Techniques in Hot and Humid Climates," Proceedings of

ACEEE 2004 Summer Study on Energy Efficiency in Buildings, American Council

for an Energy Efficient Economy, Washington, DC, August 2004. (Also available online at www.baihp.org under Current Data and Publications)

Ventilation Study

The MHLab (Figure 72) is a research and training facility of $1600 \mathrm{ft}^{2}$. This Energy

Star® manufactured home has two separate heating and cooling systems:

1. An overhead duct system connected to a package unit air conditioner with electric resistance heating.

2. A floor-mounted duct system connected to a split system air conditioner, also with electric resistance heating.

Only the floor mounted duct system was used in these ventilation experiments.

$\underline{\text { Introduction }}$

Ventilation is a HUD code requirement. The goal of ventilation is to add fresh air to the home. This may be accomplished by supplying outside air to the house or mechanical system, exhausting air from the house (which consequently pulls air into the house through joints in the walls, floor, and ceiling), or a combination of the two.

Supply based ventilation tends to slightly

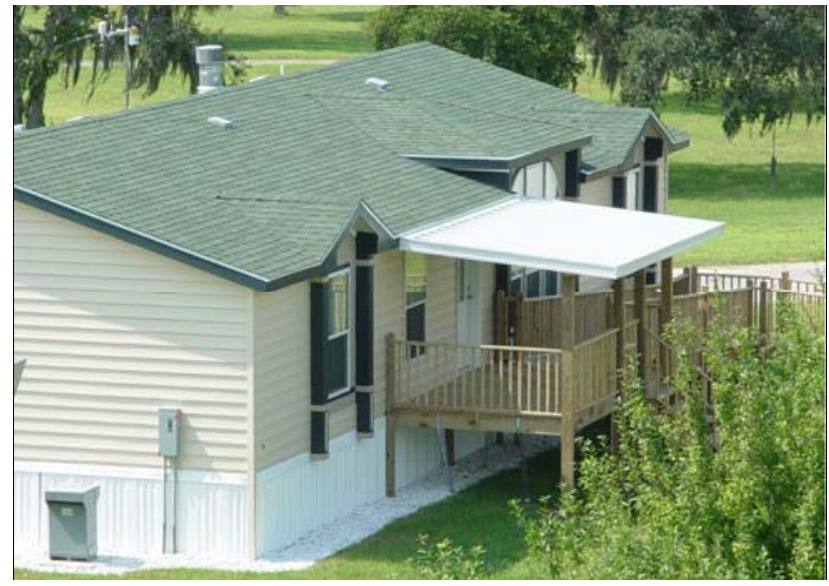

Figure 72 Manufactured Housing Laboratory at FSEC (above and below) was site for study of six residential ventilation systems.

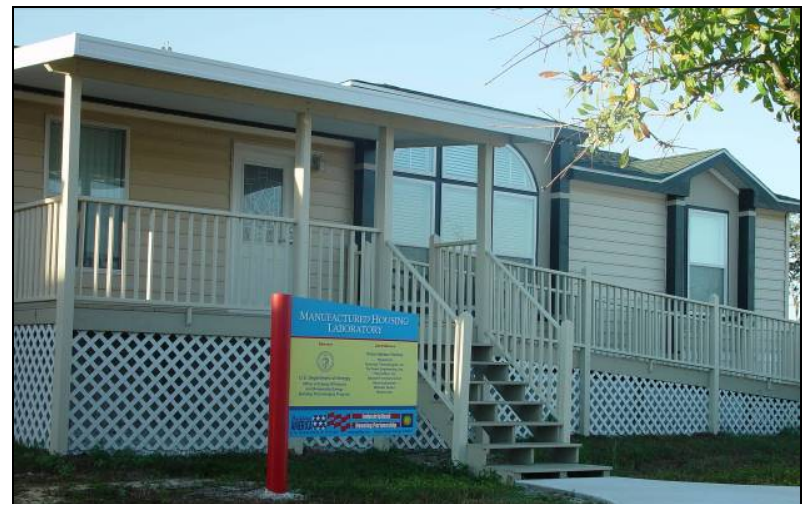
pressurize the home whereas exhaust based ventilation does the opposite slightly depressurizing the house. The disadvantage of supply based ventilation is that it forces conditioned air into the floor, wall, and ceiling cavities, possibly leading to condensation or mold growth in cold climates and during the heating season. Likewise the disadvantage of exhaust systems is that they pull unconditioned outside through the floor, wall, and ceiling cavities into the conditioned space, possibly leading to condensation, mold growth, or uncomfortably high indoor humidity levels in hot and hot-humid climates and during the cooling season. The six residential ventilation strategies evaluated are described in Table 50. 


\section{House Operation and Experimental Procedure}

Occupancy Simulation: Automated computer controlled devices, such as appliances, showers, and lighting, simulate the sensible/latent heat generation and carbon dioxide $\left(\mathrm{CO}_{2}\right)$ production of a family of four persons with periodic showers, cooking and cleaning.

The simulated latent occupancy load from breathing, bathing, cooking, and laundry was achieved by adding 14 to 15 pounds of water per day based on documentation of "average" household operation based on ORNL research conducted by Jeff Christian. Water vapor was injected into the space using a vaporizer at a rate of approximately $0.4 \mathrm{lbs}$ per hour continuous and an additional $0.4 \mathrm{lbs}$ per hour during the evening hours.

Table 50 Ventilation Strategies Studied in the MHLab

\begin{tabular}{|c|c|c|}
\hline $\begin{array}{c}\text { Case } \\
\text { (Name) }\end{array}$ & Strategy & Description \\
\hline $\begin{array}{c}\# 1 \\
\text { (None). }\end{array}$ & $\begin{array}{l}\text { No mechanical } \\
\text { ventilation }\end{array}$ & $\begin{array}{l}\text { Base Case scenario included only the heating and cooling system of the } \\
\text { home with no outside air (OA) ventilation. }\end{array}$ \\
\hline $\begin{array}{c}\# 2 \\
(\text { Spot })\end{array}$ & $\begin{array}{l}\text { Spot ventilation } \\
\text { (exhaust only) }\end{array}$ & $\begin{array}{l}\text { Bathroom and kitchen exhaust fans. Operation scheduled for } 30 \text { minutes } \\
\text { after a simulated moisture producing event such as a shower or oven use. }\end{array}$ \\
\hline $\begin{array}{l}\# 3 \\
(\mathrm{OA})\end{array}$ & $\begin{array}{l}\text { Outside air (supply } \\
\text { based) }\end{array}$ & $\begin{array}{l}\text { Dedicated, filtered outside air duct to return plenum when the heating or } \\
\text { cooling system is operating. Quantity of ventilation air provided depends } \\
\text { on air handler run-time. }\end{array}$ \\
\hline $\begin{array}{c}\text { \# } 4 \\
\text { (Dehumid) }\end{array}$ & $\begin{array}{l}\text { Outside Air plus } \\
10 / 20 \text { Cycle and } \\
\text { Dehumidification } \\
\text { (Supply Based) }\end{array}$ & $\begin{array}{l}\text { Same as \#3, except with an added air handler fan controller (10-minute } \\
\text { "on" - 20-minute "off" minimum duty cycle). Provides scheduled } \\
\text { ventilation when no cooling or heating is called for. A stand alone room } \\
\text { dehumidifier (set to approximately } 50 \% \mathrm{RH} \text { ) located in vicinity of the } \\
\text { return air grill. }\end{array}$ \\
\hline $\begin{array}{l}5 \\
(10 / 20 \\
\text { Cycle })\end{array}$ & $\begin{array}{l}\text { Outside Air plus } \\
10 / 20 \text { cycle (Supply } \\
\text { Based) }\end{array}$ & Same as \#4, except without the room dehumidifier. \\
\hline $\begin{array}{l}\text { \# } 6 \text { (ERV1) } \\
\text { (ERV2) }\end{array}$ & $\begin{array}{l}\text { Energy recovery } \\
\text { ventilator (ERV1, } \\
\text { ERV2) }\end{array}$ & $\begin{array}{l}\text { Two different enthalpy transfer media were used. Outside air was drawn } \\
\text { in through the ERV at a rate to meet the ventilation requirements. }\end{array}$ \\
\hline $\begin{array}{l}\text { \# } \\
\text { (Hstat) }\end{array}$ & $\begin{array}{l}\text { Outside Air plus } \\
\text { Humidistat (Supply } \\
\text { Based) }\end{array}$ & $\begin{array}{l}\text { This is a modified air handler fan speed control. When dehumidification } \\
\text { is needed, the air handler fan is operated at lowest speed for enhanced } \\
\text { latent control. A higher speed is selected when sensible cooling is } \\
\text { needed. Ventilation air supplied via an outside air duct, with air handler } \\
\text { fan operation controlled as in } \# 4 \text {. }\end{array}$ \\
\hline
\end{tabular}

Ventilation Rate: Researchers conducted whole house air tightness tests using sulfur hexafluoride as a tracer gas for a decay analysis (Figure 73) to determine if each ventilation strategy met the ASHRAE 62-2 Ventilation Standard during the test period. The spot ventilation strategy (\#2) did not meet the standard on a daily basis as the runtime was not long enough. The outside air method (\#3) was marginal in meeting the standard. Strategies \#4-\#7 met the standard.

Whole House and Duct Air Tightness: The average whole house air leakage (CFM50) was 1224 (ACH50 of 5.4). The target normalized duct leakage is $\mathrm{Qn} \# 6 \%$, where $\mathrm{Qn}=\mathrm{CFM} 25 /$ conditioned area, this is the same as the duct leakage target in the Manufactured Home Energy Star program. The total duct system leakage in the MHLab $\mathrm{Qn}_{\text {total }}=5 \%\left(\mathrm{CFM} 25_{\text {total }}=75\right)$ with leakage to the outside measured to be $\mathrm{Qn}_{\text {(out) }}=3 \%\left(\mathrm{CFM} 25_{\text {out }}=45\right)$, well under the leakage target. 
Interior temperature and relative humidity: A digital thermostat maintained interior temperature at $75^{\circ}$ degrees Fahrenheit. Interior temperature and relative humidity sensors are located on the same wall as the thermostat, at approximately the same height from the floor. Dedicated interior relative humidity control was only available with the dehumidifier strategy, and was a byproduct of cooling coil operation in the other strategies.

\section{Cooling/ventilation power usage}

With all mechanical ventilation systems, additional energy use from both increased conditioning loads and fan (if present) power is expected. The split system with the floor duct system is a 12

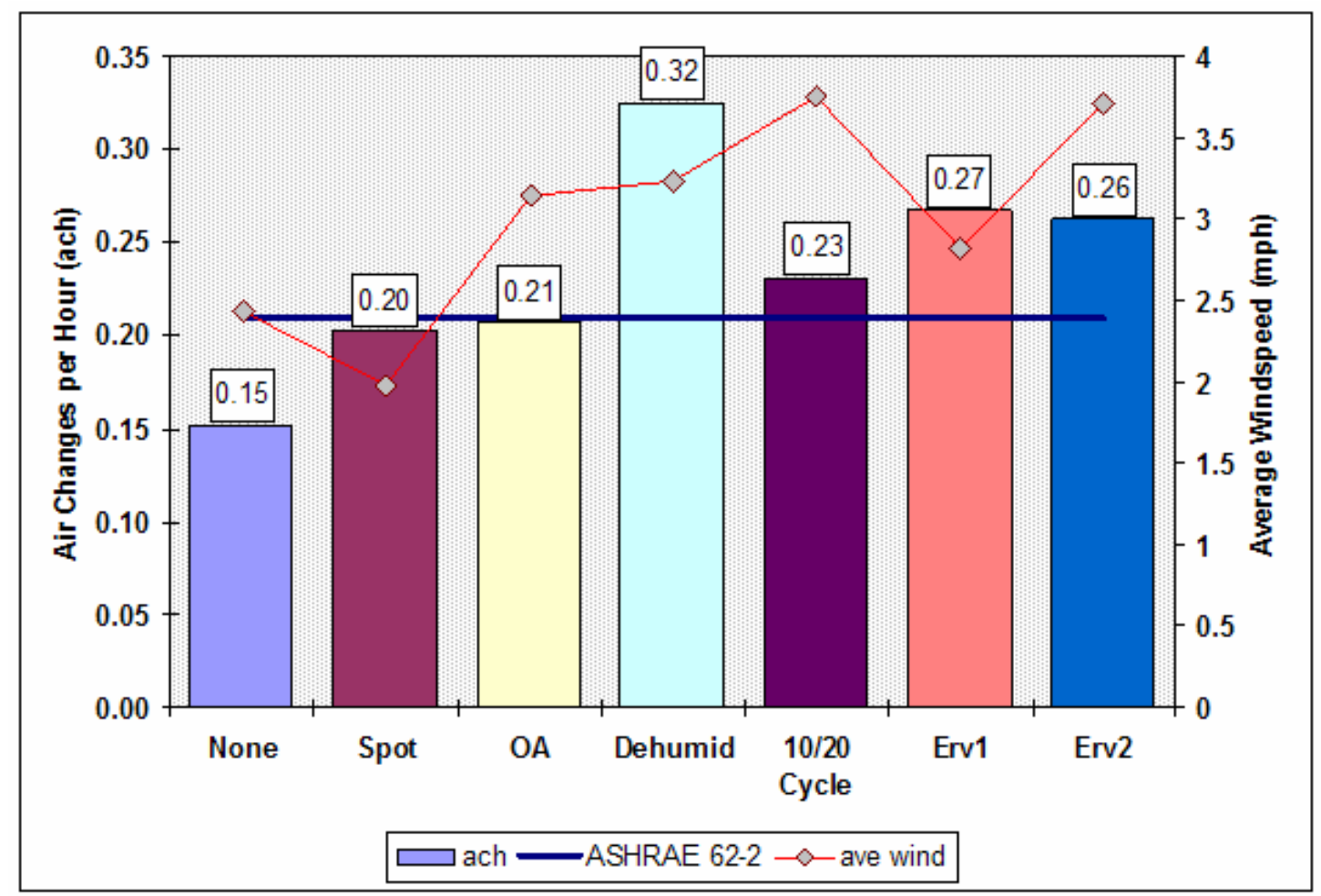

Figure 73 Results of tracer gas decay testing indicating operational infiltration (house not under test pressure) rates measured for each ventilation strategy. ASHRAE Standard 62.2 was the target ventilation rate, not met by Spot or OA strategies. Note: Wind speed averaged over 2 hour infiltration test.

SEER system with a rated cooling capacity of $30.2 \mathrm{kBtu}$. The ventilation strategies that required the use of the air handler fan, an energy recovery ventilator, or the dehumidifier had the energy use added to the cooling energy. The dehumidifier strategy did use the most energy for cooling; however, it should be noted that this test occurred during the hottest ambient conditions. 
Table 51 Average Ambient and Building Conditions

\begin{tabular}{|c|c|c|c|c|c|c|c|c|}
\hline & $\begin{array}{l}\text { Case } 1 \\
\text { None }\end{array}$ & $\begin{array}{c}\text { Case } 2 \\
\text { Spot }\end{array}$ & $\begin{array}{c}\text { Case } 3 \\
\text { OA }\end{array}$ & $\begin{array}{c}\text { Case } 4 \\
\text { Dehumid }\end{array}$ & $\begin{array}{c}\text { Case } 5 \\
10 / 20\end{array}$ & $\begin{array}{l}\text { Case } 6 \\
\text { ERV1 }\end{array}$ & $\begin{array}{l}\text { Case } 6 \\
\text { ERV2 }\end{array}$ & $\begin{array}{c}\text { Case } 7 \\
\text { Hstat }\end{array}$ \\
\hline Indoor Temp $\left({ }^{\circ} \mathrm{F}\right)$ & $74.5^{\circ}$ & $74.5^{\circ}$ & $74.7^{\circ}$ & $74.9^{\circ}$ & $74.0^{\circ}$ & $74.1^{\circ}$ & $74.4^{\circ}$ & $74.8^{\circ}$ \\
\hline Indoor Temp Max $\left({ }^{\circ} \mathrm{F}\right)$ & $75.0^{\circ}$ & $75.2^{\circ}$ & $75.5^{\circ}$ & $76.0^{\circ}$ & $75.0^{\circ}$ & $74.9^{\circ}$ & $75.4^{\circ}$ & $76.0^{\circ}$ \\
\hline Indoor RH (\%) & $49.2 \%$ & $45.7 \%$ & $49.5 \%$ & $47.9 \%$ & $49.1 \%$ & $47.8 \%$ & $47.2 \%$ & $45.7 \%$ \\
\hline Indoor Dewpoint $\left({ }^{\circ} \mathrm{F}\right)$ & $52.4^{\circ}$ & 54.2 & 54.5 & 53.9 & 53.7 & 53.1 & 53.0 & 52.4 \\
\hline Outside Temp $\left({ }^{\circ} \mathrm{F}\right)$ & $78.6^{\circ}$ & $78.6^{\circ}$ & $78.4^{\circ}$ & $82.1^{\circ}$ & $79.8^{\circ}$ & $79.3^{\circ}$ & $80.8^{\circ}$ & $79.2^{\circ}$ \\
\hline Outside RH $(\%)$ & $89.2 \%$ & $79.5 \%$ & $87.7 \%$ & $83.4 \%$ & $87.0 \%$ & $90.0 \%$ & $86.9 \%$ & $88.1 \%$ \\
\hline$\Delta$ Temp $\left({ }^{\circ} \mathrm{F}\right)$ & $4.3^{\circ}$ & $4.0^{\circ}$ & $3.7^{\circ}$ & $7.1^{\circ}$ & $5.8^{\circ}$ & $5.1^{\circ}$ & 6.5 & 4.4 \\
\hline$\Delta$ Dewpoint $\left({ }^{\circ} \mathrm{F}\right)$ & $18.6^{\circ}$ & $20.7^{\circ}$ & $19.5^{\circ}$ & $22.4^{\circ}$ & $21.4^{\circ}$ & $22.7^{\circ}$ & $23.3^{\circ}$ & $22.6^{\circ}$ \\
\hline Solar Rad. $\left(\mathrm{kWh} / \mathrm{m}^{2}\right)$ & 53.5 & 107.3 & 68.9 & 76.3 & 86.8 & 66.3 & $101.9^{\circ}$ & $77.1^{\circ}$ \\
\hline Rainfall (Inches) & 3.6 & 0.5 & 4.7 & 0.1 & 4.0 & 5.1 & 3.2 & 4.9 \\
\hline Condensate (lbs) & 617 & 905 & 920 & 1131 & 1118 & 1034 & 1685 & 1282 \\
\hline$\Delta \mathrm{P}$ WRT Out $(\mathrm{Pa})$ & -0.2 & 0 & 0.1 & 0.4 & 0 & -0.2 & -0.2 & 0.1 \\
\hline Minimum RH & $42.1 \%$ & $38.8 \%$ & $45.8 \%$ & $46.2 \%$ & $46.3 \%$ & $44.2 \%$ & $39.3 \%$ & $39.7 \%$ \\
\hline Maximum RH & $53.3 \%$ & $55.2 \%$ & $53.2 \%$ & $51.0 \%$ & $58.4 \%$ & $64.8 \%$ & $53.0 \%$ & $61.4 \%$ \\
\hline Mean RH & $46.1 \%$ & $49.2 \%$ & $49.5 \%$ & $47.9 \%$ & $49.0 \%$ & $47.8 \%$ & $47.2 \%$ & $45.7 \%$ \\
\hline RH Standard Deviation & 1.272 & 1.471 & 1.673 & 0.845 & 1.231 & 2.194 & 2.108 & 3.07 \\
\hline RH Range & $11.2 \%$ & $16.3 \%$ & $7.4 \%$ & $4.8 \%$ & $12.1 \%$ & $20.6 \%$ & $13.7 \%$ & $21.7 \%$ \\
\hline
\end{tabular}

\section{Findings}

The cooling energy required to maintain the $75^{\circ} \mathrm{F}$ interior set-point appeared to vary as a result of the temperature difference across the envelope (Table 51). A linear regression analysis was performed to compare energy use of the ventilation strategies as a function of temperature difference across the envelope (Table 52). The power use at the average temperature difference of five degrees Fahrenheit is shown in bold.

- Case 4 , the dehumidifier system, has the highest average power at 1592 watts.

- Case 7 (humidistat controlled fan speed or Hstat) is second highest at 1485 watts.

- Case 5 (10/20 cycle controller) used the least power at 1315 watts.

As might be expected, interior relative humidity had the least variance with the dehumidification system with a low of $46 \%$ and a high of $51 \%$ (Table 51 and Figure 74 ). The best performing system, Case 4 (10/20 cycle plus dehumidifier), was able to maintain the relative humidity at a nearly constant level for almost $80 \%$ of the test period. The next best performer was Case 2 (spot ventilation). Humidity levels during the test period are graphed in Figure 74.

Table 52 Cooling and ventilation power (watts) usage as a function of temperature difference across the building envelope

\begin{tabular}{|c|c|c|c|c|c|c|c|c|}
\hline \multirow{2}{\Delta}{$\begin{array}{c}\Delta \text { Temp } \\
\left({ }^{\circ} \mathbf{F}\right)\end{array}$} & Case 1 & Case 2 & Case 3 & Case 4 & Case 5 & \multicolumn{2}{|c|}{ Case 6 } & Case 7 \\
\cline { 7 - 9 } \cline { 6 - 8 } & Spot & OA & Dehumid & $\mathbf{1 0} / \mathbf{2 0}$ & ERV1 & ERV2 & Hstat \\
\hline-5 & 487 & 499 & 475 & 499 & 411 & 459 & 367 & 526 \\
\hline 0 & 924 & 911 & 949 & 1046 & 863 & 915 & 880 & 1006 \\
\hline $\mathbf{5}$ & $\mathbf{1 3 6 1}$ & $\mathbf{1 3 2 4}$ & $\mathbf{1 4 2 4}$ & $\mathbf{1 5 9 2}$ & $\mathbf{1 3 1 5}$ & $\mathbf{1 3 7 0}$ & $\mathbf{1 3 9 3}$ & $\mathbf{1 4 8 5}$ \\
\hline 15 & 2236 & 2150 & 2372 & 2685 & 2219 & 2280 & 2418 & 2443 \\
\hline
\end{tabular}




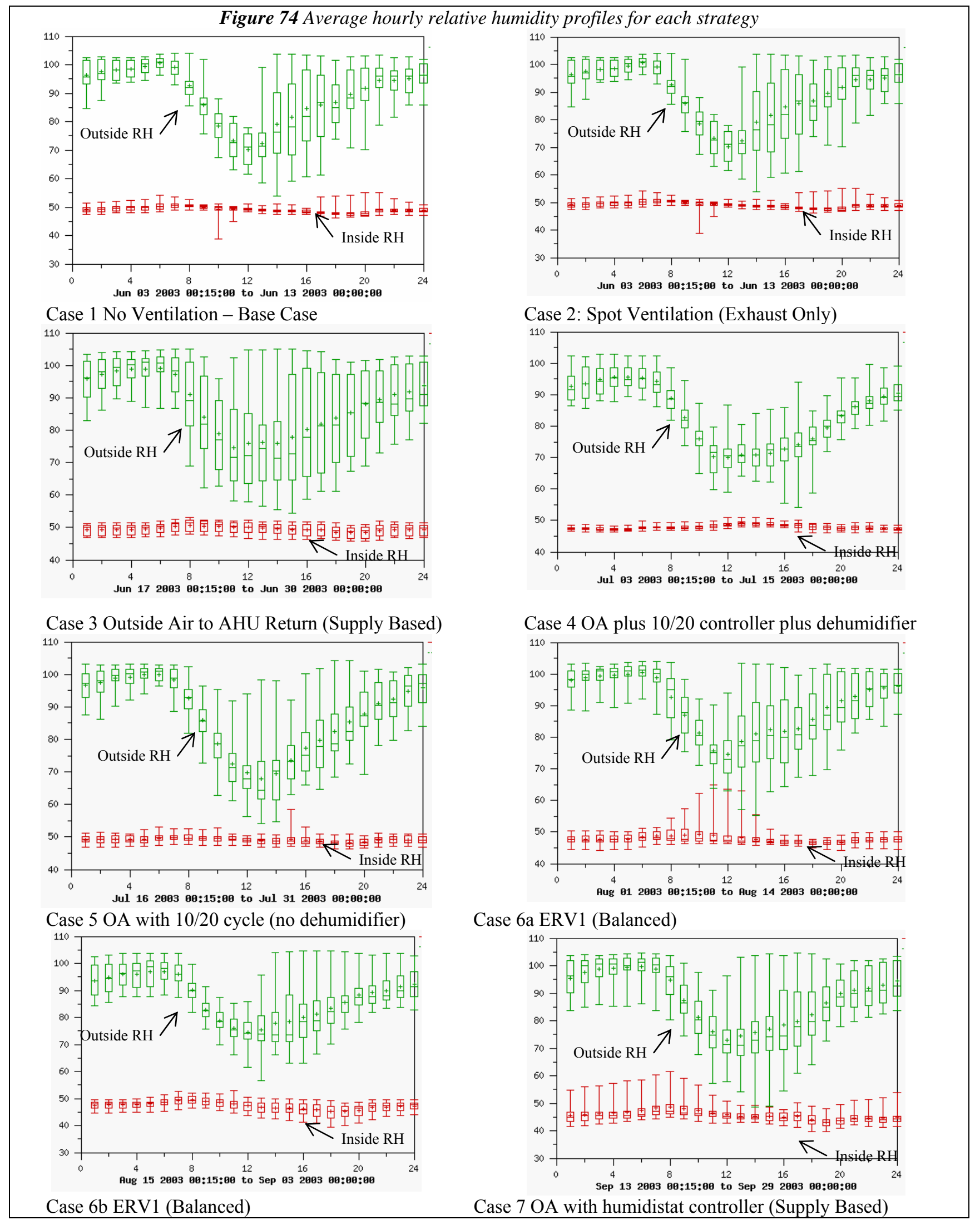




\section{Conclusions}

The operation of a correctly sized air conditioning system with a supplemental dehumidification system to pre-condition the outside air and provide additional dehumidification of the space appears to provide the best interior humidity control (Table 52, in bold) with only a slight increase in energy usage - about 200 watts (Table 53). This is represented by Case 4 of this study. Only this strategy was able to maintain the interior humidity conditions in a range of less than 5\% (Table 53, in italics).

Though all of the strategies did provide some humidity control over the test period, it is most likely a result of the run time afforded by the correctly sized air conditioning system and the consistent simulated interior sensible load. When an air conditioning system operates for extended periods of time, the removal of moisture from the air stream is enhanced (Khattar, Swami \& Ramanan 1987).

In the final year of the project, researchers began installation of Building Science's ACDM (Advanced Cooling with Dehumidifier Mode) heat pump forced air system and monitoring equipment in the Manufactured Housing Lab in April of 2006. The duct system was modified to accept the new unit, the package unit removed and the new heat pump system installed. An alternate method of measuring condensate by using a condensing furnace condensate pump with a modified pump on the sensor was developed and tested.

Also, all BA teams were surveyed on their current ventilation practices in November 2005, and the summary was presented at the BA team meeting in December. Members discussed conducting new experiments to quantify ventilation efficiency of various ventilation strategies with Building Science Corp. and NREL.

\section{Side by Side Manufactured Housing Energy Use Study, North Carolina A\&T}

Paper: $\quad$ W. Mark McGinley, Alaina Jones, Carolyn Turner, Subrato Chandra, David Beal, Danny Parker, Neil Moyer, and Janet McIlvaine. Optimizing Manufactured Housing Energy Use. Symposium on Improving Building Systems in Hot and Humid Climates, Richardson, Texas, May 17-19, 2004.

Side-by-side monitoring of two manufactured homes at North Carolina Agricultural and

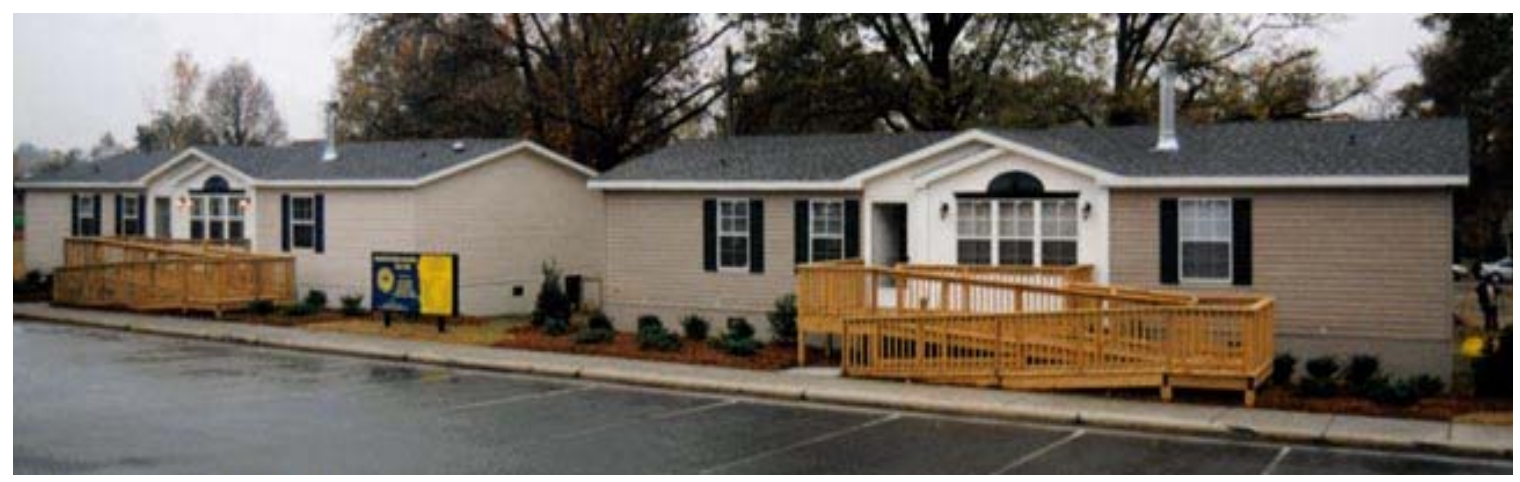

Figure 75 Side-by-side monitoring of manufactured homes at NCA\&TSU.

Technical State University (NCA\&TSU), evaluated the value of a variety of energy saving technologies and techniques. (Figure 75 and Table 54) Home instrumentation measured energy 
consumption as well as interior and exterior climatic conditions. The "standard home," designed and built to basic HUD code requirements, represented the control home. Modified to use at least $50 \%$ less energy, the "energy home" met Building America standards. Cooperating researchers at NCA\&TSU and FSEC investigated energy feature performance and compared actual energy used to energy modeling program predictions. In-situ energy performance data provided researchers with interesting information on both issues.

Each model contained 1,528 $\mathrm{ft}^{2}$ of living area with nearly identical floor plans. Though the homes were unoccupied during the testing, home lighting and water heating use was simulated with timers. A datalogger in each home recorded: (1) the interior and exterior temperature and humidity along with solar radiation and wind speed, (2) the home's total power consumption, (3) the air conditioning/heat pump compressor, air handler fan, and electric resistance heater use (primary heater in the standard house, backup or emergency heater for the energy house), and (4) water heating and water usage data.

The energy house features combined higher insulation values, improved windows, centralized and airtight duct design, high efficiency heat pump, and a solar water heater. Feature-by-feature construction differences are highlighted in Table 54.

Table 54 Specifications of Standard and Energy Construction

\begin{tabular}{|c|c|c|}
\hline Characteristic & Standard House & Building America House \\
\hline square footage & 1528 & 1528 \\
\hline floor insulation & $\mathrm{R}-11$ & $\mathrm{R}-22$ \\
\hline wall insulation & $\mathrm{R}-11$ & $\mathrm{R}-13$ \\
\hline ceiling insulation & $\mathrm{R}-20$ & $\mathrm{R}-33+$ roof deck radiant barrier \\
\hline windows & single pane with interior storm & low-E double pane \\
\hline exterior doors & storm door on front & storm door on all \\
\hline marriage wall seal & fiberglass pad & SOF-SEAL $®$ gasket \\
\hline heating system & resistance electric & heat pump HSPF 7.5 \\
\hline cooling system & central air conditioning SEER 10 & central heat pump SEER12 \\
\hline system size & 3 tons & 2 tons \\
\hline water heating & electric water heater -40 gallon & solar water heater -66 gallon \\
\hline duct joints & industry standard & sealed with mastic \\
\hline duct leakage & $*$ CFM5out $=145$ & $\mathrm{CFM} 25$ out $=83$ \\
\hline house leakage & $* * \mathrm{ACH} 50=10$ & $\mathrm{ACH} 50=9$ \\
\hline
\end{tabular}

Data collection on the two homes began in early January 2001. Palm Harbor Homes in Siler City manufactured both homes, the results for program year three and four are detailed below.

Year 4 Side-by-Side Monitoring Results

During Phase 2, modifications were made to the solar water heating system in the energy efficient housing unit to help improve the performance this system. Further, a number of the incandescent light bulbs in the energy unit were replaced with compact fluorescent bulbs. These changes were staged to allow an evaluation of the effect of each measure on the home's energy use. 
Based on investigative results, it can be concluded that:

- Changes in the building envelope, HVAC and duct systems, and fenestrations in the energy home met researchers' 50\% energy use reduction goal. Measured annual energy savings for heating and cooling energy was 58\%, and 53\% for heating, cooling, and hot water production.

- Care should be exercised in the manufactured housing unit setup or relatively minor construction deficiencies can significantly reduce a home's energy efficiency. Many of these items are invisible to the homeowner; therefore procedures must be developed to ensure that deficiencies do not occur during setup.

- The Energy Gauge energy analysis program appears to give a reasonably accurate prediction for expected energy use reduction in a typical manufactured housing configuration. The predicted energy savings for the housing units evaluated in this investigation ranged from $54 \%$ to $63 \%$, while the measured values ranged from $53 \%$ to $58 \%$. Version 2.0 of the Energy Gauge Program provided a more accurate energy savings prediction than the older software versions.

- An increase in pipe and tank insulation can increase not only the energy efficiency of a solar water heater by reducing stand-by losses, but also can reduce the cooling load in a manufactured housing unit and increase the overall energy efficiency of the water heating unit. Even small amounts of exposed piping can significantly affect the energy efficiency of the water heating system.

- While providing essentially the same lighting levels, replacing incandescent lamps with compact fluorescent bulbs not only reduces lighting energy use, but also reduces the home cooling load.

The total measured energy used by each of the housing units for cooling and heating are shown in tables below. Table 55 shows the energy used for heating and cooling the standard housing unit from January through August of 2002. The standard home datalogger was struck by lighting in mid-August 2002. Data after this point was not included since only partial data is available and performance comparisons were not possible. Table 56 shows a summary of the cooling and heating energy used by the energy housing unit. Tables 57 and 58 list the energy use for hot water production for the standard and energy units, respectively.

Table 55 Cooling and Heating Energy Use, Standard House Actual Values (kWh)

\begin{tabular}{|l|c|c|c|c|c|c|c|c|c|c|c|c|c|}
\hline & SEP & OCT & NOV & DEC & JAN & FEB & MAR & APR & MAY & JUN & JUL & AUG \\
\hline Phase 1 & 492.4 & 447.6 & 648.6 & 1741.1 & 2495.3 & 849.6 & 628.8 & 384 & 566.3 & 990.8 & 852.9 & 1066 \\
\hline Phase 2 & & & & & 2120.2 & 1717.1 & 1227.6 & 502.0 & 438.0 & 939.4 & 1079.4 & 511.2 \\
\hline
\end{tabular}

Table 56 Cooling and Heating Energy Use, Energy Star House

\begin{tabular}{|l|c|c|c|c|c|c|c|c|c|c|c|c|c|}
\hline & SEP & OCT & NOV & DEC & JAN & FEB & MAR & APR & MAY & JUN & JUL & AUG \\
$\begin{array}{ll}\text { Phase 1 } \\
\text { Phase 2 }\end{array}$ & 337.3 & 205.7 & 150.8 & 452.8 & 1087.3 & 472.8 & 426.9 & 184.8 & 528.3 & 891.5 & 850.9 & 671.6 \\
\hline
\end{tabular}

Table 57 Domestic Hot Water Use, Standard House

\begin{tabular}{|l|c|c|c|c|c|c|c|c|c|c|c|c|c|}
\hline & SEP & OCT & NOV & DEC & JAN & FEB & MAR & APR & MAY & JUN & JUL & AUG \\
\hline Phase 1 & 197.8 & 267.7 & 250.2 & 212.6 & 0 & 0 & 217.6 & 244.9 & 258.1 & 227.5 & 207.9 & 213.5 \\
\hline Phase 2 & & & & & 294.6 & 280.9 & 283.2 & 264.9 & 280.2 & 192.2 & 200.3 & 85.2 \\
\hline
\end{tabular}

Table 58 Domestic Hot Water Use, Energy Star House

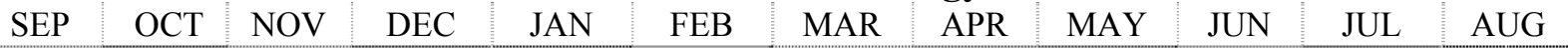




\begin{tabular}{|l|l|l|l|l|l|l|l|l|l|l|l|l|l|}
\hline Phase 1 & 133.4 & 176.2 & 204.2 & 189.9 & 0 & 0 & 245.5 & 184.4 & 183.0 & 141.2 & 152.3 & 126.6 \\
\hline Phase 2 & & & & & 251.1 & 212.0 & 202.8 & 145.9 & 157.3 & 74.8 & 80.3 & 83.0 \\
\hline
\end{tabular}

Also listed in each table are the monthly energy use values measured during the first phase of this investigation, January through August 2001. Please note that the energy housing unit data prior to August 2001 is suspect due to duct and HVAC system problems later corrected. The entire data set, including, temperature, relative humidity, solar radiation, and power use is listed on the FSEC web site www.infomonitors.com.

The total energy used for water heating and central cooling over the period of August 1 through August 15 was $363.5 \mathrm{kWh}$ for the energy home and $596 \mathrm{kWh}$ for the standard home. This represents a $40 \%$ reduction in energy use between the two homes.

The total energy used over the period of August 1 through August 15 for water heating was $27.13 \mathrm{kWh}$ for the energy house and $85.18 \mathrm{kWh}$ for the standard home. This represents a $68 \%$ reduction in energy use with the solar water heating system and compares well with the June and July reductions of $63 \%$ and $60 \%$, respectively. Consistent findings indicate that the tank and piping insulation has reduced the standby tank losses and improved the solar water system efficiency.

In the energy housing unit, three of the 100 watt incandescent lamps that were on the evening four-hour timed duration were exchanged for 25 watt compact fluorescent lamps on June 4th. This change did appear to have a small effect on the cooling load in the energy housing unit. The relative cooling energy used by each of the housing units from June, 2002 through August 2002 showed a small change. The percentage reduction in cooling energy used by the energy housing unit increased from about $30 \%$ to $38 \%$. However, it is difficult to isolate the effects of the improvements in the solar water heating system insulation and the effects of the compact fluorescent bulbs. In any event, these effects appear to be much smaller than that produced by the hot water system changes.

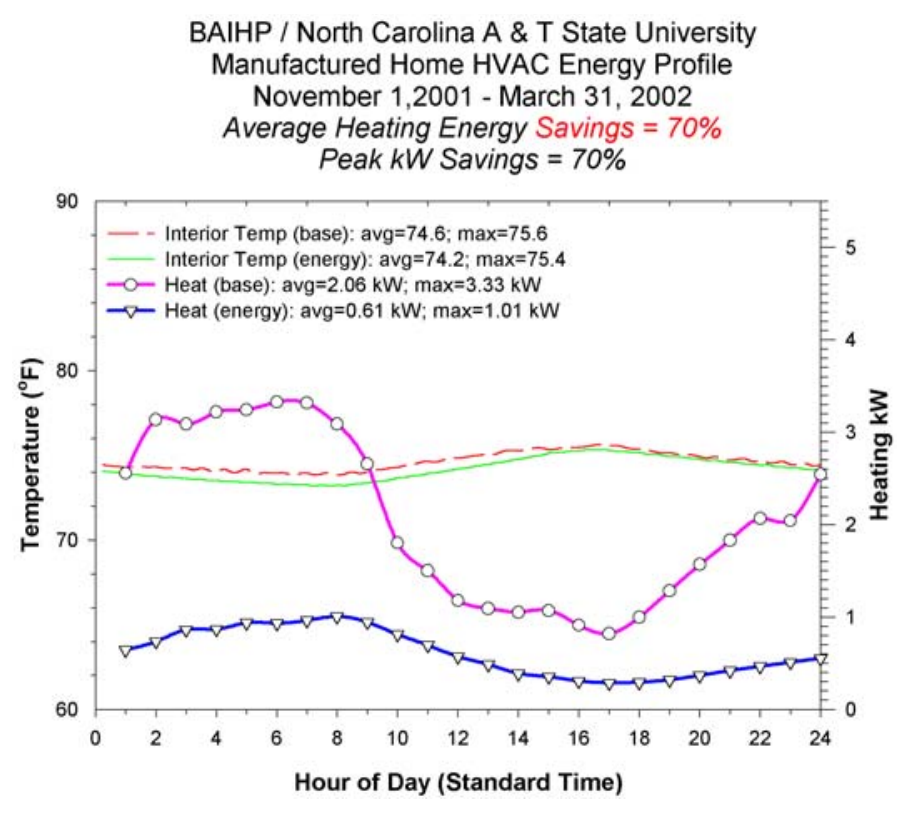

Figure 76 Heating season consumption and savings for side by side study of Energy Star Manufactured Housing. 
Year 3 Side-by-Side Monitoring Results:

Heating system savings (2001 to 2002) were a remarkable 70\% during Phase 1. Cooling energy season savings were $36 \%$, less than heating but still very substantial. The combined heating, cooling, and water heating savings were $52 \%$ for a 9-month period. (Figure 76)

In addition to the energy monitoring effort, NCA\&TSU researchers investigated the feasibility of replacing the conventional framing/envelope used in manufactured/industrial housing with alternative systems. Included in this evaluation, was an analysis of the energy impact of using aerated autoclaved concrete (AAC) flooring systems and structural insulated panels (SIP) to supplant traditional wall and roofing systems. The economic viability of using AAC blocks for structural skirting/foundation around the model units also was evaluated.

Analysis' results determined:

The best manufactured home energy performance can be achieved using the SIP wall and roof systems with the AAC plank. This performance can be further enhanced with an R-8 unvented crawl space. Though a manufactured home performs best with these alternative systems, the cost to include them may not make economic sense.

- AAC planks can be designed to replace both the steel frame and flooring systems for HUD code manufactured housing units and modular units. These planks also can be modified to incorporate built-in insulated ducts.

- $\quad$ AAC planks are pre-manufactured and require less assembly labor than a typical stick framed unit, but including the plank flooring would increase framing costs by $28 \%$. The heavier weight of an AAC system might exacerbate high framing costs. Similarly, comparative analysis results found that replacing a conventional framing system with a SIP system would increase framing costs by $66 \%$.

- At the 2001-02 prices for energy and wood products, neither the AAC plank system nor the SIP systems are as economically effective as improvements in the current conventional HVAC systems, steel and wood framing, sheathing systems, and air barriers with respect to improving energy performance.

- The use of AAC planks has the potential to be economically viable in the modular housing market, especially if used with sealed crawl space foundation systems, where their improved resistance to moisture degradation would be very important.

- SIP wall and roof systems also could prove to be economically viable if the price of wood energy increases, and the SIP manufacturing costs decrease through large volume purchases.

- The proposed AAC planking system presents a system that is significantly less affected by water and moisture degradation and may be effective in reducing manufactured housing units' susceptibility to flood damage. These systems also are not susceptible to termite attack.

- The savings from reduced transportation damage from greater durability and increased floor system stiffness were not addressed in this investigation. It wouldn't take many days of damage repair (at about $\$ 300 /$ person-day for personnel costs related to transportation) to vastly improve the economics of these alternative systems. 


\section{Portable Classrooms}

Portland, OR; Boise, ID; Marysville, WA

\section{Project Overview}

This was primarily a WSU (with subcontractors Oregon and Idaho) and Pacific Northwest National Lab (PNNL) task. Other partners included FSEC, UCFIE, the State Energy Offices of Oregon and Idaho, school districts in Portland, Oregon, in Boise, Idaho and Marysville, Washington, regional utilities, manufacturers, and other stakeholders in the Pacific Northwest.

The objective of this task is to promote the adoption of energy efficient portable classrooms in the Pacific Northwest that provide an enhanced learning environment, high indoor air quality, and both substantial and cost-effective energy savings. BAIHP staff focus on four main goals: (1) offering technical assistance to portable classroom manufacturers, school districts, and related organizations, (2) field assessment, monitoring, and analysis of innovative building technologies and energy saving features to determine their value, (3) facilitation of collaborative agreements among regional utilities, northwestern portable classroom manufacturers and materials and equipment suppliers, as well as school districts, and state education departments and their affiliates, and (4) conducting and creating educational opportunities to advance the widespread adoption of energy efficient portable classrooms in school districts nationwide.

The experiences working on the energy efficient portable were instructive, particularly in the identification of flaws in portable classroom design. The difficulties that BAIHP staff encountered demonstrate the importance of well-defined commissioning protocols, documentation, and coordination among all personnel that service and install HVAC equipment.

\section{Findings:}

- Portable classrooms in the Pacific Northwest are occupied about 1225 hours per year, or about $14 \%$ of the total hours in a year.

- The average number of occupants in the standard $28^{\prime}$ x $32^{\prime}$ portable classroom provide an internal heat of about $480 \mathrm{kWh} /$ year, or $8 \%$ to $10 \%$ of space heating requirements.

- Most of the heat loss in portable classrooms manufactured after 1990 occurs by air leaking through the T-Bar dropped ceilings, because they have no sealed air/vapor barrier. This newly created phenomenon occurred with the incorporation of the less expensive dropped T-Bar ceiling in place of the more expensive sheet rock used in older portables. Air leakage also is increased because of unsealed marriage lines now used as a low cost method of meeting the state attic ventilation requirements.

- Since all portables tested in the project used a simple seven-day programmable thermostat, the HVAC systems operate during vacations and holidays.

- Energy codes in Washington, Oregon, and Idaho are high enough to make beyondcode envelope measures non cost-effective.

- Older portable classrooms under removal consideration could be retrofitted with new energy efficiency measures at much less cost than purchasing a new portable classroom. Installing low-E, vinyl framed windows, insulated doors, T-8 light fixtures, and caulking and sealing air leaks can all be cost-effective when refurbishing older portable classrooms. HVAC system replacement in older portable classrooms will be the biggest single cost item, ranging from $\$ 4500$ to $\$ 6500$. 
- $\mathrm{CO}_{2}$ sensors appear to be unreliable as a control strategy. Those installed by field crews and monitored by dataloggers in this study did not match the readings shown by the $\mathrm{CO}_{2}$ sensors which controlled the ventilation systems.

Based on data analysis from years one through four, the following measures were recommended.

\section{Recommendations:}

- Install 365 day programmable thermostats in all existing portables and specify these thermostats for new construction.

- In portable classrooms constructed with T-Bar dropped ceilings, install an air/vapor barrier above the T-Bar system on the warm side of the insulation. Completely seal all edges and overlaps.

- If roof rafter insulation is used, seal the marriage line at the roof rafter joint with approved sealant such as silicon caulk or foam. Make sure there is adequate ventilation between the insulation and the roof.

- Conduct an audit of older portables scheduled for disposal to determine if retrofitting would be more cost effective than purchasing a new unit.

- Install occupancy sensors to control the ventilation system.

- Specify that new portables contain windows on opposing walls.

- Specify that new portable units contain exhaust fans on the opposite side of the classroom from the fresh air supply.

$\underline{\text { School Partnerships }}$

Washington Schools - Pinewood Elementary

An $895 \mathrm{ft}^{2}$ portable classroom (P5) was sited at the Pinewood Elementary School in Marysville, Washington in August 2000. This unit exceeded current Washington State Energy Code standards with upgraded insulation in the floor, roof and walls, low$\mathrm{E}$ windows, and a sensor-driven ventilation system that detects volatile organic compounds (VOCs). A second portable, built in 1985, and also located at Pinewood Elementary (P2), served as the control unit. (Figure 77)

Energy use comparisons of the two

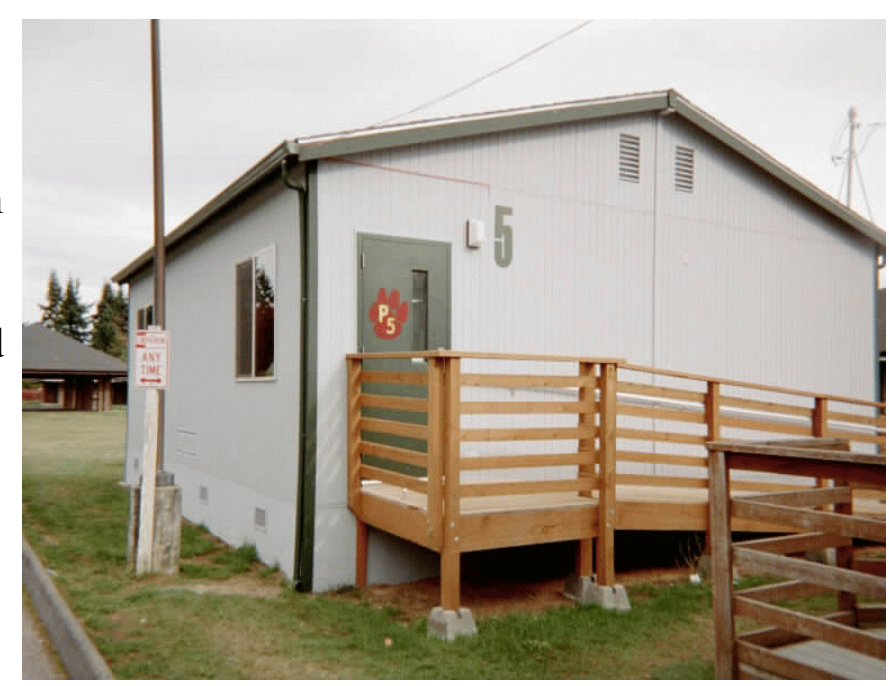

Figure 7764 Energy efficient portable classroom at Pinewood Elementary School in Marysville, Washington classrooms show that the energy efficient portable used considerably more energy than the control portable. This was attributable to several factors:

- Incorrect wiring of the exhaust fan, causing it to run continually. The fan was rewired in 2000 during the summer break. Once corrected, energy use in the portable declined.

- Incorrect programmable thermostat settings which were not programmed to turn the heating and cooling system off during holidays and vacations. Though energy 
use was reduced when the portable was unoccupied, use was still excessive (Figure 78).

- Higher air leakage in the energy efficient portable than the control portable. Blower door testing found $19 \mathrm{ACH}$ at $50 \mathrm{~Pa}$ in the energy efficient classroom compared to nine $\mathrm{ACH}$ at $50 \mathrm{~Pa}$ in the control classroom. Follow-up blower door, smoke stick, and APT pressure tests indicated that the predominant leakage path tracked through the T-bar ceiling and into the vented attic due to an ineffective air barrier in the energy efficient portable. The control portable contains taped ceiling drywall.

- No initial HVAC commissioning by the HVAC supplier or the school district.

- Significant HVAC system alterations (including rewiring, ventilation system VOC sensor replacement with a $\mathrm{CO}_{2}$ sensor, and modifications to other aspects of the HVAC control system) during 2001 by maintenance

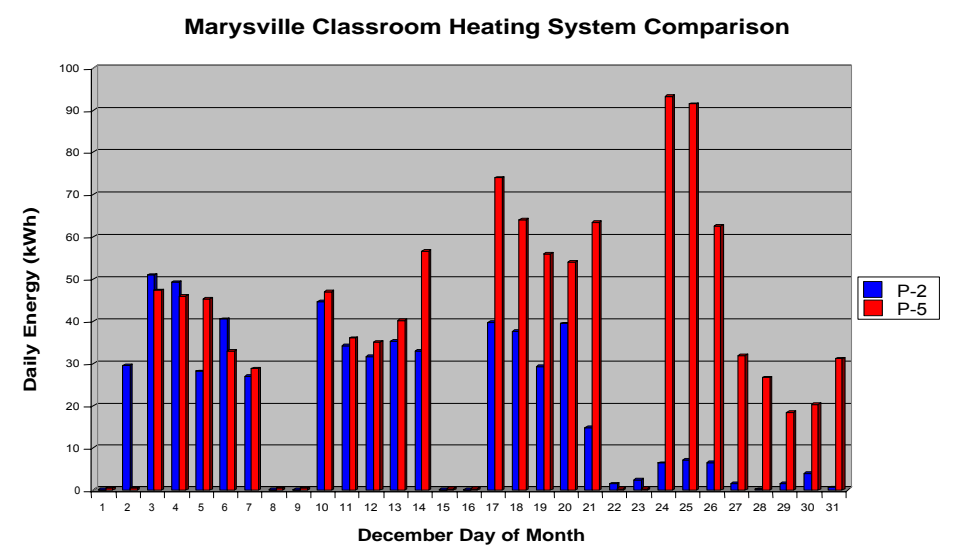

Figure 78 Graph comparing heating system use of the Pinewood control portable (P2-Blue) with the energy efficient portable (P5Red). Note the energy efficient portable's high energy use during the Christmas holidays due to incorrectly configured heating system controls.

staff and the HVAC supplier, unbeknownst to BAIHP staff. Calibration testing done by scientists at the Florida Solar Energy Center on the $\mathrm{CO}_{2}$ sensors showed significant drift in output results. This made data collected virtually unusable.

- The use of plug-in electric heaters during the winter of 2001 by the resident teacher because of room comfort problems. This led to significant room temperature variations and monitoring data showed high plug-load energy use.

- Poor fresh air flow design with the fresh air intake and exhaust fan positioned so they create a "short circuit" of fresh air, bypassing the students and teacher.

BAIHP staff proposed the following recommendations to Pinewood Elementary:

- Well-defined commissioning protocols, documentation, and coordination among all personnel that service and install the HVAC equipment. This is a critical component of efficient and healthy classroom operation and should include outside airflow rate measurements to assess adequate ventilation and control testing to insure correct system operation.

- Design changes to the portable classroom manufacturer, including the use of a structural insulated panel system (SIPS), tighter ceiling barrier and sheetrock ceilings, elimination of the vented attic, and relocation of the exhaust fan to the wall opposite the supply air vent.

- Removal of current HVAC controls and replacement with both an occupancy sensor-driven control for the ventilation system and a heating system programmable thermostat. Staff also proposed a classroom on/off switch to simplify the system turnoff during unoccupied summer and school vacations. 
- Location of exhaust fans in future portables on the wall opposite the supply air vent.

- Window installation on opposing sides of the classroom to increase daylight penetration and to assist in passive cross-ventilation.

Based on the above recommendations, WSU researchers worked with Marysville school facility manager and customer representatives from Snohomish Public Utility District to assist them in setting new construction specifications for 13 portable classrooms they will procure during the next reporting period. Marysville School District will specify a completely sealed ceiling barrier, a new model heating/ventilation system, a 365 day programmable thermostat, window placement on opposite sides of the classroom, and exhaust fan placement on an opposite wall from the fresh air supply.

\section{Washington Schools - North Thurston School District} BAIHP staff also worked with the North Thurston School District to troubleshoot a portable classroom in Lacey, Washington. (Figure 79) The classroom was experiencing high energy use and poor indoor air quality. BAIHP staff tested the classroom, made recommendations including opening the supply dampers, installing a wall side vent to better ventilate the classroom and discussed the specification development process with district staff. The North Thurston School District now is including most of the measures listed in the new procurement guidelines for their future portable classroom purchases. The school district will investigate the feasibility of installing an air/vapor above the T-bar dropped ceiling and will record costs for making these improvements. Idaho Schools - Boise School District Retrofit BAIHP staff located a portable classroom at the West Boise Junior High School in the Boise Idaho School District, occupied by a teacher who was interested in having the classroom monitored and retrofitted. The teacher also is an Idaho State legislator active in education issues, which staff members believe will increase the chances of implementing the final recommendations. (Figure 80)

BAIHP staff performed a baseline audit, and installed

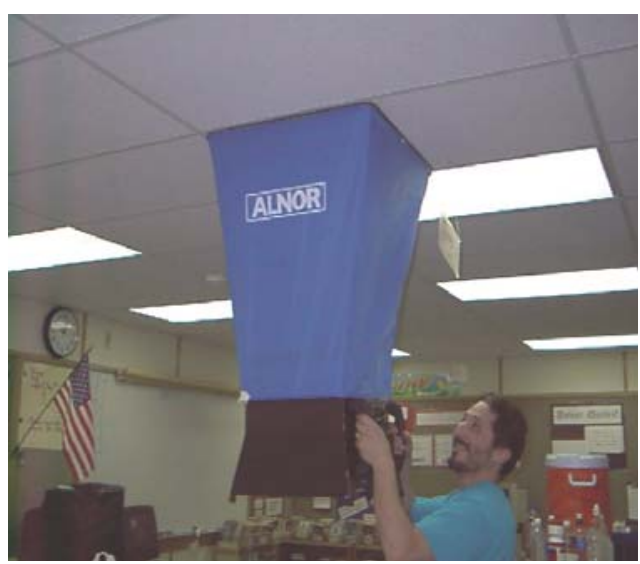

Figure 79 Ventilation system testing at North Thurston School District.

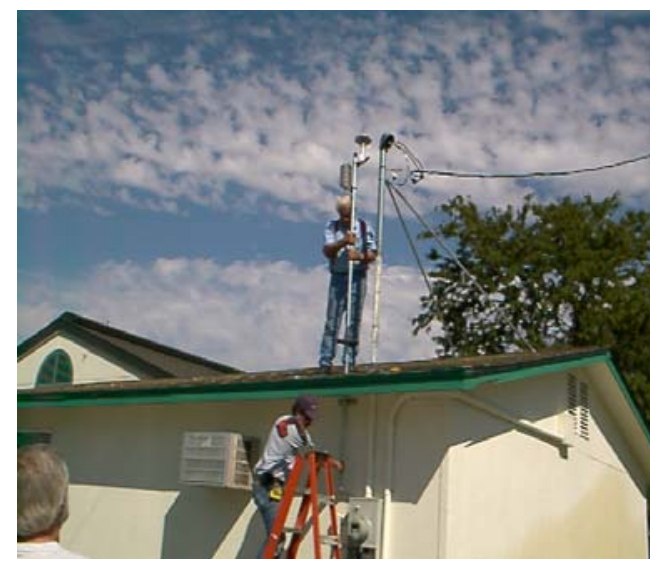

Figure 80 Weather monitoring system installation in the Boise portable classroom. monitoring equipment to track the classroom's energy use during 2000. In 2001, the classroom was retrofitted with an efficient HVAC system (controlled by $\mathrm{CO}_{2}$ sensors), lighting, and envelope measures. The classroom was then reaudited, and monitored for the remainder of the year.

BAIHP staff worked with Pacific Northwest National Laboratories (PNNL) on the pre- and postretrofit audits, and installation of the monitoring equipment. In their capacity of providing energy management services to the school district, the local utility Avista Corporation, collected lighting and occupancy data. 
Monitoring data indicates a 58\% reduction in energy usage post-retrofit. Blower door tests indicate a reduction in air leakage from nine $\mathrm{ACH}$ at $50 \mathrm{~Pa}$ to five $\mathrm{ACH}$ at $50 \mathrm{~Pa}$. Data also revealed that heating use actually increased on weekends and holidays because of lack of internal heat gain and because the HVAC control systems are not programmed to shut off on weekends and holidays. The total retrofit cost was $\$ 9,892$.

Monitored data suggests that the $\mathrm{CO}_{2}$ sensor that controls the HVAC system is not correctly configured. The system does seem to react to an increase in $\mathrm{CO}_{2}$ levels early in the day, but does not remain on; $\mathrm{CO}_{2}$ levels only begin to significantly dissipate after one o'clock PM. BAIHP researchers have noted the difficulty of correctly configuring these sensors in other monitored classrooms.

\section{Oregon Schools}

Oregon BAIHP staff worked with the Portland Public School District to procure two energy efficient classrooms. These were constructed to BAIHP staff specifications and included increased insulation, high efficiency windows, transom windows for increased daylighting, a high efficiency heat pump, and efficient lighting. Staff videotaped the construction of one classroom.

Monitoring equipment was installed by PNNL staff. Estimates using the software Energy-10 indicated a total energy consumption of $9200 \mathrm{kWh}$, or $\$ 583$ per year at Portland energy rates. Measured results showed the Oregon portable used about $6600 \mathrm{kWh}$ for the monitored period.

Incremental costs for the energy efficiency measures were $\$ 6,705$ over Oregon commercial code, including approximately $\$ 2,500$ for the HVAC system. This suggests a simple payback of 10 to12 years.

Initial blower door tests found air leakage rates of $11.3 \mathrm{ACH}$ at $50 \mathrm{~Pa}$. BAIHP staff also identified significant leakage through the T-bar dropped ceiling and up through the ridge vents. Other monitoring results indicated that the same HVAC control problems exist with the Oregon classroom as with the others studied in this project.

The Energy Efficient model outperformed code level models in the Portland area. The older the classroom, the more energy consumed. Even when compared with new code level models from the same year, the Energy Efficient model used 35\% less energy. Conventional code level classrooms do not include energy efficient measures which greatly increases the unit's operating costs. Classrooms built more than 10 years ago, use twice as much energy as the efficient model. Those older than 20 years consume more than three times the amount of energy. From this study, researches determined that high performance classrooms can save anywhere from $\$ 200$ to $\$ 1000$ dollars a year in energy costs compared to older, less efficient portables.

A survey sent to teachers and maintenance staff indicates a high degree of satisfaction with the efficient portables; the teachers were most impressed with the improved indoor air quality and increased light levels due to the daylighting windows.

\section{Historical Data Collection}


In Idaho, Oregon, and Washington, BAIHP staff worked with local utilities and school districts to obtain historic energy use data on portable classrooms. This data will be used to compare energy usage from the energy efficient portables monitored in this study.

In Idaho, BAIHP staff worked with Avista Corporation's energy manager to collect historic data on 14 portable classrooms in the Boise School District. The classrooms each were equipped with discrete energy meters; as a result, BAIHP staff was able to obtain energy usage data for the past three to four years. A procedure was developed to collect information on portables at each school in cooperation with the physical facilities manager and each school lead.

\section{Duct Testing Data from Manufactured Housing Factory Visits}

Paper: $\quad$ McIlvaine, Janet, David Beal, Neil Moyer, Dave Chasar, Subrato Chandra. Achieving Airtight Ducts in Manufactured Housing. Report No. FSEC-CR-1323-03.

Over the past 10 years, researchers at FSEC have worked with the Manufactured Housing industry under the auspices of the U.S. Department of Energy (DOE) funded Energy Efficient Industrialized Housing Program and the Building America (BA) Program (www.buildingamerica.gov). FSEC serves as the prime contractor for DOE's fifth Building America Team: the Building America Industrialized Housing Partnership (BAIHP) which can be found online at: www.baihp.org.

Data and findings presented here were gathered between 1996 and 2003 during 39 factory visits at 24 factories of six HUD Code home manufacturers interested in improving the energy efficiency their homes. Factory observations typically showed that building a tighter duct system was the most cost effective way to improve the product's energy efficiency.

BAIHP and others recommend keeping duct system leakage to the outside (CFM25 out) equal to or less than $3 \%$ of the conditioned floor area, termed $\mathrm{Qn}_{\text {out }}$. However, most homes seen in a factory setting cannot be sealed well enough to perform a CFM25 $5_{\text {out }}$ test. Results of many field tests suggest that CFM25 out will be roughly $50 \%$ of total leakage (CFM25 total). Thus, to achieve a Qnout of less than 3\%, manufacturers should strive for a CFM $25_{\text {total }}$ of less than $6 \%$ of the conditioned area $\left(\mathrm{Qn}_{\text {total }}\right)$.

Researchers measured total duct leakage and/or duct leakage to the outside in 101 houses representing 190 floors (single wide equals one floor, double wide equals two floors, etc.). Ducts systems observed in these tests were installed either in the attic (ceiling systems) or in the belly (floor systems). Researchers tested 132 floors with mastic sealed duct systems and 58 floors with taped duct systems.

Of the 190 floors tested by BAIHP, the results break down thus:

For mastic sealed systems $(n=132)$ :

- Average $\mathrm{Qn}_{\text {total }}=5.1 \%(\mathrm{n}=124) ; 85$ systems $(68 \%)$ achieved the $\mathrm{Qn}_{\text {total }} \leq 6 \%$ target.

- Average $\mathrm{Qn}_{\text {out }}=2.4 \%(\mathrm{n}=86) ; 73$ systems $(85 \%)$ reached the $\mathrm{Qn}_{\text {out }} \leq 3 \%$ goal.

For taped systems $(n=58)$

- Average $\mathrm{Qn}_{\text {total }}=8.2 \%(\mathrm{n}=56) ; 19$ systems $(34 \%)$ reached the $\mathrm{Qn}_{\text {total }} \leq 6 \%$ target.

- Average $\mathrm{Qn}_{\text {out }}=5.7 \%(\mathrm{n}=30)$, more than twice as leaky as the mastic average; 5 systems $(17 \%)$ reached the $\mathrm{Qn}_{\text {out }} \leq 3 \%$ goal. 
The results show that, while it is possible to achieve the BAIHP Qn goals by using tape to seal duct work, it is far easier to meet the goal using mastic. What isn't illustrated by the results is the longevity of a mastic sealed system. The adhesive in tape can't stand up to the surface temperature differences and changes or the material movement at the joints and often fails. Mastic provides a much more durable seal.

Typical factory visits consist of meeting with key personnel at the factory, factory observations, and air tightness testing of duct systems and house shells. A comprehensive trip report is generated reporting observations and test results, and pointing out opportunities for improvement. This is shared with factory personnel, both corporate and locally. Often, a factory is revisited to verify results or assist in the implementation of the recommendations.

The most commonly encountered challenges observed in the factories include:

- Leaky supply and return plenums

- Misalignment of components.

- Free-hand cutting of holes in duct board and sheet metal.

- Insufficient connection area at joints.

- Mastic applied to dirty (sawdust) surfaces.

- Insufficient mastic coverage.

- Mastic applied to some joints and not others.

- Loose strapping on flex duct connections.

- Incomplete tabbing of fittings.

- Improperly applied tape

Duct system recommendations discussed in this report include:

- Set duct tightness target Qn equal to or less than 6\% total and 3\% to outside.

- Achieve duct tightness by properly applying tapes and sealing joints with mastic

- Accurately cut holes for duct connections

- Fully bend all tabs on collar and boot connections

- Trim and tighten zip ties with a strapping tool

- Provide return air pathways from bedrooms to main living areas

Summary of BAIHP Approach to Achieving Tight Ducts in Manufactured Housing:

- Set goal with factory management of achieving Qnout $<=3 \%$ using Qntotal $<=6 \%$ as a surrogate measurement while houses are in production.

- Evaluate current practice by testing a random sample of units

- Report Qntotal and Qnout findings; make recommendations for reaching goals

- Assist with implementation and problem solving as needed

- Evaluate results and make further recommendations until goal is met

- Assist with development of quality control procedures to ensure continued success

Finally, duct tightness goals can be achieved with minimal added cost. Reported costs range from $\$ 4$ to $\$ 8$. These costs include in-plant quality control procedures critical to meeting duct tightness goals.

Achieving duct tightness goals provides benefits to multiple stakeholders. Improving duct tightness diminishes uncontrolled air (and moisture) flow, including infiltration of outside air, 
loss of conditioned air from supply ducts, and introduction of outside air into the mechanical system. Uncontrolled air flow is an invisible and damaging force that can affect the durability of houses, efficiency and life of mechanical equipment, and sometimes occupant health. With improved duct tightness, manufacturers enjoy reduced service claims and higher customer satisfaction, while homeowners pay lower utility bills, breathe cleaner air, and have reduced home maintenance.

\section{Crawl Space Moisture Research for HUD Code Homes}

Research led by David Beal

Paper: Beal, D. and Chasar, D. (2006). "Measured Crawlspace Conditions in a HUD-code Home", Fifteenth Symposium on Improving Building Systems in Hot and Humid Climates, July 24-26, 2006 Orlando, FL

Article: Manufactured Home Merchandiser. "Measured Conditions in a MH Crawl Space" June 2005.

When BAIHP started to respond to HUD code manufactures' floor damage complaints, the diagnosis often pointed to air distribution system leaks which created negative pressure in the house pulling hot, humid, outside air into air conditioned spaces and unconditioned interstitial spaces such as wall and floor cavities.

In some cases this led to condensation and rot. From this research and the resultant recommendations, HUD Code Home manufactures have learned to prevent such

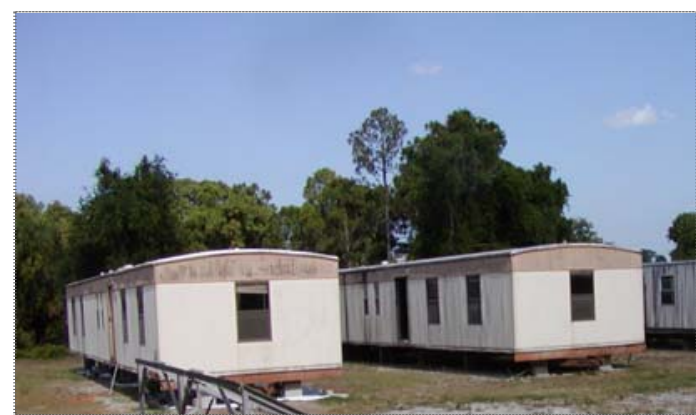

Figure 81 The test units in place. Note white ground cover under unit on left, exposed dirt under unit on right. occurrences and have dramatically improved distribution system air tightness practically eliminating such problems For background on this matter, see these sections of this report:

- Building Science and Moisture Problems in Manufactured Housing

- BAIHP Field Visits to Moisture Problem Homes

- Manufacturers Participating in Building Science Research

- Duct Testing Data from Manufactured Housing Factory Visits

Successfully sealing HUD code home crawlspaces may be the last piece of the solution for preventing floor failures plaguing homes in hot, humid climates. Merely curing the duct leakage has proven not to enough to keep all floors intact. Proper techniques to seal these crawlspaces need to be developed. The research reported here and BAIHP's research plan for 2005 addresses this need.

\section{Field Experience}

BAIHP researchers have observed that some houses with rotting floors have acceptably tight ductwork, suggesting that factors other than distribution system dynamics are influencing moisture flow. The rot manifests primarily under vinyl flooring which acts a vapor barrier between the conditioned space and floor substrate, which suggests an external source of 
moisture. BAIHP researchers further observed that the crawlspaces in these homes are damp and musty, often showing signs of standing or running water in the crawlspace.

FSEC concluded that the only uncontrolled moisture source is the humid air in the crawl space of the home driven by vapor pressure toward the cool conditioned space. Several manufacturers address this potential moisture source by requiring a vapor retarder to be placed over the dirt in the crawl space prior to the installation of the house. However, a further exacerbation of the problem stems from the current trend toward extending the siding of the house all the way down to the grade level, in place of the traditional vented skirting. This tends to reduce ventilation, the primary mechanism for dissipating moisture leaching from the ground into the crawls

Other researchers (www.crawlspaces.org) have reported on sealed crawl spaces, and recommended them as a solution to the crawl space moisture problem. The findings from those studies indicate that merely covering the ground without truly sealing the crawl space is not sufficient to solve the problem of high crawl space humidity. The joints and penetrations in the crawl space must be seal to prevent air infiltration as well.

\section{Summer 2004 Research}

To determine if a sealed crawl space solution could be achieved in HUD Code Homes, research needed to be done to address the unique building techniques in that industry, namely the use of vinyl skirting to enclose the crawl space. To that end, in 2004, BAIHP conducted research utilizing two single-wide manufactured houses at FSEC's auxiliary test site in Cocoa, FL..

The crawl space research plan involved two unconditioned, singlewide manufactured homes sited side-by-side, one home with a ground cover under it, the other without a ground cover (only exposed dirt.). A third identical home was available; however, it was not called into use in this experiment. In each of the two experiment houses, three different skirting (crawl space enclosure) options were evaluated: open or no skirting, perforated skirting, and solid skirting. The solid skirting mimics the effect achieved by extending siding down to the ground instead of stopping it at the band joist, described above. Additional evaluations were planned, however, the Florida's four hurricanes dramatically curtailed the testing schedule.

The homes (all three) were instrumented with temperature and humidity sensors, two in the crawl space and one in the interior. The site has a weather station, recording ambient conditions. The temperature and relative humidity was used to calculate the dewpoint at the measurement location.

\section{Data Analysis, Interpretation, and Conclusions}

The presented data is the ambient dewpoint, the dewpoint of the two crawl spaces. The ambient readings are subtracted from the average of the two crawl space readings to show the temperature difference or )T. The final column of the Table 59 ("Difference") is the difference between the ground cover and the non-ground cover crawl space, showing how much dryer a crawl space with a ground cover is; negative numbers indicating that the ground covered crawl space was dryer. 
Table 59 Dewpoint Temperatures

\begin{tabular}{|l|c|c|c|c|c|c|}
\hline & $\begin{array}{c}\text { Ambient } \\
\text { Dewpoint }\end{array}$ & $\begin{array}{c}\text { Dewpoint with } \\
\text { Ground Cover }\end{array}$ & $\begin{array}{c}\text { )T } \\
\mathbf{T}_{\mathbf{a m b}^{-} \mathbf{T}_{\mathbf{c w l}}}\end{array}$ & $\begin{array}{c}\text { Dewpoint with } \\
\text { No Ground Cover }\end{array}$ & $\begin{array}{c}\text { )T } \\
\mathbf{T}_{\text {amb }}-\mathbf{T}_{\mathbf{c w l}}\end{array}$ & Difference \\
\hline $\begin{array}{l}\text { No Skirting } \\
06 / 09-07 / 08\end{array}$ & $73.3^{0} \mathrm{~F}$ & $73.3^{0} \mathrm{~F}$ & $0.0^{0} \mathrm{~F}$ & $73.3^{0} \mathrm{~F}$ & $0.0^{0} \mathrm{~F}$ & $0.0^{0} \mathrm{~F}$ \\
\hline $\begin{array}{l}\text { Perforated } \\
\text { Skirting } \\
07 / 18-07 / 30\end{array}$ & $73.5^{0} \mathrm{~F}$ & $73.7^{0} \mathrm{~F}$ & $0.2^{0} \mathrm{~F}$ & $75.4^{0} \mathrm{~F}$ & $1.9^{0} \mathrm{~F}$ & $-1.7^{0} \mathrm{~F}$ \\
\hline $\begin{array}{l}\text { Solid Skirting } \\
08 / 23-09 / 03\end{array}$ & $74.3^{0} \mathrm{~F}$ & $76.3^{0} \mathrm{~F}$ & $2.0^{0} \mathrm{~F}$ & $78.6^{0} \mathrm{~F}$ & $4.3^{0} \mathrm{~F}$ & $-2.3^{0} \mathrm{~F}$ \\
\hline
\end{tabular}

This data clearly illustrate a potential problem for manufactured houses, or any home on a crawl space. As can be seen, the average crawlspace dewpoint with skirting and no ground cover was over $75^{\circ} \mathrm{F}$. Both crawlspaces with solid skirting were above $76^{\circ} \mathrm{F}$. Any surface in the crawl space that is at or below the dewpoint will condense moisture. Surfaces that could be problematic are exposed floors, A/C ductwork, and plumbing. Also, note that these numbers are averages gathered over at least one week of measurements. The maximums are much higher in all cases, but of a short duration.

The research shows that if a ground cover and perforated skirting are used, the dewpoint in the crawl space will stay near the ambient dewpoint, on average. Often, this is sufficient to avoid problems in homes with crawl spaces. However, if overly cool conditions are maintained in the house (interior temperatures below the ambient dewpoint), problems can still occur.

Research (www.crawlspaces.org) into site built housing with block stem walls has shown that unvented crawlspaces with a ground cover are significantly dryer than vented crawlspaces if they start out as a dry crawlspace or provisions were made to dry them out after completion, such as a dehumidifier or supply air provided to the space. However, the BAIHP data from the "solid skirting and a ground cover" condition do not support this conclusion.

The conclusion is that the solid skirting did not create an adequate seal of the crawl space, allowing significant moisture into the crawlspace. Suspected entry paths for the moisture intrusion were along the joint behind the skirting starter strip, as well as under the molding used to hold the skirting in place at the ground.

HUD code homes (and older site built homes) placed on piers and skirted pose unique challenges to executing the sealed crawl spaces detail. To overcome the air infiltration points associated with skirting described above (at the top and bottom of the skirting) a continuous vapor barrier is needed from the band joist down to and covering the ground. This however would interfere with visual inspect for termite mud tunnels, possibly voiding the termite protection company's bond. The problem is overcome in crawlspaces with a block walls by stopping the vapor barrier a few inches below the band joist, to allow for inspection.

\section{Summer 2005 Crawlspace Research}

In the final year of the project, to further research into finding a successful way to seal the crawlspaces of HUD code housing, BAIHP installed a vapor retarder in our on-site, well instrumented, manufactured housing laboratory (MHLab). 
The experiment was designed to investigate ways to allow for insect inspection, as well as sealing around penetrations such as piers, anchors, plumbing, and $\mathrm{A} / \mathrm{C}$ duct work (to package units). The research also addressed ways to dry the crawlspace, both from ambient moisture and potential flood problems.

Air tightness testing of the "sealed" crawl space showed that although the crawl space is much tighter than that provided by solid skirting, it was still too leaky. The crawlspace was more tightly sealed in June 2005. A dehumidifier was installed in "Cleanspace" sealed crawlspace in MHLab with a runtime logger to reduce high RH levels, and a fan to blow $50 \mathrm{cfm}$ from main body into crawlspace.

Researchers conducted a series of MHLab crawlspace tests. A sealed crawlspace was conditioned using five different strategies.

- Dehumidifier set at $40 \%$ relative humidity

- Dehumidifier set at 50\% relative humidity

- Forced ventilation rates using house air - ASHRAE 62.2.

- Forced ventilation rates using house air - 50 CFM

- Forced ventilation rates using house air - 20CFM/1000ft2

This BAIHP research was been accepted by the trade journal "Manufactured Home Merchandiser" in an effort to get the information to the people in the manufactured home industry that can alter installation requirements

Recommendations for FEMA Ruggedized Manufactured Home for Temporary Housing Paper: Thomas-Rees, Stephanie, Chandra, S., Barkaszi, S., Chasar, D., and Colon, Carlos (2006). "Improved Specifications For Federally Procured Ruggedized Manufactured Homes For Disaster Relief in Hot/Humid Climates," Fifteenth Symposium on Improving Building Systems in Hot and Humid Climates, July 24-26, 2006 Orlando, FL.

In response to hurricane Katrina in September 2005, BAIHP researchers conducted a literature review and provided information to DOE and others on energy consumption of manufactured and site built homes in the region and desirable characteristics of FEMA manufactured homes. In response, DOE has provided additional funding to develop detailed specifications for FEMA manufactured homes that will offer superior performance. Researchers conducted a simulation comparison of FEMA single-wide houses with comparable Therma-Save (SIP) panel homes and furnished information to DOE, FAS and others.

Subsequently, BAIHP received supplemental funding to develop recommended specifications for federally procured ruggedized manufactured homes that the Federal Emergency Management Agency (FEMA) uses to provide short term housing solutions during the repair and rebuilding phase after a natural disaster.

Federally procured manufactured homes are currently constructed in accordance with the Housing and Urban Development's (HUD) manufactured housing standards and typically built to the minimum code requirements. These homes can consume more energy than their site built comparatives and use materials and mechanical systems that can potentially contribute to poor indoor quality and low durability. Two improved specifications are presented in this report to 
enhance energy efficiency, sustainability, and indoor air quality and provide back up power, without compromising human health, safety or comfort, in typical ruggedized temporary housing.

Starting with the specifications from the base case or typically procured ruggedized home, two specifications were developed, the EnergyStar (ES) and the Building America Structural Insulated Panel (BASIP) manufactured home. These were evaluated using the FSEC developed EnergyGauge ${ }^{\circledR}$ USA (Version 2.5.9) software which, predicts building energy consumption. The ES home saved $14 \%$ in energy costs over the base case, which amounts to savings of $\$ 25.9$ million during the first year of existence (\$4.5 million in energy savings and \$21.4 million in construction costs) when procuring 25,000 ruggedized manufactured homes for temporary use. The BASIP home, which has a roof integrated, $3.25 \mathrm{kWp}$ photovoltaic (pv) array, projects energy savings of $78 \%$ or $\$ 25.4$ million over the base case. The BASIP without the pv array would be about $38 \%$ more energy efficient than the base case (analysis based on units located in New Orleans, LA and utility rates of $\$ 0.13 / \mathrm{kWh}$ ). The annual equivalent life cycle costs for the base case and the two alternatives were calculated to be $\$ 5,413$ per year, $\$ 3,670$ per year and $\$ 3,649$ per year for the base, ES and BASIP respectively.

Analysis considered not only tangible benefits such as having back up power capability for essential loads during extended power outages but also intangible benefits like more daylit spaces and potential mating of two units. This report also generated areas for further investigation of innovative technologies and construction methods.

The improved specification presented by this work will allow for better quality control of construction and also include renewable energy strategies that encourage occupants to take ownership if the situation warrants. The inclusion of renewable energy would create a selfpowered strategy that would provide power for essential functions during power outages and interferences associated with neighborhood reconstruction following a natural disaster.

\section{Comboflair Integrated HVAC System}

Delima Associates

Austin, Texas, Palm Harbor Homes

The Comboflair HVAC unit is a combination domestic water heater and hydronic coil heating unit produced by Delima Associates. It needs only half the space of a stand alone gas furnace and water heater, and is more cost effective than electric heating and water heating. Designed specifically for the HUD-code home market, it is installed during production and eliminates the need for mechanical contractor during the set up process at the home site. Palm Harbor Homes has installed the Comboflair unit in several manufactured homes with Unico's small-duct highvelocity (SDHV) air distribution system.

During the final year of the project, FSEC researchers discussed testing requirements for the Comboflair system Delima and Unico and developed a non-disclosure agreement. They also tested a PHH home in Austin, TX and used a datalogger to collect interior living conditions throughout the home as well as detailed measurements of the Comboflair's thermal and electrical performance. Analysis of the data began. Researchers redesigned the water injection system to provide a less problematic delivery of interior water vapor. 


\section{B. Site Built Housing Research}

BAIHP continues to foster the research the implementation of the systems engineering approach with site builders which includes the incorporation of multiple concepts toward achieving the Building America program goals of saving $40 \%$ of total energy use while improving durability, indoor air quality, and comfort. Industry Partners in this area of BAIHP rise above "business as usual" production to strive toward this goal. BAIHP assists the builders, much as described in Section II, Technical Assistance, but goes on to instrument and collect relevant data from the house in an effort to validate the approach taken by the builder and add to our knowledge base of how to achieve the Building America goals.

BAIHP conducted research for site built housing which is reported in the following summaries:
- $\quad$ Building America Prototype, Cambridge Homes
- $\quad$ Sharpless Construction, Hoak Residence Energy and Moisture Studies
- Zero Energy Affordable Housing, ORNL and Loudon County Habitat for
- $\quad$ Apumanity
- $\quad$ Federation of American Scientists' Rasbach Provident Home
- $\quad$ Radiant Floor Heating Research
- $\quad$ Hurricane Water Intrusion Research
-

\section{Building America Prototype, Cambridge Homes \\ Orlando, Florida \\ Category B: 2 houses \\ Research led by BAIHP Researcher Eric Martin}

The partnership between BAIHP and production builder Cambridge Homes began late in 2001 . Cambridge Homes had recently signed on with the EPA Energy Star Homes Program as a 100\% Energy Star builder and expressed interest in increasing energy efficiency even further, as well as adding some "healthy home" features to their product. Also, Cambridge Homes expressed interest in BAIHP helping them design and build in a way that would prevent moisture related problems and call backs.

BAIHP began by conducting analysis on several typical home designs and presenting results and strategies in a number of meetings with the builder. BAIHP also arranged a special meeting with the American Lung Association of Central Florida to discuss achieving the ALA Health House designation on the showcase model. However, the builder decided not to pursue the health house designation at that time.

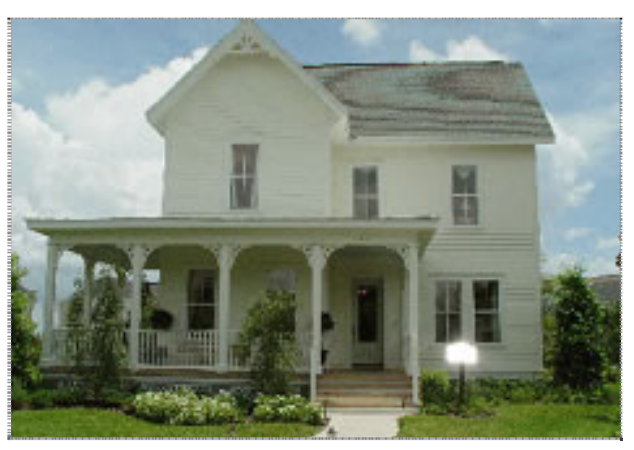

Figure 82 The Augusta, Cambridge Homes Building America Prototype.

To implement Building America strategies outlined by FSEC researchers, Cambridge Homes constructed a "prototype house" (Figure 82) to ensure that the strategies mate well with their 
current building practices (Table 60). A variety of home plans were reviewed to select an appropriate demonstration home, as well as a standard-practice counterpart. During construction, both homes were outfitted with dataloggers and associated monitoring equipment.

The homes were built in Baldwin Park, a new Orlando subdivision being developed on land that was once home to the Orlando Naval Training Center. The development will be $30 \%$ larger than New York's Central Park, totaling approximately 1100 acres. Four hundred acres have been set aside for parks and open space, while 700 acres will be used for the construction of 3,000 homes, one million square feet of office space, and 200,000 square feet of retail space. Cambridge Homes is one of ten builders constructing homes in the community and plans to build 700 homes in Baldwin Park over the next five years.

Table 60 Cambridge Homes Specifications

\begin{tabular}{|c|c|c|}
\hline Component & $\begin{array}{l}\text { Base Case } \\
\text { (Covington) }\end{array}$ & Prototype (Augusta) \\
\hline Conditioned Area & $2446 \mathrm{ft} 2$ & $2672 \mathrm{ft} 2$ \\
\hline \multicolumn{3}{|l|}{ Envelope } \\
\hline Above-Grade Wall Structure & $\begin{array}{l}\text { CMU first floor } \\
\text { 2X4 Frame second } \\
\text { floor }\end{array}$ & Same \\
\hline $\begin{array}{l}\text { Above-Grade Wall } \\
\text { Insulation }\end{array}$ & $\begin{array}{l}\text { R-3.5 rigid foam } \\
\text { R-13 Fiberglass Batt }\end{array}$ & $\begin{array}{l}\mathrm{R}-3.5 \text { rigid foam } \\
\mathrm{R}-13\end{array}$ \\
\hline $\begin{array}{l}\text { Above-Grade Wall } \\
\text { Sheathing }\end{array}$ & OSB & Same \\
\hline Attic & Vented r-30 batt & Unvented r-19 Icynene \\
\hline Roof & $\begin{array}{l}\text { Owens corning } \\
\text { shingle }\end{array}$ & $\begin{array}{l}\text { Elk architectural } \\
\text { shingle }\end{array}$ \\
\hline Windows & $\begin{array}{l}\text { Single pane, clear } \\
\text { Metal frame }\end{array}$ & $\begin{array}{l}\text { Double pane, low-e } \\
\text { Metal frame }\end{array}$ \\
\hline Infiltration (ACH50) & Not tested by FSEC & 3.0 \\
\hline \multicolumn{3}{|l|}{ Equipment } \\
\hline \# Of Systems & 2 & 1 \\
\hline Heating & $\begin{array}{l}\text { Heat pump HSPF = } \\
8.65\end{array}$ & Same \\
\hline Cooling & $\begin{array}{l}2.5 \text { ton, } 13 \text { SEER } \\
2 \text { ton, } 13 \text { SEER }\end{array}$ & 5 ton, 13 SEER \\
\hline Thermostat & $\begin{array}{l}\text { Programmable } \\
\text { Standard }\end{array}$ & Programmable \\
\hline Ventilation & None & Thermastor Ultra-Aire \\
\hline Water Heater & $\begin{array}{l}\text { 50gallon Electric EF } \\
0.88\end{array}$ & Same \\
\hline Lighting & $10 \%$ fluorescent & $100 \%$ fluorescent \\
\hline Appliances & Standard & Energy Star \\
\hline Hers Score & 87 & 87.6 \\
\hline
\end{tabular}

The demonstration home gave the builder firsthand experience with unfamiliar design elements, some of which have been incorporated into their standard practices. Such unfamiliar design 
elements included vapor permeable wall insulation, low-e windows, whole house dehumidifiers, unvented attics, and compact fluorescent lighting. FSEC researchers closely monitored the construction of the prototype and standard practice home, which was built to the Energy Star level. A duct test was performed in the prototype house during mechanical rough in to ensure leakage specs were met. Meetings also were held with the builder's HVAC contractor to discuss installation of the whole-house high efficiency dehumidification, filtration, and ventilation unit in the prototype model.

Upon completion of the home, duct testing was repeated to include inspection of the whole house dehumidification unit, and infrared camera analysis was conducted on the home. Data (Figures 83 and 84) collected from the two homes showed marked improvement in attic temperature (a primary cooling load) and indoor relative humidity control.

BAIHP performed training for Cambridge Homes' sales staff in March 2003. The training took place within the completed "prototype" model. Training focused on the advanced features of the Building America showcase model which Cambridge Homes began offering in April 2003. 


\section{Comparison of Attic Temperatures Between Models}

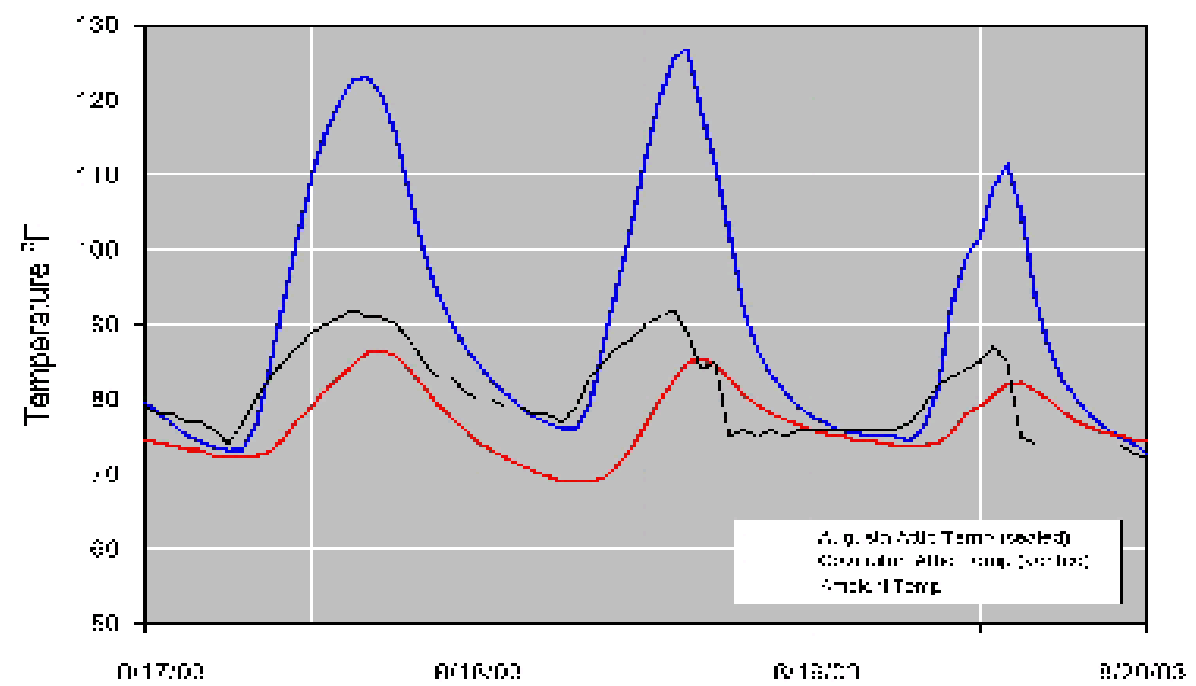

Figure 83 Comparison of attic temperatures between Cambridge Homes BA Prototype (Augusta) and Standard Cambridge Homes construction (Covington). Graph shows how sealed attic construction in Augusta results in lower attic temperatures than vented attic construction during cooling season in Orlando, FL.

\section{Comparison of First Floor RH Between Models}

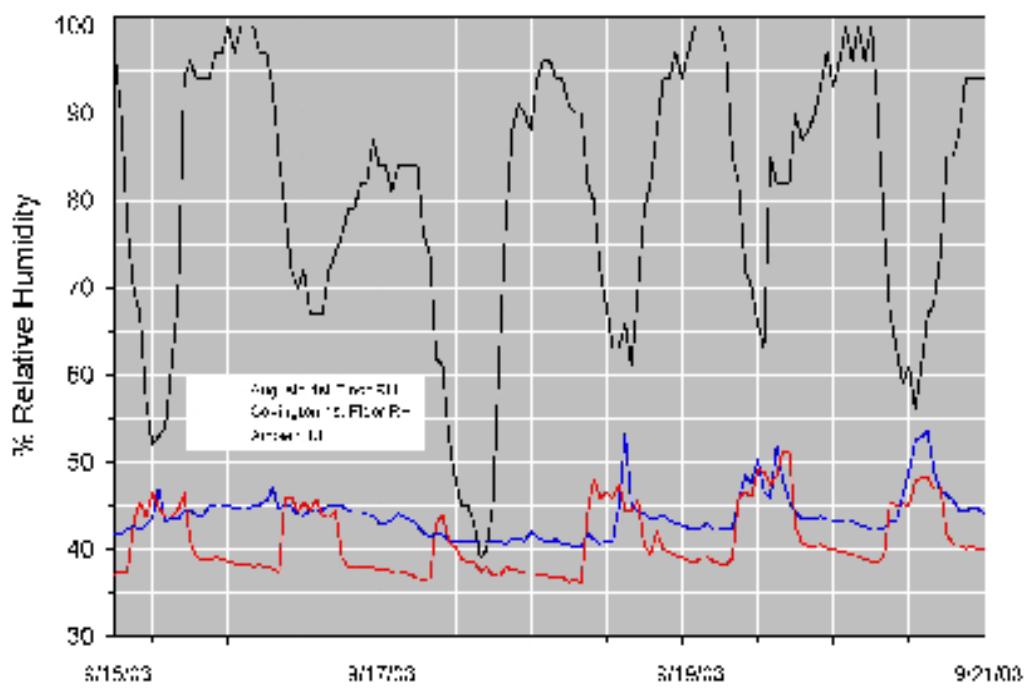

Figure 84 BA Prototype (Augusta) contains whole house dehumidification system. Plot shows daily cycling of the system resulting in a lower relative humidity in the prototype home than in the standard Cambridge Homes construction. 
Late in 2003, Cambridge Homes began construction of a second home similar to the "prototype" model, which was purchased by a customer impressed with its attributes. FSEC staff conducted training for builder and sales staff in December 2003 to review design methodologies and lessons learned from the prototype model. A second meeting was held in January 2004 inspect progress of the home. Upon moving into the home, Cambridge Homes reports that the new homeowner is extremely happy with the home.

To assist Cambridge Homes with reducing callbacks and moisture reduction problems, FSEC researchers have also conducted "total" and to "out" duct tests on six other Cambridge homes to determine why the total duct leakage numbers were high ( $>10 \%$ of fan flow) despite low to "out" duct leakage. "Out" is defined as outside the conditioned space, including buffer spaces like an attic or garage. Consistent leakage was found around the boot to register grill connections. FSEC worked with Cambridge Homes and their HVAC contractor, DEL-AIR, to specify air tight register grills.

In May 2004 additional instrumentation was installed in the prototype and base case homes to collect more detailed data on the different attic designs of the two instrumented homes (unvented vs. vented). Data collection continued until October 2004.

\section{Unvented Attic Study, Rey Homes}

\section{Orlando, Florida}

Technical Assistance by BAIHP Researchers Eric Martin and Neil Moyer

Rey Homes, a production builder in Orlando, in 2001 pledged to build a community of 200 homes that meet both Energy Star standards (HERS '99 score = 86) and the Florida Green Home Designation Standard. Rey's partnership with FSEC began in October 2001 when researchers analyzed Rey's standard home designs and construction and made recommendations for complying with these standards.

In the fourth budget period, Rey built 2 homes in their Villa Sol community for side by side comparison of unvented attic construction, a BAIHP recommended strategy. FSEC installed monitoring equipment in both homes, one with an unvented attic and one with a standard vented attic including a set of moisture pins in each house to monitor the moisture content of roof trusses in addition to the usual complement of temperature, humidity, and energy use meters. Instrumentation was complete early in the fifth budget period; however, data collection was not successful due to equipment and site complications. Monitoring equipment was removed during the sixth budget period and relocated to an active monitoring project. 


\section{Sharpless Construction, Hoak Residence Energy and Moisture Studies}

Longwood, Florida

Category A

Technical Assistance led by BAIHP Researchers Subrato Chandra and Dave Chasar

Reports: Case Study

This three-story, 4,250 square foot home was completed in February 2001 by Mr. David Hoak and Sharpless Construction in Longwood, Florida near Orlando. (Figure83) FSEC assisted the owner and builder by recommending a package of features that produced an exceptionally energy efficient design at a reasonable cost. Because the building envelope design and mechanical equipment selection work together as a system, the home can be cooled with a much smaller air conditioner than is needed by most homes of this size in this climate.

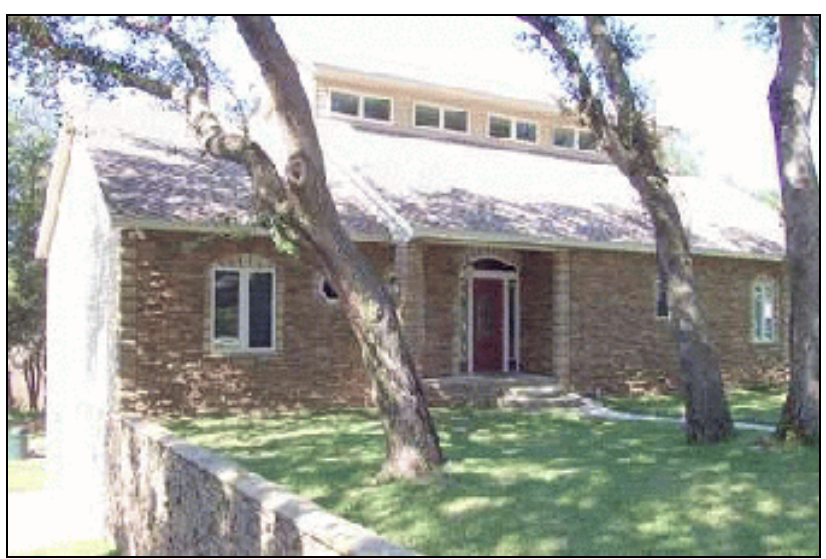

Figure 83 Hoak residence in Longwood, Florida.

Envelope Features:

\section{High Performance Windows}

Roughly $25 \%$ of the annual cooling load in a typical Central Florida home is introduced through the windows. Recent advances in window technology allow this load to be greatly reduced. The windows in this residence are particularly useful in Florida because they have a very low Solar Heat Gain Coefficient (SHGC) to reduce direct solar gains, and a relatively high Visible Transmittance (VT) for natural daylighting.

\section{Unvented Attic}

Most Florida homes have vented attics with batt or blown insulation applied just above the ceiling. This exposes the air conditioning ductwork to very high temperatures and magnifies duct leakage problems. Sealing the attic envelope and insulating at the roof deck, as shown in Figure 84, provided a semi-conditioned space for the ductwork. This reduced conductive heat gain and minimized the detrimental impact of duct leakage.

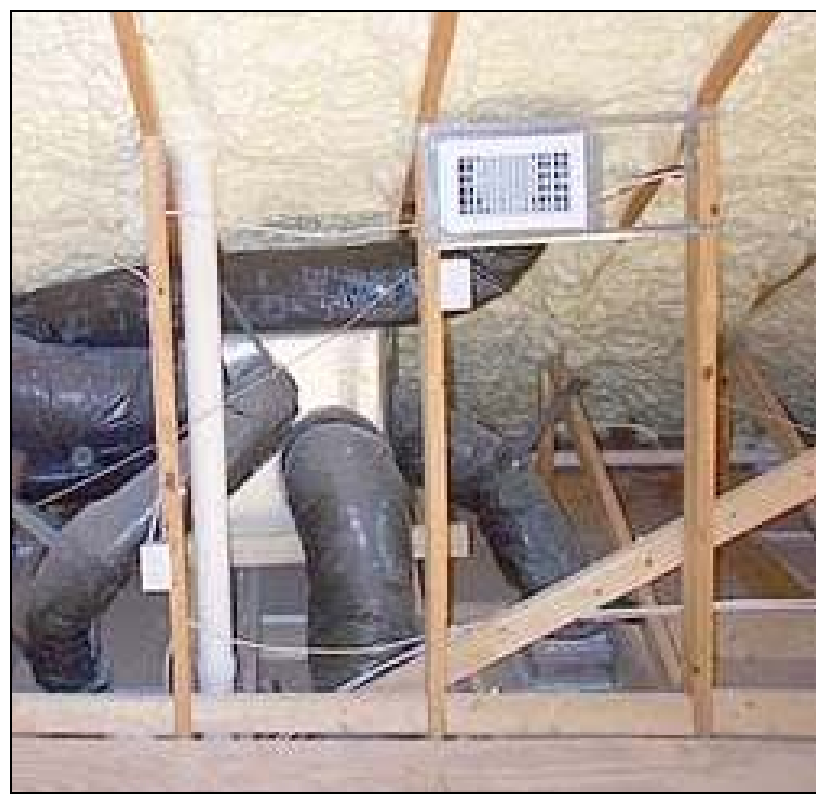

Figure 84 Semi-conditioned space for the ductwork.

\section{Expanding Foam Insulation}

A layer of expanding foam insulation (Figure 84) was applied to the underside of the roof deck to create an unvented, semi-conditioned attic (R-22). The same insulation was applied to all 
above-grade walls (R-11). While the insulation R-values were standard, the foam created a nearly airtight seal and greatly reduced outside air infiltration.

\section{Continuous Air Barrier}

Infiltration of Florida's hot and humid outside air can have a big impact on energy use, building durability, and occupant health. The continuous air barrier, placed toward the outside of the building envelope, reduces this infiltration. Indoor air quality concerns were addressed by installing an energy recovery ventilator to introduce outside air.

The air barrier consists of a tightly taped housewrap installed over the exterior sheathing on all above-grade frame walls, and extruded polyurethane foam boards glued to the interior of the below-grade block walls. Expanding foam insulation provided an extra measure of air tightness at all above-grade exterior surfaces including the roof deck. Special care was taken to seal wall details such as corners, floor interfaces, and the roof junction. Blower door performance tests verified the home's level of air tightness $(\mathrm{ACH} 50=2.0)$.

\section{Equipment Features:}

\section{2-Speed, Zoned Heat Pump}

The building envelope design features described above greatly reduced the required air conditioner size. Manual-J HVAC equipment-sizing calculations showed the need for only $2 \frac{1}{2}$ tons of heating and cooling capacity. In this case the owner opted for a two-speed compressor, which provides either $2 \frac{1}{2}$ or 5 tons of cooling or heating depending on the need.

The Hoak home air conditioning unit typically operated in the $2 \frac{1}{2}$-ton mode until the late afternoon when it switched to the 5-ton mode for a few brief periods. In this home, energy use stays low because the low compressor speed operates the majority of the time. But, when quick cool-down or excessive loads require more capacity, the high speed compressor can meet the need.

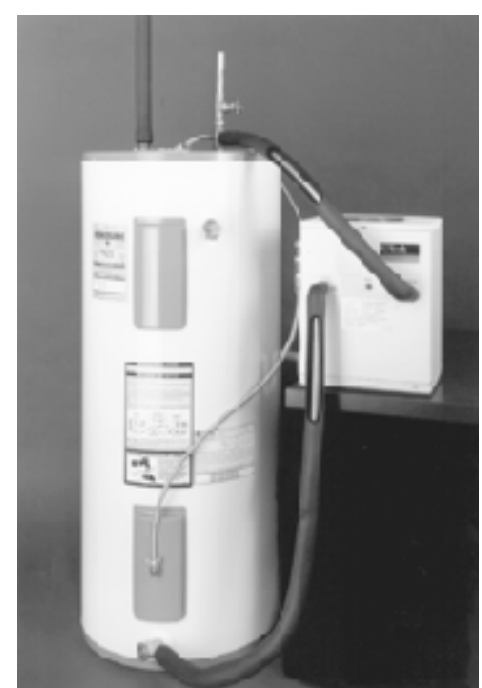

Figure 85 Heat pump water heater.

Measured data indicated that the 5-ton mode operated about one in every four days during the three hottest summer months (June to August), usually for periods of 15 minutes or less. Even these short periods of high-speed compressor operation might have been avoided with proper use of a programmable thermostat. These results verify the Manual J sizing calculations and indicate that if a single speed HVAC system were installed, the optimum size would be $2 \frac{1}{2}$ to 3 tons.

\section{Variable-speed Air Handler}

Two benefits of using a variable-speed motor for air distribution are better moisture removal and energy efficiency. During the cooling season, slower airflow across a cold coil allows for more moisture removal. Wintertime comfort also is enhanced with this operation, since the coil has more time to warm before the air is brought to full flow.

Indoor relative humidity tends to increase during the fall and winter months when air conditioning activity declines. Without a dedicated dehumidifier, the air conditioner is the only 
means of reducing indoor relative humidity. When there is a call for cooling - the low-speed compressor in a variable speed system operates more consistently than a larger system and keeps relative humidity from rising to unhealthy levels.

\section{Heat Pump Water Heater}

Solar water heating would have been the first choice for this home, but poor orientation and too many shade trees forced a search for other options. (Figure 83) Natural gas also was unavailable in the area. To avoid the inefficiency of electric resistance water heating, a 6,000 BTU/hour heat pump water heater (Figure 85). Heat pump water heater produced all the hot water needs for a four-person household from April to September.

The water heater was connected to a standard 80-gallon electric water heater. By locating the heat pump inside the home, homeowners gained a summertime benefit of additional cooling and year 'round dehumidification because the system removes moisture each time it operates.

\section{Energy Recovery Ventilator}

The energy recovery ventilator acts as a conduit to flush out stale indoor air and replace it with outdoor air. As the indoor air is expelled, a heat exchanger recovers up to $80 \%$ of the energy used to heat or cool the air and transfers it to the incoming air stream. This unit also transfers a portion of the moisture between the airstreams, which is useful during periods of high outdoor humidity.

\section{Airtight Ducts}

Attic and duct heat gain contribute to about $22 \%$ of the cooling needs of a typical Central Florida home when are ducts located in a vented attic above the insulation. While some home efficiency is lost by direct heat-gain through the duct insulation, a great deal more efficiency can be lost from unintended duct leakage from the ductwork into the vented attic. Duct leakage test results showed only 50 CFM of air was lost at $25 \mathrm{~Pa}$ of pressure differential in the Hoak residence. This leakage equates to $1.2 \%$ leakage per square foot of conditioned floor area - far below the leakage normally found in new Florida homes.

\section{Energy Monitoring:}

Monitors on the Hoak residence include 11 attic temperature and relative humidity sensors, three indoor sensors, a Hobo event logger to record the dehumidifier cycling time, and a tipping bucket rain gauge with Hobo logger to monitor the combined condensate of the air conditioner, dehumidifier, and heat pump water heater. In 2002, Alten Design also assembled a new logger monitoring computer with the capability of reading data from two Campbell $21 \mathrm{X}$ loggers. This computer was configured with remote monitoring and control capacity so that Partners can program and maintain the system without traveling to the site.

\section{Findings}

\section{Duct Leakage}

Duct leakage test results showed the Hoak home air loss was only $50 \mathrm{CFM}$ at $25 \mathrm{~Pa}$ or $1.2 \%$ leakage per square foot of conditioned floor area - far below the amount of leakage normally found in new Florida homes.

Total duct leakage is less than $10 \%$ of air handler flow (200 CFM). Blower door performance tests verified the home's level of air tightness at two air changes per hour at $50 \mathrm{~Pa}(\mathrm{ACH} 50=$ 
2.0). When including leakage around the supply grills, house leakage increased about $30 \%$. Slightly more than half of the house leakage (1479 CFM at $50 \mathrm{~Pa})$ is located in the sealed attic space $(760 \mathrm{CFM}$ at $50 \mathrm{~Pa})$.

\section{Cooling Energy}

Initial data comparisons were made against data collected from a Lakeland, Florida residence (PVRes), designed by FSEC and monitored for more than a year. The PVRes home contained the most energy-efficient provisions researchers could devise, including a $5 \mathrm{~kW}$ photovoltaic system. Data collected at the Hoak home shows the cooling energy is nearly on par with the PVRes Home on a per square foot basis.

\section{Envelope}

Weekly data logs of the Hoak home provided by Alten Design from the 14 Hobo temperature and relative humidity sensors and pressure tests through March 2003, confirm that air pathways between the unvented attic and outdoors still exist. Researchers suspect that these pathways may be the primary source of moisture intrusion into the unvented attic space. Several whole house pressure tests (smoke tests) were performed by Alten Design and FSEC to isolate these external sources of air infiltration. Identified leaks were sealed, though actions have shown some benefit moisture levels are still higher than desired.

In order to isolate areas of leakage, barriers will be placed in the house splitting the areas under test into easier to monitor individual zones.

New Features in $6^{\text {th }}$ Budget Period

An EnergyViewer to monitor whole house power use and the ERV control was modified to respond in tandem with bathroom vents. The ERV runs for a 15 min period of time. Also, new anticipating thermostats by Honeywell were installed.

Final Year of the Project

Researchers are studying heat pump water heater performance in this home with alternating two week periods of conventional water heating and heat pump water heating.

\section{Zero Energy Affordable Housing, ORNL and Loudon County Habitat for Humanity Lenoir City, Tennessee \\ Category A \\ Research by ORNL with BAIHP Support \\ Paper: Christian, J.E., D. Beal, and P. Kerrigan (2004). “Towards Simple Affordable Zero Energy Houses.” Proceedings of Performance of Exterior Envelopes of Whole Buildings IX, Clearwater, Florida, December 5 -10, 2004}

In partnership with Oak Ridge, BAIHP has instrumented two a zero energy homes (ZEH) built by Loudon County (TN) HFH in partnership with Oak Ridge National Laboratory. (Figure 86) See description in the Technical Assistance section of this report under Habitat for Humanity, Tennessee, Loudon County. 
Data is available on-line at www.baihp.org on the "Current Data" page. A paper on the study was presented at the Buildings IX conference by Jeff Christian (ORNL) and David Beal (BAIHP-FSEC).

\section{Apartment Ventilation and Humidity Study with Sandspur Housing Gainesville, Florida}

In April and May of 2003, four of 111 newly built apartments at the Brookside Apartment Complex were evaluated for potential moisture problems. Characteristics of the

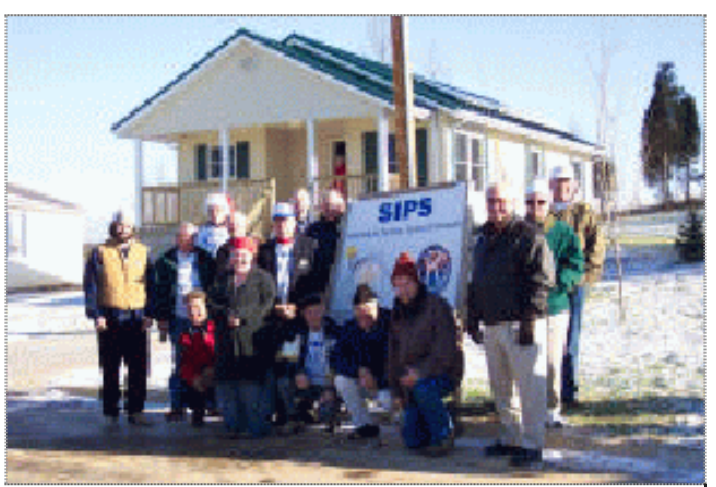

Figure 86 Local sponsors in front of 2nd ZEH built by Loudon County HFH in partnership with ORNL. FSEC provided monitoring for the $1^{\text {st }}$ and $4^{\text {th }}$ ZEHs four apartments are summarized in Table 61.

The ventilation strategy introduced untempered outside air to the return side of a central air handler.

\begin{tabular}{|c|c|c|c|l|c|c|}
\hline \multicolumn{7}{|c|}{ Table 61 Apartment Characteristics } \\
\hline Apt ID & Floor & Occupants & $\begin{array}{c}\text { RH } \\
\text { Control }\end{array}$ & $\begin{array}{l}\text { Outside } \\
\text { Air Flow }\end{array}$ & $\begin{array}{c}\text { Infiltration } \\
(\text { ACH50) }\end{array}$ & $\begin{array}{c}\text { Thermostat } \\
\text { Setting }\end{array}$ \\
\hline 1 & 1 st & 1 & AC only & $25 \mathrm{cfm}$ & 2.8 & Variable \\
\hline 2 & 2 nd & 2 & AC only & $17 \mathrm{cfm}$ & 2.5 & Variable \\
\hline 3 & 2 nd & 0 & AC only & $27 \mathrm{cfm}$ & 3.2 & $76^{\circ}$ \\
\hline 4 & $1 \mathrm{st}$ & 0 & AC only & $28 \mathrm{cfm}$ & 3.9 & $76^{\circ}$ \\
\hline
\end{tabular}

Sensors were installed in four apartments that monitored Temperature and RH in three locations: the air handler cabinet, the kitchen, and the master bedroom close (Table 62). The readings from Apartment 2 were within recommended guidelines in all living spaces monitored, with no changes recommended.

\begin{tabular}{|c|c|c|c|c|}
\hline \multicolumn{5}{|c|}{ Table 62 Apartment Results } \\
\hline & \multicolumn{2}{|c|}{ Kitchen } & \multicolumn{2}{c|}{ MB Closet } \\
\hline Apt ID & Temp Av. & RH Av. & Temp Av. & RH Av. \\
\hline 1 & $71.9^{\circ}$ & $54.3 \%$ & $71.7^{\circ}$ & $62.0 \%$ \\
\hline 2 & $76.0^{\circ}$ & $47.6 \%$ & $76.9^{\circ}$ & $53.5 \%$ \\
\hline 3 & \multicolumn{2}{|c|}{ Invalid data (See Figure) } & N/A & N/A \\
\hline 4 & $71.4^{\circ}$ & 50.2 & N/A & N/A \\
\hline $\begin{array}{l}\text { Note: Data from the Air Handler sensors were similar for all four apartments (reflecting the } \\
\text { extremes expected in this locations with RH as high as 90\% and 100\%), and was not pertinent to } \\
\text { the living space temperature and } R H .\end{array}$ \\
\hline
\end{tabular}

The temperature in Apartment 1 was lower than Apartment 2, the other occupied unit. The readings were within the acceptable level for comfort and mold control, but because the air conditioner ran longer, it also had a longer period to remove moisture. Inspection found that the windows were opened about $11 / 2$ ". When the occupant (the maintenance man for the complex) was asked why, he indicated that it was being done for "health purposes". 
The master bedroom closet reflected the lower temperatures of the kitchen but with a slightly higher RH level. The higher RH level in this space was likely due to the closet door being closed which would slow the passage of the dryer kitchen air into the closet space.

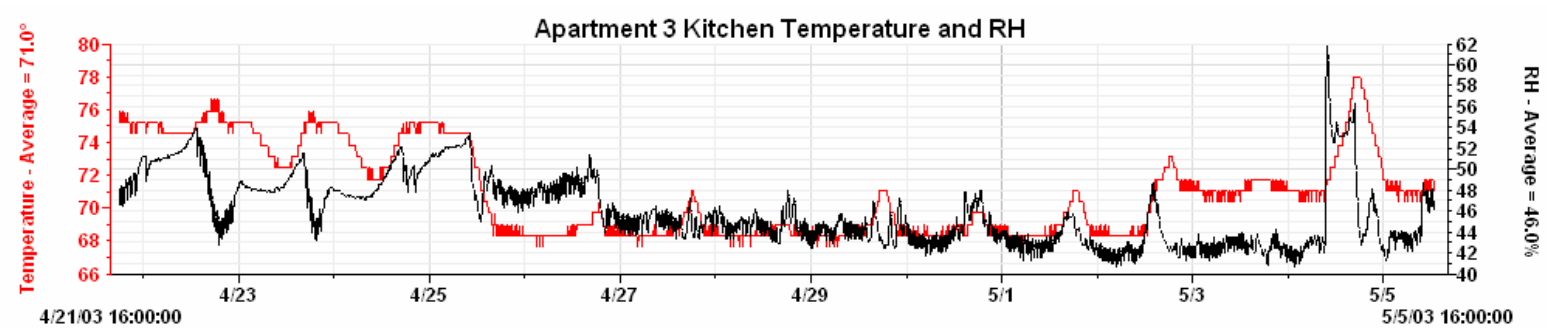

Figure 87 Apartment 3 Kitchen Temperature and $\mathrm{RH}$

The remaining apartments tested varied a large amount over the period of test. Apartment 4 had wide swings in temperature readings. With no significant period of time in which the temperature was stable, it is assumed that the AC was not running properly in this unit. Apartment 3 is notable because this unit was vacant and its temperature should have stayed stable within three degrees. The good RH levels were likely due to the longer Air Conditioner run times required to maintain the low temperature.

Outside Temperature and $R H$ : The test period was during the beginning of Florida summer temperature and RH trends. Daytime high temperatures reach into the low 90's with associated high RH levels in the afternoon. These cycles are reflected in the data collected, the most obvious of these being the Apartment 2 closet (Figure 88) where daily outdoor temperature peaks mimic those of the indoor temperature peaks.

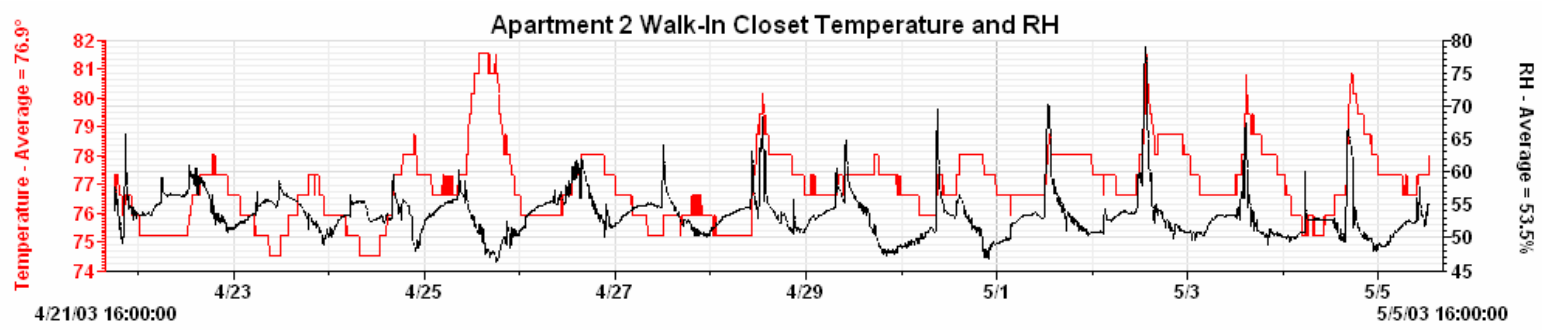

Figure 88 Apartment 2 Walk-In Closet Temperature and $R H$

Final observations: If all of the apartments have similar characteristics to those of Apartment 1 and Apartment 2, then no changes to lower interior RH levels are required at this time. RH level averages are well within the acceptable range - even in spaces where RH levels tend to get rather high (i.e. - closet) validating, at least preliminary the adequacy of the design principle of using outside ventilation air as has been implemented in these units. 


\section{Recommendations}

1. Educate those involved in the care and maintenance of apartment complexes in basic principles of building science.

2. In future apartments locate a supply register in the closet to provide better humidity control for this area.

3. Check Apartment $3 \& 4$ equipment for proper operation, and calibration of thermostat.

Experiments were completed in September, 2004. On March 31 BAIHP researchers met with Sandspur staff to go over the report. The report was approved for release and was emailed out to DOE and others.

\section{Federation of American Scientists' Rasbach Provident Home} Houston, Texas

BAIHP is assisting FAS and builder Joe Ecrette with envelope and mechanical system design on this home built with cementitious faced SIP panels. The home serves as a demonstration of an affordable, efficient home that is also well-suited for areas prone to seismic disturbance. A preliminary HERS ' 99 score of 89 is estimated.

BAIHP will provide data monitoring design assistance, equipment and installation to document energy savings. Data collection, processing and archiving will be provided through FSEC's Infomonitors service, online at www.infomonitors.com.

\section{Radiant Floor Heating Research Franklin, West Virginia}

Radiant floor heating systems are becoming more common; however, there is little measured performance data documenting energy use and comfort indicators. Almost Heaven Habitat for Humanity in Franklin, West Virginia installs a slab mounted radiant floor system fed by a dedicated conventional, 80 gallon water heater. They have built approximately 15 houses with this system, designed from off the shelf components. In the final year of the project, BAIHP installed ground and slab instrumentation for radiant floor heating in Habitat house being constructed in West Virginia. Instrumentation so far consists of temperature probes embedded in the ground one and three meters from the slab, on the sides of the slab, and at three interior locations under and in the slab; the middle of the house, one meter from the edge of the slab, and in between these two locations. The house will be completed in the spring of 2007.

\section{Hurricane Water Intrusion Research Central Florida area}

In September 2004 Hurricane Jeanne struck Florida. Most of the damage in the Orlando and surrounding central Florida area resulted from severe water intrusion. The local Home Builders Association received over 1,000 complaints from new home owners. The water intrusion was perplexing for several reasons. First, most complaints were from residents of newer homes.

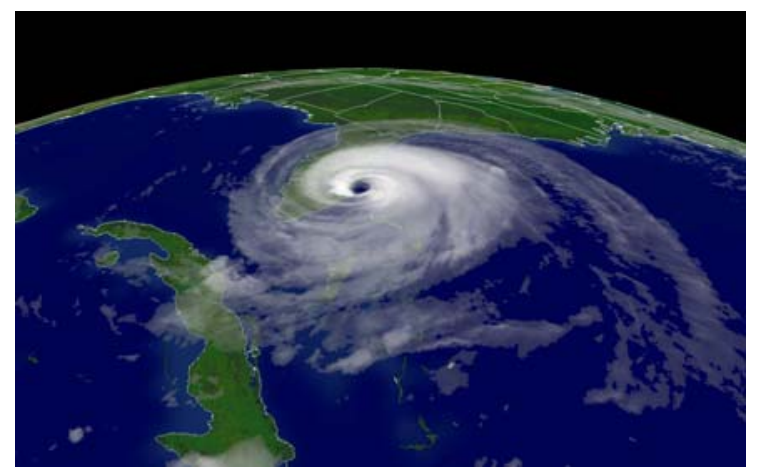

Figure 89 Hurricane Jeanne at landfall (NOAA Satellite and Information Service 2004) 
Second, in many cases there were no obvious reasons for the water intrusion (e.g., roofing materials were not blown off, windows were not damaged, and there was no surrounding flooding). Water, lots of water, seemed to just appear at the base of exterior walls inside newer homes. The objective of this research is to characterize what actually happened, to explain why it happened and to develop recommendations to reduce future water intrusion. To allow better focus, the scope was limited to:

- Recent construction - homes receiving certificates of occupancy in 2001 and afterwards.

- Stucco-clad masonry $\left(1^{\text {st }}\right.$ floor $)$ and frame $\left(2^{\text {nd }}\right.$ floor $)$ walls - the predominant building system in central Florida.

Several approaches were used to collect data:

- An extensive literature search was performed in the areas of masonry walls, stucco finishes, cracks, and water intrusion.

- Experts were interviewed to discuss findings and provide direction.

- Homeowners were surveyed by telephone to learn more about their home and what they experienced during the storm.

- Home inspections were performed to learn more about affected homes.

- Selected elements of the construction process were observed to better understand workmanship issues.

- Field tests were performed on new and existing homes to measure the extent of water intrusion due to wind driven rain.

Survey results indicate that $20 \%$ of all new homes built in central Florida in 2003 experienced water intrusion related to walls during Hurricane Jeanne. A survey of homeowners that reported water intrusion revealed that:

- Although many builders experienced the problem, some builders were affected far more than their market share would suggest.

- $\quad$ Single and two story homes were equally affected.

- The vast majority of intrusion occurred on eastern walls, with some occurring on northeast and northern walls.

A follow-up inspection of these homes found a variety of possible causes including: poorly sealed windows, unsealed wall penetrations (dryer vents, plumbing, electrical, rain gauge, etc.), poorly sealed expansion joints, and numerous cracks of varying shapes and sizes. Findings from an earlier inspection study confirmed the prevalence of these issues throughout the central Florida new home market. This earlier study found that $50 \%$ of homes between one and two years old had significant stair step cracking. (Figure 90)

On-site testing (Figure 91) was used to assess the relative importance of these factors. Testing of new homes (both under construction and occupied) revealed that stucco clad masonry walls without cracks did not leak, even without paint. Tests of homes that had leaked during Hurricane Jeanne demonstrated that cracks can facilitate water intrusion. Cracks did not need to be wide cracks less than $0.39 \mathrm{~mm}(1 / 64 \mathrm{inch})$ wide allowed water to penetrate the wall, run down and accumulate on the floor in one to two hours of simulated wind driven rain conditions. It is important to note that $57 \%$ of the cracks observed were wider than this, but could not be tested because they were not in a testable area of the house. It is also important to note that Hurricane Jeanne brought sustained winds of over 40 miles per hour with rain for a period of over 8 hours. 
Given the prevalence of stair step cracks in new central Florida homes and their propensity to allow water intrusion, the remaining analysis and recommendations focused on the cause, prevention and mitigation of water intrusion through stair step cracks. The causes of the stair step cracks observed are not obvious. No significant stair step cracks were observed immediately after laying the block. However, after the cells were grouted and the roof was installed, numerous stair step cracks were visible. There were no discernable cracks in the footings related to the stair step cracks observed in the walls. No problems with soil compaction were found and the required rebar was installed in the footings. No significant stair step cracks were observed immediately after stucco was applied. However, within one year after the homes were completed, 50\% exhibited significant stair step cracking. The most likely cause of stair step cracking cited in the literature is differential settlement. However, the absence of discernible cracks in the footings casts some doubt on this explanation as the sole cause. A more likely cause of many stair step cracks is shrinkage. A common cause of shrinkage cracks in masonry walls is using 'wet' or uncured concrete masonry units (blocks). When uncured blocks are used to construct a masonry wall, they continue to cure and experience a significant amount of shrinkage. Typical shrinkage in a 50 foot masonry wall ranges from 3.1 to $6.9 \mathrm{~mm}$.

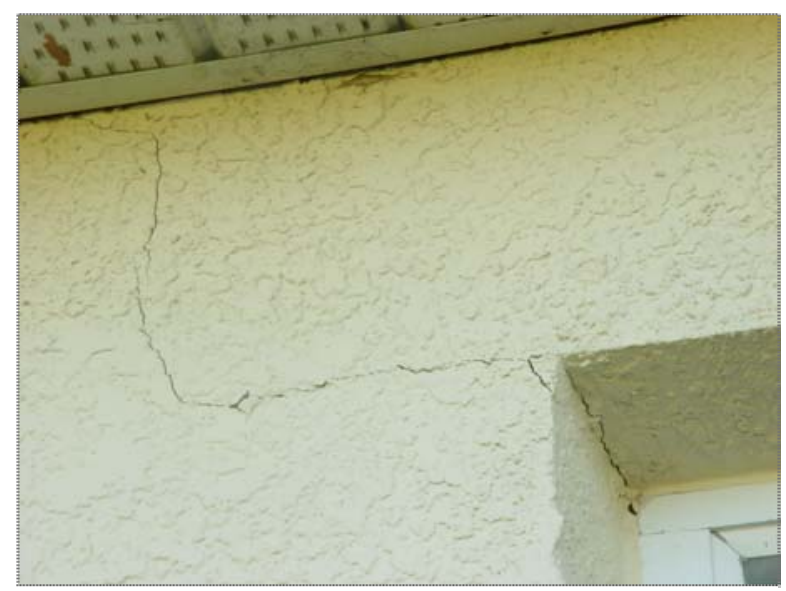

Figure 90 Window corner crack

Recommendations to homebuilders were made to reduce the incidence and magnitude of water intrusion during hurricanes. Given the prevalence of stair step cracks in new central Florida homes and their propensity to allow water intrusion, the recommendations focus on the reduction

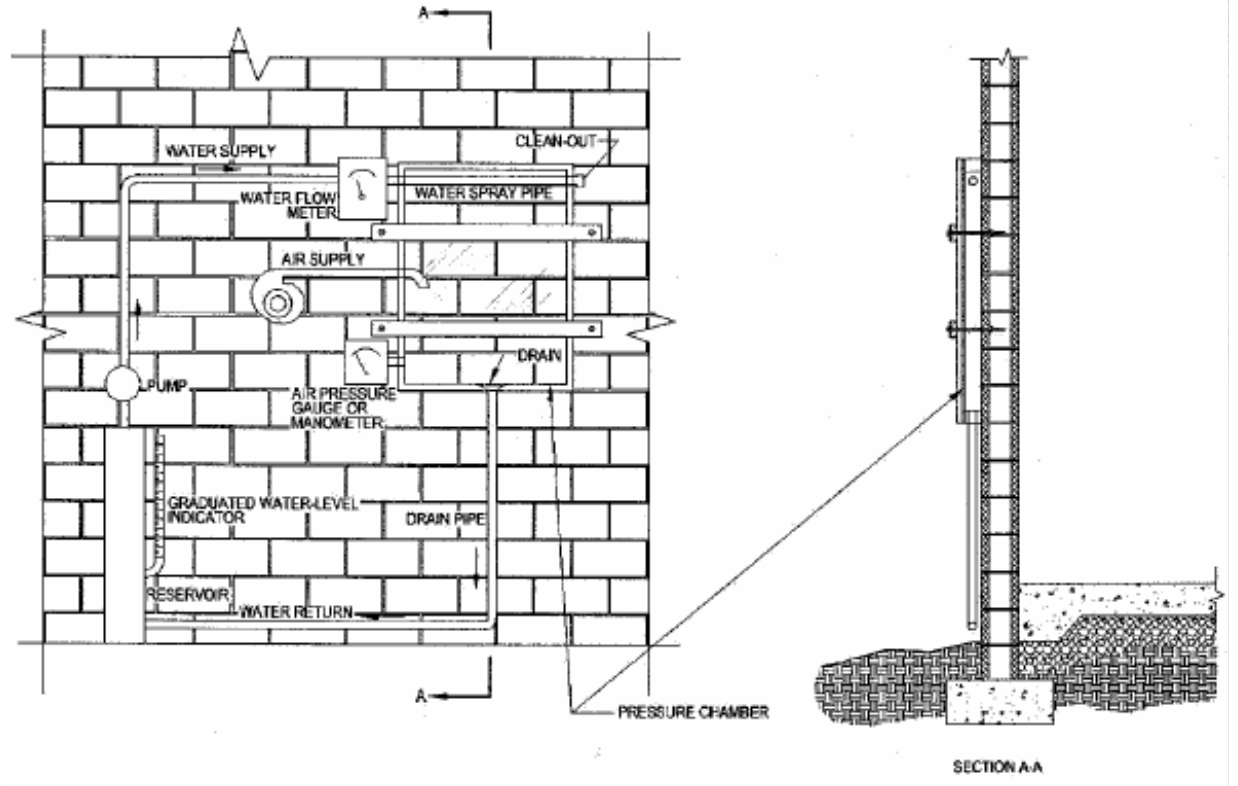

Figure 91 Schematic of test equipment and setup (ASTM 1604 - 04 2004) 
of water intrusion through stair step cracks. Several recommendations are also provided for homeowners. Recommendations are provided at two levels. Level I recommendations should be implemented immediately. They are believed to be low cost and high impact. Level II recommendations involve substantive changes to the construction process and should be carefully evaluated by each builder, possibly involving longer term testing.

Level I recommendations should be implemented immediately. They include:

- Ensure proper support for footings by ensuring that site work for foundations meets code requirements as well as recommendations from the National Concrete Masonry Association.

- Provide a step down ledge or seat for the concrete block approximately one inch below the slab to provide holding capacity for water that penetrates the exterior surface of the wall. Provide weep holes in the first course of block to allow this trapped water to escape.

- Age concrete block 21 days before use to permit early shrinkage before walls are constructed.

- Ensure that stucco is installed to ASTM standard C926 for 2 coat stucco. Curing times should allow the first coat to fully cure (some experts have suggested seven days), allowing the first coat to crack before the second coat is applied. The second coat should cure for 28 days before painting. The stucco should be reinforced with fibers to reduce cracking.

- Use a premium, high build, acrylic coating that: meets Federal Specifications for resistance to wind driven rain (TT-C-555B), allows water vapor transmission permitting water to evaporate from the wall to the exterior, and provides high flexibility/elongation to cover existing and new cracks.

- Near the end of the warranty period, repair all visible cracks with elastomeric sealant/patching compound and apply a second coat of paint.

Level II recommendations involve substantive changes to the construction process and should be carefully evaluated by each builder for impacts on market acceptance, cost, building system, and the construction process. They include:

- Consider adding reinforcement to footings to lessen the effects of differential settlement on footings and thus reduce the incidence and severity of wall cracks.

- Investigate and consider alternatives for floor/wall joint details that promote water entry into home.

- Consider crack control strategies to address shrinkage: control joints and reinforcement to limit crack width. If walls are longer than 40 feet, control joints should be considered no further than 25 feet on center. Add joint reinforcement every other course to help hold cracks tightly together. Reinforcement (typically 9-gauge wire in either a "ladder" or "truss" configuration) is placed in bond beams, horizontal courses of U-shaped masonry block into which the reinforcing steel and grout is placed.

- To better contain the water that does penetrate the exterior surface of the wall and direct it to the weep holes (see Level I recommendations), flashings should be considered at the base of the walls.

- Alternative building systems such as cast-in-place concrete or pre-cast concrete panels may greatly reduce the risk of cracks and water intrusion associated with concrete masonry construction. 


\section{Energy Efficient Renovations of Storm Damaged Residences - Florida Case Studies}

Contract Report: Chasar, Dave (P.E.), Neil Moyer, and Eric Martin. (2006) Energy Efficient Renovations of Storm Damaged Residences - Florida Case Studies. FSECCR-1648-06. Florida Solar Energy Center, Cocoa, Florida. September, 2006.

Storm-damaged homes offer the opportunity for repairs that reduce energy use, improve comfort and enhance resistance to future storms. Case studies of four Florida homes damaged in the summer of 2004 were documented to show the costs and benefits of various retrofit strategies. All four homes required roof replacement and each took advantage of roof cladding with higher reflectance than the original - a proven means of reducing cooling energy use. Two of the case studies included improvements to attic insulation, tightening of the envelope and/or duct system and improved efficiency equipment and lighting. Energy savings attributable to storm repairs were estimated through detailed computer simulation and in one case savings were directly measured in a before/after fashion.

Whole-home energy savings estimates derived by computer simulation ranged from a high $27 \%$, in the home requiring the greatest amount of renovation, to a low of $1 \%$ in the home with a light colored shingle roof replacement. Cooling energy savings was also analyzed as it typically makes up the largest single subset of whole-home energy use in Central Florida. Cooling savings derived from the computer model ranged from $3 \%$ to $45 \%$ and, as in the case of whole home energy, was directly impacted by the level of home repair. Measured data obtained from one home showed a $19 \%$ reduction in cooling energy use after the dark shingle roof was replaced with white metal. This fell roughly in line with computer estimated cooling savings of $16 \%$. 


\section{Field and Laboratory Building Science Research}

BAIHP builds on a 20 year foundation of basic building science research at the Florida Solar Energy Center. This research generally focuses on issues important in hot-humid climates similar to Florida's but is relevant to our understanding of building science concepts manifest in all climatic regions. BAIHP has conducted field and laboratory building science research in these areas:

- Air Handler Air Tightness Study

- Air Conditioning Condenser Fan Efficiency

- Fenestration Research

- Reflective Roofing Research

- Return Air Pathway Study

- Heat Pump Water Heater Evaluation

- $\quad$ NightCool - Building Integrated Cooling System

- $\quad$ Plug Load Reduction Study

- Solar Integrated Roofing Panels

- Hot Water Distribution Systems Research

- Building America Benchmark Toolkit for Programmers

- $\quad$ Comparison of Current Building Energy Analysis Standards for Building America, Home Energy Ratings and the 2006 International Energy Conservation Code

- Cooling Performance Assessment of Building America Homes 


\section{Air Handler Air Tightness Study}

Central Florida

Research by FSEC Researchers Chuck Withers, Jim Cummings, and Janet McIlvaine

Papers: Cummings, J., C. Withers, J. Mcllvaine, J. Sonne, M. Lombardi (2003). Air Handler

Leakage: Field Testing Results in Residences. ASHRAE Transactions V.109 pt.1

February 2003. To be published in ASHRAE Journal.

To determine the impact of air handler location on heating and cooling energy use, researchers measured the amount of air leakage in air handler cabinets, and between the air handler cabinet and the return and supply plenums. To assess this leakage, testing was performed on 69 air conditioning systems. Thirty systems were tested in the 2001 and 39 in 2002. The 69 systems were tested in 63 Florida houses (in six cases, two air handlers were tested in a single house) located in seven counties across the state - four in Leon County in or near Tallahassee, 17 in Polk County, three in Lake County, 13 in Orange County, one in Osceola County, two in Sumter County, and 29 in Brevard County. All except those in Leon County are located in central Florida. Construction on all houses was completed after January 1, 2001, and most homes were tested within four months of occupancy.

In each case, air leakage $\left(\mathrm{Q}_{25}\right)$ at the air handler and two adjacent connections was measured. $\mathrm{Q}_{25}$ is the amount of air leakage which occurs when the ductwork or air handler is placed under $25 \mathrm{~Pa}$ of pressure with respect to its surrounding environment. $\mathrm{Q}_{25}$ also can be considered a measurement of ductwork perforation.

To obtain actual air leakage while the system operated, it was necessary to measure the operating pressure differential between the inside and outside of the air handler and adjacent connections. In other words, it was necessary to know the perforation or hole size and the pressure differential operating across that hole. By determining both $\mathrm{Q}_{25}$ and operating pressure differentials, actual air leakage into or out of the system was calculated.

\section{Field Testing Leakage Parameters}

Testing was performed on 69 air conditioning systems to determine the extent of air leakage from air handlers and adjacent connections. Testing and inspection was performed to obtain:

- $\mathrm{Q}_{25}$ in the air handler, $\mathrm{Q}_{25}$ at the connection to the return plenum, and $\mathrm{Q}_{25}$ at the connection to the supply plenum.

- Operating pressure at four locations - the return plenum connection, in the air handler before the coil, in the air handler after the coil, and at the supply plenum connection.

- Return and supply air flows were measured with a flow hood. Air handler flow rates were measured with an air handler flow plate device (per ASHRAE Standard 152P methodology).

- Overall duct system and house air tightness in 20 of the 69 homes.

- Cooling and heating system capacity based on air handler and outdoor unit model numbers.

- The location and type of filter.

- Dimensions and surface area of the air handler cabinet.

- The fractions of the air handler under negative pressure and under positive pressure.

- The types of sealants used at air handler connections.

- Estimated portion of the air handler leak area that was sealed "as found." 
Air Handler Leakage

Leakage in the air handler cabinet averaged $20.4 \mathrm{Q}_{25}$ in 69 air conditioning systems. Leakage at the return and supply plenum connections averaged 3.9 and 1.6 $\mathrm{Q}_{25}$, respectively. Using the operating pressures in the air handler and at the plenum connections, these $\mathrm{Q}_{25}$ results convert to actual air leakage of 58.8 CFM on the return side (negative pressure side) and 9.3 CFM on the supply side (positive pressure side). The combined return and supply air leakage in the air handler and adjacent connections represents $5.3 \%$ of the system air flow $(4.6 \%$ on the
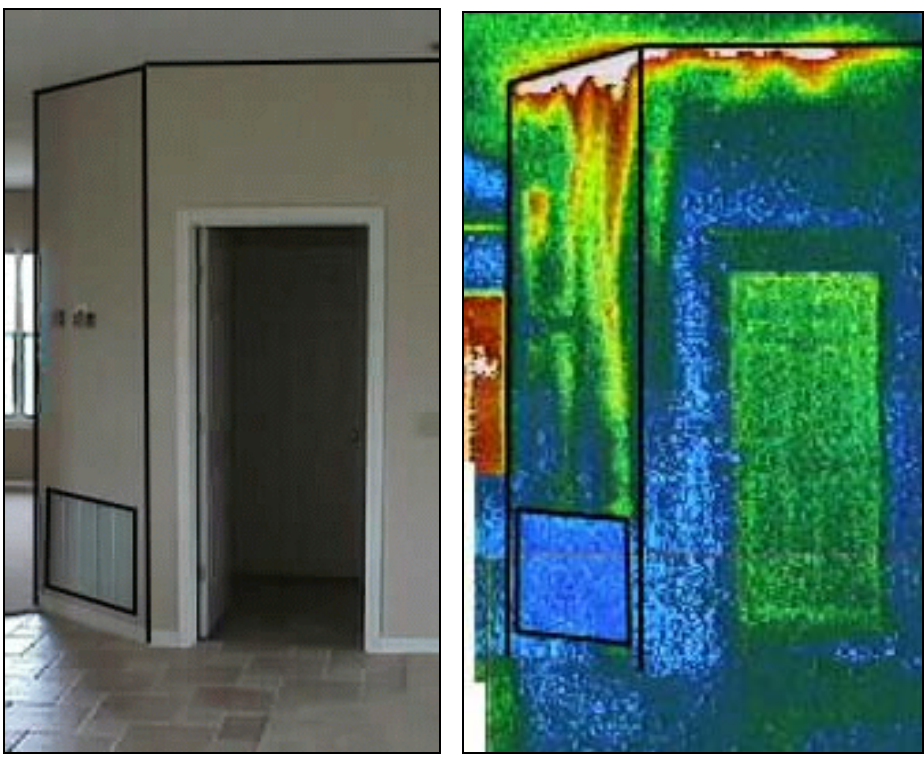

Figure 92 Thermograph of air being drawn from the attic to the air handler in a Florida house return side and $0.7 \%$ on the supply side). This is a concern, when considering that a $4.6 \%$ return leak from a hot attic (peak conditions; $120^{\circ} \mathrm{F}$ and $30 \% \mathrm{RH}$ ) can produce a $16 \%$ reduction in cooling output and $20 \%$ increase in cooling energy use (Cummings and Tooley, 1989), and this was only from the air handler and adjacent connections. (Figure 92)

\section{"Total" Duct Leakage}

Some important observations were made from the extended test data in 20 houses. Total leakage on the return side of the system (including the air handler and return connection) was $53 \mathrm{cfm}$ with weighted operating pressure on the return side of about $-100 \mathrm{~Pa}$ (including the air handler), operating return leakage was calculated to be 122 CFM, or $9.7 \%$ of the rated system air flow.

Total leakage on the supply side of the system $\left(\mathrm{Q}_{25 s, \text { total }}\right)$ was very large, at 134 . The ASHRAE $152 \mathrm{P}$ method suggests using half of the supply plenum pressure as an estimate of the overall supply ductwork operating pressure, if the actual duct pressures are not known. For the 20 systems with extended testing, supply plenum pressure was $73.3 \mathrm{~Pa}$. Based on a pressure of 37 $\mathrm{Pa}$, actual leakage should be 167 CFM or about $13.3 \%$ of the rated air flow. To test the ASHRAE divide-by-two method, supply duct operating pressure measurements were taken from 14 representative systems. These averaged $35.9 \mathrm{~Pa}$, compared to $65.7 \mathrm{~Pa}$ for the supply plenums for those same 14 systems. For these systems, the duct pressure was $55 \%$ of the supply plenum pressure - making the ASHRAE method a reasonable method for estimating central Florida home's supply ductwork operating pressures.

However, the ASHRAE method wasn't reasonable for estimating central Florida home's return ductwork operating pressures. For these 20 systems, $38 \%$ of the $\mathrm{Q}_{25 \text {,total }}$ was in the air handler and $62 \%$ of the $\mathrm{Q}_{25 \text { r,total }}$ was in the return ductwork. Given an air handler pressure of - $133 \mathrm{~Pa}$, a return plenum pressure of $-81.5 \mathrm{~Pa}$, and return duct pressure of approximately $-70 \mathrm{~Pa}$, the weighted return side pressure was approximately $-95 \mathrm{~Pa}$. By contrast, the ASHRAE method predicted $-41 \mathrm{~Pa}$. Clearly, in systems with a single, short return duct plenum like those 
commonly found in Florida, the actual operating pressure should be greater than the return plenum, maybe by as much as 1.2 times the plenum pressure.

Return side leakage is available on 58 of the 69 systems. Return leak air flow $\left(\mathrm{Q}_{\mathrm{r}, \text { total }}\right)$ combined for the air handler, return connection, and the return ductwork was found to be $152.4 \mathrm{CFM}$, or $11.8 \%$ of total rated system air flow for this group. For this larger sample, $\mathrm{Q}_{\mathrm{r} \text {,total }}$ is considerably greater than for the 20 houses with extended testing. These alarming results show that even in these newly constructed homes about $12 \%$ of return air and $13 \%$ of supply air duct systems are leaking.

Duct Leakage to "Out":

In 20 homes, duct leakage to "out" was measured. (Table 63) On average, 56\% of the leakage of the return ductwork and supply ductwork was to "out." "Out" is defined as outside the conditioned space, including buffer spaces like an attic or garage. The fraction of leakage that was to "out" varied by air handler location. For return ductwork, the proportion of total leakage to "out" is $81.4 \%$ for attic systems, $67.6 \%$ for garage, and $28.0 \%$ for indoors. For supply ductwork, the proportion of total leakage to "out" was in the range of $52 \%$ to $56 \%$ for all three locations.

Table 63 Portion of duct leakage to outdoors $\left[\left(Q_{25,0 u t} / Q_{25, \text { total }}\right) * 100\right]$

\begin{tabular}{|l|l|l|l|}
\hline Air Handler Location & Return & Supply & Entire Duct System \\
\hline Attic & $81.4 \%$ & $56.5 \%$ & $63.2 \%$ \\
\hline Garage & $67.6 \%$ & $51.7 \%$ & $56.0 \%$ \\
\hline Indoors & $28.0 \%$ & $52.6 \%$ & $37.1 \%$ \\
\hline
\end{tabular}

The attic return ductwork was the most predictive variable to "out" leakage findings. All of the return ductwork for attic units was located in the attic. Much of the return ductwork for other units was located in the house. As a consequence, the energy penalty associated with locating the air handler in the attic was greater than indicated in the computer modeling results in Table 64, since the modeling only considered the leakage of the air handler cabinet and the adjacent connections, and not the return ductwork leakage.

Table 64 Duct leakage "total" and to "out" for three locations, for both 25 Pa test pressure and for actual system operating pressure. Sample size is in [brackets]

\begin{tabular}{|c|c|c|c|c|c|c|c|c|}
\hline \multirow[b]{2}{*}{ Test } & \multicolumn{2}{|c|}{ Attic (cfm) } & \multicolumn{2}{|c|}{ Garage (cfm) } & \multicolumn{2}{|c|}{ Indoors (cfm) } & \multicolumn{2}{|c|}{ Combined (cfm) } \\
\hline & Total & Out & Total & Out & Total & Out & Total & Out \\
\hline $\mathrm{Q}_{25, \mathrm{r}}[58]$ & 61.9 & 50.4 & 93.3 & 63.1 & 67.8 & 19.0 & 75.7 & 44.9 \\
\hline $\mathrm{Q}_{25, \mathrm{~s}}[20]$ & 109.1 & 61.6 & 170.6 & 88.2 & 119.5 & 62.9 & 134.3 & 71.4 \\
\hline $\mathrm{Q}_{\mathrm{r}}[58]$ & 118.1 & 96.1 & 194.4 & 131.4 & 134.6 & 37.7 & 152.4 & 90.4 \\
\hline $\mathrm{Q}_{\mathrm{s}}[20]$ & 135.6 & 76.6 & 212.0 & 109.6 & 148.5 & 78.1 & 166.9 & 88.7 \\
\hline
\end{tabular}


Table 64 shows that the operating supply leakage to "out" was large for all three air handler locations, averaging 89 CFM. The average operating return leakage to "out" was slightly larger, at $90 \mathrm{CFM}$. However, there was a large variation between air handler locations; $96 \mathrm{CFM}$ for attic systems, $131 \mathrm{CFM}$ for garage systems, but only $38 \mathrm{CFM}$ for indoor systems. From an energy perspective, the attic systems experienced the greatest "real" energy penalties, because all of the return ductwork and air handlers were located in the attic. (Table 63) By contrast, a majority of the return leakage for the garage systems likely came from the garage (which is considerably cooler than the attic). For indoor systems, the return leakage to "out" most likely originated from the attic. However, since the return leakage was so much smaller, the energy impact was likely considerably less than both the attic and the garage systems.

Correlation of Supply Duct Leaks with Number of Registers: When analyzing the supply leakage in the extended test data, a surprising correlation was observed. This correlation indicated a systematic and consistent duct fabrication problem across a wide range of air conditioning contractors. Figure 93 illustrates this correlation, showing that each supply duct has a remarkably predictable total duct leakage. The coefficient of determination is 0.86 , indicating that $86 \%$ of the variability in total supply duct leakage was explainable by the number of supply registers. Figure 94 shows a similar relationship between supply leakage to "out" and the number of supply registers. In this case the coefficient of determination was 0.69 , indicating that $69 \%$ of the variability in total supply duct leakage was explainable by the number of supply registers.

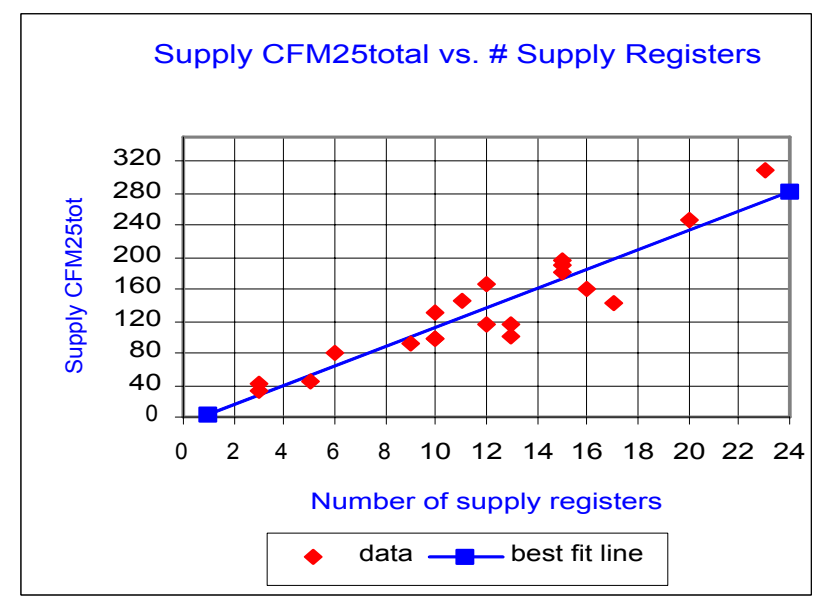

Figure 93 Supply CFM25 “total” leakage versus the number of supply registers.

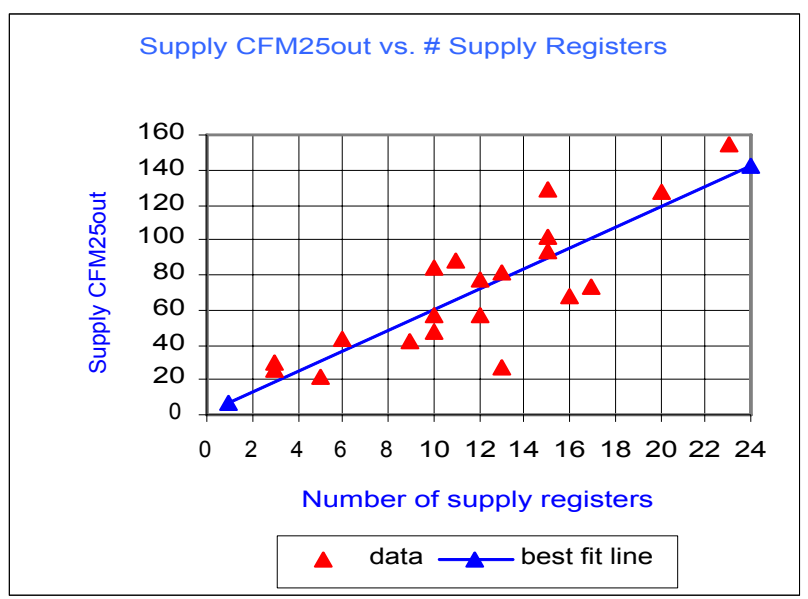

Figure 94 Supply CFM25 “out” leakage versus the number of supply registers.

Note that one of the two houses with 13 registers showed considerably less leakage than expected. In this case, supply ducts were located in the interstitial space between floors. When the house was taken to $-25 \mathrm{~Pa}$, it is probable (though not measured) that the interstitial spaces were substantially depressurized as well, so leaks in those supply ducts would show less air flow (i.e., less pressure differential = less leakage air flow) and therefore be under-represented.

The data suggest that a duct leakage problem occurs in nearly all new homes. Researchers identified three issues that create most of the leakage: (1) the connection of the supply register or return grill (Figure 95), (2) the boot (supply box) to sheet rock connection (Figure 96), and (3) the flex duct to collar connection. The supply register or return grill leakage typically shows as 
supply leakage in the "total" test. It usually occurs when the register or grill does not fit snugly to the ceiling or wallboard. Issues two and three show up as leakage to both "out" and "total."

Figure 96 shows how flexible duct connections typically are made. In some cases metal tape is used, but the tape wrinkles when applied to complex angles and over bumps associated with these connection types. Although small in size, these cumulative wrinkles at each connection allow air to pass through.

Computer Modeling for Florida Energy Code Air Handler Multipliers:

FSEC researchers performed simulations and developed air handler multipliers for the Florida Energy Code using this study's simulation results. Researcher used the FSEC 3.0 model, a general building simulation program developed in 1992. This program provided simultaneous detailed simulations of a whole building system, including energy, moisture, multi-zone air flows, and air distribution systems.

In 2001, modeling had been performed to develop initial air handler multipliers. These multipliers were based on estimated $\mathrm{Q}_{25}$ and duct operating pressures. At the time of the 2001 modeling, there was essentially no data on air handler and connection leakage. Modeling for this project was performed again, but this time using the results of the 69 field tested homes.

The modeling inputs used in 2001 and those from the current study are shown below. (Table 65) Note that the same $\mathrm{Q}_{25}$ and operating depressurization (dP) values was used for all air handler locations, since there was essentially no difference between the $\mathrm{Q}_{25}$ values for attic, garage, and indoor air handler locations when gas furnace units were removed from the analysis.

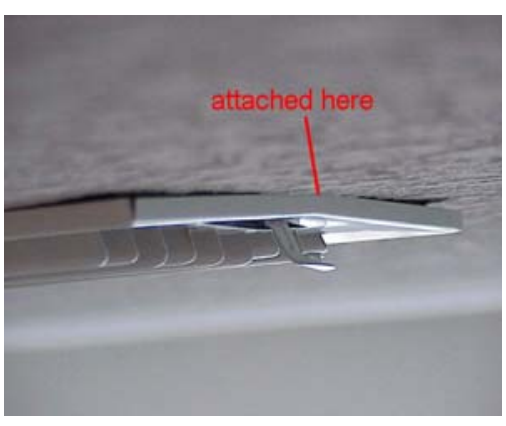

Figure 95 Gaps at the supply register to drywall joint

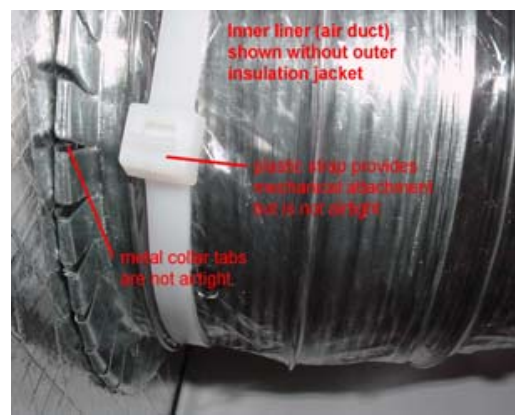

Figure 96 Flexible duct to metal collar connection.

Table 65 Air Handler (AH) And Connection Inputs For 2001 And Current Project Computer Modeling

\begin{tabular}{|l|l|l|l|l|}
\hline & $\mathbf{2 0 0 1} \mathbf{Q}_{\mathbf{2 5}}$ & AH Study $\mathbf{Q}_{\mathbf{2 5}}$ & $\mathbf{2 0 0 1} \mathbf{~ d P ~}$ & AH Study dP \\
\hline Return connection & 8.7 & 3.9 & -40 & -86.1 \\
\hline AH - depressurized portion & 48.5 & 17.6 & -42 & -139.1 \\
\hline AH - pressurized portion & 9.6 & 2.8 & 43 & 106.5 \\
\hline Supply connection & 7.8 & 1.6 & 32 & 58.2 \\
\hline Total & $\mathbf{7 4 . 6}$ & $\mathbf{2 5 . 9}$ & & \\
\hline
\end{tabular}


While the $\mathrm{Q}_{25}$ leakage for the air handler and connections was about $65 \%$ less than earlier estimates, operating pressures were much higher. The air handler multipliers based on the current computer modeling results are presented in Tables 66, 67, and 68. Modeling of air handler energy use also was performed for the air handlers located outdoors, despite the fact that no field data was collected for outdoor units. The modeling input parameters were the same as the other air handler locations as shown in Table 65. Note also that the air handler multipliers for the attic, indoors, and outdoors are normalized to the garage, since this location was considered the baseline. The final report for this study can be viewed online at: http://www.fsec.ucf.edu/bldg/pubs/cr1357/index.htm.

Table 66 Florida Energy Code AH Multipliers for South Florida

\begin{tabular}{|c|c|c|c|c|c|c|}
\hline \multirow[b]{2}{*}{ AH Location } & \multicolumn{3}{|c|}{ Winter } & \multicolumn{3}{|c|}{ Summer } \\
\hline & Old & 2001 & new & old & 2001 & new \\
\hline Attic & 1.04 & 1.15 & 1.12 & 1.04 & 1.09 & 1.06 \\
\hline Garage & 1.00 & 1.00 & 1.00 & 1.00 & 1.00 & 1.00 \\
\hline Indoors & 0.93 & 0.91 & 0.94 & 0.93 & 0.91 & 0.92 \\
\hline Outdoors & 1.03 & 1.08 & 1.06 & 1.03 & 1.03 & 1.01 \\
\hline
\end{tabular}

Table 67 Florida Energy Code AH Multipliers for Central Florida

\begin{tabular}{|l|l|l|l|l|l|l|}
\hline \multirow{2}{*}{ AH Location } & Winter & Summer & Sum & old & 2001 & new \\
\cline { 2 - 7 } & Old & 2001 & new & 1.00 & 1.10 & 1.08 \\
\hline Attic & 1.04 & 1.11 & 1.08 & 1.04 & 1.00 & 1.00 \\
\hline Garage & 1.00 & 1.00 & 1.00 & 1.00 & 0.90 & 0.92 \\
\hline indoors & 0.93 & 0.92 & 0.94 & 0.93 & 1.02 & 1.01 \\
\hline outdoors & 1.03 & 1.09 & 1.05 & 1.03 &
\end{tabular}

Table 68 Florida Energy Code AH Multipliers for North Florida

\begin{tabular}{|c|c|c|c|c|c|c|}
\hline \multirow[b]{2}{*}{ AH Location } & \multicolumn{3}{|c|}{ Winter } & \multicolumn{3}{|c|}{ Summer } \\
\hline & Old & 2001 & new & old & 2001 & new \\
\hline attic & 1.04 & 1.10 & 1.03 & 1.04 & 1.11 & 1.08 \\
\hline garage & 1.00 & 1.00 & 1.00 & 1.00 & 1.00 & 1.00 \\
\hline indoors & 0.93 & 0.93 & 0.94 & 0.93 & 0.91 & 0.92 \\
\hline outdoors & 1.03 & 1.07 & 1.02 & 1.03 & 1.02 & 1.01 \\
\hline
\end{tabular}




\author{
Air Conditioning Condenser Fan Efficiency \\ Florida Solar Energy Center, Laboratory Facilities \\ Cocoa, Florida \\ Paper Parker, D., Sherwin, J., Hibbs, B., " Development of High \\ Efficiency Air Conditioner Condenser Fans", Draft paper \\ to be published in ASHRAE Transactions in June 2005.
}

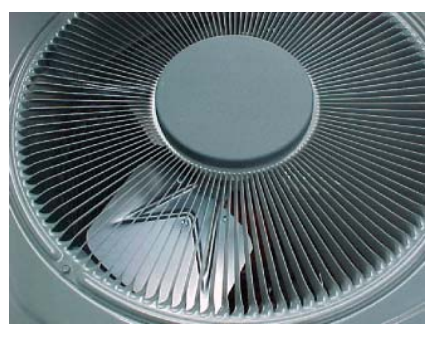

Figure 97 Air conditioning condenser fan and diffuser.

The purpose of this study is to develop an air conditioner condenser fan that reduces the electric energy use of the condensing unit (Figure 97). To accomplish this, researchers are designing and producing more aerodynamic fan blades and substituting smaller horsepower (HP) motors which achieve the same air flow rates as the larger, less efficient motors typically used.

$4^{\text {th }}$ Budget Period

During the 4th budget period, researchers developed baseline data for the fan power use in a standard condensing unit (Trane 2TTR2036) and tested a new prototype design: "Design A5" with five asymmetrical blades

Baseline data included condenser airflow, motor power, sound levels, and condenser cabinet pressures. Test results favorably compared with the manufacturer's test data. An experimental set of fan blades, "Design-A5," designed for a $1 / 8 \mathrm{hp}$ motor at $850 \mathrm{rpm}$ was numerically created and then successfully produced using rapid prototyping. These prototype blades were substituted on the original condenser, and all test measurements were redone. Design-A5 was found to reduce power use by $20 \%$ (40 watts) with approximately equivalent airflow to the original condensing blade design.

$5^{\text {th }}$ Budget Period

During the 5th budget period, activities included re-calibration and improvement of the test equipment configuration, refinement of various designs, and patent filing.

\section{Re-calibration and Improvement of Test Equipment Configuration}

The air flow measurement equipment was re-calibrated by the Energy Conservatory in Minneapolis in accordance with ANSI/ASHRAE 51-1985 ("Laboratory Methods of Testing Fans for Rating."). Testing determined that the "flow cube" could be modified with settling screens and a flow straightener to yield a 5\% absolute flow accuracy and a $2 \%$ relative accuracy from the test equipment. Also, the test configuration was moved indoors in order to better measure sound and also to reduce test variability from wind-related effects. Noise measurement protocol improved to comply with procedures used by the air conditioning industry.

Continued Testing to Refine the Identified Condenser Fan and Condenser Top Design All fans were re-evaluated after bringing the test apparatus into compliance with ANSI/ASHRAE 51-1985 ("Laboratory Methods of Testing Fans for Rating.") New fan prototypes "Design-D" and "Design E" were tested as well as a diffuser for a 27" fan and a specially prepared Electronically Commutated Motor (ECM) provided by General Electric.

All designs were also tested with the conical diffuser with $20-27 \%$ increases in measured flow from the low rpm designs, which use 8-pole motors. Sound measurements (Table 66) also 
showed large advantages with as much as a $4 \mathrm{~dB}$ reduction in fan sound level over the standard fan. The final test prototype with diffuser and fan is shown in Figure 98.

Table 66 Sound Measurements For Various Fan And Housing Designs

\begin{tabular}{|l|l|l|l|l|l|}
\hline Top & Fan & Motor & Flow & Power & Sound \\
\hline OEM/Starburst & OEM & 6-pole & $2170 \mathrm{cfm}$ & $197 \mathrm{~W}$ & $63.0 \mathrm{~dB}$ \\
\hline OEM-Foam & OEM & 6-pole & $2230 \mathrm{cfm}$ & $198 \mathrm{~W}$ & $63.0 \mathrm{db}$ \\
\hline Wire top & OEM & 6-pole & $2180 \mathrm{cfm}$ & $188 \mathrm{~W}$ & $62.0 \mathrm{~dB}$ \\
\hline Wire-Foam & OEM & 6-pole & $2250 \mathrm{cfm}$ & $190 \mathrm{~W}$ & $62.0 \mathrm{db}$ \\
\hline OEM-foam & A5 & 8-pole & $1945 \mathrm{cfm}$ & $145 \mathrm{~W}$ & $62.0 \mathrm{~dB}$ \\
\hline Wire-foam & A5 & 8-pole & $2110 \mathrm{cfm}$ & $146 \mathrm{~W}$ & $60.0 \mathrm{~dB}$ \\
\hline WhisperGuard w/foam & A5 & 8-pole & $2300 \mathrm{cfm}$ & $143 \mathrm{~W}$ & $58.5 \mathrm{~dB}$ \\
\hline
\end{tabular}

Presentation and Commercialization

In January, BAIHP researcher Danny Parker made a presentation at the DOE Expert meeting on HVAC and Fans in Anaheim, California and participated in productive meetings with Trane Corporation in May 2004 to discuss licensing of the technology under an existing non-disclosure agreement.

\section{Patents Pending}

U.S. Application Serial No. 10/400,888, Provisional applications 60/369,050 / 60/438,035 \& UCF-449CIP; WhisperGuard (UCF-Docket No. UCF-458)

Key Improvements from WhisperGuard Technology Tested Performance with Trane TTR2036 Condenser:

- $\quad$ Provides 46 Watt reduction in fan power (144 W vs. 190 Watts)

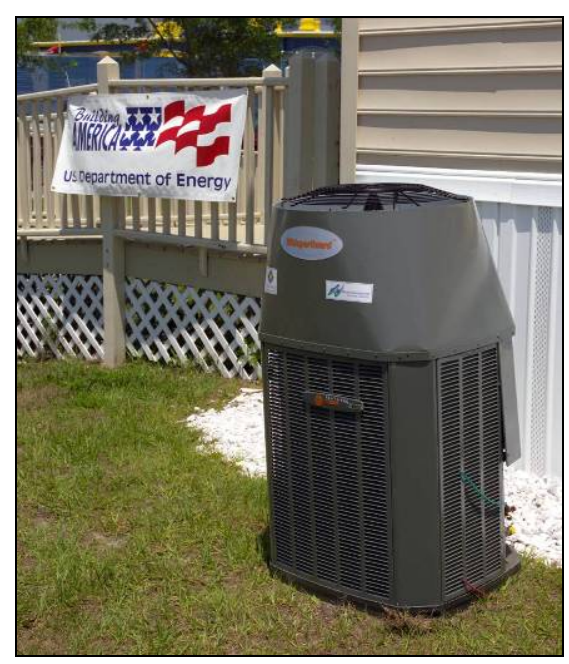

Figure 98 Final test prototype with diffuser and fan.

- Increases condenser air flow by $130 \mathrm{cfm}(6 \%$ increase in fan flow)

- Provides $102 \mathrm{~W}$ power reduction with ECM 142 motor

- Reduce ambient fan-only sound level by 4-5 dB

- ECM motor allows lower fan speeds for ultra-quiet night operation, higher flows for maximum capacity during very hot periods (temperature based control)

- Attractive hi-tech diffuser appearance

Key Technologies Employed

- High efficiency 5-bladed asymmetrical fan moves air quietly at lower fan speeds

- Diffuser top for effective pressure recovery increasing air flow at slow speed ranges

- Conical center body reduces exhaust swirl

- Acoustic sound control strip to reduce tip losses and control tip vortex shedding

Final Year of the Project

A detailed research paper on the progress on the condenser fan research and associated findings has been published within the ASHRAE Summer 2005 transactions and also is now published on-line. The paper was presented to a large audience in Denver at the meeting. The meeting was 
well attended by many HVAC manufactures. Both Lau Corp and Morrison Industries (large fan manufacturers for the AC industry) showed interest.

Work has been completed on larger 27.6" fans which will provide better performance for higher performance equipment (SEER 14+) with larger condensers. Detailed testing was performed on a 4-bladed fan with an annular diffuser with both PSC and ECM motors. Good results were obtained: $4580 \mathrm{cfm}$ at 202 Watts against $4260 \mathrm{cfm}$ and 244 Watts in the baseline configuration. Multiple tests with the ECM motors were obtained in April. We also produced a shorter diffuser for test which showed little compromise to air moving performance. With the ECM motor we obtained results with equivalent flow to the original test condition (4260 cfm at 244 watts) with only 147 Watts- almost a hundred watt power reduction ( $40 \%$ reduction in motor power). A version of this fan and assembly was delivered to California for their work on a hot-arid climate air conditioner. It is being tested in laboratories at Southern California Edison, however testing of the unit is not expected before November 2005 due to scheduling issues.

After describing performance to industry last summer, we are entering into discussions with Freus Air Conditioning about creating a fan with this advanced evaporatively pre-cooled air conditioner. Current fan power is on the order of 120 Watts. We expect we can reduce this by $30-50 \%$ with improved fan and exhaust section design. We have begun discussion with Rocky Bacchus regarding potential experimentation.

\section{Fenestration Research}

Florida Solar Energy Center, Laboratory Facilities

Cocoa, Florida

Research by BAIHP Researcher Ross McCluney

Fenestration: Windows \& Daylighting Website

In the $6^{\text {th }}$ budget period major revisions and additions were made to this website, located at http://www.fsec.ucf.edu/bldg/active/fen/index.htm.

\section{Website}

The website is now an effective education tool, and will help the consumer make informed, quality decisions concerning the technologies available for existing and new windows.

Work continues on the web site's Decision Tree, which, when complete, will be an interactive process to guide the consumer through a number of questions, providing the specifics for a particular application. At the end, a report will be prepared giving recommendations for the specifications to be used in selecting the correct combination of windows and/or shades for the windows in the home. An Oracle Forms runtime file has been completed and illustrations readied.

\section{AWNSHADE 3.0 Software Revision}

AWNSHADE was given an extensive revision, making it a fully Windows-compatible computer program. It is available online as a beta version. The program facilitates the calculation of solar heat gain through vertical windows having exterior shading surfaces, using overhangs, awnings, sidewalls, or a combination. 


\section{ASAP Ray Tracing}

The focus of this work is toward quantifying edge and other effects associated with Dr. McCluney's previously published model for solar heat gain through planar interior shades attached to single and double pane glazing systems. Other assumptions used to create the model will also be analyzed. In this way, the magnitude of the errors in those assumptions can be quantified, and perhaps the model improved.

A Visual Basic program to calculate the transmittance of a parallel plate of glass as a function of incidence angle was completed and used to generate glass transmittance data for comparison with results of ASAP ray trace calculations of this same quantity. The ray traces were completed and the Fresnel calculations and ray trace results were compared. The two different methods of calculation yielded plots that are indistinguishable, providing confirmation that the ray tracing methodology is completely equivalent to the results of exact calculations using the Fresnel Equations.

ASAP ray trace simulations of both specular and diffuse reflection from a planar shade behind a single pane glazing at any angle of incidence were made. Considerable effort was expended to get the traces of both the specular and diffuse shade cases running properly and plotting results as a function of the ratio of shade width to spacing from the glazing.

Measured data from David Tait will be compared with the model predictions and with the ray trace results. This data is the result of some calorimeter measurements of the solar heat gain coefficient for various glazings plus interior planar shade combinations, as well as the properties of the glazings and shades needed to perform the calculations of McCluney/Mills interior shade solar heat gain algorithm.

We continued ray tracing work on the solar transmittance through a glazing and interior shade and succeeded in setting up a loop over the aspect ratio (shade width divided by the glass-toshade gap spacing) for a given reflectance. This was repeated for different reflectances. The results of these and additional ray traces will be used to assess the assumptions used in the original model and to improve the model where needed.

The diffuse and specular shade files were run for a range of reflectances from 0.9 down to 0.2 . The results show that the specular model is not as terrible as its over-simplifications might indicate, as long as the aspect ratio is above a certain set of values.

Future work includes searching for ways to improve the model, especially at high shade reflectance values. We will look at the edge effects more closely and improve the analytical model at smaller aspect ratios. The results will be presented in a technical paper to be submitted to ASHRAE for publication later this year or early 2006. The timing of this additional work was extended, due to Dr. McCluney's semi-retirement from the university. 
American Society of Heating, Refrigerating, and Air Conditioning Engineers (ASHRAE)

Technical Committee

In 2002, BAIHP researchers wrote a statement of work for the development of a methodology to calculate solar spectral distributions incident on windows for various sun positions and atmospheric conditions. ASHRAE approved the project and sent it out for bid. Completion of this work project should make it much easier to determine the true solar heat gain through spectrally selective fenestration systems for varying atmospheric conditions and solar altitude angles.

\section{Calorimetric Measurements of Complex Fenestration Systems}

FSEC's research calorimeter will be used both indoors with the FSEC Vortek solar simulator and outside under natural solar radiation, on its Sagebrush solar tracker, for window solar heat gain experiments. The results of this testing will offer a way to test the solar gain properties of complex and other non-standard fenestration options for industrialized housing, such as exterior and interior shades and shutters, and those placed between the panes of double pane windows.

\section{Sagebrush Solar Tracker}

The computer program running the calorimeter, the Sagebrush tracker, and both together is complete. It contains a user-friendly graphic interface and offers a wide variety of experimental opportunities. There are many channels for adding additional temperature sensors and the calorimeter/tracker can be operated with either the sun as a source - in a variety of tracking modes - or with FSEC's Vortek solar simulator.

To conduct outdoor testing, the Neslab chiller must be connected to the flow meter, the temperature sensors to the calorimeter, and the calorimeter mounted on the tracker. The Sagebrush tracker now is functional, responding properly to commands sent from the computer, rotating in altitude, and azimuth and stopping when the limit switches are encountered. A telescopic sight and level for positioning it outdoors in the proper orientation for accurate solar tracking has been designed and is near fabrication completion.

The Neslab chiller and remote controller have been connected to a Gateway laptop computer and a RS-485 serial interface card necessary to operate the calorimeter has been installed. Researchers can now send commands and receive data from the chiller. Although the calorimeter is designed to work directly with the existing FSEC hydronic loop used for testing solar collectors, the Neslab will give an independent, standalone capability to the calorimeter. (Figure 99)

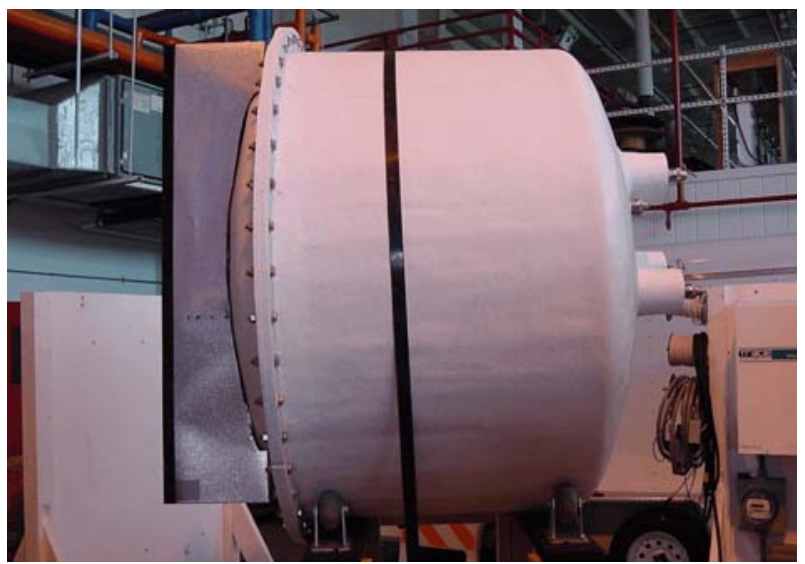

Figure 99 Side view of calorimeter before it was mounted on the Sagebrush Tracker.

The water flow meter purchased for measuring the flow into the calorimeter has been successfully connected to the Agilent (HP) 34970A data acquisition system and its measurements were incorporated into the calorimeter operating program. Temperature sensors also successfully connected to the data acquisition system, are reading properly, and have been 
incorporated into the calorimeter program. The program has coding to include a number of additional temperature channels once the temperature probes have been received and installed in the calorimeter. Another 20-channel input card is being purchased for the Agilent, to permit additional temperature readings. Knowing the flow rate and temperature difference, the heat delivered to the water by the calorimeter can now be accurately determined.

Now that all portions of the system are operational, researchers will configure the outdoor system, verify, and begin testing in Year 5.

\section{Vortek Solar Simulator}

In 2003, the Vortek Simulator was fired up and operated reliably on the calorimeter testing with FSEC's solar collector test apparatus. As expected, a few computer and other problems delayed initial data collection by a couple of days. However, these problems were corrected and testing proceeded normally.

During testing, the calorimeter was connected to the existing facility's hydronic loop, which was developed over a period of years to a temperature stability of 0.01 degrees centigrade. The irradiance level measured about 820 watts per square meter over an aperture of 0.557 square meters. The calorimeter was tested as though it were a flat plate collector, to obtain its efficiency curve. This was used to infer the thermal losses and solar heat gain coefficient of the eighth inch clear single pane of glass used for the test. The nominal wind speed was set by the laminar blower to five miles per hour. The coolant flow was run at levels of $0.2,0.5$, and 1.0 gallons per minute (GPM), and at varying inlet temperatures.

For all test runs, steady state conditions were established by observing the outlet temperature in a real-time plot as equilibrium was approached. During periods of non-equilibrium, the recorded data was used to measure the first-order system time constant, a function of the flow rate. The calorimeter time constant varied from 1.5 minutes at $1.0 \mathrm{GPM}$ to 6.9 minutes at $0.2 \mathrm{GPM}$. These time constants were obtained by blocking the incident beam and watching the decay in outlet temperature.

\section{Skylight Dome Transmittance}

Researchers completed work on the skylight dome transmittance, adding a spherical shape to the cylindrical one previously used. The ray tracing programming was changed to eliminate reflection of rays approaching the dome from the inside, for comparison with the analytical model, which does not yet include internal reflections. The difference between the two computational approaches, at a $30 \mathrm{E}$ solar zenith angle is $1.7 \%$, considered acceptable for rating skylight performance.

With both cylindrical and spherical dome models, transmittance at large solar zenith angles above 60 is substantially greater than for a horizontal flat plate. This is because most of the rays incident on the dome and entering the skylight are incident on the dome close to perpendicular, where dome transmittance is highest. 
EnergyGauge USA and EnergyGauge FlaRes

BAIHP mapped a table of window and shade characteristic simulations that could be run with these two programs. These runs will be used to determine the energy use of various fenestration options for Florida residences and to guide the preparation of instructional materials.

\section{Florida Market Transformation}

From the beginning of the BAIHP program, researchers have provided technical background information and support to the Alliance to Save Energy and the Efficient Windows Collaborative to promote the sale and installation of energy efficient fenestration in hot climates (such as Florida) and other areas for both conventional and industrialized homes. BAIHP also provides advice, technical information, and educational information to energy companies regarding window energy performance.

\section{National Fenestration Rating Council (NFRC) Technical Committee} In 2002, BAIHP presented a final report at a Task Group meeting in Houston, on the NFRCfunded work to develop a draft standard practice for the rating of tubular daylighting devices. That project is now complete.

In 2001, BAIHP researchers performed a number of ray traces on a highly reflective cylinder of varying lengths, using the trace results to determine the cylinder's transmittances for different interior surface reflectivities (from $90 \%$ to 100\%). These results generated a "default table" for determining the transmittance of this tubular daylighting component. Using simplified assumptions, and then multiplying the tube transmittance by the top and bottom dome transmittance results, researchers determined the total transmittance for a chosen sun angle. Based on the findings, BAIHP provided NFRC and the industry with a list of suggested research projects to test and develop this methodology further. One of these submitted projects was sent out for bid by ASHRAE in Year 4 and is expected to begin in Year 5.

\section{Tubular Daylighting Device SHGC and VT Value Calculations}

Following a request from the TDD industry, a sequence of operations and a new computer program were written to access the Window 5 glazing database and obtain from it the spectral transmittance and front and back reflectance data for any sheet of glazing in that database which might be used in making the top dome of a tubular daylighting device. This permits determination of the input parameters needed to run TDDTrans. The computer program was posted for free download and is available by clicking on http://www.fsec.ucf.edu/bldg/active/fenestration/Software/Software Download.htm

Access sequence:

- Download and run the Optics 5 program.

- Select the glazing to be used in the tubular daylighting device.

- Export its spectral data file as a standard ASCII text file. 


\section{Reflective Roofing Research}

Florida Solar Energy Center, Laboratory Facilities

Cocoa, Florida

Research by BAIHP Researchers Danny Parker and John Sherwin

Papers: $\quad$ Parker, D., J. Sherwin, J. Sonne, "Flexible Roofing Facility: 2004 Summer Test Results", FSEC July 2005

Parker, D., J. Sonne, J. Sherwin (2004). "Flexible Roofing Facility: 2003 Summer

Test Results", Prepared for U.S. Department of Energy Building Technologies Program, July 2004.

Parker, D., Sonne, J., Sherwin, J. (2003). Flexible Roofing Facility: 2002 Summer Test Results, Prepared for: U.S. Department of Energy Building Technologies Program, July 2003.

Parker, D. K., Sonne, J. K., Sherwin, J. R., \& Moyer, N. (2000). "Comparative Evaluation of the Impact of Roofing Systems on Residential Cooling Energy Demand." Florida Solar Energy Center Contract Report \#FSEC-CR-1220-00, Cocoa, FL.

Sonne, J K, D S Parker and J R Sherwin (2002). Flexible Roofing Facility: 2001 Summer Test Results. FSEC-CR-1336-02. Florida Solar Energy Center, Cocoa, FL.

Improving attic thermal performance is fundamental to controlling residential cooling loads in hot climates. Research shows that the influence of attics on space cooling is not only due to the change in ceiling heat flux, but often due to the conditions within the attic, and their influence on duct system heat gain and building air infiltration. (Figure 100)

The importance of ceiling heat flux has long been recognized, with insulation a proven means of controlling excessive gains. However when ducts are present in the attic, the magnitude of heat gain to the thermal distribution system can be

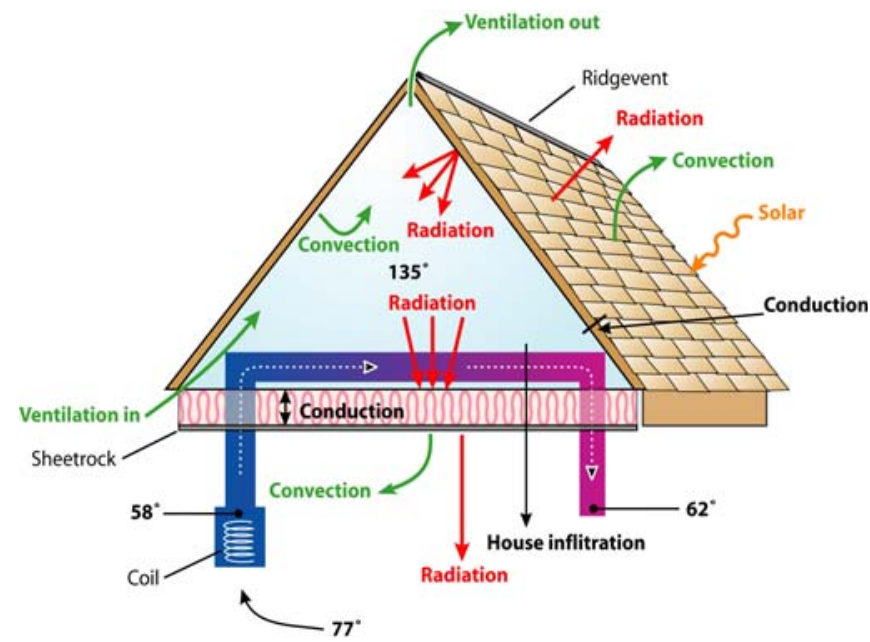

Figure 100 Vented attic thermal processes. much greater than the ceiling heat flux. This influence may be exacerbated by the location of the air handler within the attic space - a common practice in much of the southern US. Typically an air handler is poorly insulated and has the greatest temperature difference at the evaporator of any location in the cooling system. It also has the greatest negative pressure just before the fan so that some leakage into the unit is inevitable.

The Flexible Roof Facility (FRF) is an FSEC test facility designed to evaluate five roofing systems at a time against a control roof with black shingles and vented attic (Figure 101). The testing evaluates how roofing systems impact summer residential cooling energy use and peak demand. 


\section{Final Year Experiments}

The summer of 2005 featured the final reconfiguration of the test cells (Table 67) in FSEC's Flexible Roof Facility (FRF). Test Cell \#6 remained a white metal standing seam roof (best performer so far). Research will collect data on varied ventilation rates for FRF testing 2005 - a gap within the FSEC and roofing industry related research which is important to address. Instrumentation will obtain plywood decking moisture and attic moisture measurements as part of the protocol. All test cells were altered to R-30 insulation installed on the attic floor with the ventilation areas carefully verified by blower door pressurization. All test cells, except test cell \#6, now have black shingle roofs. Relative humidity sensors are being used to evaluate how the different attic ventilation strategies influence attic moisture conditions.

\begin{tabular}{|c|c|c|}
\hline \multicolumn{3}{|c|}{$\begin{array}{l}\text { Table } 67 \text { Roofing systems tested at the } \\
\text { FSEC Flexible Roofing Facility, Summer of } 2005\end{array}$} \\
\hline Cell \# & Description & $\underline{\text { Justification within experiment }}$ \\
\hline$\underline{6}$ & White metal roof, 1:300 ventilation & $\overline{\text { Best performing roofing system }}$ \\
\hline$\underline{5}$ & Reference, 1:300 ventilation area & Standard requirement for building codes \\
\hline$\underline{4}$ & Black shingles, 1:150 vent area & Added attic ventilation area per codes \\
\hline$\underline{3}$ & Black shingles, Sealed & $\begin{array}{l}\text { New ASHRAE recommendation to reduce } \\
\text { attic humidity }\end{array}$ \\
\hline$\underline{2}$ & Black shingles, 1:300, soffit & Evaluate impact of soffit vs. ridge venting \\
\hline$\underline{1}$ & Black shingles, 1:300, ridge & Evaluate impact of soffit vs. ridge venting \\
\hline
\end{tabular}

Early research results show that the balance of the ridge vs. soffit ventilation is critical in the performance of added ventilation - solely ridge or soffit vents (Cells 1 and 3) are barely more effective than no ventilation at all. As expected, 1:150 ventilation is more thermally advantageous than 1:300 ventilation, but not by a large amount.

Tests were made by alternately opening and closing midway the ridge vents in Test cell \#2 through the summer season to examine influences on performance. Relative humidity sensors were used to evaluate how the different attic ventilation strategies influence attic moisture conditions. Final analysis results will be published in the fall of 2006.

$6^{\text {th }}$ Budget Period Experiments

In the summer of 2004, the following roofing systems were tested (Table 68). Cell numbering is from left to right.

Table 68 Roofing systems tested at the FSEC Flexible Roofing Facility, Summer of 2004

\begin{tabular}{|c|c|}
\hline Cell \# & Description \\
\hline 1 & $\begin{array}{l}\text { Galvalume }{ }^{\circledR} * \text { unfinished (unpainted) 5-vee metal with vented attic (3rd year of } \\
\text { exposure) }\end{array}$ \\
\hline 2 & Proprietary test cell \\
\hline 3 & Proprietary test cell \\
\hline 4 & Galvanized unfinished 5-vee metal with vented attic (3rd year of exposure) \\
\hline 5 & Black shingles with standard attic ventilation (Control Test Cell) \\
\hline 6 & White standing seam metal with vented attic (3rd year of exposure after cleaning) \\
\hline
\end{tabular}


All had R-19 insulation installed on the attic floor. The measured thermal impacts include ceiling heat flux, unintended attic air leakage and duct heat gain. Test Cells \#2 and \#3 had proprietary test configurations that are not further described in this report.

The white metal roof results in the coolest attic over the summer, with an average day peak air temperature of only $95.7^{\circ} \mathrm{F}-22.2^{\circ}$ cooler than the peak in the control attic with dark shingles.

This was the third year of

comparative testing metal roofing (galvanized and Galvalume ${ }^{\circledR}$ ) under long term conditions. Galvalume ${ }^{\circledR}$ roofs are reported to better maintain their higher solar reflectance than galvanized types. Average daily midattic maximum temperatures for the Galvalume ${ }^{\circledR}$ and galvanized metal roof systems showed significantly better performance for Galvalume ${ }^{\circledR}$ product $\left(10.9^{\circ} \mathrm{F}\right.$ and $2.1^{\circ} \mathrm{F}$ cooler than the control dark shingle respectively). However, both unfinished metal roofs showed significant degradation in their performance over the three year period compared to the white metal roof.

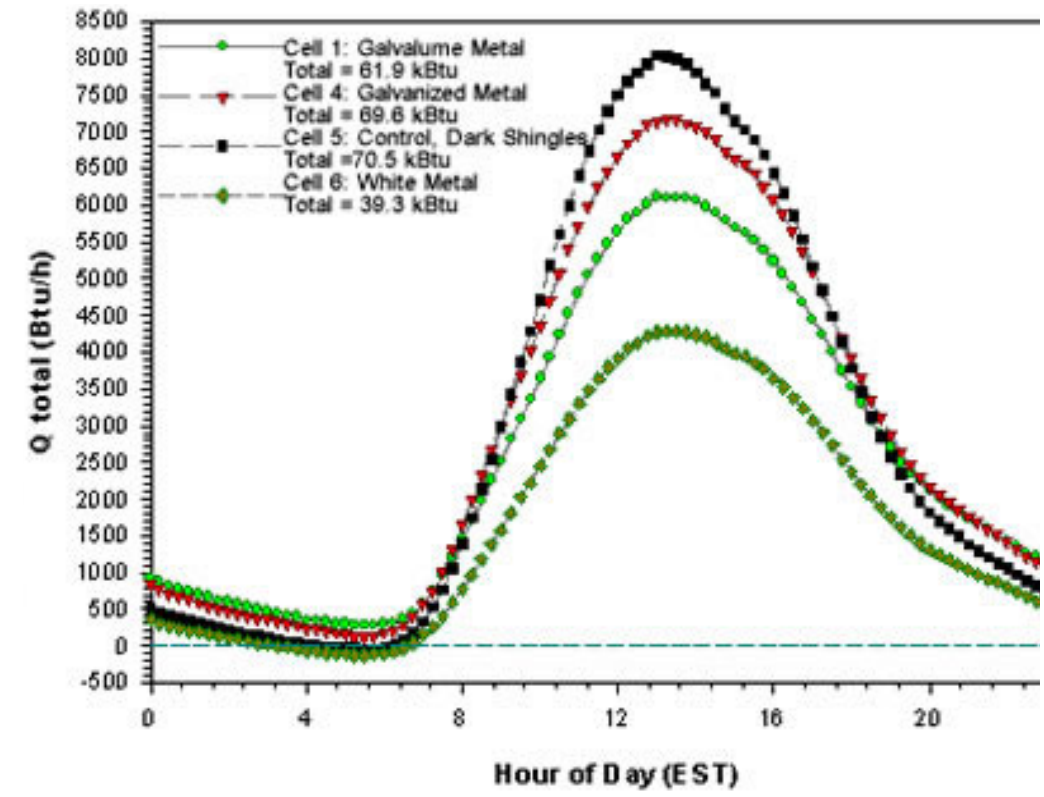

Figure 1022004 Results Estimated combined impact of duct heat gain, air leakage from the attic to conditioned space and ceiling heat flux on space cooling needs on an average summer day in a 2,000 ft2 home.

We also estimated the combined impact of ceiling heat flux, duct heat gain and unintended attic air leakage from the various roof constructions. The alternative constructions produced lower estimated cooling energy loads than the standard vented attic with dark shingles. The Galvalume ${ }^{\circledR}$ roof clearly provided greater reductions to cooling energy use than the galvanized roof after three summers of exposure, although both suffered significant degradation relative to the first year's performance. More specifically, the Galvalume ${ }^{\circledR}$ and Galvanized roof system provided a $32 \%$ and $22 \%$ savings in the first year of exposure, but only $12 \%$ and $1 \%$ respectively after three years of exposure.

One important fact from our testing is that nighttime attic temperature and reverse ceiling heat flux have a significant impact on the total daily heat gain, particularly for the metal roofs. The rank order below shows the percentage reduction of roof/attic related heat gain and approximate overall building cooling energy savings (which reflect the overall contribution of the roof/attic to total cooling needs):

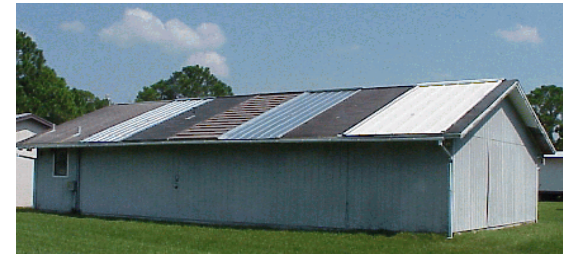

Figure 101 Flexible Roof Facility in summer of 2003 configuration. 
Table 69 Cooling Load Reduction and Savings

\begin{tabular}{|l|l|l|c|}
\hline Rank & Description & $\begin{array}{l}\text { Roof Cooling Load } \\
\text { Reduction }\end{array}$ & $\begin{array}{l}\text { Overall Cooling } \\
\text { Savings }\end{array}$ \\
\hline 1 & White Metal with vented attic (Cell \#6) & $44 \%$ & $15 \%$ \\
\hline 2 & $\begin{array}{l}\text { Galvalume } \mathbb{R} \text { unfinished metal with } \\
\text { vented attic (Cell \#1) }\end{array}$ & $12 \%$ & $4 \%$ \\
\hline 3 & $\begin{array}{l}\text { Galvanized unfinished metal roof with } \\
\text { vented attic (Cell \#4) }\end{array}$ & $1 \%$ & $0 \%$ \\
\hline
\end{tabular}

The relative reductions are consistent with the whole-house testing recently completed for FPL in Ft. Myers (Parker et al., 2001). This testing showed white metal roofing having the largest reductions, followed by darker constructions. After long-term exposure, test results indicate that galvanized metal roofing is no better than a standard asphalt shingle roof after three years of exposure. On the other hand, the Galvalume roof does maintain some advantage although not nearly so great as the white metal type.

$\underline{5^{\text {th }} \text { Budget Period Experiments }}$

The roofing systems tested in the summer of 2003 are listed in Table 70. Cell numbering is from left to right beginning with the second cell in from the left.

Table 70 Roofing systems tested at the FSEC Flexible Roofing Facility, Summer of 2003

\begin{tabular}{|c|c|}
\hline Cell \# & Description \\
\hline 1 & Galvalume ${ }^{\circledR} *$ unfinished 5 -vee metal with vented attic $\left(2^{\text {nd }}\right.$ year of exposure $)$ \\
\hline 2 & Sealed attic with proprietary configuration \\
\hline 3 & High reflectance brown met \\
\hline 4 & Galvanized unfinished 5-vee metal with vented attic $\left(2^{\text {nd }}\right.$ year of exp \\
\hline 5 & Black shingles with standard attic ventilation (Control Test Cell) \\
\hline 6 & Standing seam metal with vented attic ( $2^{\text {nd }}$ year of exposure after cleaning) \\
\hline \multicolumn{2}{|c|}{$\begin{array}{l}\text { * Galvalume is a quality cold-rolled sheet to which is applied a highly corrosion-resistant hot-dip metallic coating } \\
\text { consisting of 55\% aluminum } 43.4 \% \text { zinc, and } 1.6 \% \text { silicon, nominal percentages by weight. This results in a sheet } \\
\text { that offers the best protective features characteristic of aluminum and zinc: the barrier protection and long life of } \\
\text { aluminum and the sacrificial or galvanic protection of zinc at cut or sheared edges. According to Bethlehem Steel, } \\
\text { twenty-four years of actual outdoor exposure tests in a variety of atmospheric environments demonstrate that bare } \\
\text { Galvalume sheet exhibits superior corrosion-resistance properties. }\end{array}$} \\
\hline
\end{tabular}

All had R-19 insulation installed on the attic floor except in the configuration with the sealed attic (Cell \#2) which had R-19 of open cell foam sprayed onto the bottom of the roof decking. The measured thermal impacts include ceiling heat flux, unintended attic air leakage and duct heat gain. Cell \#2 had a proprietary configuration which is not reported upon in this report. A major thrust of the testing for 2003 was comparative testing of metal roofing under long term exposure. Given the popularity of unfinished metal roofs, we tested both galvanized and Galvalume ${ }^{\circledR}$ roofs in their second year of exposure.. Average daily mid-attic maximum temperatures for the Galvalume ${ }^{\circledR}$ and galvanized metal roof systems showed significantly better performance for Galvalume ${ }^{\circledR}$ product $\left(17.5^{\circ} \mathrm{F}\right.$ and $13.1^{\circ} \mathrm{F}$ cooler than the control dark shingle respectively). 
Other than the sealed attic case, the white metal roof results in the coolest attic over the summer, with an average peak of only $94.6^{\circ} \mathrm{F}-22.1^{\circ}$ cooler than the peak in the control attic with dark shingles. The highly reflective brown metal shingle roof (Cell \#3) provided the next coolest peak attic temperature. Its average maximum daily mid-attic temperature was $101.5^{\circ} \mathrm{F}\left(15.2^{\circ} \mathrm{F}\right.$ lower than the control dark shingle cell). While the brown metal shingle roof's reflectance was lower than the two metal roofs and white metal roof we observed evidence that the air space under the metal shingles provides additional effective thermal insulation.

We also estimated the combined impact of ceiling heat flux, duct heat gain and unintended attic air leakage from the various roof constructions. All of the alternative constructions produced lower estimated cooling energy loads than the standard vented attic with dark shingles (Figure 103). The Galvalume ${ }^{\circledR}$ roof clearly provided greater reductions to cooling energy use than the galvanized roof after two summers of exposure.

Nighttime attic temperature and reverse ceiling heat flux have a significant impact on the total daily heat gain, particularly for the metal roofs. The rank order in Table 71 shows the percentage reduction of roof/attic related heat gain and approximate overall building cooling energy savings (which reflect the overall contribution of the roof/attic to total cooling needs):

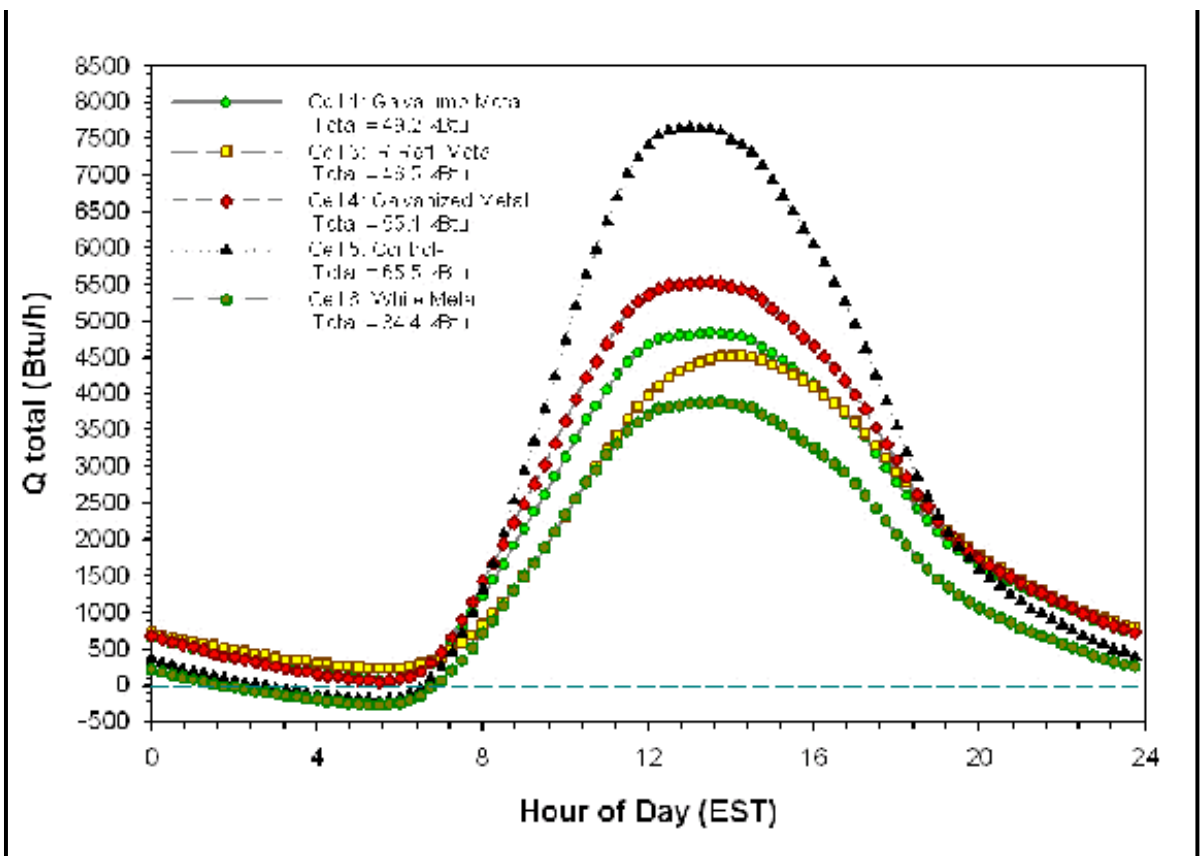

Figure 103 Estimated combined impact of duct heat gain, air leakage from the attic to conditioned space and ceiling heat flux on space cooling needs on an average summer day in a 2,000 $\mathrm{ft}^{2}$ home. 
Table 71 Roof cooling load reduction and overall cooling savings, Summer 2003

\begin{tabular}{|l|l|c|c|}
\hline Rank & $\begin{array}{l}\text { Roof Cooling } \\
\text { Load } \\
\text { Reduction }\end{array}$ & $\begin{array}{c}\text { Overall } \\
\text { Cooling } \\
\text { Savings }\end{array}$ \\
\hline 1 & $\begin{array}{l}\text { Description } \\
\text { White metal with vented attic (Cell \#6) }\end{array}$ & $47 \%$ & $15 \%$ \\
\hline 2 & $\begin{array}{l}\text { High reflectance brown metal shingle with vented attic (Cell } \\
\# 3)\end{array}$ & $29 \%$ & $10 \%$ \\
\hline 3 & Galvalume $R$ unfinished metal with vented attic $($ Cell \#1) & $25 \%$ & $8 \%$ \\
\hline 4 & Galvanized unfinished metal roof with vented attic $($ Cell \#4) & $16 \%$ & $5 \%$ \\
\hline
\end{tabular}

$4^{\text {th }}$ Budget Period Experiments

In the summer of 2002, six roofing systems were evaluated as described in Table 72 and Figure 104.

Table 72 Roofing systems tested and associated energy savings at the FSEC Flexible Roofing Facility, Summer of 2002

\begin{tabular}{|c|l|l|c|c|}
\hline Cell \# & Roof Material & $\begin{array}{l}\text { Venti- } \\
\text { lation }\end{array}$ & $\begin{array}{l}\text { Roof Cooling } \\
\text { Load Reduction }\end{array}$ & $\begin{array}{l}\text { Overall Cooling } \\
\text { Savings }\end{array}$ \\
\hline$\# 1$ & Galvalume $\mathbb{R}$ unfinished 5-vee metal & vented & $32 \%$ & $11 \%$ \\
\hline$\# 2$ & double roof with radiant barrier (ins roof deck) & sealed & $7 \%$ & $2 \%$ \\
\hline$\# 3$ & high reflectance ivory metal shingle & vented & $38 \%$ & $12 \%$ \\
\hline$\# 4$ & galvanized unfinished 5-vee metal & vented & $22 \%$ & $7 \%$ \\
\hline$\# 5$ & black shingles (control cell) & vented & control & control \\
\hline$\# 6$ & white standing seam metal & vented & $7 \%$ & $2 \%$ \\
\hline
\end{tabular}

All roof cells had R-19 insulation installed on the attic floor, except the double roof configuration (Cell \#2) which had a level of R-19 open cell foam sprayed onto the bottom of the roof decking. Measured thermal impacts included ceiling heat flux, unintended attic air leakage, and duct heat gain.

The sealed attic double roof system (Cell \#2) provided the coolest attic space of all systems tested (average maximum mid-attic temperature was $81.1^{\circ} \mathrm{F}$ ), and therefore had the lowest estimated impact due to return air leakage and duct conduction heat gains. However this cell also had the highest ceiling heat flux of all strategies tested, and recorded the most modest space cooling reduction $(7 \%)$, relative to the control roof.

Metal roof testing was given more emphasis in 2002

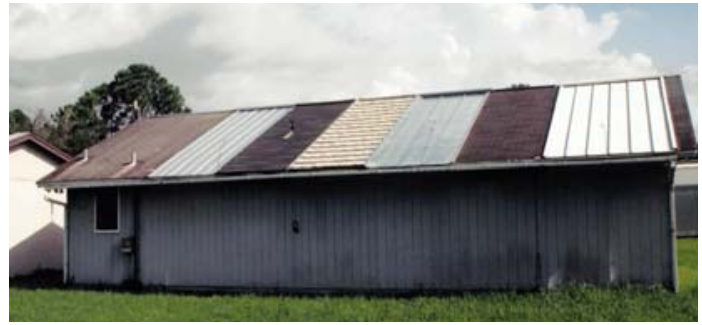

Figure 104 Flexible Roof Facility in summer 2002 configuration. Cells are numbered from left to right starting with the second cell in from the left. due to the popularity of these products. Researchers tested both galvanized and Galvalume ${ }^{\circledR}$ roofs. Galvalume is a cold-rolled sheet with a highly corrosion-resistant hot-dip metallic coating application of 55\% aluminum $43.4 \%$ zinc, and 1.6\% silicon. These roofs are reported to better maintain solar reflectance than galvanized roofing 


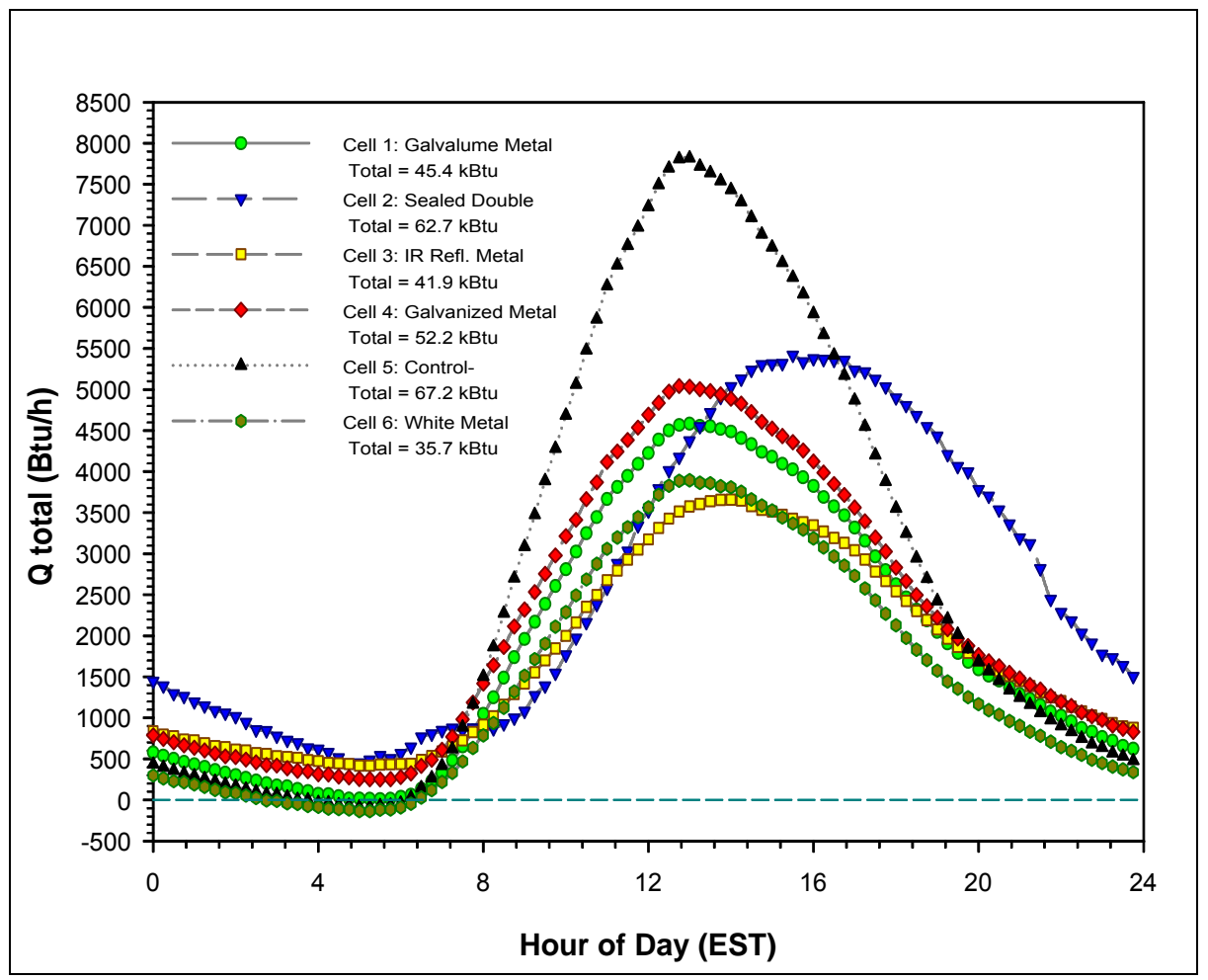

Figure 1052002 estimated combined impact of duct heat gain, air leakage from the attic to conditioned space, and ceiling heat flux on space cooling needs on an average summer day in a 2,000 $\mathrm{ft}^{2}$ home.

systems. Average daily mid-attic maximum temperatures for the Galvalume ${ }^{\mathbb{B}}$ and galvanized metal roof systems were roughly similar $\left(19.6^{\circ} \mathrm{F}\right.$ and $17.3^{\circ} \mathrm{F}$ cooler than the control roof, respectively). The estimated total heat gain for these roof cells also was relatively close. The highly reflective ivory metal shingle roof (Cell \#3) provided the coolest peak attic temperature of all the cells without roof deck insulation. Its average maximum daily mid-attic temperature was $93.3^{\circ} \mathrm{F}\left(23.4^{\circ} \mathrm{F}\right.$ lower than the control dark shingle cell $)$. While the ivory metal shingle roof's reflectance was slightly lower than the two metal roofs and white metal roof, researchers noted that the air space under the metal shingles provided additional effective thermal insulation.

Researchers also estimated the combined impact of ceiling heat flux, duct heat gain, and unintended attic air leakage from the various roof constructions. All of the alternative roofing treatments produced lower estimated cooling energy loads than the standard vented attic with dark shingles. (Figure 105) The Galvalume ${ }^{\circledR}$ roof clearly provided a greater cooling energy use reduction than the galvanized roof. This also was true during the 2001 study. Nighttime attic temperatures and reverse ceiling heat flux have a significant impact on the total daily heat gain, particularly for metal roofs. 
$3^{\text {rd }}$ Budget Period

In the 2001 testing, Cell \#2 with the double roof/sealed attic showed the lowest attic temperatures and narrowest temperature range. (Table 73; Figures 107 and 108) Peak attic temperatures in Cell $\# 2$ were $5^{\circ} \mathrm{F}$ to $6^{\circ} \mathrm{F}$ lower than this same sealed cell the year before, without the double roof. This indicates that the double roof did provide a substantial benefit. Since there is no insulation on the

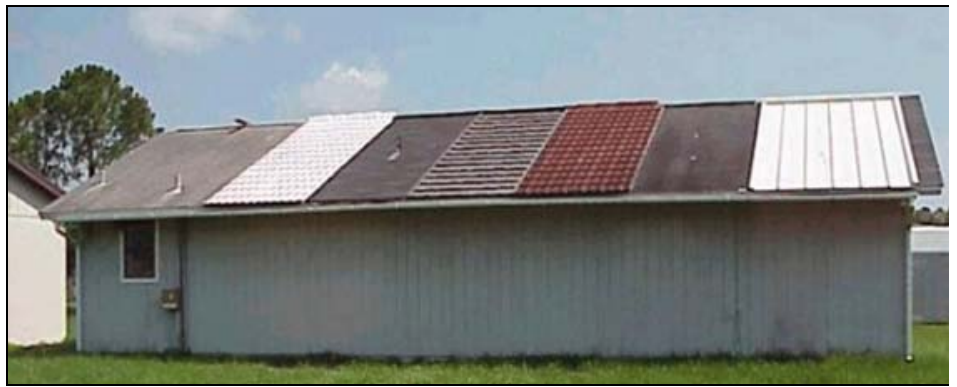

Figure 1062001 Experimental roof cell. Cells are numbered from left to right starting with the cell second in from the left. attic floor though, there still is a significant heat gain across the ceiling. In fact, the ceiling heat fluctuation actually is higher than the reference Cell \#5. (Figure 107)
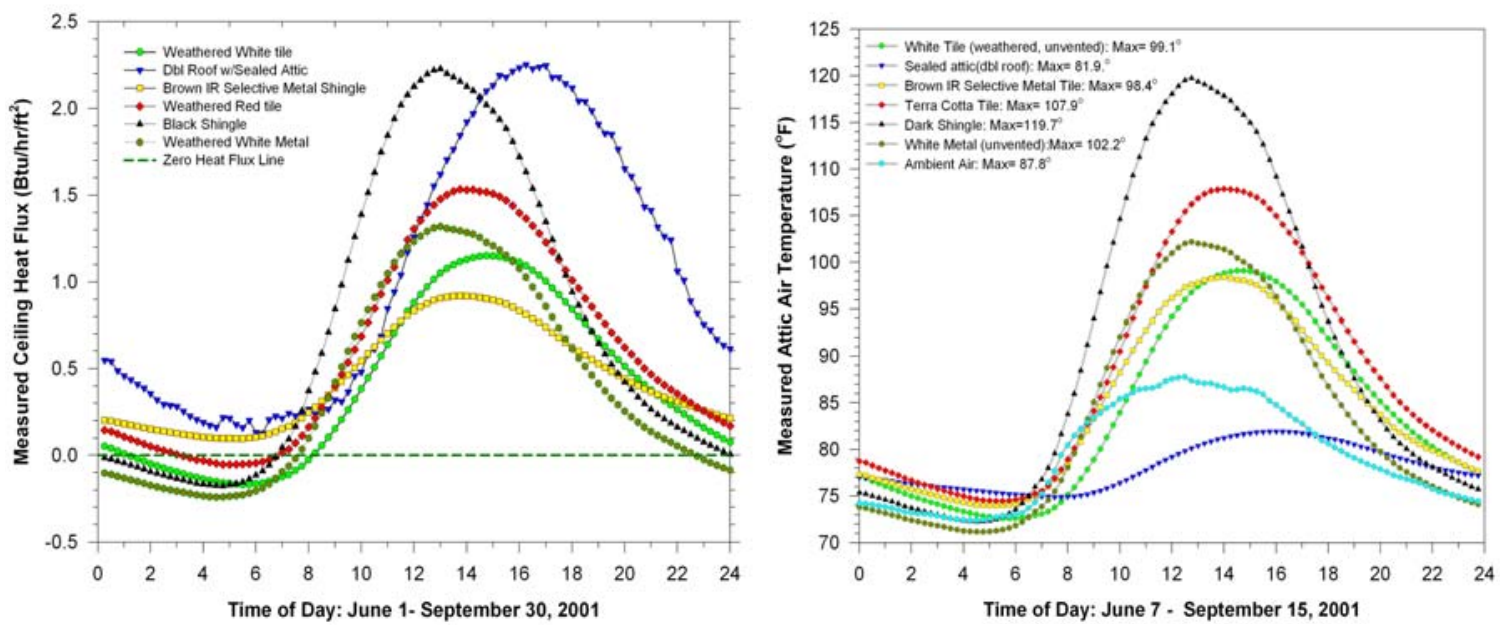

Figure 107 (left) 2001 heat flux measurements across attic. Figure 108 (right) 2001 mid-attic temperatures.

The true impact of the double roof construction of Cell \#2 is most likely a combination of the benefits of a cooler attic space that reduces duct heat gain and minimizes the effects of air leakage from the attic into the house, and the drawback of the higher ceiling heat flux. Cell \#3 with its spectrally selective dark brown metal shingles, produced lower attic temperatures at night, but higher roof deck temperatures (which were most likely due to the insulating quality of the shingles which have an air space underneath them). 
Table 73 Roofing systems tested and attic temperatures at the FSEC Flexible Roofing Facility, Summer of 2001

\begin{tabular}{|c|l|l|l|l|}
\hline Cell \# & Roof Material & $\begin{array}{l}\text { Venti- } \\
\text { lation }\end{array}$ & $\begin{array}{l}\text { Avg Attic } \\
\text { Temp }\end{array}$ & $\begin{array}{l}\text { Max Attic } \\
\text { Temp }\end{array}$ \\
\hline$\# 1$ & white tile (weathered) & sealed & 84.6 & 111.2 \\
\hline$\# 2$ & double roof with radiant barrier (ins roof deck) & sealed & 78.4 & 85.4 \\
\hline$\# 3$ & brown IR selective metal shingle & vented & 85.0 & 110.8 \\
\hline$\# 4$ & terra cotta tile (weathered) & vented & 89.0 & 124.3 \\
\hline$\# 5$ & dark shingles (control) & vented & 91.0 & 143.4 \\
\hline$\# 6$ & white standing seam metal (weathered) & sealed & 84.0 & 115.5 \\
\hline
\end{tabular}

Roofing Experiment with Habitat for Humanity in Fort Myers, Florida In July 2000, FSEC and Florida Power and Light instrumented six side-by-side Habitat for Humanity homes in Ft. Myers with identical floor plans, orientation, and ceiling insulation, but with different roofing systems as described in Table 74. A seventh monitored house contained an unvented attic with insulation on the underside of the roof deck rather than on the ceiling.

Each unoccupied home was monitored from July 8 through July 31, 2001 to collect building thermal and air conditioning power data. Table 75 presents the cooling performance of the roofing systems clearly showing the energy-saving benefits of reflective roofing systems in Florida, especially the tile and metal roofs with solar reflectance between $65 \%$ and $75 \%$.

Table 74 Roofing systems tested at side-by-side Habitat for Humanity homes in Ft. Myers Summer of 2000

\begin{tabular}{|l|l|l|l|}
\hline Code & Description & Code & Description \\
\hline RGS & Standard dark shingles (control) & RTB & Terra cotta "barrel" S-tile roof \\
\hline RWS & Light colored shingles & RWB & White "barrel" S-tile roof \\
\hline RWM & White metal roof & RWF & White flat tile roof \\
\hline RSL & $\begin{array}{l}\text { Standard dark shingles with sealed attic } \\
\text { \& R-19 roof deck insulation }\end{array}$ & & \\
\hline
\end{tabular}


Table 75 Energy use and savings from roofing systems in Habitat for Humanity roofing study, summer of 2000

\begin{tabular}{|l|l|l|l|l|l|l|}
\hline Site & $\begin{array}{l}\text { Total } \\
\mathbf{k W h}\end{array}$ & $\begin{array}{l}\text { Savings } \\
\mathbf{k W h}\end{array}$ & $\begin{array}{l}\text { Saved } \\
\text { Percent }\end{array}$ & $\begin{array}{l}\text { Demand } \\
\mathbf{k W}\end{array}$ & $\begin{array}{l}\text { Savings } \\
\mathbf{k W}\end{array}$ & $\begin{array}{l}\text { Saved } \\
\text { Percent }\end{array}$ \\
\hline RGS & 17.03 & ---- & ---- & 1.63 & ---- & ---- \\
\hline RWS & 15.29 & 1.74 & $10.2 \%$ & 1.44 & 0.19 & $11.80 \%$ \\
\hline RSL & 14.73 & 2.30 & $13.05 \%$ & 1.63 & 0.01 & $0.30 \%$ \\
\hline RTB & 16.02 & 1.01 & $5.9 \%$ & 1.57 & 0.06 & $3.70 \%$ \\
\hline RWB & 13.32 & 3.71 & $21.8 \%$ & 1.07 & 0.56 & $34.20 \%$ \\
\hline RWF & 13.20 & 3.83 & $22.5 \%$ & 1.02 & 0.61 & $37.50 \%$ \\
\hline RWM & 12.03 & 5.00 & $29.4 \%$ & 0.98 & 0.65 & $39.70 \%$ \\
\hline
\end{tabular}

Significant findings: Reflective roofing materials represent one of the most significant energysaving options available to homeowners and builders. These materials also reduce cooling demand during utility coincident peak periods, and are potentially one of the most effective methods for controlling demand.

- Based on comparative data from August of 2000, the maximum decking temperatures in the sealed attic home were 23EF higher than the control home (177E versus 154E). After the installation of white shingles in midsummer, the highest deck temperature from the sealed attic home measured only $7 \mathrm{E}$ higher than the control in August of 2001 (161E versus 154E).

- An additional month's data was collected with the homes occupied and thermostat set points kept constant. Average cooling energy use for the homes rose by $36 \%$, but there was no decrease in the highly reflective roofing system savings.

Additional heat gained from the occupants and their appliance use increased the cooling system runtime and introduced more hot air into the air conditioning duct system.

- In 2001, the average maximum attic air temperature in the terra cotta barrel tile roof home was $15 \mathrm{EF}$ hotter than the maximum ambient. After installing a radiant barrier the average difference in August was +9EF. A similar evaluation with the light colored shingles showed that peak attic air temperatures dropped from $+29 \mathrm{E}$ to $+20 \mathrm{EF}$ after installing a radiant barrier.

- Household interior temperature settings varied from one year to the next, making direct energy saving comparisons impossible. Still, the collected data did show that attic air temperatures were reduced by the radiant barrier. On the other hand, measured maximum plywood decking temperatures rose by $11 \mathrm{E}$ to $13 \mathrm{EF}$.

- Based on previously evaluated roof buckling problems on the decking of the sealed attic home, researchers decided to install white shingles similar to those on the RWS roof. It was thought that buckling problems likely were caused by excessive heat buildup in this roofing system. White shingles replaced the dark shingles to see if this would drop the roof decking temperature spikes. 


\section{Return Air Pathway Study}

Research by BAIHP Researcher Neil Moyer with BAIHP Industry Partner Tamarack

\section{$\underline{\text { Scope }}$}

In effect since March 2003, Section 601.4 of the Florida Building Code applies to residential and commercial buildings having interior doors and one, centrally located return air intake per heating and cooling system.

Objective Of The New Florida HVAC Code Requirement Reduce pressure difference in closed rooms with respect to (wrt) the space where the central return is located to 0.01 " water column (wc) or 2.5 Pascal $(\mathrm{Pa})$ or less. Pressure imbalances created by restricted return air flow from rooms isolated from the central return by closed interior doors create uncontrolled air flow patterns.

\section{Technical Background}

Ideally, forced-air heating and cooling systems circulate an equal volume of return air and supply air through the conditioning system, keeping air pressure throughout the

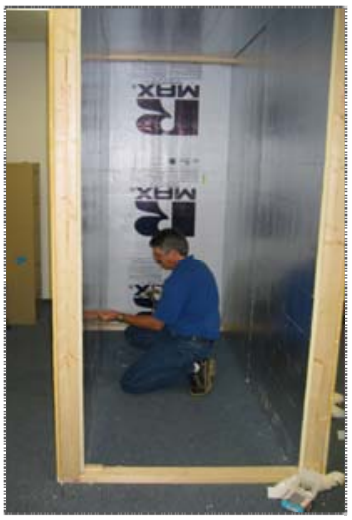

Figure 107 Return Air Flow Test Chamber building neutral. Each conditioned space in the building should, ideally, be at neutral air pressure at all times.

When a space is under a positive air pressure, indoor air will be pushed outward in the walls, floor and ceiling. When a space is under a negative pressure, air will be pulled inward through the walls, floor and ceiling. Negative and positive air pressures in buildings result from uncontrolled air flow patterns.

Section 601.4 of the Florida Building Code specifically deals with the uncontrolled air flow pattern when interior doors are closed thereby reducing return air flow from the closed room, while maintaining the same supply air flow to the room. This imbalance of supply and return air has been addressed conventionally by the common practice of undercutting interior doors to allow return air to flow from the room. This research quantifies the volume of air flow provided by this and other methods of return air egress from closed rooms.

Section 601.4 limits the air pressure imbalance in closed rooms to 0.01 " wc or 2.5 pascals when compared to, or with respect to (wrt), the main body of the building where the return is located. With door undercuts, researchers have regularly observed room pressures with respect to the main body of the house ( wrt $_{\text {mainbody }}$ ) of +7 pascals (pa) or more. A room with this level of air pressure ( $+7 \mathrm{pa}$, wrt $\left._{\text {mainbody }}\right)$ is trapping air, starving the heating/cooling system of return air. As the heating/cooling system struggles to pull in the designed amount of air, the resulting negative pressure pulls air into the main body of the building along the path(s) of least resistance. Usually this means that air is flowing through the walls, floor and ceiling from unconditioned spaces or outside environment to makeup for the trapped air in the closed room.

In the closed room, positive pressure builds up when return air is trapped. Conversely, the space with the central return gets depressurized because extra return air is being removed to make up for the air trapped in the closed room. More air is leaving the space (return air) than is entering 
the space (supply air). The positive pressure in the closed rooms pushes air into unconditioned spaces, such as the attic and wall cavities. The negative pressure in the main body of the building pulls air from unconditioned spaces. In Florida, the air brings heat and moisture with it that becomes an extra cooling load. This air is referred to as "mechanically induced infiltration" since the negative pressure drawing infiltration air in was created by the mechanical system.

\section{Styles of Pressure Relief}

When return air flow is restricted by closed doors, it creates pressure differences between parts of the building. This can be prevented by installing a fully ducted return system, by creating a passive return air pathway such as a louvered transoms, door undercut, "jump duct", throughwall grilles, or a baffled through-wall grill.

A "jump duct" is simply a piece of flex duct attached to a ceiling register in the closed room and another ceiling register in the main body of the house. A jumper duct provides some noise control while providing a clear air flow path.

A through-wall grille is the simplest and least expensive approach to pressure relief for closed rooms. Holes opposite each other on either side of the wall within the same stud bay are covered with a return air grilles. The downside of this approach is a severe compromise the privacy of the closed room. An improvement on this theme would be to locate one of the grilles high on the wall and the opposing opening low on the wall. Also, such openings in interior wall cavities introduce conditioned air into what is typically an unconditioned space possibly contributing to other building problems.

However, connecting the two openings with a sleeve of rigid ducting forms an enclosed air flow path that limits introduction of conditioned air into the wall cavity but doesn't solve the visual and sound privacy issues. To address this problem, BAIHP Industry Partner Tamarack developed a sleeve with a baffle that can reduce the transfer of light and sound but still provide adequate air flow to minimize pressure differences. The product is called a Return Air Path (RAP).

To validate the effectiveness of this product and other approaches to providing return air pathways, Tamarack and BAIHP researchers devised a test apparatus and conducted experiments in FSEC's Building Science Laboratory.

\section{Testing Protocol}

In May of 2003, a chamber was constructed at FSEC (Figures 107-110) that simulated a frame construction room with an 8 foot high ceiling. A "Minneapolis Duct Blaster" was connected to one end of the room with a flexible duct connection leading out of the room to provide control over pressure in test chamber.

In the middle of the chamber, on a stool, a radio was tuned "off station" to effectively create a standardized level of "white noise" at $57 \mathrm{dBA}$ inside the chamber with the "door" closed. The temperature at the start of the tests was $80^{\circ} \mathrm{F}$ at $40 \% \mathrm{RH}$. A sound meter was located outside the chamber on a stand 4 feet above the floor and 20 inches from the middle of the chamber wall surface.

The sound level in the test facility outside the chamber with the "white noise" turned off was $36.4 \mathrm{dBA}$ and with the "white noise" turned on was $41.5 \mathrm{dBA}$, an average, sampled over a 30 
second period. A series of tests on 31 different set-ups were performed, measuring the flow at 3 different pressure levels and recording a 30 second sound sample with the "Duct Blaster" deactivated.

Tests were made for 6" and 8" jump ducts, five different sized wall openings (Figure 107) in different configurations including straight through with and without sleeves, straight through with sleeve and privacy baffle (Figure 108), and high/low offset using the wall cavity as a duct, and three different slots simulating three different size undercut doors.

\section{$\underline{\text { Results }}$}

Table 76 summarizes the results of these tests arranged in ascending air flow order based on the results at 2.5 Pascals $(0.01$ " wc), the maximum allowable pressure in a closed room under new requirement in Florida Building Code, Section 601.4.

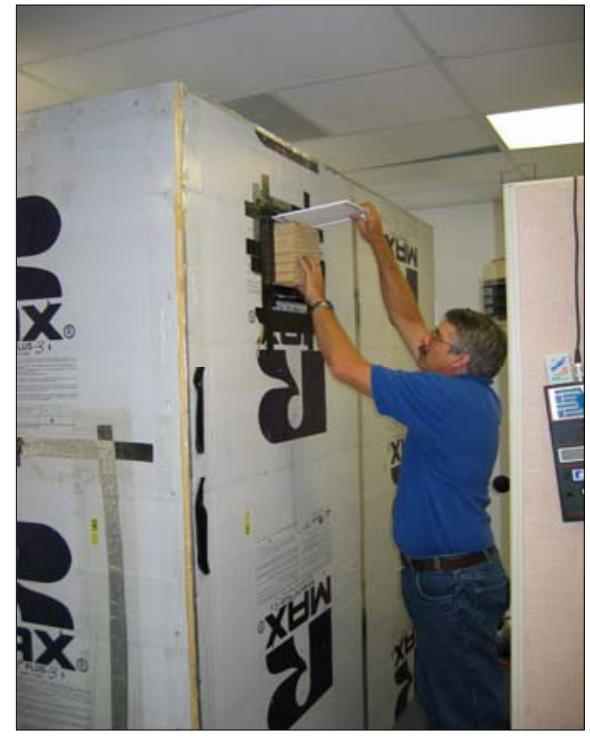

Figure 108 Installing sound baffled return air flow through wall insert made by Tamarack.

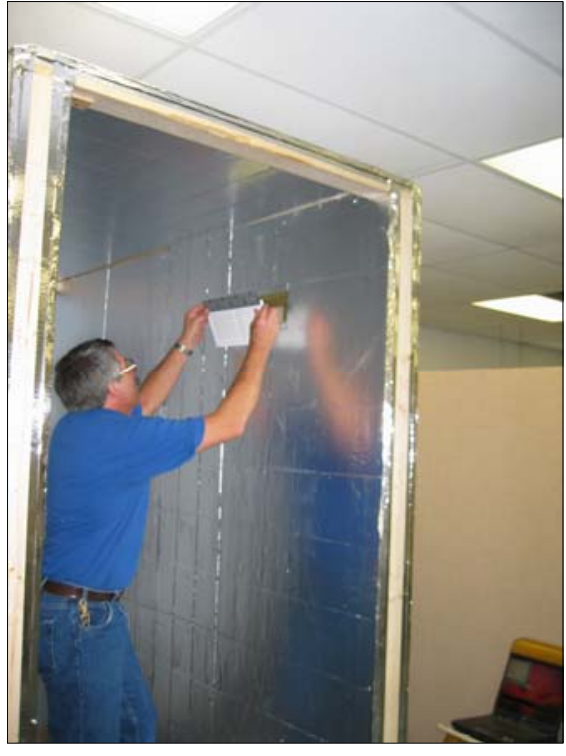

Figure109 Installing unbaffled return air flow through wall grille 


\begin{tabular}{|c|c|c|c|c|c|c|c|}
\hline \multirow[b]{2}{*}{ Dim. } & \multicolumn{3}{|c|}{ Air Flow (cfm) at } & \multirow[b]{2}{*}{ Area } & \multirow{2}{*}{$\begin{array}{c}\text { Air } \\
\text { Flow to } \\
\text { Area } \\
\text { Ratio }\end{array}$} & \multirow{2}{*}{$\begin{array}{c}\text { Return Air } \\
\text { Path } \\
\text { Configuration }\end{array}$} & \multirow[b]{2}{*}{ Extra } \\
\hline & $\begin{array}{c}\Delta P=1 \\
\text { pa }\end{array}$ & $\begin{array}{c}\Delta P=2.5 \\
\text { pa }\end{array}$ & $\begin{array}{c}\Delta \mathrm{P}=5 \\
\text { pa }\end{array}$ & & & & \\
\hline 6 dia & 22 & 36 & 52 & 28 & 1.29 & Jumper Duct & \\
\hline $4 \times 12$ & 26 & 41 & 60 & 48 & 0.85 & Wall Cavity & \\
\hline $4 \times 12$ & 25 & 42 & 61 & 48 & 0.88 & Wall Sleeve & $\begin{array}{l}\text { RAP } \\
\text { Insert }\end{array}$ \\
\hline $4 \times 12$ & 28 & 45 & 65 & 48 & 0.94 & No Sleeve & \\
\hline $4 \times 12$ & 29 & 46 & 68 & 48 & 0.96 & Wall Sleeve & \\
\hline $8 \times 8$ & 31 & 49 & 72 & 64 & 0.77 & Wall Cavity & \\
\hline $12 \times 6$ & 32 & 52 & 75 & 72 & 0.72 & Wall Cavity & \\
\hline $12 \times 6$ & 33 & 56 & 82 & 72 & 0.78 & Wall Sleeve & $\begin{array}{l}\text { RAP } \\
\text { Insert }\end{array}$ \\
\hline $8 \times 8$ & 35 & 57 & 81 & 64 & 0.89 & No Sleeve & \\
\hline $8 \times 8$ & 34 & 58 & 83 & 64 & 0.91 & Wall Sleeve & $\begin{array}{l}\text { RAP } \\
\text { Insert }\end{array}$ \\
\hline $8 \times 8$ & 36 & 59 & 85 & 64 & 0.92 & Wall Sleeve & \\
\hline $12 \times 6$ & 36 & 60 & 88 & 72 & 0.83 & No Sleeve & \\
\hline $12 \times 6$ & 37 & 60 & 88 & 72 & $\mathbf{0 . 8 3}$ & Wall Sleeve & \\
\hline $1 \times 30$ & 39 & 61 & 88 & 30 & 2.03 & Slot & \\
\hline 8 dia & 38 & 62 & 90 & 50 & 1.24 & Jumper Duct & \\
\hline $1 \times 32$ & 42 & 65 & 92 & 32 & 2.03 & Slot & \\
\hline $8 \times 8$ & 40 & 67 & 95 & 64 & 1.05 & Wall Cavity & $\begin{array}{l}\text { Two } \\
\text { Inside } \\
\text { Holes }\end{array}$ \\
\hline $8 \times 14$ & 44 & 70 & 100 & 112 & 0.63 & Wall Cavity & \\
\hline $12 \times 12$ & 45 & 72 & 103 & 144 & 0.50 & Wall Cavity & \\
\hline $1 \times 36$ & 49 & 73 & 103 & 36 & 2.03 & Slot & \\
\hline $8 \times 14$ & 61 & 101 & 146 & 112 & 0.90 & Wall Sleeve & $\begin{array}{l}\text { RAP } \\
\text { Insert }\end{array}$ \\
\hline $8 \times 14$ & 68 & 107 & 153 & 112 & 0.96 & No Sleeve & \\
\hline $8 \times 14$ & 68 & 110 & 154 & 112 & 0.98 & Wall Sleeve & \\
\hline $12 \times 12$ & 75 & 119 & 170 & 144 & 0.83 & No Sleeve & \\
\hline $12 \times 12$ & 74 & 120 & 169 & 144 & 0.83 & Wall Sleeve & \\
\hline $12 \times 12$ & 74 & 120 & 174 & 144 & 0.83 & Wall Sleeve & $\begin{array}{l}\text { RAP } \\
\text { Insert }\end{array}$ \\
\hline
\end{tabular}

By comparing the air flow of the slots (door undercut) to the openings with grilles, the detrimental effect of the grille becomes clear. The ratio of air flow $(\mathrm{cfm})$ to the surface area of the slot $\left(\mathrm{in}^{2}\right.$ ) is more than 2 to 1 (for example; $30 \mathrm{in}^{2}$ to $61 \mathrm{cfm}$ ), whereas with grilles in place the ratio of air flow to area averages 0.83 to 1 (for example; $72 \mathrm{in}^{2}$ to $60 \mathrm{cfm}$ ). Similarly, the jump duct (Figure 110) assemblies' air flow to area ratios average 1.19 to 1 . In any calculation for the size of the through wall assembly, the resistance of the grille becomes the critical factor in determining the size of the opening for achieving the desired flow. 
The following formulas account for the grille resistance and maybe used to size return air path openings.

Door undercuts: Area Sq. In. $=\mathrm{CFM} / 2$
Wall opening with grilles: Area Sq. In. $=\mathrm{CFM} / .83$
Flexible jumper duct with grilles: Diameter $=\sqrt{ } \mathrm{CFM}$

Although there does not appear to be significant flow improvement when a sleeve is used, such an assembly will reduce the possibility of inadvertent air flow from the wall cavity itself.

The high/low grilles using the wall cavity reach maximum flow at $72 \mathrm{cfm}$ because of the dimensional limitations of the wall cavity itself. Increasing the opening of each grille beyond 112 square inches does not significantly increase the flow of air through the wall cavity.

The accompanying bar chart (Figure 111) can be used to select the best method at various air flows while maintaining the room-to-building pressure difference at .01 " wc. The strategies are ranked by air flow allowance $(\mathrm{cfm})$ on equivalent to supply air delivered to the room. For example, an 8 " jumper duct could be used to maintain $0.01 \mathrm{wc}$ in rooms with supply air up to $60 \mathrm{cfm}$. Note that these transfer methods are additive so that, for example, combining a 6" transfer duct with a 1 " undercut a 30 " door, will provide a flow of $95 \mathrm{cfm}$ to be delivered at .01" wc (Figure 99) or combining a R.A.P. 12.12 with a 1" undercut would allow up to $175 \mathrm{cfm}$ to be delivered. It should be noted that door undercuts are under builder not HVAC control and that the actual dimensions are greatly affected by the thickness of the floor coverings.

\section{Summary}

Ideally buildings with forced air heating/cooling systems are pressure neutral. The same amount of air is removed from the building (and each room) as is supplied to it. However, this balance can be disturbed in homes that have one, centrally located return intake when interior doors are closed, blocking return of air supplied to private rooms. Other factors outside the scope of this study may also result in household pressure imbalances.

These research results are relevant to homes with forced air heating and cooling systems having a single, centrally located return air inlet with no engineered path for return air to exit closed rooms. Such systems pull return air from the whole house as long as interior doors are open. When an interior door is closed, more air is supplied to the closed room than can be removed, or returned, from the room.

Positive pressure builds up in the closed room while a negative pressure occurs in the connected spaces. Positive pressure presses outward on all surfaces and may eventually reduce supply air flow into the closed room and while pushing conditioned air through small breaks in the room's air barrier. 


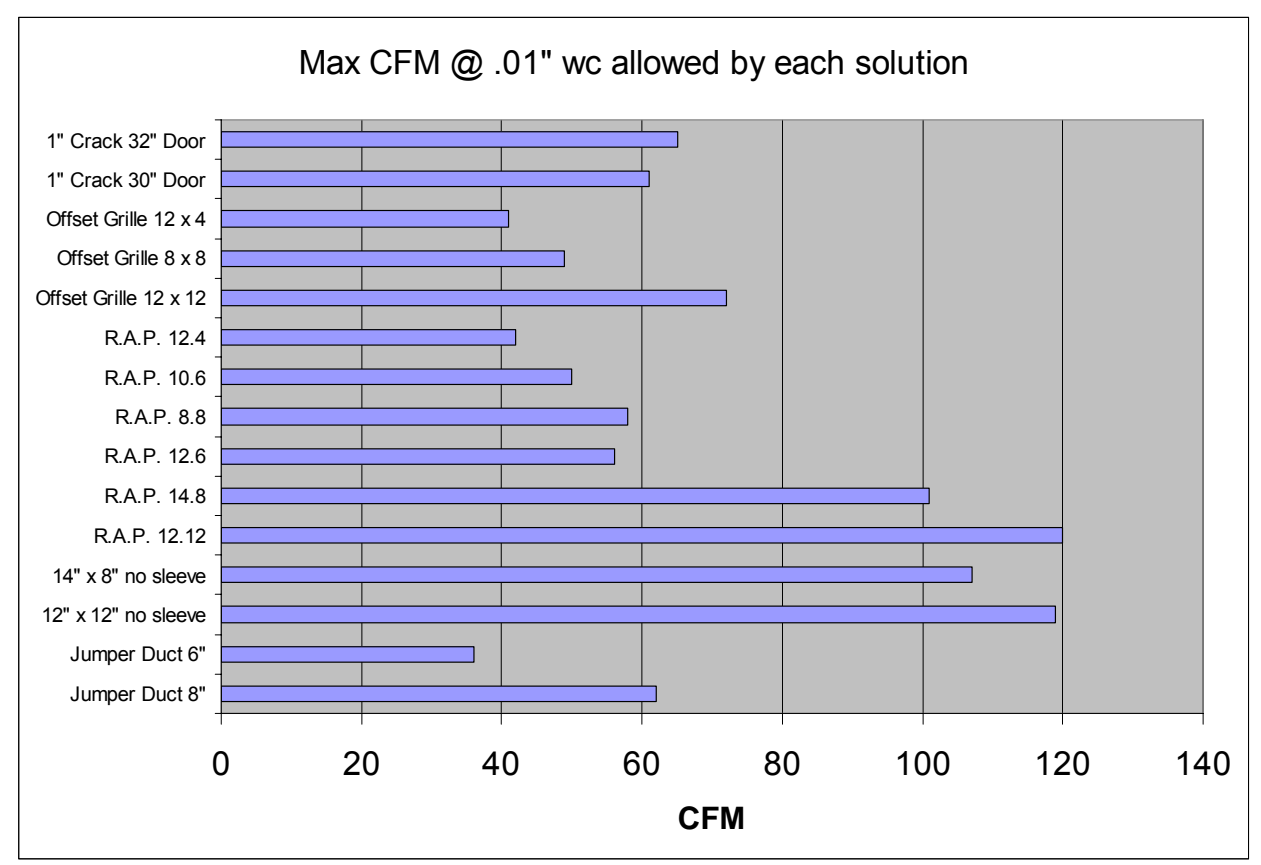

Figure 111 Maximum air flow achievable using various return air paths from closed rooms for a give supply at a room pressure of 2.5 pa or 0.1 " wc with respect to the return zone. For example, an 8" jumper duct could be used to maintain 0.01 wc in rooms with supply air up to $60 \mathrm{cfm}$.

To overcome house pressure imbalances caused by door closure, a variety of passive return path strategies are studied including a product produced by BAIHP Industry Partner Tamarack that overcomes privacy issues associated with through-wall grills. Achievable air flows for jump ducts, through-wall grilles, sleeved through-wall grilles, and the Tamarack baffled through-wall grille are presented.

\section{Heat Pump Water Heater Evaluation Research by BAIHP Researcher Carlos Colon}

BAIHP researcher tested the efficiency of a heat pump water heater manufactured by EMI, a division of ECR International. The unit features a compressor (R-134A refrigerant) with a wraparound heat exchanger mounted on top of a 50-gallon storage tank. The latest controller board model \#AK 4001 was installed during the test.

The temperature regulation of the unit is achieved by an adjustable potentiometer which sets a resistance that is measured by the controller board and translated into the corresponding temperatures. The set temperature is stored in the controller's memory.

The controller logic is designed to operate the heat pump when the temperature in the bottom of the tank drops below the effective dead band temperature of $30^{\circ} \mathrm{F}\left(20^{\circ} \mathrm{F}\right.$ dead band + assumed stratification of $10^{\circ} \mathrm{F}$ ). The heat pump shuts off when the temperature in the bottom of the tank 
has reached $10^{\circ} \mathrm{F}$ below the set point temperature. The upper element of the tank operates only when the temperature in the upper tank reaches $27^{\circ} \mathrm{F}$ below the set point temperature.

During laboratory testing the controller's performance was evaluated by measuring inlet and outlet water temperatures using thermocouples mounted to the copper inlet and outlet pipes as well as a Fluke hand-held thermometer inserted into the hot water outlet stream. One minute average measurements during draws were in agreement with the $10^{\circ} \mathrm{F}$ stratification logic utilized by EMI.

Also, following a series of hot water draws during the efficiency test (described below), the compressed refrigerant heat was able to replenish the tank to the $130{ }^{\circ} \mathrm{F}$ temperature level. However, following the heating recovery, neither compressor or resistance element were activated during standby until three days later when bottom tank temperatures dropped below $95^{\circ} \mathrm{F}$. The compressor was called into operation when the tank was submitted to a hot water draw which triggered the ON compressor event in less than a minute.

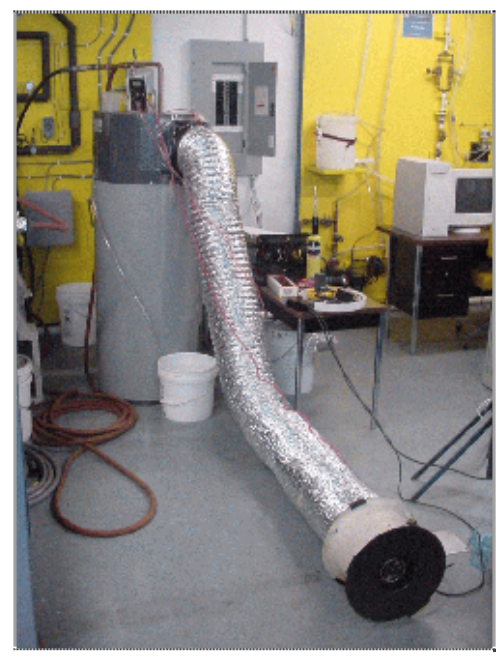

Figure 112 Airflow measurements using a Duct tester on heat pump cold air discharge side.

Table 77 is a summary of electrical efficiency results generated from three tests performed in the laboratory. Tank pre-heating for test \#1 and \#2 were performed in a similar way, by forcing the compressor to turn "ON". The tank was allowed to loose heat on standby (1-2 days) and then purged with a draw of at least 30 gallons of new water. The purge forced the compressor to operate. Preheating for the test \#3 was performed with the tank relatively hot and only twelve gallons of hot water were purged. This might explain the higher outlet temperatures read during test 3. For all three tests, we attempted to heat water so that initial hot water draws were near 130 ${ }^{\circ} \mathrm{F}\left(+/-5^{\circ} \mathrm{F}\right)$. However, we noticed that temperatures at the top of the tank (upper level) increased slightly with each purge (i.e., 10.7 gallon draw). During the third test shown in Table 61 for example, outlet temperatures during the first draw averaged $129.2^{\circ} \mathrm{F}$, but during the last draw temperatures reached an average of $143.4^{\circ} \mathrm{F}$. The values for test $\# 3$ show an overall hot water delivery temperature $\left(\mathrm{T}_{\text {outlet }}\right)$ of $136.6^{\circ} \mathrm{F}$. The controller never called for compressor or auxiliary energy when left on standby during the completion of the test (24-hr.).

Table 77 Electrical Efficiency Results from Laboratory Tests

\begin{tabular}{|c|c|c|c|c|c|c|}
\hline Test & $\begin{array}{c}\text { Total } \\
\text { Gallons } \\
\text { Drawn }\end{array}$ & $\begin{array}{c}\text { Average } \\
\mathbf{T}_{\text {inlet }} \\
\left({ }^{\circ} \mathbf{F}\right)\end{array}$ & $\begin{array}{c}\text { Average } \\
\mathbf{T}_{\text {outlet }} \\
\left.\mathbf{(}^{\circ} \mathbf{F}\right)\end{array}$ & $\begin{array}{c}\text { Total } \\
\text { Qout } \\
\mathbf{k W h}\end{array}$ & $\begin{array}{c}\text { Total } \\
\text { Qin } \\
\mathbf{k W h}\end{array}$ & $\mathbf{C O P}$ \\
\hline$\# 1$ & 63 & $82.3^{\circ} \mathrm{F}$ & $133.2^{\circ} \mathrm{F}$ & 7.756 & 3.974 & 1.95 \\
\hline$\# 2$ & 53.5 & $82.1^{\circ} \mathrm{F}$ & $131.2^{\circ} \mathrm{F}$ & 6.533 & 3.516 & 1.86 \\
\hline$\# 3$ & 65.9 & $82.0^{\circ} \mathrm{F}$ & $136.4^{\circ} \mathrm{F}$ & 8.789 & 4.254 & 2.06 \\
\hline
\end{tabular}

\section{Conclusions}

The WattSaver ${ }^{\mathrm{TM}}$ heat pump water heater is rated with an energy factor (EF) of 2.45 and clearly demonstrates that heating water can be accomplished at a relative higher efficiency when 
compared to conventional electric water heaters. Installed in a conditioned space, and under operation with inlet water temperatures above $80^{\circ} \mathrm{F}$ (e.g., Central Florida summer water mains temperatures), an average electrical (COP) efficiency of 2.0 was attained. Other measurements and performance indicators are summarized in Table 78.

Two caveats to the heat pump water heater's performance was first the delayed recovery during standby which would present larger hot water temperature variation to the residential user. This also leads to diminished hot water capacity during long periods of no hot water use activity. Second, because the compressor's discharge refrigerant (i.e., hottest temperatures) enter the wrap-around heat exchanger at the top of the tank, the unit demonstrated larger hot temperature variations at the tank's upper levels when the top portion was all pre-heated. These stratified tank temperature levels differ from those obtained when heating is started with the tank filled up with mains (colder) water conditions.

Table 78 Summary of Other Measurements and Performance Overview

Typical Cooling

Air Flow rate: 87 CFM (Figure 87)

Top cavity/Fan operating : $-6.4 \mathrm{pa}$

Evaporator Air temp: $73^{\circ} \mathrm{F}(63 \% \mathrm{RH}$ entering)

$/ 53.1^{\circ} \mathrm{F}$ (leaving)

Condensate: $502.6 \mathrm{~g} / \mathrm{hr}$. $(1.1 \mathrm{lb} / \mathrm{hr})$

Sensible: $1900 \mathrm{Btu} / \mathrm{hr}$.

Latent: $957 \mathrm{Btu} / \mathrm{hr}$

Total Capacity : $2,857 \mathrm{Btu} / \mathrm{hr}$
Current consumption (208 VAC)

Compressor2.9 amps

Fans (2) : 0.08 Amps/each

Total 3.08 amps

\section{NightCool - Building Integrated Cooling System}

Study led by BAIHP Researcher Danny Parker

Papers: $\quad$ Parker, D. S.. "Theoretical Evaluation of the NightCool Nocturnal Radiation

Cooling Concept". Submitted to: U.S. Department of Energy. FSEC-CR-1502-05. April 2005.

Parker, Danny S. and John R. Sherwin, 2006. "Experimental Evaluation of the NightCool Nocturnal Radiation Cooling Concept: Progress Report: Initial Thermal Performance Assessment of Test Buildings. FSEC-CR-1657-06, Florida Solar Energy Center, Cocoa, Florida. September 2006.

\section{Technical Background}

Using a building's roof to take advantage of long-wave radiation to the night sky has been long identified as a potentially productive means to reduce space cooling in buildings. This is because a typical roof at $75^{\circ} \mathrm{F}$ will radiate at about $55-60 \mathrm{~W} / \mathrm{m}^{2}$ to clear night sky and about $25 \mathrm{~W} / \mathrm{m} 2$ to a cloudy sky. For a typical roof (250 square meters), this represents a cooling potential of 6,000 14,000 Watts or about 1.5 - 4.0 tons of cooling potential each summer night. Various physical characteristics (differential approach temperature, fan power, convection and conductance) limit what can be actually achieved, so that perhaps half of this rate of cooling can be practically obtained. Even so, careful examination of vapor compression space cooling in many homes in 
Florida shows that typical homes experience cooling loads averaging $33 \mathrm{kWh}$ per day from June - September with roughly $9.2 \mathrm{kWh}(28 \%)$ of this air conditioning coming between the hours of 9 PM and 7 AM when night sky radiation could greatly reduce space cooling.

A big problem with night sky radiation cooling concepts has been that they have typically required exotic building configurations. These have included very expensive "roof ponds" or, at the very least, movable roof insulation with massive roofs so that heat is not gained during daytime hours. The key element of our new configuration is that rather than using movable insulation with a massive roof or roof ponds, the insulation is installed conventionally on the ceiling. The operation of the system is detailed in the attached schematic.

During the day, the building is de-coupled from the roof and heat gain to the attic space is minimized by a white reflective metal roof. During this time the space is conventionally cooled with a small air conditioner. However, at night as the interior surface of the metal roof in the attic space falls two degrees below the desired interior thermostat set point, the return air for the air conditioner is channeled through the attic space by way of electrically controlled louvers with the variable speed. The warm air from the interior then goes to the attic and warms the interior side of the metal roof which then radiates the heat away to the night sky. As increased cooling is required, the air handler fan speed is increased. If the interior air temperature does not cool sufficiently or the relative humidity is not kept within bounds $(<55 \% \mathrm{RH})$ the compressor is energized to supplement the sky radiation cooling. A dehumidifier is used when temperature conditions are favorable, but moisture conditions are not. The massive construction of the building interior (tile floor and concrete interior walls) will store sensible cooling to reduce space conditioning needs during the following day.

\section{Experimental Design}

To verify the potential of the concept, the radiative cooling system will be tested in two 10 x 16 ' test structures. These highly instrumented buildings are located just south of the Building Science Lab (Figure 113) at the Florida Solar Energy Center (FSEC). Design and siting issues were resolved in 2004, and construction began in 2005.

One of the test sheds will be the control structure with a standard attic with R-19 ceiling insulation and an asphalt shingle roof with 1:300 ventilation rate. The experimental unit will have a white metal roof on metal battens and a sealed attic, which can be convectively linked to the main

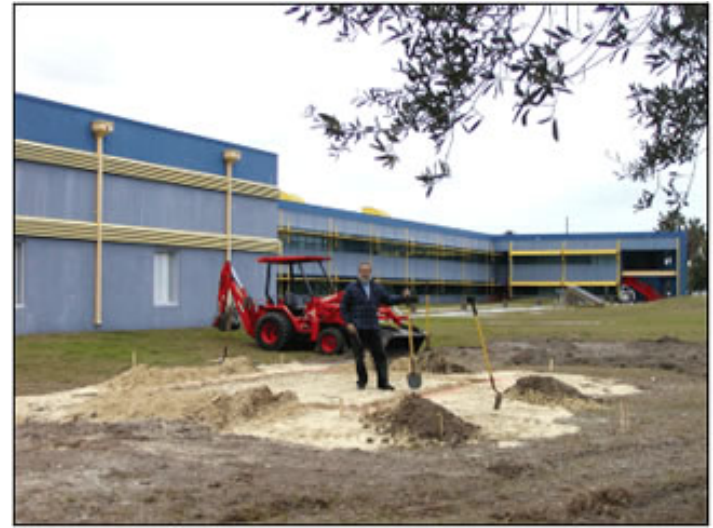

Figure 113 Groundbreaking for the Nightcool instrumented experimental buildings, Florida Solar Energy Center zone by a powered circulation fan. Both units will have slab floors, frame walls and solar control small double glazed windows. A schematic of the test case and a similar drawing of the concept in a real home are shown in Figures 115 and 116. 
$\underline{6}^{\text {th }}$ Budget Period: Detailed Simulation Model

During the $6^{\text {th }}$ budget period a detailed simulation model was created. Once the simulation model was validated against known solutions (Givoni, 1994 and Santamouris and Asimakopolous, 1996), the model was then mated to TMY2 hourly weather data to predict performance around the year under realistically changing weather conditions. For the calculations we use Tampa, Florida TMY2 data adjusting the weather data wind speed to account for the greatly diminished velocity seen over roof tops in experiments done at the Flexible Roof Facility (Parker and Sherwin, 1998). Florida weather is less advantageous for the analysis than many other locations since high summer dew points will often limit cooling potential. However, this allows evaluation of the concept under difficult environmental conditions

The seasonal analysis for Tampa from June - September showed that the nocturnal system would operate an average of 8.6 hours per day, producing an average of $15.2 \mathrm{kWh}$ of cooling per day for a home with a consumption of fan energy of $1.4 \mathrm{kWh}$. In a typical Florida house using 33 $\mathrm{kWh} /$ day this could offset about $46 \%$ of required space cooling if all could be effectively utilized. The system average operating energy efficiency ratio (EER) was 37.1 compared too 1015 for common vapor compression air conditioners. The average daily profile of performance is shown in Figure 103 which shows the system performance.

\section{Simulation in Other Climates}

To examine concept performance elsewhere, we conducted the same simulation in three additional climates which we expected to evidence substantially different potentials. These were Atlanta, Georgia, reflecting a more moderate cooling dominated climate, Baltimore, Maryland with a mixed heating and cooling climate and Phoenix, Arizona with an arid, very hot climate. Results are shown in Table 79. For comparison, performance indicated from the simulation for June - September are provided alongside those for Tampa, Florida. We also provide the results for the month of July in parentheses to illustrate how the cooling potential varies during the hottest conditions in each location.

Table 79 NightCool Simulation Results for Other Climates June - September and (July Only)

\begin{tabular}{|l|c|c|c|c|}
\hline \multicolumn{1}{|c|}{ Parameter } & Tampa, FL & Atlanta, GA & Baltimore, MD & Phoenix, AZ \\
\hline Avg Daily Cooling kWh & $15.2(10.8)$ & $50.3(42.4)$ & $62.4(45.4)$ & $23.2(11.2)$ \\
Avg Hrs per Night & $8.6(7.6)$ & $14.3(13.9)$ & $14.6(13.6)$ & $7.9(5.3)$ \\
Fan kWh & $1.4(1.3)$ & $2.4(2.3)$ & $2.4(2.3)$ & $1.3(0.9)$ \\
COP & $10.9(8.3)$ & $21.0(18.4)$ & $26.0(19.7)$ & $17.8(12.4)$ \\
SEER (Btu/Whr) & $37.1(28.4)$ & $71.5(62.9)$ & $88.7(67.4)$ & $60.9(42.5)$ \\
\hline
\end{tabular}

Note that each climate other than Tampa shows better performance for the concept, both in absolute cooling and in overall cooling efficiency. Atlanta and Baltimore clearly indicate the concept to produce more cooling during evening hours than could be effectively utilized. For these locations, this would suggest both interior thermal storage and nighttime dehumidification to further offset daytime cooling needs. 
The very hot climate of Phoenix, however, shows that like Tampa, the concept would only be able to offset $20-30 \%$ of daily cooling needs, although seemingly with the potential to essentially eliminate air conditioning loads during the swing months of April - May and October. Although Phoenix has less cloud cover, and greater diurnal temperature swing, the ambient evening temperatures tend to be hotter. Consequently, in this location, the NightCool system often does not start operation until after midnight. Even so, the concept showed efficient operation in all climates along with substantial ability to offset cooling needs in more temperate locations.

\section{Progress during the Final Year of the Project}

A contract report on theoretical performance was completed in April 2005 and placed online: "Theoretical Evaluation of the NightCool Nocturnal Radiation Cooling Concept". Submitted to: U.S. Department of Energy. FSEC-CR-1502-05. This report has garnered considerable interest. Parker presented data on the evaluation of the NightCool concept at the World Energy Sustainable Energy Conference in Wels, Austria on 1 March 2006. There was considerable international interest in the concept given the number of metal roofs in northern Europe. (Travel expenses were covered by non-BAIHP sources)

Both the control building and experimental buildings were completed and the empirical evaluation of the concept is in progress. The control unit is configured like a conventional home with a dark shingle roof and insulated ceiling under a ventilated attic. The experimental unit features a white reflective roof on battens with a sealed attic

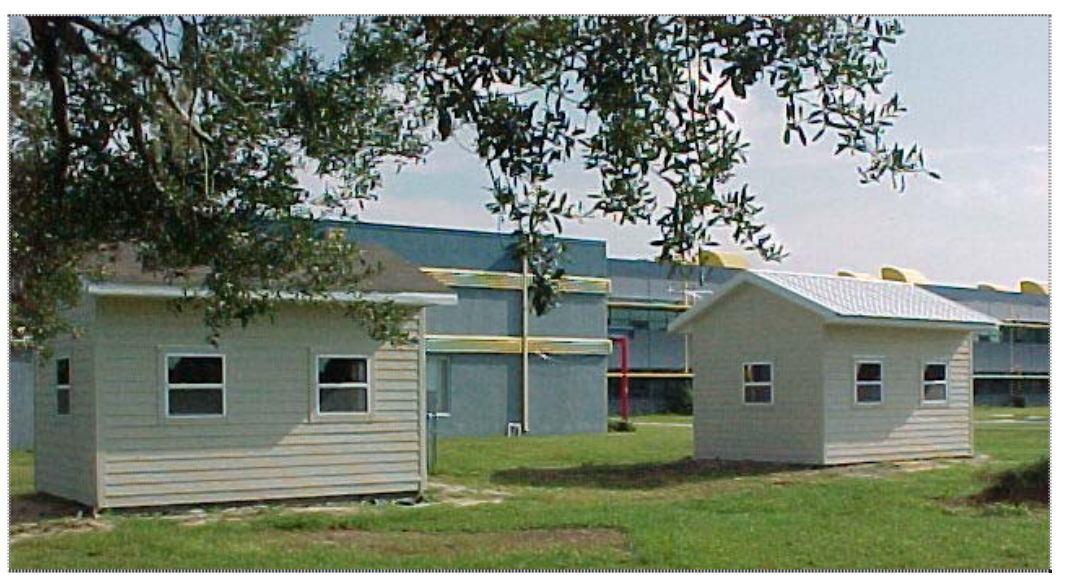

Figure 114 NightCool buildings at FSEC where the air from the shed interior can be circulated to the sealed attic and roof radiator when the roof temperature drops well below the room target cooling temperature. A second contract report in September 2006 provides a brief evaluation of the performance of NightCool under static conditions with no mechanical cooling. Two experimental configurations were evaluated:

- No NightCool cooling with the attics sealed to the interior (Null test)

- NightCool by convective linkage to the building only (open aperture to the attic so that cooled night air could drop out of the attic into the interior to be replaced by warmer air below.

The experiments shows that NightCool performed better thermally under both configurations. With the NightCool linkage to the main zone disabled the average nighttime temperatures in the unconditioned experimental and control test buildings from $8 \mathrm{PM}$ to $8 \mathrm{AM}$ was 82.0 and $82.6^{\circ} \mathrm{F}$ respectively. This shows the experimental buildings runs slightly cooler at night, largely because of the lower attic temperatures across the insulation and the effectiveness of the R-30 SIPs panels in the ceiling against the R-30 fiberglass batts in the control. 
However, in the second configuration with an attic hatch opened to the attic to allow warm air to naturally convect into the attic and heavier cool air to naturally convect to the interior below, the NightCool building showed superior performance. The experimental building's interior ran $1.9^{\circ} \mathrm{F}$ cooler during nighttime hours without any mechanical air movement to aid heat transfer- this is about three times the temperature drop seen without any nighttime cooling. A good demonstration of nocturnal cooling within the concept. 


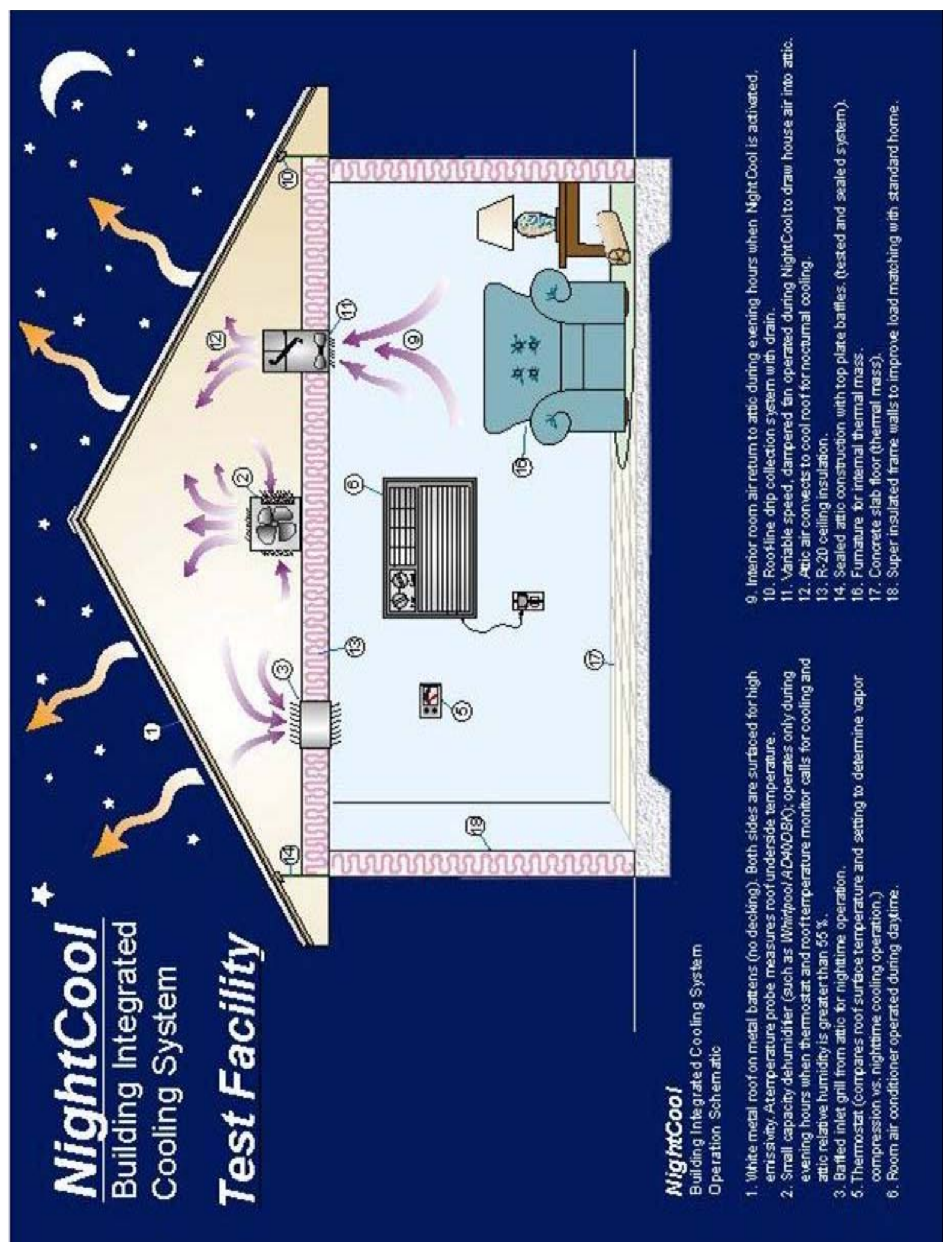

Figure 115 -Scehmatic design for NightCool test facility. 


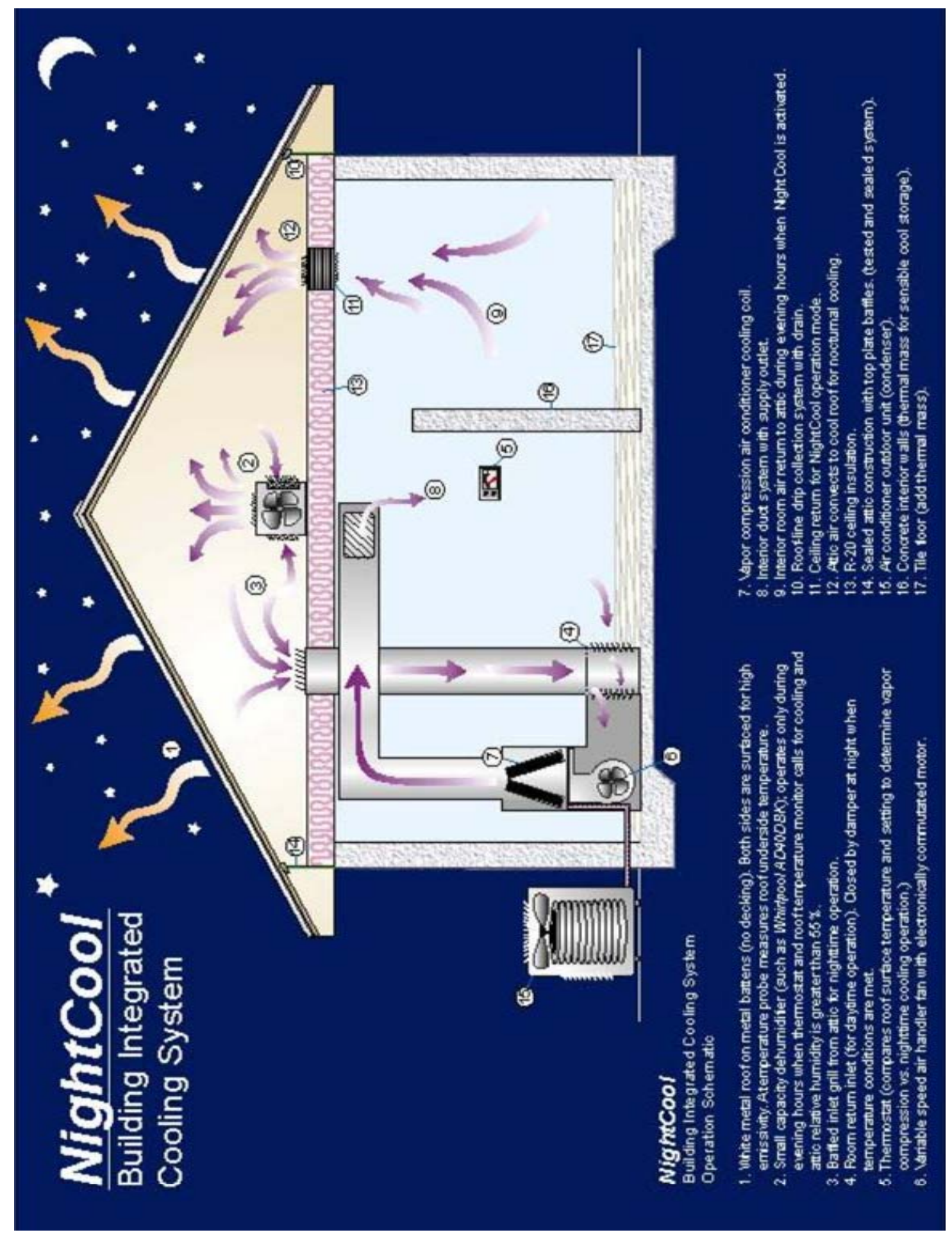

Figure 116 Schematic of NightCool concept in typical residential building. 


\section{Plug Load Reduction Study}

Central Florida

Papers: $\quad$ Parker, D., Hoak, D., Meier, A., Brown, R., "How Much Energy Are We Using?

Potential of Residential Energy Demand Feedback Devices", Proceedings of the 2006 Summer Study on Energy Efficiency in Buildings, American Council for an Energy Efficient Economy, Asilomar, CA., August 2006.

Richard Brown, William Rittelmann, Danny Parker, and Gregory Homan. Appliances, Lighting, Electronics, and Miscellaneous Equipment Electricity Use in New Homes Proceedings of the 2006 Summer Study on Energy Efficiency in Buildings, American Council for an Energy Efficient Economy, Asilomar, CA., August 2006

In the final year of the project, BAIHP began investigations into plug loads. This aspect of home energy use is changing rapidly with the constant expansion of the home electronics industry. To achieve DOE's long range 70\% energy saving goal, researchers will need to address control strategies and plug load management. Since occupant life style dictates this area of energy use, control strategies will need to be user friendly with simple readouts and operating instructions.

\section{Miscellaneous Electricity Use}

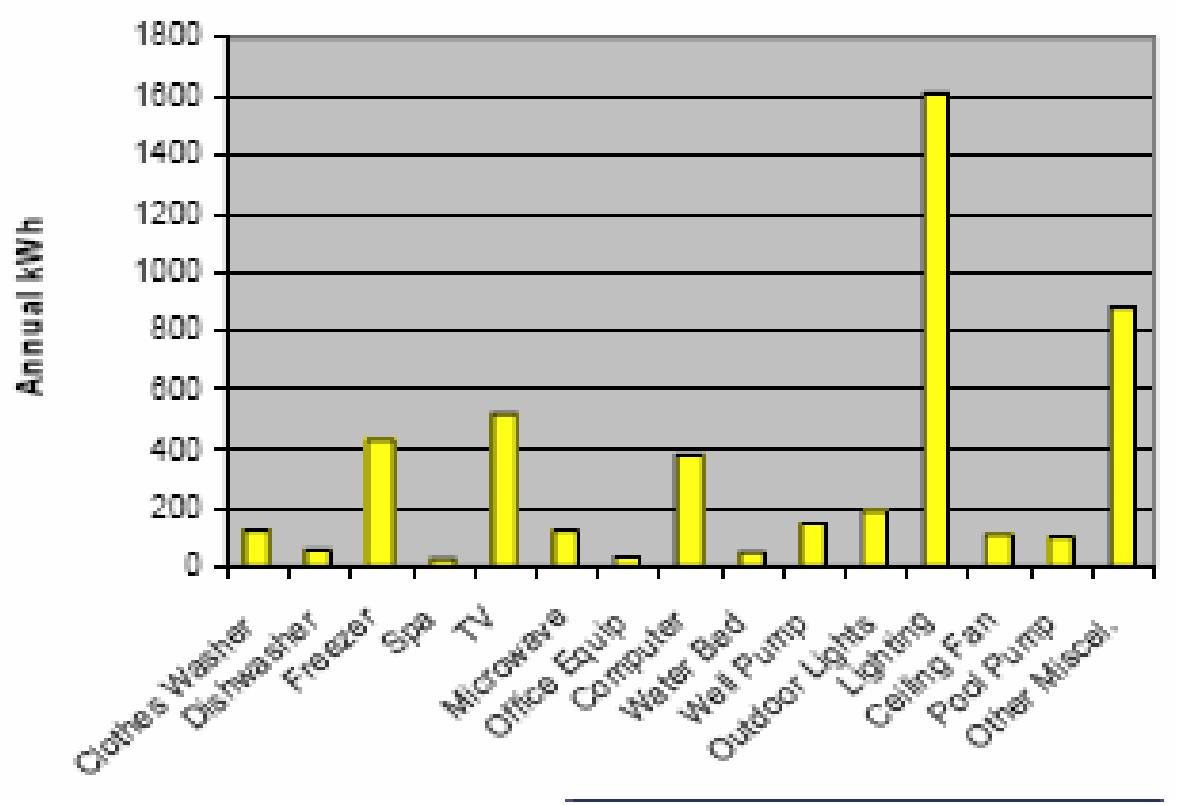

Figure 117 Plug load energy use profile developed from data collected using commercially available residential feedback monitor and an FSEC developed audit protocol.

Before development of control systems, researchers need a clearer understanding of the energy use profile of plug loads BAIHP began to characterize plug loads by installing commercially available residential energy feedback monitors in five homes. Researchers developed an audit protocol which was successfully conducted in each home (Figure 117). Demonstrated savings of 
$2 \mathrm{kWh} /$ day using simple switches and controls in one home through using the protocol with the feedback device to understand which devices were using power when appearing to be "off." Switchable power strips reduced "off" loads. Coordinating effort with Rich Brown and Alan Meier at LBNL.

\section{Solar Integrated Roofing Panels Stuart, Florida}

In the final year of the project, design assistance was provided to Nat Schwartz of NatMax for solar systems to be installed on the proposed homes in Coral Gables, Florida. Options presented included building integrated photovoltaic (BIPV) metal or tile systems. Technical assistance was provided during conference calls with Steven Crimi regarding the construction of new homes using SIP construction. Mr. Crimi is very interested in developing a new technique for BIPV in SIP construction. The concept would be evaluated side-by-side with currently available BIPV products to compare performance, ease of construction, cost, and aesthetics.

\section{Hot Water Distribution Systems Research}

During the final year of the project, researchers conducted a literature search on the topic of hot water distribution and re-circulation systems for residential/commercial buildings including magazine articles, professional papers, presentation files, independent roadmap plan strategies, and documents from the California Energy Commission's (CEC) 2005 Building Energy Efficiency Standards and Action Items for the 2008 Standards on Hot Water Distribution Systems These two CEC documents analyze distribution loss sensitivity to floor area and number of stories, including parallel, trunk-branch distribution systems and hot water re-circulation strategies.

Researchers began further investigation of the current advances in hot water distribution models from Davis Energy Group (DEG - HWSIM), Oak Ridge National Laboratory Model (Synergistic Water Heating Technology PIER program) and NREL - NAHB using TRNSYS to assess the strengths, weaknesses, and development needs of each model.

\section{Building America Benchmark Toolkit for Programmers}

Paper: Vieira, R., L. Gu, S. Se, C. Colon (2006.) "Improving the Accuracy and Speed for Building America Benchmarking." Florida Solar Energy Center, FSEC-CR-1651-R00, Aug. 29, 2006

The Building America Benchmarking process is time consuming. No simulation software currently is available to automatically generate the Bench mark version of the prototype home. Thus, analysts must first enter the parameters of the prototype home design into the Building America Benchmark Spreadsheet tool to create the parameters of the Building America benchmark home and then use detailed software to simulate both the benchmark home and the prototype home. Results for the prototype and the benchmark comparison homes are entered into a post-processing spreadsheet to determine the percent improvement for the prototype.

To reduce this effort, FSEC has created a BA Toolkit that allows programmers to incorporate calls to functions and procedures that produce the Building America Benchmark characteristics. 
This will enable programmers to more easily incorporate Benchmark analysis into their software. The toolkit has been tested against the Department of Energy developed Building America Spreadsheet Tool and found to produce the same results.

The Benchmarking process goes into great detail to determine hot water use for the benchmark and the prototype homes. However, the benchmark process has not included hot water distribution effects, which can be larger than many of the water use differences currently painstakingly calculated. FSEC has developed a simple routine and verified it against measured data as a method to simulate distribution effects to a reasonable degree of accuracy. It shows that typical losses in a Miami home may represent an increase of $2.4 \%$ in hot water energy use and also a slight increase in cooling energy. This routine can be incorporated into or run separately from other software should the Building America program decide to include this element.

FSEC has also accomplished another enhancement for Building America teams that facilitates extraction of ventilation fan energy use from DOE2 reports. As part of this effort, but outside of this funding, FSEC also added a capability within EnergyGauge USA to simulate mechanical air handler ventilation with a controller that closes a damper after a certain amount of runtime or turn on the blower to assure a minimum amount of runtime, or both. This report presents simulation results for controlling mechanical ventilation via nine strategies. Fresh air provided by systems as well as energy use due to ventilation air flow and fan energy consumption can vary significantly depending on control characteristics. Simple runtime vent systems may only bring in air $20 \%$ to $25 \%$ of the time on an annual average basis compared to continuous vent systems and if designed for small quantities of air will likely not provide much more outdoor air than simple infiltration in the wintertime when the natural driving forces are large. Ensuring that a runtime vent system operates $25 \%$ of every hour results in increased energy use due to increased fan use (4\% and 13\% of heating and cooling energy, respectively) in the modeled St. Louis example used in this study.

These developments allow modelers to more accurately and more readily perform energy analysis for Building America homes.

\section{Comparison of Current Building Energy Analysis Standards for Building America, Home Energy Ratings and the 2006 International Energy Conservation Code \\ Paper: $\quad$ Fairey, Philip, Carlos Colon, Eric Martin, and Subrato Chandra (2006.) "Comparing Apples, Oranges and Grapefruit: An Analysis of Current Building Energy Analysis Standards for Building America, Home Energy Ratings and the 2006 International Energy Conservation Code.” FSEC-CR-1650-06. Florida Solar Energy Center, Cocoa, Florida. September 2006.}

The overall purpose of the work presented in this report is to determine the relationship, if any, between the U.S. Department of Energy's Building America (BA) Benchmarking Analysis methods and the energy-efficiency analysis methods used by the International Energy Conservation Code (IECC) and the Residential Energy Services Network (RESNET) and the Home Energy Rating Systems (HERS '99) industry for similar purposes.

The IECC allows code compliance through a performance-based comparative analysis method and the HERS ' 99 industry uses very similar standards and methods to determine a relative measure of energy-efficiency performance called the HERS ' 99 Index. 
The simple goal of the work is to be able to say with certainty that a whole-building HERS ' 99 Index of ' $x$ ' corresponds to a BA whole-building \% savings of ' $y$.' Similarly, the goal is to be able to also say with certainty that this BA \% savings of ' $y$ ' corresponds to a savings of ' $z$ ' with respect to the IECC minimum code standard.

The study is accomplished using homes of three different sizes (intended to represent 'typical' small, medium and large home plan options), on three different foundation types (slab-on-grade, vented crawlspace and conditioned basement), using both 1-story and 2-story models, in all 7 of the contiguous U.S. climate zones identified by the 2006 IECC.

The analysis is conducted using version 2.5 , release 9 of EnergyGauge ${ }^{\circledR}$ USA, RESNET accredited software, produced and marketed by the Florida Solar Energy Center, for Home Energy Ratings, IECC performance-based code compliance and federal tax credit qualification. The basis for the analysis was the Building America Benchmarking Analysis procedures and all home cases were evaluated in accordance with the methods of this procedure for the purposes of creating an apples-to-apples comparison.

The results of the analysis are informative, showing not only the differences between the 3 methods of comparing the energy-efficiency performance of buildings, but also the origins of these differences and their impact on the primary goal of the analysis.

Every effort is made to accomplish the analysis using a consistent set of "rules" for all three methods, one that results in the ability to state with certainty that on an apples-to-apples basis, system A corresponds to system B in the following way. However, as the title of the report suggests, this goal is not achieved. The analysis results and findings do not support any consistent correlation between the Building America Benchmarking Analysis procedure and the HERS ' 99 or IECC analysis procedures. The analysis does show a reasonably consistent relationship between HERS ' 99 and IECC but the relationship ends at that point. Hence, the title of the report, indicating that while two of the analysis methods are, in fact, citrus fruits, the other is not.

Perhaps the most illustrative example of this finding - the inability to relate one system to another - comes from the analysis of Building America prototype homes that are $30 \%$ more energy efficient than the Building America Benchmark home standard, as evaluated against the alternative standards examined in this study. 


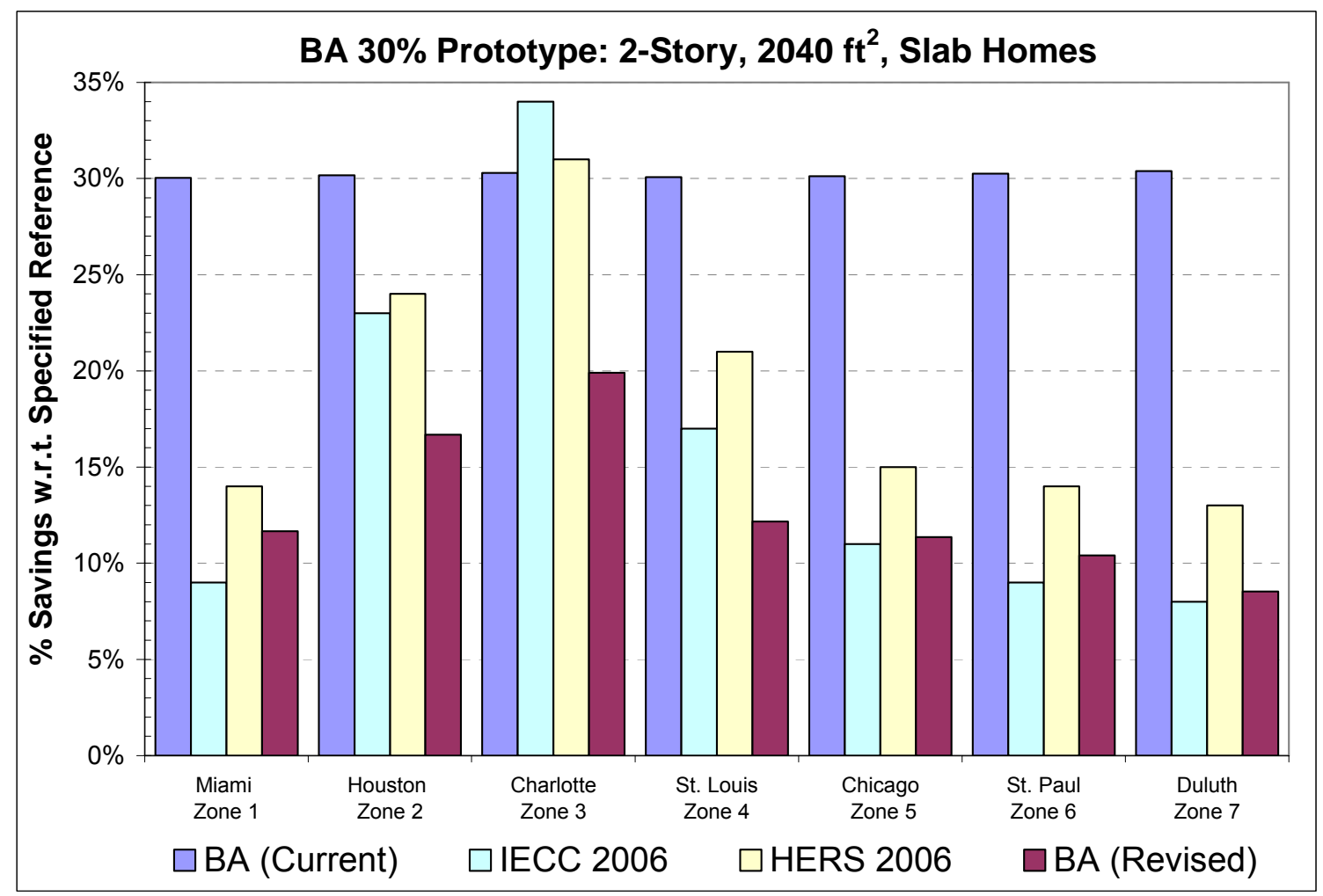

Figure 118 Bar chart showing the Building America "30\% Prototype" home evaluated using the various performance analysis standards that were examined by this study.

Figure 118 provides one example of why it is not possible to state with certainty how the $30 \%$ better than Benchmark home compares with either the IECC, HERS '99 or even with a hypothetical revised Building America standard [BA (Revised)]. One can calculate the HERS '99 Index for these homes from the yellow bars as 1-the \% savings. They illustrate that the HERS '99 Index for the homes range from 87 in Duluth (not meeting ENERGY STAR standard, which requires a HERS ' 99 Index of 80 or lower in cold climates) to 69 in Charlotte, which is significantly better than ENERGY STAR and, as a matter of fact, which qualifies for the $\$ 2,000$ tax credit!

While the BA (Current) standards are very consistent at 30\% savings across all climate zones, as Figure 1 shows, there simply is no correlation between that BA figure of merit and any of the other figures of merit evaluated by this study.

This study provides additional examples of differences among the standards that are equally disparate. For example, Section 3.3 of the report highlights differences among the standards for number of stories, foundation type, fuel type and home size that illustrate that BA \% savings can not be well correlated to the HERS '99 Index, even within the same climate.

It is difficult to make recommendations based on this analysis. There can be pros and cons for any given method used to project energy savings. For example, the BA method was originally 
developed to measure progress toward a set of U.S. DOE energy savings milestones called Joules. The intent was to have a consistent standard of performance tied to mid 1990's era home standards. However, in the mid 1990's there were no definitive code standards for windows that are analogous to those that became effective in 1998. In addition, there were no standards or methods in the mid 1990's for the evaluation of distribution system efficiency, mechanical ventilation or lighting and appliances in homes.

Since the original objective of this study - to establish a correlation between the BA \% savings value and the HERS '99 Index value - could not be accomplished, there appear to be three potential options for moving forward. While options may not be considered recommendations in the conventional sense of the term, they, along with their advantages and disadvantages, are presented below:

I. Maintain the current BA rule set. This option allows BA program milestones to continue to be measured from a constant reference point. While this reference point can not be directly correlated to current codes or to the HERS ' 99 Index, it does allow program goals to remain consistent with past objectives. However, this advantage also works as a disadvantage. Potential builder partners can not be told with certainty how much better than code their homes will be as the savings with respect to minimum code standards varies greatly with climate. Thus, builder partners are left in a bit of a quandary as to how they can advertise these homes in a way that can be simply explained to their potential customers.

II. Revise the BA rule set. While revising the BA rule set may bring it more in line with alternative, more current rule sets, the analysis presented here did not show that this would result in a complete correlation between the revised BA \% savings values and the HERS '99 Index (or Code e-Ratio). The revised BA rule set examined here consistently resulted in lower \% savings values than the HERS '99 rule set. Thus, adopting the revised BA rule set used in this analysis would cause the BA program goals to appear significantly more difficult than code-based programs.

III. Migrate to the HERS '99 Index. A large disadvantage of migrating to the HERS '99 Index is that it would change the basis of BA program savings goals and milestones. Of course, the previous option, revising the BA rule set, would do the same. There are, however, some advantages of this option. The HERS ' 99 Index is widely used as a performance metric. It is used as the basis for the ENERGY STAR new homes program and other emerging national programs like USGBC's pilot LEED-H program. The HERS '99 rule set also forms the basis for the EPAct 2005 federal tax credit for highly efficient new homes.

As a metric, the HERS '99 Index includes all of the energy uses of a home. This is one of the basic tenets of the BA program - that whole home energy use forms the basis of the program. While changing the BA program standard to the IECC rule set would violate this tenet, changing to the HERS "99 rule set standard would not. The HERS '99 rule set a methodology to "score" the use of on-site energy production, whether by solar, wind or other "free" fuel resources or by highly efficient on-site conventional fuel technologies like micro-turbines and small combined heat and power plants. A significant advantage of the HERS ' 99 rule set standard is that it is a consensus-based national standard. 
A disadvantage of the HERS "99 Index is that the "scoring method" used by the rule set does not use energy use as the metric. The metric used by the HERS ' 99 rule set is called the normalized modified loads method. It was derived as a compromise consensus method of avoiding the fight between site energy use and source energy use. It can be shown to reasonably reflect energy cost in a market where the ratio between site costs for electricity and natural gas are near the ratio of 3 to 1 .

Finally, one advantage of using the HERS '99 Index is that it can be explained fairly simply the "American Standard New Home" has an index of 100 and a home that uses no purchased energy has an index of 0 . In other words, zero is zero and anything greater than 100 probably doesn't meet current minimum energy standards.

\section{Cooling Performance Assessment of Building America Homes}

Paper: Chasar, D., Chandra, S., Parker, D., Sherwin, J., Beal, D., Hoak, D., Moyer, N., McIlvaine, J., "Cooling Performance Assessment of Building America Homes", Fifteenth Symposium on Improving Building Systems in Hot and Humid Climates, July 24-26, 2006 Orlando, FL.

As of 2004, 46\% of new single-family homes are currently built in the South where air conditioning makes up the largest portion of the annual electric bill (USDOE 2005). Through systems engineering, significant reductions in cooling energy have been successfully achieved in these climates by rigorous application of cooling load reduction strategies. Lower cooling loads lead to smaller air conditioners which, when coupled with high efficiency equipment, have led to reductions of over $70 \%$ in cooling energy use.

Long-term monitoring of building energy use and environmental conditions has been a strong component of FSEC research since the 1980s. Fully-automated data collection, verification, archiving and management ensure accurate logging of large amounts of data simultaneously from numerous field sites prior to being made available for analysis and display via the internet. Homes are typically monitored using 15 to 50 channels of data to measure indoor and outdoor environmental conditions and energy use of heating, cooling, water heating, whole house, and other points (e.g. Solar PV or Solar DHW) if needed.

Energy performance in many Building America homes has been documented with measured data collected over several years to verify savings projections. An evaluation of measured cooling performance is presented with data from nine homes in three climate regions. Data from potential zero energy homes and minimum code homes provide upper and lower performance bounds.

The nine homes in this comparison study were:

- Combined Baseline (2 identical homes) in Cocoa, Florida

- BAIHP's Manufactured Housing Lab (MHLab) in Cocoa, Florida

- White Metal Roof Home in Cocoa, Florida

- Not-So-Big-Showhouse in Orlando, Florida

- Zero Energy Manufactured Home (ZMH) in Idaho

- Sharpless/Hoak Home in Longwood, Florida 
- Loudon County Habitat Zero Energy House in Lenoir City, Tennessee

- FSEC's Low Energy House in Lakeland, Florida

\section{Data Plotting Methodology}

Comparisons are based on regression analysis of daily cooling energy per 1,000 square foot of floor area versus average daily temperature difference (outdoor-indoor).

In all of the studied homes, the cooling equipment consisted of split systems with ducted central air handlers. Sub-metered energy from the condenser and air handler was stored at 15 minute intervals and subsequently combined and totaled on a daily basis during the summer months of various years from 1998 to 2005. Daily cooling energy totals were then divided by the total conditioned area of the home to arrive at daily cooling energy per 1,000 square feet. This provided a means of comparing all homes which range from 1,200 to 4,200 square feet.

The daily cooling energy totals were plotted against average daily temperature difference between outdoors and indoors. Weather stations installed at each site collected dry bulb temperature, relative humidity and solar radiation. Indoor temperatures were taken at or very near the thermostat. The $\mathrm{x}$-axis for each data set consists of the difference between the daily average outdoor and indoor temperatures for the 24 hour period starting at midnight. The values generally fell between negative 10 and positive 15 degrees (outdoor minus indoor). Those residences with lower thermostat settings were characterized by large positive values during the hot summer months. The use of temperature difference is intended to account for both indoor and outdoor temperature variations due to occupant determined thermostat settings and outdoor weather variations.

One pair of homes in the data set can be compared without the generalizations discussed above (except for indoor set point) as they were constructed together with identical floor plans and orientation. These two dwellings located in Lakeland, Florida only differed in equipment efficiency and construction. One was built to minimum code requirements while the other was extensively engineered for reduced cooling load and high efficiency. The original measured results from this 1998 project have since formed the basis for the national Zero Energy Homes program (Parker 1998). The pair effectively sets the upper and lower bounds of the data plotted here.

\section{Baseline For Comparison}

A single baseline was needed to provide a common comparison point for cooling performance in the eight research houses. This was achieved with data from two minimum-code homes located in Central Florida. The Lakeland home provided the majority of this data collected over five summers from 1998 to 2002. The other home contributing to the baseline was a code-minimum frame structure located in Cocoa, Florida; built in 1991. Data from this home was collected over three summers from 2002 to 2004. Each of these residences is cooled by the originally installed, minimum efficiency equipment, SEER 10 in Lakeland and SEER 9 in Cocoa.

\section{Performance Comparison}

The Lakeland high efficiency home was the oldest of those studied ( 8 years), yet it continues to set the bar for cooling efficiency. The data shown in Figure 119 is typical of the last two years of data collection (2002 \& 2003) and represents 72\% less cooling energy use than the baseline. 
While newer the research houses have higher efficiency and sometimes dual-speed cooling equipment, this particular home took advantage of well-designed cooling reduction strategies coupled with a smaller 2-ton cooling system.

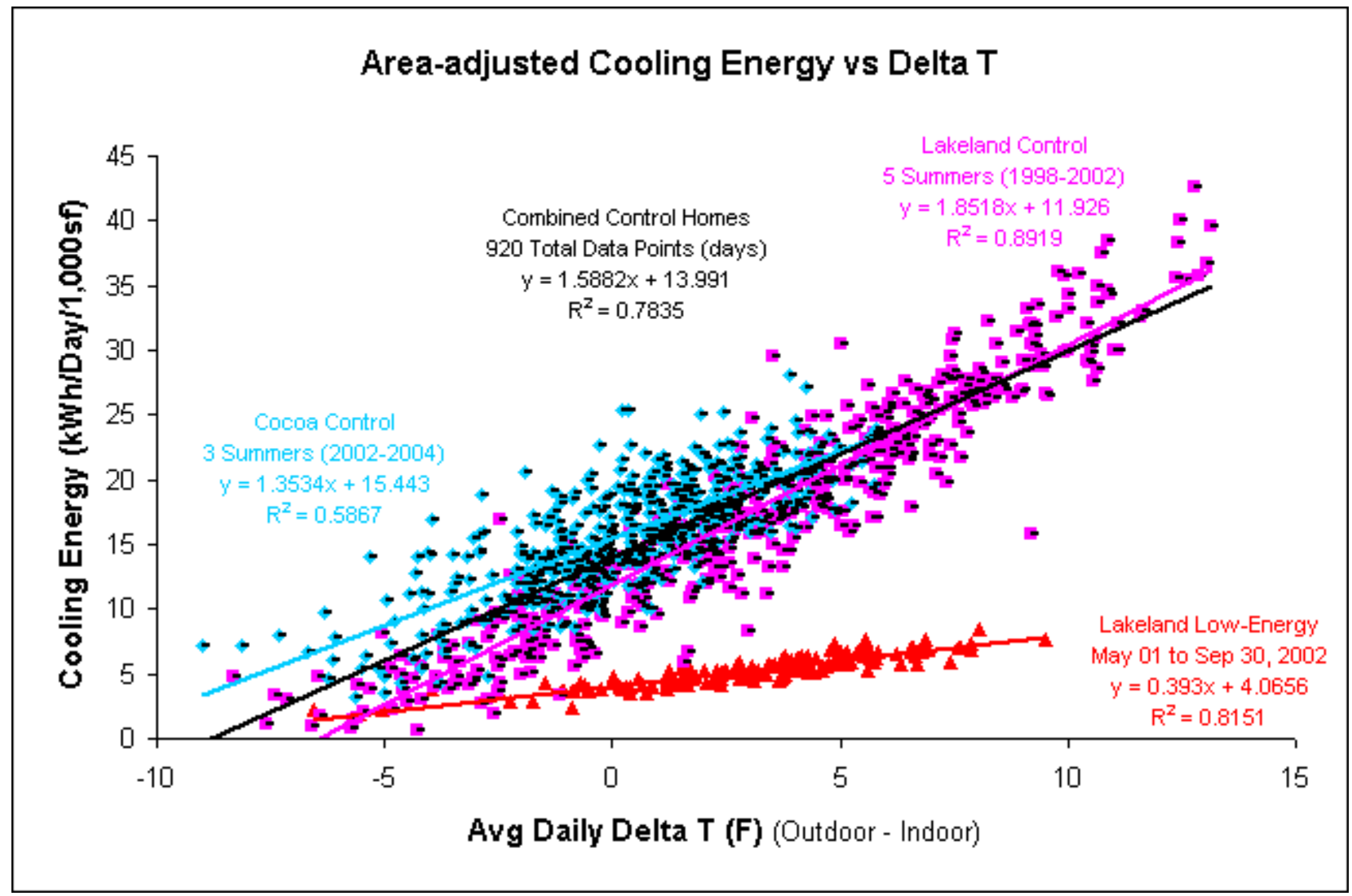

Figure 119. Data and trendlines from two control and one efficient home

\section{Conclusions}

Field-collected home performance measurements are needed to gauge progress toward the Building America goal of 70\% whole house efficiency. The method developed here made use of measured cooling energy and temperature data analyzed through least-squares linear regression on both code-minimum and research homes. Figure 120 directly compares the linear regression of each data set.

The cooling energy savings of each research home was determined in reference to a combined baseline established with data from two homes built to minimum code. While the baseline houses do not necessarily represent "typical" code-minimum homes, they nonetheless provide a useful baseline for comparison of the eight research houses. Additional data from homes built to standard construction practices are needed to further refine the baseline.

Additional work is required to determine the influence of home size on cooling performance level. A greater number of people and equipment per square foot tends to concentrate internal loads in smaller homes more so than in larger ones. This may partially explain the MHLab 
performance, which was below the baseline despite its efficient design. The MHLab was $34 \%$ to $62 \%$ smaller than the other research homes in the same climate (Florida).

Further research on the influence of ground-coupling on cooling performance will improve the accuracy of comparisons between homes in different climate regions and with different levels of ground contact. All but three homes in this study were of slab-on-grade construction. The basement design of the smallest research home (Tennessee Habitat) was likely a strong contributor to its excellent performance, just as the crawlspace design of the MHLab negatively impacted its cooling efficiency.

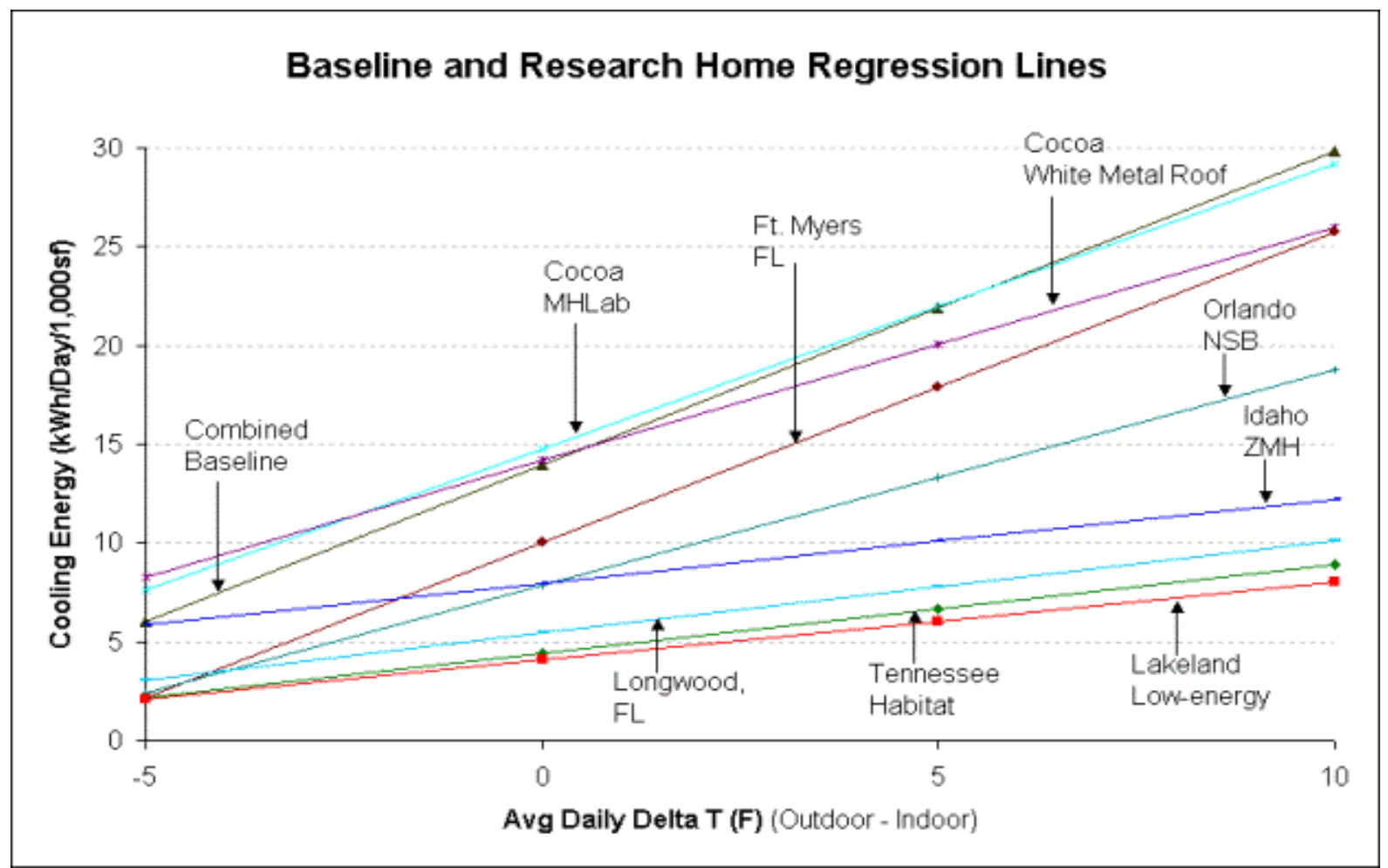

Figure 120 . Trendline comparison of Combined Baseline and 8 Research Homes 


\section{IV \\ BAIHP WEB PAGE, TRAINING PRESENTATIONS, and PUBLICATIONS}




\section{BAIHP WEB PAGE, TRAINING, and PUBLICATIONS}

\section{BAIHP Web Site}

During the final year of the project, the BAIHP web page layouts were revised and content was enhanced with material from 6th Budget Period Annual Report.(www.baihp.org and Figure 121)

\section{Summary of Web Site Content}

- Overview Project history, goals, and areas of activity

- Case Studies Links to 26 summaries of research projects, technical assistance activities, and resources for the home building community

- Current Data Descriptions of eight sites that BAIHP is currently or recently monitoring with links to the online data sites (housed on www.infomonitors.com)

- Partners BAIHP significantly expanded the content of this section of the web site during the final year of the project using the technical assistance summaries from the BAIHP annual report for the $6^{\text {th }}$ budget period.

- $\quad$ Presentations BAIHP researchers make presentations from conferences and workshops available on this page

- Publications Heading the page is a comprehensive list of BAIHP publications followed by a selection of 35 online publications

- Researchers Links to 17 BAIHP researcher bios

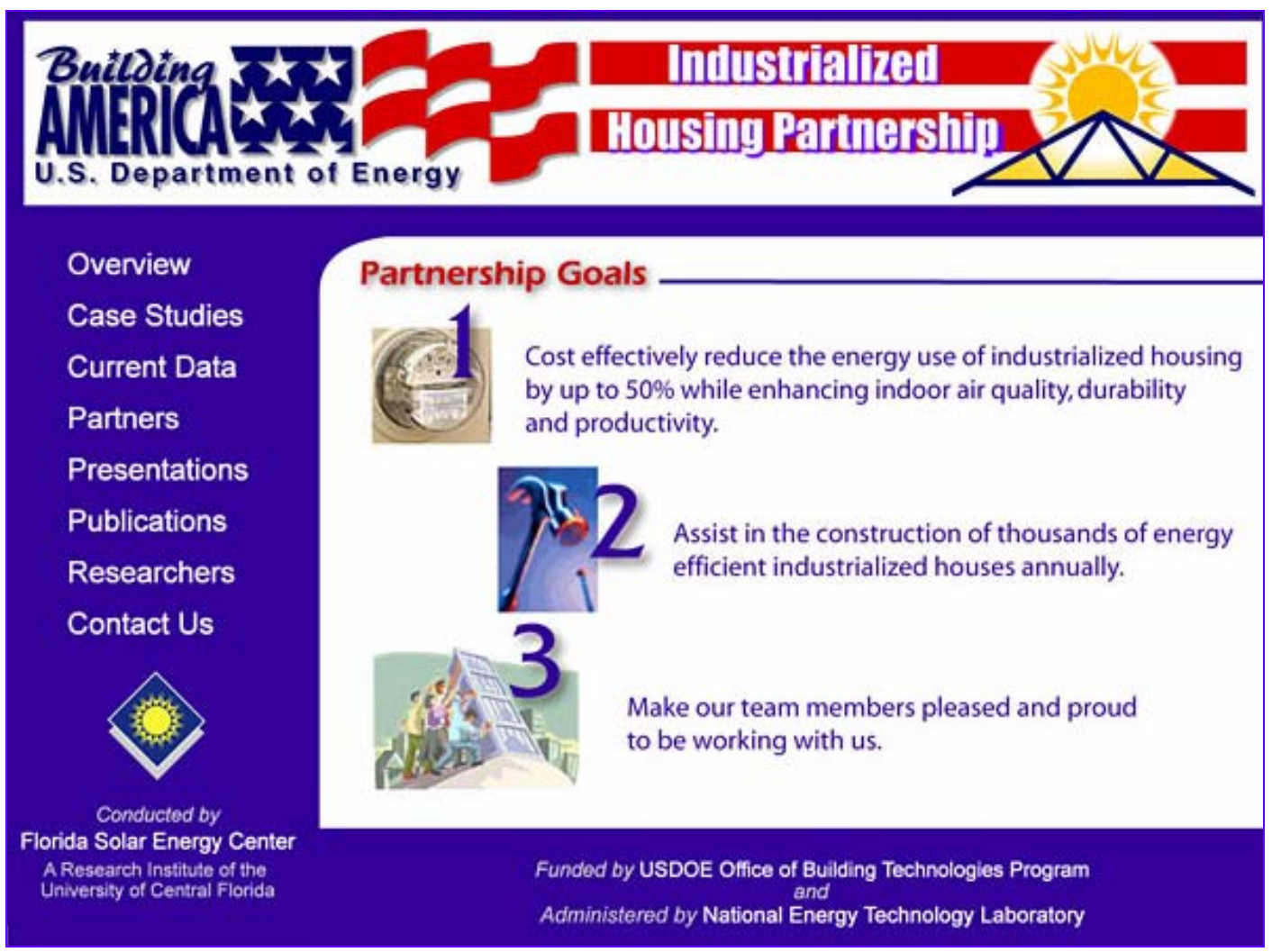

Figure 121 BAIHP Home Page at www.baihp.org 


\section{BAIHP Training and Presentations}

BAIHP research is communicated to public and industry audiences through the BAIHP web page, conference papers and presentations, and various media coverage. Table 80 shows training events in reverse chronological order and is divided by budget period. Following the table are summaries of training events organized by audience and a summary of BAIHP web page and media coverage.

Table 80 Training and Presentations by BAIHP Staff January 2002 - June 2006

\begin{tabular}{|c|c|c|c|c|}
\hline Month & Venue & Description & Researcher & Audience/Attendees \\
\hline June 2006 & $\begin{array}{l}\text { National Community } \\
\text { Development } \\
\text { Association } \\
\text { Conference }\end{array}$ & $\begin{array}{l}\text { Panel Discussion on } \\
\text { Energy Efficiency and } \\
\text { Green Building in } \\
\text { Affordable Housing }\end{array}$ & McIlvaine & $\begin{array}{l}12 \text { Community } \\
\text { Development } \\
\text { specialists }\end{array}$ \\
\hline June 2006 & $\begin{array}{l}\text { BA Quarterly Meeting, } \\
\text { Washington DC }\end{array}$ & $\begin{array}{l}\text { Update of work with } \\
\text { Habitat for Humanity }\end{array}$ & McIlvaine & DOE, BA teams \\
\hline May 2006 & $\begin{array}{l}\text { Affordable Comfort } \\
\text { Conference, Austin TX }\end{array}$ & $\begin{array}{l}\text { Keynote Presentation: } \\
\text { Lighting One corner of } \\
\text { the World }\end{array}$ & Parker & $\sim 600$ attendees \\
\hline May 2006 & $\begin{array}{l}\text { Affordable Comfort } \\
\text { Conference }\end{array}$ & Factory Build Housing & WSU & $\begin{array}{l}\text { Builders, Building } \\
\text { Scientists, Sub- } \\
\text { contractors }\end{array}$ \\
\hline May 2006 & $\begin{array}{l}\text { Affordable Comfort } \\
\text { Conference, Austin TX }\end{array}$ & Overview of BAIHP & Chandra & $\begin{array}{l}\text { Builders, Building } \\
\text { Scientists, Sub- } \\
\text { contractors }\end{array}$ \\
\hline May 2006 & $\begin{array}{l}\text { Affordable Comfort } \\
\text { Conference, Austin TX }\end{array}$ & $\begin{array}{l}\text { Improved } \\
\text { Specifications for } \\
\text { Federally Procured } \\
\text { Ruggedized } \\
\text { Manufactured Homes } \\
\text { for Disaster Relief in } \\
\text { Hot/Humid Climates }\end{array}$ & Thomas-Rees & $\begin{array}{l}\text { Builders, Building } \\
\text { Scientists, Sub- } \\
\text { contractors }\end{array}$ \\
\hline May 2006 & $\begin{array}{l}3^{\text {rd }} \text { Annual } \\
\text { GreenTrends } \\
\text { Conference }\end{array}$ & $\begin{array}{l}\text { Organized and } \\
\text { moderated session on } \\
\text { Green Products and } \\
\text { Processes }\end{array}$ & Martin & \\
\hline Apr 2006 & $\begin{array}{l}\text { Structural Insulated } \\
\text { Panel Association } \\
\text { Annual Conference } \\
\text { and Meeting }\end{array}$ & $\begin{array}{l}2006 \text { Energy Policy Act } \\
\text { Tax Credits }\end{array}$ & Mcllvaine & 70 builders \\
\hline Apr 2006 & BuildSmart Expo & $\begin{array}{l}\text { Keynote Address on } \\
\text { Motivation toward } \\
\text { Energy Efficient } \\
\text { Rebuilding in the Gulf } \\
\text { Coast }\end{array}$ & McIlvaine & $\begin{array}{l}35 \text { builders and } \\
\text { consumers }\end{array}$ \\
\hline
\end{tabular}


Table 80 Training and Presentations by BAIHP Staff January 2002 - June 2006

\begin{tabular}{|c|c|c|c|c|}
\hline Month & Venue & Description & Researcher & Audience/Attendees \\
\hline Mar 2006 & $\begin{array}{l}\text { Greater Houston } \\
\text { Builder Assoc. } \\
\text { Conference }\end{array}$ & $\begin{array}{l}\text { "Green Building" } \\
\text { Presentation }\end{array}$ & $\begin{array}{l}\text { Fonorow and } \\
\text { Chandra }\end{array}$ & $50+$ builders \\
\hline Mar 2006 & $\begin{array}{l}\text { RESNET Conference, } \\
\text { San Antonio }\end{array}$ & $\begin{array}{l}\text { BAIHP-Habitat for } \\
\text { Humanity Partnership } \\
\text { and Invitation to } \\
\text { RESNET members }\end{array}$ & $\begin{array}{l}\text { Mcllvaine, } \\
\text { Fonorow, and } \\
\text { Stroer }\end{array}$ & $\begin{array}{l}25 \text { Home Energy } \\
\text { Raters }\end{array}$ \\
\hline Mar 2006 & $\begin{array}{l}\text { ACEEE Emerging } \\
\text { Technologies: Next } \\
\text { Big Ideas 2006, } \\
\text { Washington DC }\end{array}$ & $\begin{array}{l}\text { Presentation: Air } \\
\text { Distribution Systems in } \\
\text { Conditioned Spaces }\end{array}$ & Moyer & \\
\hline Mar 2006 & $\begin{array}{l}\text { World Energy } \\
\text { Sustainable Energy } \\
\text { Conference, Wels, } \\
\text { Austria }\end{array}$ & $\begin{array}{l}\text { Presentation of data on } \\
\text { the evaluation of the } \\
\text { NightCool concept }\end{array}$ & D. Parker & \\
\hline Mar 2006 & $\begin{array}{l}\text { Habitat for Humanity } \\
\text { International National } \\
\text { Building Science } \\
\text { Focus Training, } \\
\text { Phoenix, AZ }\end{array}$ & $\begin{array}{l}\text { Establishing a Building } \\
\text { Science Program }\end{array}$ & McIlvaine & \\
\hline Mar 2006 & RESNET conference & $\begin{array}{l}\text { Presentation: Congress } \\
\text { Build America Action } \\
\text { Plan }\end{array}$ & McIlvaine & Home Energy Raters \\
\hline Feb 2006 & $\begin{array}{l}\text { Tropical Green } \\
\text { Conference, Miami }\end{array}$ & $\begin{array}{l}\text { Presentation of BAIHP } \\
\text { Activities }\end{array}$ & Chandra & $250+$ \\
\hline Jan 2006 & $\begin{array}{l}\text { International Builders } \\
\text { Show }\end{array}$ & $\begin{array}{l}\text { Structural Insulated } \\
\text { Panels: Indoor Air } \\
\text { Quality, Moisture, and } \\
\text { Energy Efficiency Pros } \\
\text { and Cons }\end{array}$ & McIlvaine & 100 builders \\
\hline Jan 2006 & FSEC & $\begin{array}{l}\text { EnergyGauge Refresher } \\
\text { and Recertification } \\
\text { Class, Refresher Class }\end{array}$ & Moyer & Home Energy Raters \\
\hline Dec 2005 & $\begin{array}{l}\text { BA Quarterly Meeting, } \\
\text { Washington DC }\end{array}$ & $\begin{array}{l}\text { Update of work with } \\
\text { Habitat for Humanity }\end{array}$ & Mcllvaine & DOE, BA Teams \\
\hline Nov 2005 & $\begin{array}{l}\text { USGBC Technical } \\
\text { Assistance Charrette, } \\
\text { GreenBuild, Atlanta }\end{array}$ & $\begin{array}{l}\text { Abbreviated Building } \\
\text { America and building } \\
\text { science overview } \\
\text { presentation }\end{array}$ & McIlvaine & $\begin{array}{l}50 \text { Green building } \\
\text { specialists and HFH } \\
\text { Gulf Coast affiliates }\end{array}$ \\
\hline Oct 2005 & $\begin{array}{l}\text { Joint National HFH } \\
\text { Rural and SE } \\
\text { Leadership } \\
\text { Conference, Portland, } \\
\text { OR } \\
\end{array}$ & $\begin{array}{l}\text { Building America and } \\
\text { Establishing a Building } \\
\text { Science Program }\end{array}$ & McIlvaine & $\begin{array}{l}50 \text { HFH Construction } \\
\text { Managers }\end{array}$ \\
\hline
\end{tabular}


Table 80 Training and Presentations by BAIHP Staff January 2002 - June 2006

\begin{tabular}{|c|c|c|c|c|}
\hline Month & Venue & Description & Researcher & Audience/Attendees \\
\hline Sep 2005 & FSEC & $\begin{array}{l}\text { EnergyGauge Rater } \\
\text { Refresher and } \\
\text { Recertification }\end{array}$ & Moyer & Home Energy Raters \\
\hline Sep 2005 & FSEC & $\begin{array}{l}\text { Class } 1 \text { EnergyGauge } \\
\text { Rater Training }\end{array}$ & Moyer & Home Energy Raters \\
\hline Sep 2005 & $\begin{array}{l}\text { Florida Housing } \\
\text { Coalition } 05 \\
\text { Conference } \\
\end{array}$ & & Moyer & $\begin{array}{l}\text { Non-profit housing } \\
\text { providers }\end{array}$ \\
\hline Aug 2005 & $\begin{array}{l}\text { ISIS (International } \\
\text { Solar Energy Society) } \\
\text { Conference }\end{array}$ & $\begin{array}{l}\text { Presentation: } \\
\text { Preliminary results of } \\
\text { white roof hurricane } \\
\text { retrofit analysis }\end{array}$ & Chasar & Engineers \\
\hline July 2005 & $\begin{array}{l}\text { Joint meeting of } \\
\text { Oregon and } \\
\text { Washington State HFH } \\
\text { construction managers. }\end{array}$ & $\begin{array}{l}\text { Building America and } \\
\text { building science } \\
\text { overview presentation }\end{array}$ & McIlvaine & $\begin{array}{l}30 \mathrm{HFH} \text { Construction } \\
\text { managers }\end{array}$ \\
\hline July 2005 & $\begin{array}{l}\text { Southeast Builders } \\
\text { Show, Orlando }\end{array}$ & $\begin{array}{l}\text { One hour presentation } \\
\text { on energy efficiency } \\
\text { guidelines }\end{array}$ & $\begin{array}{l}\text { McIlvaine, } \\
\text { Barkaszi }\end{array}$ & $\begin{array}{l}100 \text { home building } \\
\text { industry }\end{array}$ \\
\hline July 2005 & $\begin{array}{l}\text { Southeast Builders } \\
\text { Show, Orlando }\end{array}$ & $\begin{array}{l}\text { 2-hour course on high } \\
\text { performance homes }\end{array}$ & $\begin{array}{l}\text { Moyer, } \\
\text { Chandra }\end{array}$ & $\sim 100$ builders \\
\hline June 2005 & $\begin{array}{l}\text { Alaska Building } \\
\text { Science Network } \\
\text { Conference }\end{array}$ & $\begin{array}{l}\text { BAIHP and NEEM } \\
\text { Presentation }\end{array}$ & WSU & Building Scientists \\
\hline June 2005 & FSEC & $\begin{array}{l}\text { Class } 1 \text { Rater Training } \\
\text { and Rater } \\
\text { Recertification Training }\end{array}$ & $\begin{array}{l}\text { EG Office, } \\
\text { Moyer }\end{array}$ & Home Energy Raters \\
\hline June 2005 & FSEC & $\begin{array}{l}\text { Florida Green Home } \\
\text { Designation Course }\end{array}$ & Martin & $\begin{array}{l}50 \text { Students, most } \\
\text { employed by the } \\
\text { Sarasota County } \\
\text { Building Dept. }\end{array}$ \\
\hline June 2005 & $\begin{array}{l}\text { ASHRAE Annual } \\
\text { Meeting, Denver CO. }\end{array}$ & $\begin{array}{l}\text { Condenser Fan } \\
\text { Research Presentation }\end{array}$ & Parker & Engineers \\
\hline May 2005 & FSEC & EnergyGauge Class & Moyer & Home Energy Raters \\
\hline April 2005 & FSEC & $\begin{array}{l}2 \text { sessions: Rater } \\
\text { Certification Class } 1\end{array}$ & $\begin{array}{l}\text { Moyer, Sonne } \\
\text { Kucharski }\end{array}$ & Home Energy Raters \\
\hline April 2005 & FSEC & $\begin{array}{l}\text { Rater Recertification } \\
\text { Class }\end{array}$ & $\begin{array}{l}\text { Moyer, Sonne } \\
\text { Kucharski }\end{array}$ & Home Energy Raters \\
\hline April 2005 & '05 SIPA National Mtg & $\begin{array}{l}\text { Overview of Building } \\
\text { America and Systems } \\
\text { Engineering }\end{array}$ & McIlvaine & SIP Industry/ 130 \\
\hline
\end{tabular}


Table 80 Training and Presentations by BAIHP Staff January 2002 - June 2006

\begin{tabular}{|c|c|c|c|c|}
\hline Month & Venue & Description & Researcher & Audience/Attendees \\
\hline April 2005 & '05 SIPA National Mtg & $\begin{array}{l}\text { Benefits and } \\
\text { Challenges of SIPS, a } \\
\text { Building America, } \\
\text { Systems Engineering } \\
\text { Perspective }\end{array}$ & McIlvaine & SIP Industry/ 130 \\
\hline Feb 2005 & Sarasota FL & $\begin{array}{l}\text { Florida Green Home } \\
\text { Certification Course }\end{array}$ & Martin & $\begin{array}{l}27 \text { students including } \\
15 \text { builder's reps. }\end{array}$ \\
\hline Jan 2005 & $\begin{array}{l}\text { ASHRAE Technical } \\
\text { Program - Orlando, FL }\end{array}$ & $\begin{array}{l}\text { Presentation: } \\
\text { Ventilation Strategies } \\
\text { in Hot and Humid } \\
\text { Climates }\end{array}$ & Moyer & $\begin{array}{l}\text { ASHRAE } \\
\text { Engineers/HVAC } \\
\text { Industry }\end{array}$ \\
\hline Jan 2005 & $\begin{array}{l}\text { ASHRAE Technical } \\
\text { Program - Orlando, FL }\end{array}$ & $\begin{array}{l}\text { Presentation: Whole } \\
\text { Buildings: Why } \\
\text { Everything Interacts }\end{array}$ & Moyer & $\begin{array}{l}\text { ASHRAE } \\
\text { Engineers/HVAC } \\
\text { Industry }\end{array}$ \\
\hline Dec 2004 & $\begin{array}{l}\text { Performance of } \\
\text { Exterior Envelopes of } \\
\text { Whole Buildings IX, } \\
\text { Clearwater (FL) }\end{array}$ & $\begin{array}{l}\text { Accepted Paper on Side } \\
\text { by Side Monitoring of } \\
\text { Energy Star and } \\
\text { Standard HUD Code } \\
\text { Home. }\end{array}$ & McGinley & $\begin{array}{l}\text { Energy Efficiency } \\
\text { Industry }\end{array}$ \\
\hline Dec 2004 & $\begin{array}{l}\text { Performance of } \\
\text { Exterior Envelopes of } \\
\text { Whole Buildings IX, } \\
\text { Clearwater (FL) }\end{array}$ & $\begin{array}{l}\text { Accepted Paper: Cold } \\
\text { Climate Case Study of } \\
\text { North Dakota Twin } \\
\text { Homes for Performance } \\
\text { of Exterior Envelopes }\end{array}$ & Chasar & $\begin{array}{l}\text { Energy Efficiency } \\
\text { Industry }\end{array}$ \\
\hline Dec 2004 & $\begin{array}{l}\text { Performance of } \\
\text { Exterior Envelopes of } \\
\text { Whole Buildings IX, } \\
\text { Clearwater (FL) }\end{array}$ & $\begin{array}{l}\text { Accepted Paper: } \\
\text { Residential Ventilation } \\
\text { Techniques }\end{array}$ & Moyer & $\begin{array}{l}\text { Energy Efficiency } \\
\text { Industry }\end{array}$ \\
\hline Nov 2004 & $\begin{array}{l}\text { ASHRAE Puget Sound } \\
\text { Chapter Annual } \\
\text { Meeting, Seattle (WA) }\end{array}$ & $\begin{array}{l}\text { Invited speaker } \\
\text { Presentation on } \\
\text { ASHRAE TC6.3 } \\
\text { Activities }\end{array}$ & Lubliner & $\begin{array}{l}\text { ASHRAE } \\
\text { Engineers/HVAC } \\
\text { Industry }\end{array}$ \\
\hline Nov 2004 & Ft. Walton Beach & $\begin{array}{l}\text { Greening Our Growth: } \\
\text { Using Green Standards } \\
\text { to Guide Our Growth. }\end{array}$ & Martin & $\begin{array}{l}\text { Local Government / } \\
\text { Utilities } \sim 10\end{array}$ \\
\hline Nov 2004 & Ft. Walton Beach & $\begin{array}{l}\text { Florida Green Home } \\
\text { Certification Course }\end{array}$ & Martin & $\begin{array}{l}\text { Builders/consultants } \\
\sim 10\end{array}$ \\
\hline Nov 2004 & $\begin{array}{l}\text { USGBC GreenBuild } \\
\text { Conference - Portland, } \\
\text { OR }\end{array}$ & $\begin{array}{l}\text { Impact of Roofing } \\
\text { Systems on Residential } \\
\text { Cooling Energy } \\
\text { Demand. }\end{array}$ & Martin & Green Industry \\
\hline Oct 2004 & FSEC & $\begin{array}{l}\text { Training: Green Home } \\
\text { Construction Practices }\end{array}$ & E. Martin & WSI Architects - 13 \\
\hline Oct 2004 & FSEC & $\begin{array}{l}\text { Presentation: High } \\
\text { Performance Homes }\end{array}$ & S. Chandra & $\begin{array}{l}\text { FSEC Policy } \\
\text { Advisory Board }\end{array}$ \\
\hline
\end{tabular}


Table 80 Training and Presentations by BAIHP Staff January 2002 - June 2006

\begin{tabular}{|c|c|c|c|c|}
\hline Month & Venue & Description & Researcher & Audience/Attendees \\
\hline Oct 2004 & FSEC & $\begin{array}{l}\text { EnergyGauge Class } 1 \\
\text { Rating Course }\end{array}$ & N. Moyer & 2 students \\
\hline Oct 2004 & $\begin{array}{l}\text { WCI Communities - } \\
\text { Bonita Springs, FL }\end{array}$ & $\begin{array}{l}\text { Florida Green Home } \\
\text { Certification Course }\end{array}$ & Martin & Architects $\sim 15$ \\
\hline Oct 2004 & $\begin{array}{l}\text { WCI Communities - } \\
\text { Bonita Springs, FL }\end{array}$ & $\begin{array}{l}\text { Overview of Home } \\
\text { Building Programs in } \\
\text { Florida: Getting to Zero } \\
\text { Energy. }\end{array}$ & Martin & Architects $\sim 25$ \\
\hline Oct 2004 & $\begin{array}{l}\text { MHI Annual Meeting, } \\
\text { Energy Roadmap } \\
\text { session Palm Springs } \\
\text { (CA) }\end{array}$ & $\begin{array}{l}\text { Invited speaker } \\
\text { Presentation on BAIHP } \\
\text { in the PNW }\end{array}$ & Lubliner & $\begin{array}{l}\text { MHI-HUD Code } \\
\text { Industry }\end{array}$ \\
\hline Oct 2004 & EEBA, Dallas, TX & $\begin{array}{l}\text { Presentation: Producing } \\
\text { Airtight Ducts }\end{array}$ & Moyer & $\begin{array}{l}\text { Energy Efficiency } \\
\text { Industry }\end{array}$ \\
\hline Oct 2004 & EEBA, Dallas, TX & $\begin{array}{l}\text { Presentation: } \\
\text { Ventilation in Humid } \\
\text { Climates Data from } \\
\text { Field Experiments }\end{array}$ & Moyer & $\begin{array}{l}\text { Energy Efficiency } \\
\text { Industry }\end{array}$ \\
\hline Sept 2004 & $\begin{array}{l}\text { AIVC Conference } \\
\text { Prague, (CZ) }\end{array}$ & $\begin{array}{l}\text { Invited paper } \\
\text { Performance and } \\
\text { Application of } \\
\text { Gossamer Wind Solar } \\
\text { Powered Ceiling Fans }\end{array}$ & $\begin{array}{l}\text { Lubliner, } \\
\text { Parker, Chaser }\end{array}$ & $\begin{array}{l}\text { International } \\
\text { Building Science } \\
\text { Community }\end{array}$ \\
\hline Aug 2004 & FSEC & $\begin{array}{l}\text { EnergyGauge Class } 1 \\
\text { Rating Course }\end{array}$ & N. Moyer & 8 students \\
\hline Aug 2004 & $\begin{array}{l}\text { Solar Energy Society } \\
\text { of Canada, Waterloo }\end{array}$ & $\begin{array}{l}\text { Invited paper: } \\
\text { Justification for Energy } \\
\text { Efficient and } \\
\text { Renewable Energy } \\
\text { Systems }\end{array}$ & McCluney & $\begin{array}{l}\text { Energy Efficiency } \\
\text { Industry }\end{array}$ \\
\hline Aug 2004 & $\begin{array}{l}\text { Florida Pollution } \\
\text { Prevention Conference } \\
\text { - Gainesville, FL } \\
\end{array}$ & $\begin{array}{l}\text { Creating a Green and } \\
\text { Profitable Work } \\
\text { Environment. }\end{array}$ & Martin & $\begin{array}{l}\text { Local Governments, } \\
\text { researchers, industry }\end{array}$ \\
\hline Aug 2004 & $\begin{array}{l}\text { SE Builder Conference } \\
\text { - Orlando, FL }\end{array}$ & $\begin{array}{l}\text { Presentation: Health } \\
\text { House Design and } \\
\text { Construction }\end{array}$ & $\begin{array}{l}\text { Moyer, } \\
\text { Chandra }\end{array}$ & Builders \\
\hline Aug 2004 & $\begin{array}{l}\text { SE Builder conference } \\
\text { - Orlando, FL }\end{array}$ & $\begin{array}{l}\text { Presentation: Indoor } \\
\text { Air Quality - } \\
\text { Positioning Yourself } \\
\text { for This Growing } \\
\text { Market }\end{array}$ & $\begin{array}{l}\text { Moyer, } \\
\text { Chandra }\end{array}$ & Builders \\
\hline Aug 2004 & $\begin{array}{l}\text { ACEEE Summer } \\
\text { Study, Pacific Grove } \\
\text { (CA) }\end{array}$ & $\begin{array}{l}\text { Accepted Paper: Six } \\
\text { Residential Ventilation } \\
\text { Techniques in Hot and } \\
\text { Humid Climates }\end{array}$ & $\begin{array}{l}\text { Chasar for } \\
\text { Moyer }\end{array}$ & $\begin{array}{l}\text { Energy Efficiency } \\
\text { Industry }\end{array}$ \\
\hline
\end{tabular}


Table 80 Training and Presentations by BAIHP Staff January 2002 - June 2006

\begin{tabular}{|c|c|c|c|c|}
\hline Month & Venue & Description & Researcher & Audience/Attendees \\
\hline Aug 2004 & $\begin{array}{l}\text { ACEEE Summer } \\
\text { Study, Pacific Grove } \\
\text { (CA) }\end{array}$ & $\begin{array}{l}\text { Accepted Paper: } \\
\text { Energy Star } \\
\text { Manufactured Homes: } \\
\text { The Plant Certification } \\
\text { Process }\end{array}$ & Chasar & $\begin{array}{l}\text { Energy Efficiency } \\
\text { Industry }\end{array}$ \\
\hline Aug 2004 & $\begin{array}{l}\text { ACEEE Summer } \\
\text { Study, Pacific Grove } \\
\text { (CA) }\end{array}$ & $\begin{array}{l}\text { Accepted Paper: } \\
\text { Revision to the Energy- } \\
\text { Efficiency } \\
\text { Requirements in } \\
\text { MHCSS }\end{array}$ & $\begin{array}{l}\text { Lubliner, } \\
\text { Conner, Dillon, } \\
\text { Lucas }\end{array}$ & $\begin{array}{l}\text { Energy Efficiency } \\
\text { Industry }\end{array}$ \\
\hline Aug 2004 & $\begin{array}{l}\text { ACEEE Summer } \\
\text { Study, Pacific Grove } \\
\text { (CA) }\end{array}$ & $\begin{array}{l}\text { Panel Moderators: } \\
\text { Residential } \\
\text { Technologies } 24 \text { papers }\end{array}$ & $\begin{array}{l}\text { Lubliner, } \\
\text { Parker }\end{array}$ & $\begin{array}{l}\text { Energy Efficiency } \\
\text { Industry }\end{array}$ \\
\hline July 2004 & $\begin{array}{l}\text { American Lung } \\
\text { Association }\end{array}$ & $\begin{array}{l}\text { Energy Efficiency and } \\
\text { IAQ seminar }\end{array}$ & S. Chandra & $\begin{array}{l}\text { American Lung } \\
\text { Association staff }\end{array}$ \\
\hline July 2004 & FSEC & $\begin{array}{l}\text { RHVAC Manual J } \\
\text { Software and Manual } \\
\text { J8 Instruction }\end{array}$ & FSEC staff & $\begin{array}{l}10 \text { Building } \\
\text { Scientists }\end{array}$ \\
\hline Jul 2004 & $\begin{array}{l}\text { American Solar Energy } \\
\text { Society Conference }\end{array}$ & $\begin{array}{l}\text { Invited Paper: } \\
\text { Introducing Solar } \\
\text { Ready Manufactured } \\
\text { Housing }\end{array}$ & $\begin{array}{l}\text { Lubliner, } \\
\text { Hadley, } \\
\text { and Gordon }\end{array}$ & $\begin{array}{l}\text { Solar Energy } \\
\text { Industry }\end{array}$ \\
\hline Jun 2004 & Sarasota, FL & $\begin{array}{l}\text { Florida Green Homes } \\
\text { Certification Course }\end{array}$ & Mcllvaine & 23 students \\
\hline Jun 2004 & $\begin{array}{l}\text { ASHRAE Annual } \\
\text { Meeting, Nashville, } \\
\text { (TN) }\end{array}$ & $\begin{array}{l}\text { Invited Author } \\
\text { ASHRAE 2004 HVAC } \\
\text { and Equipment } \\
\text { Handbook Chapter } 9 \\
\text { Residential HVAC } \\
\text { Systems }\end{array}$ & $\begin{array}{l}\text { Lubliner, } \\
\text { Andrews, et. al }\end{array}$ & $\begin{array}{l}\text { ASHRAE } \\
\text { Engineers/HVAC } \\
\text { Industry }\end{array}$ \\
\hline Jun 2004 & $\begin{array}{l}\text { ASHRAE Annual } \\
\text { Meeting, Nashville, } \\
\text { (TN) }\end{array}$ & $\begin{array}{l}\text { Invited symposium } \\
\text { Abstract - HVAC } \\
\text { Systems and } \\
\text { Performance in } \\
\text { Building America } \\
\text { Homes }\end{array}$ & $\begin{array}{l}\text { Lubliner, } \\
\text { Vorha }\end{array}$ & $\begin{array}{l}\text { ASHRAE } \\
\text { Engineers/HVAC } \\
\text { Industry }\end{array}$ \\
\hline Jun 2004 & $\begin{array}{l}\text { Lakewood Ranch Polo } \\
\text { Club - Sarasota, FL }\end{array}$ & $\begin{array}{l}\text { Florida Green Home } \\
\text { Certification Course }\end{array}$ & Martin & $\begin{array}{l}\text { Builders/consultants } \\
\sim 25\end{array}$ \\
\hline May 2004 & $\begin{array}{l}\text { Seaside Institute - } \\
\text { Seaside, FL }\end{array}$ & $\begin{array}{l}\text { Building Science and } \\
\text { Home Building } \\
\text { Programs in Florida (w/ } \\
\text { SouthFace) }\end{array}$ & Vieira & Builders $\sim 35$ \\
\hline
\end{tabular}


Table 80 Training and Presentations by BAIHP Staff January 2002 - June 2006

\begin{tabular}{|c|c|c|c|c|}
\hline Month & Venue & Description & Researcher & Audience/Attendees \\
\hline May 2004 & $\begin{array}{l}\text { Florida GreenTrends } \\
\text { Conference }\end{array}$ & $\begin{array}{l}\text { Green Building at the } \\
\text { Municipality Level: } \\
\text { Developing a Standard } \\
\text { for Florida Local } \\
\text { Governments. }\end{array}$ & Martin & Green Industry \\
\hline Apr 2004 & FSEC - Cocoa, FL & $\begin{array}{l}\text { Florida Green Home } \\
\text { Certification Course }\end{array}$ & Martin & $\begin{array}{l}\text { Builders/consultants } \\
\sim 25\end{array}$ \\
\hline Apr 2004 & $\begin{array}{l}\text { 14th Symposium on } \\
\text { Improving Building } \\
\text { Systems in Hot and } \\
\text { Humid Climates, } \\
\text { Dallas TX }\end{array}$ & $\begin{array}{l}\text { Presentation: Achieving } \\
\text { Airtight Ducts in } \\
\text { Manufactured Housing }\end{array}$ & McIlvaine & $\begin{array}{l}\text { Energy Efficiency } \\
\text { Industry }\end{array}$ \\
\hline Apr 2004 & $\begin{array}{l}\text { 14th Symposium on } \\
\text { Improving Building } \\
\text { Systems in Hot and } \\
\text { Humid Climates, } \\
\text { Dallas TX }\end{array}$ & $\begin{array}{l}\text { Presented Referred } \\
\text { Paper: Optimizing } \\
\text { Manufactured Housing } \\
\text { Energy Use }\end{array}$ & McGinley & $\begin{array}{l}\text { Energy Efficiency } \\
\text { Industry }\end{array}$ \\
\hline Apr 2004 & $\begin{array}{l}\text { 14th Symposium on } \\
\text { Improving Building } \\
\text { Systems in Hot and } \\
\text { Humid Climates, } \\
\text { Dallas TX }\end{array}$ & $\begin{array}{l}\text { Presented Referred } \\
\text { Paper: An Overview of } \\
\text { Experimental Research } \\
\text { on Houses by the } \\
\text { Building America } \\
\text { Industrialized Housing } \\
\text { Partnership }\end{array}$ & Chandra & $\begin{array}{l}\text { Energy Efficiency } \\
\text { Industry }\end{array}$ \\
\hline Apr 2004 & $\begin{array}{l}\text { 14th Symposium on } \\
\text { Improving Building } \\
\text { Systems in Hot and } \\
\text { Humid Climates. }\end{array}$ & $\begin{array}{l}\text { Presented Referred } \\
\text { Paper: Air Duct } \\
\text { Tightness in } \\
\text { Manufactured Housing }\end{array}$ & McIlvaine & $\begin{array}{l}\text { Energy Efficiency } \\
\text { Industry }\end{array}$ \\
\hline Apr 2004 & $\begin{array}{l}\text { HFH National } \\
\text { Leadership Conference }\end{array}$ & $\begin{array}{l}\text { Presentation, } 1.5 \text { hours: } \\
\text { Advanced Building } \\
\text { Science and Moisture } \\
\text { Control }\end{array}$ & McIlvaine & $\begin{array}{l}\text { HFH Construction } \\
\text { Managers and } \\
\text { Leaders }\end{array}$ \\
\hline Apr 2004 & $\begin{array}{l}\text { SPIE Defense and } \\
\text { Security Symposium, } \\
\text { Orlando FL }\end{array}$ & $\begin{array}{l}\text { Presentations: } \\
\text { Introduction to } \\
\text { Radiometry and } \\
\text { Photometry }\end{array}$ & McCluney & Optical engineers \\
\hline Apr 2004 & $\begin{array}{l}\text { Affordable Comfort } \\
\text { Conference, } \\
\text { Minneapolis }\end{array}$ & $\begin{array}{l}\text { Presentation: } \\
\text { Summertime Humidity } \\
\text { Control: High } \\
\text { Performance Home } \\
\text { Challenges }\end{array}$ & Moyer & $\begin{array}{l}\text { Energy Efficiency } \\
\text { Industry }\end{array}$ \\
\hline Apr 2004 & $\begin{array}{l}\text { Affordable Comfort } \\
\text { Conference, } \\
\text { Minneapolis }\end{array}$ & $\begin{array}{l}\text { Presentation: Vented \& } \\
\text { Unvented Roof } \\
\text { Assemblies: What Not } \\
\text { To Do }\end{array}$ & Moyer & $\begin{array}{l}\text { Energy Efficiency } \\
\text { Industry }\end{array}$ \\
\hline
\end{tabular}


Table 80 Training and Presentations by BAIHP Staff January 2002 - June 2006

\begin{tabular}{|c|c|c|c|c|}
\hline Month & Venue & Description & Researcher & Audience/Attendees \\
\hline Mar 2004 & $\begin{array}{l}\text { IBACOS/FSEC } \\
\text { Monitoring Workshop } \\
\text { Meeting }\end{array}$ & $\begin{array}{l}\text { FSEC co-hosted 1-day } \\
\text { workshop session with } \\
\text { IBACOS. Presentations } \\
\text { by researchers from } \\
\text { NREL, Davis Energy } \\
\text { Group, IBACOS and } \\
\text { FSEC as well as reps } \\
\text { from Campbell } \\
\text { (dataloggers) and Data } \\
\text { Taker. }\end{array}$ & $\begin{array}{l}\text { Chasar, } \\
\text { Kalaghchy } \\
\text { (FSEC } \\
\text { Computer } \\
\text { Resources } \\
\text { Manager), } \\
\text { BAIHP Staff }\end{array}$ & BA Researchers \\
\hline Mar 2004 & $\begin{array}{l}\text { GreenPrints } \\
\text { Conference, Atlanta }\end{array}$ & $\begin{array}{l}\text { Presentation: } \\
\text { Techniques You Should } \\
\text { Incorporate In Your } \\
\text { New Home or How to } \\
\text { Star in the High } \\
\text { Hurdles, }\end{array}$ & Vieira & $\begin{array}{l}\text { Builders, Energy } \\
\text { Efficiency Industry } \\
\sim 75 \text { attendees }\end{array}$ \\
\hline Mar 2004 & www.baihp.org & $\begin{array}{l}\text { Posted } \\
\text { Standards for Clean Air } \\
\text { Florida Homes }\end{array}$ & Chandra & $\begin{array}{l}\text { Builders, } \\
\text { Manufacturers, } \\
\text { Building Scientists, } \\
\text { Public }\end{array}$ \\
\hline Feb 2004 & $\begin{array}{l}\text { Central Atlantic Coast } \\
\text { HFH Conference }\end{array}$ & $\begin{array}{l}\text { Presentation, } 2 \text { hours: } \\
\text { Advanced Building } \\
\text { Science and Moisture } \\
\text { Control }\end{array}$ & McIlvaine & $\begin{array}{l}\sim 100 \mathrm{HFH} \\
\text { Construction } \\
\text { Managers/Staff }\end{array}$ \\
\hline Feb 2004 & www.baihp.org & $\begin{array}{l}\text { Posted } \\
\text { Achieving Airtight } \\
\text { Ducts in Manufactured } \\
\text { Housing }\end{array}$ & McIlvaine & $\begin{array}{l}\text { Builders, } \\
\text { Manufacturers, } \\
\text { Building Scientists, } \\
\text { Public }\end{array}$ \\
\hline Feb 2004 & www.baihp.org & $\begin{array}{l}\text { Posted } \\
\text { Alleviating Moisture } \\
\text { Problems Hot, Humid } \\
\text { Climate Housing }\end{array}$ & Moyer & $\begin{array}{l}\text { Builders, } \\
\text { Manufacturers, } \\
\text { Building Scientists, } \\
\text { Public }\end{array}$ \\
\hline Feb 2004 & www.baihp.org & $\begin{array}{l}\text { Posted Case Study: } \\
\text { WCI Communities at } \\
\text { Evergrene }\end{array}$ & Martin & $\begin{array}{l}\text { Builders, } \\
\text { Manufacturers, } \\
\text { Building Scientists, } \\
\text { Public }\end{array}$ \\
\hline Feb 2004 & FSEC, Cocoa (FL) & $\begin{array}{l}\text { Workshop, } 3 \text { day } \\
\text { course: Class } 1 \text { Florida } \\
\text { Home Energy Rater } \\
\text { Training. Included } \\
\text { Certification exam }\end{array}$ & Moyer & Energy Raters \\
\hline
\end{tabular}


Table 80 Training and Presentations by BAIHP Staff January 2002 - June 2006

\begin{tabular}{|c|c|c|c|c|}
\hline Month & Venue & Description & Researcher & Audience/Attendees \\
\hline Jan 2004 & $\begin{array}{l}\text { USDOE Expert } \\
\text { Meeting, Anaheim } \\
\text { (CA) }\end{array}$ & $\begin{array}{l}\text { Expert meeting co- } \\
\text { developed with } \\
\text { ASHRAE: Residential } \\
\text { HVAC Fans and } \\
\text { Systems }\end{array}$ & & Building Scientists \\
\hline Jan 2004 & $\begin{array}{l}\text { Southeastern Habitat } \\
\text { for Humanity } \\
\text { Conference, Jekyll } \\
\text { Island (GA) }\end{array}$ & $\begin{array}{l}\text { Short Course: } \\
\text { Advanced Building } \\
\text { Science and Moisture } \\
\text { Control }\end{array}$ & McIlvaine & $\begin{array}{l}\sim 60 \mathrm{HFH} \\
\text { Construction } \\
\text { Managers/Staff }\end{array}$ \\
\hline Jan 2004 & $\begin{array}{l}\text { BAIHP Task Meeting, } \\
\text { Cocoa, FL }\end{array}$ & Moisture in Housing & Moyer & BA Team members \\
\hline Jan 2004 & $\begin{array}{l}\text { BAIHP Task Meeting, } \\
\text { Cocoa, FL }\end{array}$ & $\begin{array}{l}\text { Ventilation \& Moisture } \\
\text { Research }\end{array}$ & Moyer & BA Team members \\
\hline Jan 2004 & $\begin{array}{l}\text { International Builders' } \\
\text { Show/NAHB } \\
\text { Conference, Las Vegas }\end{array}$ & $\begin{array}{l}\text { Represented BAIHP at } \\
\text { DOE booth }\end{array}$ & Chandra & Builders \\
\hline Jan 2004 & $\begin{array}{l}\text { NAHB International } \\
\text { Builder Show, Las } \\
\text { Vegas (NV) }\end{array}$ & $\begin{array}{l}\text { Presentation at Energy } \\
\text { Value Housing Awards } \\
\text { Workshop }\end{array}$ & Lubliner & $\begin{array}{l}\text { Energy Efficiency } \\
\text { Industry }\end{array}$ \\
\hline Jan 2004 & $\begin{array}{l}\text { ASHRAE Winter } \\
\text { Meeting, Anaheim, CA }\end{array}$ & $\begin{array}{l}\text { Presentation: } \\
\text { Ventilation in Hot- } \\
\text { Humid Climates }\end{array}$ & Moyer & HVAC Industry \\
\hline Jan 2004 & $\begin{array}{l}\text { ASHRAE Winter } \\
\text { Meeting, Anaheim, } \\
\text { (CA) }\end{array}$ & $\begin{array}{l}\text { Symposium Session } \\
\text { Chairman - "Factors } \\
\text { Influencing Energy } \\
\text { Performance of } \\
\text { Residential HVAC" }\end{array}$ & $\begin{array}{l}\text { Lubliner, } \\
\text { Parker, et. al }\end{array}$ & $\begin{array}{l}\text { ASHRAE } \\
\text { Engineers/HVAC } \\
\text { Industry }\end{array}$ \\
\hline Jan 2004 & $\begin{array}{l}\text { ASHRAE Winter } \\
\text { Meeting, Anaheim, CA }\end{array}$ & $\begin{array}{l}\text { Moderator/Coordinator } \\
\text { for USDOE Building } \\
\text { America Fan Energy } \\
\text { Expert Meeting }\end{array}$ & Lubliner & $\begin{array}{l}\text { ASHRAE } \\
\text { Engineers/HVAC } \\
\text { Industry }\end{array}$ \\
\hline Dec 2003 & FSEC, Cocoa (FL) & $\begin{array}{l}\text { Workshop, } 1 \text { day } \\
\text { course: Green Home } \\
\text { Certifying Agents for } \\
\text { Florida Green Building } \\
\text { Coalition }\end{array}$ & Martin & $\begin{array}{l}\text { Green Home } \\
\text { Certifying Agents, } \\
\text { Candidates }\end{array}$ \\
\hline Nov 2003 & $\begin{array}{l}\text { GreenBuild } \\
\text { Conference and Expo, } \\
\text { Pittsburgh (PA) }\end{array}$ & $\begin{array}{l}\text { Presented Paper: } \\
\text { Complying with } \\
\text { Florida's Green Land } \\
\text { Development Standard: } \\
\text { Case Studies and } \\
\text { Lessons Learned } \\
\end{array}$ & & $\begin{array}{l}\text { Builders, Public, } \\
\text { Building Scientists } \\
\text { and Related } \\
\text { Specialists }\end{array}$ \\
\hline
\end{tabular}


Table 80 Training and Presentations by BAIHP Staff January 2002 - June 2006

\begin{tabular}{|c|c|c|c|c|}
\hline Month & Venue & Description & Researcher & Audience/Attendees \\
\hline Nov 2003 & www.baihp.org & \multicolumn{2}{|c|}{$\begin{array}{l}\text { Revised Partner contact information and } \\
\text { maps for each region }\end{array}$} & $\begin{array}{l}\text { Builders, } \\
\text { Manufacturers, } \\
\text { Building Scientists, } \\
\text { Public }\end{array}$ \\
\hline Oct 2003 & $\begin{array}{l}\text { Workshop with } \\
\text { ALACF, Orlando }\end{array}$ & $\begin{array}{l}\text { Workshop, } 2 \text { day, } \\
\text { Building Health Houses }\end{array}$ & $\begin{array}{l}\text { Chandra and } \\
\text { Hutchinson }\end{array}$ & $\begin{array}{l}14 \text { Builders and } \\
\text { Suppliers }\end{array}$ \\
\hline Oct 2003 & $\begin{array}{l}\text { AIVC Conference, } \\
\text { Washington }\end{array}$ & $\begin{array}{l}\text { Presented Referred } \\
\text { Paper: Building } \\
\text { Envelope, Duct } \\
\text { Leakage and HVAC } \\
\text { System Performance in } \\
\text { HUD-Code } \\
\text { Manufactured Homes }\end{array}$ & Lubliner & Building Scientists \\
\hline Oct 2003 & $\begin{array}{l}\text { AIVC Conference } \\
\text { Washington, DC }\end{array}$ & \multicolumn{2}{|c|}{$\begin{array}{l}\text { Accepted Paper: Building Envelope, } \\
\text { Duct Leakage and HVAC System } \\
\text { Performance In HUD-Code } \\
\text { Manufactured Homes }\end{array}$} & Lubliner, Moyer \\
\hline Oct 2003 & FSEC, Cocoa (FL) & \multicolumn{2}{|c|}{$\begin{array}{l}\text { BAIHP staff hosted a full day meeting } \\
\text { for } 4 \text { person team from India. Topics: } \\
\text { codes and standards, tools, training, } \\
\text { voluntary green building programs, } \\
\text { Florida regulatory and voluntary house } \\
\text { building programs }\end{array}$} & $\begin{array}{l}4 \text { person team from } \\
\text { India }\end{array}$ \\
\hline Oct 2003 & $\begin{array}{l}\text { International } \\
\text { Conference for } \\
\text { Enhanced Building } \\
\text { Operations, Berkeley, } \\
\text { California }\end{array}$ & $\begin{array}{l}\text { Accepted Paper: An } \\
\text { Assessment of Six } \\
\text { Residential Ventilation } \\
\text { Techniques in Hot and } \\
\text { Humid Climates }\end{array}$ & $\begin{array}{l}\text { Moyer, Parker, } \\
\text { Chandra }\end{array}$ & $\begin{array}{l}\text { Energy Efficiency } \\
\text { Industry }\end{array}$ \\
\hline Oct 2003 & $\begin{array}{l}\text { EEBA, Lincolnshire, } \\
\text { IL }\end{array}$ & $\begin{array}{l}\text { Presentation: Thermal } \\
\& \text { Moisture Control of } \\
\text { Wall Surfaces - Hot \& } \\
\text { Humid Climate } \\
\text { Perspective }\end{array}$ & Moyer & $\begin{array}{l}\text { Energy Efficiency } \\
\text { Industry }\end{array}$ \\
\hline Sept 2003 & $\begin{array}{l}\text { Florida Housing } \\
\text { Coalition Conference, } \\
\text { Miami }\end{array}$ & $\begin{array}{l}\text { Presentation: BAIHP } \\
\text { benefits and } \\
\text { applicability to } \\
\text { affordable housing }\end{array}$ & Martin & $\begin{array}{l}225 \text { Affordable } \\
\text { Housing Providers }\end{array}$ \\
\hline Sept 2003 & $\begin{array}{l}\text { Sierra Club, } \\
\text { Melbourne (FL) }\end{array}$ & Green Buildings & Martin & $\begin{array}{l}\text { Environmental } \sim 30 \\
\text { attendees }\end{array}$ \\
\hline
\end{tabular}


Table 80 Training and Presentations by BAIHP Staff January 2002 - June 2006

\begin{tabular}{|c|c|c|c|c|}
\hline Month & Venue & Description & Researcher & Audience/Attendees \\
\hline Sept 2003 & www.baihp.org & \multicolumn{2}{|c|}{$\begin{array}{l}\text { Created Infomonitors data page for Zero- } \\
\text { Energy Manufactured Home } \\
\text { www.infomonitors.com/zmh } \\
\text { Created Infomonitors data page for Zero } \\
\text { Energy Habitat House (with ORNL) } \\
\text { http://www.infomonitors.com/onl }\end{array}$} & Building Scientists \\
\hline Aug 2003 & FSEC, Cocoa (FL) & $\begin{array}{l}\text { Workshop, } 1 / 2 \text { day } \\
\text { course: Why the } \\
\text { Ceiling Fell In }\end{array}$ & Moyer & $\begin{array}{l}\text { Public, Construction } \\
\text { Industry }\end{array}$ \\
\hline Aug 2003 & FSEC, Cocoa (FL) & $\begin{array}{l}\text { Workshop, } 1 \text { day } \\
\text { course: Diagnosing } \\
\text { Moisture Problems }\end{array}$ & Moyer & $\begin{array}{l}\text { Public, Construction } \\
\text { Industry }\end{array}$ \\
\hline Aug 2003 & FSEC, Cocoa (FL) & $\begin{array}{l}\text { Workshop, } 3 \text { day } \\
\text { course: Class } 1 \text { Florida } \\
\text { Home Energy Rater } \\
\text { Training includes } \\
\text { certification exam }\end{array}$ & Moyer & Energy Raters \\
\hline Aug 2003 & FSEC, Cocoa (FL) & $\begin{array}{l}\text { Workshop, } 1 \text { day: } \\
\text { Green Home Certifying } \\
\text { Agents for the Florida }\end{array}$ & Martin & $\begin{array}{l}9 \text { Attendees seeking } \\
\text { certification }\end{array}$ \\
\hline Aug 2003 & www.baihp.org & $\begin{array}{l}\text { MHLab Ventilation } \\
\text { Study }\end{array}$ & Moyer & $\begin{array}{l}\text { Builders, } \\
\text { Manufacturers, } \\
\text { Building Scientists, } \\
\text { Public }\end{array}$ \\
\hline Jul 2003 & $\begin{array}{l}\text { American Lung } \\
\text { Association: Mid- } \\
\text { Florida, Builder } \\
\text { Training, Orlando }\end{array}$ & $\begin{array}{l}\text { Presentation: Health } \\
\text { House Builder Training } \\
\text { (1.5 days) }\end{array}$ & $\begin{array}{l}\text { Chandra, } \\
\text { Moyer }\end{array}$ & $\begin{array}{l}\text { Potential ALA } \\
\text { Health House } \\
\text { Builders }\end{array}$ \\
\hline July 2003 & $\begin{array}{l}\text { Southeast Builders } \\
\text { Show, Orlando (FL) }\end{array}$ & $\begin{array}{l}\text { Short Course, } 3 \text { Hour: } \\
\text { Health House Builder } \\
\text { Guidelines }\end{array}$ & $\begin{array}{l}\text { Chandra, } \\
\text { Hutchinson, } \\
\text { Tim Kensok } \\
\text { (Honeywell) }\end{array}$ & $\begin{array}{l}100+\text { attendees, } 90 \\
\text { builders attended all } \\
\text { or part of course. } 19 \\
\text { builders indicated } \\
\text { desire to be certified } \\
\text { Health House } \\
\text { Builders }\end{array}$ \\
\hline July 2003 & www.baihp.org & $\begin{array}{l}\text { Brookside Apartment } \\
\text { testing }\end{array}$ & Chandra & $\begin{array}{l}\text { Builders, } \\
\text { Manufacturers, } \\
\text { Building Scientists, } \\
\text { Public }\end{array}$ \\
\hline July 2003 & www.baihp.org & $\begin{array}{l}\text { Palm Harbor Energy } \\
\text { Star Plan certification }\end{array}$ & Chasar & $\begin{array}{l}\text { Builders, } \\
\text { Manufacturers, } \\
\text { Building Scientists, } \\
\text { Public }\end{array}$ \\
\hline
\end{tabular}


Table 80 Training and Presentations by BAIHP Staff January 2002 - June 2006

\begin{tabular}{|c|c|c|c|c|}
\hline Month & Venue & Description & Researcher & Audience/Attendees \\
\hline July 2003 & $\begin{array}{l}\text { Florida Local } \\
\text { Environmental } \\
\text { Resource Agencies } \\
\text { Conference, Jupiter } \\
\text { Beach (FL) }\end{array}$ & $\begin{array}{l}\text { Green-home elements } \\
\text { and Florida standards; } \\
\text { How local governments } \\
\text { can foster green } \\
\text { building within their } \\
\text { community. }\end{array}$ & Martin & $\begin{array}{l}\text { Local Government } \\
\text { Staff } \sim 15 \text { attendees }\end{array}$ \\
\hline July 2003 & $\begin{array}{l}\text { World Resources } \\
\text { Institute Bell } \\
\text { Conference, Ft. } \\
\text { Lauderdale (FL) }\end{array}$ & $\begin{array}{l}\text { Panel Session: The } \\
\text { Business of Green } \\
\text { Construction }\end{array}$ & Martin & $\begin{array}{l}\text { Business, local } \\
\text { government, state } \\
\text { regulatory agencies } \\
\sim 20 \text { attendees }\end{array}$ \\
\hline June 2003 & $\begin{array}{l}\text { Recycle Florida Today } \\
\text { Conference, St. } \\
\text { Petersburg Beach (FL) }\end{array}$ & $\begin{array}{l}\text { Presentation, } 30 \\
\text { minutes: Green-home } \\
\text { elements and Florida } \\
\text { standards }\end{array}$ & Martin & $\begin{array}{l}\sim 35 \text { attendees, } \\
\text { government (local } \\
\text { and state), solid } \\
\text { waste management } \\
\text { /recycling industry }\end{array}$ \\
\hline June 2003 & $\begin{array}{l}\text { U.S. - Spain } \\
\text { Construction Forum, } \\
\text { Miami (FL) }\end{array}$ & $\begin{array}{l}\text { Presentation: Florida } \\
\text { Green Building } \\
\text { Coalition }\end{array}$ & Chandra & $\sim 20$ attendees \\
\hline June 2003 & $\begin{array}{l}\text { ASHRAE Summer } \\
\text { Meeting, Kansas City } \\
\text { (KS) }\end{array}$ & $\begin{array}{l}\text { Presentation: Duct } \\
\text { Leakage in New } \\
\text { Washington State } \\
\text { Residences: Findings } \\
\text { and Conclusions }\end{array}$ & Lubliner & $\begin{array}{l}\text { Energy Efficiency } \\
\text { Industry }\end{array}$ \\
\hline May 2003 & $\begin{array}{l}\text { Energy Efficiency }+ \\
\text { Solar Energy = Zero } \\
\text { Energy Homes, } \\
\text { Orlando (FL) }\end{array}$ & $\begin{array}{l}\text { Presentation: Florida } \\
\text { Green Home } \\
\text { Designation; } \\
\text { Panel included } 3 \\
\text { BAIHP builder partners }\end{array}$ & Martin & $\begin{array}{l}\sim 30 \text { attendees } \\
\text { eligible for } 2 \text { CEUs }\end{array}$ \\
\hline May 2003 & www.baihp.org & $\begin{array}{l}\text { Posted Case Study: } \\
\text { Show Me the Money: } \\
\text { Selling Builders on } \\
\text { Systems Engineering. }\end{array}$ & Fonorow & $\begin{array}{l}\text { Builders, } \\
\text { Manufacturers, } \\
\text { Building Scientists, } \\
\text { Public }\end{array}$ \\
\hline May 2003 & www.baihp.org & $\begin{array}{l}\text { Posted Technical } \\
\text { Services Provided to } \\
\text { the HUD Code and } \\
\text { Modular Industry }\end{array}$ & Chandra & $\begin{array}{l}\text { Builders, } \\
\text { Manufacturers, } \\
\text { Building Scientists, } \\
\text { Public }\end{array}$ \\
\hline April 2003 & $\begin{array}{l}2003 \text { MHI Conference, } \\
\text { Las Vegas (NV) }\end{array}$ & $\begin{array}{l}\text { Presentations: Use of } \\
\text { innovative crossover- } \\
\text { duct system; Duct } \\
\text { mastic riser system } \\
\text { Exhibit: BAIHP booth }\end{array}$ & $\begin{array}{l}\text { Chandra, } \\
\text { Mullens }\end{array}$ & $\begin{array}{l}\text { BAIHP partners and } \\
\text { conference attendees }\end{array}$ \\
\hline
\end{tabular}


Table 80 Training and Presentations by BAIHP Staff January 2002 - June 2006

\begin{tabular}{|c|c|c|c|c|}
\hline Month & Venue & Description & Researcher & Audience/Attendees \\
\hline April 2003 & $\begin{array}{l}\text { Puyallup Manufactured } \\
\text { Home Show, Puyallup, } \\
\text { (WA) }\end{array}$ & $\begin{array}{l}\text { Exhibit: Technical and } \\
\text { marketing assistance, } \\
\text { worked with utility } \\
\text { representatives to } \\
\text { promote incentives }\end{array}$ & Lubliner & $\begin{array}{l}\text { General public, } \mathrm{MH} \\
\text { dealers, home } \\
\text { manufacturers and } \\
\text { other industry } \\
\text { representatives }\end{array}$ \\
\hline Apr 2003 & $\begin{array}{l}\text { Affordable Comfort } \\
\text { Conference, Kansas } \\
\text { City }\end{array}$ & $\begin{array}{l}\text { Presentation: } \\
\text { Dehumidification- } \\
\text { Principles and } \\
\text { Strategies }\end{array}$ & Moyer & $\begin{array}{l}\text { Energy Efficiency } \\
\text { Industry }\end{array}$ \\
\hline Apr 2003 & $\begin{array}{l}\text { Affordable Comfort } \\
\text { Conference, Kansas } \\
\text { City }\end{array}$ & $\begin{array}{l}\text { Presentation: Cooling, } \\
\text { Ventilation, \& } \\
\text { Dehumidification in } \\
\text { Energy Efficient } \\
\text { Homes }\end{array}$ & Moyer & $\begin{array}{l}\text { Energy Efficiency } \\
\text { Industry }\end{array}$ \\
\hline Nov 2002 & $\begin{array}{l}\text { The Quality Modular } \\
\text { Building Task Force }\end{array}$ & $\begin{array}{l}\text { Presentation: Research } \\
\text { Results: } \\
\text { Energy Benchmarking }\end{array}$ & $\begin{array}{l}\text { Moyer, } \\
\text { Mullens }\end{array}$ & $\begin{array}{l}\text { Modular Builders \& } \\
\text { Suppliers }\end{array}$ \\
\hline Oct 2002 & EEBA, Phoenix, AZ & $\begin{array}{l}\text { Presentation: BAIHP } \\
\text { Updates }\end{array}$ & Moyer & $\begin{array}{l}\text { Energy Efficiency } \\
\text { Industry }\end{array}$ \\
\hline Apr 2002 & $\begin{array}{l}\text { Affordable Comfort } \\
\text { Conference, Cincinnati } \\
(\mathrm{OH})\end{array}$ & $\begin{array}{l}\text { Presentation: BA: New } \\
\text { Buildings that Last }\end{array}$ & Moyer & $\begin{array}{l}\text { Energy Efficiency } \\
\text { Industry }\end{array}$ \\
\hline Mar 2002 & $\begin{array}{l}2002 \text { RESNET } \\
\text { Conference, Cocoa, FL }\end{array}$ & $\begin{array}{l}\text { Presentation: Moisture } \\
\text { "Opportunities" For } \\
\text { Manufactured Housing }\end{array}$ & Moyer & $\begin{array}{l}\text { Energy Efficiency } \\
\text { Industry }\end{array}$ \\
\hline
\end{tabular}

Conference and Training prior to $5^{\text {th }}$ Budget Period

Year 4 (April 2002 to March 2003)

- NAHB International Builders Show in Las Vegas, NV.

- Southeastern Regional Habitat for Humanity Conference, exhibiting and providing information on Florida's new Energy Code, building science, energy efficiency details for hot-humid climates, and the Building America program during educational sessions

- Idaho Energy Conference (IEEC 2002 commercial code training)

- RESNET Conference in San Diego, CA.

- Basement, Crawlspace, Slab Insulation \& Moisture Control Seminar in Westford, MS. (a Building Science Corporation expert meeting)

- Salem Home Show in Salem, WA.

- Westford Building Science Seminar

- ACCA Manual J Training Class

- Zero Energy Manufactured House dedication ceremony in Nez Perce tribal fish facility near Lewiston.

- The Health Home Media Tour in Orlando, FL. (covered by local television stations, Channels 2 and 35, and an AM radio station). 
Year 3 (April 2001to March 2002)

- Design charrette organized by Steven Winter Associates and McStain Enterprises in Boulder, CO.

- National Association of Home Builders Conference in Atlanta, GA.

- 16th Annual National Low-Income Energy Conference in Ft. Lauderdale, FL., introducing Building America and building science principals

- Building VIII Conference in Clearwater Beach, FL.

- NCA\&TSU manufactured housing advisory committee meeting in Raleigh (NC)

- Zero Energy Buildings workshop in Orlando, FL.

- Mold seminar put together by the Mid-Florida Home Builder Association

- Seminar on WUFI, a moisture analysis software developed by ORNL

- Council of State Administrative Agencies' Spring Workshop in San Antonio, TX, representing BAIHP and sharing Building America research.

Tours

In 2002, BAIHP conducted a tour of the National Institute of Standards and Technologies (NIST) facilities in Gaithersburg, Maryland for HUD, DOE, and EPA staff. BAIHP also led a Beaverton Classroom tour for DOE, WSU, and PNNL staff.

\section{BAIHP Publications List - All Budget Periods (09/99-06/06)}

Peer Reviewed Papers -

Arif, M., Mullens, M., Espinal, D., \& Broadway, R. (2002). "Estimating, Planning and Controlling Labor in the Industrialized Housing Factory." Industrial Engineering Research '02 Conference Proceedings, Orlando, FL.

Armacost, R., J. Pet-Armacost,, M. Mullens, and A. Salem (2001). "Information Support for Efficient Assembly of Roof Trusses," in Khattab, M. (ed.), Proceedings of the International Conference on Information Systems in Engineering and Construction (ISEC 2001), Cocoa Beach, FL, 2001, CD-ROM.

Armacost, R., J. Pet-Armacost, M. Mullens, and A. Salem (2001). "Scheduling for Roof Truss Manufacturing," in Harris, R. (ed.), Proceedings of the ICC\&IE and IEMS 2001 Joint Meeting, Cocoa Beach, FL 2001, pp. 644-649.

Baechler, M.; Lubliner, M; Gordon, A (2002). "Pushing the Envelope: A Case Study of Building the First Manufactured Home Using Structural Insulated Panels" 2002 ACEEE Summer Study on Energy Efficiency in Buildings Conference, Pacific Grove, CA.

Beal, D. and Chasar, D. (2006). "Measured Crawlspace Conditions in a HUD-code Home", Fifteenth Symposium on Improving Building Systems in Hot and Humid Climates, July 24-26, 2006 Orlando, FL

Broadway, R. and M. Mullens (2004). "Shop Floor Information Systems for Industrialized Housing Production,” Industrial Engineering Research '04 Conference Proceedings, Houston, May, 2004. 
Brown, Richard, William Rittelmann, Danny Parker, and Gregory Homan (2006). Appliances, Lighting, Electronics, and Miscellaneous Equipment Electricity Use in New Homes Proceedings of the 2006 Summer Study on Energy Efficiency in Buildings, American Council for an Energy Efficient Economy, Asilomar, CA., August 2006

Chandra, Subrato, Danny Parker, David Beal, David Chasar, Eric Martin, Janet McIlvaine, Neil Moyer (2004). Alleviating Moisture Problems in Hot, Humid Climate Housing. Position Paper for NSF Housing Research Agenda Workshop, UCF Feb. 12-14, 2004.

Chandra, Subrato, Fonorow, Ken, McCloud, Matthew, Moyer, Neil, Beal, David, Chasar, David, McIlvaine, Janet, Parker, Danny, Sherwin, John, Martin, Eric, Mullens, Michael, Lubliner, Michael, McSorley, Michael (2002). "The Building America Industrialized Housing Partnership" Symposium on Improving Building Systems in Hot, Humid Climates - Houston, Texas, May 20-22, 2002.

Chandra, S., \& Beal, D. (2001). 'Preventing House Dust Mite Allergens in New Housing.' In ASHRAE IAQ Conference Proceedings, San Francisco, CA.

Chandra, S., Moyer, N., Beal, D., Chasar, D., McIlvaine, J., \& Withers, C. (2001). "The Building America Industrialized Housing Partnership (BAIHP): Enhancing Energy Efficiency, Durability and Indoor Air Quality of Industrialized Housing." In XXIX IAHS World Congress on Housing Conference Proceedings, Ljubljana.

Chasar, D., Chandra, S., Parker, D., Sherwin, J., Beal, D., Hoak, D., Moyer, N., McIlvaine, J. (2006). "Cooling Performance Assessment of Building America Homes", Fifteenth Symposium on Improving Building Systems in Hot and Humid Climates, July 24-26, 2006 Orlando, FL.

Chasar, D., Moyer, N., McIlvaine, J., Beal, D. and Chandra, S. (2004). "Energy Star Manufactured Homes: The Plant Certification Process," Proceedings of ACEEE 2004 Summer Study, American Council for an Energy Efficient Economy, Washington, DC, August 2004.

Chasar, D., Moyer, N., Chandra, S., Rotvold, L., Applegren, R. (2004). "Cold Climate Case Study; High Efficiency North Dakota Twin Homes," Performances of Exterior Envelopes of Whole Buildings IX International Conference, Clearwater Beach, Florida, December 2004.

Chasar, D., Moyer, N., Rudd, A. F., Parker, D., \& Chandra, S. (2002). "Measured Cooling Performance of Two-story Homes in Dallas, Texas: Insulated Concrete Form Versus Frame Construction." Thirteenth Symposium of Improving Building Systems in Hot and Humid Climates, Houston, TX.

Chasar, D., Moyer, D., Rudd, A. F., Parker, D. K., \& Chandra, S. (2002). "Measured and Simulated Cooling Performance Comparison; Insulated Concrete Form Versus Frame Construction." 2002 ACEEE Summer Study on Energy Efficiency in Buildings, Pacific Grove, CA. 
Christian, J.E., D. Beal, and P. Kerrigan (2004). "Towards Simple Affordable Zero Energy Houses." Proceedings of Performance of Exterior Envelopes of Whole Buildings IX, Clearwater, Florida, December 5-10, 2004

Cummings, J., C. Withers, J. Mcllvaine, J. Sonne, M. Lombardi (2003). Air Handler Leakage: Field Testing Results in Residences. ASHRAE Transactions V.109 pt.1 February 2003. To be published in ASHRAE Journal.

Elshennawy, A., M. Mullens, and I. Nahmens (2004). "Quality-Based Compensation Schemes for Modular Homebuilding,” Industrial Engineering Research '04 Conference Proceedings, Houston, May, 2004.

Elshennawy, A., Mullens, M., \& Nahmens, I. (2002). "Quality Improvement in the Modular Housing Industry.” In Industrial Engineering Research '02 Conference Proceedings, Orlando, FL.

Fonorow, K., Chandra, S., Martin, E., McIlvaine, J. (2006). "Energy and Resources Efficient Communities through Systems Engineering: Building America Case Studies in Gainesville, FL.", Proceedings of the 2006 Summer Study on Energy Efficiency in Buildings, American Council for an Energy Efficient Economy, Washington, DC, August 2006.

Fuehrlein, B., Chandra, S., Beal, D., Parker, D.K., \& Vieira, R. (2000). "Evaluation of EnergyGauge ${ }^{\circledR}$ USA, a Residential Energy Design Software Against Monitored Data." In ACEEE Summer Study Proceedings, Pacific Grove, CA.

Hales, D; M. Lubliner, A. Gordon (2003). "Duct Leakage in New Washington State Residences: Findings and Conclusions" - Proceedings of the 2003 ASHRAE Summer Meeting.

Hodgson, A.T., Apte, M.G., Shendell, D.G., Beal, D. and McIlvaine, J.E.R. (2002). Implementation of VOC source reduction practices in a manufactured house and in school classrooms. In Levin, H. (Ed.), Proceedings of the 9th International Conference on Indoor Air Quality and Climate. Indoor Air 2002, Santa Cruz, CA, Vol. 3. pp. 576-581.

Hodgson, A.T., Moyer, N., and Beal, D. (2005). "Effect of residential ventilation techniques for hot and humid climates on indoor concentrations and emission rates of volatile organic compounds." February 2005, LBNL-57030, Lawrence Berkeley National Laboratory, Berkeley, CA.

Hodgson, A.T., D. Beal and J.E.R. Mcllvaine. 2002. Sources of formaldehyde, other aldehydes and terpenes in a new manufactured house. Indoor Air12: 235-242.

Hodgson, A.T., A.F. Rudd, D. Beal and S. Chandra. 2000. Volatile organic compound concentrations and emission rates in new manufactured and site-built houses. Indoor Air10: 178-192.

Lombardi, Matthew, Parker, Danny, Vieira, Robin, Fairey, Philip (2004). "Geographic Variation in Potential of Rooftop Residential Photovoltaic Electric Power Production in the United 
States," Proceedings of ACEEE 2004 Summer Study on Energy Efficiency in Buildings, American Council for an Energy Efficient Economy, Washington, DC, August 2004.

Lubliner, M., Gordon, A., Hadley, A., and Parker, D. (2005). "Heat and Non-Heat Recovery Ventilation Performance in Energy Efficient HUD Code Manufactured Housing", 26th Air Infiltration and Ventilation Centre (AIVC), 26th Conference Ventilation in Relation to the Energy Performance of Buildings, Page 235-242, International Energy Agency, Energy Conservation in buildings and community systems programme.

Lubliner, M, A. Hadley, A. Gordon (2004). "Introducing Solar Ready Manufactured Housing". Proceedings of the 2004 National Solar Energy Conference, pp. 1151-1155. July 2004.

Lubliner, M.; Gordon, A.; Hadley, A. (2004). "Manufactured Home Performance; Comparing Zero Energy and Energy Star". Proceedings of Performances of Exterior Envelopes of Whole Buildings IX International Conference, Clearwater Beach, Florida, December 2004.

Lubliner, M, Nelson, M, \& Parker, D. (2003). “Gossamer Wind Solar Power Ceiling Fan.” In 2003 ASES Conference Proceedings, Austin, TX.

Lubliner, M.; Gordon, A.; Persily, A.; Moyer, N.; Richins, W.; Blakeley, J (2003). "Building Envelope, Duct Leakage and HVAC System Performance in HUD-Code Manufactured Homes" 23 rd Annual AIVC Conference Proceedings.

Lubliner, M, Kunkle, R, Devine, J, \& Gordon, A. (2002). "Washington State Residential Ventilation and Indoor Air Quality Code (VIAQ) - Whole House Ventilation Systems Field Research Report.” 2002 ACEEE Summer Study on Energy Efficiency in Buildings Conference, Pacific Grove, CA.

Lubliner, M., \& Gordon, A. (2000). "Ventilation in US Manufactured Homes: Requirements, Issues and Recommendations." 21st Annual AIVC Conference Proceedings, The Hague.

Martin, E. (2005). "Making the right choices: Finding green products is now easier than ever, but a systems approach must be employed to select the right products for a green project." Guest editorial for Florida Real Estate Journal, March 2005.

McCluney, R. (2003). "Methodologies for Determining the SHGC of Complex Fenestration Systems.” Paper presented at the 2003 National Fenestration Rating Council Meeting, Houston, TX.

McGinley, W. Mark, Alaina Jones, Carolyn Turner, Subrato Chandra, David Beal, Danny Parker, Neil Moyer, Janet McIlvaine (2004). Optimizing Manufactured Housing Energy Use. Symposium on Improving Building Systems in Hot and Humid Climates, Richardson, Texas, May 17-19, 2004.

McIlvaine, Janet, David Beal, Neil Moyer, Dave Chasar, Subrato Chandra (2004). Achieving Airtight Ducts in Manufactured Housing. Symposium on Improving Building Systems in 
Hot and Humid Climates, Richardson, Texas, May 17-19, 2004.Report No. FSEC-CR1323-03.

Moyer, Neil, Chasar, Dave, Hoak, Dave, Chandra, Subrato, (2004). "Assessing Six Residential Ventilation Techniques in Hot and Humid Climates," Proceedings of ACEEE 2004 Summer Study on Energy Efficiency in Buildings, American Council for an Energy Efficient Economy, Washington, DC, August 2004.

Moyer, N., Beal, D., Chasar, D., McIlvaine, J., Withers, C, \& Chandra, S. (2001). "Moisture Problems in Manufactured Housing: Probable Causes and Cures." ASHRAE - IAQ 2001 Conference Proceedings, San Francisco, CA.

Moyer, Neil, Chasar, Dave, Hoak, Dave, Chandra, Subrato (2004). "Assessing Six Residential Ventilation Techniques in Hot and Humid Climates," Proceedings of ACEEE 2004 Summer Study on Energy Efficiency in Buildings, American Council for an Energy Efficient Economy, Washington, DC, August 2004.

Moyer, Neil. Home Energy, “HVAC System Pressure Relief,” July/August 2006, pp. 42-45.

Mullens, Michael A. and Mark E. Kelley III.(2004.) "Lean Homebuilding Using Modular Technology.” Housing and Society. January 31, 2004 pp.41-54.

Mullens, M., I. Nahmens, and R. Hoekstra, "Lean Homebuilding: Lessons Learned from a Precast Concrete Panelizer," Engineering Management Journal. Accepted November 2004.

Mullens, M. and M. Arif, "Structural Insulated Panels: Impact on the Residential Construction Process." The Journal of Construction Engineering and Management.

Mullens, M. and M. Hastak (2004). "Defining a National Housing Research Agenda: Construction Management and Production" Proceedings of the NSF Housing Research Agenda Workshop, Feb. 12-14, 2004, Orlando, FL. Eds. Syal, M., Mullens, M. and Hastak, M. Vol. 2.

Mullens, M. (2004). "Production flow and shop floor control: Structuring the modular factory for custom homebuilding" Proceedings of the NSF Housing Research Agenda Workshop, Feb. 12-14, 2004, Orlando, FL. Eds. Syal, M., Mullens, M. and Hastak, M. Vol. 2.

Mullens, M. and I. Nahmens (2003). "Lean Principles Applied to Pre-cast Concrete Homebuilding,” Industrial Engineering Research '04 Conference Proceedings, Houston, May, 2004.

Mullens, M., \& Kelley, M. (2003, January). "Lean Homebuilding Using Modular Technology.” NAHB International Builders Show Conference Proceedings, Las Vegas, NV.

Mullens, M., \& Kelley, M. (2002). "Introducing Revolutionary Change in the Modular Housing Construction Process Using a Kaizen Blitz.” In Industrial Engineering Research '02 Conference Proceedings, Orlando, FL. 
Nahmens, I., M. Mullens and A. Elshennawy (2004). "The Impact of Demographics on New Homebuyer Satisfaction,” Industrial Engineering Research '04 Conference Proceedings, Houston, May, 2004.

Nasereddin, M., Mullens, M., \& Cope, D. (2002). “The Development of a Reusable Simulation Model for the Modular Housing Industry Using Promodel and Visual Basic." In Industrial Engineering Research '02 Conference Proceedings, Orlando, FL.

Parker, D., Hoak, D., Meier, A., Brown, R.(2006). "How Much Energy Are We Using? Potential of Residential Energy Demand Feedback Devices", Proceedings of the 2006 Summer Study on Energy Efficiency in Buildings, American Council for an Energy Efficient Economy, Asilomar, CA., August 2006.

Parker, D., Sherwin, J., Hibbs, B. (2005) "Development of High Efficiency Air Conditioner Condenser Fans." Proceedings of the 2005 Summer ASHRAE Conference, ASHRAE Transactions in June 2005.

Parker, Danny S., John R. Sherwin, and Jeffrey K. Sonne (2004). “Cooling Related Performance of Finished and Unfinished Metal Roofing Systems." Proceedings of the 2004 ACEEE Summer Study on Energy Efficiency in Buildings Conference, Pacific Grove, CA.

Parker, Danny S. and John R. Sherwin (2005). "Development of High Efficiency Air Conditioner Condenser Fans.” Proceedings of the 2005 ASHRAE Summer Meeting.

Syal, M., M. Hastak, and M. Mullens. "Housing Research Agenda for NSF-PATH." ASCE Journal of Architectural Engineering. Accepted 11/04.

Thomas-Rees, Stephanie, Chandra, S., Barkaszi, S., Chasar, D., and Colon, Carlos (2006). "Improved Specifications For Federally Procured Ruggedized Manufactured Homes For Disaster Relief in Hot/Humid Climates," Fifteenth Symposium on Improving Building Systems in Hot and Humid Climates, July 24-26, 2006 Orlando, FL.

Withers, C., Moyer, N., Chasar, D., \& Chandra, S. (2001). "Performance and Impact from Duct Repair and Ventilation Modifications of Two Newly Constructed Manufactured Houses Located in a Hot and Humid Climate." Paper presented at the 13th Symposium on Improving Building Systems in Hot and Humid Climates, Houston, TX.

\section{Contract Report}

Beal, David and Janet McIlvaine (2006.) "Energy and Indoor Air Quality Recommendations for Cold Climate Habitat for Humanity Homes.” FSEC-CR-1647-06, Florida Solar Energy Center, Cocoa, Florida. August 2006.

Chandra S, Moyer N, Parker D., Beal, D. et al BUILDING AMERICA INDUSTRIALIZED HOUSING PARTNERSHIP (BAIHP) Final Technical Report - Fourth Budget Period, December 2003. 
Chandra S, Moyer N, Parker D., Beal, D. et al BUILDING AMERICA INDUSTRIALIZED HOUSING PARTNERSHIP (BAIHP) Final Technical Report - Third Budget Period, March, 2003.

Chandra S, Moyer N, Parker D., Beal, D. et al BUILDING AMERICA INDUSTRIALIZED HOUSING PARTNERSHIP (BAIHP) Final Technical Report - Second Budget Period, Dec. 2001

Chandra S, Chasar D, Moyer $\mathrm{N}$ et al BUILDING AMERICA INDUSTRIALIZED HOUSING PARTNERSHIP (BAIHP) Final Technical Report - First Budget Period FSEC-CR-123901 March 2001

Chasar, Dave, (P.E.), Neil Moyer, and Eric Martin (2006.) "Energy Efficient Renovations of Storm Damaged Residences - Florida Case Studies." FSEC-CR-1648-06. Florida Solar Energy Center, Cocoa, Florida. September 8, 2006

Cummings, J., Withers, C., Gu, L., McIlvaine, J., Sonne, J. K., \& Lombardi, M. (2002). "Field Testing and Computer Modeling to Characterize the Energy Impacts of Air Handler Leakage." Florida Solar Energy Center Contract Report \# FSEC-CR-1357-02, Cocoa, FL.

Fairey, Philip, Carlos Colon, Eric Martin, and Subrato Chandra (2006.) "Comparing Apples, Oranges and Grapefruit: An Analysis of Current Building Energy Analysis Standards for Building America, Home Energy Ratings and the 2006 International Energy Conservation Code." FSEC-CR-1650-06. Florida Solar Energy Center, Cocoa, Florida. September 2006.

Florida Solar Energy Center, \& York Unitary Products Group. (2000). “The Coleman ${ }^{\circledR}$ Pressure Control System: A Comprehensive and Proactive Process to Eliminating Pressure Driven Moisture Damage in Manufactured Housing." Florida Solar Energy Center Contract Report, Cocoa, FL.

Hodgson, A.T., N. Moyer and D. Beal (2005). "Effect of residential ventilation techniques for hot and humid climates on indoor concentrations and emission rates of volatile organic compounds.” February 2005, LBNL-57030, Lawrence Berkeley National Laboratory, Berkeley, CA.

McCluney, R., L. Mills (2003). The Benefits of Using Window Shades " Florida Solar Energy Center Nov. 01, 2003.

McCluney, R., N. Dhere (2002). "Industry Guide to Selecting the Best Residential Window Options for the Florida Climate " Florida Solar Energy Center, Pf-358-00, Dec. 01, 2002.

McGinley, M. (2002). "Study of Innovative Manufactured Housing Envelope Materials." BAIHP Subcontract Report, Greensboro, NC.

McIlvaine, J.S Chandra, N. Moyer, D. Parker, D. Beal, et al. (2005.)“Building America Industrialized Housing Partnership (BAIHP) Annual Report - Sixth Budget Period", October 2005. 
McIlvaine, J., Chandra S, Moyer N, Parker D., Beal, D. et al BUILDING AMERICA INDUSTRIALIZED HOUSING PARTNERSHIP (BAIHP) Final Technical Report Fifth Budget Period, March 2005.

McIlvaine, Janet, David Beal, Philip Fairey (2001). Design and Construction of Interior Duct Systems. FSEC PF-365-01. Florida Solar Energy Center. Cocoa, Florida, May 2001.

Mullens ,Dr. Mike (PE), Dr. Bob Hoekstra, Isabelina Nahmens, and Felix Martinez (2006.) "Water Intrusion in Central Florida Homes During Hurricane Jeanne in September 2004." UCF Housing Constructability Lab, Orlando Florida. August 2006

Mullens, M., \& Burdick, J. (2003). "Energy Test Results and Recommendations for Avis America Homes." University of Central Florida Housing Constructability Lab BAIHP Report, Cocoa, FL.

Mullens, M., Gallas, K., \& Moyer, N. (2002). "Energy Test Results and Recommendations for General Homes Corporation.” University of Central Florida Housing Constructability Lab BAIHP Report, Cocoa, FL.

Mullens, M., Gallas, K., Chasar, D. (2002). "Energy Test Results and Recommendations for Nationwide Homes." University of Central Florida Housing Constructability Lab BAIHP Report, Cocoa, FL.

Mullens, M., \& Chasar, D. (2002). "Energy Test Results and Recommendations for Cardinal Homes." University of Central Florida Housing Constructability Lab BAIHP Report, Cocoa, FL.

Parker, D. (2005) "Theoretical Evaluation of the NightCool Nocturnal Radiation Cooling Concept". FSEC-CR-1502-05. Florida Solar Energy Center, Cocoa, Florida. April 2005.

Parker, D., J. Sherwin, J. Sonne,(2005). "Flexible Roofing Facility: 2004 Summer Test Results", Prepared for U.S. Department of Energy Building Technologies Program, July 2005.

Parker, D., Sonne, J., Sherwin, J. (2004). "Flexible Roofing Facility: 2003 Summer Test Results", Prepared for U.S. Department of Energy Building Technologies Program, July 2004.

Parker, D., Sonne, J., Sherwin, J. (2003). Flexible Roofing Facility: 2002 Summer Test Results, Prepared for: U.S. Department of Energy Building Technologies Program, July 2003.

Parker, D. K., Sonne, J. K., Sherwin, J. R., \& Moyer, N. (2000). “Comparative Evaluation of the Impact of Roofing Systems on Residential Cooling Energy Demand.” Florida Solar Energy Center Contract Report \#FSEC-CR-1220-00, Cocoa, FL.

Sonne, J K, D S Parker and J R Sherwin (2002). Flexible Roofing Facility: 2001 Summer Test Results. FSEC-CR-1336-02. Florida Solar Energy Center, Cocoa, FL. 
Thomas-Rees, Stephanie, Subrato Chandra, Stephen Barkaszi, Dave Chasar, and Carlos Colon (2006). "Improved Specifications for Federally Procured Ruggedized Manufactured Homes for Disaster Relief in Hot/Humid Climates." FSEC-CR-1645-06. Florida Solar Energy Center, Cocoa, Florida. Revised - September 2006.

Vieira, R., L. Gu, S. Se, C. Colon (2006.) "Improving the Accuracy and Speed for Building America Benchmarking." Florida Solar Energy Center, FSEC-CR-1651-R00, Aug. 29, 2006.

Articles in Trade Press, Popular Press, and DOE Program Newsletters

Automated Builder Magazine. "WSU Energy House." October 2000.

Automated Builder Magazine "Northwest Portable Classroom Study." August 2003.

Automated Builder Magazine. "Zero Energy Manufactured Home." October 2003.

Builder/Architect. G.W. Robinson, Builder/Founder of Cobblefield, "Healthy Homes for a Healthy Bottom Line". August/September 2004.

Building Edge Magazine. "Environmental Perspective: Innovation in Home Building. December 2004.

Building Edge Magazine. “Tommy Williams Homes, Building From the Heart”. December 2004.

Buildings for the 21st Century. "Genesis Homes Showcases Innovative, High-performance Home.” Spring 2002, p. 2.

Energy Design Update. "Transforming Manufactured Housing: The Building America Way." January 2002, pp. 11-13.

Energy Design Update. "Palm Harbor's Prototype Home Scores Impressive Energy Savings." December 2001, pp. 7-8.

Energy Design Update. "Field Tests Commence on the World's Most Energy-efficient Manufactured Home," December 2000, p.3.

Energy Design Update. "New Building America Consortium to Focus on Industrialized Housing." March 2000, pp. 3-4.

Energy Design Update. "Energy Savings (and Unsolved Mysteries) Draw Attention to Georgia Habitat Project." Vol. 20 Number 4. April 2000.

Energy Design Update. "Ventilation System Decision Flow Chart." February 1999, p.16.

FlaSEIA Industry News. "SunBuilt and Building America Partnership." Spring 2002, Vol. 23, N.1 pp.5-8.

Florida Home Builder. "Today's Home Buyers Seeking Resource-efficient New Homes.” May/June 2002, p.25.

Florida Home Builder (Ad). "Their Lifestyle Demands Quality and Comfort: Their Values Dictate a Healthy House.” May/June 2002, p.25.

Gainesville Sun - Issues \& Trends Section. "The Good News on Solar Homes." April 14, 2002, pp. G1 \& G3.

Home Energy. "ICFs in North Texas." Nov/Dec 2002, pp. 39-40.

Home Energy. "Energy-efficient Manufactured Homes." May/June 2002, pp. 16-17.

Home Energy. "Chasing Interior Ducts." May/June 2002, Vol. 19.3.

Home Energy. "Building America: Seven Years of Progress." May/June 2002, p.2.

Home Energy. "Allergy Relief in Humid Climates." March/April 2002, pp. 30-33.

Home Energy. "Moisture Problems in Manufactured Housing." March/April 2002, pp. 24-29.

Indoor Environment Business. "Center Finds IAQ Problem from Leaky Air Handlers, Ducts in Florida.” April 2002, p.4. 
Manufactured Home Merchandiser. "Measured Conditions in a MH Crawl Space" June 2005, pp31-33.

Orlando Sentinel - Home Section. “A Clean Sweep: Simple Steps Can Improve a Home's Indoor Air." September 22, 2001 (OrlandoSentinel.com)

Orlando Sentinel - Home Section. "In the Name of Energy." September 2, 2001. (OrlandoSentinel.com)

Pendleton Times. "Simpson Home Is First of Its Kind in WV." March 17, 2005. Vol. 92, N. 11, pg. 5.

Rebuild America - Building America Partner Update. "Portable Classrooms: An Efficiency Challenge." March/April) 2002, p. 7.

Rebuild America - Building America Partner Update. "Building America: Solving Problems with Energy Efficiency.” January/February 2002, p. 10.

Solar Today. "Home Energy Use Halved." November/December 2001, pp. 54-55.

Washington Post "Susanka's Signatures -- and Surprises -- Fill Demo Home in Orlando", Saturday, March 12, 2005; Page F05

One Page Fact Sheets

Building America Industrialized Housing Partnership,

Transforming the Market: Super-Efficient Manufactured Housing.

Manufactured Housing Laboratory: A Research and Training Facility.

Durable, Resource-Efficient Achievable Model (DREAM) Home.

Habitat for Humanity Collaborations: Affordable Energy Efficiency.

2005, 2006 Fact Sheets for IBS Showhomes 


\section{V \\ BAIHP COLLABORATIONS}




\section{BAIHP COLLABORATIONS}

BAIHP researchers collaborate with a variety of entities in the homebuilding industry and the energy efficiency and research realm. Table 81 lists collaborators in the following categories:

- DOE National Labs (e.g. NREL, LBNL, ORNL)

- $\quad$ Code and Standards Bodies (e.g. RESNET, NFPA)

- Industry and Professional Organizations, Universities, and Suppliers

Table 81 BAIHP Collaborations

\begin{tabular}{|c|c|c|}
\hline Collaborators & Description/Subject of Collaboration & Month \\
\hline \multicolumn{3}{|l|}{ DOE National Labs } \\
\hline $\begin{array}{l}\text { DOE-ATLANTA \& } \\
\text { Pacific Northwest } \\
\text { National Lab } \\
\text { (PNNL) }\end{array}$ & $\begin{array}{l}\text { Hosted Traci Leath (DOE Atlanta Regional Office) and } \\
\text { Michael Baechler (PNNL) for a tour of BAIHP facilities } \\
\text { (FSEC in Cocoa) and BAIHP partners and projects in } \\
\text { Florida (Orlando, Plant City, and Gainesville.) }\end{array}$ & JULY 03 \\
\hline $\begin{array}{l}\text { NIST and the } \\
\text { Energy } \\
\text { Conservatory }\end{array}$ & NIST test home in Gaithersburg, Maryland. & $\begin{array}{l}\text { JULY } 03 \\
\text { on-going }\end{array}$ \\
\hline PNNL & $\begin{array}{l}\text { Worked with Michael Beachler to produce draft of Systems } \\
\text { Engineering for Habitat for Humanity }\end{array}$ & $05-06$ \\
\hline PNNL & $\begin{array}{l}\text { Technical Assistance for PNNL's efforts to evaluate HUD } \\
\text { Uo value. }\end{array}$ & $\begin{array}{l}\text { JULY } 03 \\
\text { on-going }\end{array}$ \\
\hline PNNL & $\begin{array}{l}\text { Finalized efforts with PNNL and DOE on BAIHP cost data } \\
\text { and duct research efforts. }\end{array}$ & AUG 03 \\
\hline LBNL & $\begin{array}{l}\text { Hosted Al Hodgson at FSEC and participated with } \mathrm{Al} \text { on } \\
\text { VOC sampling at the MHLab }\end{array}$ & JUNE 03 \\
\hline LBNL & $\begin{array}{l}\text { Coordinated plug load research with Rich Brown and Alan } \\
\text { Meier. }\end{array}$ & $05-06$ \\
\hline ORNL & $\begin{array}{l}\text { Participated in ORNL partnership with Loudon County } \\
\text { (TN) Habitat for Humanity. Instrumentation, data } \\
\text { collection, and web hosting of data. }\end{array}$ & $\begin{array}{l}\text { APR } 03- \\
\text { MAR } 04 \\
05-06\end{array}$ \\
\hline NREL & $\begin{array}{l}\text { Philip Fairey and Danny Parker assisted with the BA } \\
\text { benchmark development and review process. }\end{array}$ & $\begin{array}{l}\text { APR } 03- \\
\text { MAR } 04\end{array}$ \\
\hline \multicolumn{3}{|c|}{ Code and Standards Bodies, Federal and State Programs } \\
\hline NFPA & $\begin{array}{l}\text { Integrated BAIHP research and cost information into } 5 \\
\text { proposals for the NFPA501 standards committee }\end{array}$ & $\begin{array}{l}\text { JULY } 03 \\
\text { completed }\end{array}$ \\
\hline NFPA & $\begin{array}{l}\text { Presented BAIHP cost and duct research efforts which } \\
\text { resulted in adoption of a new standard on duct air tightness } \\
\text { and testing protocol. }\end{array}$ & $\begin{array}{l}\text { SEPT } 03 \\
\text { completed }\end{array}$ \\
\hline HUD-PATH & $\begin{array}{l}\text { Reviewed and commented on PATH MHRA mfg home } \\
\text { retrofit project. }\end{array}$ & Aug05 \\
\hline HUD - NFPA & $\begin{array}{l}\text { Supported HUD's John Steven proposals to NPFA-501 } \\
\text { committee. Proposals regard ducts and ventilation systems. } \\
\text { Reflected in HUD } 2004 \text { federal register. }\end{array}$ & $\begin{array}{l}\text { JAN, FEB } \\
04-\text { DEC } \\
04 \\
\text { completed }\end{array}$ \\
\hline RESNET & BA Benchmark Support, Philip Fairey. & $\begin{array}{l}\text { APR } 03- \\
\text { MAR } 04\end{array}$ \\
\hline
\end{tabular}


Table 81 BAIHP Collaborations

\begin{tabular}{|c|c|c|}
\hline Collaborators & Description/Subject of Collaboration & Month \\
\hline \multicolumn{3}{|c|}{ Industry and Professional Organizations, Universities, Utilities, and Suppliers } \\
\hline ABSN & Coordinate with Alaska BAIHP stakeholder. & On-going \\
\hline ACEEE & $\begin{array}{l}\text { Residential Buildings Panel Co-Chairs, Danny Parker and } \\
\text { Mike Lubliner ACEEE } 2004 \text { Summer Study. }\end{array}$ & $03-04$ \\
\hline ACEEE & $\begin{array}{l}\text { Residential Buildings Panel Chairs Mike Lubliner, ACEEE } \\
2006 \text { Summer Study. }\end{array}$ & $05-06$ \\
\hline ACEEE & $\begin{array}{l}\text { Began peer review on papers submitted to ACEEE } \\
\text { Residential Building's panel; followed up on issues for } \\
\text { ACEEE } 2004 \text { Summer Study. }\end{array}$ & $\begin{array}{l}\text { MAR } 04 \\
\text { completed }\end{array}$ \\
\hline AFC & Planning and coordination for 2005 Conference Workshop. & On-going \\
\hline $\begin{array}{l}\text { AUBURN } \\
\text { UNIVERSITY }\end{array}$ & $\begin{array}{l}\text { Department of Architecture, Design, and Construction on } \\
\text { DESIGNHabitat, a sustainability and energy efficiency } \\
\text { project - Worked with undergraduate fellowship winner to } \\
\text { draft a monitoring plan and select HOBO sensors. }\end{array}$ & JUNE 03 \\
\hline $\begin{array}{l}\text { AUBURN } \\
\text { UNIVERSITY }\end{array}$ & $\begin{array}{l}\text { HOBOs installed in, and data collected from } 2 \\
\text { DESIGNHabitat homes and } 1 \text { conventional Habitat home } \\
(\sim 3 \text { yrs old }) .\end{array}$ & $\begin{array}{l}\text { JULY, } \\
\text { AUG } 03\end{array}$ \\
\hline $\begin{array}{l}\text { AUBURN } \\
\text { UNIVERSITY }\end{array}$ & $\begin{array}{l}\text { Data from HOBO monitoring sensors posted online and } \\
\text { utility bill analysis completed. Review of data and } \\
\text { refinement of utility bill analysis. }\end{array}$ & $\begin{array}{l}\text { SEPT 03- } \\
\text { NOV } 04\end{array}$ \\
\hline $\begin{array}{l}\text { AUBURN } \\
\text { UNIVERSITY }\end{array}$ & $\begin{array}{l}\text { Fellow completed study and presented paper to senior } \\
\text { thesis committee. Student took and passed USGBC's } \\
\text { LEED certification test as result of fellowship experience. }\end{array}$ & DEC 03 \\
\hline $\begin{array}{l}\text { AUBURN } \\
\text { UNIVERSITY }\end{array}$ & $\begin{array}{l}\text { BAIHP participated in studio jury and technical support to } \\
\text { faculty and students at the Auburn School of Architecture } \\
\text { for bi-annual DESIGNHabitat program. }\end{array}$ & 2006 \\
\hline ASHRAE & $\begin{array}{l}\text { Submitted draft of revised Chapter } 9 \text { of ASHRAE } \\
\text { Handbook for HVAC Systems and Equipment Systems to } \\
\text { Building America partners. }\end{array}$ & $\begin{array}{l}\text { APR } 03 \\
\text { completed }\end{array}$ \\
\hline ASHRAE & $\begin{array}{l}\text { Submitted draft of revised Chapter } 43 \text { of ASHRAE } \\
\text { Applications Handbook - Thermal Envelopes. }\end{array}$ & $\begin{array}{l}\text { JAN } 04 \\
\text { on-going }\end{array}$ \\
\hline ASHRAE & $\begin{array}{l}\text { Chapter } 9 \text { approved by ASHRAE TC } 6.3 \text { with revisions } \\
\text { suggested by TC } 6.3 \text { members. }\end{array}$ & $\begin{array}{l}\text { MAY } 03 \\
\text { completed }\end{array}$ \\
\hline ASHRAE & Submitted Chapter 9 to ASHRAE for publication. & $\begin{array}{l}\text { MAY } 03 \\
\text { completed }\end{array}$ \\
\hline ASHRAE & $\begin{array}{l}\text { Chapter } 9 \text { published in } 2004 \text { Systems and Equipment } \\
\text { Handbook }\end{array}$ & JUNE 04 \\
\hline ASHRAE & $\begin{array}{l}\text { Lubliner, FSEC researchers active committee member } \\
\text { TC6.3 on heat pumps }\end{array}$ & On-going \\
\hline ASHRAE & $\begin{array}{l}\text { Lubliner, FSEC researchers active committee member } \\
\text { TC } 9.5 \text { on heat pumps }\end{array}$ & On-going \\
\hline ASHRAE & $\begin{array}{l}\text { Worked with TC6.3 members and BAIHP partners to } \\
\text { coordinate committee activities for } 2004 \text { ASHRAE } \\
\text { Symposium in Anaheim, CA. }\end{array}$ & $\begin{array}{l}\text { JUNE, } \\
\text { JULY } 03 \\
\text { on-going }\end{array}$ \\
\hline
\end{tabular}


Table 81 BAIHP Collaborations

\begin{tabular}{|c|c|c|}
\hline Collaborators & Description/Subject of Collaboration & Month \\
\hline ASHRAE & $\begin{array}{l}\text { For } 2004 \text { Symposium, review of papers on HVAC } \\
\text { performance. }\end{array}$ & $\begin{array}{l}\text { MAY, } \\
\text { JUNE, } \\
\text { JULY } 03 \\
\text { completed }\end{array}$ \\
\hline BPA & $\begin{array}{l}\text { Demonstration, Research analysis and publications on Zero } \\
\text { Energy Mfg Home. }\end{array}$ & On-going \\
\hline $\begin{array}{l}\text { CITY OF SANTA } \\
\text { MONICA, CA }\end{array}$ & $\begin{array}{l}\text { City began planning a community of Green manufactured } \\
\text { homes. }\end{array}$ & JUNE 03 \\
\hline Energy Trust of OR & Technical assistance on mfg housing incentive program. & On-going \\
\hline $\begin{array}{l}\text { Enterprise } \\
\text { Foundation }\end{array}$ & $\begin{array}{l}\text { Meeting and follow on discussions to provide technical } \\
\text { assistance to the Green Communities program in Florida. }\end{array}$ & $\begin{array}{l}\text { March 05- } \\
\text { April 05 }\end{array}$ \\
\hline HONEYWELL & $\begin{array}{l}\text { Organized a meeting with Honeywell to exchange } \\
\text { information on Indoor Air Quality research and products. }\end{array}$ & $\begin{array}{l}\text { MAY } 03 \\
\text { completed }\end{array}$ \\
\hline HONEYWELL & Honeywell joined BAIHP team. & JULY 03 \\
\hline HONEYWELL & $\begin{array}{l}\text { Monthly/periodic conference calls to exchange } \\
\text { information. }\end{array}$ & $\begin{array}{l}\text { SEPT 03- } \\
\text { MAR } 04\end{array}$ \\
\hline IBACOS & $\begin{array}{l}\text { Support IBACOS technical assistance to the New } \\
\text { American Home to be displayed during the International } \\
\text { Builders Show in Orlando, FL. in } 2005 \text { and again in } 2006 . \\
\text { Site Work (testing and inspections), photos, and Florida } \\
\text { Energy Star rating. } \\
\text { Photo/video of the stages of construction provided on a } \\
\text { weekly basis. }\end{array}$ & $\begin{array}{l}\text { SEPT 03- } \\
\text { MAR } 06\end{array}$ \\
\hline IBHS & $\begin{array}{l}\text { IBHS has agreed to become a BAIHP partner and work in } \\
\text { the area of expanding their Fortified program to HUD code } \\
\text { housing }\end{array}$ & $05-06$ \\
\hline LSU & $\begin{array}{l}\text { Worked with LAHouse Program Manager Claudette } \\
\text { Reichel to develop monitoring plan }\end{array}$ & On-going \\
\hline MHRA & $\begin{array}{l}\text { Met in DC and Las Vegas, NV to discuss potential } \\
\text { collaborations. }\end{array}$ & APR 03 \\
\hline MHRA & $\begin{array}{l}\text { M. Mullens and S. Chandra participated in MHRA } \\
\text { planning conference for } 2005\end{array}$ & APR 03 \\
\hline MHRA & $\begin{array}{l}\text { At MHRA request, Neil Moyer assisted MHRA staff in } \\
\text { testing single a wide home in Alabama for the MHRA } \\
\text { moisture study. }\end{array}$ & MAY 03 \\
\hline MHRA & $\begin{array}{l}\text { Provided feedback to MHRA on their moisture research } \\
\text { plan. MHRA attended BAIHP Project Review Meeting }\end{array}$ & JAN 04 \\
\hline MHRA & $\begin{array}{l}\text { Continued collaborations with MHRA on testing houses } \\
\text { for their moisture study. Written and oral feedback } \\
\text { provided. }\end{array}$ & MAR 04 \\
\hline
\end{tabular}


Table 81 BAIHP Collaborations

\begin{tabular}{|c|c|c|}
\hline Collaborators & Description/Subject of Collaboration & Month \\
\hline NAHB & $\begin{array}{l}\text { Participated in the NAHB Building Systems Councils plant } \\
\text { tour. Networked with D. Kaufman, exec director and began } \\
\text { a dialogue to significantly participate in BSC activities. }\end{array}$ & MAY 03 \\
\hline NAHB & $\begin{array}{l}\text { Mike Lubliner participated in Energy Value Housing } \\
\text { Award judging at NAHB Research Center. }\end{array}$ & on-going \\
\hline NEEA & $\begin{array}{l}\text { Technical Assistance to Northwest Energy Star Site Built } \\
\text { Program. }\end{array}$ & On-going \\
\hline NEEM & $\begin{array}{l}\text { Implementation of PNW Energy Star/BAIHP Program } \\
\text { Including factory and site inspections, specification } \\
\text { improvements, tracking and certification of homes. }\end{array}$ & On-going \\
\hline NIST & $\begin{array}{l}\text { Worked with NIST staff to coordinate retrofit study and } \\
\text { Delta Q testing }\end{array}$ & DEC 05 \\
\hline NOMACO & $\begin{array}{l}\text { Continued collaborations with Mike Schroeder, Nomaco } \\
\text { representative on potential new product. Non disclosure } \\
\text { agreement was finalized. }\end{array}$ & $\begin{array}{l}\text { APR } 03- \\
\text { MAR } 04\end{array}$ \\
\hline NSF/PATH & $\begin{array}{l}\text { Participated in NSF/PATH Housing Research Workshop } \\
\text { (Feb 12-14) and presented paper. }\end{array}$ & FEB 03 \\
\hline SouthFace & $\begin{array}{l}\text { Participated in building science/green builder training in } \\
\text { the Florida Panhandle. }\end{array}$ & May 2004 \\
\hline SSHC, Inc. & $\begin{array}{l}\text { Met with SSCI, manufacturer of ENERJOY radiant heating } \\
\text { panels, on continued BAIHP research efforts. }\end{array}$ & $\begin{array}{l}\text { JUNE } 03 \\
\text { on-going }\end{array}$ \\
\hline USGBC & $\begin{array}{l}\text { Bi-monthly conference calls with core committee, } \\
\text { additional for TSAC committees }\end{array}$ & $\begin{array}{l}\text { APR } 03- \\
05-06\end{array}$ \\
\hline UCF & $\begin{array}{l}1 \text { hour lecture to about } 250 \text { students as part of UCF Life } \\
\text { activities on improving residential energy efficiency and } \\
\text { indoor air quality }\end{array}$ & MAR 04 \\
\hline $\begin{array}{l}\text { WA Mfg Housing } \\
\text { Working Group }\end{array}$ & $\begin{array}{l}\text { Provide technical assistance on state-level HUD-code } \\
\text { housing issues. }\end{array}$ & On-going \\
\hline WSU & Supported WSU Solar Decathlon effort. & $\begin{array}{l}\text { SEPT, } \\
\text { OCT } 05\end{array}$ \\
\hline
\end{tabular}

Northwest Energy Efficient Manufactured Housing Program (NEEM) Collaborations

ASHRAE: During 2003, in the capacity of chairing ASHRAE's 6.2 Technical committee, BAIHP staff directed a major effort to revise Chapter 9 of the ASHRAE Systems Handbook, "Design of Small Forced-air Heating and Cooling Systems." The revisions to the chapter, which incorporated BAIHP research, were accepted by the committee, and forwarded to ASHRAE for publication. In 2004 BAIHP staff provided assistance to other BA teams to improve chapter 43 of the ASHRAE Applications Handbook - Envelopes.

BAIHP staff have also participated in ASHRAE research projects, conferences, symposiums, seminars and forums, including:

- Authoring a paper on duct leakage, which was submitted and approved for presentation at ASHRAE summer meeting in 2004. 
- Making a presentation at the ASHRAE summer meeting in 2003, "Uncontrolled Air Flow in Small Commercial Buildings."

- Moderating a forum on HVAC experiences in HUD code housing at ASHRAE's summer meeting in 2002. 20 industry and building science professionals participated in the forum.

- Co-chairing ASHRAE's Technical Committee 6.3 - Residential Forced Air Heating and Cooling Equipment, which is responsible for ASHRAE standard 152 - Thermal Distribution Systems.

- Building America research on ductwork and HVAC systems will be included in the next version of the ASHRAE standards. Building America research will also be a part of future efforts in TC 6.3.

- NAHB Research Center: Throughout the BAIHP effort, WSU staff provided technical assistance and guidance to the NAHB Research Center Energy Value Housing Awards, judging submittals, providing de-briefing to builders, and participating on workshops. NEEM builders Fleetwood, Champion, Valley and Marlette have received EVHAs for factory built housing.

NFPA-501: BAIHP continues to support the NFPA standards process. The NFPA standard is typically incorporated into the HUD code, which governs the construction of over 250,000 HUD code homes each year.

- In 2003, BAIHP staff integrated BAIHP duct leakage and cost data into proposals to the NFPA-501 committee. Based on this data, NFPA approved a new standard on duct tightness, as well as a refined duct testing protocol.

- In 2002, BAIHP staff cited Building America research and demonstration efforts in support of additional successful proposals for standards revision, including duct testing, and use of mastic in duct sealing.

\section{ACEEE}

- BAIHP staff have co-authored two papers presented at ACEEE Conferences, "Pushing the Envelope: A Case Study of Building the First Manufactured Home Using Structural Insulated Panels," and "Washington State Residential Ventilation and Indoor Air Quality Code (VIAQ) - Whole House Ventilation Systems Field Research Report."

- In 2004, BAIHP staff coordinated 24 peer reviewed papers for the Residential technologies track at the Summer Study and coordinated informal sessions on HUD-code housing.

National Institute of Standards and Technologies (NIST): BAIHP staff continues to work with NIST staff and industry representatives to evaluate ventilation and IAQ issues in HUD code homes.

- BAIHP staff also worked with NIST and the Energy Conservancy to perform tests on a typical HUD code model house on the NIST campus in Gaithersburg, Maryland. Testing indicates low flow rates of the whole house ventilation system and significant duct leakage.

- In 2004, discussions with NIST, LBL, Ecotope and Energy Conservatory continued on a retrofit research effort with Dupont Tyvek, and development of new ventilation system controls with Panasonic. These discussions will continue. 
National Manufactured Housing Research Alliance (MHRA): BAIHP staff continues to participate on MHRA's ENERGY STAR committee, which is developing Quality Assurance procedures with USEPA on ENERGY STAR manufactured homes. An article on the ZEMH appeared in the MHRA newsletter. WSU worked with MHRA to provide an article on the ZEMH project. WSU continues to provide technical support to MHRA on ENERGY STAR and other building science/energy related efforts such as the MHI roadmap. 


\section{VI \\ BAIHP PROJECT MANAGEMENT}




\section{PROJECT MANAGEMENT}

BAIHP project management includes participating in Building America program reviews/meetings and preparing monthly and yearly reports for project activities as well as managing all project tasks (see Sections 1-6) and subcontracts. In the $6{ }^{\text {th }}$ Budget Period BAIHP participated in the Peer Review conducted by DOE. A list of project management activities is included in Table 83.

Note that only project management activities for the last budget period of the project are available here; if activities from previous budget periods are desired, please contact BAIHP project manager Subrato Chandra at subrato@fsec.ucf.edu or review previous year's final reports on the BAIHP web page at www.baihp.org.

Table 82: Project Management Activities for April 2005 - June 2006 In January of 2006, prior to the International Builders Show, FSEC hosted DOE's David Rodgers, Acting Deputy Assistant Secretary for EERE, and David Moorer for a half day tour and research discussion.

Manage Project and Subcontracts, Attend DOE Meetings and Produce Reports

Issued subcontracts and develop scopes of work.

Participation in BA Quarterly Review Meeting

Compiled and summarized results from 6th Budget Period Annual Report

Compiled and summarized monthly results from research, implementation research, presentations, and publications.

DOE Peer Review Process

Prepared Peer Review documents and submitted to DOE

Prepared Peer Review Presentations

Participated in the DOE peer review process and made several presentations.

Available online at: http://www.baihp.org/pubs/doe review/index.htm

30\% Joule Reports

Reviewed and provided feedback on DOE Cold Climate and hot dry climate 30\% reports

Provided feedback on DOE Cold Climate 30\% Design Report and provided maps of project locations superimposed on the climate zone map to NREL.

National Energy Technology Laboratory (NETL)

Prepared BAIHP proposal in response to the NETL solicitation.

Responded to NETL requests for additional information after their selection of the

BAIHP team to receive new funding for the new BAIHP work.

UCF/FSEC received signed award from NETL for a new 5 year agreement to continue the BAIHP work

California Lighting Technology Center

Began paperwork to issue purchase order to the California Lighting Technology Center

for assistance in lighting design.

Plan to subcontract with CLTC on lighting upgrade package in MHLab.

Monitored ongoing data collection for comparison of ventilation packages

DOE FY07Annual Operating Plan 


Finalized FY06 AOP and submitted to DOE
Prepared the BAIHP FY07AOP and submitted to DOE
Subrato Chandra, Danny Parker, Janet Mcllvaine and Rob Vieira participated in the DOE
FY07AOP planning meeting in Washington DC

Table 83 BAIHP Project Management Activities for April 2004 - March 2005

\begin{tabular}{|c|c|}
\hline BAIHP Task/Staff & Description/Subject \\
\hline \multicolumn{2}{|c|}{ Task: Participation in BA Quarterly Review Meetings } \\
\hline $\begin{array}{l}\text { Chandra, Fairey, } \\
\text { Vieira, Parker, } \\
\text { Mcllvaine, }\end{array}$ & Participation in BA Quarterly Review Meetings \\
\hline \multicolumn{2}{|c|}{ Participation in other BA Meetings } \\
\hline WSU & $\begin{array}{l}\text { Met with WSDUE and PNNL to discuss BAIHP research support for } \\
\text { NFPA-501 future. (April 04)) }\end{array}$ \\
\hline WSU & $\begin{array}{l}\text { Attended MHI Congress, representing Building America. Met with } \\
\text { BAIHP industry partners and submitted ideas for } 2 \text { papers for } 2005 \\
\text { International conference. (April } 04\end{array}$ \\
\hline Chandra, Mullens & $\begin{array}{l}\text { MHRA pre conference to define agenda for the } 2005 \text { International } \\
\text { Conference on factory built housing (April 2004) }\end{array}$ \\
\hline WSU & Attended ASHRAE conference and chaired TC 6.3 (June 04) \\
\hline Martin, Chandra & BA all teams meeting in Washington D.C (June 04) \\
\hline Lubliner, Moyer & $\begin{array}{l}\text { Annual NEEM meeting with special focus on integrating NEEM and } \\
\text { BAIHP efforts. }\end{array}$ \\
\hline Chandra, Vieira & BA quarterly meeting (August 2004) \\
\hline FSEC & $\begin{array}{l}\text { Teleconference call organized by the DOE Seattle regional office to } \\
\text { discuss Building America approach with Hawaii state energy } \\
\text { personnel. (September 2004) }\end{array}$ \\
\hline WSU & $\begin{array}{l}\text { Met with USDOE staff in Washington, focus on BAIHP activities. } \\
\text { (September 2004) }\end{array}$ \\
\hline WSU & $\begin{array}{l}\text { Conference calls on BAIHP activities with USDOE regional office. } \\
\text { (September 2004) }\end{array}$ \\
\hline Chandra & $\begin{array}{l}\text { Meeting, DOE-Atlanta to discuss FY05 solicitation for BA tech } \\
\text { transfer activities. (October, 2004) }\end{array}$ \\
\hline WSU & $\begin{array}{l}\text { Met with USDOE staff in Washington, focus on BAIHP activities. } \\
\text { (October 2004) }\end{array}$ \\
\hline Fairey, Parker & BA quarterly review in Washington, D.C. (November 204) \\
\hline FSEC & $\begin{array}{l}\text { Met with Robin Pharo - Aprilaire (discussion on BAIHP and FSEC } \\
\text { collaboration). (February 2005) }\end{array}$ \\
\hline $\begin{array}{l}\text { Chandra, Moyer, } \\
\text { Parker }\end{array}$ & Pre peer review meeting in Washington, D.C. (March 2004) \\
\hline \multicolumn{2}{|l|}{ Prepare Reports } \\
\hline $\begin{array}{l}\text { Chandra, All } \\
\text { Researchers }\end{array}$ & $\begin{array}{l}\text { Compiled and summarized results from } 5^{\text {th }} \text { Budget Period Annual } \\
\text { Report }\end{array}$ \\
\hline $\begin{array}{l}\text { Chandra, Alidina, } \\
\text { All }\end{array}$ & $\begin{array}{l}\text { Compiled and summarized monthly results from research, } \\
\text { implementation research, presentations, and publications. }\end{array}$ \\
\hline \multicolumn{2}{|c|}{ Manage Project and Subcontracts and Perform Related Activities } \\
\hline Chandra & BAIHP subcontracts issued and scope of work developed. \\
\hline
\end{tabular}




\begin{tabular}{|c|l|}
\hline Chandra & $\begin{array}{l}\text { Continued meetings and discussion with Sam Taylor regarding } \\
\text { Building America deployment through Energy Extension services. }\end{array}$ \\
\hline Chandra & Prepared response to DOE solicitation \# DE-FC2699GO10478 \\
\hline Chandra & Preparation of FY06 AOP proposal submission to DOE. \\
\hline
\end{tabular}

\section{Project Contact}

Subrato Chandra, BAIHP Project Director

www.baihp.org

Florida Solar Energy Center

1679 Clearlake Road

www.fsec.ucf.edu

Cocoa, FL 32922

subrato@,fsec.ucf.edu

321-638-1412 
